UNIVERSIDADE DE BRASÍLIA

INSTITUTO DE CIÊNCIAS SOCIAIS

DEPARTAMENTO DE ANTROPOLOGIA

PROGRAMA DE PÓS-GRADUAÇÃo

EM ANTROPOLOGIA SOCIAL

\title{
corpo de planta
}

terapias e magias dxs curiosxs da baixa Amazônia do Peru, sob uma perspectiva situada de gênero e de saúde popular

\section{Ana Gretel Echazú Böschemeier}

Tese de Doutorado apresentada ao Programa de Pós-Graduação em Antropologia Social, Universidade de Brasília, como parte dos requisitos necessários à obtenção do título de Doutora em Antropologia Orientadora: Profa. Dra. Soraya Fleischer

Iquitos/Salta/Brasília

Fevereiro de 2015 


\section{corpo de planta}

terapias e magias dxs curiosxs da baixa Amazônia do Peru, sob uma perspectiva situada de gênero e de saúde popular

\section{Ana Gretel Echazú Böschemeier}

Tese de Doutorado apresentada ao Programa de Pós-Graduação em Antropologia Social,

Universidade de Brasília, como parte dos requisitos necessários à obtenção do título de Doutora em Antropologia. Orientadora: Profa. Dra. Soraya Fleischer.

Aprovada por:

Profa. Dra. Soraya Fleischer (presidente)

Profa. Dra. Sônia Weidner Maluf

Prof. Dr. Luis Abraham Cayón

Profa. Dra. Sílvia Ferreira Guimarães

Profa. Dra. Martina Ahlert

$\overline{\text { Profa. Dra. Fabiene Gama (Suplente) }}$ 


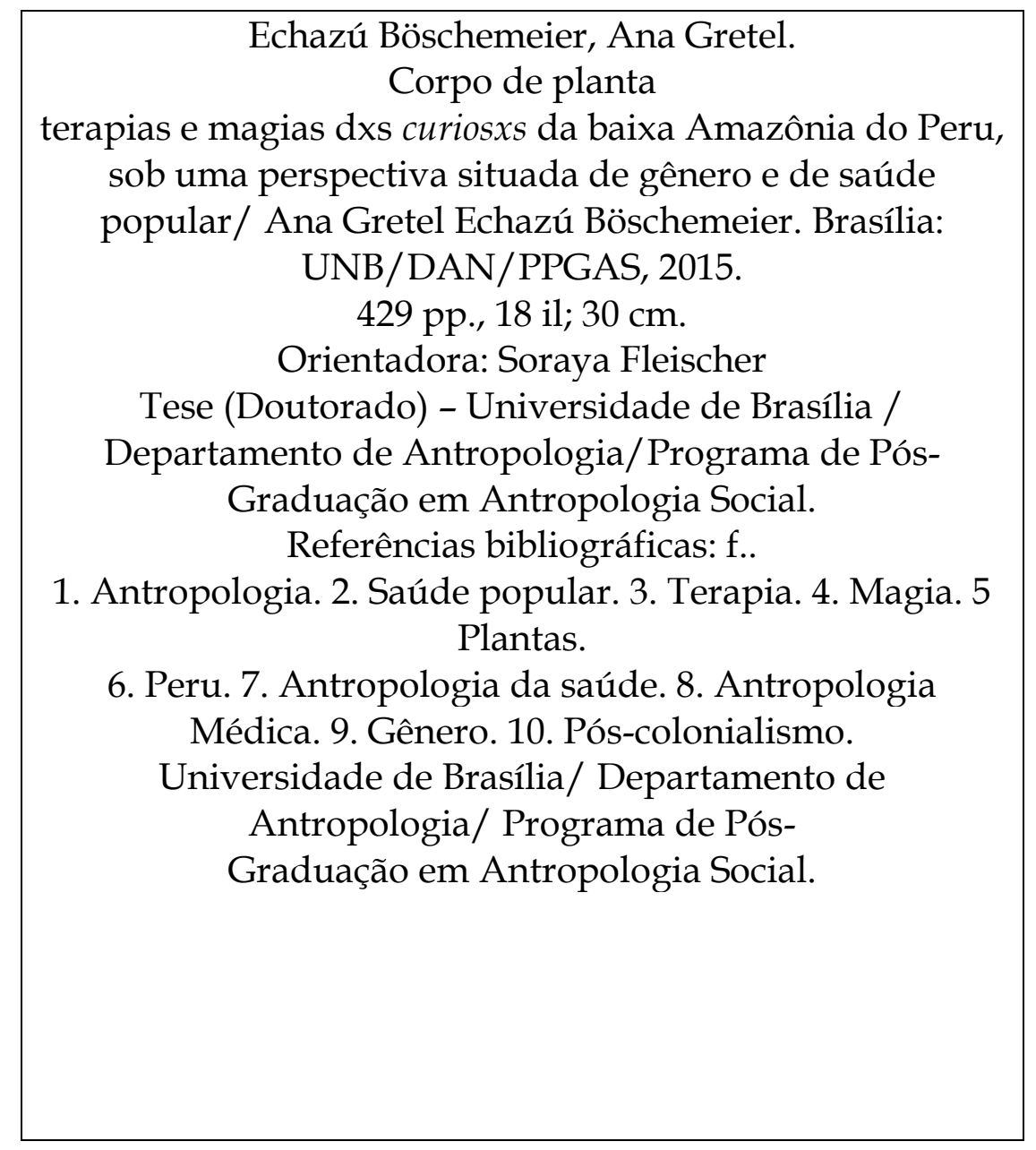


Dedico todas e cada uma das horas que alimentaram o presente trabalho para Aimée Malva, Pedro Valentín, Carl Kevin, César Eddy, Marianela Torino, Paula Massa, Bibiana Marton, Patricia Guiscafre e Natalia Cabanillas, que são a minha própria alma em constelação 
À abuelita Elsa, amiga peruana que faleceu, idosa e lúcida, nesse chuvoso início de 2015. Ao meu pai César, com quem aprendi a alegria de cada façanha da minha infância. Ao Carl $\mathrm{Mu}$, roti, curri and dmt, com quem transito a aventura da vida em todos seus tons, graus e temperaturas.

Às mulheres que me acompanharam em Tamshiyacu: Isabel, curandeira que sabe ver além do imediato; Gerónima, vizinha e amiga; Eva e Rosa, amigas empreenderoras do mercado; Jenny, mãe trabalhadora; Nathálie turista psiconâutica; Milena, María e Pasquita, parteiras e sobadoras sabedoras e finalmente Lorena, prima da genealogia espiritual peruana. Ao Gerlyn, Julio, Carlos, Antonio e Walter, gentis homens da floresta. À minha madrinha de umbigo, Maria Albertina. À Maud Rouppe e Monina Alemandi, madrinhas das escolhas conscientes. Às belas pessoas que conheci nos percursos transitados: Jane, Eliana e Lis de Alto Paraíso; Preta, ativista da negritude do interior de Natal; ao Igor Leça, Paulinha, Vânia Maria, Pablo Martínez, Rodolfo Ribeiro e Tatiana Pereira, de Natal; Marilú Milanez, Marcelo Bousada e Luciane Madeira, de Brasília; Rafa Beznos, cosmopolita; Marian Rodríguez Cabral, psicoangêlica. À Paula Massa e Pato Guiscafre, aliadas vaquereñas. Às minhas velhas novas sobrinhas Ana Sol, Florencia e Natalia, por trazer juventude à árvore anhosa da genealogia do sangue. Ao Flavio Ruiz Alemandi, bom amigo e melhor pai e à sua boa companheira, Lariane. À parteira de Aimée, Sandra Martínez, ao seu esposo, Rolando motorista e à Bibiana Marton, doulamiga, por ter me dado de presente um parto que foi um dos mais belos momentos da vida. Às fueraloquefuere dos Valles Calchaquíes: Marianela, Edith Miranda e Marcela Mendoza, pela criatividade compartilhada.

À minhas e meus colegamigxs de longe e de perto: Natalia Cabanillas, Paulo Henrique da Silva, Luíza Rabello, Elisa Paiva, Rafael Antunes Almeida, Lurecia Greco, Victoria Espinoza, Felipe Areda, Marcelo Caetano, Alicia Silvestre, Eugenia Flores, Jaína Alcântara, Sandra Rodríguez Echazú, Mélissa Girard, Víctor Petrone, Sandybelle Pérez del Águila, Roger Rengifo Ruiz, Rosa Melo e Bia Labate, por enriquecerem, de tantas maneiras, as minhas buscas. Às inspiradoras professoras Norma Naharro, Sonia Álvarez, Julie Cavignac e Maria Betânia Albuquerque, por juntarem inteligência e alma de maneiras tão criativas. Ao professor José Jorge de Carvalho, incansável poeta da diferença.

À minha querida orientadora Soraya Fleischer, pelo seu apoio, afeto e paciência comigo; pela sua idoneidade nesta arte de guiar a escrita de uma história e a escrita de uma vida, assim como pela sua sutil maneira ética de fazer, que inspira as minhas práticas cotidianas nesta profissão. Ao Thiago Novaes desde Brasília e à Coreen Rogers desde Nova Iorque, por me ajudar na correção do texto na língua portuguesa e inglesa, respectivamente. Ao Programa de Pós-Graduação em Antropologia Social da Universidade de Brasília, por me receber na sua usina de ideias. Às cidadãs e cidadãos brasileirxs através da CAPES/PEC-PG, por me darem a oportunidade de materializar as condições da presente pesquisa. 


\title{
RESUMO
}

\section{Corpo de planta}

\section{Terapias e magias dxs curiosxs da baixa Amazônia do Peru, sob uma perspectiva situada de gênero e de saúde popular}

\section{Ana Gretel Echazú Böschemeier}

\author{
Orientadora: Profa. Dra. Soraya Fleischer
}

Resumo da Tese de Doutorado submetida ao Programa de Pós-Graduação em Antropologia Social /Departamento de Antropologia/ Universidade de Brasília, UNB, como parte dos requisitos necessários à obtenção do título de Doutora em Antropologia.

A presente tese é uma etnografia situada em Tamshiyacu, povoado da baixa Amazônia peruana que é muito conhecido por seus albergues destinados a cerimônias com ayahuasca no marco do turismo xamânico. Partindo da proposta de uma desconstrução daquilo que chamo aqui o mito político do "homem-xamãque-cura-com ayahuasca", delineio uma análise crítica da literatura relativa a magias e terapias populares na floresta do Peru. Com base na etnografia realizada estabeleço que: xs especialistas em questão não são somente homens, não são exclusivamente xamãs, não apenas curam - mas também podem fazer dano intencionalmente - e não só lançam mão da ayahuasca na preparação de seus remédios mágicos e terapêuticos. Com o intuito de apresentar uma diversidade que excede à restrição conceitual inerente a esse mito, o trabalho de campo se baseia em observações participantes e narrativas de vida que focalizam as relações de gênero entre mulheres/homens e plantas a partir das práticas terapêuticas e mágicas de curiosxs locais (entre elxs, xamãs, curandeirxs, purguerxs, sobadorxs [de mulheres grávidas], sobadoxs de lisiadxs, naturalistas, yerberxs e parteirxs) e na relação com suas/seus pacientes. Como proposta de análise, desenvolvo aqui uma reflexão sobre aspectos do corpo humano que, na concepção local, são idênticos aos das plantas. $\mathrm{O}$ fato de entrar em contato com um vegetal específico provoca uma ressonância corporal que, na direção desejada, facilita ou promove o alívio ou a cura da perturbação. A noção corriqueira que coloca ao corpo humano como uma materialidade fundamentalmente afim com as plantas favorece paralelos imaginários e práticos entre as mulheres e homens do mundo humano e uma multiplicidade de seres que pertencem ao mundo não-humano, propiciando magias e curas através da permanente relação de tensão e colaboração entre esses dois territórios. Muitas vezes, esses vínculos se estabelecem em uma linguagem que é genderizada 
[gendered], e que se define através do caminho da escolha de palos, que são certo tipo de vegetais vinculados à masculinidade, assim como de hierbas, vegetais que se relacionam com a feminilidade. A presente tese também explora as exceções que representam as mulheres e os homens que acessam, de maneira alternada, aos dois mundos.

\section{ABSTRACT}

The present thesis is an ethnography located in Tamshiyacu, a small town of the low Peruvian Amazon that is well known by its resorts dedicated to Ayahuasca ceremonies on the context of shamanic tourism. Starting from the proposal of deconstruction of what I call the political myth of the "male-shaman-that healswith Ayahuasca" I critically analyze the literature related to magic and popular therapies in Peru. Based on the ethnographic fieldwork, I conclude that: healers/magicians are not only men, they are not exclusively shamans, they do not only heal - but also intend to cause harm - and not only administrate Ayahuasca in their magic/therapeutical preparations. In order to present a diversity that exceeds the conceptual restriction inherent to that myth, the fieldwork is based on participant observations and life narratives that focalize the gender relationship between women/men and plants readable on the therapeutic and magic practices of local curiosxs [specialists on magics and therapies], between those who we can count xamãs, curandeirxs, purguerxs, sobadorxs [of pregnant women], sobadoxs de lisiadxs, naturalistas, yerberxs and parterxs, and in the relationship with their patients. As an analysis proposal, I develop here a reflection on aspects of human body that are identical to those of plants. The fact of getting in touch with a specific vegetal creates a corporeal resonance that facilitates ou promoves the release ou cure of the perturbation. The common notion that human body has a materiality that is fundamentally related with plants enhances imaginary and practical parallels between women, men and a multiplicity of beings that belong to the non-human world, propiciating magic and healing by the permanent tension between those two territories. Many times, those relationships are stablished in a language that is gendered, and its defined from the choice of palos, certain kind of vegetals linked to masculinity, as well as of hierbas, vegetals related to feminility. The present thesis explores also the exceptions that represent women and men that access on alternative ways to both worlds. 


\section{RESUMEN}

La presente tesis es una etnografía situada en Tamshiyacu, pueblo de la baja Amazonía peruana que es muy conocido por sus albergues destinados a ceremonias con ayahuasca en el marco del turismo chamánico. Partiendo de la propuesta de una deconstrucción de aquello que llamo aquí el mito político del "hombre-chamán-que-cura-con ayahuasca", delineo un análisis crítico de la literatura relativa a magias y terapias populares en la selva del Perú. Con base en la etnografía realizada establezco que: lxs especialistas en cuestión no son solamente hombres, no son exclusivamente chamanes, no solamente curansino que también pueden hacer daño intencionalmente - y no solamente acuden a la ayahuasca en la conformación de sus remedios mágicos y terapéuticos. Con la intención de presentar una diversidad que excede a la restricción conceptual inherente al mito, el trabajo de campo se basa en observaciones participantes y narrativas de vida que focalizan las relaciones de género entre mujeres/hombres y plantas a partir de las prácticas terapéuticas y mágicas de lxs curiosxs locales (entre ellxs, chamanxs, curanderxs, purguerxs, sobadorxs [de mujeres embarazadas], sobadoxs de lisiadxs, naturalistas, yerberxs y parterxs) y en la relación con sus pacientes. Como propuesta de análisis, desarrollo aquí una reflexión sobre aspectos del cuerpo humano que, en la concepción local, son idénticos a los de las plantas. El hecho de entrar en contacto con un vegetal específico provoca una resonancia corporal que, en la dirección deseada, facilita o promueve el alivio o la cura de la perturbación. La noción común que coloca al cuerpo humano como una materialidad fundamentalmente afín con las plantas favorece paralelos imaginarios y prácticos entre las mujeres y hombres del mundo humano y una multiplicidad de seres que pertenecen al mundo no humano, propiciando magias y curas a través de la permanente relación de tensión y colaboración entre esos dos territorios. Muchas veces, esos vínculos se establecen en un lenguaje que es genderizado [gendered], y que se define a través del camino de la elección de palos, que son cierto tipo de vegetales vinculados a la masculinidad, así como de hierbas, vegetales que se relacionan con la feminidad. La presente tesis también explora las excepciones que representan las mujeres y los hombres que acceden, de manera alternada, a los dos mundos. 


\section{SUMÁRIO}

Introdução

Entre plantas "mágicas", "medicinais" e "sagradas" 13

O início da trilha desta pesquisa: do Brasil ao Peru 13

Uma história da apropriação: das "plantas mágicas" às "plantas medicinais" no Peru

A "planta sagrada": oficialização da ayahuasca e turismo xamânico na pós-modernidade peruana 17

Detalhes para delinear uma posição

Proposta da tese: de uma estática unidade ao reconhecimento da multiplicidade 41

$\underline{\text { Parte I }}$

$\underline{\text { Dissolvendo a univocidade }}$ 46

Capítulo 1

Perspectivas críticas: a desconstrução do mito 47

O mito do "homem-xamã-que-cura-com ayahuasca" 48

A invisibilização das mulheres 52

Limites do conceito de xamanismo 58

A higienização das práticas 68

A centralidade da ayahuasca 77

Capítulo 2

Propostas de aproximação 85

Uma etnografia das relações de gênero entre plantas 85

Curiosxs do povoado de Tamshiyacu Reconhecendo a magia para aquém do território da cura

As outras plantas O mito desconstruído

$\underline{\text { Parte II }}$

Multiplicidades

Capítulo 3

Oficina do campo Mergulho no campo

Narrativas de vida, entre a biografia e o estudo etnográfico 112 115

Isabel: ela se conta, eu a escrevo, nós criamos (o texto) 120

$O$ acesso a outros espaços e sujeitxs 134

Formas de compromisso corporal em campo 135

Capítulo 4 O tempo com Isabel: memórias 143 


\section{Capítulo 5}

O espaço de Isabel e suas redes

Etnografia visual: ayahúma contra a saladera

Receitas, redes e remédios

Victoria, paciente local

Uma cerimônia com mulheres turistas

Primeira dieta com Isabel e Jorge

A vida com Jorge

Mulher chamana, curandera, onanya

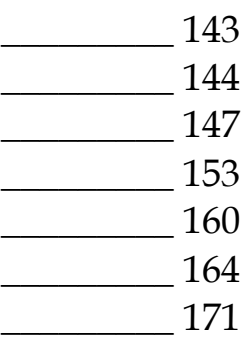

Isabel vai para o mercado

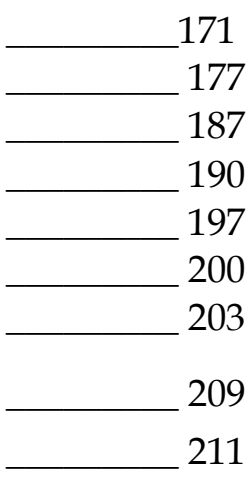

Capítulo 6

Maneiras de fazer com plantas

Doenças como território de desequilíbrio

Frio/quente

Formas de preparar os vegetais

Interações

Patco

Mapachos e a proteção contra o invisível Madres, donos, gênios e duendes das plantas

Gerlyn, as belas piñón e o exigente tabaco

Isabel, Asteria, Clarina e a masculinidade das patiquinas

Román e uma malva orientadora

Estela e a camalonga que cura

Espelhos de diversidade

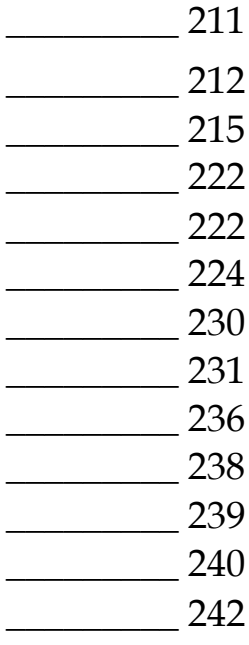

\section{Capítulo 7 Escopo aberto: a diversidade de terapeutas de Tamshiyacu}

$\underline{\text { Parte III }}$

Capítulo 8

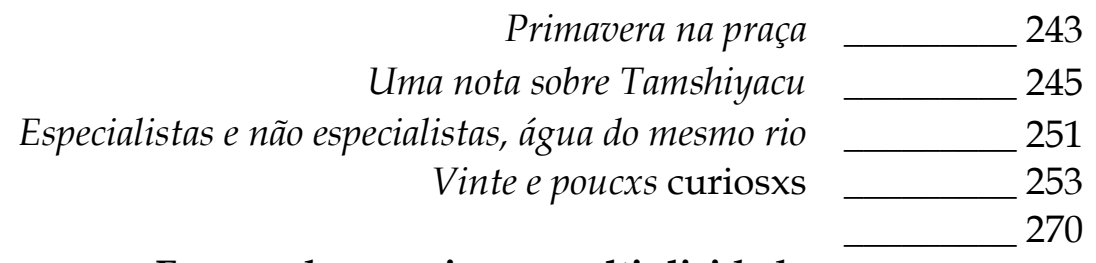

Formas de organizar a multiplicidade

Palos e hierbas

Mal de dios e mal de gente As plantas e xs curiosxs

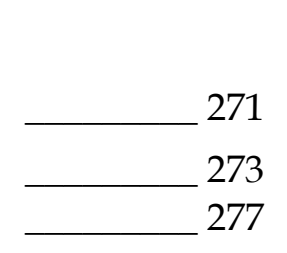




$$
\begin{array}{r}
\text { Palos e hierbas } \\
\text { Vocações: as práticas de risco, a coragem e o serviço } \\
\text { O gênero da ayahuasca e dxs ayahuasqueirxs } \\
\text { Casais no meio das plantas }
\end{array}
$$

\section{Capítulo 9}

$$
\begin{array}{r}
\text { O corpo dxs curanderxs e os males de gente } \\
\text { Realidades mágicas } \\
\text { Anoitece em Tamshiyacu } \\
\text { Icaros: chamando às entidades pelo nome } \\
\text { A mulher, o curandeiro e o marido dela } \\
\text { Corpo de curanderx, corpo de pacientes } \\
\text { Dietar, ver e materializar } \\
\text { Visões e conflitos entre curandeirxs } \\
\text { O norte político e um olhar colonial sobre a "magia negra" }
\end{array}
$$

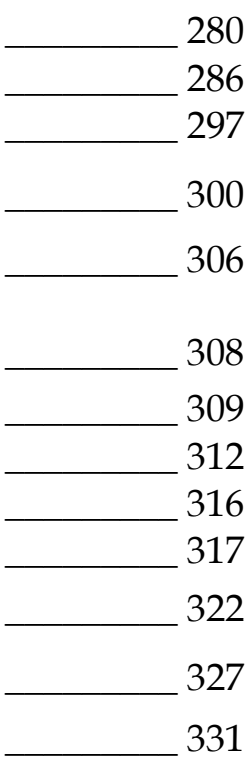

Capítulo 10

O corpo dxs yerberxs e os males de dios 336

Rita Gretel e Anita del Carmen, yerberita e yerbera Segredinhos e outras rezas O corpo feminino e o mundo O corpo da mulher quando é mãe Sobada de uma partera Mulher, corpo e saúde mental Corpo da criança: o mal aire e os cutipados

Capítulo 11 Trajetórias excepcionais
Desvios e exceções
Dois homens, Julio e Ernesto
Três mulheres, Adela, Pasquita e Isabel
Artes de fazer 340 345 345 347 349 352 355 360

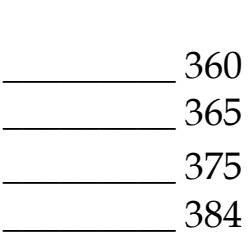

Capítulo 12 Transações: saberes escritos, sistema de saúde e dinheiro Grafocentrismo e os saberes que vêm dos livros
Uma díade constante: remedios vegetales, remedios de botica
O território do intercambiável
"Essencialismos estratégicos" e os gêneros da floresta
Referências bibliográficas Grafocentrismo e os saberes que vêm dos livros
Uma díade constante: remedios vegetales, remedios de botica
O território do intercambiável
"Essencialismos estratégicos" e os gêneros da floresta
Referências bibliográficas Grafocentrismo e os saberes que vêm dos livros
Uma díade constante: remedios vegetales, remedios de botica
O território do intercambiável
"Essencialismos estratégicos" e os gêneros da floresta
Referências bibliográficas Grafocentrismo e os saberes que vêm dos livros
Uma díade constante: remedios vegetales, remedios de botica
O território do intercambiável
"Essencialismos estratégicos" e os gêneros da floresta
Referências bibliográficas Conclusão 388 389 393 398 404 410 419 
FOTOGRAFIAS

\begin{tabular}{ccc|}
\hline Número da imagem & Título & Página \\
\hline $\mathbf{1}$ & Tratamento da ayahuasca & $14-15$ \\
$\mathbf{2}$ & Turismo xamânico & $29-30$ \\
$\mathbf{3}$ & Isabel & $125-126$ \\
$\mathbf{4}$ & Acampamento de Agustín Rivas & 152 \\
$\mathbf{5}$ & Desenhando o mundo das plantas no mundo humano & $158-159$ \\
$\mathbf{6}$ & Banho de ayahúma & $174 a 176$ \\
$\mathbf{7}$ & Pasaje Paquito & $180-181$ \\
$\mathbf{8}$ & A palavra escrita dx curandeirx & $202-203$ \\
$\mathbf{9}$ & Maneiras de fazer com plantas, I & $218-219$ \\
$\mathbf{1 0}$ & Maneiras de fazer com plantas, II & $220-221$ \\
$\mathbf{1 1}$ & Ilha San Pedro & $227-228$ \\
$\mathbf{1 2}$ & Mapas & $245-246$ \\
$\mathbf{1 3}$ & Alguns curandeiros & $267-268$ \\
$\mathbf{1 4}$ & Casais & $304-305$ \\
$\mathbf{1 5}$ & As Plantas e o Corpo & $320-321$ \\
$\mathbf{1 6}$ & Yerberas & $339-340$ \\
$\mathbf{1 7}$ & Parteras & $351-352$ \\
$\mathbf{1 8}$ & Isabel, Pasquita e Adela & $376-377$ \\
\hline
\end{tabular}

TABELAS

\begin{tabular}{lll}
\hline Número da ilustração & Título & Página \\
\hline $\mathbf{1}$ & O mito do “homem-xamã-que cura-com ayahuasca" & 47 \\
$\mathbf{2}$ & Natureza fria ou quente de vegetais e não vegetais & 213 \\
& & \\
$\mathbf{3}$ & & 256 \\
$\mathbf{4}$ & Especialistas e não especialistas & 258 \\
$\mathbf{5}$ & Sub-especialidades dxs curiosxs & 282 \\
$\mathbf{6}$ & Gênero, especialista, perturbação e planta & \\
\hline \multicolumn{3}{c}{ CROQUIS } \\
\hline Número da ilustração & Título & Página \\
\hline $\mathbf{1}$ & Croqui Albergue Mundo de la Yacuruna & $168-169$ \\
\hline
\end{tabular}




\section{Introdução: entre plantas "mágicas", "medicinais" e "sagradas"}

- O início da trilha desta pesquisa: do Brasil ao Peru •Uma história da apropriação: das "plantas mágicas" às "plantas medicinais" no Peru • A "planta sagrada": oficialização da ayahuasca e turismo xamânico na pós-modernidade peruana • Detalhes para delinear uma posição •

Proposta da tese: de uma estática unidade ao reconhecimento da multiplicidade.

\section{- O início da trilha desta pesquisa: do Brasil ao Peru}

Ayahuasca é o nome de uma planta, a Banipsteriosis caapi na taxonomia botânica científica e moderna, e também é o nome quéchua de uma bebida que, podendo conter outras plantas, possui duas plantas como núcleo básico de ação: a Banipsteriosis caapi e a Psychotria viridis. A beberagem se forma a partir de um preparo farmacologicamente complexo que na sua decocção liberaria um princípio ativo chamado de DMT, ou N-Dimetiltriptamina, um alcaloide triptamínico de núcleo indólico com potente efeito psicoativo. A bebida ayahuasca está sendo descrita, estimulada e oficializada por um conjunto de práticas consideradas de caráter tradicional, religioso ou terapêutico (Ver Imagem 1, Tratamento da ayahuasca). As práticas sociais ao redor da ayahuasca criaram nos últimos vinte anos aquilo que poderíamos chamar um verdadeiro campo ayahuasqueiro que se organiza ao redor dos países amazônicos (especialmente o Brasil, a Colômbia e o Peru) e que vem integrar o território globalizado dos estudos sobre o xamanismo.

Iniciei essa caminhada acadêmica em meados de 2011 a partir de um interesse pelos estudos de gênero, corpo e saúde direcionados ao campo ayahuasqueiro. $\mathrm{O}$ interesse que se delineava naquele momento era por encontrar formas de cuidado e cura através das plantas, e especificamente por meio do uso de ayahuasca. 


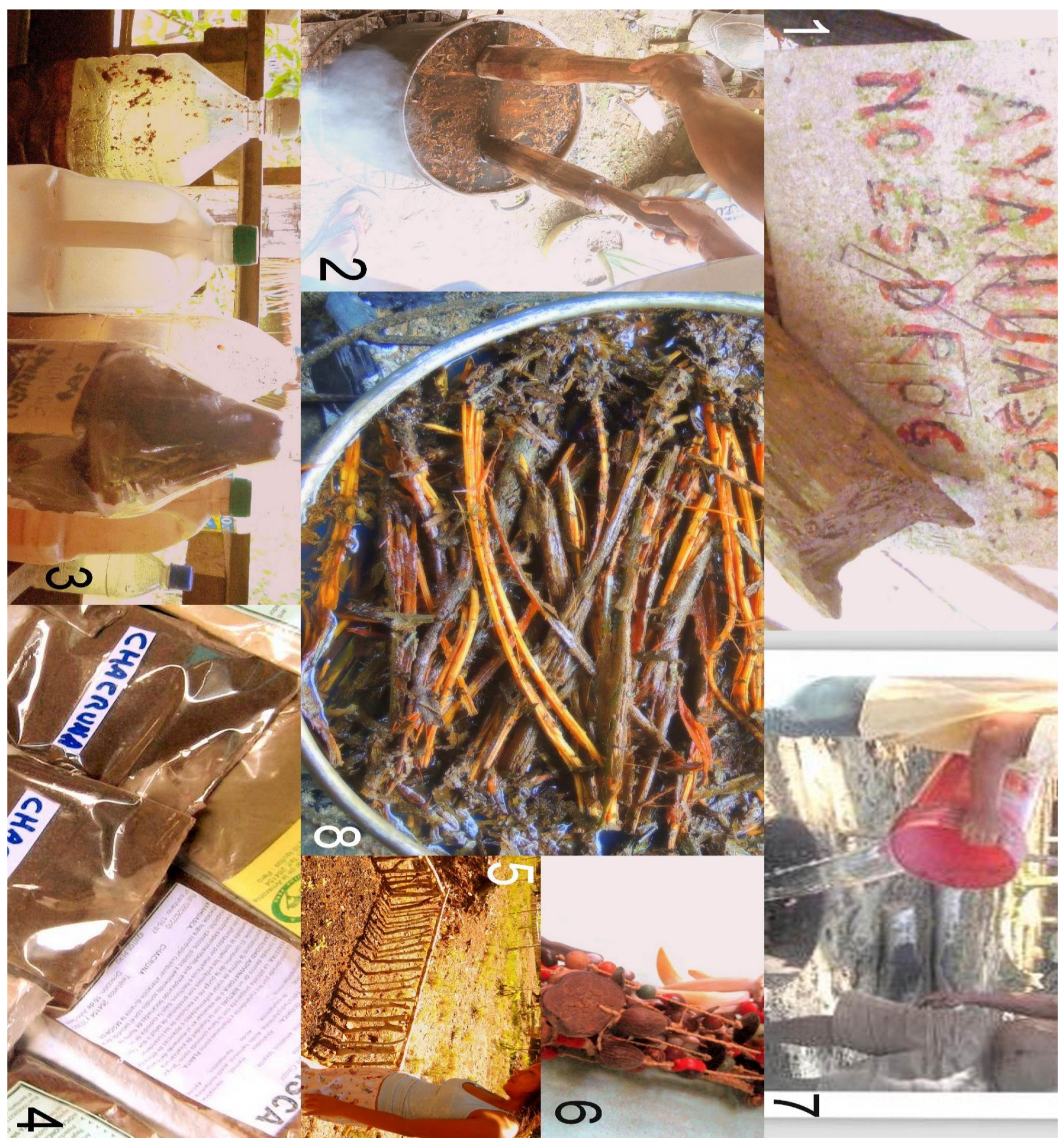


Imagem 1 (pág. anterior): Tratamento da ayahuasca 1 - A ayahuasca não é droga, reza o cartaz que encontramos no albergue de Agustín Rivas.

2 - Paus que são utilizados durante a decocção da beberagem da ayahuasca com a finalidade de evitar que a planta flutue na superfície. Fotografia: Gentileza de Carl Carew.

3 - Garrafas com preparados de plantas prestes para serem utilizados em dietas e cerimônias.

4 - Chacruna [Psychotria viridis] e ayahuasca [Banipsteriosiscaapi], secas e moídas, são vendidas no Pasaje Paquito para facilitar o traslado internacional dos produtos vegetais.

5 - Lisete, filha do curandeiro Lucho, me mostrando os primeiros brotos de ayahuasca que eles plantaram perto das cabanas de seu novo acampamento.

6 - Colares de sementes, realizados com rodelhas de madeira de ayahuasca. Realizado por Milena e Julio Rengifo.

7 - Vertendo a água em uma grande panela que será esquentada na lenha e ao ar livre. O processo de decocção da ayahuasca demora entre dois e três dias.

8 - Superfície da panela onde se cozinha a ayahuasca. Fotografia: Gentileza de Carl Carew.

Conhecia pessoalmente algumas experiências das igrejas ayahuasqueiras brasileiras, com sua particular proposta de ingestão da ayahuasca em meio a rituais plurais, onde o cristianismo, o espiritismo kardecista, o esoterismo europeu, os cultos afro-brasileiros e o curandeirismo amazônico confluíam 
prolífica e vivamente. Sabia da luta social por parte dos membros destas igrejas para destituir a ayahuasca de seu lugar de "droga" dentro das normativas do Estado-Nação brasileiro, e colocá-la como "sacramento", aludindo à comunhão cristã com o divino a partir da ingestão de uma substância sagrada. Ainda com as particularidades impressas por cada vertente religiosa como o Santo Daime, a União do Vegetal e a Barquinha, eu observava que no Brasil a ênfase tendia a ser colocada nos aspectos predominantemente religiosos da ayahuasca. De fato, estudiosxs do tema indicam que a formalização de grupos que usam a erva dentro de igrejas só aconteceu no Brasil (Labate, Mc Rae e Goulart, 2012). As legislações acompanharam: no ano de 2010, a ayahuasca foi legalizada no Brasil explicitamente para uso religioso e é nesse molde dos "fenômenos da fé" que são compreendidas, de maneira geral, as terapêuticas ao redor desta planta ${ }^{1}$.

Alimentada por um interesse nesses aspectos terapêuticos da planta, desloquei meu olhar para a construção nacional de uma oficialidade ayahuasqueira em um país vizinho: o Peru. No caso do Peru, a relação entre religiosidades, terapêuticas e práticas ayahuasqueiras acontecia de maneira bastante diferente: desde os discursos hegemônicos, como o Estado e a produção acadêmica, a ênfase era colocada nos aspectos terapêuticos da planta dentro de um enfoque "tradicional" da cultura indígena e mestiça, sem que elas necessariamente fossem compreendidas como parte de certa abordagem ou prática religiosa determinadas. O contexto que se sublinhava para a realização dessas práticas "ancestrais" era o do xamanismo vegetalista dentro de um multifacetado cenário

\footnotetext{
1 O uso terapêutico da bebida ayahuasca no Brasil se encontra em suspenso, pois se espera que sejam realizadas mais provas médicas que confirmem seu valor terapêutico (GMT, 2006). De forma paralela, existem grupos que incluem a possibilidade de um tratamento terapêutico por meio do uso de ayahuasca. Eles pertencem, na sua grande maioria, a grupos religiosos. Alguns deles são: Centro de Recuperação Caminho de Luz (Rio Branco, Acre), Centro Espiritual Céu Sagrado (Sorocaba, São Paulo) e o Centro Espírita Céu da Nova Vida (Curitiba, Paraná). Para uma análise destes centros, ver Mercante (2009 e 2012).
} 
turístico, onde os costumes "tradicionais" do Peru apontavam para a construção da diversidade cultural da nação imaginada.

O caminho que percorro nesta tese vai desde a procura de uma figura mítica, a do "homem-xamã-que-cura-com-ayahuasca" até uma pausada desconstrução da mesma, alimentada por conceitos surgidos em campo que, heuristicamente munidos de uma significatividade original, abriram as portas de um mundo diverso, plural e dinâmico onde mulheres e homens vivem suas histórias de vida, acompanhados de relações afetivas e de longo prazo com essas sujeitas privilegiadas que são as plantas.

\section{- Uma história da apropriação: das "plantas mágicas" às "plantas medicinais" no Peru}

Em cada nação, a história das plantas mágicas e terapêuticas, assim como dxs especialistas que melhor as conhecem, tem sido contada de uma maneira diferente, de acordo com a construção interna dos aspectos chave do desenvolvimento interno de cada nação. No caso do Peru, as terapias e magias populares têm sido perseguidas pelas missões evangelizadoras, coisificadas pelo folclore e ignoradas ou exotizadas pela antropologia. Essa genealogia tem muitas raízes e galhos, mas o que interessa aqui é a transformação de sentidos ao redor desses poderosos significantes que são, por um lado, as plantas, e por outro, xs especialistas que as sabem preparar.

Cronistas e viageiros europeus descreveram, desde o século XVI, alguns aspectos da vida das sociedades amazônicas a partir das suas experiências de primeira mão. La Serna Salcedo (2010) afirma que, para o caso da região Amazônica, tais descrições foram principalmente de missionários católicos, evangélicos e adventistas, ademais de viageiros e botânicos. Nessas descrições, 
os rituais de passagem e as cerimônias que envolviam feitiçaria eram relatadas em detalhe e incessantemente. A preocupação pela integração das almas à doutrina, por um lado, assim como pela compreensão dos usos médicos de uma diversidade extenuante de plantas potencialmente medicinais, pelo outro, marcou o tom dos relatos sobre saúde, corpo, doença e magia na Amazônia peruana.

O folclore peruano se desenvolveu justamente com a imaginação da nação do Peru. Durante finais do século XIX e até meados do século XX, xs folcloristas, que eram eruditos amantes da ruralidade, se declaravam defensores da identidade cultural do "homem peruano": diverso em cores e formas, orgulhoso de seus costumes, quase sempre masculino. $\mathrm{O}$ "homem peruano" era retratado com vestimentas coloridas, dançando alegres músicas, contando diferentes estórias. A construção do espaço discursivo dos folcloristas peruanos se centrou no privilégio das dimensões expressivas da cultura (música, artesanato, rituais, narrativas), imaginando uma nação singular e autêntica feita a partir da colagem de tradições que contribuiria, com seu peso simbólico ímpar, na construção de uma maneira de ser peruana para o mundo. Essa nação era imaginada de maneira tríplice a partir dos três espaços geográfico-sociais instituídos: a floresta, as montanhas e a costa (Degregori e Sandoval, 2007).

A aproximação dos primeiros folcloristas tendia a focalizar nas expressões culturais consideradas moralmente enriquecedoras, colocando de lado aquelas que pudessem ameaçar um civismo moderno desejado pelas elites nacionais, desejosas de serem contempladas dentro dos países que são considerados dentro do cânone ocidental (Degregori e Sandoval, 2007). Naquele esquema seletivo, as práticas rituais mágicas da Amazônia, tão estendidas em todo o 
território, foram abruptamente silenciadas. A tendência se continuou até a constituição da antropologia como ciência do diverso (Degregori e Sandoval, 2007). A partir dos anos 1960, o auge da perspectiva culturalista no Peru levou a retomar os interesses nos espaços e temas clássicos do folclore, porém a partir de uma nova perspectiva. As comunidades locais passaram a ser o âmbito central de trabalho e a pesquisa de campo, sacralizada como rito de iniciação, foi reconhecida como o método principal de construção da narrativa científica (Degregori e Sandoval, 2007). Porém, aqui também as magias amazônicas e suas diversas formas de feitiçaria foram sistematicamente ignoradas e emudecidas. Talvez, inscrevê-las nos textos científicos da emergente disciplina envolvia tocar temas tais como assassinatos, mortes e vinganças, o que ameaçava o tom, culturalmente múltiplo, mas politicamente neutro, dos eruditos construtores do ideário moderno da nação.

Há outra compreensão possível do silêncio do folclore culturalista e da antropologia peruana a respeito do tema. Ele pode ser também interpretado como o produto discursivo de certas alianças entre antropólogos e grupos indígenas estrategicamente decididos a evitar temas polêmicos na coconstrução das identidades étnicas, já estigmatizadas. Sustenta o antropólogo peruano Carlos La Serna Salcedo, que estudou a bruxaria contemporânea no contexto da tribo amazônica asháninka (2010: 83):

Si bien la antropología amazónica, presente en la selva central desde la década de 1960, había anotado la persistencia de este tipo de prácticas rituales, no había podido elaborar ningún tipo de explicación, limitándose a describirlo y, en otros casos, a ocultarlo por el temor a que la prensa y opinión pública reforzase sus prejuicios acerca del «salvajismo innato» de los grupos indígenas amazónicos. Más aún, cuando se trataba de contextos en los cuales los indígenas luchaban por conseguir de parte del Estado y la 
sociedad nacional el derecho al autogobierno, el respeto a su territorio y el reconocimiento de sus propias organizaciones ${ }^{2}$.

Seja como expressão de uma dominação cultural das elites nacionais, ou como estratégia de inserção diferencial dentro da sociedade nacional por parte de grupos subalternos, certo é que as formas de fazer magia próprias da Amazônia permaneceram em um obscuro silêncio até bem avançado o século XX. Desta maneira, não é a produção antropológica a que vai se interessar na feitiçaria e nos territórios das práticas populares referentes a doenças espirituais e/ou físicas. Serão intelectuais vindos da área da medicina os que iniciarão a discussão sobre a integração do sistema científico e moderno de saúde às culturas locais.

Desde meados do século XX, eles começam a escrever extensos trabalhos, monografias e informes, muitas vezes vinculados a organismos estatais. Eles estão preocupados não tanto com a "desaparição do autêntico" quanto pela compreensão da maneira como as pessoas que habitam tanto as cidades quanto as comunidades rurais podem viver, podem produzir e reproduzir a sua existência com acesso dificultoso ou inexistente ao sistema de saúde "moderno", "científico", "ocidental". Como afirma o estudioso peruano Alexander del Carpio (1989:124):

El estado de abandono y marginación social y cultural del campesino peruano, permite que los brujos dominen con sus creencias mágicas

\footnotetext{
2 "Se bem que a antropologia amazônica, presente na floresta central desde a década de 1960, tinha descrito a persistência deste tipo de práticas rituais, não havia podido elaborar nenhum tipo de explicação, se limitando a descrever e, em outros casos, a ocultar pelo temor a que a imprensa e opinião pública reforçassem seus prejuízos a respeito da «selvageria inata» dos grupos indígenas amazônicos. Mais ainda, quando se tratava de contextos nos quais os indígenas lutavam por conseguir de parte do Estado e a sociedade nacional o direito ao autogoverno, o respeito a seu território e o reconhecimento das suas próprias organizações".
} 
religiosa la mayor parte del campesinado de los valles andinos, costeños o selváticos, que es integrado por masas explotadas, miserables y embrutecidas (...) Los brujos aprovechan (...) la carencia de hospitales y médicos en las áreas rurales, para proliferar entre ellos el curanderismo mágico, las pócimas, los exorcismos, los brebajes y la hechicería ${ }^{3}$.

A bruxaria, compreendida como o contrário da civilização, se torna uma prática anti-cívica, enquanto que os espaços rurais começam a ser considerados carentes e não desenvolvidos, e tais carências são atribuídas às práticas mágicas e terapêuticas "tradicionais". Nosologias como essa, baseadas na carência, são muito comuns na compreensão da medicina popular em toda a América Latina (Novión, López e Serra, 1973; Loyola, 1978; Xavier, 2009): a partir delas, compreende-se que o sistema de curas na base de vegetais se usufrui porque não há recursos e porque a medicina científica é de difícil acesso. Na Monografia del Departamento San Martín, escrita por Ricardo Cavero, um intelectual oriundo da floresta peruana, e publicada no ano 1928, consta o retrato do que é percebido como uma realidade vergonhosa (p. 112):

Los dos únicos médicos existentes en el Departamento [San Martin] no pueden atender a todos los enfermos del territorio, que es bien extenso. Además, la mayor parte de los enfermos no acede al servicio profesional, unos por la considerable distancia a que se encuentra el lugar y el médico, y otros por sus miserables condiciones de existencia. Pero, por lo general, los mestizos y aún las personas blancas emplean para sus curativos, con admirable acierto, remedios caseros especiales que son preparados con hierbas y vegetales ${ }^{4}$.

\footnotetext{
3 "O estado de abandono e marginação social e cultural do camponês peruano, permite que os bruxos dominem com suas crenças mágicas e religiosas a maior parte do campesinato dos vales andinos, da costa ou da floresta, que é integrado por massas exploradas, miseráveis e embrutecidas (...) Os bruxos aproveitam (...) a carência de hospitais e médicos nas áreas rurais, para proliferar entre eles o curandeirismo mágico, as poções, os exorcismos, as beberagens e a feitiçaria".

$4 \quad$ "Os dois únicos médicos existentes no Departamento [San Martin] não conseguem atender a todos os doentes do território, que é bem extenso. Ademais, a maior parte dos doentes não acede ao serviço profissional, uns pela considerável distância em que se encontra o local e o médico, e outros pelas suas miseráveis condições de existência. Mas, pelo geral, os mestiços e ainda as pessoas brancas empregam para seus curativos, com admirável acerto, remédios caseiros especiais que são preparados das ervas e vegetais".
} 
Ademais de uma clara apreciação das maneiras de fazer com plantas locais, Cavero abre os sentidos para o acesso social às plantas, condicionado sob o pertencimento racial: indígenas, mestiçxs e brancxs convivem em uma sociedade rigidamente hierarquizada e compartilham umas poucas práticas comuns. De maneira mais ou menos aberta, as três classes parecem ter uma tendência comum em lançar mão de "remédios caseiros" com plantas.

Essa própria valorização das plantas (apresentada, porém, com notória desconfiança por autorxs e editorxs) deu lugar a compêndios e tratados de "medicina tradicional" ou "herbolária popular", frequentes hoje nas bibliotecas escolares de todo o país. Elas seguem uma estrutura típica: as listas de plantas apresentadas são elaboradas de acordo com suas propriedades farmacológicas, enquanto que as perturbações costumam ser reduzidas a um compêndio de reações sintomatológicas, localizadas nos órgãos previamente definidos pela anatomia moderna. A partir daí, se realiza um cálculo vis à vis que leva em conta dosagens, espécie vegetal e órgão particular. Desta maneira, há vegetais que "servem" para a dor de barriga e que se devem administrar de determinada maneira, enquanto que há outros que "servem" para combater os cálculos nos rins e cujo consumo não pode superar tantos gramas, colheres, punhados diários.

Nas entrelinhas deste tipo de produto textual, é possível encontrar uma espécie de taxonomia moral que organiza e atribui valores que são centrais à espécie humana e que se impõem no mundo vegetal. Assim, enquanto que se detectam algumas plantas, outras são esquecidas; nos casos das que se registraram, tendem a ser destacados somente determinados aspectos do uso dessas plantas. A diversidade vegetal da floresta se torna laboratório de remédios e receitas. As plantas que "servem para" não custam a se tornar as plantas que "servem a", em uma relação que se verticaliza e que torna homogênea a complexidade do 
contato entre humanxs e vegetais sob uma aparência de pacata simplicidade. Um intuito didático parece guiar esses processos de inscrição textual e higienização das plantas. Quando se resgatam somente suas qualidades "medicinais" para uso humano, as plantas perdem a alma. Esse movimento - que não é tão didático quanto moral e político - as torna espécimes, seres objetificados, entidades sem agência.

- A "planta sagrada": oficialização da ayahuasca e turismo xamânico na pósmodernidade peruana

Ao contrário da racionalização do mundo esperada pelos pensadores da modernidade, o mundo se fragmentou e, como Alice no poço, depois de uma longa queda, nos encontramos em um mundo de racionalidades diversas e pouco conhecidas. Ao contrário da modernidade, que é somente uma, as pósmodernidades multiplicam lugares de enunciação e prometem nada mais do que acordos provisórios entre perspectivas parciais.

Foi assim como aconteceu, no final do século XX e início do século XXI, uma forte ressignificação das práticas relativas às "plantas medicinais" no Peru. Nesse contexto, o Peru é expressão de um cenário mais amplo: as organizações internacionais destinadas à promoção da saúde como a Organização Mundial da Saúde e a Organização Pan-Americana da Saúde têm reivindicado o uso de plantas medicinais como parte de sistemas médicos, "tradicionais", "alternativos" ou "complementares" à biomedicina, elevando-os como um direito à saúde dos povos ${ }^{5}$. As normativas elaboradas a esses efeitos resgatam o caráter histórico destas práticas e o lugar dxs especialistas dentro delas, como

5 Desde o encontro de Alma Ata, em 1978, a medicina tradicional vem sendo valorizada e incentivada pela OMS. Iniciativas expressas na "Estratégia Global de Medicina Tradicional" implementada pela OMS pela primeira vez entre 2002 e 2005; e na recomendação de uso de tratamentos alternativos da OPS. 
versa no sítio eletrônico da OMS: "A medicina tradicional vem sendo utilizada há séculos, e seus praticantes têm contribuído enormemente para a saúde humana, particularmente como provedores de atenção primária da saúde no nível da comunidade" ${ }^{\prime}$.

Em termos de política internacional era preciso observar o papel do Peru como nação, no contexto da discussão internacional relativa a políticas de patrimônio material e imaterial e ao reconhecimento formal de práticas terapêuticas ditas "tradicionais". Nesse sentido, as organizações internacionais destinadas à promoção da saúde como a Organização Mundial da Saúde e a Organização PanAmericana da Saúde têm reivindicado o uso de plantas medicinais como parte de sistemas médicos, "tradicionais", "alternativos" ou "complementares" à biomedicina, elevando-os como um direito à saúde dos povos": "a medicina tradicional vem sendo utilizada há séculos, e seus praticantes têm contribuído enormemente para a saúde humana, particularmente como provedores de atenção primária da saúde no nível da comunidade" ${ }^{\prime \prime}$.

O caso da ayahuasca é, nesse sentido, exemplar. Ele desenha com claridade a maneira como acontece a emergência das cisões do pós-moderno no âmbito da oficialidade. No passado ano de 2014, houve uma manifestação sem precedentes de apoio global às práticas alvitradas no cenário ayahuasqueiro. A Conferência Mundial da Ayahuasca, sediada na espanhola ilha de Ibiza e acontecida no mês de setembro de 2014, contou com a participação de dezenas de especialistas de diversas áreas do conhecimento (xamãs, médicxs, neurocientistas, antropólogxs,

\footnotetext{
6 "Medicina Tradicional", Organização Mundial da Saúde.

7 Iniciativas expressas na "Estratégia Global de Medicina Tradicional" implementada pela OMS pela primeira vez entre 2002 e 2005, e na recomendação de uso de tratamentos alternativos da OPS.

8 "Medicina Tradicional", Organização Mundial da Saúde.
} 
advogadxs, ambientalistas) e com o apoio oficial da UNESCO, órgão das Nações Unidas dedicado à educação, a ciência e a cultura. No web site da conferência se declara:

Durante la última década, el interés y el uso de la ayahuasca se ha expandido de manera exponencial. Este fenómeno ha activado tanto el alance de la investigación científica sobre sus efectos, riesgos y potencial terapéutico, como serios desafíos legales, éticos y de sostenibilidad ${ }^{9}$.

Com o apoio de organizações internacionais e das legislações nacionais de vários países, não há dúvidas de que a ayahuasca está passando por um forte processo de oficialização: popularização, aceitação social, circulação mediática, comercialização. Como todo devir na oficialidade, isso envolve a generalização de certas imagens sobre as práticas oficializadas. $\mathrm{O}$ elemento que define com maior nitidez esta nova oficialidade da ayahuasca é seu uso terapêutico espiritual. A sua apropriação enquanto um saber tido como ancestral, sua vinculação com práticas espirituais da new age, a ênfase nas cerimônias de cura coletiva, a sua orientação terapêutica enfocada no tratamento de distúrbios da saúde espiritual, mental e física.

A Resolución Directorial Nacional Número 836/INC do Estado peruano, aprovada em junho de 2008, delineia um marco discursivo que fornece hoje o enquadramento oficial da questão que tange especificamente à ayahuasca como planta medicinal de origem amazônica. Ali se declaram Patrimônio Cultural da Nação os "conhecimentos e usos tradicionais da ayahuasca praticados por comunidades nativas amazônicas". Vejamos parte da resolução:

Que los efectos que produce la Ayahuasca, ampliamente estudiados por su complejidad, son diferentes de aquellos que usualmente producen los

9 "Durante a última década, o interesse e uso da ayahuasca tem se expandido de maneira exponencial. Esse fenômeno tem ativado tanto o alcance da pesquisa científica sobre seus efeitos, riscos e potencial terapêutico, como sérios desafios legais, éticos e de sustentabilidade". Disponível em: www.aya2014.org. Acesso em 18/09/2014. 
alucinógenos. Parte de esa diferencia consiste en el ritual que acompaña su consumo, que conduce a diversos efectos, mas siempre dentro de un margen culturalmente delimitado y con propósitos religiosos, terapéuticos y de afirmación cultural (...). Que se procura la protección del uso tradicional y del carácter sagrado del ritual de Ayahuasca, diferenciándolo de los usos occidentales descontextualizados, consumistas y con propósitos comerciales ${ }^{10}$.

No âmbito desta normativa, prescreve-se não qualquer uso, mas sim um uso legítimo da erva. Diferenciam-se, assim, dois tipos de apropriação da erva: aquele baseado em um "uso ancestral", "sagrado", "religioso" e "terapêutico", frente a outro tido como "ocidental", "consumista", "descontextualizado" e "comercial" da mesma. A ayahuasca não é uma droga, é um remédio: tal é o argumento que se coloca para fazer da bebida um objeto que é, pela via terapêutica, passível de legitimação e patrimonialização. No Peru, diferentemente do Brasil, prevalece hoje um olhar que coloca a ayahuasca como "remédio ancestral", como saber próprio das culturas "nativas" da região vinculado a certa espiritualidade original. Tal espiritualidade não se entende como sendo parte de um corpus religioso particular, e sim de um heterogêneo conjunto de práticas atribuídas à tradição vegetalista da região amazônica do país. Como a sombra que projeta um objeto que se encontra sob uma potente luz, a cristalização desta oficialidade da ayahuasca envolve a existência de formas não oficiais de relação com esta planta que fervem nas margens. Dentro dessa luz intensa que produz a grande área da oficialidade, se projeta a vontade do Estado peruano, que patrimonializa a ayahuasca como bem cultural de consumo, em contexto terapêutico tradicional. O estudo desse movimento que solidifica uma série de ativismos, vontades e

\footnotetext{
10 "Que os efeitos que produz a Ayahuasca, amplamente estudados pela sua complexidade, são diferentes daqueles que usualmente produzem os alucinógenos. Parte dessa diferença consiste no ritual que acompanha seu consumo, que conduz a diversos efeitos, mas sempre dentro de uma margem culturalmente delimitada e com propósitos religiosos, terapêuticos e de afirmação cultural (...). Que se procura a proteção do uso tradicional e do caráter sagrado do ritual de Ayahuasca, diferenciando-o dos usos ocidentais descontextualizados, consumistas e com propósitos comerciais".
} 
tendências internacionais e se condensa ao redor desta oficialidade da ayahuasca é de uma imensa riqueza.

Porém, para aquém dos discursos cristalizados em normativas oficiais, pululam as práticas sociais que se diversificam incessantemente no dinâmico campo ayahuasqueiro. Dentro delas, se encontra o fenômeno do "turismo xamânico", protagonizado por centenas de milhares de pessoas que pertencem a países do Norte e que procuram, basicamente, ter uma experiência de ingestão de ayahuasca em uma cerimônia "tradicional" dentro da floresta (Ver Imagem 2, Turismo xamânico). Não é possível entender o turismo xamânico, um dos vários tipos de turismo que misturam noções sobre viagem e peregrinação (Steil, 2000) sem levar em consideração o número global de viajantes crescendo incessantemente no mundo. Em 2012, houve um bilhão de turistas internacionais se deslocando de um país a outro no mundo inteiro (Mantere, 2013:1). Uma massa global se deslocando em múltiplas direções, composta por sujeitxs particulares, com interesses definidos a partir de imperativos como o desejo de aventura, a necessidade de uma cura ou a expectativa de uma experiência de vida inesquecível.

O estudioso sueco Ville Mantere comenta que, nos últimos anos, começou a se desenvolver uma teoria dos chamados "nichos de turismo", que promovem viagens específicas para conseguir um determinado tipo de experiência. Assim, definiu-se um turismo de vinhos, um ecoturismo, um turismo sexual, um turismo de filmes (Mantere, 2013: 17). O turismo que convoca experiências místicas na Amazônia peruana foi chamado das mais diversas maneiras: "turismo psiconáutico" para Jean Langdon (em Labate, 2009); foi definido como "drug turism" [turismo de drogas] por Marlene Dobkin de Rios (1994); enquanto que a definição escolhida por Andrea Herbert (2008) foi a de "turismo 
espiritual". Roberta Hamayon (2004) o denomina "turismo estático" e também foi designado como "entheogen tourism" [turismo com enteógenos] (Davidov 2010). Outrxs escolheram a denominação "mystical tourism" [turismo místico] (Znamenski, 2007) e ainda outrxs, "psychedelic tourism" [turismo psicodélico] (Shanon, 2002). Finalmente também se chamou, de maneira explícita, "ayahuasca tourism" [turismo de ayahuasca, ou turismo ayahuasqueiro] (Grunwell, 1998). O fenômeno é complexo e, ainda quando no nível dos discursos macro ativa noções como "iluminação", "evolução espiritual", "propósito de vida", "plantas sagradas" e "auto-transformação", no espaço das micro práticas da vida cotidiana revela uma tendência geral à apropriação consumista das experiências, à exotização e à coisificação dxs Outrxs, sejam elxs plantas ou seres humanxs. Dom José Campos, xamã peruano que recentemente editou um livro na língua inglesa, reflete: "ayahuasca moves its presence into a political realm"11 (2011: 102): encarnando as vontades do espírito, é esse um campo contraditório, cheio de espelhos, difícil de apreender na sua complexidade desde um ponto de vista definido a priori. $\mathrm{O}$ estudo das práticas deste campo merece a atenção não só daquelxs interessadxs em terapias "alternativas" e em manifestações espirituais ou místicas: ele merece ser tratado também como uma questão com profundas consequências políticas, sociais, de classe e de gênero. 


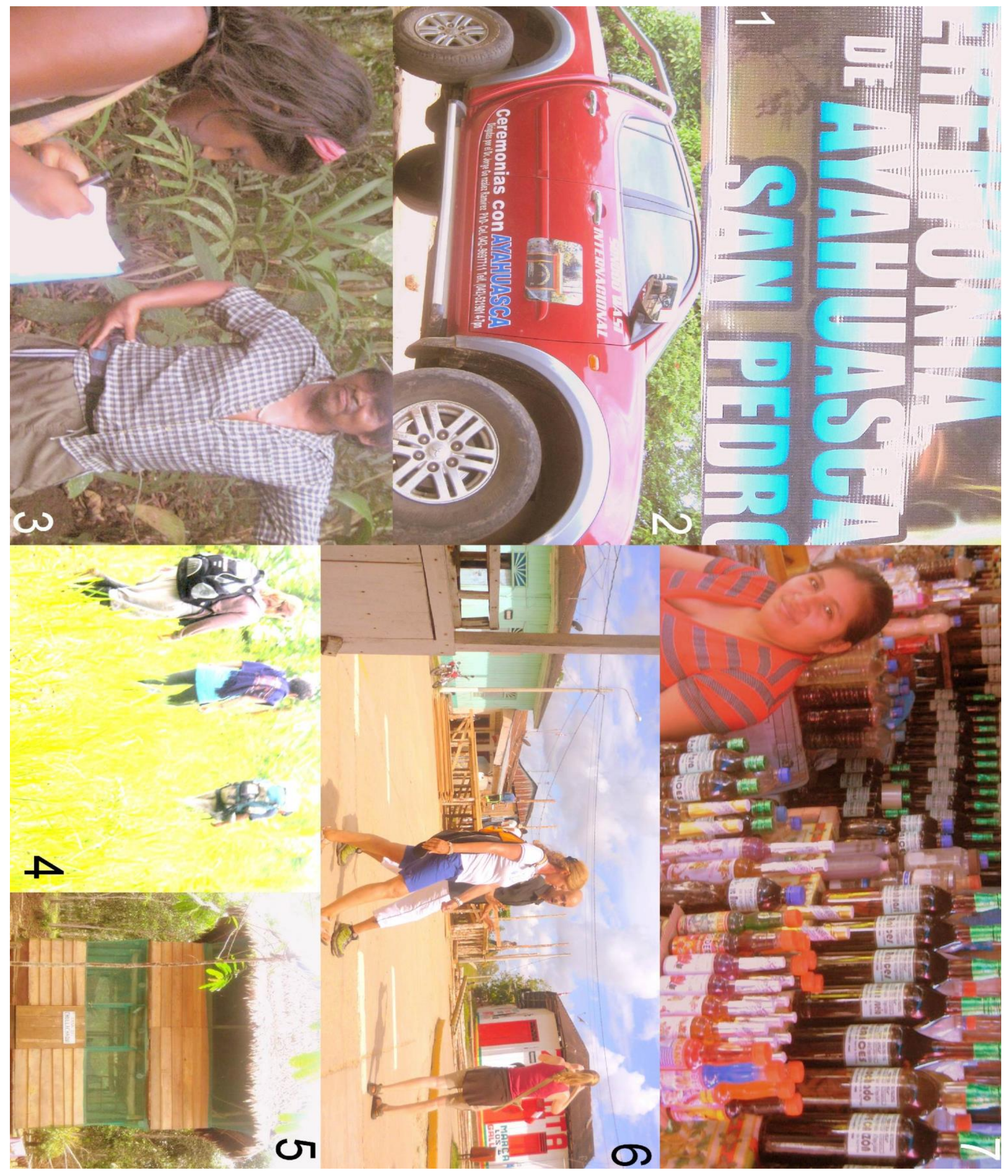




Imagem 2 (pág. anterior): Turismo Xamânico
1 - Propaganda de cerimônias com ayahuasca (da floresta) e
San Pedro (da serra) pendurada no Pasaje Paquito, mercado
de Belén.
2 - Camionete de propriedade de um xamã que, como ali
mesmo anuncia, realiza cerimônias com ayahuasca.
3 - Nathálie, turista de Sri Lanka radicada na Inglaterra,
tomando nota das propriedades das plantas medicinais
durante uma caminhada com Jorge, curandeiro, ao interior
da floresta.
4 - Grupo de turistas caminhando na direção de um
albergue xamânico. Tarapoto, 2012.
5 - Cabana do albergue Mundo de la Yacuruna,
propriedade de Isabel e Jorge.
6 - Grupo de turistas em pleno centro de Tamshiyacu.
7 - Vendedora de licores mágicos e medicinais no Pasaje
Paquito, mercado de Belén.

Imagem 2 (pág. anterior): Turismo Xamânico 


\section{- Detalhes para delinear uma posição}

"Las tradiciones intelectuales de las que provengo fabrican la teoría a partir de las vidas compartidas en lugar de encargarla por correo. Mi pensamiento se ha nutrido directamente de la escucha de mis propias turbaciones, reconociendo a quienes las compartían, quienes las validaban, intercambiando historias sobre nuestras experiencias comunes y hallando pautas, sistemas, explicaciones de cómo y por qué ocurrían las cosas. Éste es el proceso central de la toma de conciencia, del testimonio colectivo. Así es como crece la teoría hecha en casa"12. Aurora Levins Morales.

O campo das "plantas mágicas e medicinais" que construíram as aproximações sobre o folclore peruano se sobrepõe, em alguns pontos, ao campo das "plantas sagradas" próprio dos estudos sobre o xamanismo. A minha posição não se apoia nem um nem no outro totalmente, mas se delineia a partir de algumas variáveis inexoráveis que condicionam e sustentam meu ponto de vista. O diálogo que provoco/me é provocado em campo é o material para uma "teoria feita em casa", o produto parcial da minha própria prática reflexiva como mulher, antropóloga, argentina e emigrada ${ }^{13}$, que se interessou pela ingestão terapêutica da ayahuasca a partir de uma experiência própria e positiva de ingestão da ayahuasca em contexto religioso na UDV, União do Vegetal, na cidade de Natal/RN, Brasil.

No ato de explicitação de uma posição, pequenos detalhes podem desenhar toda uma paisagem. Começarei, então, pelas notas mínimas, até delinear, em traços amplos, as influências gerais do presente produto de escrita etnográfica. Primeiro, introduzirei uma breve nota a respeito da relação com a língua espanhola estabelecida na escrita desta tese, outra a respeito da minha escolha de

\footnotetext{
12 "As tradições intelectuais das que eu provenho fabricam a teoría a partir das vidas compartilhadas em lugar de encomendá-las pelos correios. Meu pensamento tem se nutrido diretamente da escuta das minhas próprias turbações reconhecendo a quem as compartilhava, quem as validava, intercambiando histórias sobre as nossas experiências comuns e encontrando pautas, sistemas, explicações de cómo e por qué aconteciam as coisas. Esse é o proceso central da tomada de consciência, do testimônio coletivo. É assim como cresce a teoría feita em casa".
}

13 Ao Brasil nove anos atrás, para a continuação da minha formação nesse país. 
uso dos marcadores de gênero na composição do texto e outra relativa ao uso de pseudônimos ao longo desta narrativa etnográfica. Em segundo lugar, farei um comentário a respeito das influências expressivas que inspiraram a intervenção das fotografias na proposta. Em terceiro lugar, me deterei sobre a minha aproximação à etno-botânica e a maneira particular em que abordo o diálogo com essa disciplina. E finalmente, no ponto quarto, apresentarei brevemente os movimentos temporais nos quais fui delineando a posição teórica que demarco neste trabalho.

Uma primeira nota diz respeito à migração da língua espanhola para a portuguesa, e vice-versa. Xs "interlocutorxs imaginárixs" de meu trabalho de pesquisa se colocam entre dois mundos em tensão: o território onde se realizou o trabalho de campo, cuja língua oficial é a espanhola, e o espaço onde meu trabalho será avaliado e lido formalmente, cuja língua oficial é a portuguesa. A minha língua materna é o espanhol. Durante o trabalho de campo, mergulhei de novo nele, encantando-me nas delícias que proviam às expressões da oralidade as gírias linguísticas locais. Já durante a escrita do presente texto, me vi entre a possibilidade de manter todas as expressões em espanhol ou traduzi-las para o português. Decidi não renunciar a uma nem a outra possibilidade, colocando imediatamente entre colchetes a expressão em português quando se tratava de uma expressão breve; ou quando as notas eram mais longas, mantendo-as na sua língua original no texto e colocando as suas respectivas traduções para o português no pé da página. O texto teve uma revisão final por parte de um revisor técnico cuja língua materna é a língua portuguesa. Assim, naquilo que um tanto jocosamente posso denominar uma tentativa de escrita do tipo ganhaganha, conciliei entre a inteligibilidade do texto para xs leitorxs luso-falantes e a própria e deliciosa cor da língua espanhola. Além disso, as notas vindas da leitura de textos em outras línguas foram todas da minha tradução para o 
português, seguindo a mesma dinâmica de colchetes dentro do texto para expressões curtas e notas de rodapé traduzidas para o português no caso de frases mais alongadas.

Em relação aos marcadores de gênero com os quais foi elaborada a presente tese, optei pela linguagem inclusiva na maioria dos casos. No caso de artigos, substantivos ou adjetivos que possam ser masculinos ou femininos, coloquei uma letra " $x$ " na vogal correspondente. Por exemplo, como nesse caso, "estudiosxs". Porém, a marcação de gênero é diferenciada em casos específicos: isso acontece em virtude de uma maior inteligibilidade e fluidez na leitura do texto nesses casos. Nessas situações, tenho optado por colocar no lugar da letra " $\mathrm{x}$ ", que representa o gênero indiferenciado, as vogais diferenciadas " $\mathrm{o} / \mathrm{a}$ ". Isso acontece em situações particulares onde a palavra acaba em masculino e sem vogal diferenciadora no final, tal como no caso do termo "pesquisador". Ao ser impossível colocar o " $x$ " que marca o gênero inclusivo é preciso adicionar a letra "a". Nessas situações, optei por colocar as vogais diferenciadoras de maneira conjunta, separadas por um grafo de barra. Ao não ser muito habitual, talvez essa opção de escrita faça a leitura do texto um pouco mais trabalhosa: peço paciência a leitoras e leitores. As implicações desta estratégia continuam a valer a pena ainda quando as modificações a respeito da escrita convencional possam entorpecer o decorrer da leitura.

$\mathrm{Na}$ maior parte dos casos, preferi colocar os nomes reais das pessoas entrevistadas/etnografadas. Contudo, o uso de pseudônimos foi ativado no caso em que considerei que a identificação da pessoa em certos cenários etnográficos pudesse afetar, de múltiplas maneiras, a própria identidade pessoal/social/laboral desta pessoa. Para todas as situações em que são usados 
pseudônimos, há uma marcação no pé da página consignando a existência desta intervenção textual.

As fotografias, que foram tiradas às vezes por Carl, meu companheiro, às vezes por minhas/meus interlocutorxs e às vezes por mim mesma, estão definidas e trabalhadas aqui como textos que não falam de uma realidade per se, mas que foram escolhidos, construídos e delimitados artificialmente sob o mesmo intuito desta tese: elas remetem, em uma outra linguagem, aos itinerários de sentido apresentados nessa tese. Diversos movimentos de representação visual "urbano amazônica" hoje produzem fotografias, pinturas, tecidos e collages dentro das cidades da floresta Amazônica peruana (Bendayán, 2006), desde uma perspectiva indígena, mestiça local, mestiça peruana e/ou estrangeira. Essas expressões, de uma ou outra maneira, compartilham as balizas de uma linguagem comum: brincam com formas e cores fluorescentes que lembram do acesso às realidades da ayahuasca e outras plantas psicoativas, que retratam a abundância animal e vegetal da floresta, revisitam os mitos de origem de seres humanxs, plantas e outros seres animados, propondo paisagens onde nunca há silêncio: ou é o ruído dos motocarros nas cidades ou o constante "zunzunzum" da miríade de seres animados da floresta adentro.

Escolhi trabalhar com a ideia de uma "etnografia visual" como método (Riviera, 2010) e, questionando noções de realismo na representação, me dediquei a intervir nas fotografias com o interesse em focalizar, contornar, suavizar alguns elementos das mesmas. Como toda fotografia pode ser de interesse etnográfico, enquanto sejam explicitados os motivos da escolha, as imagens eleitas fazem parte do continuum do texto escrito, esgarçadas nele através de excertos tomados do mesmo. Assim, as fotografias estão acompanhadas de fragmentos textuais que podem representar as minhas palavras ou palavras de outrxs interlocutorxs 
desta pesquisa. As palavras acompanham às imagens, mas não as esgotam. São ficções do estar lá, e também são uma proposta de imaginação etnográfica. Muitas das vezes, elas estão colocadas como colagens: concebidas aqui como pastiches, as fotografias fluem na direção do território da expressão cromática e da superposição de sentidos, que se oferecem aqui como disparadores de imaginação sensível, etnográfica e social. Xs leitorxs próximxs a esse mundo tamshiyaquino $^{14}$ poderão brincar com os novos arranjos de elementos conhecidos, enquanto que xs leitorxs distantes exercitarão a construção imagética de conceitos através da visualidade do universo aqui apresentado.

Considero que aquela que provém da etno-botânica é uma linguagem que pode ser de utilidade, sobretudo no que tange à uma identificação rápida das plantas às quais se alude na etnografia. Para isso, foi especialmente proveitosa a companhia especializada de Carl, com quem fizemos um pequeno herbário de plantas de acesso frequente, e com quem fizemos uma coleção fotográfica das plantas vivas nos jardins, caminhos e chacras e das plantas colhidas nas cozinhas, salas e malocas cerimoniais. Também me foram preciosos os ensinamentos concretos de Isabel, Luis, Milena, Anita del Carmen, Gerónima, Walter e Genoveva: elxs me mostraram flores e frutos das plantas, me brindaram com plantas para fazer remédios em casa, me ensinaram a colhê-las e interpretá-las. Finalmente, foram de muita utilidade os manuais compreensivos de plantas de uso medicinal da baixa Amazônia peruana. Tive na mão especialmente dois destes trabalhos: Plantas medicinales de uso popular em la Amazonía peruana, do ano 1995, escrito por Kember Meía e Elsa Rengifo Salgado e Las ramas floridas del bosque. Experiencias en el manejo de plantas medicinales amazónicas, do ano 2007, escrito doze anos depois por uma das coautoras do livro anterior, Elsa Rengifo Relativos à Tamshiyacu, povoado onde foi realizado o trabalho de campo desta tese. 
Salgado. Os dois manuais, de caráter prático e calidamente didático, são materiais excepcionalmente informativos que foram elaborados no marco de pesquisas pertencentes ao IIAP (Instituto de Investigaciones de la Amazonía Peruana).

Os nomes científicos consignados nesta tese podem facilitar o reconhecimento de espécies no caso que for necessário. Porém, levando em conta o princípio de que "the chemical constitution of the herb depends on the time plants are harvested, the location of where the plants grow, on their preparation and application"15 $(\mathrm{Hsu}, 2012$ : 93), considero impossível reduzir as plantas das que fala a minha tese a espécies vegetais com características etno-botânicas fixas, e são colocadas com fines de mera orientação.

A presente tese se alimenta do diálogo que tenho estabelecido, durante meu itinerário como antropóloga em devir, com as correntes dos feminismos críticos, o olhar dos estudos do pós-colonialismo e as reflexões brasileiras sobre saúde popular. As três linhagens, que em muitas partes se tocam, foram aproveitadas aqui como ferramentas que fazem possível o questionamento sistemático de um "mito", entendido aqui como mito político, construção contumaz de meias verdades que se repetem a si mesmas na base de critérios de autoridade, acriticismo e desatenção às dinâmicas históricas e de contexto.

Acredito que dentro das correntes mais influentes e transformadoras nas últimas décadas nas ciências humanas se contam os estudos pós-coloniais. A estreita ligação do euro-centrismo com a materialidade do imperialismo e seu caráter cultural (Said, 1979), a desconstrução dos paradigmas do conhecimento ocidental

15 "A constituição química da planta depende do momento em que as plantas são colhidas, a locação onde a planta cresce e sua preparação e aplicação". 
(Spivak, 2010) e a crítica ao feminismo branco enquanto produtor de sentidos colonialistas para as mulheres do sul político (Mohanty, 1983) são alguns dos diversos projetos de conhecimento que abriram novos olhares, sustentáculos teóricos e perspectivas sobre o mundo que habitamos e, porventura, pesquisamos. Desde a América Latina também se desenvolveram caminhos similares, com ênfase na face colonial da modernidade, na persistência da colonialidade do poder (Quijano, 2000), do saber (Mignolo, 2006) e da ergopolítica na produção de conhecimento (Grosfoguel, 2009). Assim, abriram-se portas teóricas abrangentes e, por que não dizê-lo, deslumbrantes. As teorias foram sendo construídas com a finalidade de dar um sentido às informações obtidas nas pesquisas e valiosos insights foram, nesses processos, levantados. Não obstante, é pouco o que tem sido sistematizado a respeito dos caminhos metodológicos que podem dar uma força viva à teoria pós-colonial na produção de conhecimento no terceiro mundo.

Desta maneira, qualquer metodologia inspirada nas propostas do feminismo e nas aproximações teóricas da pós-colonialidade latino-americana deve ter um ânimo aberto para se formular em campo, em estreita conexão crítica com as leituras e perspectivas destas correntes. Desde a minha própria perspectiva, considero que os métodos científicos são dispositivos de acesso a realidades sociais determinadas e que eles estão orientados à construção, parcial e transitória, de formas de saber e saber-fazer. Considero que nenhuma aproximação metodológica é neutra, nem pode ser realizada a priori. Elas vão se edificando na medida em que avança a pesquisa, traçando um caminho de conceitos locais, suposições, memórias e afirmações teóricas no próprio andar.

Em tempos de aguda incerteza sobre as possibilidades que a ciência tem de tornar viável o próprio ato de conhecer, e nos quais o estatuto da representação 
se encontra tão questionado, a presente proposta se apresenta como um espaço de desconstrução dos micro-processos de pesquisa que fazem da produção de conhecimento um procedimento meramente extrativo, e que, como alternativa a isso, constrói narrativas de vida inspiradas para serem situadas entre a particularidade da experiência impressa no estudo biográfico e a rede maior de afetos proporcionada pelo estudo etnográfico.

Uma atitude metodológica aberta, tendo a escuta como prerrogativa e com diferentes fases de envolvimento corporal em campo, me levou a escrever cinco cadernos de campo tipo ofício (umas mil páginas) com informações, sensações e reflexões de primeira mão, redigidos à mão; que foram redigidos nesta tese evocando reflexivamente esses espaços, sujeitxs e situações vivenciadas. Assim, as reflexões mais gerais sobre autocuidado, espiritualidade, cura, mediação cultural, essencialismos estratégicos e o lugar do feminino na produção da vida, ainda sendo tão interessantes e importantes, foram refletidas somente enquanto conectadas com o lugar como espaço de produção da vida e das próprias práticas dxs sujeitxs.

Foi assim que, durante o processo de escrita das primeiras versões desta tese, me entreguei à compreensão de conceitos locais, garantindo para elxs um espaço de relativa autonomia em relação às grandes teorias da área. Essa postura, que é metodológica, mas é também teórica, epistemológica e política, foi fortemente estimulada a partir da minha leitura do artigo da feminista norte-americana Laura Donaldson (1999), que aponta críticas instigantes às correntes das terapias new age que reivindicam uma essência feminina e se apropriam acriticamente dos conteúdos culturais de outros grupos do mundo inteiro, tomando para elas, sem permissão nem perguntas sobre a tradução, conceitos e práticas que não thes pertencem, e usando-os para consolidar uma identidade feminina pretensamente 
universal. Donaldson clama pela reivindicação das "éticas de contexto", isto é, pela necessidade de fazer análises que, sem perder a sua vocação de universalidade, estejam primeiramente situadas no espaço social onde xs sujeitxs criam a sua própria existência e que é o local da pesquisa.

No momento da escrita das versões intermediárias desta tese, em diálogo íntimo com os cadernos, com fotografias, com vídeos e com entrevistas, fui recriando aquele trabalho de campo com um objetivo: a busca por uma nova coerência, uma coerência que pudesse emergir a partir da formação de categorias e da correlação entre elas. Nesse ponto, sem requerer do nível de formalização e codificação que são próprios do enfoque da grounded theory desenvolvida por Barney Glaser e Anselm Strauss (1967), me inspirei em ideias gerais da proposta desses dois autores. Da mesma maneira que elxs, entendi aqui que pode haver enfoques múltiplos e não contraditórios sobre um mesmo fenômeno social, pois cada realidade social pode ser e significar mais de uma coisa ao mesmo tempo. Sobretudo, se considerarmos a premissa ética de que cada pessoa e grupo de pessoas possuem uma compreensão do mundo que lhes é própria, considero duvidoso que, em uma análise sobre determinada situação social, não exista referência a conceitos locais. Nesse sentido, a análise etnográfica deve favorecer as condições para que do próprio trabalho de campo emerjam os conceitos locais. A tarefa $\mathrm{dx}$ pesquisador/a se alimenta desta conexão entre conceitos locais e outros conceitos que provêm da sua própria formação; e dessa mediação permanente surge a proposta de uma teoria não já pretensamente nativa, mas sim enraizada no chão, que possa somente a partir dele se "alçar" na direção de considerações mais amplas.

Foi assim que, nesse construto ficcional que é o texto escrito, e dentro das particularidades que delineiam o formato do gênero etnográfico, me mantive 
atenta aos detalhes, os silêncios e as insidiosas repetições de termos ou ideias dificilmente compreensíveis. Como fruto da reflexão sobre esse material foi que surgiram categorias fundamentais para a presente tese, tais como curios $x$ e males de dios e males de gente assim como palos e hierbas. Tais categorias resistiram a uma tradução a conceitos mais gerais e conhecidos pela antropologia, pelo que escolhi macerá-las dentro de seus próprios termos.

No que eu definiria como um último momento de escrita da tese, posterior ao contato inicial com os cadernos e à construção da análise a partir de categorias nativas, entrei novamente em contato com as grandes propostas teóricas com as quais dialoguei durante a minha formação, e que marcaram meu caminho. Elas agora estavam menos expostas a serem acionadas em termos da força de certa autoridade automática, e se manifestaram como ferramentas para a compreensão mais ou menos produtivas. Desta maneira, sem outra fidelidade do que fazer inteligível um contexto local com suas próprias regras e a sua irreduzível especificidade, fui definindo os termos da análise em virtude do rendimento da teoria especializada às teorias vernáculas.

Hoje posso observar que um programa mais amplo no qual essa pesquisa poderia ser inserida é aquele que se constrói a partir da enunciação coletiva de epistemologias localizadas deste lado da linha, no Sul (Santos, 2009; Albuquerque, 2009) e na reflexão sobre objetividades parciais e localizadas (Haraway, 2005; Mohanty, 2008), as quais contribuem para desfazer o construto referente ao Homem moderno, seu corpo, o que ele ingere e o espaço ao qual ele pertence, ao mesmo tempo em que retomam as múltiplas conexões possíveis entre espaços e sujeitxs, humanxs e não-humanxs. Essa pesquisa retoma também algumas preocupações dxs folcloristas sobre noções como o "popular" e o "tradicional", tentando criar espaços para novas definições possíveis. Com 
Fleischer (2013: 13), também creio que seria uma maneira apressada de começar uma análise que pensasse às

... práticas de saúde popular como uma falta de alternativa. (...) ela não acontece somente quando a biomedicina está ausente. Ela acontece a todo momento, dentro e fora da biomedicina e de outras medicinas. Ela tampouco é tolerada porque é supostamente barata ou inócua (placebo, simbolização, acolhimento comunitário, bem-estar subjetivo, para ficar com algumas associações ao "popular") (...) o adjetivo "popular" tenta ser uma ideia que não encapsula um conjunto de pessoas ditas também populares. Não equivale a "pobres", mas tenta se aproximar de "povo." (...) saúde popular, como estou tentando desenvolver aqui, supõe um conjunto de práticas - muito diversas e por isso de difícil delimitação totalizante - que dialogam, mas também desafiam as práticas médicas auto-intituladas como oficiais e hegemônicas.

Finalmente, as limitações das noções de "racionalidade" para o campo em estudo se apoiam em inspirações vindas da área de estudos da antropologia e o "extraordinário" (Young e Goulet, 1994). Assim, feminismos críticos, desenvolvimentos paralelos de epistemologias pós-coloniais, antropologia dos detalhes dos espaços populares e aproximações para uma antropologia das experiências "extraordinárias" enquadraram a minha compreensão e análise, dando lugar a uma "teoria feita em casa", composta pela bricolagem de todos esses elementos a partir de essa prática íntima e artesanal do enlaçamento de mundos diversos que é a escrita antropológica.

- Proposta da tese: de uma estática unidade ao reconhecimento da multiplicidade

A presente tese parte de um movimento de crítica, um contra-movimento de propostas, uma imersão no campo, uma análise e uma nuance. Primeiro, apresento a crítica de um mito, e uma proposta que traz conceitos vindos do trabalho de campo local. A tese continua propondo conceitos vindos a partir da compreensão de dinâmicas locais de construção de categorias. Na imersão em 
campo, exploro uma trajetória biográfica única, a de Isabel, e saliento os desafios metodológicos e teóricos que um trabalho de campo focado nela despertou. Depois, construo uma estrutura que abrange a todxs xs curiosxs de Tamshiyacu no esquema genderizado [tradução portuguesa que escolhi para o anglicismo gendered, que significa produzido em termos de gênero] de palos e hierbas, através do qual, sugiro, podem ser lidos aspectos tão diversos da prática dxs especialistas como o tipo de planta com a qual se estabelece a comunicação, a natureza do tipo de doença em questão e x especialista que vai tratar da perturbação. Finalmente, matizo essa mesma estrutura através do relato de experiências de vida que não seguem essas regras: as vidas excepcionais. Dentro dessas cinco pessoas se encontra Isabel, que é a curiosa e com a qual abro a presente tese. Deste modo, a tese adquire certo caráter circular, onde a presença de Isabel abre e fecha o ciclo da leitura, ao mesmo tempo em que permanece em um segundo plano nas passagens intermediárias.

De maneira esquemática, a presente tese foi dividida em três grandes partes: parte I, Dissolvendo a univocidade, que denota o esforço apesentado aqui por apresentar uma aproximação, sensível etnograficamente, à diversidade existente por trás do que tenho chamado o mito do "homem-xamã-que cura-com ayahuasca"; parte II, Multiplicidades, onde abro o escopo para uma diversidade de relações possíveis entre mulheres e homens e delxs com as plantas; e uma parte III, Formas de organizar a multiplicidade, onde proponho, na base de categorias nativas, pautas para a análise do território das magias e curas praticadas por mulheres e homens da Amazônia peruana. A parte I compreende, por sua vez, os capítulos 1 e 2; a parte II inclui os capítulos que vão do 3 ao 7; e finalmente a parte III engloba os capítulos compreendidos entre os números 8 e 12 . 
O conteúdo dos capítulos é como segue: o capítulo 1, "Perspectivas críticas: a desconstrução do mito" apresenta as principais características do mito do "homem-xamã-que-cura-com ayahuasca", e as coloca em questão. A saber: a invisibilização das mulheres, um conceito etnocêntrico de xamanismo, a higienização das práticas e a centralidade da ayahuasca. Já o capítulo 2, está dedicado à apresentação das "Propostas de aproximação" ao campo social desta tese. Assim, propõe uma etnografia das relações de gênero entre plantas, a utilização do estudo de caso da categoria de curiosx, e sugere o reconhecimento da magia para além do território da cura. Enfatiza também a existência de outras plantas no espectro do mágico e do terapêutico, utilizando todas essas propostas como fundamento para uma desconstrução reflexiva do mito apresentado no capítulo 1.

Já integrando a parte II, o capítulo 3, "Oficina do campo" narra as condições relativas ao mergulho no campo que delinearam a presente tese, trazendo uma reflexão sobre os posicionamentos políticos e epistemológicos que farão com que o método das narrativas de vida seja o escolhido para capturar as trajetórias biográficas dxs sujeitxs que são interlocutorxs desta tese. Apresento então Isabel, uma das pessoas com as quais mais tempo compartilhei e que foi, sem dúvidas, a curiosa que mais interpelou os meus pressupostos sobre o campo e o meu posicionamento posterior. Aludo às dificuldades de apreensão dos saberes que ela possui, e às estratégias que foram colocadas em marcha enquanto ela se contava, eu a escrevia e entre as duas criávamos a estória. Também aludo ao posterior acesso a outros espaços e sujeitxs em campo, assim como às diversas formas de compromisso corporal que assumi em campo. Já no capítulo 4, “O tempo com Isabel: memórias" me detenho nos relatos que Isabel traz do passado para interpretar seu presente. Apresento alguns traços significativos do tecido da sua vida, que a levaram de ser aprendiz de onanya shipiba, para curandera no 
contexto mestiço e ribeirinho, e finalmente chamana, no contexto do seu trabalho no marco do turismo xamânico. O capítulo que segue é o lugar onde Isabel sai do espaço interior das suas experiências de vida e se manifesta em contato com uma rede de afetos que a sustenta, condiciona e limita. É assim que no capítulo 5, “ $O$ espaço de Isabel e suas redes" conto algumas experiências de Isabel em interação com pacientes, via receitas, dietas, cerimônias com ayahuasca e outros remédios. No capítulo 6, aproximo-me da diversidade de "Maneiras de fazer com plantas" existente em Tamshiyacu, assim como das implicações mágicas e terapêuticas que elas exibem. O capítulo seguinte, número 7 , é dedicado a apresentar outro tipo de diversidade, a "Diversidade de terapeutas de Tamshiyacu" e a navegar entre as categorias de auto-reconhecimento e os territórios de especialização por elxs propostos.

O capítulo 8, "Palos e hierbas" já integra a parte III, e é um dos centrais da tese, pois é nele que desenvolvo um esquema de compreensão da diversidade exposta, em termos das categorias genderizadas de plantas palos e hierbas, dos tipos de perturbação mal de dios e mal de gente e do tipo de especialistas que se dedica a cada uma dessas dimensões da vida social. Também resgato dinâmicas de casais que trabalham com plantas, apropriações genderizadas da ayahuasca e as práticas da coragem e o serviço como definidoras do tipo de orientação que cada curiosx escolha. No capítulo 9, "Curanderos e males de gente", dedico-me a apontar o caráter deste ofício, preponderantemente masculino, assim como algumas técnicas de acesso e controle das realidades da perturbação como os icaros, a visão, as dietas na floresta. Também observo como a prática da magia entre curandeirxs tende a sublinhar conteúdos que não estão desprovidos de violências de gênero e conflitos, e como se delineiam a partir de éticas relacionais condensadas no marco de uma densa rede social de favores. Logo depois, no capítulo 10, presto especial atenção a "O corpo dxs yerberxs e os males de dios", 
apresentando algumas características da ocupação dxs yerberxs, ofício que é, sobretudo, feminino. Observo as dinâmicas de constituição subjetiva de um/a yerberx, com exemplos etnográficos de crianças cuja curiosidade é "descoberta" pelxs adultxs próximxs a ela. Analiso técnicas de trabalho, como os segredos e as rezas, e maneiras de relacionar o corpo e o mundo que sustentam a prática dxs yerberxs. Conto uma experiência etnográfica no consultório de uma partera, e finalizo com algumas perturbações comuns no corpo das crianças, como o mal aire e os cutipados, relativas à invasão de espíritos de mortos, objetos ou animais no próprio espaço espiritual. O capítulo 11 narra as "trajetórias excepcionais" e as relaciona ao esquema anteriormente apresentado. Ele trata em detalhe de cinco casos particulares que representaram exceções à regra genderizada dos homens, dedicados a trabalhar com palos e das mulheres, aplicadas em trabalhar com hierbas. Escolho apreender os diversos motivos que levam a essxs dois homens e três mulheres por caminhos diferentes: não desde uma perspectiva que os entenda como desvios, mas como exceções, paisagens únicas, histórias originais. Finalmente, o capítulo 12 se centra em três territórios que eu chamo de "Espaços de transações: saberes escritos, sistema de saúde e dinheiro". As três dimensões escolhidas correspondem a aspectos da realidade que, mesmo não sendo costumeiros nem tradicionais, influenciam no dia-a-dia $\mathrm{dxs}$ curiosxs da localidade. Expõem-se então três aspectos: primeiro, o grafocentrismo e os saberes que vêm dos livros; segundo, a medicina oficial que prescreve os remédios de botica e sustenta a força institucional do espaço do hospital; e terceiro, o dinheiro, como elemento que expressa limites e possibilidades dentro do território do que é considerado intercambiável pelo trabalho dxs curiosxs. 


\section{Parte I: Dissolvendo a univocidade}




\section{Capítulo 1 \\ Perspectivas críticas: a desconstrução do mito}

- O mito do "homem-xamã-que-cura-com ayahuasca" • A invisibilização das mulheres • Limites do conceito de xamanismo • A higienização das práticas • A centralidade da ayahuasca

O presente capítulo apresenta os primeiros traços de uma estratégia analítica feita com base em dois movimentos: o da crítica, seguido da proposta. Assim, após apresentada a noção do mito do "homem-xamã-que cura-com ayahuasca", onde exponho o caráter desta construção caricaturesca e política, apresento quatro críticas pontuais ao mito. O capítulo seguinte está constituído de maneira vis à vis com as quatro propostas para a pesquisa, que serão então apresentadas e depois desenvolvidas ao longo do texto. Desta maneira, a crítica à invisibilização das mulheres está intrinsecamente vinculada à etnografia das relações de gênero entre plantas que apresento na tese. O comentário sobre os limites do conceito de xamanismo tem como consequência a escolha do termo local curiosx, partindo da valorização do caso. A revisão daqueles dois processos, que chamo a higienização das práticas e a focalização na cura, tem a sua contraparte na proposta dos conceitos de práticas terapêuticas e práticas etótropas, que estão integrados no trabalho diário dxs curiosxs. Finalmente, a crítica à centralidade da ayahuasca encontra a sua contrapartida na informação etnográfica, que mostra um mundo de plantas e maneiras de preparo que são muito diversas. De maneira gráfica:

\begin{tabular}{|c|c|c|}
\hline \multicolumn{3}{|c|}{ Tabela 1: O mito do "homem-xamã-que cura-com ayahuasca" } \\
\hline Conceito do mito & Crítica & Proposta \\
\hline homem & a invisibilização das mulheres & uma etnografia das relações de \\
\hline xamã & $\begin{array}{l}\text { limites do conceito de } \\
\text { xamanismo }\end{array}$ & $\begin{array}{c}\text { curiosxsdo povoado de } \\
\text { Tamshiyacu }\end{array}$ \\
\hline que cura & a higienização das práticas & $\begin{array}{l}\text { práticas terapêuticas, práticas } \\
\text { etótropas: encontrando a } \\
\text { magia para aquém do } \\
\text { território da cura }\end{array}$ \\
\hline com ayahuasca & a centralidade da ayahuasca & as outras plantas \\
\hline
\end{tabular}


Deste modo, a análise de cada conceito que compõe o mito do "homem-xamã-quecura-com ayahuasca" realizada aqui funciona como o alicerce para a construção das propostas teóricas, metodológicas, epistemológicas e políticas que guiarão o percurso da presente tese.

\section{- O mito do "homem-xamã-que-cura-com ayahuasca"}

A minha crítica se baseia na desconstrução de uma imagem. Entendo essa imagem como um mito, isto é, como um construto político que está sendo ativado por determinados atores sociais em cenários históricos específicos (Haraway, 1995). Nesse movimento, afasto-me da interpretação levistraussiana do mito oriundo das sociedades "frias", para inseri-lo na sociedade contemporânea híbrida por definição - e compreendê-lo como uma ferramenta que faz possível certo uso político da história. Para a formação de tal imagem, que não é outra coisa que um construto analítico elaborado aos fins da presente tese, inspiro-me no texto de Raoul Girardet, "Mitos e Mitologias Políticas", onde o autor elabora as imagens de quatro mitos da historiografia francesa do século XIX (o Mito da Conspiração, o Mito do Salvador, o Mito da Idade de Ouro e o Mito da Unidade) e posteriormente os desconstrói, valendo-se das ferramentas da micro história e de uma história dos conflitos políticos. Permito-me aqui um exercício de imaginação, de exageração, de sátira, a criação de uma representação imaginária à qual atribuo a forma de um mito político contemporâneo. A exageração de uma realidade que já é, por si mesma, extrapolada. Observa a pesquisadora em temas amazônicos Daniela Peluso (2014: 247):

The production of ayahuasca tourism privileges shamans as idealized, nearly supernatural beings. This is reflected in the propaganda, websites, and blogs that hail these men as celestial beings, obliterating their humanity and often their economic reality. This corresponds with a general trend that 
privileges "masculinized themes" and glorifies "Great Men", scripting all other needs and desires as subservient to a male norm ${ }^{16}$.

Durante as leituras correspondentes à minha pesquisa, através de comunicações informais com especialistas e em meio a encontros que tive a possibilidade de assistir (congressos, reuniões, palestras), observei uma tendência persistente à construção, por parte de científicxs em particular e escritorxs em geral, tanto estrangeirxs quanto peruanxs, de tons lendários nas suas narrativas em torno dos usos da ayahuasca na floresta Amazônica peruana, da cura de doenças incuráveis para os países do norte, do estatuto heroico dos curandeiros locais, dos mistérios da tradição vegetalista ayahuasqueira, da primazia do masculino quando é preciso destacar xs sujeitxs centrais dessa tradição. $O$ mito político parecia assumir, de maneira recorrente, o lugar de um específico tropos discursivo, um lugar aparentemente inquestionável conformado por aspectos da realidade que eram vistos e reconhecidos como verdadeiros. Observei que tal percepção mítica funcionava na realidade: ativava encontros sobre medicina tradicional, livros sobre xamanismo e preparava os discursos dos lodges mais prestigiosos do turismo xamânico na floresta peruana. A legitimidade deste mito obrava com a força de um fato da realidade para explicar fenômenos, sustentar práticas, legitimar posições de poder no campo do que se convencionou em chamar xamanismo ou curandeirismo peruano, e que aqui, por motivos que nos trazem a presente proposta, escolho chamar de maneiras de fazer com plantas.

Como argumenta também Jeanne Atkinson (em Bonnie Glass-Coffin, 2003), "las construcciones académicas de la categoría de chamán revelan suposiciones sumamente

16 "A produção do turismo ayahuasqueiro privilegia os xamãs como seres idealizados, que estão próximos do sobrenatural. Isso se reflete na propaganda, web sites e blogs que postulam esses homens como seres celestiais, obliterando a sua humanidade e, frequentemente, a sua realidade econômica. Isso se corresponde com uma tendência geral que privilegia "temas masculinizados" e glorifica "Grandes Homens", inscrevendo todas as outras necessidades e desejos como subservientes da norma masculina". 
determinadas por las categorías de género"17 (p.3). Porém, é preciso sublinhar que o construto do "homem-xamã-que-cura-com ayahuasca" que eu aqui proponho não é, necessariamente, um conceito instrumentalizado por nenhum/a estudiosx em particular. Ele é um objeto artificial que elaboro aqui, uma espécie de lupa analítica cunhada a partir da exageração dos traços da própria realidade corriqueira. Assim, uma infinidade de aspectos que tenho observado em contínua repetição no campo dos estudos sobre maneiras de fazer com plantas na Amazônia do Peru é aqui caricaturada. Uma caricatura, compreendida como a acentuação explícita dos traços formais de uma imagem dada, é o que aqui apresento como o mito do "homem-xamã-que-cura-com ayahuasca". Resgatando o humor próprio do gênero plástico do cartum, esse retrato pretende ser analisado em um primeiro movimento crítico, e desconstruído em uma segunda instância, pela via da introdução de uma diversidade de possibilidades formais de existência de outras maneiras de fazer com plantas existentes no campo em questão.

É preciso dizer aqui que o principal interesse da tese (e, consequentemente, o material escrito nela) se desenvolveu mais no segundo movimento do que no primeiro. O primeiro movimento, a crítica do mito do "homem-xamã-que-cura-com ayahuasca", constituiu-se como o impulso inicial e necessário para construir a motivação instrumental para o movimento da proposta: elaborar uma etnografia localizada, genderizada e reflexiva daquela complexa realidade social. Na presente pesquisa, o mito político dos "homens-xamãs-que-curam-com ayahuasca" me serviu como imagem caricaturesca que ajudou a despejar o que pude perceber como um silêncio a respeito da diversidade, enraizado em torno deste campo de práticas. Desconfortável silêncio. A caricaturização de um "mito político" presente no campo de práticas em questão me permitiu abrir uma rica diversidade de

17 "As construções acadêmicas da categoria xamã revelam suposições sumamente determinadas pelas categorias de gênero". 
sentidos a respeito de práticas não hegemônicas em termos de gênero, da categoria do ofício, da intenção dos trabalhos e da constituição da própria herbolária regional. A mesma diversidade destas práticas a respeito do mito político do "homem-xamã-que-cura-com ayahuasca" e a relação intrínseca entre essas quatro dimensões são o objeto da presente tese.

Continuando, eu proponho uma análise crítica e sistemática de quatro aspectos da imagem hegemônica do mito político do "homem-xamã-que-cura-com ayahuasca": a) o gênero $\mathrm{dx}$ sujeitx em questão, b) a categoria que $\mathrm{x}$ sujeito atribui ao próprio ofício, c) a intenção dos trabalhos que se realizam e d) a constituição, em termos de tipos de plantas disponíveis, da própria herbolária regional. Realizarei em seguida uma revisão pontual de cada um desses aspectos: gênero dxs sujeitxs (são somente homens?), categorias do ofício (são somente xamãs?), intenção dos trabalhos (costumam somente curar?) e constituição da herbolária (é a ayahuasca uma planta central dentro da sua herbolária?). Na segunda parte deste capítulo, proponho os insumos necessários para a problematização, de base etnográfica, dos aspectos silenciados por esse mito. O resultado é o conteúdo da presente tese: uma etnografia situada em Tamshiyacu, povoado da baixa Amazônia peruana, das relações de gênero entre plantas a partir da valorização local do conceito de curiosx e suas práticas, conceitualizadas não só como terapêuticas - isto é, tendentes à cura, mas também etótropas - isto é, orientadas ao fazer fazer de outros elementos ou pessoas de maneira mágica - no contexto do acesso a uma diversidade de plantas que se classificam em palos e hierbas, e dentro da qual a ayahuasca possui um lugar específico, compartilhando sua estima com outras plantas da herbolária local.

\section{- Perspectivas críticas, 1: A invisibilização das mulheres}


Ao estudarmos as maneiras de fazer com plantas na Amazônia do Peru, deparamonos com um "vazio semântico" no que diz respeito a mulheres na literatura sobre o tema. Da mesma maneira, é possível observar que esse campo tem sido inscrito, de forma majoritária, por autores masculinos: o privilégio de um ponto de vista masculino ativo e o foco nas mulheres, colocadas em um lugar de passividade (Peluso, 2014). Desde o lugar de uma epistemologia feminista, é possível questionar as duas pontas desta sub-representação: de quem é o conhecimento que está sendo considerado? A quem representa? Que sujeitxs o inscrevem nos territórios da visibilidade social? Como afirma Lauren Pressley (2005: 1):

Feminist epistemologists do not suggest that empirical evidence is wrong, but rather that it is necessary to understand that most beliefs are as much a result of their social context as they are factually true. The particulars of knowledge construction are the main focus for feminist epistemologists, rather than universal circumstances for justifying knowledge ${ }^{18}$.

Nesse sentido, é preciso observar se os conhecimentos inscritos no mundo social possuem uma lógica que distorce a ciência a partir do silenciamento das perspectivas femininas. Trata-se de quem escreve assim como de sobre o quê $\mathrm{x}$ tal sujeitx escreve. Em relação a quem escreve, o fenômeno é extenso: na antropologia, assim como em outras áreas da ciência, a tecnologia e a literatura, as vozes femininas têm sido levadas ao silêncio da enunciação por critérios atribuíveis à valoração sexista (Golubov, 1993; Haraway, 1995). No que diz respeito a sobre o quê se escreve, nos estudos sobre maneiras de fazer com plantas da Amazônia peruana, é possível encontrar um amplo número de trabalhos que apontam a especialistas (prioritariamente, xamãs e curandeiros) homens e a sua

18 "As epistemologias feministas não sugerem que a evidência empírica esteja errada, mas que é preciso compreender que a maioria das crenças é o resultado de seu contexto social, como elas mesmas o são. Os particulares da construção do conhecimento são o foco central das epistemologias feministas, não assim as circunstâncias universais de justificação do conhecimento." 
prática vegetalista, composta por uma gramática terapêutica tríplice de purgas, dietas e, no centro da cena terapêutica, cerimônias com ayahuasca ${ }^{19}$. Mas isso faz parte de uma tendência histórica no campo discursivo que apresentou a Amazônia para o os países do norte político. Evgenia Foutiu (2014: 172) argumenta que "most early ethnographies we have on Amazonian cultures were written by men (...) [and] the ethnographers were focused on male activities". De fato, trabalhos de botânicos e médicos do início do século XX se enfocam no uso masculino das plantas. Alguns deles postulam a própria ayahuasca como propriedade exclusiva dos homens. Richard Spruce, o botânico de origem inglesa que introduziu a planta ayahuasca como espécie vegetal, a Banipsteriosis caapi, dentro da racionalidade científica moderna, afirma: "los niños varones no pueden experimentarla (...) así como tampoco las mujeres de cualquier edad"20 (1908: 425).

Em 1912, o médico alemão Peter Reinburg escreveu: "los niños de sexo masculino adquieren el hábito a los 10-12 años"21 (p. 11). Segundo o autor, a bebida é tomada somente pelos homens: "los adultos machos son los únicos que están autorizados a beber el tóxico"22 (p. 21). Adultos machos perto do reino animal, adultos machos próximos da primitividade da horda. Reinburg atribui à ayahuasca características concordantes com as que atribuí ao gênero masculino: a beberagem aparece aqui como uma "bebida violenta" (p. 28), "fuertemente erótica"23

19 O vegetalismo tem sido definido como "uma forma de medicina popular na base de (...) vegetais, cantos e dietas" (Narby, 1997: 27, minha tradução). De maneira sintética, as purgas são limpezas físicas do estômago por meio de vômitos. As dietas consistem em períodos de isolamento que podem durar dias ou meses. As cerimônias com ayahuasca são rituais coletivos de ingestão da planta. Essas categorias serão desenvolvidas ao longo do trabalho.

20 "Os meninos não podem lhe experimentar (...) assim como tampouco as mulheres de qualquer idade".

21 "As crianças de sexo masculino adquirem o hábito aos 10-12 anos".

22 "Os adultos machos são os únicos que estão autorizados a beber o tóxico".

23 "Fortemente erótica". 
(p. 22) e também própria do hedonismo da juventude, que os homens costumam beber quando são ainda solteiros, "por el simple placer de soñar" 24 (p. 23).

Com o ingresso de antropólogxs do norte político vindxs para estudar a floresta Amazônica, o panorama não observou mudanças maiores. Nem em termos de sujeitos que escrevem, nem em termos dos sujeitos que são descritos. A antropóloga canadense Anna Marie Colpron (2005) argumenta que os estudos sobre o campo do xamanismo na floresta Amazônica do Peru têm sido escritos quase unicamente por homens. Ela se refere a isso como o "monopólio das representações sobre xamanismo" por parte dos homens. Ela cita um período dourado de produção estrangeira sobre xamanismo amazônico que, entre os anos 1960 e 1970, assumiu os trabalhos clássicos do francês Jacques Métraux (1967) como paradigmáticos. Outros exemplos mais recentes de estudos etnológicos sobre "xamanismo" escritos por autores homens são o trabalho de outros dois etnólogos franceses, Phillippe Descola (2006) com a etnia achuar, que hoje habitam a fronteira entre Equador e o Peru, e Pierre Chaumeil (2009) com os aguaruna do alto Maranhão.

A partir dos anos 1990 em diante, após o boom global da ayahuasca como fenômeno social e objeto de estudo (Labate, 2011), o interesse no xamanismo amazônico tem crescido e os estudos sobre xamanismo nas cidades, xamanismo mestizo, ganharam relevância. Nesse processo, a voz dos homens e sobre os homens manteve a sua preponderância. Alguns dos trabalhos desta fase abordam as trajetórias biográficas de xamãs (Dom Fernando, registrado por Mark Plotkin em 1993; Fernando Payaguaje compilado por Nathan Horowitz em 2006; José Campos compilado por Geraldine Overton em 2011), enquanto outros

24 "Pelo simples prazer de sonhar". 
trabalhos enfatizam os cenários mais amplos onde essxs sujeitxs circulam, principalmente nos circuitos urbanos com acesso à floresta que desenham as correntes comerciais do turismo xamânico (Grumwell, 1998; Demange, 2002; Dobkin de Rios e Rumrill, 2008; Chaumeil, 2009; Labate, 2011, dentre muitxs otrxs autorxs). Tais estudos se circunscrevem ao hibridismo da cena etnográfica e ao protagonismo da beberagem da ayahuasca em meio às cerimônias, enquanto costumam aludir só marginalmente a questões de gênero e imaginar como óbvia uma maioria de xamãs homens. A antropóloga brasileira Bia Labate entrevistou seis xamãs da etnia shipibo e seis xamãs mestizos em sua tese doutoral. Alude marginalmente às mulheres xamás, as quais estariam mais fortemente ligadas às suas comunidades de origem: "não entrevistei mulheres curandeiras, embora tenha ouvido falar de algumas delas" (2011: 78). Por sua vez, outrxs autorxs recortam as possibilidades da área de maneira quase impaciente, justificando certo bias androcêntrico na pesquisa: "I will use male forms throughout, because about 93 percent of practitioners I encountered in the Field were male" (Brabec de Mori, 2014) ${ }^{25}$. Pontua-se a falta de tempo, a falta de pessoas disponíveis para entrevistar sobre o tema, a falta de informação sobre o assunto. Clancy Cavnar salienta que o xamanismo é considerado explicitamente um "domínio masculino" desde perspectivas tanto internas quanto externas ao próprio campo de práticas que ele determina (2014: 172).

Em termos de uma aproximação epistemológica e política neste campo, há um nome possível para essa dificuldade, um conceito que significa essa quase impossibilidade de dizer. A antropóloga argentina Rita Segato se refere, em um artigo sobre a relação entre gênero e antropologia à instauração de certa lei, historicamente mediada, ao "masculino invisível" (1998:10) nos textos

\footnotetext{
25 "Vou usar formas masculinas ao longo do texto, pois ao redor de 93 por cento dos praticantes que eu encontrei eram homens".
} 
antropológicos. Essa sutil, mas implacável regra, tende a definir a grade de inteligibilidade do masculino e do feminino, modulando as perspectivas que fazem com que algumas coisas sejam vistas, enquanto outras permaneçam invisíveis. Nesta tese, argumento que no espaço/tempo históricos correspondentes aos estudos sobre maneiras de fazer com plantas da Amazônia peruana, a lei do masculino invisível é reforçada pelo ideário do "homem-xamãque-cura-com ayahuasca" e as consequências cognitivas que dele se desprendem.

Porém, toda hegemonia ostenta, de maneira latente ou manifesta, movimentos contra-hegemônicos. A partir dos anos 2000, a escrita sobre as maneiras de fazer com plantas na Amazônia peruana está sendo revisada em novas pesquisas sobre a área, a partir da reflexão especialmente de antropólogas mulheres, tanto peruanas quanto não peruanas. Desta maneira, tanto quem escreve quanto como sobre o quê x sujeitx escreve estão, pausadamente, se enriquecendo e adquirindo um bias que é genderizado. Algumas pesquisadoras se referiram explicitamente nas suas pesquisas a uma falta de perspectivas femininas na literatura sobre o tema (Colpron, 2005; Herbert, 2010; Espinoza, 2013) e começaram a registrar a realidade social da experiência com plantas e das maneiras de fazer com plantas das mulheres sob diversas aproximações. A pesquisadora canadense Anne Marie Colpron (2005) escreveu um belo artigo onde relata vividamente a experiência de mulheres que curam e realizam atos mágicos entre xs shipibo, as unayas ainbo. A antropóloga norte-americana Clancy Cavnar defendeu, no ano de 2011, uma tese sobre gays e lésbicas na qual apresenta um estudo qualitativo relativo à autopercepção corporal e ao caráter terapêutico da ayahuasca na constituição da própria identidade de gênero. A filósofa equatoriano-canadense Yalila Espinoza apresentou no ano 2011 uma tese de doutorado onde analisa o potencial terapêutico da ayahuasca na construção da identidade feminina. A pesquisadora de origem argentina Daniela Peluso publicou, no ano 2014, um interessante 
artigo sobre sedução sexual de mulheres por parte de xamãs homens em cerimônias com ayahuasca. A antropóloga grega Evgenia Foutiu apresentou, na mesma compilação, um artigo sobre turismo xamânico, com relevância a uma nova categoria: a da feminilização da ayahuasca [feminization of ayahuasca], onde, ainda que se reconheça que o xamanismo Amazônico esteja claramente povoado por homens, a ayahuasca está sendo crescentemente considerada, tanto por xamãs quanto por turistas, como um espírito feminino e maternal. Com o espírito de criar espaços mais "feminizados" para o consumo ayahuasqueiro, estão se criando lodges que contratam mulheres xamãs, honrando certo "divino feminino" crescentemente popular entre xs turistas. Beber ayahuasca com mulheres minimizaria os assédios e todo tipo de agressões sexuais que são muitas vezes relatados como parte da própria experiência de campo das turistas mulheres (Peluso, 2014).

As pesquisas sobre maneiras de fazer com plantas que envolvem questões femininas são relativas a: a) aspectos de gênero inscritos no turismo xamânico, e b) trajetórias de vida de mulheres indígenas amazônicas. As primeiras estão sendo desenvolvida especialmente por pesquisadoras não peruanas (Colpron, 2005; Herbert, 2008; Cavnar, 2011; Cavnar, 2014; Foutiu, 2014; Peluso, 2014), enquanto que as segundas foram elaboradas, de forma majoritária, por autoras de origem peruana (Muratorio, 2000; González, 2002; Valenzuela Bismarck e Valera Rojas, 2004; Belaunde, 2013). No primeiro caso, o criticismo do monopólio de uma perspectiva masculina sobre o campo é explícito, enquanto que no segundo caso, ainda quando também esteja presente, é mais sutil.

Os elementos aqui colocados nos habilitam a delinear uma primeira característica do mito político do "homem-xamã-que-cura-com ayahuasca": ele tem sido historicamente inscrito por uma lei do masculino invisível, que invisibiliza o 
feminino. Cronistas, médicos, botânicos, antropólogos: os autores que escreveram sobre xamanismo amazônico são, na sua ampla maioria, homens; e seus comentários ou pesquisas abordam, de maneira quase que exclusiva, sujeitos masculinos em campo.

Neste trabalho, problematizo o homem que emerge deste campo de estudos como uma figura delineada e indelével a partir da multiplicação de perspectivas das autoras em questão. Tais perspectivas favorecem um novo ponto de vista epistêmico, uma enunciação diferencial sobre as maneiras de fazer com plantas próprias da região. Continuo, a partir do impulso delas, um esforço que é teórico, etnográfico, epistemológico e político, a partir da visibilidade destas específicas maneiras de ser mulher ou homem em meio às plantas.

\section{- Perspectivas críticas, 2: limites do conceito de xamanismo}

É sabido que o termo xamã é uma denominação nativa para xs especialistas em medicinas e magias da tribo tsunki, localizada na Sibéria. Ele é um termo nativo para uma prática que, em traços gerais, pode ser encontrada em todas as culturas nativas do globo. Quais foram as derivas históricas que levaram à universalização do termo xamã, então? $\mathrm{O}$ antropólogo mexicano Roberto Martínez González (2007) introduz na sua análise um ponto que podemos considerar chave na inscrição dos estudos sobre xamanismo no norte político: a introdução do conceito em 1765, por parte do filósofo e escritor francês Denis Didérot, quem nunca tinha conhecido pessoalmente a Sibéria ou algum xamã. Contudo, os relatos de viagens de europeus para o leste lhe serviram de base informativa para definir o termo xamã, que fez da seguinte maneira:

Chamanes. Sustantivo, masculino, plural: es el nombre que los habitantes de Siberia dan para los impostores que realizan las funciones de sacerdotes, charlatanes, hechiceros y doctores. Estos chamanes claman tener influencia sobre el diablo, a quien consultan para conocer el futuro, para curar 
enfermedades y hacer trucos sobrenaturales para esas ignorantes y supersticiosas gentes $^{26}$ (p. 137).

Podemos observar aqui que a inscrição do termo no campo de saberes racionais e modernos sobre o mundo foi definida nos termos de uma persecução cognitiva: lugar do abjeto e da mentira, o xamanismo siberiano recebeu uma primeira definição atestada de impropérios por parte do pensamento racional. A partir de então, o termo xamã se converteu em uma nova entrada para as enciclopédias de saberes da ilustração. O pesquisador sul-africano David Chidester afirma que, durante os séculos XVIII e XIX, "while allegedly serving the devil and his demons, shamans were also represented as fakes, frauds, or imposters, thus combining genuine evil with deception"'27 (Chidester, 2004: 44).

Com o passar do tempo, o termo xamã foi sendo recuperado, não sem sofrer, a cada reinterpretação, de uma progressiva higienização. A antropóloga francesa Roberte Hamayon (2004:142) apresenta alguns aspectos chave do desenvolvimento dos estudos sobre xamanismo no mundo:

The word shaman progressively extended to the world on the $19^{\text {th }}$ century (...) the term came to be used liberally in literature to replace a series of European terms deemed unsatisfactory (sorcerer, diviner, healer, magician, juggler, and the like). It was used with no reference to a well-established definition and rather served as a term that could be all-encompassing: a shaman could be both sorcerer and healer, with no contradiction between these two activities ${ }^{28}$.

\footnotetext{
26 "Xamãs. Substantivo, masculino, plural: é o nome que os habitantes da Sibéria dão para os impostores que realizam as funções de sacerdotes, charlatãs, feiticeiros e doutores. Esses xamãs clamam ter influencia sobre o diabo, a quem consultam para conhecer o futuro, para curar doenças e fazer truques sobrenaturais para essas ignorantes e supersticiosas gentes."

27 "Enquanto se alegava que serviam aos demônios e outras entidades do mal, os xamãs foram também representados como falsos, fraudulentos ou impostores, combinando genuína maldade com enganos".

28 "A palavra xamã se estendeu progressivamente ao mundo durante o século XIX (...) o termo começou a ser utilizado livremente na literatura para substituir uma série de termos europeus tidos como insatisfatórios (feiticeiro, adivinho, curandeiro, mágico, prestidigitador, e similares). Foi usado sem
} 
Desta maneira, a condenação moral dos escritores iluministas continuou como uma consideração da "ambiguidade moral" da prática e do termo. Durante três séculos, estudiosxs das áreas de história das religiões, teologia, psicologia, medicina, artes e antropologia se valeram do conceito como chave explicativa das mais diversas realidades sócio-etnográficas. Finalmente, o conceito ganha ampla popularidade em meados do século $\mathrm{XX}$ a partir dos tratados sobre história das religiões do teólogo, filósofo e historiador romeno Mircea Eliade (1951), quem o define como o "técnico arcaico do êxtase" e acentua o caráter prístino da prática, a qual seria o fruto de uma conexão simples, direta e natural com a divindade. Nos anos de 1960, o conceito se traslada do campo de estudos da religião para o da psicologia e da neuropsicologia, sendo abraçado por intelectuais da contracultura norte-americana e da geração beat, vinculados crescentemente a experiências psicodélicas com famílias de fungos que contêm Psiloscibina [Psilocybe mexicana, entre outros], cactos San Pedro [Echinopsis pachanoi], marihuana [Cannabis sativa] e outros psicoativos em contextos tradicionais e especialmente fora deles (Langdon, 2010). O modelo neuropsicológico aliado aos estudos sobre o xamanismo tende a dar pouca importância às variáveis contextuais, ressaltando a relação entre processos orgânicos, enzimáticos e moleculares e a conexão destes com espaços do místico/transcendente/extraordinário através da consecução de estados modificados de consciência, mediado pelo uso de psicoativos (Langdon, 1996; Martínez González, 2009; Echazú Böschemeier, 2013ª).

referência a nenhuma definição bem estabelecida, e serviu como um termo guarda-chuvas: um xamã podia ser ao mesmo tempo feiticeiro e adivinho, sem contradição entre essas duas atividades". 
Fruto da translação dos estudos acadêmicos da religião para um misticismo beat de popularidade crescente nos países do norte ${ }^{29}$, o conceito de xamanismo se fundiu com outros saberes do mundo que são tidos como "tradicionais" e que guardaram certa marginalidade a respeito da modernidade, tais como o budismo, o hinduísmo e as mais diversas formas de animismo. Xamanismo então se tornou uma ferramenta central nos discursos e práticas que fazem parte do desenvolvimento da corrente religiosa-espiritual da new age [nova era] (Heelas, 1993). O conceito de neo-xamanismo é cunhado dentro desse espírito, na tentativa de definir uma corrente de práticas híbridas contemporâneas que engloba elementos comuns de várias tradições xamânicas e que, desde uma perspectiva interna, se supõem universais e acessíveis para o público ocidental (Harner, 1985).

Na minha perspectiva, o prefixo "neo" adicionado ao contexto de xamanismo pouco explica a realidade social em questão. De fato, o conceito de neo-

29 Creio necessário redigir uma nota a respeito da escolha de "países do norte político" ou bem do mais curto "países do norte" - por sobre a de "Ocidente" para denominar o território de origem dxs turistas que viajam à Amazônia do Peru - território que considero correspondente a Europa e América do Norte assim como aos derivados coloniais destes países, como Austrália e Nova Zelândia. Bem tem notado Brabec de Mori (2014) na sua etnografia na floresta peruana: desde o ponto de vista local, é sabido que os gringos vêm do norte. A designação países do norte/países do sul é interessante, pois não esconde o bias político deste tipo de classificações sociais: no uso local, as denominações norte/sul são compreendidas enquanto que metáforas, não mais enraizadas nas localizações espaciais que lhes deram origem. De fato, elas designam hoje espaços demarcados por relações históricas onde a divisão do mundo em termos de norte e sul foi fundamental e marcou uma geopolítica específica para o mundo moderno. Já no que respeita à categoria "Ocidente", tenho observado que, para designar a alteridade turistas/pessoas da localidade, ela aparece como sendo uma denominação enganosa. Muitas pessoas que tive a possibilidade de conhecer na floresta do Peru se consideram a si mesmas "ocidentais". Nesse sentido, colocar o Ocidente como um conceito que se encontra completamente de fora da realidade peruana seria incorrer, no mínimo, em uma imprecisão. Ainda, considero que a própria ideia de Ocidente deve ser repensada, desde que ela é relativa a uma homogeneidade que situa a força da sua construção simbólica em processos históricos de caráter imperialista. A esse respeito, há toda uma reflexão sobre a necessária provincialização, descentralização e desconstrução de espaços geográficos como a Europa e a América do Norte que pode ser medular sustento para essa crítica. Aos fins de ampliar essa última discussão, ver Dipesh Chakrabarty, 2007. 
xamanismo tende a reforçar o suposto da existência per se de certo xamanismo originário. O xamanismo é uma categoria cunhada com a intenção de universalizar práticas locais vinculadas com os domínios do terapêutico e o mágico que são díspares e heterodoxas. $\mathrm{Na}$ atualidade, há uma tensão intrínseca ao próprio conceito de xamanismo que faz com que uma enorme diversidade interna ao conceito (composta da multiplicidade de práticas de magia e cura próprias de cada tradição local) conviva com uma sofisticada homogeneidade externa (constituída pelo suposto de que existem características universais que fariam com que houvesse xamãs em todas as culturas).

A tensão entre universais e particulares, que é própria à constituição e reconstituição da antropologia como ciência, manifesta-se aqui com toda a sua força. A esse respeito, é muito ilustrativa a revisão do conceito de xamanismo. Os estudos críticos de história da religião, próximos dos interesses particularistas da antropologia, expuseram que a tendência a classificar o xamanismo como uma forma de "religiosidade primitiva", na procura de um contato direto com o divino, tende a se fundar em critérios arbitrários para diagnosticar essa prática entre culturas; ao mesmo tempo em que, assumindo uma suposta propensão do sistema psico-neurológico e fisiológico dxs xamãs, que pretensamente teriam os mesmos comportamentos sob condições ambientais similares, parte-se deste fato e não se discute a historicidade ou a heterogeneidade do conjunto de práticas que são colocadas sob a rubrica de xamanismo. Por outra parte, esses estudos, ao procurarem o mesmo tipo de elementos externos como formas de acesso ao Divino, sublinham implicitamente um Ser Divino que tende a ser representado desde uma perspectiva hegemônica que se entende como monoteísta, ocidental e branca (Hawthorne, 2007; Sidky, 2010). 
Dentro da área da antropologia também houve propostas alternativas. Em seu artigo de 1966, Religion As Cultural System, o antropólogo norte-americano Clifford Geertz designa xamanismo como uma categoria insípida e idiossincrática que não pode fazer outra coisa que "desvitalizar qualquer informação etnográfica" (p.122). A antropóloga norte-americana Jane Atkinson, em seu sugestivo artigo "Shamanisms Today" (1993), revisa a relação do conceito de xamanismo com a área da antropologia. Ela salienta o fato de existir uma miríade de aproximações etnográficas aos processos locais relativos à magia e terapias por parte de especialistas populares que, por não usarem o termo "xamã" nos seus títulos, abstracts e palavras-chave, são relegadas à margem do mainstream dos estudos sobre xamanismo. Tais pesquisas, relacionando aspectos micro destas práticas à integração dessas à vida cotidiana dxs sujeitxs, teriam um baixo impacto na área trans-disciplinar dos estudos sobre xamanismo, constituída pela teorização sobre os universais relativos à Humanidade como um todo, a construção de modelos e arquétipos e uma permanente auto-atualização a partir do uso descontextualizado de informações localizadas (Atkinson, 1993: 308). A pesquisadora norte-americana radicada no Brasil, Jean Langdon, sustenta que, ao se tornar universal, o termo xamã perdeu a sua especificidade, convertendo-se em um conceito geral e impreciso, pouco útil para fins comparativos (Langdon, 1996:13). De acordo com uma rigorosa análise histórica da diversidade interna à própria cultura siberiana, o estudioso do xamanismo siberiano Homayun Sidky (2010) propõe dar visibilidade a outros "intercessores rituais", que foram anteriormente classificados como xamãs, ao mesmo tempo em que sugere delimitar o escopo do próprio fenômeno do xamanismo à Ásia do Norte e Central, assim como ao extremo norte da América do Norte. As conseqüências desta circunscrição não são menores (p. 231): 
It excludes a vast majority of magic-religious practitioners from around the world who have long been deemed to be shamans, for example indigenous healers in South America, Africa, and Australia ${ }^{30}$.

A crítica mais radical ao conceito que encontrei na literatura especializada sobre o tema é aquela elaborada pelo antropólogo mexicano Roberto Martínez González, que provocativamente argumenta (pp. 212-213):

¿De qué sirve remplazar los vocablos indígenas, suficientemente específicos, por un término tan oscuro como chamán? A mi parecer, el éxito de este último se explica porque su origen nos es tan remoto que, a fin de cuentas, actúa como un significante vacío (...) la supuesta universalidad del fenómeno chamánico ha dado pie al encasillamiento de las más diversas prácticas culturales bajo la muy estereotipada imagen del chamán (...) a esto podemos agregar que, en la mayoría de los casos conocidos, ninguno de estos criterios es pertinente en el discurso indígena. De hecho, basta con echar una ojeada a los escritos de la colonia temprana para darse cuenta de que la terminología indígena es mucho más rica y específica ${ }^{31}$.

Ao invés de pretender fazer caber à diversidade social local dentro de um conceito guarda-chuvas, com validade para tão diversas épocas, regiões e práticas, prefiro nessa pesquisa me voltar para uma sensibilidade etnográfica onde possa observar quais conceitos estão, de fato, ativando as maneiras de fazer com plantas da localidade. Contudo, é inegável que xamanismo, xamã e xamânico têm se tornado categorias usadas de forma extensiva na antropologia aplicada aos estudos do fenômeno das maneiras de fazer com plantas na Amazônia do Peru.

\footnotetext{
$30 \quad$ "Isso exclui a vasta maioria de praticantes mágico-religiosos de todo o mundo que têm sido largamente tidos como xamãs como, por exemplo, os curandeiros indígenas da América do Sul, África e Austrália".

31 "Qual é o objetivo de substituir os vocábulos indígenas, suficientemente específicos, por um termo tão obscuro como xamã? No meu parecer, o sucesso desse último se explica porque sua origem é tão remoto para nós que, no final das contas, age como um significante vazio (...) a suposta universalidade fenômeno xamânico tem dado lugar ao encurralamento das mais diversas práticas culturais sob a muito estereotipada imagem do xamã (...) a isso podemos adicionar que, na maioria dos casos conhecidos, nenhum desses critérios é pertinente no discurso indígena. De fato, é suficiente com dar uma olhada aos escritos dos primeiros tempos da colônia para se dar conta de que a terminologia indígena é muito mais rica e especifica".
} 
Durante a minha pesquisa de campo, tive a possibilidade de observar que o conceito xamã também ostenta um peso etnográfico importante, pois apesar da sua aparição relativamente recente, ela é usada com bastante frequência nos contextos do turismo xamânico.

Devido ao fato de que o trabalho de campo se situou não dentro, mas às margens dos circuitos do turismo xamânico, tive a possibilidade de entrar em contato com um número majoritário de pessoas hispano-falantes da localidade, não necessariamente vinculadas com o turismo. Em virtude desta particular entrada no campo, observei que outro termo era utilizado com frequência, não tanto já por turistas estrangeirxs ou xamãs de renome dos lodges ayahusqueiros, quanto por pessoas da localidade. Esse termo é o de curanderx. Pesquisei a constituição do termo e encontrei alguns dados de interesse, como saliento no ponto seguinte, referente à higienização das práticas e a centralidade do processo de cura.

Durante a elaboração da análise das informações obtidas em campo, percebi que muitas das mulheres (e alguns homens) especialistas nas diversas maneiras de fazer com plantas apresentavam uma clara resistência a se auto-identificar como curanderxs. E, em consonância com as anotações do médico e folclorista peruano Fernando Cabieses (1993: 166), comecei a ter em conta que:

El vocablo "curandero" es un término exógeno, es decir, es la palabra que califica a una profesión desde un punto de vista foráneo. Un término como éste, necesariamente corre el peligro de distorsionar en alguna forma la realidad $^{32}$.

Se bem que, diferentemente de Cabieses, eu não adiero pessoalmente à ideia da existência de uma realidade única e unidimensional à qual uma "boa ciência", se

32 "O vocábulo 'curandero' é um termo exógeno, é dizer, é a palavra que qualifica a uma profissão desde um ponto de vista externo. Um termo como esse, necessariamente corre o risco de distorcer de alguma maneira a realidade". 
tiver as ferramentas adequadas, pode acessar; compartilho, contudo, da consideração do autor a respeito da externalidade do termo curander $^{33}$. Se a presente etnografia tivesse incluído essxs sujeitxs que não se auto-identificam como curanderxs, preservando o mesmo vocábulo de curanderx para lhes denominar, eu estaria não só denegando um fato etnográfico básico, mas também exercendo uma modalidade de violência cognitiva com xs sujeitxs com xs quais teve lugar a minha pesquisa. Curandero, da mesma maneira que xamã, não apareciam como categorias suficientemente abrangentes para o presente recorte de pesquisa, enquanto que a sua significatividade e fertilidade se encontravam fortemente sujeitas aos contextos particulares.

Ainda tive a possibilidade de trabalhar com termos cunhados dentro de subespecialidades da área da antropologia. Eram categorias propriamente analíticas, isto é, alheias à realidade cultural $\mathrm{dxs}$ sujeitxs em questão e desconhecidas por elxs. Os conceitos de ritualista (Martínez González, 2009) e de intercessores rituais e praticantes mágico-religiosos (Sidky, 2010), que se acunharam a partir da revisão crítica do termo xamã, apareceram como interessantes, pois eles definem, de maneira ampla, aquelas pessoas vinculadas a atos simbólicos e mágicos dentro das comunidades locais. Também se apresentaram como possibilidades de trabalho as noções de agente terapêutico e terapeuta popular. A primeira, agente terapêutico, é desenvolvida em um belo estudo sobre a pajelança no Maranhão, escrito pelo antropólogo Gustavo Freire Pacheco (2004), e é "usada para abarcar do modo mais abrangente possivel toda e qualquer pessoa que se dedique mais ou menos sistematicamente ao tratamento de perturbações" (p. 19). A segunda está sendo aproveitada com força dentro do que é o campo da antropologia da saúde em Brasília, como é possível ver na proposta da

33 Externalidade, porém, de longa data no campo peruano, como veremos no próximo ponto, A higienização das práticas... 
antropóloga Soraya Fleischer (2013), e que designa, de maneira geral, às pessoas que cuidam e curam dentro das comunidades locais, rurais, urbanas ou periurbanas.

Os três primeiros conceitos (ritualista, intercessor ritual, praticante mágicoreligioso) se referem aos aspectos rituais e mágicos da prática dxs sujeitxs em questão; enquanto que a terceira e quarta denominações (terapeuta popular e agente terapêutico) colocam um maior peso nos aspectos propriamente terapêuticos das mesmas práticas. Segundo tenho observado em minha etnografia, as práticas dxs especialistas da região se encontram entre duas águas, isto é, entre uma e outra dimensão, a mágica e a terapêutica.

Por esse motivo, pareceu-me conveniente preservar o esforço de não reduzir uma dimensão à outra. Contornando os riscos de medicalizar à religião, assim como de tornar religioso o que é terapêutico (Whyte, 1989) e, sem pretender que uma linguagem seja absorvida pela outra, faço questão de compreender as categorias locais na sua própria complexidade, dentro dos marcos de sentidos nos quais elas são acionadas. Desta maneira, abriu-se para o presente trabalho a possibilidade de apresentar o termo curios $x$ e as mais de dez sub-especialidades que se desprendem dele como o marco conceitual feito à medida da presente tese. Em vez de um único conceito universalizante, escolhi uma miríade de conceitos locais mais adequados à compreensão, próxima e muito particular, das práticas dxs sujeitxs que ativam terapias e magias com plantas na Amazônia do Peru e que eu tive a possibilidade de entrevistar. Nesse sentido, o interesse foi o de preservar a dimensão das terapias, assim como a das magias, observando as potencialidades possíveis advindas da interseção dessas duas dimensões. 


\section{- Perspectivas críticas, 3: A higienização das práticas}

"La [idea de] comunicación con los espíritus buenos y amigos (...) [y] con los espíritus malignos y demonios parece haber surgido (...) después de la Conquista, cuando los misioneros españoles rompieron la cosmovisión andina e introdujeron el concepto del diablo y los demonios (...) Este razonamiento teológico es degradado hasta el nivel de la vida diaria del chamán:

- El chamán es todopoderoso. - El chamán quiere ayudamos y es bueno con nosotros. - El bien y el mal existen y son opuestos". Fernando Cabieses, 1993: 172.

Em dezembro de 2014, uma equipe de pesquisadorxs da ayahuasca elaborou uma carta pública (Rush et al, 2014) manifestando o seu desconforto e preocupação perante as expressões de uma organização não-governamental orientada às práticas sociais relativas à ayahuasca na Amazônia, o EtnhoBotanical Stewardship Council (ESC). Eu fui convidada a assinar a carta e assim o fiz, discordando do teor etnocêntrico e alarmista com o qual começaram a ser elaboradas as campanhas de arrecadação de fundos desta organização - a qual, desde a data da sua criação, vem arrecadando $\$ 90,000$ a serem destinados a uma regulamentação dos usos da ayahuasca dentro das comunidades amazônicas. Como consta no texto (p.2):

The ESC project to "modernize" and "sanitize" indigenous uses of ayahuasca threatens to create an unnecessary and Western-imposed bureaucratization and professionalization/institutionalization of traditional medicine ${ }^{34}$.

No marco de um discurso com destaque para demandas elaboradas unilateralmente, pretende-se a promoção da segurança para xs turistas xamânicxs e a limpeza de bruxarias [cleaning up sorcery] a partir da certificação dos centros ayahuasqueiros e dxs xamãs que sejam consideradxs "segurxs" para a organização. Na carta pública se enfatiza a importância da magia e o segredo nas

34 “O projeto do ESC de 'modernizar' e 'sanitizar' os usos indígenas da ayahuasca ameaça com criar uma profissionalização/institucionalização da medicina tradicional que é desnecessária e imposta por Ocidente". 
sociedades Amazônicas, assim como a existência de um complexo moralmente ambíguo de cura e feitiçaria presente nessas sociedades. Também salientou-se a falta total de participação de membrxs das comunidades locais dentro da equipe do ESC, e se rejeitou a pretensão da instituição de sentar bases normativas para o consumo de ayahuasca nas localidades desde uma perspectiva compreendida como exclusivamente externa.

Contudo, as ideias desta organização não são completamente destoantes com uma tendência que tenho observado nos estudos sobre o xamanismo: a ênfase na universalização das práticas xamânicas está unida, muitas vezes, a uma construção $\mathrm{dxs}$ xamãs como sujeitxs que vestiriam as roupas $\mathrm{dxs}$ "sacerdotes/sacerdotisas primitivxs" feitos à medida do desespero ocidental. A excessiva atenção ao "lado positivo y socialmente integrativo" (Whitehead, 2004: 398) das práticas terapêuticas e mágicas destxs especialistas da Amazônia é uma tendência muito marcada, tanto dentro do campo dos estudos sobre o xamanismo quanto dentro dos próprios circuitos do turismo xamânico.

No campo de estudos sobre o xamanismo peruano, da mesma maneira que as mulheres foram sujeitas silenciadas, é possível observar, de maneira geral, que os aspectos que se referem à magia foram progressivamente retirados de cena. Considero que essa higienização dos aspectos mágicos dentro do escopo de ações destxs praticantes não é um fato recente: ela tem suas raízes em um processo antigo de cristianização que se viveu, de diferentes maneiras, em toda a América Latina. É nesse processo que desejo, por um instante, me deter.

Ao longo da história do nosso continente, a medicina oficial se constituiu não só a partir do aperfeiçoamento das técnicas modernas e mais tarde biomédicas, mas, conjuntamente e, sobretudo, a partir do combate e exclusão das outras formas 
existentes de cuidar, curar e influenciar sobre o mundo por parte $\mathrm{dxs}$ especialistas vernáculxs. Tais "anatomias populares" (Novión, Novión y Serra, 1973), heterodoxas e dificilmente classificáveis, foram objeto de estudo de folcloristas em etapas prévias à constituição profissional do campo da antropologia na América Latina. A historiadora brasileira Tânia Pimenta (2009) anota, para o caso de terapeutas populares do século XIX no Brasil, uma diversidade de termos de referência para essxs sujeitxs: "ignorante" "curiosx", "empíricx", "analfabetx", "supersticiosx", "sem moral"; "charlatã/o", e inclusive "criminal" e "infanticida" - esse último termo destinado especialmente às parteiras, as quais, ademais de trazerem crianças ao mundo, também praticavam abortos, considerados moralmente puníveis.

Na mesma linha, os termos para falar das práticas mágicas e terapêuticas dxs especialistas populares foram similarmente desestimados no Peru. Em um tratado de folclore escrito em 1928 por Ricardo Cavero, um intelectual oriundo da alta Amazônia, os brujos [bruxos] gozam de uma especial classificação (p. 170):

Nosotros, que conocemos a estos muy de cerca, podemos clasificarlos en los cuatro siguientes grupos o especies: Curanderos; Hechiceros; Maleros y Magos o Adivinos, estando unos especializados en una materia, como hay otros que entienden de todas en general. Pertenecen a la primera categoría los que mediante el uso de determinados brebajes preparados de yerbas, hojas, raíces o cortezas curan ciertas enfermedades con éxito admirable, en cuyo procedimiento hacen observar al paciente una prolongada y severa dieta; corresponden al segundo grupo aquellos que en sus procedimientos emplean, además de determinadas propiedades de las plantas, las de los huesos de algunos animales de los que extraen los elíxires para el amor; a la tercera especie pertenecen los que, apelando a sus conocimientos cabalísticos, hacen creer que su poder es capaz de conocer los misterios de la naturaleza o de influir en el destino de la otra persona para hacerle daño [Finalmente] se los considera magos o adivinos a los que, usando el tabaco masticado, bebiendo o dando de beber una cocción de un bejuco llamado 
'ayahuasca', cuyos efectos no son otros que el de producir visiones, descubren secretos" 35 .

Sob a severa lente de Cavero, é possível observar nesse fragmento: a) a diversidade de práticas $d x$ especialistas locais, b) o reconhecimento de seu ofício em termos da sua eficácia terapêutica e c) o desprezo e o tom de superioridade moral do folclorista frente a essas práticas. Essa aversão pode ser traçada na linha de realidades históricas ainda mais densas. A "extirpación de idolatrias", processo pelo qual, a partir do século XVI começaram a ser perseguidxs xs praticantes mágico-terapêuticxs da Colônia ${ }^{36}$, levou a que 20.893 pessoas fossem acusadas do crime da idolatria, 1.619 praticantes locais fossem processados e mais de 1.700 huacas ou lugares sagrados tenham sido destruídos (Tauro del Pino, 2001; Valencia, 2010).

Como também foi assinalado por otrxs autorxs (Thompson, 2004; Chidester, 2004), as mais diversas formas de perseguição, extirpação e silenciamento das chamadas idolatrias foram práticas costumeiras nos estados coloniais de todo o

35 "Nós, que conhecemos a esses de muito perto, podemos lhes classificar nos quatro seguintes grupos ou espécies: Curandeiros, Feiticeiros, Maleros e Mágicos ou Adivinhos, estando uns especializados em uma matéria, assim como há outros que entendem de todas em geral. Pertencem à primeira categoria os que, por meio do uso de determinadas beberagens preparadas com ervas, folhas, raízes ou cascas, curam certas doenças com sucesso admirável, em cujo procedimento fazem observar ao paciente uma prolongada e severa dieta; correspondem ao segundo grupo aqueles que em seus procedimentos empregam, ademais de determinadas propriedades das plantas, as dos ossos de alguns animais dos que se extraem os elixires para o amor; à terceira espécie pertencem os que, apelando a seus conhecimentos cabalísticos, fazem crer que são capazes de conhecer os mistérios da natureza ou de influenciar no destino da outra pessoa para lhe fazer um dano. [Finalmente] se consideram mágicos ou adivinhos os que, usando o tabaco mascado, bebendo ou dando de beber una cocção de uma liana chamada "ayahuasca", cujos efeitos não são outros que o de produzir visões, descobrem segredos".

36 Desencadeou esse fenômeno a descoberta, no ano de 1600 e por parte do sacerdote Francisco de Ávila, de uma série de estatuetas ocultas nas localidades de San Damián, San Pedro e Santiago de Tuna, três povoados da serra peruana. A população foi convocada a um Auto de Fe na Praça de Armas de Lima, a capital do país. Lá os objetos considerados contrários à doutrina cristã foram queimados e os indígenas que eram considerados culpáveis, açoitados e desterrados. A partir de então se estabeleceu, com o apoio da coroa da Espanha, uma campanha estatal de visitas às casas e perseguição das práticas mágicas e terapêuticas locais, tidas então sob o nome de idolatrias (Tauro del Pino, 2001). 
globo. Em meio àquele desgastante processo histórico de destruição explícita deste tipo de práticas, instituiu-se o termo curanderx para designar, de uma maneira externa, a essxs especialistas. A noção de curanderx deve ser compreendida como uma categoria colonial, externa às culturas indígenas, que se popularizou com a mestiçagem. Ela inclui fusões de saberes dxs grupos dominantes e dos grupos dominados, como a teoria dos humores de origens árabes/gregas, o catolicismo, formas de religiosidade popular europeia, como o espiritismo, e as próprias concepções indígenas locais (Cernadas e Wright, 2004: 411). Essa breve genealogia do conceito de curandeirx salienta a perseguição às formas de fazer terapias e magias locais como sendo parte de um processo histórico de longa data, que se encontra imbricado da própria constituição das práticas dxs especialistas locais contemporâneos. A perseguição das tradições locais, tidas como idolatrias, não aconteceu em um vácuo, mas no marco de processos de dominação social e exploração das comunidades amazônicas. A relação entre colonialismo e as práticas terapêuticas e mágicas locais é inegável. Como argumenta David Chidester (2004: 41):

Not only a system of military, political, and economic power, colonialism is also a cultural project, advancing a cultural agenda, but also entailing intercultural contacts, relations, and exchanges (...) Often legitimated by explicit appeals to religion, colonialism inevitably affects indigenous religious life ${ }^{37}$.

Dentro do território da Amazônia, o processo colonial envolve múltiplos ciclos extrativos e entradas predatórias por parte dos capitais estrangeiros, cujo ingresso na floresta lhes garantiu ganâncias rápidas sob baixos custos e precários investimentos (Barclay e Santos Granero, 2002). O antropólogo inglês Peter Gow mergulhou nas crônicas e nos relatos dos viageiros, missionários e empresários

\footnotetext{
37 "Não somente um sistema de poder militar, político e econômico, o colonialismo é também um projeto cultural, que avança em uma agenda cultural mas também reforça contatos, relações e intercâmbios interculturais (...) Com frequência legitimado por apelos explícitos à religião, o colonialismo afeta a vida religiosa".
} 
na Amazônia durante os séculos XVIII, XIX e XX, procurando uma compreensão do que ele chama o xamanismo mestiço. O pesquisador observa que as práticas de magia e cura dxs curiosxs locais foram originadas nas cidades e permanecem nelas desde longa data (1994:97):

I argue that (...) ayahuasca shamanism has been evolving in the urban context in the past three hundred years, and that it has been exported from these towns to isolated tribal people to become the dominant form of shamanic curing practice in the region. It evolved as a response of the specific colonial history of Western Amazonia and is absent precisely from those few indigenous people who were buffered from the processes of colonial transformation caused by the spread of the rubber industry in the region $^{38}$.

Um insight importante desta pesquisa é, ao contrário do que uma percepção purista que a cultura local poderia projetar, os saberes dxs especialistas em curar e fazer magias emigraram da cidade para as tribos, e não o inverso. Ao fazer uma análise das fontes históricas do período da borracha na Amazônia desde finais do século XIX, Gow releva que junto com o deslocamento da população das comunidades indígenas amazônicas - e, dentro delas, especialmente dos homens de meia idade -, apareceu a noção de mestizo e, contemporaneamente, a de um curandeirismo mestizo cuja bagagem prospera nas cidades: "I suggest that the origins of ayahuasca shamanism must besought in the origins of mestizo as a social category and in the origins of Amazonian cities" ${ }^{39}$ (1994: 105), ressalta o autor.

\footnotetext{
38 "Eu coloco que (...) o xamanismo ayahuasqueiro tem estado presente no contexto urbano dos últimos trezentos anos, e que tem sido exportado desde as cidades para os povos tribais até se tornar uma forma dominante de cura xamânicas na região. Ele evoluiu como resposta à específica história colonial da Amazônia ocidental, e está precisamente ausente no contexto daqueles povos indígenas que foram reservados dos processos de transformação colonial causados pela dispersão da indústria da borracha na região".

39 "Eu sugiro que as origens do xamanismo ayahuasqueiro devem ser procuradas nas origens da categoria social mestizo e na mesma origem das cidades amazônicas".
} 
Certamente a borracha é o caso clássico, mas há muitos outros produtos que foram colocados dentro dessa dinâmica de ciclos extrativos igualmente predatórios, como barbasco [Lonchocarpus nicou], yute [Corchurus capsularis], madeiras para construção, coca [Erythroxylum coca] e petróleo. Tais ciclos alimentaram o crescimento da classe mestiza, uma classe sócio-étnica marginal, arrancada do indígena e excluída do branco. A marginalização teve, porém, uma vantagem: permitiu uma conexão, à maneira de uma dobradiça, entre os dois domínios. A pesquisa de Gow mostra a importância de colocar o xamanismo peruano em perspectiva e em estreita relação com uma sociedade urbana estratificada em termos de classes e "raças" socialmente designada.

As análises do curandeirismo/xamanismo mestiço Amazônico (segundo seja a perspectiva desde a qual se escreva) nos levam a concluir que as hibridações, misturas e sobreposições de saberes não são fruto exclusivo da pressão globalizante da new age sobre certo xamanismo indígena originário, mas que elas têm uma existência de longa data. Essa existência foi iniciada com o violento processo de choque de práticas entre dominadorxs e dominadxs do período propriamente colonial, e continua até o presente com as diversas formas de exploração econômica, sexual e cultural da floresta. A perseguição das moralidades alheias aos grupos dominantes, tidas como "moralidades ambíguas" forma parte fundamental deste processo, e a maneira como os grupos dominantes as assumem é, igualmente, ambígua.

Temos visto que a influência de Eliade sobre os estudos do campo do xamanismo foi fundamental para uma constituição do arquétipo do xamã como um homem que, através de um contato direto com o divino, possui a capacidade de curar o corpo e a alma dxs seus consulentes. No caso dos estudos sobre xamanismo Amazônico, descreveu-se o lado "moralmente bom" das curas, dos remédios e 
dos benefícios, deixando-se de lado aqueles aspectos mágicos que se referem a conquistar, matar, influenciar, fazer adoecer outras pessoas, igualmente importantes no contexto em estudo. É interessante salientar que não só na literatura especializada, mas também no ethos dxs próprixs turistas, o discurso da higienização das práticas é similar. Sustenta o antropólogo norte-americano Neil Whitehead (2004: 399):

The "dark" side - the shaman's power to destroy or inflict harm through sorcery and witchcraft (...) has received little in-depth attention. In several of the most important contributions to the South American shamanism literature in recent years, the weight of attention is on the shaman's capacities to harness cosmic forces for the benefit of humanity ${ }^{40}$.

A higienização do campo de estudos do xamanismo, que tornou as práticas dxs especialistas em práticas essencialmente "terapêuticas", provou a eficácia ritual dos procedimentos levados a cabo pelos praticantes, voltando-se os resultados dos mesmos para a "cura". Atkinson (1993:313) argumenta que talvez se trate de um esforço - talvez excessivo, quando não inadequado, a meu ver - de legitimação das práticas em questão frente aos olhos do pensamento racional:

Likening shamans to physicians and psychotherapists was a move that elevates the former and jocularly taunts the latter with the reminder that Western biomedicine too makes use of rituals, impression management, and faith. ${ }^{41}$

As maneiras de fazer com plantas são, até hoje, concebidas sob o modelo clínico da eficácia terapêutica. Como afirmam os estudiosos da relação entre medicina, magia e terapias Csordas e Kleinman (1996; apud. Pacheco, 2004: 22):

\footnotetext{
40 "O 'lado escuro' - o poder do xamã para destruir ou infligir danos através da magia e feitiçaria - (...) recebeu pouca ou nenhuma atenção. Em várias das mais importantes contribuições da literatura dos últimos anos ao xamanismo Sul-Americano, o peso da atenção esteve na capacidade do xamã para compilar as forças cósmicas para o benefício da humanidade".

41 "Assemelhar xamãs com médicos e psicoterapeutas foi uma jogada que elevou os primeiros e jocosamente colocou aos segundos em um lugar incômodo, ressaltando que a biomedicina Ocidental também lança mão de rituais, manejo de impressões e fé".
} 
A tendência a analisar o processo de cura com base em uma analogia entre o curador e um médico que está tratando um paciente individual, de uma doença específica, com um tratamento específico, à espera de um resultado definitivo.

No marco deste modelo, tendem a se desdenhar os procedimentos "mágicos" enquanto que, eventualmente, reconhece-se a eficácia dos remédios fitoterápicos da Amazônia - região muitas vezes destacada como "o maior laboratório do mundo" pela conservação da sua diversidade vegetal - . Da mesma maneira em que Pacheco, assumo que essa dissociação entre magia e terapia é arbitrária e artificial. Não há maneira de dissociar, de maneira homogênea, estável e unilateral, o universo das curas e das maneiras de fazer fazer, das práticas terapêuticas e das práticas etótropas dxs especialistas desta região. Por outro lado, a retórica prática do contato direto com as práticas espirituais dxs especialistas locais, quando se aproxima da área dos estudos de uma psicologia aliada à neurociência, salienta o caráter místico e transformador de determinados princípios ativos das plantas (Atkinson, 1993; Sidky, 2010; Martínez González, 2009) e, protegidas e dulcificadas pelas doutrinas do livre arbítrio, postulam maneiras de acesso a "espiritualidades primárias" no marco das quais a função do xamã é cada vez menos necessária ${ }^{42}$. Porém, uma aproximação às dinâmicas locais requer retornar às disputas culturais pelos significados, às formas diversas de comunicação e às próprias relações de poder e dominação inerentes a esse espaço social. Parafraseando o antropólogo australiano Michael Taussig (1993), torna-se extremamente limitado compreender o campo em questão somente através das curas. É preciso lançar mão das ferramentas que nos permitam conceber, delinear e enunciar o terror inerente a o nos concentrarmos nesse

\footnotetext{
42 Para uma análise da concepção da DMT da beberagem da ayahuasca concebida como "molécula espiritual", é possível consultar meu texto sobre experiências urbanas com a síntese da Dimetiltriptamina a partir de Psychotria viridis, Piptadenia peregrina e outras espécies vegetais. Ver Echazú Böschemeier, 2013a.
} 
campo de práticas. Desta maneira, nas práticas dirigidas à "cura", tende-se a revelar importantes dimensões de bem-estar, cuidado e saúde que xs curiosxs concebem e praticam, reduzindo drasticamente a possibilidade de compreender as maneiras de se relacionar que envolvem ações negativas, secretas ou prejudiciais para com outrxs.

\section{- Perspectivas críticas, 4: a centralidade da ayahuasca}

"Alguns pensam que o eu é uma coisa que fica entre os sapatos e o chapéu". Walt Whitman, 2005. Folhas de relva.

Nesse ponto, desenvolverei o argumento segundo o qual a consideração da ayahuasca como o centro de todo o sistema terapêutico dxs curiosxs da Amazônia peruana faz parte de uma construção conceitual externa e não corresponde à realidade empírica. No marco desta crítica, faz-se necessário observar o modelo que se superpõe à realidade peruana, um modelo vindo da própria compreensão racional e moderna sobre o corpo, a maneira como ele adoece e as formas de rico-lo. Para isso, dividirei a minha análise em quatro momentos, onde: a) colocarei algumas metáforas relativas à compreensão do eu, do corpo e das fronteiras do corpo para a racionalidade moderna; b) analisarei certa tendência à compulsão pela ingestão proveniente desta compreensão do corpo; c) destacarei a superposição entre magias e curas locais com "estados alterados de consciência" delineada de maneira geral pelos estudos sobre o xamanismo; d) farei uma crítica à extrapolação deste modelo, observável na exclusividade da planta da ayahuasca e da sua ingestão como elemento e método que são considerados centrais às maneiras de fazer com plantas destxs especialistas. 
O antropólogo francês Lucien Lévi Bruhl ([1927] 1947) apontou, no início do século XX, para o fenômeno do progressivo decrescimento do sujeito no Ocidente. Na sua análise da magia entre grupos tribais, observa a dinâmica de influências que vão do "exterior" dos corpos, para o interior dos mesmos: palavras, pessoas, fases da lua, lugares, gestos, misturas ervais, alimentos, maneiras de cortar, maneiras de colher: todos esses elementos parecem afetar os corpos, e a relação correta com elxs aparece sendo importante para preservar a integridade e a saúde. Os materiais etnográficos por ele analisados habilitam a análise para uma concepção de pessoa que transcende as fronteiras do corpo individual. "Comparada com a sua, nossa individualidade parece ter sofrido uma redução" (1947: 129) afirma. De fato, a redução imaginária dx sujeitx a seu próprio corpo material, orgânico - corpo a respeito do qual elx começa a se pensar como "dono"- tem raízes históricas que podemos encontrar com o florescer da modernidade racional. A filósofa norte-americana Judith Butler (2003) afirma que o corpo tem sido compreendido pela tradição moderna como um objeto passivo, anterior ao discurso, com uma matéria inerte sobre a qual os discursos proliferaram. Ela sublinha os procedimentos de demarcação do corpo como ato político: a distinção entre uma interioridade e uma exterioridade cria sujeitxs que podem ser definíveis isoladamente, e esses limites habilitam operações históricas de manutenção através da exclusão $\mathrm{dx}$ outrx em si mesmo. A modernidade controla e exalta corpos impermeáveis, corpos íntegros, corpos fechados que se definem pela via da alteridade. Nesse mesmo ato de exclusão dx outrx da própria fronteira, tende-se a estruturar também o espaço interno e o núcleo psicológico do eu individual. Desde uma perspectiva conexa à de Butler, a estudiosa norte-americana Donna Haraway (1995) descreve determinados paradigmas da medicina moderna como planos de ação para manter as fronteiras entre eu e o outro - que ao mesmo tempo são fronteiras distintivas entre o normal e o patológico, onde o corpo pode ser traduzido como um "mapa de 
funções normalizadas" (p. 181) cujos valores e limites devem ser garantidos. Tudo aquilo que extravasa essas fronteiras desse corpo (seja de dentro para fora quanto de fora para dentro) é concebido como perigoso: território de regulações, disposições, saberes especializados.

A constituição histórica do "modelo clínico da eficácia terapêutica" (Csordas e Kleiman 1996), onde se concebe o funcionamento do corpo como uma máquina produtora de signos, teve uma relação de proximidade e colaboração como desenvolvimento da indústria farmacêutica nos países do norte político. $\mathrm{O}$ ingresso de substâncias no corpo é regulado através das técnicas da farmácia, que são as encarregadas de administrar dosagens corretas para os processos de doença. $\mathrm{O}$ especialista humano diagnostica drogas, vias de acesso às correntes de fluidos do corpo e faz um mapa com o timing das aplicações. Estritamente definidas pela "evidência", um senso comum construído historicamente e baseado em uma compreensão cultural dos sentidos, as fronteiras do corpo tendem a se compreender como independentes do restante do mundo, autônomas em seus processos do adoecer e sarar; enquanto a matéria orgânica se delineia como um território onde moléculas e células liberam batalhas pela vida ou pela morte do organismo humano. No contexto dessas práticas, xs agentes de cura lançam mão de uma concepção farmacológica da medicina e de uma via rápida e eficaz para poder ingressar ao corpo. Tal é o lugar da ingestão ${ }^{43}$, tal é a importância dos comprimidos, pílulas, cápsulas, pastilhas e beberagens que definem a importância e o crescimento da indústria farmacêutica nos países do norte e depois nos países do sul. Desde que estabelecidas como permanentes, as fronteiras desse corpo individual não entendem outras influências sobre ele que

43 Agradeço a meu colega Felipe Areda o insight a respeito da "compulsão pela ingestão" nos rituais religioso-espirituais contemporâneos. 
não sejam aquelas que penetram nele, de maneira palpável, observável, dosificável.

Eu proponho aqui que essa concepção, tão arraigada na maneira de conceber o eu, o corpo e suas fronteiras dentro da própria modernidade, influencia, por sua vez, a aproximação às magias, terapias e maneiras de fazer $\mathrm{dxs}$ especialistas de culturas que permaneceram em relação de tensão com essa modernidade. Jeanne Atkinson observou em seu arguto texto, Shamanisms Today (1993), sobre o crescente interesse no conceito de "estados alterados de consciência" (em inglês, ASC, Altered States of Consciousness) por parte dos estudos sobre o xamanismo durante as décadas de 1980 e 1990. Pelo que tenho observado, a inércia tem continuado na mesma direção. O conceito de "estados alterados de consciência", que provém da conexão entre os campos da antropologia, da psicologia e da neurociência, envolve o reconhecimento de realidades paralelas através da relação entre experiências espirituais e funções cerebrais. $\mathrm{O}$ discurso vincula, de maneira vis à vis, práticas xamânicas a estados alterados de consciência, e os dois à ingestão de psicoativos, sobretudo no campo latino-americano (Atkinson, 1993: 311), onde as substâncias psicoativas possuem um importante papel nas tradições de magia e cura. A sobreposição entre estados mentais e práticas de magia e cura chegou a tal ponto que se popôs uma denominação específica para esses estados: "estados xamânicos de consciência" (Harner, 1973); ao mesmo tempo em que se generalizou esse tipo de experiência para todxs e qualquer um dxs praticantes mágicx-religiosxs (Winkelman, 2000). A mútua identificação se tornou tão poderosa que, de fato, os dois termos são, muitas vezes, "usados de maneira intercambiável" (1993: 310-311). Silenciadas as dimensões sociais e culturais, a ênfase aqui está nos aspectos micro do orgânico em conexão direta com os macroaspectos do escorregadio território do espiritual. 
Retomando as ideias sobre corpo, fronteiras e técnicas de cura próprias da modernidade, lembramos que a medicina oficial moderna concebeu como método privilegiado de funcionamento as curas individuais veiculadas pela ingestão de substâncias. A ingestão pode ser compreendida como um movimento de elementos que penetram desde fora para dentro do corpo, permitindo de maneira explícita a transgressão da autonomia dos corpos individuais. A medicina oficial moderna procura especialistas que introduzam na soberania do corpo aquelas substâncias que ganharão a batalha contra a doença diagnosticada.

A projeção natural deste raciocínio para o contexto em estudo é a colocação das plantas no lugar de qualquer outro fármaco. Daí que se entenda que toda planta, para agir no corpo dx sujeitx deve ser, necessariamente, ingerida. Ingerir pode ser compreendido, na concepção médica oficial e moderna, como uma maneira de colocar em atividade os princípios químicos da planta dentro das fronteiras do organismo humano. Nos estudos sobre o caso da floresta peruana, o de plantas maestras é um conhecido conceito, proposto pelo antropólogo argentino Mario Luna a partir de seu trabalho de campo com curandeirxs na Amazônia peruana. De acordo ele, as plantas maestras são aqueles vegetais cujos espíritos têm a predisposição de ensinar. Ele afirma (1984: 6) que pertencem a essa categoria os vegetais que:

(1) produce hallucinations if taken alone; (2) modify in some way the effects of the ayahuasca beverage; (3) produce dizziness; (4) possess strong emetic and/or cathartic properties; (5) bring on specially vivid dreams ${ }^{44}$.

$44 \quad$ "(1) produzem alucinações se se ingerem sozinhas; (2) modificam de alguma maneira os efeitos da bebida da ayahuasca; (3) produzem enjôos; (4) possuem fortes propriedades eméticas e/ou catárticas; (5) trazem sonhos especialmente vívidos". 
$\mathrm{Na}$ proposta de Luna, as plantas maestras parecem constituir um grupo relativamente amplo, porém restrito à qualidade básica de possuírem certo grau de psico-atividade. $\mathrm{O}$ conceito destaca que, para tornar possível a relação entre vegetais e humanxs, os aspectos relativos à ingestão e modificação da consciência são fundamentais. Enquanto isso, outras formas de comunicação com as plantas, como os banhos, as fricções ou as vaporizações, não se encontram explicitadas. No caso específico da ayahuasca, três características se sobrepõem para rico-la paradigmática na aproximação contemporânea do mainstream dos estudos sobre o xamanismo: a ayahuasca é uma bebida que se ingere e é psicoativa. O especialista norte-americano em psicofarmacologia Dennis McKenna relata em um artigo do ano 1998:

Ayahuasca is a psychedelic beverage utilized in the ethnomedical and shamanic practices of numerous indigenous peoples of the Amazon Basin. (...) The hallucinogenic properties of ayahuasca derive from the presence of DMT (N,N-dimethyltryptamine), in one or more species of admixture plants, that is rendered orally active by $ß$-carbolines alkaloids, potent monoamine oxidase inhibitors (MAOI) found in the other key ingredient, the liana Banisteriopsis caapi (Malpighiaceae). Although these ingredients are necessary and sufficient for its visionary properties, in many ethnomedical traditions ayahuasca preparations often include other biodynamically active admixtures. Some are added to alter or modulate the acute effects of ayahuasca, while others may be utilized in combination with, or separately from, the ayahuasca brew as components of the "dietas." These plants are regarded as "teacher plants" and are consumed within dietas in the context of shamanic apprenticeship. Ayahuasca is, in fact, at the center of a vast and largely unstudied folk pharmacopoeia of associated medicinal plants ${ }^{45}$.

45 "Ayahuasca é uma beberagem psicodélica utilizada na etnomedicina e nas práticas xamânicas de numerosos povos indígenas da bacia Amazônia (...) As propriedades alucinógenas da ayahuasca derivam da presença de DMT (N,N-dimetiltriptamina), em uma ou mais espécies de plantas misturadas, que in se torna oralmente ativa devido a alcalóides $\beta$-carbolínicas, potentes exibidores da monoamina oxidasa (IMAO) encontrados no outro ingrediente chave, a liana Banisteriopsis caapi (Malpighiaceae). Apesar de serem esses ingredientes necessários e suficientes por suas propriedades visionárias, em muitas tradições etnomédicas as preparações de ayahuasca frequentemente incluem outras misturas biodinamicamente ativas. Algumas delas são adicionadas para alterar ou modular os agudos efeitos da ayahuasca, enquanto que outras devem ser utilizadas em combinação com, ou separadamente de, a mistura da ayahuasca durante as "dietas." Essas plantas são tidas como "plantas maestras" e são consumidas durante as dietas no 
Dennis Mc Kenna faz o esforço de trazer para a análise uma diversidade de outros vegetais e a relação local, nativa, folk entre eles, coisa inovadora para o campo. Apesar disso, não hesita em colocar a ayahuasca no centro mesmo do sistema de práticas mágicas e religiosas da Amazônia peruana. A visão deste especialista, assim como de muitxs outrxs, parte do modelo vegetalista mestiço que bebe a ayahuasca com xs xamãs (Narby, 1998), foi enfatizado pela literatura sobre xamanismo amazônico e é replicado sobre a complexa realidade em questão: uma enorme diversidade e riqueza de práticas culturais se reduzem à apreciação da ayahuasca por sobre as diversas beberagens.

Permito-me apontar aqui, junto com Atkinson (1993) e Martínez González (2009) que, em prol de realizar uma aproximação mais fiel aos contextos, as limitações do modelo dos "estados alterados de consciência", a sobreposição entre práticas de magia e cura devem ser tidas em conta. É sabido que diversxs especialistas em curas e magias do mundo não ingerem substância nenhuma para entrar em contato com outras realidades, como é o caso dxs praticantes terapêuticos e mágicos da Sibéria (Sidky, 2010). As aproximações aqui apresentadas tendem a subestimar a existência de formas de magia e cura que não requeiram, necessariamente, da ingestão como técnica e dos vegetais psicoativos como elemento principal a ser ingerido. No caso dxs curiosxs da Amazônia, como proponho demonstrar ao longo da tese, acontece que, assim como a ayahuasca, o toé e outras plantas psicoativas podem se constituir como importantes aliados, não havendo evidência etnográfica que os coloque como o centro per se do sistema mágico e terapêutico local. O conceito de maneiras de fazer com plantas que aqui proponho se constitui como uma maneira de acessar a uma diversidade de

contexto do aprendizado xamânico. A ayahuasca se encontra, de fato, ao centro de uma vasta e largamente inexplorada farmacopeia folk de plantas medicinais associadas". 
plantas e de técnicas, e, finalmente, de traçar as trilhas de compreensão que permitem o entendimento $d x s$ sujeitxs locais como entidades flexíveis e expansivas, que ultrapassam as fronteiras de seu próprio corpo individual. 


\section{Capítulo 2 \\ Propostas de aproximação}

- Uma etnografia das relações de gênero entre plantas - Curiosxs do povoado de Tamshiyacu • Reconhecendo a magia para aquém do território da cura. - As outras plantas $\bullet \mathrm{O}$ mito desconstruído.

\section{- Uma etnografia das relações de gênero entre plantas}

"Las mujeres (...) no producen historias más bonitas y menos naturales que los hombres, sino sus propias historias en la práctica (...) social, pública y llena de reglas. Colaboran en la creación de las reglas; es un asunto mundano que requiere la energía de las vidas concretas de las mujeres. La responsabilidad de la calidad de las historias (...) tiene muchas facetas, no es mística y está abierta en potencia a mujeres ordinarias de dentro y de fuera de la ciencia"46. Donna Haraway, 1995.

Nesse ponto e daqui em diante, o trabalho se desenvolve a partir do movimento que vem da crítica às categorias do mito do "homem-xamã-que-cura-comayahuasca": é o momento em que explicito as escolhas concretas dos conceitos para a análise que venho realizando no presente trabalho. E, apesar destes conceitos estarem espalhados ao longo de toda a minha etnografia, considero interessante apresentar aqui de uma maneira sistemática e ordenada quatro deles, que proponho como contraparte vis à vis da crítica do mito recém exposta. Desta maneira, quatro movimentos se esboçam no espaço desta proposta: à invisibilização das mulheres corresponde uma etnografia das relações de gênero entre plantas; a crítica dos limites do conceito de xamanismo traz consigo a proposta do estudo de caso e da categoria de curios $x$ para compreender melhor a realidade em estudo; à higienização das práticas corresponde uma consideração das práticas mágicas - ou "etótropas" - em pé de igualdade com as

$46 \quad$ "As mulheres (...) não produzem histórias mais bonitas e menos naturais do que os homens, mas suas próprias histórias na prática (...) social, pública e cheia de regras. Colaboram na criação das regras; é um assunto mundano que requer a energia das vidas concretas das mulheres. A responsabilidade pela qualidade das histórias (...) têm muitas faces, não é mística e está aberta em potência a mulheres ordinárias de dentro e de fora da ciência". 
terapêuticas, e, finalmente, a centralidade da ayahuasca, dos estados alterados de consciência e da ingestão se vê deslocada para o interesse nas outras plantas, na realidade cotidiana e nas outras maneiras de contato entre as plantas (e os espíritos delas) e xs sujeitxs em questão.

O conceito de maneiras de fazer com plantas que é utilizado no presente trabalho surgiu no transcurso da pesquisa a partir da necessidade de retirar o peso analítico das categorias utilizadas pelo campo dos estudos sobre xamanismo. A ideia de maneiras de fazer está inspirada, de forma direta, pelas arts de faire [artes do fazer] cuja definição propõe o filósofo e cientista social francês Michel de Certeau (1998). Ao analisar a urbe de Paris e seus habitantes, o autor concebe duas dimensões espaciais possíveis: por uma parte, a cidade-conceito na sua dimensão macro - a visão aérea desde longe e desde cima do espaço - e, por outra parte, as práticas urbanas mais ínfimas, aquelas coladas ao chão, que pertencem à rua, à cidade concreta, isto é, as práticas invisíveis das microhistórias que se multiplicam em Paris, assim como em qualquer outra cidade que é "vivida".

Da mesma maneira em que De Certeau, que escolhe olhar para as trajetórias dxs transeuntes e dxs pedestres, eu escolhi descrever os trabalhos dxs praticantes de magias e terapias da Amazônia do Peru desde o seu nível mais coloquial, ordinário, até banal. O conceito de maneiras de fazer que aqui proponho é relativo àquilo que é intrinsecamente qualitativo. É a compreensão de estilos, jeitos, modos de agir. Sustenta-se a partir de uma sutil diversidade entre umas e outras maneiras. Tece-se a partir de várias diferenças ínfimas. Cria exceções. Exceções que, em determinados pontos do caminho, alinham-se com outras maneiras de fazer similares. Então se tornam várias exceções, e ali existe a possibilidade de postular uma categoria. 
Meu presente esforço atentou para a observação rotineira dos diversos matizes possíveis dentro de um leque de práticas culturalmente esperadas. Variadas maneiras de fazer, heterogêneas trajetórias. $\mathrm{O}$ foco do conceito de maneiras de fazer não situa a dinâmica da sua compreensão no nível das estatísticas: as correntes majoritárias funcionam como uma mera referência de validação externa. Enquanto isso, interessa-me a validação interna das realidades sociais em estudo, a sua compreensão intrinsecamente contextual, a sutileza e dinamicidade das categorias em questão.

As pretensões universalistas dos campos de estudos sobre xamanismo amazônico se desfazem no caos ordenado do cotidiano, aquele que somente permite uma apreensão através das minúcias de uma paciente etnografia. Aqui, as trajetórias das pessoas "aparecem como indeterminadas, aparentemente desprovidas de sentido porque não são coerentes com o espaço construído, escrito e pré-fabricado onde se movimentam" (De Certeau, 1998: 97). Aqui é o lugar onde habitar, falar, fazer compras, cozinhar, cuidar, fazer magias e curar são atividades que aparecem juntas, abraçadas umas às outras, pisando no chão de uma cotidianidade aberta.

O conceito de maneiras de fazer com plantas atenta para a percepção de uma diversidade de estilos de comunicação com as plantas por parte $\mathrm{dxs}$ curiosxs do local, abrindo a percepção para práticas que se situam nas fronteiras intermediárias da magia e da cura, e que incluem vínculos pessoais, experienciais e vitais com os espíritos de cada planta. Nem estritamente curas, nem estritamente atos mágicos; nem intrinsecamente bons ou ruins; nem tecidos ao redor de uma única planta, mas sim de uma diversidade dinâmica de plantas que não se usam ou se consomem, mas às quais se acessa e com as quais se faz. 
Outras aproximações históricas, antropológicas e etnográficas contribuíram a motivar o presente argumento. Todas elas resultaram de trabalhos de pesquisa, maiormente de doutorado, nas disciplinas da história, a antropologia e a sociologia. O trabalho da historiadora paraense Maria Bethânia Albuquerque sobre história amazônica e os múltiplos contextos nos quais se ativa a beberagem da ayahuasca do lado da Amazônia brasileira (2009) foi uma delas, trazendo elementos críticos para uma compreensão epistemológica do saber das plantas e da diversidade de maneiras historicamente possíveis de se relacionar com elas. A tese sobre terecô, de Martina Ahlert (2013), foi outro desses trabalhos que desenvolve uma bela etnografia sobre pais e mães de santo na cidade de Codó, no Maranhão. Ela desenha, de maneira precisa e poética, uma paisagem de diversidade de seres em relação, enfatizando nas práticas do terecô, no que a religião $f a z$, na relação fluida entre experiências rituais e domésticas. A etnografia de Soraya Fleischer (2007) com parteiras de Melgaço, uma localidade do Pará, me ajudou a pensar nas redes de relações, nos interesses intrínsecos às transações terapêuticas e na impecável fluidez do ofício destas curiosas. A pesquisa de Gustavo de Britto Freire Pacheco (2004) sobre a pajelança como expressão religiosa e terapêutica no Maranhão é um estudo original sobre a inter-relação entre os aspectos sagrados, de cura e de prazer estético na prática dos pajés. O trabalho da antropóloga Juliana Salles Machado (2012) sobre relações de gênero e redes de intercâmbio de plantas trouxe contribuições singulares no que diz respeito à compreensão da diversidade de ofícios possíveis e às estratégias de associação com espécies de plantas; e, finalmente, a tese de Mariana Leal Rodrigues (2007) sobre a produção de remédios com plantas por parte de mulheres, organizadas na área rural Rio de Janeiro sob a "Rede Fitovida" trouxe outras experiências em rede de produção e intercâmbio de saberes terapêuticos relativos às plantas. 
Como tenho analisado na crítica à representação de e desde homens no campo de estudos sobre xamanismo na Amazônia, existe uma muito maior proporção de homens do que de mulheres neste campo, tanto desde a posição de sujeitx pesquisador quanto de sujeitxs retratadxs nas pesquisas. No caso da maioria masculina dxs sujeitxs de pesquisa, creio que é necessário trazer para a análise duas ferramentas: uma, a ferramenta da visibilização por meio do uso de categorias etnográficas; a outra, a questão da significatividade. Assim, quando nos aproximamos das pessoas que praticam as diversas maneiras de fazer com plantas, é possível observar que nem todas elas se reconhecem como xamãs. É, então, uma tarefa de visibilização do diverso que está aquém da categoria, excludente e limitante, de xamã no contexto em estudo. Por outra parte, é um fato da realidade que há muito menos mulheres do que homens que se autodefinam, explicitamente, como xamãs. Essa é uma interessante particularidade do campo cujas possíveis causas exporemos ao longo deste trabalho. Porém, ainda que haja poucas mulheres que se considerem xamãs, considero que a inclusão delas é importante em termos já não de representatividade - pois elas não fazem parte de uma maioria estatística -, mas sim de significatividade (Saltalamacchia, 1992), isto é, da sua importância para a compreensão do restante do contexto social em questão.

A antropóloga norte-americana Barbara Tedlock argumenta que, no caso dos estudos sobre xamanismo "a importância - não a primazia - das mulheres nas tradições xamânicas foi obscurecida e negada" (2008: 14). O ponto aqui é eminentemente qualitativo e pertence ao âmbito do que, nos campos do direito, da antropologia e do gênero tem sido reconhecido como o "direito à diferença": isto é, a atribuição positiva da particularidade ainda quando o grupo em questão não constitua uma maioria numérica. Em seu didático artigo sobre as estórias de 
vida, o pesquisador argentino Homero Saltalamacchia (1992: 17) aponta para os problemas da representatividade e da significatividade nas pesquisas:

El dato nunca es y nunca podrá ser lo real mismo. En tanto material simbólico, el dato es siempre una determinada estructuración de la realidad; la transposición de lo real a lo simbólico siempre representa un proceso de reducción, de síntesis y de atribución de sentido; en tanto dato, lo real es siempre un real construido. ${ }^{47}$

Desde essa perspectiva, a confiança na representatividade estatística como expressão direta da realidade social perde relevância. Desde a localização heurística que propõe às estórias de vida como método qualitativo de pesquisa social, o critério de representatividade na escolha das amostras não é excludente, nem sequer necessário. Por meio do uso da "teoria propia del objeto"48 (op cit: 7), isto é, das categorias locais, é possível conformar um desenho dinâmico da pesquisa onde a escolha das pessoas a serem entrevistadas seja orientada por critérios internos ao próprio campo. Levando em consideração que xs curiosxs de Tamshiyacu não são um grupo constituído por uma somatória de elementos homogêneos e independentes, é impossível aplicar para essa população um critério de representatividade que não violente a própria realidade social do coletivo. Desta maneira, a significatividade de um grupo de pessoas para uma pesquisa é relativa ao peso, não numérico nem necessariamente visível, da sua identidade nos termos do grupo social em questão.

Divergindo da proposta de estudos etnográficos centrados nas mulheres (ScheperHughes, 1992), e da minha própria etnografia com mulheres quilombolas do nordeste brasileiro (Echazú Böschemeier, 2014), tenho apostado aqui na

47 “O dado nunca é e nunca poderá ser o real mesmo. Em tanto que material simbólico, o dado é sempre uma determinada estruturação da realidade; a transposição do real ao simbólico sempre representa um processo de redução, de síntese e de atribuição de sentido; em tanto que dado, o real é sempre um real construído".

48 "Teoria própria do objeto". 
realização de uma etnografia levando em conta a relação entre homens e mulheres. Nos relatos locais sobre a dimensão de gênero nas práticas relativas às artes de curar e fazer magia da Amazônia peruana, encontramos divisões que são bastante claras. A médica limenha Rosa Giove, que mora na floresta peruana há décadas, salienta (Giove, 2001:36):

En el ámbito de la medicina tradicional, hay también una estratificación que discrimina el rol de la mujer: encontramos herbolarias, sobadoras y parteras que son aceptadas y actúan en forma similar a sus colegas varones, pero al buscar entre los que utilizan plantas "maestras" o de poder (chamanes, maestros, bancos, etc.), encontramos muy pocas mujeres ${ }^{49}$.

E continua, mais adiante (2001: 38$)$ :

Luego de ser ayudantes de sus maridos curanderos por muchos años, conocen y saben manejar el ritual, pese a que la mayoría permanece de por vida oculta en el papel de ayudante, de complemento. Algunas provienen de familias de curanderos, otras tienen capacidad innata, actúan ayudando a digerir los males que el curandero extrae, vomitan por él, acompañan con el canto sagrado (ikaro), equilibran la energía, muchas de ellas son muy visionarias y saben curar $^{50}$.

Quando as torna visíveis, a literatura sobre as mulheres tende a mostrar o lugar secundário que elas ocupam, à sombra dos homens e cumprindo tarefas de difícil categorização. São curadoras, cozinheiras, rezadeiras. Mudam de atividade perante as situações que se apresentam, não se especializam em um único ofício. Apesar de circularem nas ruas e nos espaços públicos, não circulam nos discursos oficiais do comércio turístico nem do Estado nacional. Evgenia Fotiou

49 "En el ámbito de la medicina tradicional, hay también una estratificación que discrimina el rol de la mujer: encontramos herbolarias, sobadoras y parteras que son aceptadas y actúan en forma similar a sus colegas varones, pero al buscar entre los que utilizan plantas "maestras" o de poder (chamanes, maestros, bancos, etc.), encontramos muy pocas mujeres".

50 "Após serem ajudantes de seus maridos curandeiros por muitos anos, conhecem e sabem como manejar o ritual, a pesar de que a maioria permanece a vida inteira oculta no papel de ajudante, de complemento. Algumas provêm de famílias de curandeiros, outras têm uma capacidade inata, atuam ajudando a digerir os males que o curandeiro extrai, vomitam por ele, acompanham com o canto sagrado (ikaro), equilibram a energia, muitas delas são muito visionárias e sabem curar". 
(2014) argumenta que, ainda que as mulheres não sejam "visíveis" (isto é, o fato de que haja poucas xamãs e muitas esposas ajudantes de xamã, atuando no segundo plano), isso não deveria levar a conclusões apressadas sobre uma "ausência putativa do feminino", ou ainda à falta de espaços de poder onde haja intervenção feminina. Como destaca a mesma autora, é preciso se trabalhar com um enfoque de gênero diversificado, que, sem excluir nem uma nem outra tendência, centre-se tanto nas complementaridades quanto nos conflitos entre gêneros. Desta maneira, o enfoque que proponho contempla às mulheres sem apagar a importante presença dos homens, resultando em uma etnografia centrada nas relações, nos vínculos, nos intercâmbios de e entre os gêneros. Por sua vez, nem mulheres nem homens estão sós: elxs se relacionam entre si em meio a uma diversidade de outrxs sujeitxs com xs quais estabelecem relações de afeto, cooperação ou inimizade: a água, a floresta, os mortos, as plantas.

Nesse ponto, quero salientar o papel experiencial que desempenham as plantas dentro das relações sociais do contexto pesquisado. $O$ interessante estudo da antropóloga Daniela Peluso sobre as relações de gênero no contexto das práticas terapêuticas e mágicas dxs curiosxs amazônicxs provê à etnografia desta autora um marco de compreensão baseado na fenomenologia e no perspectivismo (Peluso, 2014). Tanto aqui quanto em outras aproximações teóricas sobre formas de sociabilidade "pan-amazônica", a intencionalidade e a consciência formam a experiência de sujeitxs múltiplxs: humanxs, animais, plantas, espíritos, cada um com uma habilidade de ver aos/às outrxs de maneira diferente (Viveiros de Castro, 2004). A compreensão de formas costumeiras de transformação entre sujeitxs, multiplicidade e permeabilidade entre realidades permite enriquecer a presente aproximação às relações dos gêneros entre plantas. A antropóloga britânica Elisabeth Hsu convida a "be more open to a phenomenologically-inspired approach that takes seriously people's experience of plants and that focuses on the 
practices that people engage when they interact with plants"51 (2004: 92). Levando em consideração que tanto seres humanxs e plantas fazem parte do mesmo mundo, a minha pesquisa se volta para a inter-relação dxs sujeitxs humanxs com xs sujeitxs que habitam a forma das plantas. Considero que uma maior sensibilidade às experiências entre e com plantas permite captar, com maior delicadeza e profundeza analítica, as próprias experiências de vida dxs curiosxs de Tamshiyacu, aferradas às plantas como as trepadeiras a portentosas árvores.

Considerando os riscos de pretender o acesso privilegiado a um "universal feminino", a presente etnografia das relações de complementariedade e conflito entre gêneros (e destes, por sua vez, com as plantas) pode contribuir a relatar uma caleidoscópica história de diferenças múltiplas onde plantas, gênero e práticas mágicas e de cura se entrelaçam. Politicamente, uma maior visibilidade e compreensibilidade da complexidade deste campo são os objetivos desejados. Nesse sentido, assumo a responsabilidade sobre as condições nas quais é inscrita a presente história dentro das muitas outras histórias possíveis sobre gênero, terapias, magias e maneiras de fazer com plantas próprias da Amazônia do Peru, e xs convido a navegar por sua corrente.

\section{Curiosxs do povoado de Tamshiyacu}

Yo soy curiosa, me gusta mirar como es. Asteria Yauarcani, sobadora de lisiadxs de Tamshiyacu. Entrevista Agosto de 2013.

O estudo de caso consiste em uma análise compreensiva e em profundidade de um determinado grupo social, situada em um marco espacial e temporal determinado. As qualidades principais deste enfoque qualitativo são a

$51 \quad$ "Permanecer mais abertos a uma aproximação inspirada pela fenomenologia que tome seriamente as experiências das pessoas com as plantas, e que focalize nas práticas às que as pessoas aderem quando elas interagem com plantas". 
particularidade, a profundidade e a contemporaneidade. Para além das qualidades que diferenciam o grupo em questão a respeito de outros grupos e contextos sociais, os estudos de caso são janelas privilegiadas para conceber as dinâmicas de similaridade e diferença internas a cada grupo social. Através dos estudos de caso é possível seguir de perto o modo como as diferenças se transformam em desigualdade. A especificidade dos laços é o seu ponto forte. Um ponto fraco dos estudos de caso pode ser a excessiva atenção às minúcias do contexto, e a ausência de interesse na relação com os contextos maiores. Porém, um estudo de caso que se coloque em perspectiva - isto é, que elabore uma conexão entre relações locais, regionais e globais e suas mútuas dinâmicas de influência - coloca a seu favor os benefícios que a atenção ao detalhe e o particular trazem, ao mesmo tempo em que ganha perspectiva, pois não se perde sua conexão com processos mais amplos. Um estudo de caso como esse que é apresentado aqui, situado na globalidade de certos processos, permite conceder às chamadas "sociedades tradicionais" uma história "tan dinâmica y compleja como la de las restantes sociedades ${ }^{52 " ~(M a r t i ́ n e z ~ G o n z a ́ l e z, ~ 2009: ~ 214) . ~ V e j o ~ q u e ~ n a ̃ o ~ e ́ ~}$ possível falar, como consigna De Certeau (1998) "desde fora e desde cima" do espaço autêntico da chamada "medicina tradicional", impermeável às influências contemporâneas. Porém, é possível definir o campo dxs praticantes de terapias e magias em questão a partir de diferentes aproximações, sendo o desenvolvimento histórico das suas narrativas uma das mais importantes. Com a intenção de registrar essas narrativas, procurei centrar a abordagem naquelxs pessoas que nasceram e cresceram na floresta Amazônica do Peru e que se constituíram como curiosxs a partir dos mais diversos itinerários de vida.

52 "Tão dinâmica e complexa como a das restantes sociedades". 
Nessa aproximação, ainda que se lance mão de categorias de análise, não se deixa de contemplar a permeabilidade, a maleabilidade e o caráter mutável das mesmas através do tempo, característica prístina de qualquer atividade humana que, como a medicina popular, se encontrou historicamente à margem de processos de formalização. Como afirma o médico peruano Fernando Cabieses (1993: 168):

Son los especialistas (...) que no trabajan a tiempo completo. Solamente [trabajan como tales] cuando alguien se enferma, o va a parir o se torció un tobillo ${ }^{53}$.

Em uma análise realizada dentro de um tom similar, Gustavo Pacheco comenta para o caso da pajelança maranhense (2004: 153):

O pajé aproxima-se de uma série de outros especialistas com quem pode compartilhar muitas funções, conforme a inclinação e as aptidões de cada um (parteiras, benzedoras, experientes, remedistas etc). Estabelecer uma taxonomia rígida desses agentes seria extremamente empobrecedor na medida em que obscureceria o diálogo e a circulação constante existente entre eles às custas da reificação de categorias cuja autonomia nem sempre é reconhecida por seus praticantes e clientes.

Martín Ibáñez-Novión (2012) recolhe, para seu estudo de caso sobre cuidados domésticos no Noroeste de Minas Gerais, uma diversidade de dezesseis nomes diferentes para se referir às diversas práticas e especialidades médicas populares (pp. 166-167):

Protomédico, entendido protomédico, dentista prático, enfermeiro popular, entendido, raizeiro farmacêutico, parteira empírica, parteira benzedeira, raizeiro médico, médico popular, anatomista popular, rezador, rezador chazeiro, exorcista, curador rezador e curador ad-exorcista.

Interessa aqui o fato de um trabalho antropológico apontar o seu olhar para categorias vernáculas e admiti-las como possibilidades de análise. Essa

53 "São os especialistas (...) que não trabalham a completo. Somente [trabalham como tais] quando alguém adoece, ou vai a parir ou torceu o tornozelo". 
diversidade abre os sentidos para um sutil território, pouco formalizado e muito perto das vidas cotidianas das pessoas que não são especialistas. De acordo com a classificação do autor, essas ocupações fazem parte do subsistema laico de cuidados em saúde, que é aquele onde "se processam as primeiras ações em saúde, onde se tomam as decisões inerentes à crise, ao mal-estar ou ao distúrbio, onde se desencadeia o processo de significados individuais, familiares e comunitários" (op. cit, p. 169). O fato de pertencer a um espaço de práticas sociais tão próximas do cotidiano faz com que as práticas dxs "especialistas" populares tendam a ser ofícios flexíveis, fundidos com outras ocupações. Enfatizando a maleabilidade dos ofícios, elxs podem também ser denominados, segundo Sidky (2010), "parttime ritual intercessor ${ }^{\prime \prime}{ }^{54}$. Entre especialistas e não especialistas há a possibilidade de observar uma paisagem comum que une as duas classes de pessoas: $o$ território do popular.

É particularmente árduo encontrar a linha que separa entre especialistas e não especialistas no caso das mulheres. Muitas delas não se chamam a si mesmas como curandeiras e, menos ainda, como chamanas. Às vezes, a procura de um nome que materialize no discurso verbal a sua ocupação não é interessante em si mesma, mas enquanto uma possibilidade de descobrir paulatinamente as sutis conexões destas mulheres com práticas relativas a cuidar, curar e fazer magia com plantas, na sua hibridação com as outras tarefas da vida cotidiana.

É oportuno colocar aqui que o termo curiosx emergiu da dinâmica heurística do próprio estudo de caso. Durante a trajetória desta pesquisa, escrevi artigos e trabalhos de finalização de curso usando, para o mesmo campo, a categoria xamãs (Echazú Böschemeier, 2012). O caso é que acabei abandonando-a como categoria analítica por ter observado que era muito parcializada, mas continuei

54 "Intercessores rituais de tempo parcial". 
valendo-me dela como categoria nativa em casos específicos. Os novos avanços na pesquisa foram redigidos sob a denominação de curanderxs (Echazú Böschemeier, 2013b). Na medida em que se aprofundava meu contato com o campo, essa categoria apresentou, assim mesmo, limitações. Ela aparecia como sendo pouco representativa da diversidade social que eu pretendia esboçar, pois uma mínima percentagem das pessoas que trabalhavam com terapias e magias nesse contexto se auto-definia como curanderx, e muitas vezes a negação do pertencimento a essa categoria era explícita e radical - mais adiante apresentarei os casos específicos que delineiam esse problema. Foi assim que preservei a categoria de curanderx exclusivamente com aquelxs que assim se denominam. Mas como fazer fidedigna referência à diversidade?

Somente após vários meses de trabalho de campo me apareceu o conceito local de $\operatorname{curios} x$, categoria com a qual, como comprovei, a totalidade dxs praticantes que conheci eram capazes de se auto-identificar. Não sendo essa nitidez numérica suficiente, o conceito aparecia, ademais, como muito rico: ele trazia a imagem de um tipo de olhar dirigido para o mundo, uma forma de contemplação ativa, guiada pelo constante desejo de saber, de tocar, de movimentar objetos, de influenciar pessoas, de cultivar afetos e afetações. Para além da denominação mais ampla de curiosx, encontrei outras denominações, que contemplavam, além de xamãs e curandeirxs, outrxs especialistas como purguerx, sobador/a [de mulheres grávidas], sobador/a de lisiadxs, naturalista, yerberx e parterx, todas as que desenvolverei ao longo desta tese. Por sua vez, para chamar às pessoas que se consultam com essxs especialistas escolhi a categoria local de pacientes, denominação profusamente estendida no local. Nesse caso, igualmente, preferi lançar mão de categorias locais em vez de extrapolar conceitos "desde fora e desde cima" do próprio contexto social em estudo. 


\section{- Reconhecendo a magia para além do território da cura.}

Nesse ponto, apresentarei: a) uma breve incursão nas ideias sobre a magia desenvolvidas pelo campo de estudos da antropologia, b) a proposta de não dissociar as dimensões do mágico e do terapêutico na prática dxs curiosxs em estudo, c) um comentário a respeito do interesse na noção de perturbação, e d) uma definição das categorias descritivas de intenção terapêutica e intenção etótropa desenvolvidas nesta tese.

As discussões sobre magia dentro da área da antropologia remontam mesmo a seu início, quando a magia era considerada parte do chamado "pensamento irracional" dos povos tribais, um tipo de racionalidade qualitativamente oposto ao pensamento racional ocidental. O antropólogo inglês Edward Tylor definiu que o animismo - a prática social de considerar que os objetos possuem uma alma - como a forma mais antiga de religiosidade existente, uma sobrevivência de um passado menos evoluído. Outro antropólogo inglês, James Frazer, colocou a magia dentro de um esquema onde a ela própria, junto com a religião e a ciência faziam parte de uma escala evolutiva, tornando-se a primeira uma versão preliminar da segunda e da terceira e, retrospectivamente, uma "ciência bastarda" (Pacheco, 2004). Por sua vez, os humanistas Émile Durkheim (18581917) e Marcel Mauss (1872-1950) viram a magia como um conjunto de crenças de caráter intrinsecamente imoral e antissocial, em contraste com a religião, que criaria coesão social e solidariedade dentro das comunidades (Namba Walter, 2004). Esse critério foi sendo modificado em virtude de uma crítica do que se compreendeu como uma ideia feita sob o molde limitado dos modelos judeucristãos de percepção do sagrado e o extraordinário (Wilhelmi, 2004). Outros antropólogos britânicos que se dedicaram a escrever teoria no início do século XX apresentaram uma visão um tanto mais positiva da magia: compreenderam 
seus aspectos sócio-integrativos (Evans-Pritchard, 1937) e a apreciaram a magia como conjunto de técnicas com funções psicológicas e cognitivas inerentes ao conjunto da humanidade (Malinowski, 1948). Por sua vez, discussões mais recentes sobre a magia a colocam como uma forma de expressão de conexões sociais entre coisas e pessoas. Nesse contexto, determinadxs sujeitxs podem ter extraordinário poder de influência sobre outrxs sujeitxs, mediados por objetos e comportamentos à distância (Rasmussen, 2004). De maneira recente, a maior parte dxs estudiosxs da área assumem uma prévia desconstrução do modelo evolutivo dos conceitos de magia, religião e ciência, compreendendo-os como definições parciais próprias dos construtos de saber da modernidade europeia, e questionando qualquer esforço para definir diferenças taxativas entre os três sistemas (Tambiah, 1990). De maneira transversal com essas discussões, a proposta de Mircea Eliade foi similar à dos franceses Durkheim e Mauss: embebido explicitamente do marco moral cristão, Eliade postulou a existência do "xamanismo" como maneira de se diferenciar da bruxaria, considerando a segunda como uma "magia nociva", "arte obscura" ou "sortilégio prejudicial", que promove vinganças e outras atitudes consideradas moralmente negativas (Wilhelmi, 2004). Em um esforço de distanciamento de qualquer apreciação moral automaticamente etnocêntrica das práticas mágicas sob estudo, eu escolho, junto com Rasmussen (2004: 162), uma definição ampla ao mesmo tempo em que instrumental da magia, definida, sobretudo, a partir de conexões de força entre práticas:

The principles of what is called magic involve the manipulation of natural forces along a network of (...) interconnections by symbolic projections of power ${ }^{55}$.

55 "Os princípios do que se chama de magia envolvem a manipulação de forças naturais dentro de uma rede de conexões (...) dispostas por projeções simbólicas de poder". 
Contudo, no contexto das práticas dxs curiosxs que são sujeitxs desta pesquisa, há uma importância equivalente das noções sobre o terapêutico, isto é, aquilo que está referido à prevenção, cuidado paliativo ou cura de perturbações do corpo individual ou social. É nessa dimensão que o segundo ponto desta proposta se afinca. De acordo com o Dicionário Etimológico Português, a palavra terapia vem do grego therapeia, que significa "curar, sarar, fazer um serviço aos doentes, cuidar de". Aqui podemos incluir tanto aspectos relativos à prevenção, cuidados paliativos e/ou cura de perturbações. Curar é relativo à instrumentalização dos meios necessários para o restabelecimento da saúde de um organismo; prevenir se refere a preparar com antecipação o que é necessário para evitar uma situação indesejada ou doentia e, finalmente, paliar se vincula com a melhora, por meio de técnicas de acompanhamento, de situações de doença cuja cura não é mais tida como possível.

Os elementos de uma terapêutica integral são fundamentais na prática diária dxs curiosxs que a presente etnografia tem acompanhado. Porém, eles não são os únicos móveis que estimulam as suas decisões cotidianas. Magias e terapias convivem, emprestando técnicas, diagnósticos e motivações umas às outras. Da mesma maneira, analisa o antropólogo Thomas Csordas em contextos de "cura espiritual" nas igrejas carismáticas norte-americanas (1985: 1),

[I]t cannot be assumed a priori that an adequate account can be given by focusing only on the 'medical aspect' or 'clinical implications' of a phenomenon that also has an overt 'religious aspect' or 'spiritual-aesthetic implications'. Given the cross-cultural prevalence of religious healing, the ubiquitous interrelation of religion and healing, and the fact that both religion and medicine address basic existential problems of life and death, a complete account of religious healing, then, must not only examine the construction of clinical reality with respect to medical motives, but also the construction of sacred reality with respect to religious motives ${ }^{56}$.

56 "Não pode ser assumido a priori que uma descrição possa ser realizada adequadamente focalizando somente os 'aspectos médicos' ou bem as 'implicações clínicas' de um fenômeno que possui abertamente um 
Xs praticantes de magias e curas de Tamshiyacu, da mesma maneira, ativam seus itinerários laborais em um terreno altamente produtivo que alia espiritualidade e medicina, isto é, o que aqui chamo de terapias e magias. Elxs campeiam em fenômenos que muitas vezes ostentam essas duas faces e cujas dimensões não são passíveis de serem reduzidas entre si. A proposta é aqui fazer uma leitura etnográfica que permita o acesso tanto a uma dimensão quanto à outra, sem assumir, a priori, a preponderância de nenhuma delas.

Um conceito que colabora com uma percepção mais ampla dos processos terapêuticos e mágicos aplicados às/aos sujeitxs é o de perturbação (Duarte, 1986; Duarte, 1998). De caráter genérico, essa noção inclui as diversas modalidades de doenças e enfermidades físico-morais e também outros tipos de aflição e infortúnio, tais como problemas familiares e afetivos, perda de uma posição laboral, objetos ou animais perdidos ou roubados. De acordo com o antropólogo Luiz Fernando Dias Duarte, o conceito tem "um caráter de mediação entre a corporalidade e as demais dimensões da vida social" (Duarte, 1998: 22).

Para além da busca de remédios utilizados com a finalidade de eliminar distúrbios no nível do corpo individual, isto é, com a intenção de procurar a saúde e combater a doença, xs curiosxs praticam terapias e magias que se expandem e desconstroem as fronteiras do corpo individual $\mathrm{dxs}$ suas/seus pacientes. As técnicas utilizadas para combater ou evitar as perturbações podem ser guiadas por intenções tanto terapêuticas quanto etótropas (e, às vezes, pelas

'aspecto religioso' ou 'implicações estético-espirituais'. Dada a prevalência de curas religiosas entre culturas, a inter-relação geral entre religião e cura, e o fato de que as duas se confrontam com problemas de vida e morte, uma descrição completa das curas religiosas deve, então, não somente examinar a construção de uma realidade clínica baseada em motivos médicos, mas também a construção de uma realidade sagrada baseada em motivos religiosos". 
duas ao mesmo tempo). Chamo aqui de intenção terapêutica àquele intuito de prevenir, paliar ou curar que guia as ações orientadas para o tratamento de perturbações. Chamo aqui de intenção etótropa àquele intuito que orienta as ações dxs curiosxs para influenciar outras pessoas através do conjuro mágico.

Escolhi não falar diretamente em práticas terapêuticas e práticas etótropas porque me parecia importante sublinhar o poder de agência dxs curiosxs no contexto da dinâmica das magias e curas. Desta maneira, a ideia de falar em uma intenção terapêutica e em uma intenção etótropa se situa na vontade $\mathrm{dxs}$ curiosxs mais do que nos resultados vindos da sua própria prática, eventualmente tingida por essas intenções. Desta maneira, o foco da análise continua na intenção, primeiro passo no movimento de realidade criado pelx curios $x$ em seu contexto imediato. Inspiro-me na ideia de etótropo a partir da proposta do pesquisador francês Jacques Tournon (2006), que assim denomina certo tipo de plantas utilizadas pelxs unayas shipibo da Amazônia peruana. Ele chama de etótropas àquelas plantas que são preparadas com a finalidade de modificar o comportamento dxs outrxs, seja para atrair, atacar, ensinar, fortalecer, esquecer, apaixonar, engravidar ou matar. São vegetais que têm um poder especial sobre o mundo humano: elas fazem fazer. A intenção etótropa pode ser compreendida como uma força que empurra determinada ação, seja ela atrativa, criativa, repelente ou destrutiva.

Como comentei anteriormente, as práticas mágicas foram denegadas, por diversos motivos, durante a constituição histórica do campo de estudos sobre o xamanismo. Porém, elas definem, em grande parte, a dinâmica da medicina amazônica. Em seus estudos sobre o dark shamanism [xamanismo obscuro], Neil Whitehead (2004) destaca a importância de magias obscuras, secretas, de vinganças, da produção de perturbações como parte cotidiana - porém secretas 
- de curiosxs amazônicos. No curandeirismo mestiço amazônico, o fato de tentar afetar o corpo e a vontade $\mathrm{dxs}$ outrxs à distância confirma a existência de um mundo relacional onde as pessoas não estão restritas ao âmbito físico dos seus corpos, e se estendem para além deles, fundindo-se com elementos específicos de seu ambiente. Nessa concepção, há uma relação inevitável entre certxs sujeitxs humanxs, certas plantas, determinadxs animais, que propiciam esquemas de complexas relações de companheirismo, inimizade, ciúmes, colaboração ou oposição. Nesse contexto, o trabalho dxs curiosxs é de mediação e se realiza na comunicação entre línguas humanas, vegetais, animais ou elementares, cujas naturezas são díspares entre si.

Dentro do contexto em estudo, há muitas técnicas que revelam uma intenção etótropa, a vontade de fazer fazer. No caso dos amarres de amor, afeta-se a vontade da pessoa que se quer ao próprio lado. No caso das curas contra o cutipado, as que se vêem afetadas são as vontades dos animais. No caso da cura contra o mal de aire, são influenciadas as vontades de espíritos indesejados. Fronteira fluida entre as duas categorias, pois algumas ações que consideraríamos terapêuticas podem ser lidas desde uma perspectiva rápida e externa, por sujeitxs do próprio grupo, como mágicas.

$\mathrm{Na}$ prática, tanto a intenção terapêutica quanto a intenção etótropa se contaminam mutuamente, impedindo classificações rígidas e externas. Desta maneira, há perturbações que podem parecer requerer tratamento terapêutico e serem, de fato, causadas pela ação mágica vinda de uma intenção etótropa. Ao contrário, há doenças que parecem ser causadas por uma ação mágica e, porém, pertencem ao território das doenças causadas pelo desejo divino. Ainda quando as duas práticas possam se misturar mutuamente, a diferenciação se mantém, no nível local, no reconhecimento do mal de dios e mal de gente. As pessoas da 
localidade chamam de mal de dios àquela perturbação vinda do desígnio divino, e que só pode ser tratada a partir da ação de uma intenção terapêutica. Por sua vez, chamam de mal de gente àquela perturbação causada por uma intenção etótropa. Uma parte fundamental do trabalho dx curiosx é determinar de que tipo de mal ou perturbação se trata, para poder realizar os tratamentos que estejam de acordo com a natureza do mesmo.

Nesse ponto particular, introduzi os motivos pelos quais considero necessária uma integração das dimensões do mágico e do terapêutico na prática $\mathrm{dxs}$ curiosxs em estudo, colocando o valor da noção de perturbação como um conceito que inclui fenômenos que estão além das fronteiras do corpo individual e trazendo para a análise as categorias de intenção terapêutica e intenção etótropa como ferramentas de utilidade no momento de compreender diferenças que definem o curso que terão os tratamentos dxs curiosxs em questão.

\section{- As outras plantas}

Na crítica à construção da centralidade da ayahuasca no contexto das práticas relativas a terapias e magias da Amazônia peruana, apresentei algumas metáforas que se referem à compreensão do eu, do corpo e das fronteiras do corpo para a racionalidade moderna, enfatizando certa tendência à compulsão pela ingestão por parte de estudiosxs de terapias e magias da floresta. Assumo

que a extrapolação deste modelo se torna visível na exclusividade atribuída à planta da ayahuasca e à sua ingestão como privilegiadas maneiras de fazer com plantas no contexto do turismo xamânico peruano.

No que diz respeito às/aos curiosxs com xs quais foi realizada essa pesquisa, proponho aqui abrir uma sensibilidade etnográfica para a inclusão de outras 
plantas e também maneiras diversas de se relacionar com elas. Desta maneira, atento aqui para um olhar perceptivo de: a) a existência de uma diversidade de outras plantas na própria beberagem da ayahuasca, b) o fato de que a ayahuasca não precise sempre ser bebida pelo paciente e que quem a beba seja $\mathrm{x} \operatorname{curios} x ; \mathrm{c}$ ) a variada significação da bebida da ayahuasca na localidade, para além de seu uso terapêutico; e finalmente d) a organização interna de um modelo local de classificação por gêneros da diversidade de plantas preparadas, dividido entre os palos e as hierbas.

Como afirmei anterioremente, ayahuasca é o nome de uma planta, a Banipsteriosis caapi na taxonomia botânica, e também é o nome de uma bebida que, podendo conter outras plantas, possui duas plantas como núcleo básico de ação: a Banipsteriosis caapi e a Psychotria viridis. Dentro das áreas da botânica, a neuropsicologia e da antropologia abundam as pesquisas sobre a primeira, enquanto que a segunda, aliada básica na produção do efeito psicoativo da beberagem, tende a permanecer silenciada. $\mathrm{O}$ pesquisador mexicano Oscar Calavia Sáez (2014: 10) comenta:

Esa identificación es paradójica, ya que el poder visionario de la poción reside precisamente en el ingrediente no marcado, la psychotria, limitándose la acción de la banisteriopsis, en lo que toca a visiones, a evitar que el principio activo de la psychotria sea neutralizado por las enzimas del estómago (...). Fuera de la selva, una larga tradición cristiana y platónica habría conducido la imagen y la visión al centro de la experiencia de la ayahuasca $^{57}$.

\footnotetext{
57 "Essa identificação é paradoxal, devido a que o poder visionário da poção reside precisamente no ingrediente não marcado, a psychotria, se limitando a ação da banisteriopsis, no que tange às visões, a evitar que o princípio ativo da psychotria seja neutralizado pelas enzimas do estômago (...). Por fora da floresta, uma longa tradição cristã e platônica haveria conduzido à imagem e à visão ao centro da experiência da ayahuasca".
} 
Não arriscarei aqui uma hipótese sobre a origem plausível da exaltação da Banipsteriois caapi e do simultâneo esquecimento da Psychotria viridis na bebida, mas é interessante assinalar que a questão das visões, do visual, até do visionário, são traços muito enfatizados nas aproximações contemporâneas à beberagem. A procura de visões por parte dos turistas em contextos de turismo xamânico faz com que um ingrediente, a planta do toé [Brugmansia suaveolens], seja usado cada vez com maior frequência. A diferença da Banipsteriosis e da Psychotria, o toé é uma planta com um alto grau de toxicidade e pode, em doses elevadas, deter a circulação de fluidos no corpo levando, eventualmente, até a morte. Por sua vez, o toé tem sido tradicionalmente uma planta acessada em situações de magia ou cura secretas, como bruxaria, possessões, roubos ou encantamentos. É possível que a "necessidade da visão" que identifico tanto na fala dxs turistas xamânicxs quanto na própria constituição do campo de inteligibilidade do xamanismo sobre a Amazônia peruana tenha pressionado às/aos curiosxs na direção de introduzir o toé de forma cada vez mais indiscriminada.

A introdução de outras plantas além dessas duas também é frequente no preparo. A antropóloga norte-americana Marlene Dobkin de Rios (1972) apresenta em um artigo uma lista de mais de 50 possíveis tipos de composição beberagem da ayahuasca. Por sua vez, o antropólogo peruano Roger Rengifo Ruiz (2012) constatou a visão de um curioso dos arredores de Iquitos, que confirma a existência de umas cinco mil misturas da bebida ayahuasca, elaboradas conforme a necessidade dxs consulentes.

A ayahuasca é um vegetal com vastos usos além do terapêutico. $\mathrm{Na}$ região amazônica, a ayahuasca é compreendida popularmente como um "remédio", coisa que envolve uma ampla variedade de usos possíveis: como forma de saber 
o que acontece em outros tempos e locais, como veículo de intercessão frente a espíritos que assediam as pessoas, como maneira de fazer retornar ao ser amado, como indicador de possíveis inimigxs ou roubos, como entidade orientadora na direção de bons territórios para a caça ou mesmo um guia para novos empreendimentos comerciais (Albuquerque, 2009; Echazú Böschemeier, 2013b). A ayahuasca, por sua vez, se insere em uma multiplicidade exuberante de outras plantas e formas de vínculo com as mesmas. Em um livro com entrevistas editadas pela norte-americana Geraldine Overton, afirma o xamã peruano José Campos (2011: 94):

What I do often in my dietas is to concentrate on a variety of plants. Sometimes ayahuasca is not involved at all. I just want to know how a particular combination of plants works ${ }^{58}$.

Na percepção dele, a ayahuasca não se constitui como o centro das práticas: ela vem acompanhada de uma multiplicidade de outras plantas, que podem trabalhar sozinhas ou combinadas, sendo cada combinação única. De fato, contemplar no plural as maneiras como xs curiosxs trabalham com as plantas abre as possibilidades para mundos fascinantes de contato, hibridismo e mútua afetação. Na presente pesquisa, prefiro evitar os termos uso e consumo de plantas para privilegiar aqueles que estão mais sintonizados com as práticas locais, como acesso, procura e comunicação, assim como aquele, mais empírico, de preparação. Por sua vez, a comunicação com a planta não acontece somente no momento da ingestão. Às vezes, ela não é sequer necessária. $\mathrm{O}$ entendimento local da comunicação com as plantas por parte dxs curiosxs assume a forma de uma conversa incorporada com as plantas, que habilita a falar com aquelas que se conhece porque existiu um contato prévio com elas. Como destacou Langdon (2013) para o contexto colombiano, e pude conferir no trabalho de campo, para

58 "O que eu faço frequentemente nas minhas dietas é me concentrar em uma variedade de plantas. Às vezes, a ayahuasca não tem nada a ver. Eu somente quero ver como é que trabalha uma particular combinação de plantas". 
realizar o diagnóstico de uma perturbação ou o reconhecimento de um dano, muitas vezes a ayahuasca não precisa ser bebida pela pessoa afetada. A beberagem da ayahuasca aparece, porém, como sendo bebida somente pelx curiosx. Essa concepção demonstra que há outras maneiras de comunicação com a planta, que podem ser mediadas pelx curios $x$, ao mesmo tempo em que há uma relação histórica, um vínculo de longo prazo com as plantas que só é possível a partir do trabalho solitário e pessoal - sobretudo, no caso daquelxs que trabalham com palos -, como veremos adiante.

Comunicação, acesso, vínculo, visão, fala, escuta ativa: um/a especialista pode fazer vibrar ou rugir um ramalhete perto da coroa da cabeça para espantar os maus espíritos, litros de uma infusão combinada de flores podem se jogar ao corpo em baños floridos para atrair o olhar do ser desejado, um fruto desfeito na água pode se deixar apodrecer e jogar na cabeça, no porto ou em uma interseção de caminhos, durante a lua nova com a finalidade de tirar de si próprix um ciclo de infortúnio. Outras plantas podem se aplicar em friç̧ões para tirar o frio do corpo, colocar como emplasto sobre a pele para diminuir o inchaço, amarrar com um tecido preto para fazer desaparecer um mal localizado em uma parte específica do corpo. Outras plantas podem ajudar à saúde vaginal através de baños de asiento [assento], ou mesmo em vaporizaciones [vaporizações]. Finalmente, o fruto de uma planta pode ser pendurado perto de uma fonte de calor como o fogão da cozinha. Ao secar, secará também o tumor ou abcesso que afeta o corpo.

As maneiras de fazer dxs curiosxs de forma conjunta com as plantas locais são muito particulares, diversas e dinâmicas, mas há alguns princípios que as norteiam. Um deles é a relação entre as qualidades frio-quente de sujeitxs e coisas; outro é o relativo aos palos e às hierbas. Nesse trabalho, apresentarei a 
questão do frio e do quente somente de maneira marginal, dedicando-me à relação local entre gênero, tipos de doença, especificidades do ofício e conjuntos de plantas, isto é, na metáfora, altamente produtiva no meio local, da divisão do mundo entre palos e hierbas. A ideia de trazer para a análise essa classificação surgiu das conversas com curiosxs locais, a partir da importância que ela mostrou ter na definição das maneiras em que xs curiosxs tratarão as perturbações e, ainda de maneira mais definida, delimitarão o acesso ao mundo das plantas pela via do gênero. Assim, as mulheres terão um acesso mais direto ao mundo das hierbas, configuradas pelas plantas que se cultivam em jardins, hortas ou chacras, enquanto que os homens caminharão com mais liberdade no espaço dos palos, isto é, das plantas que habitam os limites da floresta. O contato com um ou outro mundo propicia conhecimentos diferentes, práticas diversas, possibilidades de tratamento variadas e maneiras de se relacionar com xs pacientes específicas em cada um dos dois casos.

Recapitulando o último ponto referente a esse capítulo, a intenção aqui foi a de sublinhar, primeiro, que a ayahuasca não é a única planta presente no preparo da bebida. Podem existir muitas outras, que podem ou não serem colocadas junto com a ayahuasca dentro da própria beberagem. Além do mais, há uma incrível multiplicidade de combinações de plantas possíveis, combinações nas quais xs curiosxs trabalham de maneira experiencial, através do estabelecimento de relações históricas com certas plantas ou certas combinações de plantas. Também, as plantas não são somente ingeridas, existindo uma ampla diversidade de outras formas de comunicação com plantas. Finalmente, o esquema local dos palos e das hierbas é um ponto de referência que pode ajudar a compreender algumas das variáveis a partir das quais se estabelecem certos circuitos de comunicação entre $\mathrm{x}$ curiosx e determinadas plantas, dando forma às 
diversas maneiras de fazer com plantas que elxs costumam praticar no seu diário afazer.

\section{- O mito desconstruído}

Apresentei no capítulo primeiro e nesse, o segundo capítulo desta tese, um esforço de desconstrução deste retrato caricaturizado dxs praticantes de magias e terapias da floresta amazônica do Peru, que escolhi chamar aqui do mito do "homem-chamã-que-cura-com ayahuasca". Desse modo, a) à critica da invisibilização das mulheres no campo de estudos sobre o xamanismo correspondeu a proposta de uma etnografia das relações de gênero entre plantas; b) a avaliação dos limites do conceito de xamanismo foi seguida da proposta de uma aproximação sobre as maneiras de fazer com plantas através do uso do conceito local de curiosx, surgido no marco do próprio estudo de caso; c) à critica da higienização das práticas foi sugerida a inclusão analítica das dimensões do terapêutico e do mágico em pé de igualdade, propondo os conceitos de perturbação assim como da díade práticas terapêuticas/práticas etótropas; e finalmente d) como consequência da crítica da centralidade da ayahuasca para o campo de estudos sobre o xamanismo na floresta Amazônica do Peru, propus a inclusão de uma diversidade de práticas: a existência de diversos preparos com outras plantas, dentro e fora da beberagem da ayahuasca, a multiplicidade de aplicações e de maneiras de se relacionar com a própria ayahuasca, por parte $\mathrm{dxs}$ curiosxs da localidade, e finalmente a divisão entre palos e hierbas, condicionante por excelência das experiências pessoais dentro das categorias de feminilidade e masculinidade socialmente subscritas. Por fim, nenhuma das propostas aqui elaboradas pode ser ratificada sem uma etnografia que as alimente, as interpele e eventualmente, as possa retratar. $\mathrm{O}$ restante do conteúdo da presente tese está dedicado a navegar na etnografia das 
práticas dxs curiosxs de Tamshiyacu guiados pelas ferramentas de compreensão aqui propostas.

\section{Parte II: Multiplicidades}




\section{Capítulo 3 Oficina do campo}

- Mergulho no campo • Narrativas de vida, entre a biografia e o estudo etnográfico • Isabel: ela se conta, eu a escrevo, nós criamos (o texto) • O acesso a outros espaços e sujeitxs • Formas de compromisso corporal em campo

\section{- Mergulho no campo}

A primeira viagem que realizei para a Amazônia do Peru foi em janeiro de 2012. O meu primeiro destino era a cidade de Tarapoto, na alta Amazônia peruana, no sudoeste do país. Naquele momento, tinha o intuito de realizar etnografias em centros xamânicos que trabalhavam com cerimônias de ayahuasca e que faziam tratamentos terapêuticos com outras plantas. Naquela cidade conheci três centros: Takiwasi, Situlli e Sonccowasi, e tive a possibilidade de conversar com outros curandeiros na casa deles. No centro de recuperação de dependências químicas Takiwasi, que realiza seus tratamentos com o apoio das plantas amazônicas, compartilhei algumas experiências coletivas com xs pacientes, dentre elas cafés da manhã, confecção de pão, confecção de uma placa de madeira e "matutinas" - como se denominam as reuniões grupais com terapeutas. Ali entrevistei pacientes e terapeutas; e fiz também, à maneira de contraprestação pelo uso do espaço com as pessoas de Takiwasi, uma oficina sobre autopercepção corporal a partir da experiência com plantas amazônicas por parte dos pacientes da instituição. Também me foi permitido fazer uso da biblioteca Takiwasi, com mais de cinco mil exemplares relativos à saúde mental, medicina 
amazônica, dependências químicas, curandeirismo, terapias alternativas e outros tópicos afins. Lá tive a oportunidade de conhecer dois antropólogxs que trabalhavam questões similares às minhas (Victor, do Uruguai e Melissa, da França) e também de fazer, em algumas ocasiões, trabalho de campo acompanhada de Melissa. Junto com Melissa, fiz uma viagem para um centro xamânico chamado Situlli, que se encontrava afastado uns cento e cinquenta quilômetros de Tarapoto, onde chegamos depois de três horas de taxi lotação, meia hora de barco e meia hora caminhando. Permanecemos hospedadas lá durante três dias junto com outras pessoas que iam à procura de diferentes tipos de "experiências", "curas" e "desenfeitiçamentos"; participando integralmente de uma purga coletiva e uma cerimônia com ayahuasca. Além do trabalho nos centros, participei da vida da cidade visitando o mercado, o museu de folclore local, bares, restaurantes, locais de venda de plantas amazônicas e lojas de artesanatos. Finalmente, realizei uma pesquisa exploratória na biblioteca municipal, atenta especialmente aos jornais e livros de autores exclusivamente locais ou regionais.

Na segunda viagem para Iquitos, em setembro de 2012, tive a possibilidade de demarcar com mais força o objeto de meu trabalho. Como tinha percebido naqueles centros xamânicos uma preponderância de curandeiros e especialistas masculinos, interessou-me encontrar curandeiras mulheres para observar e reconhecer como era o seu trabalho relativo à ayahuasca e outras plantas amazônicas. Além disso, queria conhecer o acesso a outras plantas além da ayahuasca, que me parecia obsessivamente destacada pelxs turistas e guias do turismo xamânico. Interessei-me gradualmente, e de forma cada vez mais viva, pelas formas de curandeirismo popular que se desenvolviam nas margens destes circuitos rápidos de forte interação intercultural e tão carregados de pressupostos, projeções e estigmatizações. Desta maneira, conversando com as 
pessoas da localidade, consegui o contato da dona Pasquita, curandeira ayahuasqueira e parteira da localidade de El Chino, que fica a quinze horas da cidade de Iquitos por barco, surcando o rio Tahuayo na direção oeste. Contatei à Walter, genro de Pasquita, que me deu as informações básicas para chegar. Foi assim que me aventurei pelo rio. Fiquei quatro dias na casa de Pasquita, na companhia de Walter, sua esposa Lídia, suas filhas Doyli e Gabriela e a própria Dona Pasquita, com seus noventa e poucos anos impressos em cada um de seus gestos. Dias depois, a partir do contato com a antropóloga norte-americana Marlene Dobkin de Rios e o colega dela, o jornalista de Iquitos, Roger Rumrill, marquei telefonicamente um encontro com Isabel. Roger Rumrill a conhecia, e me falou que poderia ser uma pessoa que traria insumos significativos para essa pesquisa. Nesse mês de setembro de 2012, passei uma tarde com Isabel, tempo em que ela e seu filho Gerlyn me levaram caminhando para conhecer o acampamento delxs. Voltei em Fevereiro de 2013 para ficar perto dela durante o restante do trabalho de campo, morando durante alguns meses no seu albergue, Mundo de la Yacuruna.

Além de Isabel e de algumas pessoas próximas a ela (seu companheiro Jorge, seus/suas filhxs Jenny, Gerlyn e Jordi, seus netos José e Diego), tive a possibilidade de conhecer pessoalmente um total de sessenta e uma pessoas vinculadas a terapias e magias populares. Dentre elas, vinte e duas são as que tive a possibilidade de conhecer com maior qualidade de tempo: Isabel, Adela, Pasquita, Zoila, Maria, Bernardina, Milena, Asteria, Anita del Carmen, Betina, Corina, Agustín, Lucho Jorge, Luis, Moisés, Tocayo, Leoco, Marcos, Gerlyn, Ernesto e Julio. Todxs elxs se autoclassificam como curiosxs. Por sua vez, também se entendem como curanderxs, chamanxs, vegetalistas, médicxs tradicionais, purguerx, sobadorxs [de mulheres grávidas], sobadorxs de lisiadxs, parterxs, naturalistas e/ou yerberxs. Todxs elxs praticam as mais diversas maneiras de fazer com plantas: 
enquanto alguns delxs trabalham com ervas, outrxs o fazem com palos; enquanto algumas pessoas cobram em dinheiro pelos seus serviços, outras o fazem somente através do intercâmbio de pequenos bens, e outras aceitam as duas maneiras. Enquanto algumas trabalham somente com pessoas da sua família ou vizinhxs, outrxs ampliaram seu raio de ação para a atenção de pessoas de cidades próximas e turistas de países estrangeirxs. Cada um/a delxs está moldado pela particularidade do ofício que encarna, e lhe dá um tom particular de acordo com suas preferências, rede e experiência de comunicação com as plantas. As vinte e duas pessoas acompanhadas ao longo desta pesquisa, cujos ofícios eu descrevo no capítulo 7, moram em Tamshiyacu e arredores. Com elas tive a possibilidade de desenvolver uma metodologia própria apoiada em um cruzamento entre biografia e etnografia, inspirada nas epistemologias críticas do feminismo pós-colonial. Por sua vez, tive a possibilidade de observar maneiras de fazer que fugissem da oficialidade da ayahuasca imposta pelos circuitos rápidos do turismo xamânico na região. Mais da metade das entrevistas formais e informais realizadas no povoado de Tamshiyacu foram na companhia de Carl, que às vezes tirava as fotos, gravava e, algumas vezes, filmava os encontros.

\section{- Narrativas de vida, entre a biografia e o estudo etnográfico}

Não é senão até a crise do modelo positivista e a virada pós-moderna nas ciências sociais que o método biográfico será retomado e experimentará uma grande expansão transdisciplinar, sobretudo nos ramos da sociologia, história, antropologia e psicologia social. É assim que desde os anos de 1980 e sob a gravitação de diversas matrizes disciplinares dentro do leque maior das humanísticas, começou a haver uma crescente insistência em relação à importância de reportar a fala de pessoas "comuns", observando seus itinerários e etapas de vida como ilustrativos dos processos históricos e das situações socioculturais próprias de um contexto mais amplo. 
A aproximação metodológica às narrativas biográficas (Biglia e Bonet-Martí, 2009) é parte constitutiva da análise histórica, epistemológica e política aqui apresentada. Desde a perspectiva da história social e de uma antropologia diacrônica - em consonância com o processualismo, a teoria da prática, os estudos culturais e o particularismo histórico - , os acontecimentos da vida de uma pessoa podem fornecer ricos detalhes que podem ser lidos a partir de interesses de caráter sociológico, político e histórico mais amplo (Pina Cabral e Pedroso de Lima, 2005). Já desde a perspectiva de uma epistemologia feminista, uma das perguntas centrais é "a qual gênero pertence o conhecimento que é socialmente valorizado?". As vozes das sujeitas mulheres, integrando o corpus mais ou menos coerente do relato da sua particular existência, possuem um peso que não se centra na efetividade da técnica metodológica per se, mas que também encarnam, a partir dos diálogos possíveis à pesquisa social, uma proposta epistemológica e política de caráter mais amplo. Desta maneira, "la creacióndefinición de narrativas es una toma de agencia especialmente en el momento en el que éstas se autoconstituyen como alternativas a las (meta)narrativas dominantes"59 (Biglia e Bonet-Martí, 2009). O que xs pesquisadorxs espanhóis Bárbara Biglia e Jordi BonetMartí chamam de metanarrativas dominantes é o que eu chamo, no presente trabalho, de espaços de oficialidade.

Em termos epistemológicos, a técnica da construção de narrativas (Biglia e Bonet Martí, 2009) se posiciona em espaços que se alimentam do feminismo, da antropologia crítica e do pós-estruturalismo. Nesse sentido, é um gênero transversal que não se define a partir da especificidade/amplitude das histórias contadas (como acontece com a classificação que diferencia relato de vida vs.

59 "A criação-definição de narrativas é equivalente à tomada de uma agência especialmente no momento em que elas se autoconstituem como alternativas às metanarrativas dominantes". 
história de vida) nem desde a posição bipolar fixa entre sujeito que escreve/sujeito que fala (como acontece com a classificação que diferencia biografia de autobiografia). A construção de narrativas se define a partir da escrita colaborativa de uma história a partir de múltiplas vozes; assim como da tentativa política da desconstrução dxs sujeitxs envolvidxs, a sua localização em um determinado meio social específico e assumindo as responsabilidades inerentes ao lugar de fala de cada um/a. Dessa maneira, no presente texto as nomeações "relato de vida" e "história de vida", por carecerem de interesse analítico ao presente trabalho, são usadas como sinônimas, enquanto que a escrita da biografia como gênero textual é colocada em questão, pois nela intervém a sujeita para contar, por partes, a sua história, ao mesmo tempo em que outrxs sujeitxs também aparecem para fazer parte da mesma. Por sua vez, o caráter verificacional dos fatos (Biglia e Bonet-Martí, 2009) - isto é, a probabilidade de eles serem "verdadeiros" no sentido de adequados à realidade - não é um elemento prioritário na hora da construção de narrativas. Nessa aproximação à realidade social, há um compromisso não com a objetividade, porém também não com uma subjetividade pretensamente impermeável. Assim, o compromisso desse texto se situa nesse espaço multidimensional que é o da intersubjetividade. Nele é que se situa a pessoa e sua rede de afetos, nesse espaço é que as narrativas biográficas se hibridizam para se tornarem tanto estudo biográfico quanto estudo etnográfico. No território da intersubjetividade também se encontra a relação entre as subjetividades específicas em torno ao pertencimento à ampla categoria de sujeita-mulher, que me envolve e que envolve às curiosas com as quais eu trabalhei. Isso, particularmente no caso da minha gravidez - como terei a oportunidade de pontuar mais adiante - , teve um papel fundamental no momento de definir os rumos dessa pesquisa. 
A presente proposta não pretende exaltar o conteúdo moral de uma vida: não é celebratória, nem procura classe alguma de exemplaridade nas histórias que convoca. Longe de pretender representar a pureza de um "tipo ideal" no sentido weberiano, a presente estratégia não procura personagens exemplares como "a curandeira", verdades históricas fechadas ou definitivas como "a maneira em que xs curandeirxs trabalham na Amazônia" nem afirmações universais como "as mulheres levam em si mesmas o dom de cuidar e de curar". Em meio às contradições próprias do viver, a minha aproximação tende a resgatar a originalidade e particularidade das experiências vitais enfocadas, compreendendo que elas são parte de uma rede maior de sujeitxs que a afetam e são afetadxs por ela. Nessa rede narrativa, os claro-escuros da vida possuem um lugar especial: levam-se em conta os hibridismos da complexidade das circunstâncias pessoais e sociais vividas. Assim, situações de multilinguismo (espanhol, shipibo e inglês) e multiculturalismo estão na ordem do dia, enquanto viagens, o manejo do dinheiro, da tecnologia e o interesse em valores próprios de Ocidente não são dissolvidos na tentação de resgatar a imaginária pureza de um tipo social. Esses aspectos, de uma ou outra maneira, fazem parte da vida cotidiana dxs curiosxs com xs quais tive contato, e fazem delxs pessoas em trânsito, em uma realidade que é local, mas que está também fortemente globalizada.

A narrativa biográfica, na medida em que vai se constituindo, pode dar pautas das interseções e localizações específicas de gênero, classe, raça, momento histórico e contexto social da pessoa em questão. Porém, a particular interseção entre biografia e análise etnográfica coloca o setting, o contexto social $\mathrm{dx}$ biografadx em um lugar de importância móvel. Às vezes, a imagem é a dx sujeitx com o seu contexto de fundo. Mas também é a do diálogo entre $\mathrm{x}$ sujeitx e a pesquisadora, ou a do diálogo entre $\mathrm{x}$ sujeito e algum/a outrx significativo. A 
etnografia como aproximação sutura as distâncias focais entre sujeito e contexto, e faz das narrativas de vida uma técnica dinâmica que aproxima ou afasta, segundo as experiências, à pessoa em questão da sua rede de afetos.

Assim como uma rede pode ser vivenciada como uma unidade, da mesma maneira cabe contemplar um/a sujeitx particular como constituindo uma multiplicidade viva. A dificuldade para apreender essa complexidade com as ferramentas da ciência é inerente à própria concepção moderna e colonial do corpo e da pessoa. Assim como a unificação do corpo com a pessoa é produto da modernidade, no momento em que nos situamos nas margens deste cânone, é inevitável questionar o paradigma que equaciona o sujeito com um único corpo. A antropóloga feminista Marilyn Strathern (2004) sugere explorar a produtividade a ideia de "conexão parcial" para traçar uma relação entre sujeitos, corpos e realidade mais ampla e multi-focada em sociedades que ela define como não-ocidentais. As vinculações que Strathern propõe realizam uma junção, que é parcial e efêmera, do "eu" com o mundo: enquanto aproximam o mundo, dissolvem o "eu" em múltiplos elos. Tais contatos deslocam o "eu": fazem dele um emaranhado de "coisas incompatíveis que podem ser colocadas juntas" (op. cit, p. 35) e serem dispersas de acordo com os contextos de ação. As conexões parciais entre sujeitxs não concebem o $e u$ como uma materialidade feita de certa identidade estável, mas como um feixe de forças cujas uniões são, por si mesmas, instáveis. De acordo com essa perspectiva, xs próprixs sujeitxs excedem a moldura biográfica e se conectam a outros afetos, fazendo da técnica biográfica uma ferramenta insuficiente de apreensão de uma história e uma vida, por mais única, original e diferenciada que ela pareça ser.

Se nos visualizássemos e reconhecêssemos como sendo parte de uma rede, também poderíamos assumir sem desculpas que toda história é, ao mesmo 
tempo, uma história dos afetos ligados a nós. O exercício antropológico da história de família, proposto pelxs pesquisadorxs portuguesxs João Pina Cabral e Antônia Pedroso de Lima (2005) consiste em "uma metodologia de contextualização social das pessoas" (p. 357) que leva em conta a localização das falas e dos acontecimentos das pessoas em espaços de relação mais amplos. Esses espaços são os que xs autorxs chamam de territórios da inter-subjetividade. Ela se apresenta como uma combinação do método genealógico e da história de vida em antropologia, mas não se restringe à "família" enquanto conjunto definido por laços de sangue, e sim aos conjuntos estáveis de relações dxs sujeitxs nos diversos espaços e tempos. Desta maneira, a história de família se compõe de "relatos altercentrados" (op. cit, p.359), em lugar de relatos autocentrados, como acontece no caso das biografias. Com isso, os relatos estão possibilitados de olharem para fora e de se abrirem para a rede, mais ampla, que significa o dia a dia nas vidas dxs sujeitxs biografadxs. Enquanto se compreende que as fronteiras do corpo $\mathrm{dx}$ "sujeitx individual" ainda são fluidas, é possível observar que elas incluem uma rede de afetos e materialidades. Em termos metodológicos, isso se desprende na procura da colaboração de outrxs sujeitxs próximxs que definem, por uma via relacional, a vida particular $\mathrm{dx}$ sujeito que fala. Assim acontece com a minha aproximação, móvel, à vida de Isabel - a curandeira, xamã e onanya de origem indígena shipibo a partir de quem fundamentei a narrativa biográfica desta tese.

Entre a ficção biográfica de uma sujeita que é curandeira, xamã e onanya [curandeira indígena shipibo] e uma etnografia dinâmica que a mostra dentro de uma rede maior de afetos, que são, em parte, biografados, é que a presente tese desenvolve seu curso. As múltiplas narrativas biográficas aqui apresentadas me envolveram, me comprometeram e deram como resultado as presentes histórias, tecidas a partir do interesse nas técnicas terapêuticas e mágicas que as curiosas 
acionam cotidianamente nas margens dos circuitos do turismo xamânico na Amazônia do Peru.

- Isabel: ela se conta, eu a escrevo, nós criamos (o texto)

O escrito que hoje está imóvel na armação geométrica da língua antropológica foi modelado à maneira da prática dos bricoleurs que imaginava Lévi-Strauss (1966): de pedacinhos, com palavras e com experiências de toda cor e textura, em diversos espaços e momentos, sob a influência de várias pessoas. Isabel, da mesma maneira que os países, as revoluções e as festas, ela não tem uma história única. As narrativas que se apresentam aqui não são, nem pretendem sê-lo, o documento realista de uma vida. A memória do vivido é um conjunto móvel de saberes e sentires sobre o passado. Caleidoscópica, a memória muda as suas formas, seu tom, a sua intensidade na medida em que o próprio presente flui para se tornar passado, na medida em que mudam xs nossxs interlocutorxs, na medida em que nós mesmxs mudamos. O relato de Isabel não é o depoimento finamente delineado de uma biografia. Brincando com a multiplicidade de sentidos da expressão história única, ele também não é uma história única desde o ponto de vista em que não é a história de uma única pessoa. Como relato de vida, a de Isabel é uma história inter-subjetiva que entrelaça muitas outras e se redesenha nelas. E ainda que Isabel tenha começado e acabado sendo o foco, o alicerce, o centro invisível desta história, outrxs pessoas começaram a participar da pesquisa e acabaram também sendo parte dela. À maneira de uma bricolagem, as vozes se apresentaram em camadas, se misturaram, se fundiram e se diferenciaram ao ritmo das vivências narradas.

Pessoalmente, assumo meu lugar de escritora-inventora, me torno parte da história de Isabel ao escrevê-la. Não posso, nem quero, me colocar fora dela. Posiciono o que aqui é contado como o produto do encontro específico entre 
duas subjetividades: a de Isabel e a minha. Vivemos, agimos e escrevemos sob a capacidade modeladora de outras subjetividades - as pessoas, potências vitais que constituíram e constituem o multívoco eu de cada uma de nós. Suas/seus filhxs Jenny e Gerlyn, seu companheiro Jorge. Meu companheiro Carl. Xs outrxs eu distantes, seu filho Néstor que mora em Pucallpa, meu filho Pedro que ficou no Brasil durante o tempo que durou meu trabalho de campo. Pessoas que são parte da constelação a partir da qual existimos. Pessoas às quais também nos referimos quando falamos da própria história. Nesse sentido, as narrativas aqui construídas não são as únicas possíveis. Uma mesma história pode ser contada de diferentes maneiras, e o mesmo conto que aqui é revelado foi criado na alquimia desse encontro. Nesse contexto, várias foram as histórias entrelaçadas, contadas e recontadas, e nem sempre elas permaneceram iguais a si mesmas. Até o presente, em que o relato de vida tem sido textualizado, ele me dá a impressão de que nunca irá acabar. Está sempre mudando. Sempre se renovando. Ele sempre joga uma nova luz, enquanto que se obscurece por partes.

A história de Isabel não é, nesse sentido, única: a dinamicidade e mutabilidade do que foi dito sobre o vivido faz parte constitutiva da construção dos relatos de vida. Para compreender a sua particular condição, tais narrativas demandam ser observadas de acordo com o seu caráter situado, parcial, processual e inclusive ficcional. Os relatos de vida são poesia da relembrança, alegorias do já vivido sob a luz de um presente que reflexiona e que traz sempre novos elementos com os quais é possível contrapor, sob uma nova ótica, o que foi já vivido. Creio ser oportuno dizer que no processo de pesquisa, escrita, encontro e criação destas narrativas houve uma série de elementos que me ajudaram a fazer frente às inevitáveis romantizações a partir das quais imaginei a primeira proposta de trabalho com Isabel. A primeira foi em relação à minha pretensão de escrita em co-autoria. Isabel aprendeu o espanhol como segunda língua, e arduamente lê ou 
escreve. Como criar um espaço de co-autoria que transcenda o ler e o escrever, que dê sustento científico à oralidade, à corporalidade, que aceite as múltiplas meias-traduções de uma comunicação entre duas sujeitas apoiadas em um limitado léxico hispânico?

Isso me obrigou a pensar na escrita como uma ferramenta, mas não como um fim em si mesmo. Limitação que também significava falar da vida em espanhol, a língua oficial que a sua gente teve que aprender não sem violência, e que foi a minha língua materna. Assim, descentrando o logos da escrita, me atrevo a dizer que a experiência do encontro com Isabel foi plasmada nesse escrito, mas também em bordados, comidas, cerimônias de cura e caminhadas compartilhadas que possuem o seu próprio peso ontológico, dentro ou fora deste texto.

No meio de toda escolha, há decisões políticas. De maneira mais específica, micropolíticas, daquelas que regulam o viver, o fazer juntxs, o encarar um projeto em equipe, as minúcias do se contar a si mesmx, os pormenores de escrever e sermos escritas. Desde o início do nosso encontro, foram aparecendo possibilidades de negociação do "consentimento informado", que eu particularmente trazia à tona com a finalidade de fornecer um acordo formal para essa pesquisa.

Em relação à captura etnográfica de imagens sucedeu algo bem interessante. Isabel, sua família e as pessoas da região, no geral, mostravam interesse na captura de imagens e, desde que a tecnologia foi se tornando mais acessível, tinham adquirido máquinas fotográficas e, sobretudo, aparelhos celulares com câmera. Aquelas pessoas que os detinham tiravam muitas fotografias em diversos momentos do cotidiano, pousando frente a elas com espontaneidade e, 
em muitos casos, disponibilizando-as nas redes sociais virtuais como Facebook ou Google + para serem vistas e comentadas (Ver Imagem 3, Isabel). Uma pessoa chegou a me mostrar um vídeo filmado durante o enterro da sua avó. De qualquer maneira, é claro que possuir o aparelho fotográfico e decidir os elementos e tempos de cada tomada e ser fotografadxs por outra pessoa, pouco conhecida e com intenções ainda menos reconhecíveis, são situações radicalmente diferentes. É uma questão de posição: de que lado da lente cada um se encontra? Ciente da condição na qual se colocava o jogo deste tipo de captura de imagens etnográfica foi que acostumei a ir mostrando para ela, sua família e as outras pessoas que conheci na minha estada em Tamshiyacu, os registros que delxs ia fazendo. Pelo visor da câmera e de maneira imediatamente posterior à captura, elxs podiam me dizer de quais fotos elxs gostavam e de quais elxs não gostavam. Eu conservava as primeiras e apagava as segundas. Descobri que esta era uma estratégia muito simples de habilitação de consentimentos. Decidi preservá-la. 


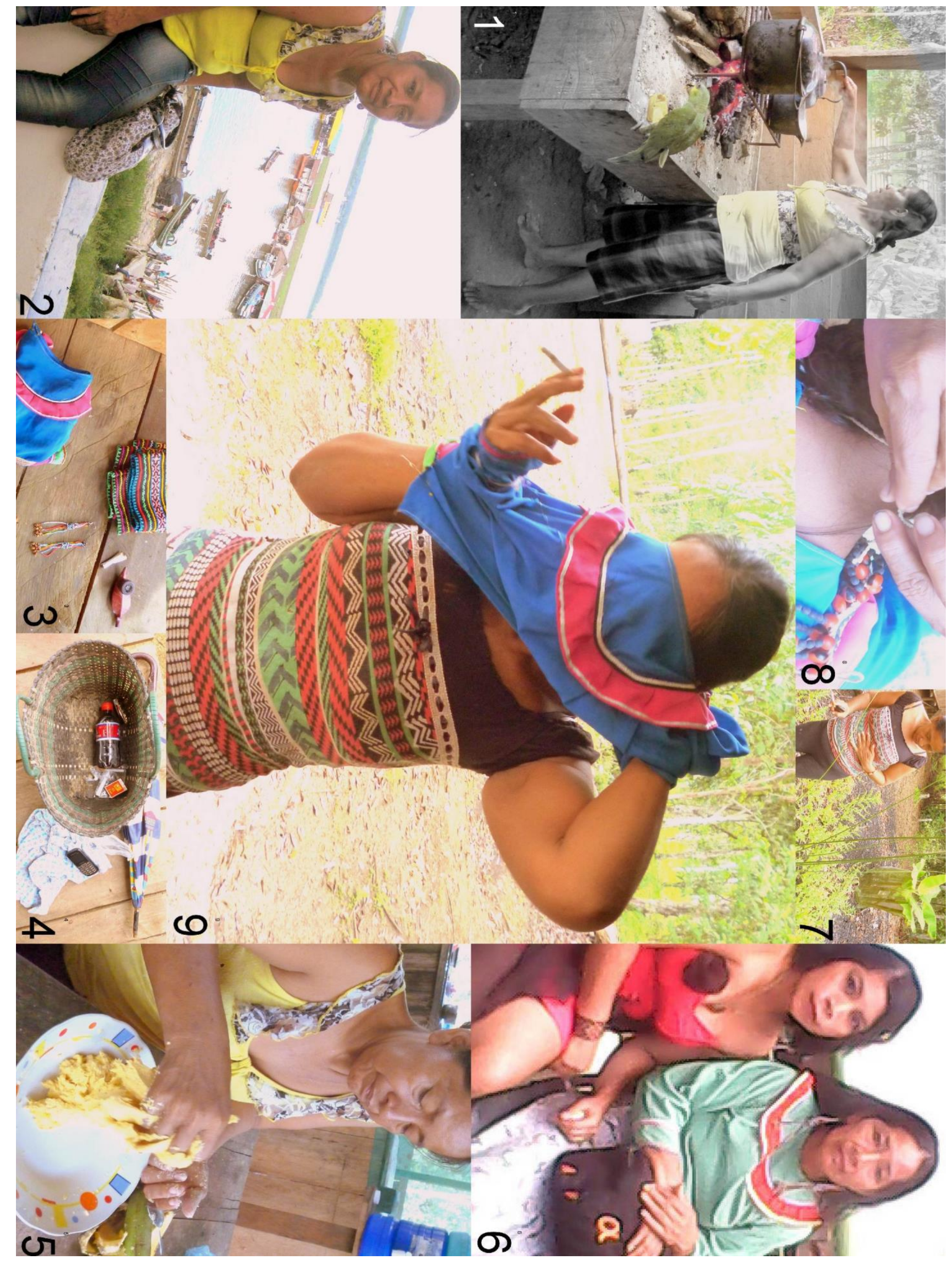




\section{Imagem 3 (pág. anterior): Isabel}

1 - Cozinhando no fogão à lenha da cozinha do acampamento.

2 - Esperando visitantes no porto El Huequito.

3 - Brincos com contas plásticas e sementes de nishi [Philodendron lechlerianum] no extremo, saia bordada por ela mesma com kenê [desenho shipibo], campanilla [camisola] azul com fitas vermelhas e brancas e cachimbo talhado pelo filho, Gerlyn: as roupas, ornamentos e ferramentas que Isabel usa em especiais cerimônias com ayahuasca.

4 - A bolsa diária de uma curandeira: mapachos, cigarros refinados, purga de uña de gato [Uncaria tormentosa] e fósforos. Do lado de fora: sombrinha, pano e telefone celular.

5 - Isabel preparando pasta de plátano para acompanhar o peixe.

6 - Isabel e Jenny, duas gerações indígenas vestidas para uma festa familiar.

7 - Isabel, mostrando os piripiri [Eleutherine plicata] cujas raízes bulbosas ela trouxe de Pucallpa.

8 - Colocando o colar de sementes amarrando as pontas na parte posterior do pescoço.

9 - Habilidade para colocar a campanilla e, ao mesmo tempo, fumar um cigarro. 
No processo de compreender as particularidades do caso que eu defrontava, cheguei à compreensão de que as múltiplas formas de consentimento informado se modelam para pactuar o que é, basicamente, um acordo comunicativo. Tal ajuste formal se elabora para evitar a violência de revelar o que é secreto, para minimizar erros referentes ao registro do que não foi dito para ser inscrito, para podermos nos colocar no lugar que nos foi dado pelx interlocutor/a na construção dessa memória. Essas possibilidades não cristalizam de maneira automática e imediata a partir da assinatura $\mathrm{dx}$ sujeitx da pesquisa em uma folha de papel. Por sua natureza suscetível de construção, elas podem ser trabalhadas e retrabalhadas com o passar do tempo. A presente pesquisa teve a graça de crescer em afeto e em comunicação, com uma dose de reflexividade que mantinha acordado o pensamento sobre a finalidade desta pesquisa para mim e os elos sociais aos quais pertenço, e o que significava fazer parte desta pesquisa para Isabel e os elos sociais aos quais pertence.

Creio ser honesto dizer que Isabel se arriscou aceitando ser sujeita privilegiada desta pesquisa. Atreveu-se a abrir a sua privacidade, intimidade e segredos do seu mágico ofício perante uma pessoa de outro país, que ela pouco conhecia, e de cuja profissão quase nada tinha ouvido. Ainda quando seu querido Roger Rumrill, o reconhecido jornalista de temas amazônicos e Anita, a amiga dele e paciente muito querida de Isabel, haviam me recomendado dando-me seu número telefônico e lhe avisando da minha chegada ao povoado, eu continuava a ser alguém novo, de intenções desconhecidas, no mundo dela.

Com o passar do tempo, porém, Isabel me fez compreender que esse tipo de disposição ao risco não era, para ela, tão novo. No transcurso da sua vida, várias das suas atitudes envolveram assumir riscos de diversos tipos: separar do marido sendo mãe de várixs filhxs, viajar para trabalhar em outras cidades, 
deixar xs filhxs no cuidado de irmã e tias. E seu próprio ofício, tão exposto. Desde jovem, ela se habituou a vivenciar formas de contato e proximidade com outrxs, alheixs à sua cultura shipiba, amazônica, peruana. Desde a ocupação de seu pai escavando restos da cultura dos seus/suas antigxs e vendendo-os a estrangeirxs, até a sua atividade diária como xamã e artesã no contexto do turismo espiritual.

Na situação de vida de Isabel, em adição aos riscos próprios do contato cultural, encontram-se os riscos que são próprios do trabalho espiritual. O ofício de Isabel é, como podemos imaginar, de uma exposição altíssima. Com as sopladas de fumaça de tabaco nas cabeças de doentes, com a ingestão de ayahuasca para ajudar a pessoas que foram embruxadxs, com a escuta de todos os tipos de problemas que se manifestam em planos físicos e sutis, com o trabalho à distância com velas negras e vermelhas chamando a espíritos de pessoas vivas e mortas para ajudar no pedido, lidando com as vinganças próprias de outrxs. Observei que em cada trabajo de curandeirismo, Isabel está expondo a própria alma através do seu corpo vivo que age como antena, para-raios, usina, raiz. $\mathrm{O}$ corpo de Isabel gera e absorbe forças de maneira permanente. A sua vida está em movimento ativo na direção do desconhecido. O seu mapacho [cigarro de tabaco feito na mão] a protege.

Por outra parte, frente à minha intenção de tornar memórias e fazeres em um texto que seria redigido para um público que se encontrava, a princípio, no Brasil houve uma atitude aberta. $\mathrm{O}$ fato da sua história ser escrita e preparada para viajar a geografias distantes certamente a entusiasmou: viajar em palavras parecia-lhe apaixonante como o viajar mesmo. 
Foi assim que ela se atreveu a compartilhar um dia a dia que era documentado, fotografado ou registrado por mim em pequenos papeis que, mais tarde, colocava nos diários de campo que tinha junto com os meus pertences, e que iam comigo onde quer que eu viajasse. Da minha parte, pude avaliar que os protocolos escritos do "consentimento informado" são formalidades que pouco podem valer por si mesmas. No processo de nos conhecermos, Isabel e eu, houve a possibilidade de transitar em uma série de steps que permitiram a elaboração gradual de um consentimento que não só adequava o relato da sua vida à minha pesquisa, mas também adequava a minha pesquisa à sua vida.

A estrada foi sinuosa, em cada parada no caminho houve negociações. No início, observei que o presente de Isabel era tão cheio de assuntos urgentes que pouco tempo parecia haver para se deter e pensar sobre o passado. Isabel acordava todo dia entre as 4.30 e às 5 da manhã, para permanecer acordada até as 12 da noite. Entre as compras no mercado, os labores domésticos na casa de Tamshiyacu, a manutenção do albergue, a atenção de pacientes na casa de Tamshiyacu, a atenção de turistas no albergue, a participação em atividades contra a exploração madeireira e a realização de trâmites e compras de plantas medicinais e outros insumos para seu trabalho na cidade de Iquitos - todas elas atividades que serão descritas no capítulo seguinte - , Isabel pouco descansava. Nas manhãs em que ela estava muito cansada, preparava um pouco de tabaco fresco em água morna e o deixava repousar por alguns minutos. Então ia por trás da cozinha, bebia-o e sentava a esperar. Pouco depois vinha o vômito. Vomitava e voltava ao trabalho. Costumava dizer que a purga com tabaco era o melhor remédio contra a preguiça. Eu aprendi a esperar que os momentos oportunos para a evocação da memória aparecessem espontaneamente. A vida os trazia. 
É interessante observar como é que acontece a relação entre memória e presente. As memórias que se contam emergem de cenários do aqui e agora, elas são trazidas à vida de hoje a partir de acontecimentos que estão sendo. Como evocações que são, precisam de um estímulo para ser desempoeiradas e expostas na linguagem. São memórias resgatadas a partir do que me atrevo a chamar um imperioso presente. As pessoas mais velhas dizem que há um tempo para fazer e um tempo para pensar. Com cinquenta e poucos anos, ainda com leite no peito de ter amamentado a seu neto Diego, creio que o tempo de Isabel ainda é tempo de fazer. Nesse sentido, a história que aqui conto é um collage entre memória e experiência etnográfica, entre presente e evocação, entre a urgência do hoje e a paisagem quieta do passado.

Isabel era a sua história passada e o que dela todo dia construía, e isso surgia nas nossas conversas no albergue, caminhando na rua, nas casas de pacientes depois da consulta, indo às compras até o mercado; depois de uma cerimônia com ayahuasca; na manhã, durante a preparação da comida para o almoço; indo a pé nas trilhas que conectavam o albergue com o povoado de Tamshiyacu; no jogo de futebol intermunicipal; indo de barco para Iquitos de manhã bem cedo; durante reuniões em festas de aniversário; na cabana onde eu fazia a minha dieta e ela ia se deitar e fumar seu mapacho. Nas inevitáveis urgências do dia a dia às quais eu a acompanhava, ela tomava seu tempo para friccionar a minha espinha dolorida, me fazia banhos de proteção com frutas maestras e me dava líquidos mágicos para colocar nas pálpebras e trazer para mim tudo que há de melhor no mundo. Eu a ajudava a escrever formulários de correios e listas de compras, escrevi alguns e-mails que ela ditara para mim desde a direção do blog Mundo de la Yacuruna e a ajudava a ler as etiquetas de fármacos de botica tais como o paracetamol ou o ibuprofeno, com a finalidade de conhecer a dosagem necessária para a sua ingestão. No último tempo, também a ajudei a fazer contas, e houve 
alguns dias nos quais ela sentou na frente do meu computador e treinou a escrita de seu nome, a sua ocupação, a sua tribo e a sua idade no teclado.

Houve ainda mais negociações, que nem sempre era preciso expor literalmente como tais. Ela percebeu que eu queria apreender as maneiras de fazer do curandeirismo que ela praticava, mas que não queria apreender o curandeirismo para exercer o ofício por minha conta. Eu percebi que ela não gostava de falar abertamente das questões mais dolorosas, e aos poucos fui aprendendo a me conter para não afetar com minha curiosidade esses espaços íntimos e sentidos. Isabel também colocou condições explícitas, poucas. A mais importante foi que os icaros que ela cantava não fossem traduzidos. Isabel assumia que, como orações de comunicação com os espíritos das plantas, eles precisavam se manter sob a forma de música e na musicalidade da língua e as palavras às quais eles pertencem. Regozijo: temos respeitado as nossas vontades.

A pesquisa biográfica e etnográfica com Isabel foi fundada nas artes em construção do diálogo a dois. Como em toda relação humana, a comunicação fluía às vezes vagarosa, às vezes potente, mas o murmúrio do rio do diálogo a dois não cessava. Para mim, foi necessário trabalhar na compreensão do movimento entre a franca exposição de si mesma e o apurado ocultamento de partes que foram marcadas para não fazerem parte desta história. Nesse jogo de aberturas e fechamentos, que eu seguia com atenção, Isabel foi se construindo a si mesma a partir de suas palavras, cantos, práticas do ofício e experiências cotidianas compartilhadas. Assim, ela se contou, eu a escrevi, e juntas criamos o texto.

As aberturas que Isabel dispôs durante esse processo, ao serem suficientemente generosas, permitiram e inclusive estimularam a inclusão das vozes de outras 
pessoas no esquema mais amplo da tese. À minha relação com Isabel somaramse novas relações, desta vez com a família de Isabel e com outrxs curandeirxs e pessoas do povoado de Tamshiyacu. A liberdade de circulação que contemplava a conexão com Isabel me permitiu conhecer outras experiências e abrir para elas uma nova faceta da minha pesquisa. Ainda que ela tenha sido a minha porta de ingresso ao mundo do curandeirismo amazônico, e tenha continuado sendo a minha mais especial interlocutora, o fato de circular entre cenários sociais diversos permitiu que novas e não menos apaixonantes vivências fluíssem dentro e fora do esquema da história que imaginei co-construir.

É destas pessoas e experiências que se tratam as partes seguintes dessa pesquisa etnográfica, narrativa e vivencial sobre o curandeirismo feminino na Amazônia do Peru, que aqui apresento sob a forma de um texto escrito. Outras vozes, outras pessoas, outras intervenções que às vezes matizam, outras reforçam e outras inclusive colocam em questão a "representatividade" das narrativas e maneiras de fazer de Isabel. Elas aparecem, de maneira equipotentes às histórias de Isabel, em um movimento de conversação compartilhada sobre o cenário em questão, enriquecendo-o a partir de uma multiplicidade de perspectivas. Todas elas formam, enfim, uma nova (e mutável) cristalização de um saber coletivo que permanece pouco visível: o conhecimento e práticas femininas de magia, cuidado e cura.

Acredito que falar e escrever sobre algo pode empoderá-lo. Por isso, dar forma de texto a essas histórias abre uma porta para que práticas femininas de magia, cuidado e cura sejam contempladas e fortalecidas em virtude da sua contribuição para um mundo mais justo, mais amoroso, mais fluido. No contexto das potencialidades que alenta a nossa sociedade grafocêntrica, e de acordo com 
meus gostos, afinidades, possibilidades e formação, essa é uma estratégia que aparece como sendo profundamente interessante para mim.

Desde certo ponto de vista, a atividade de uma sujeita antropóloga como eu, que constrói narrativas com outrxs pessoas com o fim de falar e escrever se assemelha à atividade de uma ativista política que convoca militâncias ou de uma artista que faz uma intervenção no espaço público. A aparição destas histórias é uma forma de fazê-las percorrer outros circuitos, e longe de "dar voz" a uma silenciosa mulher imaginada, procura sentar na companhia de mulheres reais e se engaja com elas em uma conversação comprometida.

Compartilhar essa sua cotidianidade foi me colocando em um lugar ad hoc, feito à medida, cada vez mais preciso para a compreensão de nós duas: o de uma espécie de filha adulta com força laboral disponível, dessas com as quais se vai e se vem, se resolve a vida diária, se conversa em momentos de descanso, se protege e se é protegida, se imaginam alternativas de vida. É assim como Isabel me lembra hoje à distância. Jenny, a filha que mora com ela em Tamshiyacu, me manda os carinhos de Isabel, me dá as novidades do albergue e uma ou outra foto instantânea através do chat de facebook.

Durante o tempo que morei no seu albergue Mundo de la Yacuruna, compartilhamos a cotidianidade desde o amanhecer até o anoitecer. Em uma das tardes que ela ia fumar seu mapacho na minha cabana, ela me disse Zuibca. Esse nome ela queria me dar. Significa, em shipibo, "bonita e suave". Foi uma honrosa alegria, a tradução da minha identidade para seu mundo mais próximo e querido. Uma maneira de estabelecer um laço apoiado na língua materna. Eu lhe dei um lugar especial dentre as pessoas mais queridas que tenho conhecido no Peru. Para mim, o tempo com ela foi tudo aprendizado. Ainda que eu nunca 
tenha podido cantar os icaros que com tanta delicadeza chamam aos espíritos das plantas, a sua presença transparece entre os bordados shipibo que ela me ensinou a fazer e na minha botica com algumas plantas com as que hoje, longe da floresta, trato pequenas moléstias do corpo e da alma dos meus entes queridos.

\section{- $\mathrm{O}$ acesso a outros espaços e sujeitxs}

A narrativa biográfica de Isabel é uma história arvorescente: ela está constituída, de maneira explícita ou implícita, sob a base da relação dela com outros seres e pessoas. Essa é o que eu chamo de rede de afetos de Isabel. A minha experiência de convivência com Isabel propiciou o desenho de uma porta de acesso inevitável para essa rede. Com o tempo, fui desenhando imaginariamente esse tecido, composto por familiares, amigxs, pacientes e outrxs curiosxs da localidade.

Ao ampliar a visão sobre a rede que se tecia ao redor de Isabel, múltiplas vozes se manifestaram. Elas trouxeram novos elementos para compreender as terapêuticas e magias locais em sua contemporaneidade, em suas contradições, em seus silêncios, em sua híbrida complexidade. Despregando a sua individualidade e originalidade em íntima interação com as possibilidades e violências do meio social local, o relato sobre Isabel ajudou a fornecer elementos para a sistematização, análise, comparabilidade e contextualização da sua forma particular e única de trabalho em relação com outras tantas maneiras de fazer com plantas escolhidas por outrxs curiosxs.

Durante meu trabalho de campo na Amazônia do Peru, conheci ou tive referência indireta a sessenta e uma pessoas que praticam alguma forma de terapia ou magia com plantas. Dentre elas, são quarenta e duas as que eu cheguei a conhecer pessoalmente. Ainda quando elxs possuem práticas e orientações bastante heterogêneas, todxs elxs se auto-classificam como curiosxs, e esse foi o 
ponto comum que eu procurei. Com a finalidade de descrever mais claramente as experiências, escolhi realizar uma amostra significativa com vinte e duas pessoas, mulheres e homens, que se auto-denominam curiosxs, e que são aquelxs com xs quais tive um contato mais direto e constante. Essas pessoas são: Isabel, Adela, Pasquita, Zoila, Maria, Bernardina, Milena, Asteria, Anita del Carmen, Betina, Corina, Agustín, Lucho, Jorge, Luis, Moisés, Tocayo, Leoco, Marcos, Gerlyn, Ernesto e Julio.

Os fazeres, saberes, estratégias de empoderamento, escolhas e tensões dxs curiosxs que exercem seu ofício no contexto contemporâneo da baixa Amazônia do Peru envolvem uma multiplicidade de formas de comunicação com as plantas. Ao mesmo tempo, acionam específicas maneiras de se relacionar com os espíritos e os objetos que remetem a elas, proporcionando uma série incansável de símbolos e práticas que potencializam os estados de vida com finalidades terapêuticas ou mágicas. Para realizar a minha etnografia com essa rede de sujeitxs, que acionam suas maneiras de fazer com plantas desde as margens da atual oficialidade ayahuasqueira, criei uma série de estratégias de escrita e análise, que detalharei no ponto que segue.

\section{- Formas de compromisso corporal em campo}

Melissa, uma antropóloga francesa que pesquisa xamanismo peruano e que tive a possibilidade de conhecer durante meu trabalho de campo na Amazônia peruana, comentou-me que um dos professores da sua banca de qualificação de mestrado na universidade de Toulouse lhe advertiu: "não queremos ir e ter que juntar teus pedaços com uma colherzinha". Segundo ela me comentava, essa é uma expressão da língua francesa que se refere à dificuldade para reinserir na sociedade às pessoas destruídas, perdidas. Frente à escolha de seu objeto de estudo - o uso de psicoativos por parte de curandeirxs da Amazônia peruana-, 
ela teve então a sensação de que a academia lamentava a "perda" de mais uma acadêmica na procura de experiências de espiritualidade radicais. Consideravam esse campo extremamente perigoso não só em termos de certa segurança corporal, ameaçada pelas imagens de abusos sexuais por parte de xamãs e de ingestão de psicoativos, mas também em termos de uma ruptura com o habitus acadêmico no marco de experiências extraordinárias que colocavam fora de resguardo tanto a objetividade quanto a racionalidade científicas. Um professor tinha lhe comentado as complicações daquelxs alunxs que iam estudar as seitas e acabavam fazendo parte delas, enquanto que se desligavam gradualmente das maneiras de fazer racionalistas da academia francesa.

O racionalismo científico é, de fato, persistente ainda hoje na produção científica no nível global. Porém, faz algumas décadas, vêm acontecendo interessantes mudanças na comunidade de pessoas que fazem as diversas ciências. Desde a física quântica, nas ciências exatas, até as correntes da pós-modernidade, nas ciências humanas, a divisão entre sujeitos/objetos, corpo/alma, eu/x outrx, traçada pelo saber da modernidade, vem sendo largamente questionada (Haraway, 1995). Em campos aparentemente tão dissimilares como a etno-botânica, a antropologia e a neurociência, a teorização sobre práticas de ingestão de psicoativos está contribuindo ao re-encantamento desse espaço que foi rejeitado como inabordável ou mesmo inexistente pelo racionalismo científico: os dejetos da não-ciência. No caso do Brasil, pesquisadorxs que se aproximam das matrizes religiosas ayahuasqueiras estão contribuindo vivamente para esse trabalho de "reencantamento" do fazer e do pensar científico, refletindo sobre experiências advindas de realidades que foram convencionalmente tidas como "extraordinárias" (David e Goulet, 1994) pelxs agentes da ciência inscritos na modernidade. 
No caso das pesquisas que investigam o curandeirismo da Amazônia peruana, o fato de participar "parcialmente" - isto é, sem ingerir a ayahuasca - ou "plenamente" - isto é, ingerindo a ayahuasca - nas cerimônias pode ser fundamental para definir uma atitude ética, metodológica e até epistemológica no próprio trabalho. A minha própria pesquisa com ayahuasca [Banipsteriosis caapi] envolveu a ingestão desta planta e também de outras plantas psicoativas: toé [Brugmansia suaveolens], tabaco [Nicotina tabacum] e chiricsanango [Brunfelsia chiricaspi]. Há autorxs que já refletiram sobre as diferenças inerentes a uma atitude distanciada e outra envolvida na ingestão de psicoativos em um campo como o presente. Para Harner (1973; em Moure, 2005), quem também estudou a interseção entre curandeirismo popular e turismo xamânico,

... é indubitável que uma das razões mais importantes pelas quais os antropólogos não deram a devida importância às substâncias alucinógenas no xamanismo e nas experiências religiosas foi porque muitos deles não tinham tomado nenhum dos ingredientes indígenas de efeitos psíquicos, não tinham vivido as experiências subjetivas que essas substâncias produzem e que tão definitivas são (...) para a compreensão dos povos que eles estudaram (meu destaque).

A antropóloga norte-americana Marlene Dobkin de Rios chamou a experiência de participação nas cerimônias com ayahuasca como sendo parte da atitude corporal de "se molhar os pés" (1977: 292) em campo, celebrando o fato de que finalmente xs antropólogxs tenham começado a superar a barreira que xs colocou do lado da realidade pretensamente objetiva e racional da ciência moderna, ao mesmo tempo em que do lado oposto das crenças irracionais do restante do mundo. Compreendo que a ingestão de psicoativos é, desta maneira, uma das variadas formas possíveis de compromisso corporal em campo. 
No caso particular desta pesquisa, ingerir o psicoativo no marco da cerimônia coletiva com ayahuasca colocou não só a minha posição como antropóloga, mas também a totalidade do meu eu em questão. Essa forma de se aproximar de uma realidade que compromete diretamente até o funcionamento metabólico e neuronal dentro do próprio trabalho de campo antropológico foi chamada pelo antropólogo brasileiro Marcelo Mercante de "observação experiencial" (2012: 50). É a partir dessa estratégia que Mercante situa a sua etnografia na comunidade ayahuasqueira da Barquinha, no estado do Acre. No trabalho dele, a prática etnográfica é lida dentro do contexto da experiência ritual destinada à comunicação entre sujeitxs humanxs e não humanxs através de cânticos e da ingestão de ayahuasca.

No caso da minha própria experiência, participei umas cinco vezes no total de experiências coletivas de ingestão de ayahuasca - apesar dos convites, de frequência semanal. Durante a etapa mais longa de meu trabalho de campo correspondente ao tempo que permaneci em Iquitos - todas as vezes que bebi ayahuasca ou outros psicoativos foi no marco de cerimônias ou dietas organizadas por Isabel. Em um cenário onde cada curandeirx ou xamã promete as melhores experiências, eu reservei a abertura de meu corpo a um espaço conhecido, a uma pessoa na qual eu me confiava. A minha decisão estava em sintonia com a ideia local de que beber a ayahuasca ou dietar com diferentes xamãs cada vez podia ser prejudicial para o próprio corpo. Xs chamãs podem ter desavenças entre si - coisa que não é rara - e competir para se introduzir na experiência dxs pacientes e tapar suas visões, deixando-x na escuridão. Isso pode afetar à/ao próprix paciente, quem expõe seu corpo, mente e espírito a esse tipo de trabalho. 
Foi assim que, entre a confiança e a precaução, eu tomei meu tempo para decidir quais iam ser as cerimônias das quais eu queria participar. Das cerimônias que eu participei, aprendi bastante. O próprio fato de atravessar essas marcantes vivências fez com que um mundo de novas relações aparecesse diante de mim: depois das práticas das vivências psicoativas, as pessoas se comunicavam, intercambiavam impressões sobre a experiência e, às vezes, reafirmavam as visões ou experiências $d x$ outrx. As conclusões provisórias que tirei desde as primeiras aproximações a esse mundo tiveram a ver, principalmente, com a dissolubilidade do $e u$ em um universo de outros seres em relação. Um mundo de relações entre as pessoas humanas e outros seres, antes pouco visíveis para mim, aparecia, sugestivo. Foi assim que constituí uma aproximação progressiva às múltiplas realidades da pesquisa, levando em conta esse espaço de intercâmbio de seres e afetos onde a multiplicidade de dimensões prima e onde não há uma única, mas muitas, realidades possíveis.

Assim, quando na presente análise pontuo as redes de afetos, não só me refiro a amigxs, vizinhxs e potenciais competidorxs de Isabel: também faço alusão a outros seres - como xs mortxs, os espíritos das plantas, os espíritos de curandeirxs - que intervêm no trabalho e nas decisões do dia a dia de Isabel.

Devo dizer que a imersão naquela realidade teve um efeito de vaivém entre minha realidade e outras novas realidades, obrigando-me a realizar periódicas paradas no caminho para enxergar a direção na qual se desenvolvia o trabalho de campo. Devo confessar que a possibilidade de me tornar também curandeira veio à minha mente algumas vezes, mas também é certo que acabaram vencendo as delícias, os costumes e as responsabilidades do habitus antropológico, que me colocava como uma antropóloga ansiosa por ter bons resultados no trabalho de campo mais longo e rico da sua carreira. Contudo, guardei certas reservas 
perante qualquer urgência de me tornar uma nativa. Nesse sentido, creio firmemente que não há espaços de vida que possam ser superpostos, por mais esforço subjetivo que dirijamos para a consecução de tal objetivo. No caso de meu contato mais próximo, soube que eu nunca seria Isabel, enquanto Isabel nunca se tornaria "eu". As identidades se conformam a partir da relação quase gravitacional com uma série de experiências e pessoas, visíveis ou invisíveis, presentes em corpo ou ausentes dele, que fazem parte do nosso cotidiano e da nossa história. Não somos intercambiáveis.

Outra forma de compromisso corporal que vivenciei em campo foi a gravidez da minha segunda criança. Carl e eu engravidamos durante o transcurso da pesquisa. A partir de então, deixei de participar da tomada de psicoativos, e comecei a frequentar outras especialistas de terapêuticas e magias populares voltadas aos processos reprodutivos femininos: parteiras como Maria, sobadoras como Asteria e yerberas como Anita del Carmen. Ainda que alguns/mas curiosxs que tinha entrevistado na época assumissem que a ayahuasca podia ser benéfica durante a gravidez, outrxs, como Isabel, asseguravam que ela podia cutipar o feto. O cutipado é resultado da influência do espírito da planta sobre a criatura, originado por um contato inapropriado entre espírito da planta e o lábil espírito da criança. Tal perturbação pode causar um aborto ou fazer com que a criança nasça fraca e com uma tonalidade amarela no semblante. Pessoalmente, não queríamos para nós nem para $x$ neném nenhum desses riscos, pelo que decidi não ingerir mais a ayahuasca ou qualquer outra planta de índole psicoativa durante todo o restante do meu trabalho de campo. Continuei, porém, me tratando com plantas pequenas, e foi assim que conheci uma diversidade de curiosxs que tratavam dores, dolências e moléstias relativas à gravidez, parto e primeira infância. Assim, eu considero que a minha gravidez me obrigou a tomar outra forma de compromisso corporal em campo: a minha participação agora 
não afetava somente a minha pessoa, mas também a gestação da minha menina. A gravidez me abriu as portas para o mundo das plantas minúsculas, aquelas plantas pequeñas que requerem um andar vagaroso para serem vistas.

Uma diversidade de plantas e pessoas às quais, em uma primeira aproximação, não tinha tido acesso, apareceram gradualmente. Assim, os benefícios e o frequente uso da malva local [Malachra ruderalis], do algodón [Gossypium barbadense] e da hierba luisa [Coix lacryma-jobi] provavelmente não teriam sido conhecidos por mim senão a partir da minha gravidez. Por sua vez, a compreensão do escopo mais amplo dxs curiosxs, que envolvia a atividade de curandeirxs, xamãs e outras categorias, talvez tenha permanecido também ignorado por mim a não ser pelos percursos que comecei a andar sendo uma mulher grávida na floresta. Primeiro e segundo trimestre de gestação: parteiras, sobadoras e yerberas apareciam cada vez com mais força na minha cotidianidade. Suas massagens, sobadas e conversas me orientaram naqueles meses tão particulares, ao mesmo tempo em que me abriram para o universo das práticas terapêuticas e mágicas do invisível universo relacionado com o feminino local.

A uma teoria "feita em casa" como a que aqui proponho corresponde a uma estratégia metodológica ad hoc: assim, nas entrelinhas das experiências em campo, sobretudo das primeiras, é possível encontrar a semente que germinará, de maneira posterior, em postura metodológica. É de tais sementes que foi constituído esse capítulo, que resgata o processo e a voz de Isabel, envolvida nele de maneira ativa. É assim que, no presente capítulo, tratei os pontos fundamentais da construção metodológica desta proposta de pesquisa, realizada de maneira dialógica com Isabel, interlocutora ativa nela, e com o universo dxs curiosxs de Tamshiyacu que me foi aberto posteriormente. Foi a partir da abordagem à cotidianidade com Isabel primeiro, e com o restante dxs curiosxs, 
que fui definindo as diversas formas de me aproximar à realidade da pesquisa. Assim, foi a partir das interações informais com elxs que escolhi as narrativas de vida como ferramenta de produção de sentidos. No que tange à Isabel, foi a partir dos trabalhos mágicos e terapêuticos que com ela compartilhei que fui elaborando as formas de "compromisso corporal" que iria adquirindo em campo. Isabel também foi a primeira pessoa com a qual fui delineando instâncias orais de negociação do consentimento do que iria ser explicitado, apresentado de maneira impessoal ou preservado no marco da pesquisa, e que foram exercitadas no contato que tive com outrxs curiosxs ao longo de toda a experiência. Desta maneira, em vez de apresentar um excerto metodológico de caráter monológico, fruto da higienização de vozes e experiências diversas, me dispus a fazer visíveis àqueles aspectos mais importantes que participaram da modulação da minha proposta em campo, assim como algumas dúvidas, silêncios, as limitações e escolhas próprias do processo. 


\section{Capítulo 4 \\ O tempo com Isabel: memórias}

-O tecido de uma vida $\bullet$ Nascer $\bullet$ Crescer $\bullet$ Casar, parir e depois viajar $\bullet$ De curandeira para xamã • Mundo de la Yacuruna

\section{- O tecido de uma vida}

O presente capítulo foi escrito na direção de duas intenções. A primeira é a de construir uma narrativa, consistente na materialização de uma história e de uma particular maneira de fazer no mundo a partir dos depoimentos de Isabel, uma mulher shipiba que é curandeira, mãe, avó e artesã. A segunda intenção é que a partir disso seja possível desenhar uma porta de acesso para a compreensão do curandeirismo local em sua contemporaneidade, em suas contradições, em seus silêncios, em sua híbrida complexidade.

A história de Isabel que é aqui contada não é, nesse sentido, somente o relato de uma vida única, original e irreprodutível, mas também a porta de acesso para outros "eu", para esse mundo de afinidades e inimizades com o qual Isabel se relaciona diariamente. Despregando a sua individualidade e originalidade em íntima interação com as possibilidades e violências do meio social local, esse relato fornece elementos que podem servir para a sistematização, análise, comparabilidade e contextualização do curandeirismo particular e único de Isabel em relação a outras tantas maneiras de fazer.

Apresento algumas memórias da vida de Isabel que ela contou e que eu escrevi para a presente pesquisa. Primeiramente, relato seu nascimento no contexto de uma família indígena shipiba. Depois, escrevo sobre o crescer e sobre o seu primeiro contato com as dietas do curandeirismo amazônico, pela mão do seu pai, Antônio. Seguidamente, narro o seu primeiro tempo como mulher adulta, 
que casa, tem filhxs e depois decide viajar para longe da sua terra natal. Em seguida, apresento o processo laboral e identitário pelo qual Isabel começa a se identificar não só como curandeira, mas também como xamã. Finalmente, observo a maneira como funciona a iniciativa Mundo de la Yacuruna, o albergue xamânico que ela compartilha há poucos anos com seu companheiro Jorge.

\section{- Nascer}

Seu documento de identidade afirma que ela nasceu no ano 1960, em Dos de Mayo, uma comunidade de menos de mil habitantes do distrito Iparia, província Coronel Portillo, departamento Ucayali. Isabel Pinedo Rengifo é uma mulher indígena shipibo originária do interior de Pucallpa (região da Amazônia peruana média), que hoje conta com 54 anos e que migrou há seis para o povoado de Tamshiyacu. Ela conta que nasceu de uma união um tanto particular entre Maria, uma mulher que era uma ativa crente no evangelismo e Antonio, um homem que cultuava seus ancestrais e encantados indígenas. A sua mãe era da localidade de Dos de Mayo e o pai dela tinha nascido em San Francisco, hoje uma cidade amazônica de médio porte e bastante turística do departamento Ucayali. Maria fazia olaria e cuidava dxs filhxs. Antonio trabalhava a chacra [extensão de cultivo semi-intensivo, usualmente de propriedade familiar]. Isabel aprendeu a falar o shipibo com a sua família e adquiriu noções de espanhol na escola. Quando terminou a educação primária, Isabel permaneceu no núcleo familiar ajudando nas tarefas da casa e da chacra [o plantio] familiar. Por sua vez, ela começou a andar seus primeiros passos nas artes do curandeirismo com o seu pai Antonio, quando ela tinha 14 anos. Antonio, por sua vez, foi estimulado a apreender a curar pela própria tia materna, Rosana Barbarán, que também era curandeira. "Ella era curandera de puro plantas, no tomaba ayahuasca"60, comenta Isabel. Ela

60 "Ela era curandeira somente de plantas, não tomava ayahuasca". 
conta que o pai dela era curandeiro conhecido na região, as pessoas diziam que ele, como qualquer outrx curandeirx shipibo, tinha relação estreita com o mundo debaixo do rio. Diziam particularmente que ele namorava com uma fêmea bufeo e que passava parte do tempo que não estava em casa nas cidades fantásticas dos bufeos [seres encantados que estão encarnados nos golfinhos de rio] sob o rio. Tais encantadxs o acompanhavam também à sua morada humana: "En casa escuchábamos que él conversaba con su gente, aunque no veíamos con quién"61, contame Isabel.

Sob a supervisão do seu pai, Isabel cumpriu dois anos de dieta [período de isolamento e aprendizado a partir do diálogo com espíritos das plantas] no interior da floresta. Antonio chacapeaba [fazia movimentos rituais de limpeza] seu corpo com yerba luisa [Coix lacryma], levava-lhe provisões e the ensinava a preparar pra si mesma as plantas que ia tomar. Ela dormia sozinha em um tambo [choça construída para retiro e abrigo] e esperava. Em momentos de seus cochilos diurnos, assim como em seus sonhos noturnos começaram a aparecer os "donos das plantas", pequenos seres animados que lhe ensinavam como preparar as plantas e qual planta era indicada para cada coisa. Também, ensinavam-lhe a cantar. Diz Isabel que com a ajuda desses seres, os cantos apareciam e tomavam conta da mente dela. Ela os memorizava para serem performados quando fosse oportuno, na hora dos trabalhos de curandeirismo.

Naquele momento, começou a dietar com a uña de gato [Uncaria tormentosa], o ajo sacha [Mansoa alliacea] e o chantaquiro [Clavija weberbaueri]. Isabel relata que, alguns meses depois do começo da dieta, apareceu frente a ela um homem pequenino, com cara de velhinho e roupas floreadas, que lhe deu as instruções para curar e também para fazer trabalhos para outras pessoas: "fuma tu mapacho,

61 "Em casa escutávamos que ele conversava com a sua gente". 
después toma tu agua florida, después le soplas la cabeza y después soplas tu corona. Ahí recién chupas ${ }^{62 "}$. Esse homem mínimo era o próprio espírito da planta que naquele momento ela estava dietando. A primeira pessoa que Isabel tratou foi uma menina que padecia de mal aire ${ }^{63}$. O pai de Isabel chegou à floresta, acompanhado da criança e da mãe da pequena. Ela tinha muito medo de errar, mas o pai dela lhe diz "anda, que ya sabes" ${ }^{4}$. A partir da intervenção de Isabel a criança sarou.

Não era somente com a finalidade de curar os males de outrxs que Isabel dietava. Ela aprendeu também a dietar com as folhas da mucura [Gallesia integrifolia], uma planta que encobre o cheiro humano e faz com que o corpo se confunda com o restante da floresta. Isso é fundamental para quem quer trazer carne do monte. Até hoje Isabel se preza como sendo boa caçadora. Quando não há o que comer, sai para caçar. Traz macacos, aves e porcos selvagens, e os integra às comidas junto com o plátano, a mandioca e o arroz, elementos básicos do prato cotidiano. Assim mesmo, Isabel aprendeu a dietar com plantas que "enseñan a hacer maldad ${ }^{65 "}$. Ela diz que as plantas são as mesmas que servem para se proteger da maldade. Que qualquer pessoa que queira se proteger da maldade deve saber como fazê-la.

Pouco depois de ter curado a sua primeira paciente, a menina com mal aire, Isabel decidiu retornar para casa com seus pais e irmãos/irmãs novamente. Passou um tempo em casa e Antonio faleceu. Diz Isabel que deixou o ataúde aberto com

\footnotetext{
62 "Fuma teu cigarro, depois bebe a tua água florida, depois sopras na cabeça da pessoa e depois na sua coroa. Então chupas [o mal]".

63 Mal aire é uma síndrome que está definida por dores inespecíficos e mal-estar geral. Está associado a práticas intencionais de curandeirismo contra a pessoa afetada.

$64 \quad$ "Vai, que já pode".

65 "Ensinam a fazer maldade".
} 
suas roupas somente: para ela, é claro que o pai desvestiu-se e foi morar com a sua família de bufeos embaixo da água.

Antes do ano da morte do pai, Maria, mãe de Isabel, instou-a a se casar com um jovem shipibo de religião evangélica. $\mathrm{O}$ evangelismo, a religião da mãe, tinha sido praticado por alguns dxs irmãos/irmãs em casa, mas não por todxs. O pai delxs não estimulava práticas religiosas cristãs, permanecia alheio a elas com silenciosa indiferença. Quando faleceu, a mãe de Isabel se viu motivada a aumentar a sua influência na vida espiritual dxs filhxs. Isso envolvia tomar decisões sobre as pessoas com as que seus/suas filhxs haveriam de compartilhar teto, chacra e vida. Especialmente as filhas mulheres, que ela considerava serem uma extensão da sua presença e rol femininos. "Me entregó... yo no queria... a los palos me entregó! ${ }^{66 ”, ~ a s s e g u r a ~ I s a b e l . ~ E ~ r e f l e t e ~ h o j e: ~ “ l o ~ q u e ~ m a ́ s ~ m e ~ h u b i e r a ~ g u s t a d o ~}$ hubiera sido continuar en ese camino" ${ }^{\prime 7}$ das dietas e das curas, sem se preocupar com questões relativas à criação dxs filhxs. Mais ainda, sem ter que se ver obrigada a viver no contexto de práticas religiosas cotidianas tão afastadas do que ela queria para si, tais como a participação em missas, a leitura dos evangelhos, a proibição taxativa da ingestão de plantas psicoativas, o cerceamento da comunicação com os mortos, a impossibilidade de curar a outras pessoas.

\section{- Crescer}

Um dia, enquanto eu preparava o almoço na cozinha do albergue, Isabel me contou:

Mi mamá me contaba historias del tiempo de mi abuela. Dice que ellos vivían en las montañas y no salían para nada. No había ropa: hombres y mujeres usaban hojas de plátano acá [señala su vientre] o andaban calatos [desnudos] nomás. En ese tiempo era la yuca, el masato [bebida de yuca

66 "Eu não queria, me dando pauladas é que me entregou!".

67 "O que mais tivesse querido era continuar nesse caminho". 
fermentada], la carne de monte. No había arroz, ni leche, ni ajo. Ni candela, se comía todo crudo. Entonces comenzaron a venir en aviones. Mis parientes les apuntaban con flechas. Eran los gringos, que bajaban de los aviones. Traían sus regalitos. Pero a mis parientes no les gustaban, los rompían con el machete. Los partían bien en pedazos. Después otra y otra vez. A mis parientes les fue gustando. Aceptaron los regalitos aunque los onaya [curanderos shipibo] rabiaban un poco al principio. Después vino la ropa. Algunos gringos eran hermanos [religiosos cristianos]. Yo estoy orgullosa de mi gente. Tomo leche, pero poquita. No como queso, ni aceitunas $^{68}$.

Esse extrato pertence a uma conversação informal de abril de 2013, no albergue Mundo de la Yacuruna, onde eu estava acompanhando a Isabel e celebrando os dias posteriores a uma dieta amazônica - consistindo na restrição de alimentos e atividades, tomando plantas mágicas e de isolamento social relativo-, restringindo a minha interação social unicamente a Isabel, Jorge e Giovanna, a cozinheira que levava a comida para minha casinha de madeira, a cabana do Chullachaqui [ser encantado que cuida da floresta]. Naquele dia, de fato, podia conversar com pessoas novas e não me esconder, isso me dava especial alegria. Eu tinha decidido investir em farinha de trigo, ovos, queijo, alho e tomate e fazer um macarrão caseiro para compartilharmos no albergue. Isso fazia parte de uma intenção minha de compartilhar vis à vis os nossos mundos, tentando deixar de lado o registro de fatos e experiências significativas na vida delxs e colocar de forma horizontal, e em uma mesa comum, tanto as coisas que resultavam

68 "A minha mãe me contava histórias do tempo da minha avó. Ela diz que eles moravam nas montanhas e não saíam para nada. Não havia roupas: homens e mulheres usavam folhas de plátano aqui [aponta no seu ventre] ou andavam calatos [nus] mesmo. Nesse tempo era a mandioca, o masato [bebida de mandioca fermentada], a carne de monte. Não havia arroz, nem leite, nem alho. Nem fogo: tudo se comia cru. Então começaram a vir em aviões. Meus parentes lhes apontavam com flechas. Eram os gringos, que bajaban de los aviones. Traziam seus presentinhos. Mas a meus parentes eles não thes agradavam, eles os quebravam com o machado. Os quebravam em pedacinhos. Depois uma e outra vez. Aí meus parentes foram gostando. Aceitaram os presentinhos mesmo quando os onaya [especialistas em terapêuticas e magias da etnia shipibo] raivaram um pouco no começo. Depois vieram as roupas. Alguns gringos eram hermanos [religiosos cristãos]. Eu estou orgulhosa da minha gente. Tomo leite, mas só um pouquinho. Não como queijo nem azeitonas". 
significativas para elxs, quanto as que o eram para mim. Foi assim que surgiram as pastas caseiras, como comida que evocava a avó italiana que as fazia para nós em casa. Naquele momento estavam Jorge, Jordi, Diego, Isabel e dois jovens que tinham ido preparar o teto da galeria próxima à maloca. Quando a massa ficou pronta e o molho de tomate em cima, todxs experimentaram. Quase ninguém gostou. Seus paladares não entendem a textura elástica da farinha de trigo com ovos e água, nem as emoções que evocam, como a mim, as pastas. E mais, para Isabel o leite, o queijo, a farinha e as azeitonas lhe lembram o tempo da primeira colonização da sua gente. E ela, que não rejeita o que é novo, mas não quer se perder nele, não ingere outras comidas alheias à sua cultura. $\mathrm{O}$ seu existir shipibo modela paladar, identidade, língua, andar.

Isabel se refere a seu pai, que trabalhou para xs gringxs durante um bom tempo. Por gringos se entende que são, na Amazônia do Peru, todas as pessoas estrangeiras, especialmente aquelas com um fenótipo que se associa à branquitude: cabelo claro, olhos claros, pele clara, altura maior do que a média na região. Dom Antonio participava de escavações de onde se extraíam restos antigos da sua cultura para serem enviados depois fora do país. Isso lembra Isabel, para quem o ambíguo contato com $x s$ gringxs não é novo: ela já nasceu em um contexto de contatos estratégicos, às vezes enriquecedores, mas a maior parte das vezes predadores, da cultura dos países do norte em relação à sua etnia shipibo.

$\mathrm{Na}$ época de seu pai, ser curandeiro era um ofício secreto, aquela ocupação que se exercia depois do trabalho de todos os dias. Naquele tempo - pensemos na colonização da fronteira pela penetração estatal e privada da Amazônia própria 
da primeira parte do século $X X^{69}{ }^{-}$, muitxs viajantes vindxs dos países do norte se interessavam pelos traços da cultura material das etnias amazônicas. Enquanto Dom Antonio comercializava objetos que se confundiam aos olhos $\mathrm{dxs}$ compradores entre peças arqueológicas e produtos de artesanato durante o dia, desde o anoitecer tinha todo o tempo do mundo para se ocupar da sua relação prática com seres de outras dimensões. Tais seres eram convocados, através da proximidade física com as plantas, para ajudar nos trabalhos de curandeirismo. Amarres, cura de doenças físicas e espirituais, orientação a respeito de conflitos sociais: dom Antonio, como xs outrxs curandeirxs shipibo, era procurado e temido pelo grupo social, e seu trabalho residia na mediação de forças invisíveis em um mundo de formas enganosas.

Dom Antonio era parte de uma família de curandeirxs, algumas/alguns dxs quais voltaram a sua prática para o turismo durante o boom do turismo xamânico do final do século XX. Ao mesmo tempo, as ricas expressões da arte shipiba se tornaram ainda mais visíveis, pois estavam diretamente ligadas aos estados modificados de consciência. As formas plásticas, cantos sagrados e formas de fazer medicinas dxs shipibos explodiram como objetos do consumo artístico e ritual das audiências dos países do Primeiro Mundo. Elxs começaram a ser destacadxs do profícuo mapa étnico regional sob a marca de serem xs melhores conhecedorxs das plantas maestras e suas potencialidades. Dois dos curandeiros mais famosos na cena ayahuasqueira peruana são Agustín Rivas e Guillermo Arévalo. Conta Isabel que o primeiro era de família ribeirinha e morava em Pucallpa e aprendeu tudo o que sabe da família indígena de Isabel. Hoje, Dom Agustín possui mais de seis albergues xamânicos nas imediações do povoado de Tamshiyacu, tem sido reconhecido como o "embaixador cultural" da Amazônia

69 Tal período está bem ilustrado no texto de Fernando Santos Granero e Frederica Barclay, "La frontera domesticada - Historia económica y social de Loreto, 1850-2000". 
peruana dentro e fora do país ${ }^{70}$ e no povoado de Tamshiyacu, onde mora, é denominado "o primeiro multimilionário ayahuasqueiro" (Ver Imagem 4, Acampamento de Agustín Rivas). O segundo é Guillermo Arévalo, reconhecido xamã, dono do centro xamânico Espíritu de la Anaconda ${ }^{71}$ e protagonista de alguns escândalos por abuso sexual e mortes relacionadas com as práticas de toma de ayahuasca. Tanto Agustín como Guillermo reformularam antigos procedimentos e modelaram as novas práticas rituais que se apresentam como shipibas no cenário do turismo xamânico contemporâneo. Infelizmente, Dom Antonio não viveu para ver e ponderar todas essas transformações, das quais a sua etnia shipiba tão ativamente participaria. Hoje, o valor de intercâmbio já não é somente a cultura material. Hoje, as pessoas alheias a essa cultura também estão interessadas em colocar o próprio corpo sob o mapa de práticas mágicas dxs curandeirxs. Hoje, o mapa da relação entre a etnia shipiba e o mundo de fora muito mudou. Dom Antonio faleceu quando Isabel tinha 17 anos. Isabel sussurra entre lábios que na verdade o pai dela não morreu, mas simplesmente retornou: ele voltou a se juntar com a gente que mora embaixo d'água, que era o meio de onde ele provinha. Isso é o que sucede com as pessoas que estão ligadas com os aspectos mais sagrados da cultura shipibo: elas vêm da água, e para a água voltarão, uma vez que passam pelas provas que esse mundo de formas humanas lhes oferece. Até hoje, nas suas cerimônias, Isabel evoca seu pai para curar. E consegue vê-lo sob a forma de uma luz difusa que o acompanha.

\footnotetext{
$70 \quad$ Nota sobre Agustín Rivas Vázquez: “Un chamán peruano en Alemania, al servicio del mundo". Em: www.dw.de, noticia do 16/06/2011.

71 Site do albergue Espíritu de Anaconda: www.anacondacosmica.net. Acesso em $11 / 03 / 2014$.
} 


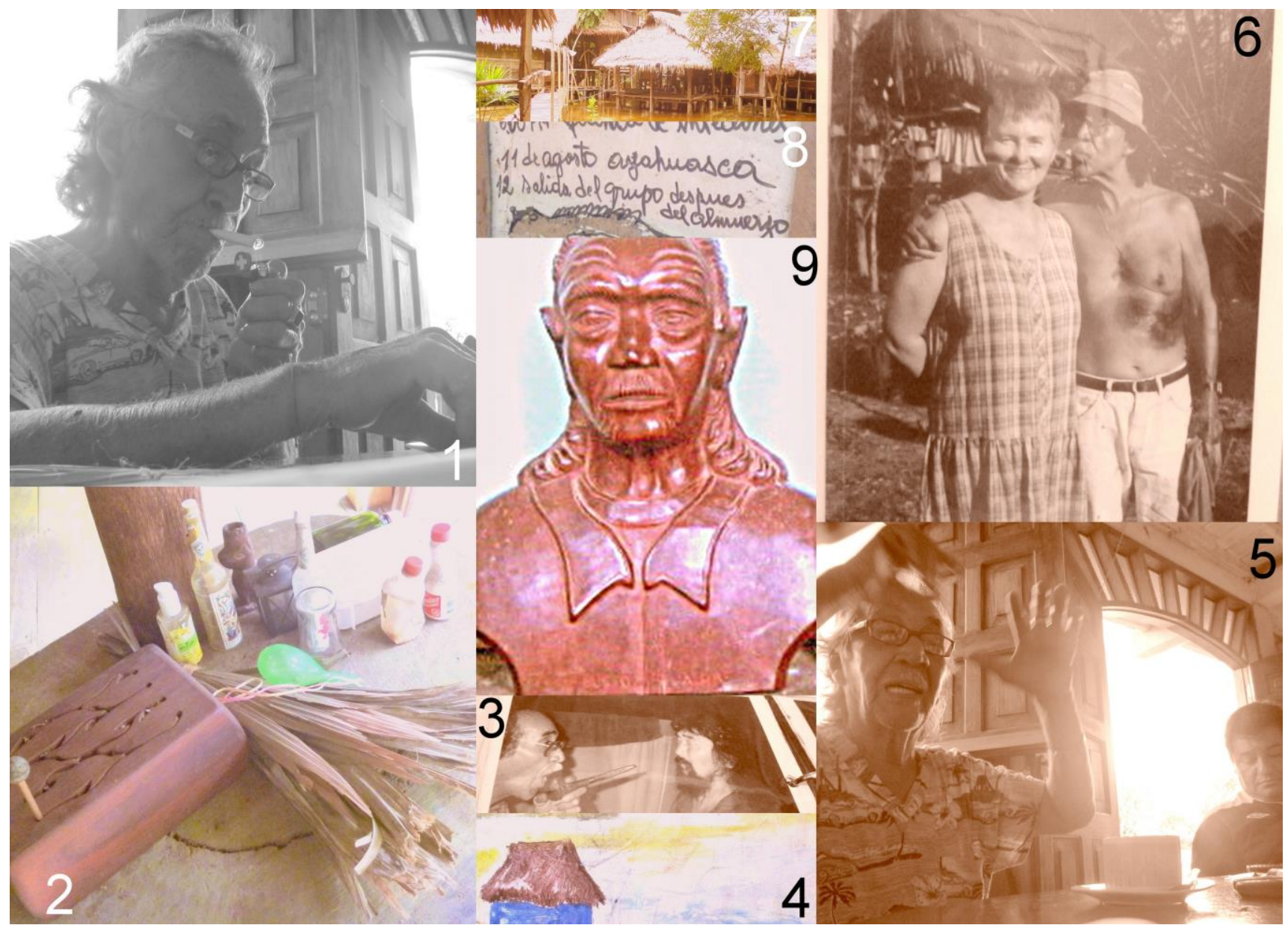

Imagem 4 (acima): Acampamento de Agustín Rivas

1 - Agustín fumando seu mapacho. Fotografia: Gentileza de Carl Carew.

2 - Instrumentos tradicionais (xacapa) e não tradicionais (xilofone) no acampamento de Agustín.

3 - Assoprando fumaça de tabaco no rosto de um turista japonês. Fotografia: Gentileza de Agustín Rivas.

4 - Quadro pendurado na parede do acampamento. Quietude de uma choça no meio à água.

5 - Agustín Rivas e o atual diretor da escola Agustín Rivas, de Tamshiyacu. Fotografia: Gentileza de Carl Carew.

6 - Agustín, abraçando uma turista (Fotografia: Gentileza de Agustín Rivas).

7 - Iushintaita, o maior acampamento de Agustín, cidadela na floresta cuja base é inteiramente atravessada por um rio.

8 - Atividades do dia do grupo de turistas hospedadxs em Iushintaita.

9 - Busto de dom Agustín, talhado por seu aluno Julio Rengifo. 
Xs indígenas shipibo desenvolveram um sistema de saúde tradicional que é rico e refinado, com uma diversidade de especialistas que ativam práticas mágicas ou terapêuticas a partir das suas relações com plantas, animais e outros seres encantados. Em cada ciclo de tempo, as gerações mais velhas se ocupam em encontrar aprendizes que tornem possível a transmissão encadeada desses saberes e práticas. Na medicina shipibo existe uma divisão tríplice dxs especialistas em terapias e magias (Cárdenas Timoteo, 1989): tobiuná (a pessoa que trabalha acomodando ossos e tonificando músculos), baquiuná (a pessoa que assiste os partos) e samatay (a pessoa que exerce o curandeirismo, em práticas terapêuticas e etótropas, isto é, orientadas de forma mágica a modificar o comportamento de outrxs). Dentro do último grupo se contam os unaya, especialistas no diálogo com seres de outros mundos. Em continuidade com esse modelo, três dxs filhxs de Dom Antonio o seguiram, cada um delxs a partir de uma das três diferentes maneiras de fazer: uma irmã mais nova, Virginia, tornando-se partera, outro irmão mais velho, Gerónimo, apreendendo as artes de ser huesero de lisiados [especialistas encarregados de endereçar os ossos e aliviar as dores musculares, entre outras coisas] e ela mesma, tornando-s e curandera e xamã. Mas, para isso, houve de contornar um caminho sinuoso que se dividiu entre as expectativas sociais relativas ao fato de ser mulher e as potencialidades de se voltar para o curandeirismo e o xamanismo.

\section{- Casar, parir e depois viajar}

A mãe da Isabel acertou seu casamento com um jovem shipibo evangélico quando ela tinha 15 anos. Elxs tiveram juntxs seis filhxs. O primeiro foi um bebê que 
morreu um ano depois de nascer. Ele morreu de uma doença chamada pelagra ${ }^{72}$. "Todito su cuerpo parecia escama de pescado"73, conta Isabel.

Depois vieram Néstor (que hoje tem 27 anos), Jenny (que hoje tem 25), Kelly (que tem 24) e dois gêmeos, dos quais só sobreviveu Gerlyn (que tem 22 anos). Anos depois, Isabel teve outro filho, Jordi, que hoje tem 12 anos. O seu primeiro filho nasceu com a ajuda da sua irmã Virginia, que é parteira. Para parir xs próximxs filhxs, Isabel não quis avisar ninguém e os pariu às vezes ajudada pelo seu primeiro esposo, às vezes sozinha. Isabel teve todxs seus/suas filhxs em casa, com exceção de Néstor: ele nasceu enquanto Isabel estava trabalhando a terra na chacra. Ela comenta que depois de parir, deixou a criança dormindo e terminou o trabalho do dia.

Isabel pariu os gêmeos na época de São João, que tanto se festeja na floresta, com canto, dança e comidas. Para essa época, todo ano, Isabel me conta que se sente triste. E cada vez que ela encontra buraquinhos na sua roupa, ela os atribui a esse irmão. "Me deja la ropa hueco-hueco. Se enoja conmigo cada vez que yo lo reto a Gerlyn"74. O diálogo e interação com os espíritos do seu pai e filho falecidos era coisa de todos os dias. Isso não a assustava, mas lhe acompanhava e lhe dava ânimos para afrontar ameaças de espíritos que podiam lhe fazer dano assim como levar diante, com sutil companhia, as rotineiras tarefas do cotidiano.

Por sua religião, seu esposo the proibiu que continuasse curando a outras pessoas. Pela constituição do dogma pentecostal, aquelxs que aderem ao

\footnotetext{
72 A pelagra é uma doença produzida por uma insuficiência relativa à falta de vitamina B3. As populações que mais a sofrem são aquelas cuja dieta é baixa em proteínas.

73 "Seu corpo todinho parecia escama de peixe".

74 "Deixa as minhas roupas cheias de buraquinhos. Se zanga comigo cada vez que eu fico brava com o Gerlyn".
} 
evangelismo não aceitam a modificação de estados de consciência ou o diálogo direto com os espíritos. Ele deve ser mediado por pastores e em reuniões especialmente dedicadas para tal fim. Porém, ela conta que queria continuar com os saberes que iniciou com a mão do seu querido pai. Desta maneira, ela costumava fazer trabalhos para seus próprixs filhxs, vizinhxs e alguns parentes às escondidas, quando seu marido ia para seu trabalho como agente sanitário na municipalidade. $\mathrm{O}$ tipo de trabalho do marido tendia a marginalizar e manter no silêncio ainda mais a sua ocupação, que ela só revelava abertamente para poucas pessoas. Um dia, enquanto passávamos por um campo onde se via um grupo de jovens jogando, ela me contou que sempre gostou de futebol. Que jogava bastante, como zagueira, antes de ter seus/suas filhxs. Que seu marido odiava vê-la jogando, e acabou the proibindo de fazê-lo, pois considerava que essa era coisa de homens, não de mulheres.

Isabel me conta que dormiam no chão de madeira da cabana onde moravam, com uma colcha que servia de amortização entre o corpo e a madeira. E os mosquiteiros definindo, de fora e por cima, o espaço da cama. O mosquiteiro é um elemento de extrema importância na cotidianidade das populações - tanto indígenas quanto mestiças ribeirinhas - da floresta: ele define não só o lugar do descanso, mas também o do abrigo e da intimidade. Isabel dormia junto com todxs seus/suas filhxs sob o mesmo mosquiteiro. O marido dela tinha um mosquiteiro para ele só.

Depois de alguns anos de convivência, ele começou a voltar tarde para casa, e durante um tempo diretamente se ausentou de lá dia e noite. Isabel não sabia o que fazer. Recebeu a notícia dos lábios da sua mãe: ele tinha já se estabelecido em outra casa com uma nova mulher, que estava grávida produto da relação com ele. Isabel foi procurá-lo e sofreu o ataque físico da nova mulher e da irmã desta 
última. Isabel conta que as duas mulheres puxaram seus cabelos com força e a jogaram no barro. Humilharam-na e a obrigaram a sair do seu terreno. Horas depois, com mais alívio do que raiva, ela decidiu então não retornar mais para procurar esse homem. Ela continuou criando as crianças na casa e na chacra, esforçando-se para que estudassem, ensinando-lhes a língua, maneiras de fazer - sobretudo, a arte de delinear kenê [desenhos próprios dxs shipibxs] - e valores da cultura shipiba (Ver Imagem 5, Desenhando o mundo das plantas no mundo humano). Aprimorou o artesanato bordado que aprendeu da mão da sua mãe enquanto criança e vivificou o seu labor como curandeira. Enquanto isso, o antigo esposo dela nunca más pudo formar pareja con otra mujer ${ }^{75}$. Ele mora sozinho e não tem companheira. Ele acusa Isabel de ter sido a responsável pela sua solidão. Isabel me conta isso e lança um breve sorriso.

Depois de se separar, Isabel se viu obrigada a procurar por ela mesma a totalidade dos elementos para seu sustento e o das crianças, que ainda estavam em idade escolar. Isabel começou a trabalhar como empregada doméstica na vizinha cidade de Pucallpa, assim como a vender os produtos da sua chacra (mamão, galinhas, mandioca, porcos); também a preparar e vender colares de sementes e roupas bordadas com kenê [desenhos com uma especial conotação mágica] shipibos, em ponto cadenilla e em ponto cruz. Paralelamente continuava, sobretudo à noite, com os trabalhos de curandeirismo. Isabel não dissimula a potencialidade financeira que essa atividade econômica apresentou para ela: como pagamento dos amarres e a cura de doenças de niñxs y adultxs, ela recebia produtos de primeira necessidade como frutas e animais, assim como dinheiro com que sustentava seus quatro filhxs. Anos depois, Isabel teve uma relação

75 "Ele nunca mais pôde casar com outra mulher". 
informal com um professor asháninka ${ }^{76}$. Fruto desta relação nasceu seu filho mais novo, Jordi, que hoje tem 12 anos e que mora junto com Isabel em Tamshiyacu. Ao perceberem um irmão vindo de um pai que pertence a uma outra etnia, xs outrxs filhxs de Isabel se ressentiram, e brincavam com Jordi the chamando de asháninka, como uma maneira de reforçar a sua desconfortável alteridade, emergida de dentro mesmo da família. Mas Isabel ensinou a conviver, a misturar, a cooperar. Foi assim que Jordi, filho de Isabel, Diego, filho de Jenny e neto de Isabel e José, filho de Kelly e também neto de Isabel se criaram tomando do mesmo leite: o leite do peito de Isabel. "Todavía tengo leche 77 ", me mostra uma tarde, levantando a camisa e apertando um dos peitos. Isabel é mãe de várias gerações, e combinou as responsabilidades e alegrias maternas com viagens, trabalhos fora de casa e aprendizados na idade adulta.

76 Os asháninkas são um grupo étnico que pertence à família linguística Arawak. A sua população hoje alcança as 90.000 pessoas, e se nucleia em torno dos seguintes rios da Amazônia peruana: Apurimac, Ene, Tambo, Perené e Alto Ucayali, entre outros.

77 "Ainda tenho leite". 


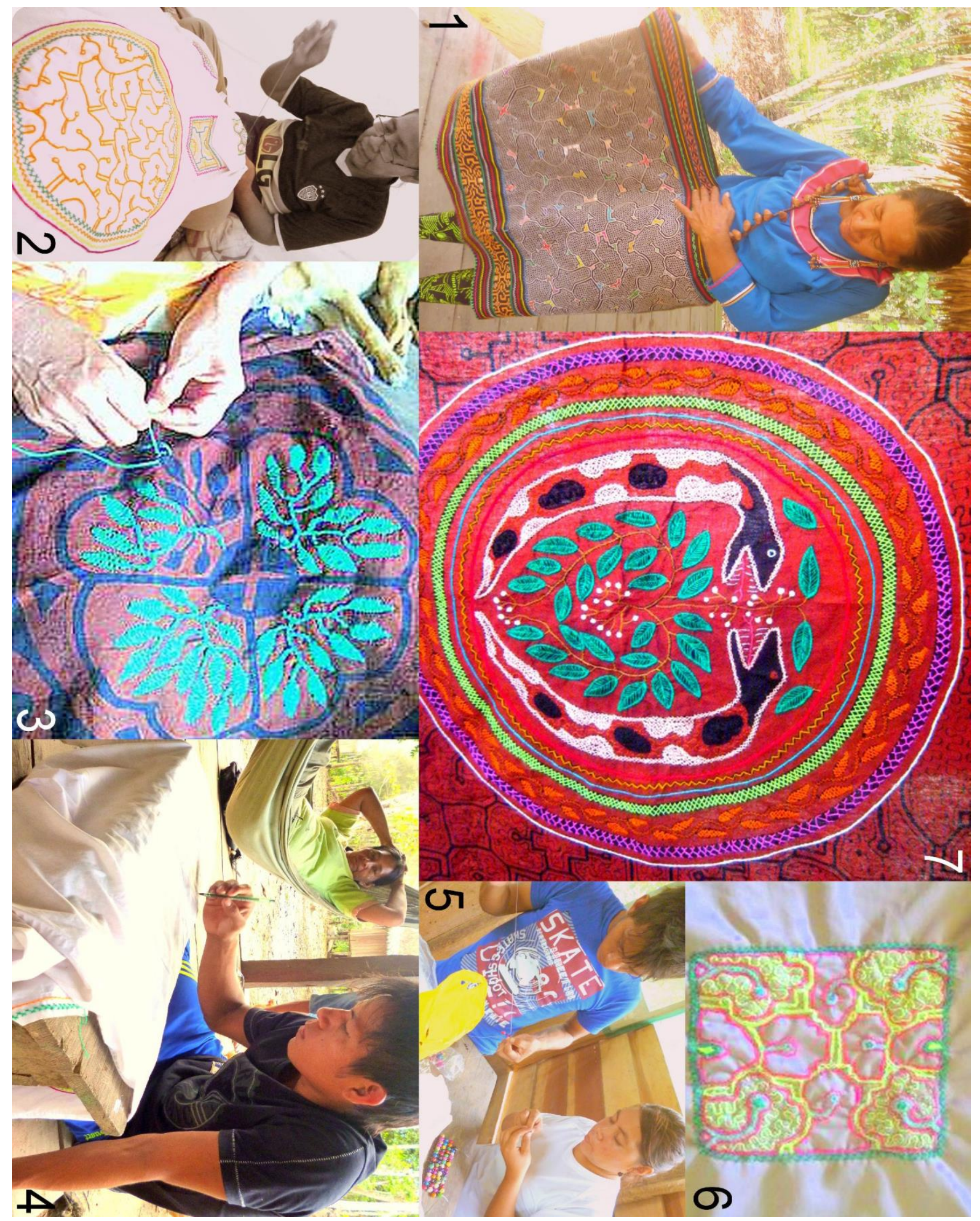


Imagem 5 (pág. anterior): Desenhando o mundo das plantas no mundo humano

1 - Isabel, colocando a saia que ela mesma bordou, e que veste em cerimônias especiais.

2 - Bordando kenê, uma maneira lenta e rítmica de dar forma às superfícies do mundo, inclusive àquelas do corpo humano e as roupas.

3 - Materialização das visões produzidas pelo contato com as plantas, o kenê manifesta a intenção etótropa dxs artesãos que o plasmam nos tecidos. Eles são uma expressão alternativa dos vibrantes ensinamentos das plantas e vê-los (ter a visão) produziria o estado de transe próprio da incorporação da planta ao próprio corpo. Isabel, bordando as folhas da ayahuasca em um pano tingido com o corante vegetal da árvore do huito [Genipa americana].

4 - Os homens shipibo costumam ter as visões, mas não as materializam em bordados. Porém, podem colaborar com os desenhos e aprender os rudimentos da arte do bordar, como é o caso de Gerlyn, filho de Isabel. Aqui, desenhando uma camisa sob o atento olhar da mãe, Isabel.

5 - Gerlyn e Jenny se dedicam também a fazer colares com contas plásticas e com sementes, para vender ao turismo.

6 - Kenê que bordei em uma camisa própria sob orientação de Isabel. A finalização do bordado me levou ao redor de uma semana.

7 - O kenê shipibo é considerado Patrimônio Cultural da Nação Peruana desde o ano 2008. Na foto, o desenho da serpente, considerada mãe da ayahuasca, junto com uma borda de folhas da planta da ayahuasca.

Pouco contava Isabel sobre o período da sua vida em que ela viajou para fora da região da floresta; e eu fiz questão de respeitar o seu silêncio. Depois de se separar do seu primeiro marido, Isabel tentou durante um tempo manter às crianças, mas não deu certo. A pressão econômica era grande, e o ex-marido voltava à casa e fazia cenas de violência reclamando seu direito de permanecer na casa. Isabel deixava Gerlyn com as irmãs da sua mãe na chacra [a casa do campo, onde ela se criou], e xs três filhxs restantes com a sua irmã Virginia, a parteira, que tinha se mudado para a cidade de Pucallpa. Foi para Trujillo, uma próspera cidade da serra do Peru e a terceira do país quanto à sua população. Naquele contexto, economicamente mais dinâmico, trabalhou como garçonete em bares e também como empregada doméstica. Lá conheceu el Chino, um jovem que também era shipibo, e começaram a namorar. Ele sabia idioma shipibo, mas não gostava de falá-lo: ela falava às vezes com ele em shipibo, ele sempre respondia em espanhol. Ao se sentir mais estabelecida naquela cidade, começou a enviar periodicamente dinheiro para a sua irmã e tias. Quatro anos depois de ter pisado em Trujillo pela primeira vez, separou-se do Chino e voltou para a sua 
terra e filhxs. Voltar para Pucallpa depois de todo esse tempo the deu a possibilidade de reorganizar a família e, agora sem uma figura persecutória, colocar a energia no seu trabalho relativo às terapias e magias.

\section{- De curandeira para xamã}

Quando Isabel tinha trinta e poucos anos e de volta à sua terra natal, recomeçou as suas atividades como curandeira, mas precisou sobreviver comercializando na rua seus produtos da chacra e peças de artesanato, que ela mesma confeccionava. Lá conheceu um turista que solicitou um trabalho de cura. Com ele cantou seus icaros. Ele ficou contente com seu trabalho e fascinado com a sua voz. Então, convidou-a para migrar para trabalhar em Iquitos. O contato proposto era com um albergue turístico que contratava mulheres shipibo para liderarem nas suas cerimônias com ayahuasca. Tanto naquele momento quanto hoje as mulheres shipibo são muito procuradas pela maneira com que cantam os icaros: uma particular doçura na voz e uma especial potência para orientar as forças que se abrem nas cerimônias. Isabel não era exceção: encontrou-se trabalhando no albergue e lodge Nihue $\operatorname{Rao}^{78}$, que é o nome shipibo de uma planta de uso mágico e medicinal. O centro foi inaugurado em 2011, e Isabel participou de seus começos. O belo estabelecimento fica a 90 minutos da cidade de Iquitos, perto da Reserva Nacional Allpahuayo Mishana, e tem uma estrutura especialmente desenhada para o turismo. Sob um habitual esquema tríplice de dietas, purgas e cerimônias com ayahuasca, o lodge é coordenado por um médico norteamericano/colombiano, Joe Tafur, uma artista e xamã canadense, Cvita Mamic e um curandeiro shipibo peruano, Ricardo Amaringo. Ele não trabalha com terapias ou trabalhos com a população nativa local, mas se dedica exclusivamente à rama do turismo xamânico. Isabel morava lá e lá trabalhava, 
em contato exclusivo com turistas do mundo todo, sobretudo Europa e a América do Norte.

O lodge se assemelhava a um pequeno país, com as suas próprias regras e concepções sobre o mundo em geral, e sobre o curandeirismo em particular. Naquele mundo privado a língua franca, que até então tinha sido o espanhol, passou a ser o inglês. A língua shipiba ganhava uma cor étnica e sagrada, e ainda que as pessoas não se dispusessem a aprendê-lo, o repetiam como um mantra nas cerimônias coletivas de ingestão de plantas.

Mudou também o ritmo e estilo dos trabalhos que Isabel, como curandeira, fazia: de trabalhos solitários (ela curava sozinha), irregulares (dependendo de quantas pessoas fossem para a sua casa procurá-la), diversos em seu objetivo (curar o susto, mal aire, aycadura, cutipado, fazer amarres de amor) e múltiplos quanto à população que os requeria (mulheres, crianças, homens, jovens e pessoas de idade), eles passaram a ser trabalhos coletivos (havia outrxs curandeirxs no albergue), regulares e rotineiros (com contingentes de turistas em determinados dias da semana), guiados em todos os detalhes da sua prática diária (purgas e limpezas com fumaça de tabaco e especialmente cerimônias com ayahuasca) e a população que os procurava passou a ser majoritariamente de turistas - na sua maioria, mulheres e homens entre 30 e 50 anos de idade.

Foi em Nihue Rao que ela começou a ser chamada de xamã. "The shipibo shaman". "The shipibo female healer" ${ }^{\prime 79}$. Lá é que ela aceitou essas nomeações, que abriam as portas de um novo mundo de atividades, redes e possibilidades. Isabel entoava a cada anoitecer, com voz aguda e potente, seus ícaros shipibo, acendia seu

\footnotetext{
79 "A xamã shipibo". "A curandeira shipibo".
} 
cachimbo com tabaco e dava de beber uma ayahuasca que tinha sido preparada em grandes quantidades pelos ajudantes do albergue. As condições, não sempre justas, dos pagamentos no albergue ainda não a constrangiam. Tinha motivos para continuar ali: não precisava mais se esconder, já que a sua prática mágica e de cura tinha se tornado o centro visível da própria vida.

Ainda que Isabel tenha permanecido por vários anos longe do seu espaço natal, e conhecido o que é a agridoce sensação do estranhamento cultural, quando começou a trabalhar como xamã, começou a lidar com ele de uma maneira que não tinha precedentes na vida dela. Um importante fator de estranhamento foi a intimidade que se estabelecia nesse novo trabalho, as confissões existenciais e as vivências de catarse eram situações delicadas que devia atravessar diariamente junto com xs turistas estrangeirxs. Pouco a pouco foi se acostumando e criando uma linguagem onde o shipibo, o espanhol, o inglês e as linguagens do corpo enriqueciam a compreensão da experiência psicoativa com ayahuasca no set psicológico das pessoas que iam fazer as suas cerimônias no centro. Uma das questões que mais chamou a atenção de Isabel foi a maneira de viver questões relativas à sexualidade feminina por parte das turistas estrangeiras:

Cuando estuve en Nihue Rao aprendí muchas cosas. Conocí gente de otros lugares. Allá hacíamos ceremonias. Después ellos preguntaban y preguntaban. Mujeres que las había violado el padre, el hermano. La del padre era de Francia, la del hermano, no me acuerdo. Y jóvenes y señoras que se habían sacado el bebé con dos o tres meses. Sufrían hasta ahora. Me contaban. Acá hay [abortos], pero las mujeres no sufren tanto. Debe ser porque toman plantas acá ${ }^{80}$.

\footnotetext{
$80 \quad$ "Quando estive em Nihue Rao aprendi muitas coisas. Conheci gente de outros lugares. Lá nós fazíamos cerimônias. Depois eles perguntavam e perguntavam. Mulheres que tinham sido estupradas pelo pai, pelo irmão. Aquela que contava do pai era da França, aquela que contava do irmão, eu já não lembro. E jovens e moç as que tinham tirado o neném quando tinham dois ou três meses [de gravidez]. Sofriam até agora. Contavam-me. Aqui há também [abortos], mas as mulheres não sofrem tanto. Deve ser porque elas tomam plantas aqui".
} 
As intensas experiências psicológicas e culturais com turistas estrangeirxs a treinaram como uma competente artista do cantar e do ouvir, do acompanhar processos dolorosos e do animar espíritos caídos ou desesperados. O trabalho não cessava. $\mathrm{Na}$ maloca [construção circular indígena] preparavam-se ao anoitecer as cerimônias coletivas de toma de ayahuasca que ela facilitava diariamente.

Isabel conta que na procura de melhores condições laborais decidiu mudar de espaço. Foi assim que um ano depois, Isabel começou a trabalhar em outro lodge destinado a turismo xamânico. Nesse caso, o dono era também uma pessoa emigrada dos países do norte para a amplidão multiplicada da floresta: Scott Petersen, norte-americano. O Refugio Atiplano, como os outros dezessete albergues da região, está destinado a realizar cerimônias de ayahuasca com turistas e a hospedá-lxs para a realização de dietas [retiros terapêuticos].

É então que xs filhxs mais novxs de Isabel (Jenny, Gerlyn e Jordi) e um neto dela (José) se reagrupam em torno dela em Tamshiyacu, uma localidade distante a 40 quilômetros da cidade de Iquitos e a uma hora do albergue Refugio Altiplano. A três dias de barco durante a época de chuvas e a seis dias durante a época seca, o rio Amazonas une e separa, serpenteante, o novo povoado do povoado natal. $\mathrm{Na}$ época em que eu fiz meu trabalho de campo perto da família, Jenny, Gerlyn e Jordi estavam entusiasmados: novamente sob o cuidado de Isabel, agrupados como família matrifocal cujo centro feminino produz e mantém a vida.

O albergue Refugio Altiplano tem uma praça interna onde semanalmente se realiza uma feira de produtos de artesanato. Ali é que a maior parte dos artesãos e artesãs de Tamshiyacu vendem seus produtos: esculturas em madeira, instrumentos musicais, pinturas, bijuteria de sementes, conchas e penas 
coloridas. Nas horas vagas que restavam a seu trabalho como xamã do centro, Isabel aproveitava para fazer seus trabalhos de bijuteria e tecidos bordados. Guardava os mais primorosos para seu próprio uso em cerimônias e colocava o restante para a venda ao público.

Conserva daquele tempo ainda hoje seus longos brincos de ínfimas contas plásticas coloridas com sementes de nishi [Philodendron lechlerianum] no extremo; assim como seu longo colar de sementes de camu camu [Myrciaria cauliflora] que dá duas voltas no pescoço, da mesma maneira que uma saia branca bordada por ela mesma com kenê [desenho shipibo] e uma campanilla [camisola] azul com fitas vermelhas e brancas ornadas na mão. Com eles se veste em cerimônias especiais, enquanto continua bordando e engastando novas peças para a sua comercialização. Enquanto Isabel preparava e vendia seu artesanato, seus filhxs Gerlyn e Jenny a acompanhavam. Elxs também davam forma e comercializavam suas próprias criações. Gerlyn realizava seus trabalhos em madeira (arcos musicais ${ }^{81}$ e esculturas que representavam as mães/donos, espíritos protetores das plantas) e Jenny engastava bijuteria com sementes, conchas, penas e contas de plástico coloridas.

\section{- Mundo de la Yacuruna}

Foi no albergue Refugio Altiplano que Isabel conheceu a Jorge, curandeiro originário da localidade ribeirinha de Nuevo Valentín, distante duas horas de Tamshiyacu, remontando o rio Tahuayo. Poucos meses depois de se conhecerem, elxs começaram a conviver e junto com elxs, Jenny, Gerlyn, Jordi e o pequeno José. Dois anos depois, elxs decidiram sair do albergue onde trabalhavam e

\footnotetext{
81 Gerlyn me contou que os arcos são um instrumento de recente aparição na Amazônia peruana. Foi introduzido nas práticas do xamanismo contemporâneo em Tamshiyacu pelo xamã e artesão da madeira Agustín Rivas Vázquez, e reproduzido pelos alunos da sua escola de escultura e talha em madeira.
} 
começar a trabalhar por conta própria. Compraram uma antiga chacra [território de caça, colheita e cultivo] de três hectares a quatro quilômetros ao oeste do povoado de Tamshiyacu, na direção da quebrada [cachoeira] de Pinche Seco. O grupo habitou a casa de uma irmã de Jorge, na saída do povoado de Tamshiyacu.

Na rua Las Palmeras, onde fica a casa delxs, há uma multidão de crianças povoando as ruas. Cada família tem entre 3 e 7 crianças em idade escolar, e elas costumam brincar juntas no espaço da rua. A casa tem teto de palha e chão de terra. Na entrada, um espaço de estar e em seguida dois quartos, um do lado direito e um do lado esquerdo. Mais na frente, a cozinha ao ar livre, onde se cozinham as comidas no chão, com lenha ou carvão. Imediatamente o quintal, onde Isabel e Jorge plantaram algumas plantas comestíveis, medicinais e mágicas tais como ubos [Spondias mombin], guaba [Inga edulis], mango [Mangifera indica], caimito [Manilkara bidentata], patiquina [Caladium bicolor], priripiri rojo [Eleutherine plicatae] e chacruna [Psychotria viridis]. E no quintal mesmo, o banheiro seco, construído com blocos de cimento e um leve plástico como porta.

A família matrifocal de Isabel adicionou um homem adulto à sua dinâmica afetiva, social e patrimonial. Muito mudou a partir de então. No período de três $\operatorname{anos}^{82}$, a família construiu as primeiras estruturas do albergue. Enquanto isso, Isabel trabalhava por conta própria fazendo trabalhos para pessoas da localidade de Tamshiyacu e era convidada para trabalhar de maneira flexível para cantar seus icaros shipibo nas cerimônias dos dois curandeiros locais com maior inserção no mundo do turismo: Dom Agustín Rivas e seu sobrinho, Dom Lucho Panduro. Jorge, fazia algum tempo, trabalhava como curandeiro para pessoas da localidade, e à exceção do albergue Refugio Quebrada Tamshiyacu, nunca tinha sido convidado para trabalhar em outros espaços.

82 Até a data da finalização do meu trabalho de campo, em finais de 2013. 
Isabel e Jorge chamaram o empreendimento "Albergue Chamánico Mundo de la Yacuruna" $^{83}$ honrando o yacuruna, encantado da água amazônica, figura masculina que rouba mulheres que estão sozinhas e distraídas perto do rio. A Yacuruna é um dos encantadxs preferidxs por Jorge, porque ele é rápido e esperto. Para Jorge, tais são as duas virtudes que todx curandeirx deve de ter. A família realizou cinco construções de madeira tipo cabanas para albergar pessoas, as quais também colocaram nomes de encantadxs amazônicxs: "Chullachaqui" (entidade protetora da floresta, que confunde aos/às humanxs para protegê-la), "Yanapuma" (felino negro que é a representação animal dos espíritos dxs bruxxs humanxs que moram na floresta), "Boa Negra" (representação animal do espírito da planta ayahuasca), "Sirenas" (sereias, entidades femininas que moram nos rios) e "Sachamama" (uma solitária serpente encantada, encarnação dos rios da floresta). Todas elas estão distribuídas nas bordas interiores do acampamento, como representa o croquis feito aqui, onde se distribuem todas as cabanas e espaços do acampamento (Croquis 1).

Com ajuda de hábeis vizinhos construtores da madeira, Isabel e Jorge realizaram uma construção central, que é a cozinha e comedor, e finalmente uma estrutura lateral que é a maloca onde se realizam as cerimônias, e onde Isabel faz, durante algumas noites e em solidão, seus trabalhos de curandeirismo. Elxs tiraram as árvores e liberaram o espaço de maneira tal que o albergue aparece como um clarão na floresta, do lado de uma sombreada plantação de grandes árvores de humarí e de uma pequena vertente de água, que é de onde se traz a água de uso doméstico e onde se lavam as roupas. Quando cheguei, elxs criavam galinhas, que tinham comido todas as plantas. Quando fui embora do albergue, não havia

83 O blog do albergue está disponível em: mundodelayacuruna.blogspot.org. Acesso em 24/02/2014. 
quase mais galinhas, que tinham sido capturadas lentamente por raposas. Nesse último tempo, Isabel estava voltando a replantar achote [Bixa orellana], contra queimaduras domésticas e solares; piripiri [Cyperus articulatus], lengua de perro [Strychnos nux-vomica] e sígueme sígueme [Piper pseudarboreum], para os trabalhos de amor; huahuahuanchi [Piper pseudarboreum] e mashiyuyo [Cucumis anguria], para os negócios; pájaro de negrito [Tessaria integrifólia] para combater os próprios ciúmes; toé [Brugmansia grandiflora], contra as bruxarias; patiquina con pitito [Caladium bicolor], para mulheres que queiram amarrar sexualmente ao homem que desejam. 


\section{Croquis Albergue Mundo de la Yacuruna}

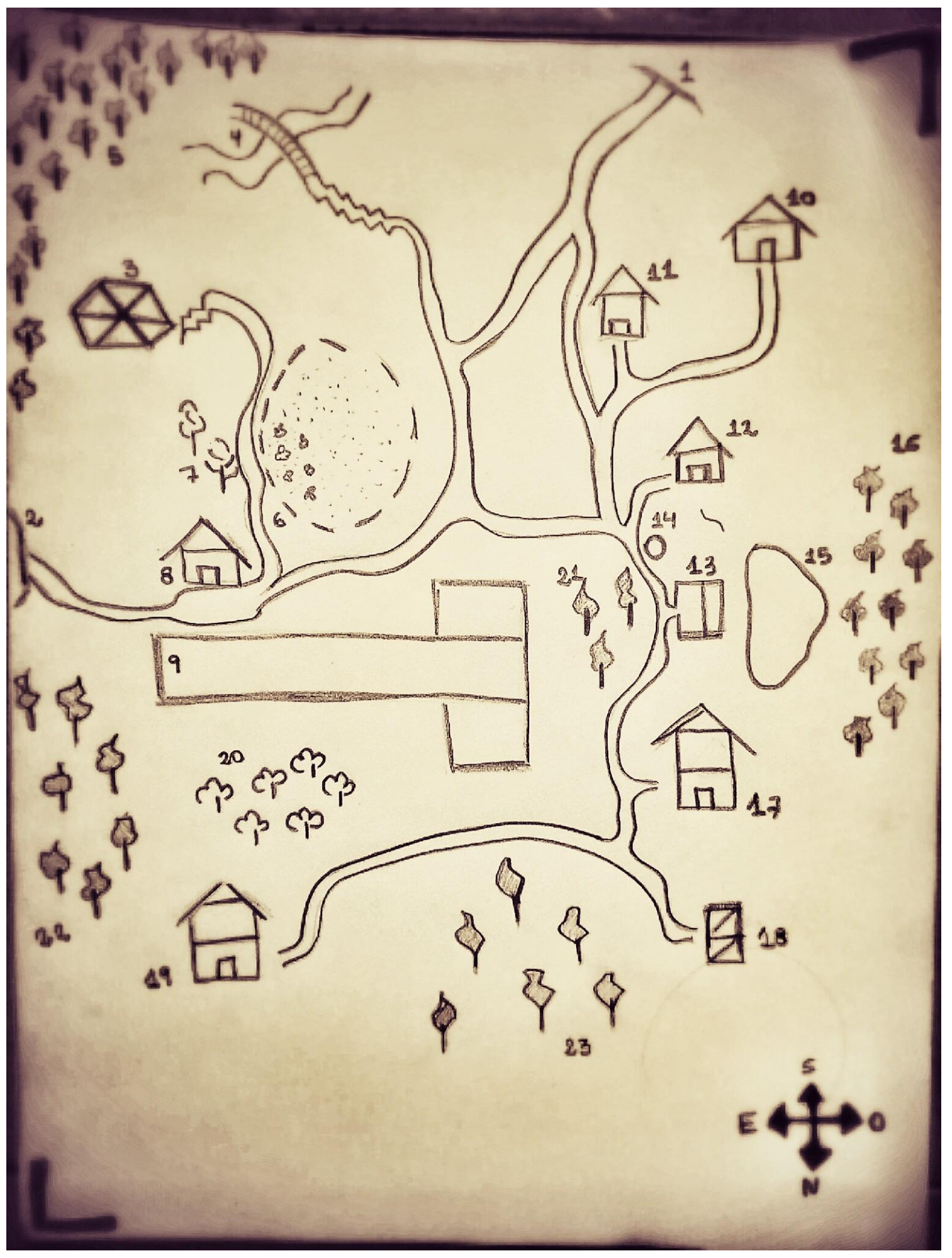




\section{Referências do Croquis}

\begin{tabular}{|c|c|}
\hline 1 & Porta de ingresso no albergue via Pinche Seco. \\
\hline 2 & Porta de ingresso no albergue via Delicia. \\
\hline 3 & Maloca. Templo cerimonial ayahuasca. \\
\hline 4 & $\begin{array}{l}\text { Quebrada. Vertente onde se lavam as roupas e } \\
\text { se obtém a água de beber. }\end{array}$ \\
\hline 5 & Limite sudeste de árvores nativas. \\
\hline 6 & $\begin{array}{l}\text { Espaço onde era queimado o carvão. Hoje há } \\
\text { plantas mágicas e medicinais. }\end{array}$ \\
\hline 7 & Plantas de achote (Bixa orellana). \\
\hline 8 & Cabana de Isabel e Jorge. \\
\hline 9 & Área aberta - campo de futebol. \\
\hline 10 & Cabana do Yanapuma. \\
\hline 11 & Cabana das Sirenas. \\
\hline 12 & Cabana do Yacuruna. \\
\hline 13 & Cozinha-comedor coletivo. \\
\hline 14 & Fogueira onde se cozinha a ayahuasca. \\
\hline$\overline{15}$ & $\begin{array}{l}\text { Horta com tomate, beterraba, bijao (Calathea } \\
\text { lutea) pimenta doce, cocona (Solanum } \\
\text { sessiliflorum), abacaxi etc. }\end{array}$ \\
\hline 16 & Limite oeste de árvores nativas. \\
\hline 17 & Cabana da Sachamama. \\
\hline 18 & Banheiros. \\
\hline 19 & Cabana Chullachaqui. \\
\hline 20 & Arbustos nativos. \\
\hline 21 & Área de esparcimiento. \\
\hline 22 & Limite nordeste árvores nativas. \\
\hline
\end{tabular}


O albergue foi construído com a intenção principal de receber turistas para orientá-lxs nas suas dietas e cerimônias com ayahuasca. Durante os meses que fiquei com ela, Isabel recebeu pelo menos vinte turistas e somente umas seis pessoas da localidade de Tamshiyacu.

A trajetória de vida de Isabel pode ser compreendida como um itinerário com diversas paisagens e uma inserção, cada vez mais acentuada, na sociedade urbana. Ao mesmo tempo, seu trabalho na cidade esteve fortemente legitimado pelo fato de ela ter crescido perto da floresta, de suas plantas, da sua silenciosa organização interna. O presente capítulo foi escrito na direção de construir uma narrativa, consistente na materialização de uma história e de uma particular maneira de fazer no mundo a partir dos depoimentos de Isabel, e que dessa narrativa fossem desenhadas linhas de compreensão com outras maneiras de fazer com plantas dxs curiosxs locais. Este é o tema do próximo capítulo. 


\section{Capítulo 5 \\ O espaço de Isabel e suas redes}

- Etnografia visual: ayahúma contra a saladera - Receitas, redes e remédios • Victoria, paciente local $\bullet$ Uma cerimônia com mulheres turistas $\bullet$ Primeira dieta com Isabel e Jorge $\bullet$ A vida com Jorge $\bullet$ Mulher chamana, curandera, onanya $\bullet$ Isabel vai para o mercado.

\section{- Etnografia visual: ayahúma contra a saladera.}

Um dia de abril de 2013, Isabel me disse: "Venga para mi casa esta nochecita, cuando el sol este cayendo. Voy a convidarte com ayahúma. Es um baño. Contra la saladera. Es un regalo que te voy a dar a $t i^{\prime \prime}{ }^{84}$. Umas horas mais tarde, eu fui à sua casa do povoado, na Rua das Palmeras. Ela me recebeu com um sorriso e rapidamente me fez entrar, direto para os fundos. Lá, descalça no chão de terra e só de calcinha, senti o frio do líquido que Isabel jogou no meu corpo. Era bastante espesso, com pedaços de um fruto rosado vivo e de um cheiro muito forte. "No te enjuagues ahora. Ni le cuentes a nadie. Tienes que dietar hasta mañana a las 10 de la mañana" ${ }^{\prime \prime 5}$.

Naquele tempo, Genoveva, que tem um posto de comidas na rua, me contava que era importante ter na mão ayahúma para se fazer, periodicamente, banhos contra a saladera [má sorte]. Ela mesma faz os banhos, para ela e a sua família. E conta a sua receita. Quando estamos com má sorte, nada dá certo, é possível que tenhamos saladera. Para afastá-la de nós, é preciso fazer uma limpeza com banhos de ayahúma. Então é preciso conseguir um fruto, que seja o maior que encontremos. Ele deve de ser chapeado [esmagado manualmente] com dois ou três mapachos durante as horas da manhã. Às doze da noite, quando todxs foram

\footnotetext{
84 "Venha pra casa hoje à noitinha, quando o sol estiver caindo. Vou te convidar com ayahúma. É um banho. Contra a saladera. É um presente que eu vou dar para você".

85 "Não é pra se enxaguar agora. Nem pra contar pra ninguém. Você vai ter que dietar [fazer jejum ou comer leve] até amanhã às 10 horas da manhã".
} 
dormir, deve de se fumar um mapacho, beber um pouco do preparo e tomar um banho com o restante. Durante os três dias que dura esse tratamento caseiro, é possível detectar uma substância clara na pele. Ela é a flema da saladera, a própria má sorte que alguém mal intencionado nos imputou. Com a saladera na superfície da pele, agora se faz necessário afastá-la para longe do corpo. Assim, se recomenda sair ali mesmo e cumprimentar à primeira pessoa que encontremos. Ela é a pessoa que vai levar, de agora em diante, a saladera. É interessante observar que não há uma ênfase em que o mal da saladera desapareça do mundo, mas a ênfase está colocada nele se deslocar do corpo da pessoa afetada, ir para outro lugar. Da mesma maneira que as noções de equilíbrio dos contrários que têm sido analisadas no capítulo 9, as práticas mágicas não pretendem o acesso a um estado definitivo de saúde ou bem-estar para todxs. A saladera faz parte de certa ordem do mundo, e essa ordem indica que ela não deve desaparecer, mas se rearranjar em outrxs sujeitxs, outras sortes, outros destinos. A receita mágica com ayahúma contra a saladera é como segue:

Se chapea la pulpa del ayahúma con tres mapachos, se lo deja descansar. A las doce de la noche, se debe fumar un mapacho, tomar un poquito de la bebida y bañarse con el resto del mismo. Durante tres días, va saliendo una flema blancuzca de la piel. Esa es la saladera, la mala suerte que a uno le ha echado alguien malintencionado ${ }^{86}$.

Segundo a prática que me conta Isabel, quando se realiza o banho de ayahúma sob a orientação $\mathrm{dx}$ curandeiro, é aquelx quem chapea [comprime com a mão] a polpa da ayahúma e sopra com mapacho o preparo. Depois, quando se realiza o banho, é x curandeirx quem joga o último copo da bebida na cabeça de quem está realizando o banho. Espera-se que a pessoa que toma banhos com ayahúma

86 "Chapea-se [comprime com a mão] a polpa da ayahúma junto com três mapachos [cigarros de tabaco fresco] e se deixa descansar. Às doze da noite, deve-se fumar um mapacho, tomar um pouquinho da beberagem e tomar um banho com o restante. Durante três dias, vai saindo uma mucosidade branquicenta da pele. Essa é a saladera, a má sorte que jogou na gente alguém com más intenções". 
comece a sonhar durante a noite, e que nos seus sonhos noturnos apareçam soluções para os problemas que esteja atravessando.

O preparo pode ser feito pelx próprix interessadx, mas é aconselhável que seja realizado pelx curandeirx para receber delx uma maior proteção. Quando se fazem banhos com plantas, recomenda-se dietar, para aguardar pela sua ação com o corpo limpo e leve. Também se recomenda manter as curas em segredo, pois na fala se perde o conjuro, elemento essencial para a cura das doenças, especialmente dos males de gente. Semanas depois do primeiro banho, Isabel me contou:

Soñé con mi primo, ese que murió, que era curandero allá en Pucallpa. Desde murió que andosoñando con él. Él me dijo que bebiese ayahúma y que me hiciera baños, en total que dietase la planta por diez días. Estoy intentando de conseguir ayahúma por aqui. Cuando yo tenga tú puedes hacerte también, va a hacerte de bien. Para sacarse esa saladera fuerte con la que andas. Voy a cobrarte baratito ${ }^{87}$.

Assim, em junho de 2013, Isabel me convenceu a fazer mais três banhos com ayahúma, desta vez na minha própria casa (Ver Imagem 6, Banho de Ayahúma). O procedimento foi feito antes do meio dia, no chão de terra da sala da minha casa. Desta vez, o preparo consistiu em um único fruto da ayahúma (cuja polpa, rosada, quase fosforescente, deve ter pesado uns dois quilos) que foi desfeito com as mãos na minha presença. Ao preparo, Isabel adicionou dois cigarros de tabaco, também desfeitos com a mão. Enquanto fazia tudo isso, Isabel permanecia em silêncio e por momentos cantava ou assobiava icaros. Agachada no chão, ela sopló [soprou] com mapacho em cima do preparo com ayahúma.

\footnotetext{
87 "Sonhei com meu primo, esse que morreu, aquele que era curandeiro lá em Pucallpa. Desde que ele morreu que estou sonhando com ele. Ele me disse pra tomar ayahúma e fazer banhos, no total, dietar a planta por dez dias. Estou tentando conseguir ayahúma por aqui. Quando tiver, você pode fazer também, vai ser bom pra você. Para tirar a saladera, essa forte com que você está. Vou te cobrar baratinho".
} 


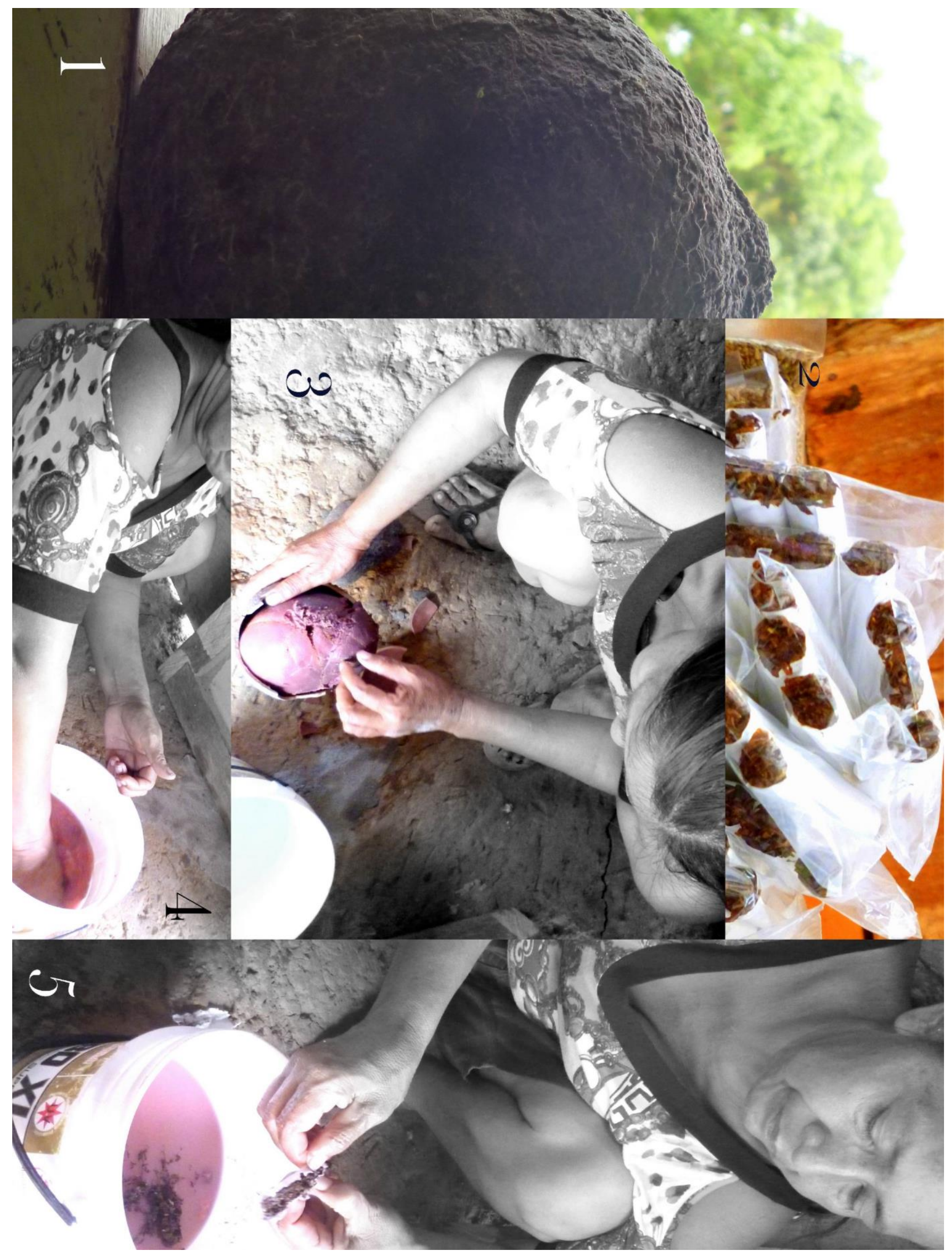




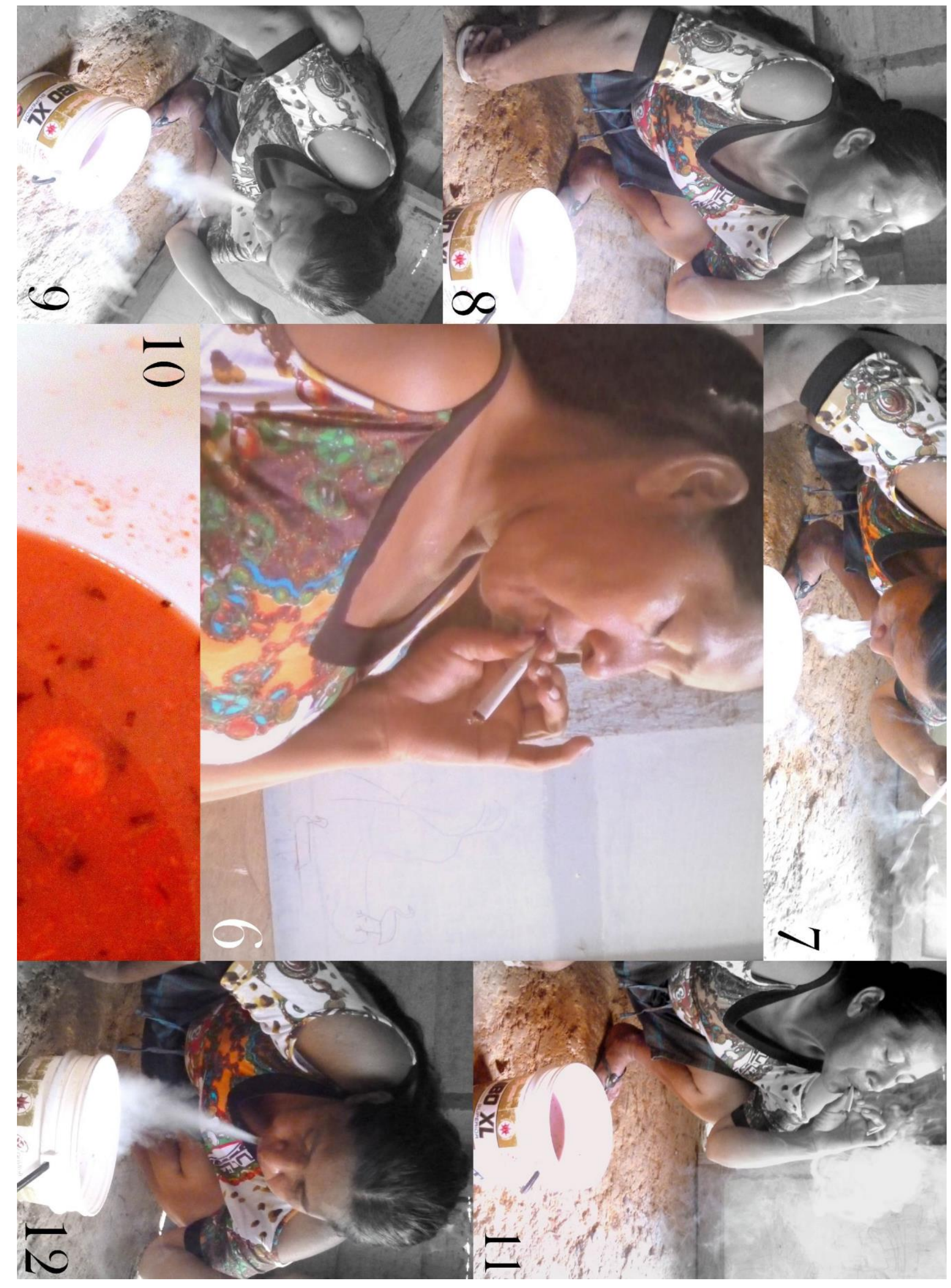


Imagem 6 (págs anteriores): Banho de ayahúma

1 - Fruto da ayahúma [Couropita guianensis].

2 - Mapachos, cigarros de tabaco [Nicotina tabacum].

3 - Isabel descascando o fruto.

4 - Chapeando a polpa na água.

5 - Rasgando cigarros de mapacho e colocando-os na água.

6 - Diz uma oração e aspira a fumaça.

7 - Assopra a fumaça do cigarro no balde.

8 - Aspira a fumaça novamente.

9 - Assopra no balde mais uma vez.

10 - Cor vibrante da ayahúma na água.

11 - Aspira a fumaça do cigarro.

12 - Assopra no balde.

O preparo devia agora ser distribuído em três banhos que eu fizesse, todos eles durante a noite, antes de ir dormir, sem enxaguar depois o viscoso e odoroso líquido do corpo. Isabel me pediu para dietar do mesmo jeito que fizera daquela primeira vez, três meses antes, e para prestar atenção nos sonhos que ocorressem durante as três noites do banho. Isabel cobrou cinquenta soles [uns 25 dólares] por esse serviço. 


\section{- Receitas, redes e remédios}

Contou-me Isabel que xs onanya, curandeirxs shipibo, não costumavam beber a ayahuasca da maneira rotineira e persistente com que o fazem hoje, impulsionados pelos benefícios e fama da beberagem da ayahuasca no contexto do turismo xamânico. Antonio, o pai de Isabel, não costumava beber a ayahuasca, e ela própria não conheceu a bebida senão quando já era uma mulher adulta e curandeira de ofício. Comenta Isabel:

Yo tengo tres maneras de curar. Juntas las tres son oraciones, ayahuasca y plantas. Hay que aprender a tomar las plantas solitas. Ayahuasca nomás no es suficiente. Las plantas te muestran sueños, visiones bien bonitas. Ellas te enseñan $\operatorname{curar}^{88}$.

Quando voltou de uma viagem a Pucallpa, Isabel me mostrou um ramo de folhas de uma planta bulbosa. Disse-me "lo voy a plantar. Es el piripiri"89. Nos dias que seguiram, Isabel me contou várias histórias de mulheres que atendeu. Muitas delas têm a ver com amarres [procedimentos para trazer consigo ou preservar à pessoa amada], com a necessidade de esquecer uma pessoa, com o desejo de conceber um/a filhx, com o desejo de conseguir um trabalho particular. "Esta es la tierra de las puisangas" ${ }^{10}$, me disse Isabel. Como ensinaram seus parentes shipibo, ela prepara vários tipos de piripiris. Tipicamente etótropos, os preparos com piripiri têm a finalidade de influenciar o espírito e a matéria de esposxs, amantes, filhxs, pais e mãe, patrões e patroas do trabalho.

Durante o mês de maio do ano 2013, fizemos uma pequena viagem juntas, Isabel e eu. Fomos para Iquitos, o centro urbano mais próximo de Tamshiyacu - fica a

\footnotetext{
88 "Eu tenho três maneiras de curar. Juntas as três são orações, ayahuasca e plantas. É preciso aprender a tomar as plantas sozinhas [sem necessidade da ayahuasca]. Ayahuasca somente não é suficiente. As plantas te mostram sonhos, visões bem bonitas. Elas te ensinam a curar".

$89 \quad$ "Eu vou lhe plantar. É o piripiri [Eleutherine bulbosa].

$90 \quad$ "Essa é a terra das puisangas [preparos mágicos para o amor]".
} 
$40 \mathrm{~km}$ deste povoado - e a maior cidade da Amazônia peruana. Ela tinha que fazer trâmites na cidade, e eu também. Ademais, queríamos ir juntas para o Pasaje Paquito ${ }^{91}$, no mercado de Belén, para comprar velas, agua florida e outros artigos que ela precisava para seu trabalho (Ver Imagem 7, Pasaje Paquito). Finalmente, Isabel deu prioridade a outras urgências. Uma delas tinha a ver com a visita a uma ex-paciente sua. Eu a acompanhei até a esquina. Ela me pediu para esperar lá. Ela bateu na porta, a uns 20 metros de mim. Saiu uma mulher. Conversaram durante uns cinco minutos, ela desde fora, a mulher apoiada na porta semi-aberta. "La doctora me ayuda porque yo le hice un buen trabajo de amarre. Volvió con su marido. Ella sufría mucho. Ahora está muy contenta"92 tinha me dito Isabel com um sorriso de satisfação: "Ahora me voy a verla, va a darme así, pastillas buenazas que voy a mandar a Pucallpa" ${ }^{\prime 3}$. A médica tinha lhe prometido pastilhas para tratar o câncer de útero do qual María, a mãe de Betina ${ }^{94}$, sofria. Na intimidade do vínculo entre Isabel e a médica, havia lugar para um conveniente intercâmbio: uma curava os males de amor com remedios vegetales, enquanto a outra pagava com remedios de botica prescritos para o tratamento do câncer. Na relação, também havia a possibilidade de obter outro tipo de benefícios. "Ella trabaja para el gobierno. Tiene pasajes gratis. Quiere que un día nos vayamos las dos a Pucallpa a ver a mi madre" ${ }^{\prime \prime 5}$. Foi assim que Isabel se despediu da médica. Mostrou-

91 O pasaje Paquito está localizado ao longo de uma rua do mercado de Belén e é especializado na venda de plantas, ossos de animais, adornos, fetiches, velas, preparos com álcool, cremes e outros produtos mágicos e medicinais.

92 "A doutora me ajuda porque eu fiz para ela um bom trabalho de amarre. Voltou com o seu marido. Ela sofria muito. Agora está muito feliz".

93 "Agora vou vê-la, ela vai me dar pastilhas muito boas que eu vou mandar para Pucallpa".

$94 \quad$ Pseudônimo.

95 "Ela trabalha para o governo. Tem passagens de graça. Ela quer que um dia vamos juntas para ver à minha mãe em Pucallpa". 
me um pacotinho plástico, contendo as pastilhas trocadas: "ahora voy a mandar para que mi hermana le dé a mi madre" ${ }^{16}$.

Isabel afirmava que é muito importante dietar quando se prepara qualquer tipo de remédio. Ela me contou uma receita para o amarre. A mesma é uma conjunção feita na base de thimolina ${ }^{97}$ com três plantas diferentes. A composição é como segue: procura-se um punhado de motelillo [Calathea roseopicta], cinco bulbos de piripiri [Eleutherine bulbosa] e um punhado de amor seco [Bidens pilosa]. Ralam-se os bulbos, amachucam-se as folhas. Coloca-se tudo em uma garrafinha e se faz descansar em um poço na terra durante sete dias. Ali, na intempérie, a garrafinha recebe o serenado da noite. Passada a semana esperada, desenterra-se e limpa-se a garrafinha, e finalmente se sopla [assopra-se] com tabaco, ao som de um ícaro especial para o amor, onde se cantam os nomes das duas pessoas que quer se unir. Dá-se para a pessoa que a solicita, a qual o usa como perfume.

\footnotetext{
96 "Agora vou enviar para minha irmã, para que ela dê para a minha mãe".

97 Produto comercial composto de álcool etílico, ácido acético e cânfora, cuja aplicação no vademécum médico é antisséptica e desinfetante.
} 




\section{Imagem 7 (pág anterior): Pasaje Paquito}

1 - Cactos, raízes, preparos, perfumes: no Mercado de Belén, uma rua inteira, o Pasaje Paquito, dedica-se às plantas, animais e objetos mágicos e terapêuticos.

2 - Lá é que xs curandeirxs se abastecem das plantas e substâncias que não possuem e que não encontram por perto (água florida, alcanfor, mapachos são obtidos desta maneira).

3 - Há lojas dedicadas especialmente a licores vigorizantes e afrodisíacos, muitos deles preparados com palos.

4 - Todas as partes da planta se aproveitam no contexto dessa herbolária mágica. À esquerda, sementes de achote [Bixa orellana]. Ao centro, embaixo, raiz do pachouli [Pogostemon patchouly]. À direita, embaixo, cascas de uma árvore não identificada. Em cima, dois baldes com variedades de piripiri [da espécie identificada como Eleuterine].

5 - Folhas frescas, colhidas cada dia, servem ao preparo de macerações e infusões.

6 - Ainda que a maior parte dos produtos seja de origem vegetal, também há outros de origem animal, como esses crânios de pequenos mamíferos usados em cerimônias mágicas.

7 - O emoliente é uma bebida preparada na base de sábila [Aloe vera] e infusões de ervas medicinais que é típico das terras altas do Peru, mas que também é possível encontrar no Pasaje Paquito. 
Em outra oportunidade, Isabel me contou: "Vino una chica y me pidió que la ayude a quedar embarazada de su amante. Él ya tiene a su esposa, pero ella le quería mucho y quería un hijo de él"98. E continuou: "Le preparé un piripiri. Ahora está contenta con su bebé, varoncito como ella me había dicho que quería"99.

Ainda que seja corriqueiro na região o conhecimento de que a colmena [mel de abelhas] "calienta el vientre"100 e ajuda às mulheres a ficarem grávidas com rapidez, há outras receitas para engravidar, que devem ser feitas por um/a curandeirx, pois envolvem o soplado [assoprado] com tabaco e o canto de ícaros, faculdades pertencentes somente àquelxs. Isabel me contou uma receita para engravidar que ela mesma prepara. Essa receita não inclui nenhum vegetal, e sim os ossos de um animal, a raposa. Pega-se um osso inteiro de uma raposa, queima-se. O carvão do osso é triturado e feito uma fina poeira. Essa fina massa é depois colocada na água, que se torna escura. Filtra-se, diferenciando o material sólido do líquido. Descarta-se o resíduo sólido. Assopra-se o líquido com tabaco. Dá-se o líquido para que a mulher beba. Deve-se tomar essa preparação durante uma semana. Isabel sugere a estimulação de uma vida sexual especialmente ativa durante esse período.

Outro aspecto da prática diária ao qual Isabel dedica bastante tempo e atenção é relativo às curas do mal feito por daños [danos] ou brujerías [bruxarias]. Também são chamados de males de gente. Retrato aqui duas situações: o da jovem de Iquitos que estava inchada e o da dona Jovita, que não podia caminhar.

\footnotetext{
98 "Veio uma menina e me pediu que a ajude a ficar grávida do amante dela. Ele já tem a sua esposa, mas ela amava muito ele e queria ter um filho dele".

99 "Eu the preparei um piripiri. Agora está feliz com o seu neném, garotinho como ela tinha me dito que queria".

$100 \quad$ "Esquenta o ventre".
} 
Isabel me comentou, em setembro, que ela havia estado recentemente em Iquitos. Foi a mirar [olhar] uma jovem que tinha todo o corpo inchado. Mirar: ela costuma usar esse termo quando se refere à sua relação com xs pacientes. Eu comecei a imaginar o mirar como uma porta aberta para vários cenários que são centrais no trabalho de Isabel: mirar é ter contato direto com x paciente e conversar com elx, é olhá-lo, é observá-lo na sua situação particular, assim como também é prestar atenção para os aspectos invisíveis que arrodeiam a pessoa.

Isabel foi, então, mirar àquela jovem. A jovem, sob um estado de violento desespero, tinha agredido fisicamente outras pessoas da família e não podia emitir uma só palavra ou ainda qualquer som com a garganta. Isabel tomou ayahuasca na casa da jovem e começou a trabajar en ella [trabalhar nela]. Com a ayahuasca, ela conseguiu acessar à visão de quem e como lhe fizeram o daño. Depois, cantou ícaros para reparar o possível mal e limpou seu corpo com a fumaça do tabaco. Isabel conta que umas poucas horas depois, a jovem desinchou e começou a falar, e contou à Isabel a sua experiência com o daño. Ela contou que costumava ver um homem negro que se jogava em cima dela e tentava lhe estrangular. Frente à tão angustiante situação, ela ficava desesperada e tentava se defender. A cura de Isabel permitiu que a jovem voltasse a sua rotina costumeira e estabelecesse novamente os laços de confiança com a sua rede de afetos.

No contexto das maneiras de fazer com plantas da região, a ayahuasca costuma ser ingerida somente nos casos mais graves, quase sempre relativos a daño. A beberagem sempre deve ser ingerida por parte $d x$ curandeirx, não sendo estritamente necessário axs pacientes que tomem também. Para Isabel, é bom que x paciente tome ayahuasca porque suas visões podem se complementar com as visões da curandeira, e ambxs podem "mirar juntxs", ou podem "mirar otra cosa 
que también ayude" a tomar decisões ${ }^{101}$. Porém, nem sempre xs pacientes desejam fazê-lo. Há pessoas idosas ou doentes para as quais a ingestão de ayahuasca representa um gasto energético que elas não desejam ou podem fazer. Muitas mulheres grávidas tampouco desejam tomar ayahuasca porque afirmam que o bebê pode nascer amarelo e fraco. E tem pessoas que simplesmente não gostam de beber a ayahuasca. Isso não é imperativo no caso da cura contra o daño. Quem deve necessariamente tomar a ayahuasca é x curandeirx.

"Nunca fallo todavía, todito sano. Mis pacientes salen puro gordo"102, costumava comentar Isabel, orgulhosa. Uma vez, Isabel me levou para ver a dona Jovita, a paciente que fazia uns três anos tinha sofrido de um daño, e tinha deixado de caminhar por causa disso. Fazia meses que estava prostrada em uma cadeira de rodas quando dona Jovita chegou à casa de Isabel, acompanhada do seu marido. Isabel a tratou e a sarou, possibilitando que ela andasse novamente sobre seus próprios pés. A respeito da composição social dxs pacientes que Isabel trata, não há exclusividade, mas é possível perceber uma especificidade em termos de gênero e idade: "Más mujeres atiendo yo, la mayoría mujeres, hombre difícil"103: essas mulheres têm entre 30 e 50 anos. Ela me conta que sabe curar do susto e do mal aire, síndromes comuns em bebês. Entretanto, ela nunca gostou de curar crianças. Diz que para isso é que existem as parteiras, que são aquelas curiosas que trabalham com ervas pequenas e com orações, assim como com a fumaça do tabaco. A sua irmã Virginia, de Pucallpa, aprendeu todas essas técnicas. Segredos, orações, receitas com plantas dessas que estão no próprio jardim, na frente da casa, nas casas dxs vizinhxs. Mas as parteiras não cantam ícaros, nem

\footnotetext{
$101 \quad$ "Mirar outra coisa que também ajude".

102 "Nunca falhei ainda. Todos ficam sarados. Meus pacientes saem [do tratamento] todos gordos".

103 "Mais mulheres atendo eu, a maior parte são mulheres, homens é mais difícil [eles virem me procurar]".
} 
usam a chacapa, nem dominam as plantas maestras, aquelas que devem ser colhidas após várias horas de caminhada floresta adentro.

Isabel me faz entender que o domínio dxs curiosxs se delimita a partir de elementos específicos. No caso particular dxs curanderxs, elxs são especializadxs em lidar com males de gente, os quais tendem a representar um maior risco de vida, tanto para xs pacientes como para xs mesmxs curanderxs. Essxs especialistas se relacionam com plantas que ensinam a fazer bruxaria e a se defender das bruxarias, tais como patiquina [Caladium bicolor], piñón negro [Jatrophagos sypiifolia], toé [Brugmansia suaveolens], huayruro [Ormosia coccínea] barbasco [Lonchocarpus nicou], mucura [Gallesia integrifólia] e a própria ayahuasca [Banipsteriosis caapi].

Xs curiosxs da região da baixa Amazônia, tanto indígenas quanto mestiçxs, lançam mão da comunicação com as plantas com as mais diversas finalidades: amarrar-abrir mão de um/a amante, curar-fazer o mal, engravidar-não engravidar, apaixonar-esquecer. Elxs lidam com uma diversidade enorme de sensações, augúrios, intuições e mal-estares, que agrupam ao redor de sintomas maleáveis, nem sempre fáceis de colocar no marco das doenças que a cultura médica moderna pode enquadrar. Elxs acompanham diariamente a suas/seus pacientes e no trabalho de acompanhamento diário vão, criativamente, observando a mutação de signos e sintomas. Assim, conjuntos de signos vão configurando síndromes, que vão mudando de composição de acordo com o decorrer clinicamente observável da doença. Essa clínica não depende somente dos cinco sentidos, mas também do apreciado sentido da intuição, sensibilidade aguçada para a compreensão de realidades invisíveis. Também estão acompanhadas de uma aguda inteligência social: são levados em conta os acontecimentos ocorridos entre pessoas que estejam ao redor da pessoa que sofre 
a perturbação. Finalmente, $\mathrm{x}$ curios $x$ também procura os sinais que apareçam em sonhos diurnos ou noturnos - tanto delx próprix quanto dx paciente. Elementos sociais, oníricos, signos e sintomas do corpo da pessoa perturbada são adicionados diariamente ao dinâmico quadro de compreensão da doença: enquanto novos elementos são incorporados, vai sendo transformado o quadro da presente situação de mal-estar. X curiosx vai provando e errando até dar com o alívio ou cura da perturbação. Isso nem sempre acontece, coisa que leva muitas vezes às/aos pacientes a trocar de especialista na procura de uma resolução.

Contudo, é importante reconhecer que o trabalho $\mathrm{dx}$ curiosx nem sempre é relativo à cura ou alívio de perturbações. É possível dividir as práticas de curandeirismo que elxs exercitam entre terapêuticas (relativas a tratamentos e cura de doenças) e etótropas (relativas à potencialidade mágica de fazer fazer a ou em outrxs sujeitxs: fazer amar, fazer esquecer, fazer um dano). As práticas terapêuticas são relativas tanto a curas contra mal de deus (doenças produzidas por causas desconhecidas, como o pulsario [síndrome parecida com a melancolia que afeta, sobretudo, às mulheres, caracterizando-se por uma específica dor na barriga e causada, costumeiramente, pela tristeza ou pela fome crônica], descenso [secreção vaginal], piedra [úlcera], hérnias) quanto a curas contra mal de gente (cura de doenças produzidas por inimigxs humanxs, como a saladera [má sorte] e a espina [obstrução física da garganta que impede de comer ou falar]). As práticas etótropas mais comuns são atrair o amor e fazer o daño. As práticas etótropas se encontram na delgada linha do antiético, da invasão da livre vontade individual: elas tendem a manipular outras pessoas e manejam um conceito limitado segundo o "bem" para alguns e que pode, perfeitamente, implicar no "mal" para outrxs. Nesse sentido, o exercício do ofício de curiosx coloca a essxs especialistas em lugares parciais, pontos definidos da rede social desde onde tecem as próprias relações que os sustentam. Longe de serem neutrais, xs curiosxs são uma 
parte ativa das relações de conflito ou cooperação dxs suas/seus pacientes com o mundo, e sabem que tratar-lhes envolve um movimento de mão dupla: por um lado, significa incluir a essxs pacientes na sua própria rede e por outro, redunda no fato de acabarem sendo incluídos como sujeitxs ativxs na rede $\mathrm{dxs}$ pacientes. É por isso que, em virtude do compromisso social que $\mathrm{x} \operatorname{curios} x$ adquire ao tratar um/a paciente, é perfeitamente comum elxs se refutarem a tratar a uma pessoa, sem precisarem de dar nenhum tipo de explicação às outras pessoas em relação a isso.

\section{- Victoria ${ }^{104}$, paciente local}

Victoria foi a primeira paciente de Isabel que conheci e com quem tive a possibilidade de conversar. María ficou durante duas noites na minha cabana. Durante esse tempo, ela contou que nasceu no Equador e foi criada no povoado de Tamshiyacu, no Peru. Que tem três filhxs, dois meninos e uma menina. Que também tem um neto, filho da filha dela. Na época daquele encontro etnográfico, Victoria tinha 52 anos.

$\mathrm{Na}$ luz das velas do comedor do albergue, ela contou que quando tinha 50 anos teve um acidente de barco. Seu bote afundou e caiu na água. Naquele momento, ela sentiu que uma mão a arrastava às profundezas. Mas conseguiu se libertar e voltou à superfície. Depois disso, a sua saúde se viu afetada em múltiplos aspectos. Foi diagnosticada por outro curandeiro local como tendo manchari [síndrome relacionada com o contato com xs mortxs]. Foi tratada e melhorou visivelmente, mas ficaram os nervios. O médico no posto de saúde lhe disse que ela tinha a pressão alta. Por isso, devia se cuidar para não ficar nervosa. Contudo, ela sentia que o nervosismo vinha de outra parte. Com o passar do tempo, ela

\footnotetext{
104 Pseudônimo.
} 
começou a ter a percepção de ter uma espinha na garganta. A sensação que ela tinha era como se um bicho farpado caminhasse pela garganta dela. Na concepção local, sofrer de uma espinha na garganta é produto indubitável de um trabajo de daño feito contra a pessoa por alguém que lhe deseja o mal.

- "A mí todo me asusta" 105 , disse a dona Victoria sob com a estranha luz das velas modificando as formas do seu rosto, "hasta las noticias de la televisión me hacen $\mathrm{mal}^{1106}$.

-"Mañana te voy a curar"107, lhe respondeu Isabel com voz pouco expressiva. Victoria falava frases curtas sobre temas que rondavam assuntos conhecidos pelas duas: doenças repentinas de vizinhos, morte de familiares, vingança de conhecidxs. Isabel fazia curtas intervenções: "Ahá", "mhm". A curandeira exercitava com precisão a arte de escutar.

- "He soñado que había un lugar con velas rojas, negras y santos. Yo pasaba nomás, de lejos" 108 , disse repentinamente Victoria, voltando para si mesma a conversação.

- "Te han hecho daño"109, declarou Isabel com a soltura de quem está dizendo uma obviedade. E a consolou: "Mañana voy a buscar ayahúma para usted ${ }^{110 " . ~}$

No dia seguinte, Victoria acordou com o rosto visivelmente cansado. No comedor, comentou conosco que não tinha conseguido dormir, que teve medo

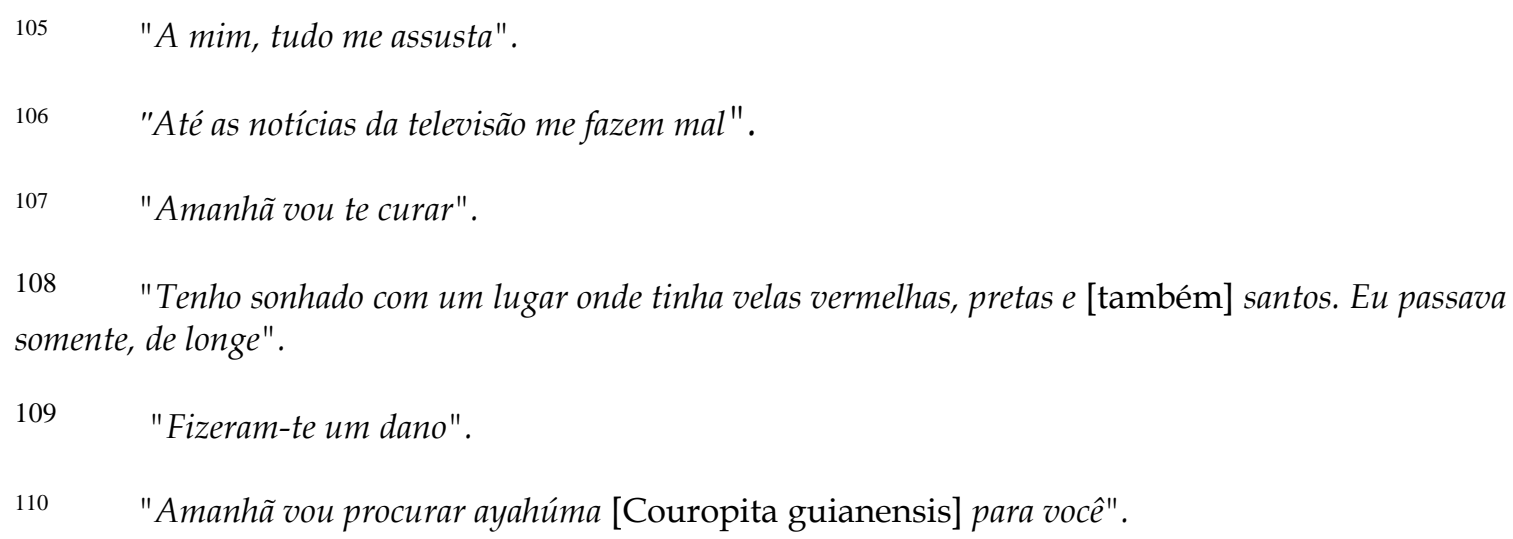


do chullachaqui [entidade protetora da floresta que pode assustar e fazer com que as pessoas se percam na floresta], que escutou barulho de folhas lá fora. Eram perto das nove da manhã do dia seguinte e Isabel já tinha despedido a Victoria, com um seguinte encontro marcado para três dias depois, na casa de Isabel no povoado de Tamshiyacu.

No dia seguinte, às 10 horas da manhã, Victoria estava novamente no albergue. Desta vez, acompanhada pelo seu marido. Ela fala da experiência de uma amiga sua que "estaba bien mal, la llevaban a la iglesia en silla de ruedas. Una vez le dieron un chicle y el chicle se volvió tierra, tierra podrida del cementerio" ${ }^{111}$. Enquanto Victoria detalha os horrores do caso, Isabel aparece com um preparo de folhas que tem chancado [apertado com a mão] e que estava macerando no álcool. "Esto tenía que estar así durante tres días, pero vamos a usarlo así nomás"112, comenta Isabel um tanto aborrecida. Victoria está sentada em um banco de madeira. Isabel se coloca por trás dela. Do seu bolso tira uma latinha de sikura [pomada comercial à base de cânfora], abre-a, coloca um pouco da pasta na mão e passa no pescoço de Victoria. Em seguida, dispõe as folhas em cima. Um cheiro forte invade o ambiente, é o ajo sacha [Mansoa alliacea] apenas macerado. Segura as folhas ao redor do pescoço com uma sacola plástica. Isabel dispensa Victoria e seu marido, que voltam para o povoado na direção de Pinche Seco.

Mais tarde, perdi de vista à dona Victoria, que não apareceu mais pelo albergue. Dias depois, Isabel me conta a causa: cansou da Victoria. Cansou desta paciente que era muito demandante, não respeitava os tempos que as plantas precisavam

\footnotetext{
111 "Estava bem mal, a levavam para a igreja em cadeira de rodas. Uma vez lhe deram um chiclete e se tornou terra, terra podre do cemitério".

112 "Isso tinha que ficar assim durante três dias, mas vamos usá-lo assim mesmo".
} 
para macerar e fazer um bom remédio, e ainda não queria lhe pagar como tinham combinado. "Tengo pereza de curarla" 113, me disse com ar cansado. "Mucho trabajo, demasiado" 114, sustenta. Em voz mais baixa, me conta que uma noite dessas, quando ela rezava de noite trabalhando na cura de Victoria e outrxs pacientes, um espírito lhe apareceu, e lhe disse: "cada vez que la cures, voy a enfermar a esa mujer de nuevo" ${ }^{115}$, se referindo a Victoria. "Y si de verdade la curas, yo mismo voy a matarte" 116.

Diante de todos esses sinais desfavoráveis, Isabel decide abrir mão da relação terapêutica com Victoria. Disse que ia despacharla [lhe dar alta] sem tratar o caso da espinha, somente ia considerar a limpeza do corpo, que tinha ajudado a acalmar os nervios dos quais a paciente sofria. Por todo o tratamento de Victoria, correspondente a pelo menos três encontros com massagens e medicinas e uma noite na cabana, Isabel cobrou o razoável preço local de um caso semicomplicado, 200 soles [uns 70 dólares].

\section{- Uma cerimônia com mulheres turistas}

Quando há turistas no albergue o clima social é bem diferente. As palavras que circulam têm outras tonalidades, os corpos buscam outras formas de se ajustar no espaço, as curas que se dão e se recebem são muito diversas. Cura del daño e trabajos para aproximar ou afastar outras pessoas são palavras extremamente infrequentes, enquanto que amor, se conhecer a si mesmx, conectar com a divinidade são conceitos que aparecem o tempo inteiro nos primeiros encontros

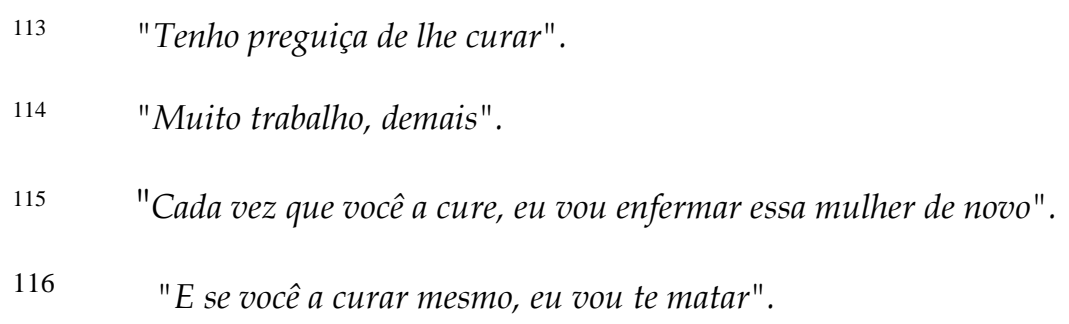


informativos, nas cerimônias com ayahuasca e nas conversas que se organizam, formal ou informalmente, depois das cerimônias.

Sem dúvidas, a prática mais demandada pelxs turistas são as cerimônias coletivas com ayahuasca. Há uns dez anos, centenas de homens e mulheres de fora da floresta amazônica viajam exclusivamente para ter essa experiência. Elxs participam da experiência da ingestão coletiva da ayahuasca com a compreensão de que a mesma é uma planta de aplicação psicoterapêutica e espiritual, deixando as possibilidades mágicas de aplicação deste vegetal fora do escopo dos seus interesses. No background de disposições sociais dxs turistas, a vontade etótropa de relação com a planta, isto é, a intenção de acudir ela como sujeitx que faz fazer, é praticamente inexistente.

Já o próprio trauma, as dores pessoais, a transformação interior, a íntima iluminação são fatores que agenciam as subjetividades destxs mulheres e homens que se congregam frente ao altar de velas onde descansa a garrafa com a espessa beberagem da ayahuasca, os mapachos [cigarros de tabaco feitos a mão] e a agua florida [perfume comercial de uso mágico]. O foco está colocado no eu, na própria experiência, no caminho pessoal.

Geralmente, xs turistas ou grupos de turistas chegam por contato telefônico prévio com Isabel ou Jorge. Ela, ele ou xs dois podem esperá-lxs no porto El Huequito, de Iquitos, onde se embarcam nos botes para Tamshiyacu; ou diretamente no porto de Tamshiyacu, em meio às famílias locais que levam cachos de banana, trazem porcos amarrados e, em maio especialmente, carregam caixões de madeira com frutos do humarí [Humiria balsamifera]. 
Ao chegarem em Tamshiyacu, xs turistas costumam se surpreender com o refinado traçado do meio urbano. Tamshiyacu é uma das poucas populações que foram urbanisticamente planejadas na floresta amazônica peruana. Obra de um pioneiro civilizador do início do século XX, Dom Toribio Fernández a desenhou a lápis, e organizou, junto com uma dezena de famílias, para fazer deste povoado um "exemplo de civilidade" na nascente do Amazonas. Tamshiyacu conta hoje com uma base urbana pequena e confortável para turistas, aparecendo como um spot de conforto capitalista rodeado de intensa vida natural.

Logo após se encontrarem com Isabel e/ou Jorge, xs turistas geralmente sobem em um motocarro [moto com carro suplementar atrás] e se dirigem, sob a ordem dx curandeirx, na direção da rua das Palmeras, que fica na saída oeste do povoado. Então, ela ou ele costuma pedir para xs turistas esperarem fora da casa, aproveitam para pegar algumas provisões e/ou ferramentas, e subindo novamente no motocarro se dirigem para o albergue. A caminhada a pé para o albergue demora uns quarenta minutos, enquanto de motocarro é possível adiantar a metade do caminho em dez minutos - com o qual acabam sendo uns trinta minutos até o albergue. Desde o povoado e na direção do centro, a maior parte do caminho é ascendente, entre bosques de humarí [Humiria balsamifera] plantados pelas famílias locais até prédios onde pastam bois e também espaços de mata nativa fechada, apenas aberta para a passagem humana. Na mesma direção do albergue, há outras dezenas de chacras [espaços dedicados à criação, colheita e caça de animais e vegetais] mais ou menos delimitadas entre si por ramas cortadas e postes de madeira com arame. Cada uma dessas chacras costuma ser trabalhada por todxs xs membrxs da família: crianças, adultxs e idosxs; mulheres e homens. Desta maneira, enquanto se percorre a senda que leva para o albergue, é habitual encontrar pessoas indo ou voltando das suas 
chacras, levando machados ou sacolas nas mãos, em suas cabeças cestas ou em suas costas vigas de madeira para lenha ou construção.

No mês de junho de 2013, tive a oportunidade de participar de uma cerimônia com ayahuasca da qual participavam várias turistas, todas elas mulheres, entre 18 e 33 anos de idade. Elas entraram em contato telefônico com Isabel através de uma conhecida desta em Iquitos. Todas elas desejavam participar de uma cerimônia com ayahuasca que fosse guiada por uma mulher. Eram vários os motivos que levavam à definição desta prerrogativa: conhecendo os diversos casos de abuso sexual por parte de xamãs locais, a mulheres turistas no meio das cerimônias e dietas, acreditavam ser mais seguro tomar ayahuasca com uma mulher ${ }^{117}$. Por outra parte, também vinculavam a energia da ayahuasca com a energia da mãe e da mulher. Waleska - uma jovem advogada de Lima que desde Iquitos fez os contatos para que suas jovens amigas chegassem a Tamshiyacu a fim de compartilhar a cerimônia com Isabel - me comentou naquele dia: "Me encantaría volver a hacer ceremonia con una mujer. Las mujeres tienen una energía diferente. Y más con una shipiba. La ayahuasca es de ellas"118.

Daquela vez, as turistas chegaram acompanhadas por Jenny, a filha de Isabel. Eram cinco jovens mulheres: duas peruanas (uma de Lima, advogada; a outra de Arequipa, dona de casa e esposa de médico); uma da Bélgica (linguista) e duas

117 Abundam notícias como a que segue nos fóruns sobre turismo xamânico na internet. O seguinte é o caso de abuso sexual por parte de um "xamã" a uma turista alemana. Cayó el 'chamán' que violo turista alemana. Em Perú 21, 23-03-2010. Em: http:// peru21.pe/noticia/450826/tarapotocayo-unochamanes-que-golpeo-violo-turista-alemana. Outra, sobre o mesmo caso: Joven alemana fue violada y golpeada salvajemente durante uma sesión de ayahuasca en Iquitos. Em El Comercio, 21-032010. Em:http://elcomercio.pe/comentarios/450258/joven-alemana-fue-violadagolpeadasalvajemente- durante-sesion-ayahuasca-iquitos. Acesso em 10/11/2012.

118 "Eu adoraria voltar a fazer cerimônia com uma mulher. As mulheres têm uma energia diferente. $E$ mais ainda com uma shipiba. A ayahuasca é delas". 
da França (estudantes de biologia). Eu me encontrava no albergue, na minha cabana do fundo, revisando algumas notas. Quando as meninas lá chegaram, eu escutei as vozes e saí. Isabel tinha disposto as diversas peças de seu artesanato em mesas na frente do espaço da cozinha.

As meninas observaram distraidamente os objetos de artesanato que lhes eram oferecidos e, em seguida, começaram a perguntar por detalhes da cerimônia, deixando-os de lado. Jorge e Isabel se encontravam lá, do outro lado da mesa cheia de cores, contas e sementes esgarçadas. Era a primeira vez que iam ingerir a beberagem, com exceção de Waleska, que tinha morado em comunidades shipibas de Pucallpa e experimentado a bebida por lá. As mulheres faziam as perguntas típicas do primeiro contato curandeirx-turista: como é que preparavam a ayahuasca, se preparavam era ayahuasca pura, se a planta era cultivada ali mesmo e se existia algum risco para a saúde advindo da ingestão da beberagem. Eu não consegui saber se era porque favoreciam a Jorge as regras de sociabilidade local, que colocam o homem como o sujeito sobre quem recai o peso das conversações públicas, ou era pela superioridade linguística dele no que faz ao manejo da língua espanhola. Mas Jorge tomou a palavra frente às jovens turistas e lhes respondeu a todas as suas perguntas, inclusive aquelas que estavam dirigidas à Isabel. No meio do contraste entre a loquacidade de Jorge e o silêncio de Isabel, eu observava uma crescente ansiedade das jovens mulheres por escutar a voz feminina de Isabel, face à crescente intervenção de Jorge nas respostas. Quando Waleska, a advogada de Lima, manifestou que queria participar de uma experiência que fosse "sólo con mujeres"119, Jorge se limitou a dizer: "es bueno que vengan en un día que no haya luna, porque con la oscuridad se

119 "Somente com mulheres". 
pueden concentrar más ${ }^{120 " .}$ Enquanto isso, Isabel, com o cabelo molhado e a cabeça baixa, deixava que sua filha Jenny a penteasse.

Elas concordaram de ficar essa noite para realizar a cerimônia. Jorge lhes indicou uma cabana próxima da minha, onde todas juntas ficariam. Às sete da noite chamaram à maloca [construção cerimonial] para iniciar o encontro. Como guias da cerimônia se encontravam Jorge, Isabel e dois convidados. Um deles, Salvador, era um argentino aprendiz de xamã que tinha estado três anos atrás sob a direção de Jorge, e o outro era Peter, um jovem sueco. Eu também participei de todas as instâncias da cerimônia, inclusive a beberagem da ayahuasca.

Jorge abriu o ritual com um pai nosso: "Padre, te pido que bendigas a las chicas que aqui se encuentran y a Salvador, mi alumno, y su amigo, para que tengan visiones bonitas y encuentren lo que están buscando. Bendícenos, Padre"121. Embora em outras ocasiões tenha sido Isabel quem fizera os procedimentos de cura individual, desta vez foi Jorge quem os praticou: soplada [procedimento do assoprar] na coroa de cada uma das pessoas, limpiada [procedimento do varrer forças invisíveis do corpo] desde os ombros com a chacapa [instrumento cerimonial realizado com o maço de folhas de um vegetal, geralmente a Olyra latifolia]. Finalmente, na hora de entoar os icaros e orações, a maior parte deles surgiu das vozes masculinas de Jorge primeiro e Salvador depois, ficando os icaros shipibo de Isabel relegados a dois ou três breves momentos dentro da cerimônia.

120 "É bom que vocês venham durante um dia que não tenha lua, porque na escuridão vocês podem se concentrar melhor".

121 "Pai, te peço que abençoes as meninas que aqui se encontram e a Salvador, meu aluno e seu amigo, para que tenham visões bonitas e encontrem o que estejam procurando. Abençoe-nos, pai". 
Não houve cantos compartilhados entre Isabel e Jorge, como em outras oportunidades. A cerimônia durou até à meia noite. Ao terminar a cerimônia e depois de uma segunda rodada de curas individuais feita por Jorge, foi Isabel quem veio conversar com cada uma de nós para nos perguntar como tínhamos nos sentido, e nos comentar as visões que ela podia ter tido durante a cerimônia a respeito de cada uma de nós. As mulheres pareciam dispostas à conversa, especialmente pelo fato de que era Isabel quem agora assumia o protagonismo, a "ação feminina" que elas tinham esperado da cerimônia. Foi assim que o grupo "de las chicas"122, entre as quais eu me encontrava, saiu para descansar nas cabanas, deixando os homens conversando à luz das velas. Contudo, a conversa durou o que durou o caminho até as cabanas das meninas. Isabel as deixou na porta, lhes desejando um bom descanso. O preço que as jovens turistas pagaram pela cerimônia e o pernoite posterior na cabana foi de 250 soles [uns 100 dólares cada uma].

A partir das vivências com turistas das quais tive a oportunidade de participar, percebi algumas notórias diferenças a respeito das vivências que envolvem a Isabel em práticas de curandeirismo com pessoas da localidade. No caso das experiências com turistas, frente à solidão de cada alma que olha para si própria na procura da sua própria revelação terapêutico-espiritual, se encontra Isabel. Ela participa, com muitos silêncios e poucas palavras estrategicamente escolhidas, de precários marcos de inteligibilidade que se trançam e destrançam a cada evento comunicativo. No caso das experiências com as pessoas da localidade, os marcos de inteligibilidade são compartilhados. As doenças, desde o daño até o pulsario, se reconhecem em virtude de genealogias do desconforto: às vezes são famílias que historicamente disputam e fazem trabajos uns aos outrxs; às vezes são doenças

122 "Das meninas". 
que xs parentes $d x s$ afetadxs deviam receber e acabaram recaindo naquelxs, por débeis ou inoportunxs. De todas as formas, os males de dios e os males de gente marcam a história das famílias humanas na Amazônia, dando conta da sua fortaleza, alianças, cumplicidades, tragédias secretas e conflitos. Isabel, que chegou em Tamshiyacu há poucos anos, conta com as ferramentas do curandeirismo indígena - considerado "poderoso" pela população ribeirinha local - e participa, como uma outsider privilegiada e com precisos movimentos de cintura, de múltiplos jogos de comunicação com três mundos diferentes do universo humano: o mundo dxs turistas gringxs com o qual interage a partir do seu lugar de xamã, o mundo dxs ribeirinhxs locais com o qual se posiciona como curandeira e o mundo shipibo onde ela cresceu, dentro do qual seria considerada hoje uma onanya.

\section{- Primeira dieta com Isabel e Jorge}

Quando cheguei em Tamshiyacu, no mês de fevereiro de 2013, veio comigo Nathálie, do Sri Lanka, uma jovem que estava muito interessada em apreender o xamanismo ayahuasqueiro da Amazônia peruana como prática complementar à sua heterodoxa formação em terapias da espiritualidade new age.

Na primeira semana da nossa permanência lá, fomos bater na porta da casa de Isabel, que eu tinha conhecido no ano anterior ${ }^{123}$. Atendeu-nos Jorge. Eu não o conhecia, ele se apresentou como o esposo de Isabel. Ele nos comentou que Isabel se encontrava em Pucallpa, sua terra natal, e voltaria em menos de uma semana. Decidimos ficar em uma hospedagem no povoado enquanto esperávamos que Isabel voltasse para Tamshiyacu. Passaram-se duas semanas e Isabel ainda não retornava. Jorge ia à nossa hospedagem e nos comentava que Isabel tinha muito

123 Passei todo o mês de Setembro de 2012 em Iquitos, aprimorando os contatos com os quais iniciaria meu trabalho de campo com terapeutas populares da região. 
trabalho por lá, mas que quando terminasse vinha direto para Tamshiyacu. Ela já sabia que havia duas jovens turistas esperando por ela. Enquanto isso, Jorge nos oferecia esperar por Isabel no albergue xamânico e aproveitar para começar lá uma dieta. No final da segunda semana de espera, Nathálie e eu decidimos ir para o albergue.

Uma vez dentro do albergue, Jorge nos ofereceu aprender com ele o xamanismo. E nos explicou: "antes éramos vegetalistas, ahora somos chamanes. Esta ciencia vegetalista es como una cadena: uno le enseña al otro, y el otro al otro, y así la ciencia no se acaba más"124. Ele se considerava a si mesmo um agente transmissor nessa cadeia, e procurava pessoas que passariam o conhecimento vegetalista para as gerações vindouras.

Eu entrei no albergue com a intenção de dietar enquanto esperava Isabel e Nathálie ingressou com a intenção de dietar e aprender o xamanismo. Foram quatro dias de silêncio e toma matutina de plantas: eu tomei chiricsanango [Brunfelsia grandiflora] e ajo sacha [Mansoa alliacea]. Comia duas porções de comida diária e não tinha contato físico e visual com ninguém, salvo com a pessoa que levava a comida diariamente à minha cabana.

Passados quatro dias de dieta no albergue, chegou Isabel. Ela trouxe dois grandes sacos com troços de lenho de ayahuasca, alguns bulbos de piripiri [Eleutherine plicata] e um loro, chamado Pedro, que falava algumas palavras em espanhol e outras em shipibo. Isabel vinha com novos projetos e satisfeita com os resultados da visita que ela tinha feito à sua família. Lá em Pucallpa, Isabel tinha

124 "Antes éramos vegetalistas, agora somos xamãs. Essa ciência vegetalista é como uma cadeia: um the ensina ao ouro, e o outro a outro, e assim a ciência não acaba mais". 
aproveitado para fazer trabalhos de cura para três parentes. Primeiro, trabalhou com a sua mãe, que tinha câncer no ventre. Para tratá-la, ela juntou-se com o primo dela, também curandeiro, e fizeram uma cerimônia com ayahuasca e orações. Depois Isabel trabalhou para a sua filha Kelly, cujo corpo tinha sido penetrado por uma alma através do umbigo e lhe provocara intensas dores nas costas. Para tratá-la, Isabel soprou seu corpo com mapacho e chupou o mal do seu peito e costas. Ela conseguiu tirar duas pedras, dessas que a bruxaria costuma deixar, de dentro do seu corpo. Finalmente soprou o corpo do seu filho mais velho, Néstor, desejando-lhe boa sorte e proteção contra a inveja dos seus colegas de trabalho.

Com o passar do tempo, e com o compartilhar do cotidiano da família, observei que as atividades que Jorge e Isabel mais orientavam para xs turistas eram: a hospedagem no albergue, a dieta individual (que podia ter uma duração entre três dias e um ano), as cerimônias periódicas (com uma frequência de uma, duas e até sete na semana), e finalmente a prática de ensinar o xamanismo. Dentro desta última alternativa, Jorge costuma organizar caminhadas pela floresta para conhecer as plantas in situ, prepara colaborativamente a beberagem da ayahuasca em grandes panelas no fogo a lenha e se concentra na transmissão de ícaros acompanhado de instrumentos tais como violões, quenas [instrumento andino de vento], charangos [instrumento andino de cordas], gaitas ou qualquer outro de preferência da pessoa que esteja desejando aprender. A proposta de Isabel e Jorge, assim como a de muitxs outrxs curandeirxs que trabalham hoje em dia com turismo na floresta amazônica do Peru, é que mulheres e homens do mundo inteiro podem passar a fazer parte desta continuidade de saberes e levar esse conhecimento prático para as suas respectivas terras natais. 


\section{- A vida com Jorge}

Quando Isabel e Jorge se conheceram, xs dois tinham percorrido já seu próprio caminho no curandeirismo. Isabel começou a curar com menos de 15 anos, enquanto Jorge começou o seu labor como curandeiro lá pelos seus trinta anos. Jorge Majipo tem uns quarenta e poucos anos e é filho de Dom José Majipo, conhecido curandeiro da localidade de Nuevo Valentín, na beira do rio Tahuayo - um dos afluentes que conjuram na nascente do Amazonas. Dom José é curandeiro, purguero e ayahuasqueiro. Por isso dizem que ele não adoece, nem frio sabe sentir. Muitos anos tomando palos, muitas dietas, muitas provas frente às quais os espíritos das plantas os colocaram. Já vai fazer 100 anos. Adora conversar, me dizem. Pode chegar o amanhecer, e ele vai continuar conversando. Jorge me conta que ele é um curandeiro muito conhecido na região, as pessoas têm muita fé nele. E me conta que até o dia de hoje, ele bebe a ayahuasca. Dom José e sua mulher tiveram dez filhos, nove homens e uma mulher só. Dois deles, Jorge e Luciano, aprenderam para serem curandeiros como o pai. Elxs começaram a tomar a ayahuasca quando seu avô paterno os convidava. Ele tinha doze anos então. Sendo quase adolescente, foi dado para uma família de Iquitos. Filho de criação, com eles Jorge terminou de crescer. Trabalhou vendendo pães doces, pasteizinhos, rosquinhas e kekes [bolos] para obter ingressos. Com vinte e poucos anos, começou a trabalhar como guia para uma agência de turismo em Iquitos, a Exploring Adventure. Tempo depois, reavivou os conhecimentos que tinha sobre plantas, adquiridos naquela primeira etapa da sua vida, e começou, através da mesma agência de turismo, a realizar cerimônias com ayahuasca em diferentes resorts da área. Mais tarde, trabalhou também como curandeiro no albergue Quebrada de Tamshiyacu. Ele conta, em singular, que um turista inglês 
lhe deu a ideia de se tornar independente: "Um año de esfuerzos y ya verás como progresas $^{\prime 125}$, tinha lhe dito.

A vida no curandeirismo the deu muitas coisas boas. Jorge me comenta: "la ayahuasca te enseña a respetar. Te da energía para leer. A los que son perezosos, les da fuerza para hacer las cosas"126. O curandeirismo e a conexão com as plantas maestras deu fortaleza, mas também tristezas a Jorge. Da mesma maneira aconteceu com a sua família de origem, completamente vinculada ao curandeirismo. Jorge me conta que a sua mãe morreu, há uns 7 anos, de daño. Jorge descreveu como uma doença horrível que eles, justamente por serem parentes, não podiam curar. "Una misma sangre no puede ayudar a su sangre"127, me diz Jorge.

Um dia, Jorge me contou na cozinha do albergue: "yo también sé hablar idioma. Hablo chayahuita y quechua. Quechua por mi abuela, la mamá de mi mamá. Chayahuita por mis andanzas en el mundo"128. Por outra parte, Isabel me contara que nas discussões que às vezes tinham como casal, ele a chamava de india ignorante ${ }^{129}$. Ele sabia falar corretamente, ela não. Ele sabia escrever, ela não (Ver Imagem 8, A Palavra Escrita do Curandeiro). O insulto de Jorge não é excepcional: no contexto da etnicidade mestiça ribeirinha, ser indígena é muitas vezes representar o lado de fora da modernidade. É assim que xs vizinhxs da localidade de Tamshiyacu

\footnotetext{
125 "Um ano de esforços e você vai ver como progride".

126 "A ayahuasca te ensina a respeitar. Te da energia para ler. Àqueles que são preguiçosos, lhes da força para fazer as coisas".

127 "Um mesmo sangue não pode ajudar o seu sangue".

128 "Eu também sei falar a língua indígena. Falo chayahuita e quechua. Quechua pela mina avó, mãe da mina mãe. Chayahuita pelas minhas andanças no mundo".

129 "Índia ignorante".
} 
não costumam traçar nenhuma origem indígena, e se vinculam aos fundadores do povoado, mestiços católicos que vieram da serra peruana. Porém, no contexto do turismo xamânico, ser indígena é um valor estratégico em termos da autenticidade que xs turistas, quimericamente, procuram. Nessa ambivalência se encontra Jorge, cuja ocupação como curandeiro e xamã, ao mesmo tempo, o coloca do lado de fora e do lado de dentro da modernidade.

SUSANARAMONA MENDEZ TMRDOZ MATIAS GABRREL SILVA MENDEC

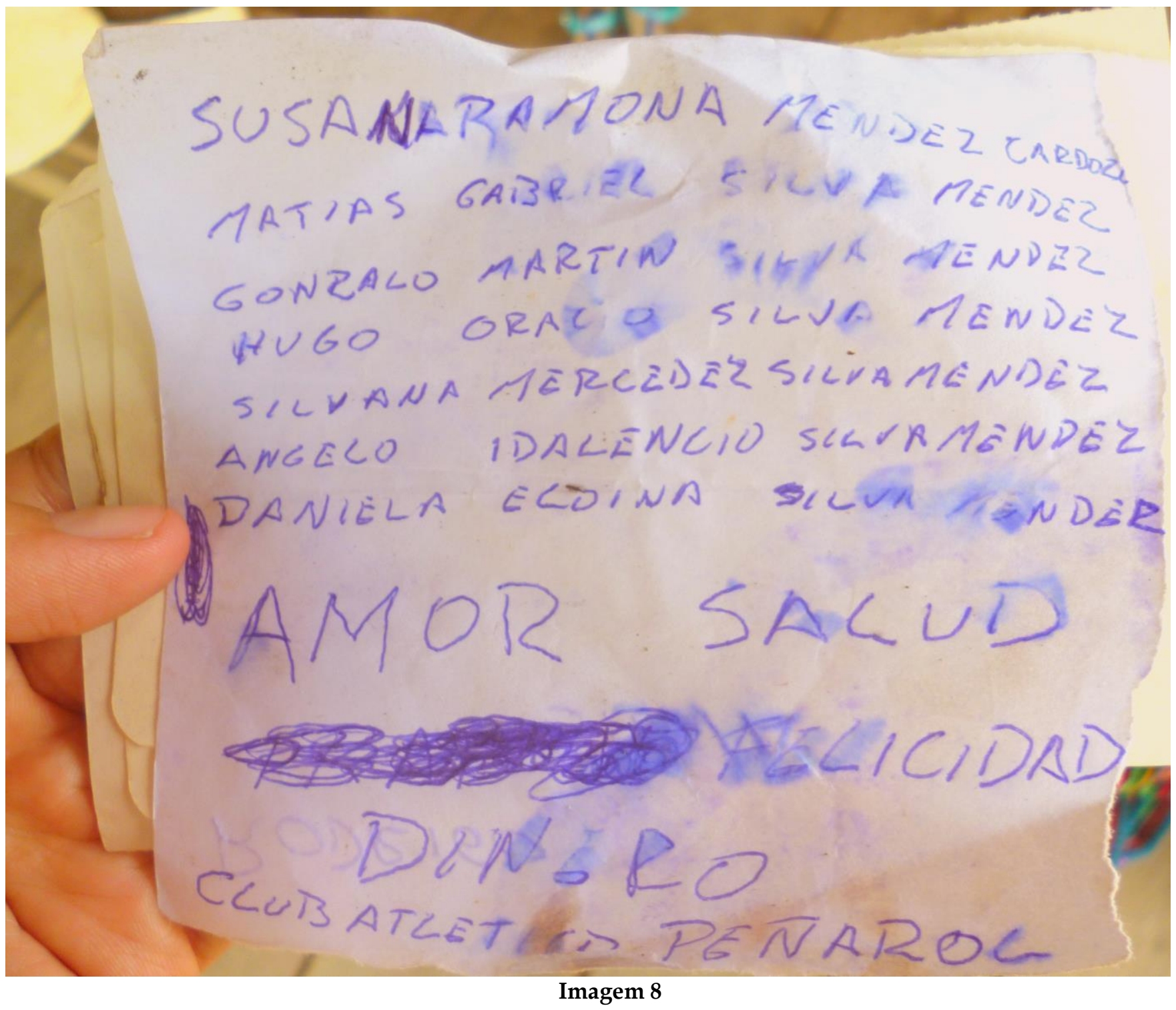

203 


\section{Imagem 8 (pág. anterior): A palavra escrita dx curandeirx}

\section{Xs curandeirxs que têm acesso à possibilidade de escrever}

são uma minoria na floresta do Peru. Esse recurso pode ser de grande utilidade na consecução de clientes e trabalhos mágicos. Aqui, papel usado para um trabalho mágico, escrito pelo curandeiro Jorge Majipo.

- Mulher chamana, curandera, onanya

No contexto regional, Isabel é uma das poucas mulheres que se declaram como curanderas. Particularmente no povoado ribeirinho de Tamshiyacu, não há nenhuma mulher que se chame a si mesma de curandera, ao menos não de forma aberta. Anita del Carmen, Milena: elas se reconhecem como mulheres que curan, curiosas, yerberas. Também há parteras como María e Zoila ou sobadoras de lisiados como Asteria: todas elas precisam saber manusear plantas. Porém, nenhuma delas assume abertamente a sua atividade como a de uma curandeira e mesmo que muitas tenham experimentado a ayahuasca, nenhuma delas lança mão desta planta no desenvolvimento rotineiro dos seus trabajos ${ }^{130}$. As curiosas de Tamshiyacu sabem, e muito, trabalhar com plantas. Mas dentro delas, são as hierbas [ervas] às que elas mais acodem. A aplicação deste tipo de plantas é relativa, sobretudo, a doenças próprias das crianças e também a males de dios. Já os males de gente são tratados com plantas que são consideradas mais poderosas aquelas que servem para fazer o daño [dano] e para se proteger dele. Não é um dado irrelevante que a maior parte dxs que lidam com esse tipo de plantas sejam

\footnotetext{
130 No capítulo 10 desenvolvo uma reflexão sobre as práticas terapêuticas e mágicas destas outras mulheres.
} 
homens. Dentre os curandeiros locais, todos os quais são, a exceção de Isabel, homens, Isabel conta com um lugar ambíguo.

No povoado, é muito frequente que xs curandeirxs façam comentários negativos uns/umas dxs outrxs. Faz parte da dinâmica de certa competitividade social entre curandeirxs que sabem curar e fazer o mal, delimitando nesses movimentos xs próximos e xs distantes, xs que estão do lado próprio e xs que estão do lado alheio. Assim, é possível escutar repetidas vezes a opinião, sempre negativa, de uns a respeito de outrxs: "X es mentirosx"131; "W no sabe nada"132, "Y sólo le quiere sacar la plata a los turistas"133; "Z aprendió con los libros! ${ }^{134 " .}$

Dom Agustín Rivas e Dom Lucho Panduro - talvez os dois curandeiros mais famosos de Tamshiyacu - convocaram a Isabel várias vezes para participar, cantando ícaros shipibo nas cerimônias de ayahuasca que destinam a turistas. Mas a sua opinião sobre a qualidade do trabalho de Isabel é duvidosa, quando não abertamente negativa. Disse para mim Dom Lucho em entrevista (março 2013; na maloca do albergue dele): "Yolo que te puedo decir sobre las mujeres curandeiras es que yo no discrimino, pero hay que ver si realmente saben. Hay que saber con quién uno se va a hacer tratar" ${ }^{135}$. Já o outro curandeiro, Dom Agustín Rivas, mostrou uma opinião elaborada a partir de uma série de princípios de organização do mundo onde há uma opinião específica sobre as mulheres que,

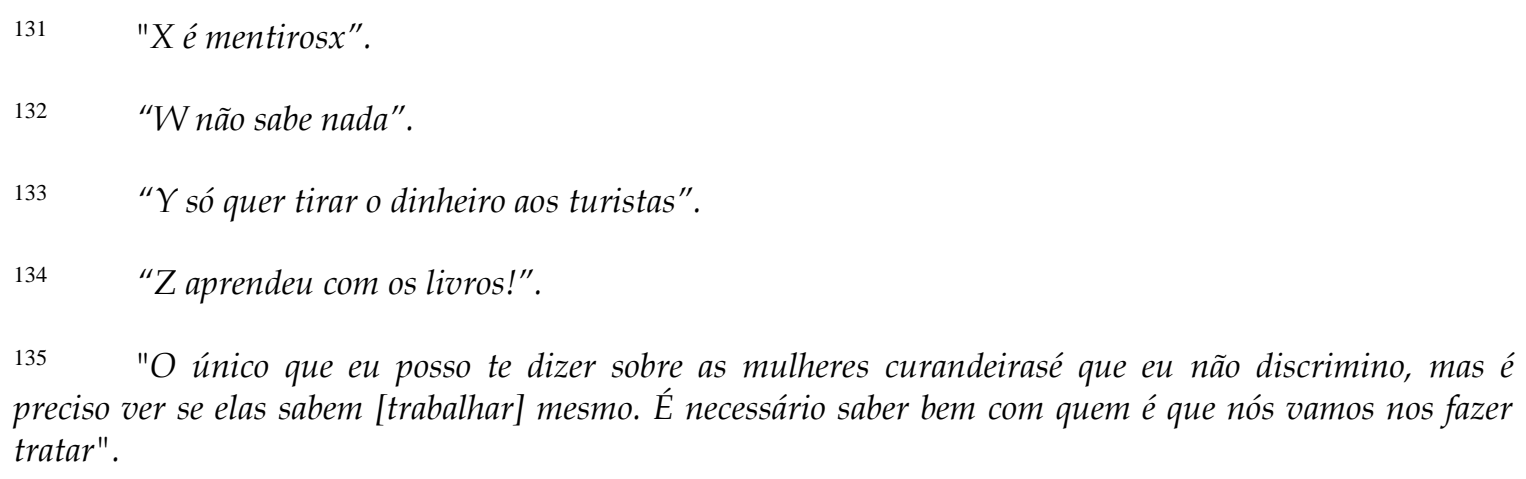
preciso ver se elas sabem [trabalhar] mesmo. É necessário saber bem com quem é que nós vamos nos fazer tratar". 
como as curandeiras, se dedicam a beber ayahuasca com frequência. É como segue (entrevista informal em um restaurante de Tamshiyacu, abril de 2013):

Hay muchas plantas femeninas y pocas plantas masculinas. La renaquilla, la chuchuasha, la ayahuasca, son plantas femeninas. Algunas plantas masculinas que te puedo nombrar son la caña de azúcar, la yuca, la chacuruna. El nombre científico de la chacuruna, psychotria viridis, alude a lo viril. Cuando tú eres hombre y tomas esas plantas masculinas, tienes sueños sexuales, con vírgenes, orgías. Cuando tomas las plantas femeninas, aprendes a curar. Las mujeres tienen que tomar plantas masculinas y los hombres tienen que tomar plantas femeninas. Las mujeres ya tienen eso, el don de la cura, esa inteligencia; en cambio los hombres lo tienen que aprender. Por eso, cuando las mujeres toman mucha ayahuasca, acaban volviéndose brutas ${ }^{136}$.

Dentro dessa concepção, uma mulher bruta seria uma mulher masculinizada, uma mulher que incursiona em espaços masculinos e se torna forte, o que, desde uma perspectiva depreciativa, seria se tornar rude, grosseira, agressiva. O discurso de Dom Agustín explicaria em parte a existência de uma grande quantidade de homens que trabalham como curandeiros, por uma parte, e a inexistência ou o baixo perfil das mulheres que curam. Além disso, a narrativa de Dom Agustín é claramente política, no sentido em que tende a imprimir valores que justificam o monopólio de certos atores e práticas sociais sobre outrxs. Assim, certas plantas de importância que, como a ayahuasca, são femininas, seriam desapropriadas do espaço do feminino para passarem ao domínio dos

\footnotetext{
136 "Há muitas plantas femininas e poucas plantas masculinas. A renaquilla [Clusia rosea], a chuchuasha [Heisteria acuminata], a ayahuasca [Banipsteriosis caapi] são plantas femininas. Algumas plantas masculinas que posso listar para você são a cana de açúcar [Paspalum conjugatum], a yuca [Manihote sculenta], a chacuruna [Psychotria viridis]. O nome científico da chacuruna, psychotria viridis, alude ao que é viril. Quando você, sendo homem, bebe dessas plantas masculinas, você tem sonhos sexuais, com virgens, orgias. Quando você bebe as plantas femininas, você aprende a curar. As mulheres têm que tomar plantas masculinas e os homens têm que tomar plantas femininas. As mulheres ja tem isso, o dom da cura, essa inteligência; em troca os homens devem aprender. Por isso, quando as mulheres tomam muita ayahuasca, acabam se tornando brutas".
} 
homens; considerando-se que nas mãos das mulheres seriam desnecessárias e, além disso, poderiam lhes prejudicar.

Na mesma entrevista, Dom Agustín aludiu às pessoas que nas cerimônias "cantan bonito, cantan icaros muy bonitos em lengua indígena, cantan com voz suavecita, pero uno ni sabe lo que estándiciendo y paga igual. Esos no saben". Quem conhece o contexto do curandeirismo local pode inferir que o comentário do curandeiro Agustín é uma alusão indireta a Isabel, curandeira indígena shipibo, a partir do fato de que: 1) refere a pessoas que cantam com voz aguda, o que as identifica genericamente como mulheres 2) alude a pessoas que cantam em língua indígena shipibo: para ribeirinhos como Dom Agustín, que cresceram falando somente espanhol, tal é uma língua incompreensível. Frente às informações providenciadas, mulheres curandeiras indígenas possuem um status duvidoso para Dom Agustín. A única mulher curandeira ayahuasqueira da região é também indígena: nessa perspectiva, só sabe cantar coisas bonitas e incompreensíveis e, devido à toma rotineira de plantas femininas, é provável que tenha se tornado bruta.

Da etnografia compartilhada com Isabel durante o tempo que passei em Tamshiyacu, é possível pontuar que Isabel possui pelo menos três marcadores de identidade que definem com força o seu lugar social: primeiro, ela é mulher; segundo, ela é indígena; terceiro, ela é curandeira. A primeira acepção é relativa a seu lugar de gênero; a segunda é relativa à sua etnicidade; a terceira é referente à sua principal ocupação. Esses marcadores não são estáticos e a colocam em posições de maior ou menor autonomia e influência de acordo com os contextos onde eles sejam ativados. Quero ressaltar aqui a riqueza da terceira dimensão, relativa à sua ocupação como especialista em terapias e magias com plantas. 
Dentro do que é seu labor principal, poderíamos dizer que Isabel é tanto chamana [xamã], quanto curandera e onanya [termo shipibo aplicado às pessoas que lidam com terapias e magias deste e de outros mundos] $]^{137}$. Tenho me referido aos múltiplos jogos de comunicação que Isabel estabelece com mundos diferentes do universo humano: o mundo dxs turistas gringxs - como as mulheres que convocou para uma cerimônia com ayahuasca - e com o qual interage a partir do seu lugar de xamã; o mundo dxs ribeirinhxs locais - dentro do qual a procuram pacientes como dona Victoria -, dimensão frente à qual Isabel se posiciona como curandeira e, finalmente, o mundo shipibo no qual ela cresceu - dentro do qual se encontra, sobretudo, a sua rede familiar -, dimensão na que ela seria considerada hoje uma onanya ainbo, mulher curandeira.

Em relação às diversas dimensões sociais pelas quais circula Isabel, gosto de imaginar um movimento de apreensão que vá de fora para dentro, e que a situa primeiro como xamã para um mundo com o qual compartilha uns poucos valores comuns - dentre eles, dois aparentemente tão diversos como a certeza da existência animada das plantas e seu valor terapêutico, assim como o valortrabalho das suas práticas mágicas e de cura -, passando a curandeira em um mundo com o qual compartilha importantes aspectos da vida cotidiana - escola, mercado, botes e instituições de saúde, amizades, vizinhxs e o uso costumeiro da língua espanhola - e finalizando no nível onde se reconhece e é reconhecida por outrxs como onanya: aquele é o mundo da sua cultura e etnia de origem, o espaço dos mitos familiares, da cor dos cantos que canta, das roupas cerimoniais que faz, da língua na qual fala com as suas crianças: a partir deste terceiro

137 Para ver uma definição nativa dos onanyas desde a perspectiva de uma mulher shipiba, pode ser consultado o livro "Koshi Shinanya Ainbo, el testimonio de una mujer shipiba", de Agustina Valera Rojas e Pilar Valenzuela. Lima: El Santo Oficio, 2004. 
mundo, que aparece como o caule mais duro da árvore da sua vida, é que ela se enraíza e traduz, até hoje, os restantes outros mundos.

Dentro dos esquemas de compreensão regionais, a ayahuasca é considerada como patrimônio étnico que é, sobretudo, indígena. Na enorme multiplicidade de grupos indígenas da Amazônia peruana - são pelo menos quarenta e dois grupos etno-linguísticos - xs shipibo são dos grupos ayahuasqueiros mais reconhecidos. A ayahuasca é considerada também uma planta feminina. Já pontuamos o que disse Waleska, visitante do albergue Mundo de la Yacuruna: "Me encantaría volver a hacer ceremonia con una mujer. Las mujeres tienen una energía diferente. Y más con una shipiba. La ayahuasca es de ellas"138. Confirma essa percepção Gerlyn, o filho de Isabel, que é artesão da madeira, aprendiz de curandeiro e fala shipibo e espanhol fluentemente (entrevista realizada em abril de 2013):

Las mujeres... es que a las plantas les atrae más... yo creo que hay pocas... muy pocas. Chamanas... sólo mi mamá. Más que todo el hombre tiene que pasar años para que sepa. Yo no sé... yo siempre le he preguntado a mi padrastro. Él también no me respondió. Sólo sé que a mí me respondía la planta que a las mujeres más le entra en el cuerpo. La ayahuasca fue la que más me lo dijo ${ }^{139}$.

Junto com dom Agustín, Gerlyn opina que é mais fácil que as mulheres tenham uma relação direta com as plantas, esa inteligencia para curar a las personas ${ }^{140}$, como

138 "Eu adoraria voltar a fazer cerimônia com uma mulher. As mulheres têm uma energia diferente. E mais ainda com uma shipiba. A ayahuasca é delas".

139 "As mulheres... são elas as que atraem mais às plantas... eu acho que são poucas... muito poucas... xamãs. Só a minha mãe. O homem tem que passar anos para aprender. Eu não sei... eu sempre perguntei para o meu padrasto. Ele também não me respondeu. Eu só sei que a planta me respondeu, [ela disse] que às mulheres a planta lhes entra mais no corpo. A ayahuasca foi a que mais me disse isso".

$140 \quad$ "Essa inteligência para curar às pessoas". 
a chama o próprio Agustín. Porém, enquanto que para o curandeiro Agustín a proximidade das mulheres com a maioria das plantas existentes (que são, assim mesmo, femininas) coloca a essa própria inteligência em risco; para Gerlyn, a relação entre plantas e feminilidade se traduz em uma potencialidade: as mulheres se tornam atoras sociais privilegiadas nas práticas de tratamento e cura.

Na dessemelhança destes dois pontos de vista (o de Agustín, o de Gerlyn) sobre Isabel é que vemos também um reflexo indireto da posição dxs sujeitxs em campo: do filho da curandeira ao curandeiro que compete com ela, as relações sociais se tecem como fios ao redor da figura de Isabel, e, de maneira aberta ou reservada, restringem ou potencializam a sua labor cotidiana. Assim, despregando a sua individualidade e originalidade em íntima interação com as possibilidades e violências do meio social local, o relato apresentado sobre Isabel fornece elementos que podem ser úteis para a sistematização, análise, comparabilidade e contextualização do curandeirismo particular e único de Isabel com as outras maneiras de fazer curandeirismo que exercitam outrxs sujeitxs da região. Tais práticas são relativas aos fazeres, saberes, estratégias de empoderamento, escolhas e tensões do que é ser curandeirx nesse contexto.

\section{- Isabel vai para o mercado}

Isabel vai para o mercado e lá compra mandioca, plátano, pinha, batata, peixe fresco e mapachos [cigarros feitos com tabaco fresco]. Ela olha para frente, caminha rápido e com passos curtos. Cumprimenta poucas pessoas, e quase nem se detém para conversar com conhecidxs. Geralmente vai sozinha: costuma deixar as crianças em casa, pois, segundo diz, elas se distraem com facilidade. $\mathrm{O}$ que ela quer é retornar cedo para continuar com as tarefas do dia, em casa, no albergue ou nas casas de pacientes. 
Provavelmente, o fato de ter trazido as crianças já crescidas de Pucallpa para Tamshiyacu tenha libertado Isabel de formas de socialização escolar que são tão conspícuas nos pequenos povoados. Ela não precisou assistir às reuniões, bingos, desfiles e concursos que se exigem como parte da vida dxs responsáveis pelas crianças em idade escolar. Em consequência, ela pôde se dedicar ao seu trabalho, e deixar de lado muitas formas de socialização não escolhidas.

É certo que esse ponto, além de vantajoso, pode ter seu lado negativo. A sua independência a respeito do sistema de relações sociais locais a torna, de certa maneira, uma outsider do mesmo. No contexto deste posicionamento, ir ao mercado para comprar as verduras, o peixe e outros ingredientes para a comida quase todos os dias era um momento no qual ela devia socializar, enfrentar olhares, confrontar opiniões. Quando eu a acompanhava para o mercado, ela me dizia que era importante ir com a cabeça na frente, não ficar olhando para os lados, focar-se na tarefa que se veio fazer. O único ponto que Isabel se permitia parar era no posto de comidas da dona Rosa, que era uma habitual paciente e amiga dela, a quem Isabel tinha ajudado a resolver crises financeiras e de saúde.

Isabel, mulher, trabalhadora e indígena, representa três caras de uma identidade muito particular. A sua liberdade de movimento, ampla em relação à maioria das mulheres da sua idade que moram em Tamshiyacu; o seu ofício, que a coloca em posição de poder e ação; o seu ser indígena, que a define como não-mestiça em um contexto ribeirinho e mestiço: todos eles são, sem dúvidas, fatores de alteridade. Eles impactam na possibilidade que Isabel pode ter de compartilhar formas abertas de sociabilidade no povoado, e a colocam como uma outsider privilegiada - jogando desde fora, mas com estratégico acesso a elementos socialmente valorados - nesse contexto. 


\section{Capítulo 6 \\ Maneiras de fazer com plantas}

- Doenças como território de desequilíbrio - Frio/quente - Formas de preparar os vegetais - Patco $\bullet$ Mapachos e a proteção contra o invisível - Madres, donos, gênios e duendes das plantas - Gerlyn, as belas piñón e o exigente tabaco - Isabel, Asteria, Clarina e a masculinidade das patiquinas - Román e uma malva orientadora - Estela e a camalonga que cura • Espelhos de diversidade

\section{- Doenças como território de desequilíbrio}

Nesse apartado, inspirarei-me na produção etnográfica do antropólogo Martín Novión ([1974] 2013: 129-130), para o caso de Sobradinho, região administrativa de Brasília/DF, a qual resgatou alguns aspectos que aparecem claramente na minha experiência amazônica. Ele afirma:

Os elementos em oposição com seus valores positivos e negativos devem existir pela imperiosa necessidade de uma interação e de uma interdependência entre eles, expressa em termos de um equilíbrio, único capaz de cristalizar a ordem. Isso se baseia com referência explícita ao corpo humano, no estado de saúde, na relação equilibrada entre quente e frio.

A respeito do equilíbrio em questão, o autor (op. cit, p. 130) sustenta:

Esse equilíbrio não é estático, muito ao contrário; está sujeito a oscilações provocadas seja por doença, seja por ingestão indevida de alimentos ou por modificações de conduta. Também é suscetível, quando alterado, de retornar à sua situação ideal.

No caso dxs curiosxs de Tamshiyacu, prefiro não falar de um "retorno à situação ideal" e sim de um restabelecimento precário de forças, que estão sendo constantemente ameaçadas por todo tipo de fatores que podem alterá-lo. Uma das maneiras de mesurar esse precário equilíbrio é o movimento entre a condição frio/quente do mundo. Desenvolverei esse aspecto no ponto seguinte. 


\section{- Frio/quente}

Zoila tem uns sessenta anos. Ela mora no bairro de Flores, em Tamshiyacu. Ela se reconhece como partera. Porém, ela não só parteja, mas também trabalha com uma diversidade de ervas que aplica segundo o conhecimento do tipo de planta e da qualidade dela. Diferentemente de muitas outras yerberas, Zoila afirma ter aprendido da vida mesma, isto é, por si só. E comenta:

Sí... simplemente se cura con las hojas... se hace, como te digo la patiquina, el piñón, la catahua, el mapacho, el ajo... se lo machaca y eso se lo mezcla se lo calienta y eso se lo apega donde está el dolor. Eso te quita como quitar con la mano! Algunos simplemente sin estar yendo a los médicos, se curan así. Todo eso se apriende, pues uno de vida sabe! ${ }^{141}$.

De acordo com a minha experiência etnográfica, o frio parece ser mais comum e problemático que o calor. É por isso, talvez, que há um maior reconhecimento de plantas e materiais (chamo assim a produtos que não são vegetais) quentes do que frios (Ver Tabela 2).

141 "Sim... simplemente se cura com as folhas... se faz, como te digo a patiquina, o piñón, a catahua, o mapacho, o alho... se machuca, se mistura e se esquenta, e isso se coloca onde seja que estiver a dor. Isso tira como tirar com a mão [faz no ar um movimento de varrido]! Alguns simplesmente sem estar indo aos médicos, se curam assim. Tudo isso se aprende, pois agente da vida mesma sabe!" 
Tabela 2. Natureza fria ou quente de vegetais e não vegetais

\begin{tabular}{|c|c|c|}
\hline Natureza & Vegetais & Elementos não vegetais \\
\hline Fria & $\begin{array}{l}\text { ajo (Allium sativum) } \\
\text { algodón (Gossypium barbadense) } \\
\text { malva (Malachra ruderalis); } \\
\text { orégano (Glandularia laciniata); } \\
\text { albahaca (Ocimum basilicum); } \\
\text { menta Mentha spicata); } \\
\text { santa maria (Piper obliquum) }\end{array}$ & \\
\hline Quente & $\begin{array}{l}\text { sangre de grado (Croton Lechieri); } \\
\text { gallinazo pango (Cassipourea peruviana); } \\
\text { jengibre (Zingiber officinale); } \\
\text { ubos (Spondias mombin); } \\
\text { sandia (Cucumis anguria); } \\
\text { chuchuasha (Maytenus macrocarpa); } \\
\text { huacapurana (Campsiandra angustifólia); } \\
\text { bolainas (Muntingia calabura) } \\
\text { wasaí (Euterpe oleracea) } \\
\text { limón (Citrus limon) } \\
\text { ipururo (Alchornea castaneifolia) } \\
\text { cumaceba (Swartzia polyphylla) } \\
\text { mururú (Brosimun acutifolium) } \\
\text { ayahuasca (Banipsteriosis caapi) }\end{array}$ & $\begin{array}{l}\text { aguardente, } \\
\text { El Abuelo }{ }^{142}, \\
\text { colmena [de abelhas], } \\
\text { ovos de galinha, } \\
\text { leite }\end{array}$ \\
\hline
\end{tabular}

A alteração nos estados de frio/calor do próprio corpo pode acontecer quando estamos fazendo as mais cotidianas atividades: lavando as roupas, pescando, caçando. Eva, lavandeira em um albergue chamánico de Tamshiyacu, pegou frio no corpo por lavar as roupas estando descalça. Segundo ela nos conta, uma curiosa the recomendou que cortasse o cabelo, pois a água entra na cabeça pelo cabelo e traz o frio no corpo. Também lhe indicou que tomasse gengibre quente por 11 dias. Ela bebia o gengibre e também molhava com ele a cabeça. Cortou o

${ }^{142}$ É a marca comercial de o porto, vinho fortificado com aguardente, de ampla circulação no país. 
cabelo, sentiu-se melhor. Walter, curioso, narrou para mim a receita em entrevista em agosto de 2013 mal de frio en el cuerpo:

Esto me lo enseñó mi padre. Y tenía razón! Cuando uno se echa al agua con el cuerpo sudado, te choca el frío. Por fuera te quedas fresco, pero por dentro está caliente. Entonces el cuerpo se quema por dentro y, como una planta, se marchita adentro. Hay que hacerse los tés ${ }^{143}$.

Nesse trecho, Walter refere a uma metáfora recorrente nas explicações dxs curiosxs: O corpo é uma planta. Há na natureza do corpo humano certos aspectos que são idênticos aos das plantas, e são esses aspectos que podem ser tratados com vegetais. Assim, o fato de entrar em contato com um vegetal específico provoca uma ressonância que, na direção desejada, facilita ou promove a cura da perturbação. Os chás a que se refere Walter são infusões de plantas específicas, preparados de acordo com a sua natureza fria/quente e a intenção mágica ou terapêutica dx curiosx. A sobadora Asteria e a partera Bernardina pontuam que o sucesso de um tratamento depende da correta utilização do seu contrário. Bernardina diz que a mordedura da víbora é fria, por ser a víbora, ela própria, um animal de sangue frio. Por isso, deve ser tratada com resinas, como sangre de grado [Croton lechleri]. Asteria afirma que quando a natureza da doença não é conhecida, é preciso provar os tratamentos com plantas ou elementos frios ou quentes, alternativamente. Por exemplo, quando há uma contusão,

Se hace una patarashka [envoltura] de hojas. Ahí le vas a poner el alcanfor, el cigarro mapacho, le vas a echar un dientecito de ajo... donde te duele, tú le apegas a la noche. Le apegas, con eso amaneces. Segundo día, dos, tres... si le va a hacer bien, bien. Si responde caliente, es bien. O sino quiere frío! Depende $^{144}$.

143 "Isso me ensinou meu pai. E tinha razão! Quando agente coloca a agua no corpo suado, o frio é chocante. Por fora, você fica fresco, mas por dentro continua quente. Então o corpo queima por dentro e como uma planta, marchita. É preciso fazer os chás".

144 "Se faz uma patarashka [envoltura] com folhas. Ali, você vai colocar a cânfora, o cigarro, você vai colocar um dentinho de alho... você cola à noite onde doi. Com isso, você amanece. Segundo dia, dois, três... Se faz bem, está bom. Se responde [é porque quer] quente. Se não, [é porque] quer frio! Depende". 
O tratamento e cura não são sempre definidos univocamente, a partir da percepção do que é a natureza da perturbação. Às vezes, eles não respondem a elementos e tratamentos de natureza fria ou quente, pelo que é preciso provar o seu contrário. Como sublinha Asteria, as provas e erros com remédios quentes ou frios também fazem possível desvendar, de maneira empírica, a natureza de uma doença. Tais provas e erros, mais do que invalidar a presença dx especialista, mostram a natureza mais simples ou mais complexa, da própria perturbação.

\section{- Formas de preparar os vegetais}

"Las plantas (...) son criaturas (...) que respiran y se comunican, dotadas de personalidad y atributos del alma (...) [poseen] una reacción de lo más violenta contra los abusos, y el agradecimiento más ferviente por los favores" ${ }^{\prime 145}$. Peter Tompkins e Christopher Bird, 1974.

Temos observado que existe uma diversidade de vegetais com os quais xs curiosxs podem estabelecer uma relação de comunicação. Porém, não se trata só do tipo de planta utilizada: até a forma do preparo das plantas dependerá da qualidade fria ou quente da doença. Milena, partera e naturalista de Tamshiyacu, segundo a sua própria definição, mostrou-me algumas técnicas de manejo da qualidade fria ou quente das plantas. Chispear é a técnica de colocar a planta na água quente, à maneira de infusão. Chapear é a técnica que consiste em enxugar a planta com a mão em água fria. É um uso corporal bastante difundido na hora dos preparos tanto culinários quanto mágicos e medicinais. As plantas que são quentes podem ser tomadas com aguardente e colmena, para potencializar o seu calor.

145 "As plantas (...) são criaturas (...) que respiram e se comunican, dotadas de personalidade e atributos da alma (...) [acionam] uma reação que é das mais violentas contra os abusos, e o agradecimento mais fervente pelos favores". 
Mezclar 12 huevos y el jugo de 30 limones. Enterrar en un lugar donde goteen las hojas de las plantas. Hacer dieta durante 8 días. Desenterrar. Agregar 20 cucharadas de raíz de wasaí machacada, dos latas de leche, 20 cucharadas de vino Abuelo. Batir con cuchara grande. Si no hay, batir con la mano. Poner en un baldecito. Guardar por un día. Tomar la medida de una tapita plástica de soda dos veces al día ${ }^{146}$.

Essa receita que Isabel me contou ${ }^{147}$ serve para curar o frio en los huesos. Veja-se que a única planta que se utiliza é a raiz do wasaí, a qual é considerada quente, mas também é classificada dentro da categoria patco, comentada adiante. A natureza fria ou quente da planta pode ser, até certo ponto, modificada. De fato, existe a possibilidade de realizar uma transição de frio para quente ou de quente para frio de um vegetal de acordo com a sua preparação. Contou-me dona Asteria, sobadora, que a malva é uma planta fria. Mas, se ela é chispeada, ela se torna quente, e pode tratar distúrbios de um órgao/corpo/pessoa frio. Disse-me Walter, curioso e aprendiz de xamã, que o algodón é frio, mas se torna cálido quando se chispea para ligar ${ }^{148}$ uma mulher. Na hora do parto, é possível que o frio entre no corpo. É um momento especial de exposição a distúrbios. Para isso, liga-se o corpo umas semanas antes do parto. Utilizam-se, ademais do algodón, a malva, o orégano, a albahaca, a menta e a santa maría, entre outras. Elas são todas plantas consideradas frias, mas que se tornam quentes quando preparadas segundo a técnica do chispeado.

146 "Misturar 12 ovos e o suco de 30 limões. Enterrar em um lugar onde pinguem as folhas das plantas. Fazer dieta durante 8 dias. Desenterrar. Adicionar 20 colheradas de raíz de wasai machucada, duas latas de leite, 20 colheradas de vinho Abuelo. Mexer com colher grande. Se não há, mexer com a mão. Colocar em un baldezinho. Guardar por um dia. Tomar a medida de uma tampinha plástica de soda duas vezes ao dia".

147 Isabel me disse essa história no 25/03/2013, durante o quarto dia da minha dieta em seu campamento.

148 A ligada é um procedimento que se utiliza para fechar à mulher antes do parto. Consiste na exposição da vagina da mulher ao vapor de certas plantas, como o algodón, a malva e a toronja. Deve de ser realizado por alguém que conheça como fazê-lo, pois a mulher pode se hinchar [produzir um alargamento flatulento da barriga], coisa que pode acarretar um desenlace fatal. 
Por sua vez, ubos [Spondias mombin] é uma árvore, por definição, quente. Mas se ele é serenado corretamente, torna-se frio e pode ser aplicado em caso de doenças do órgão/corpo/pessoa quente. Anita del Carmen, dona de casa, curiosa e vendedora de biscoitos na porta da escola de Tamshiyacu, contou-me o segredo do serenar: fazer um poço na terra, tapá-lo bem. Deixar a garrafa por oito dias, sem dizer para ninguém. Oito dias depois, destapar. Já virou uma planta fria. Desta maneira, o fato de descansar durante a noite potencializa os efeitos terapêuticos ou etótropos da planta, e pode modificar a sua própria natureza fria ou quente (Ver Imagens Maneiras de Fazer com Plantas, I e II). 


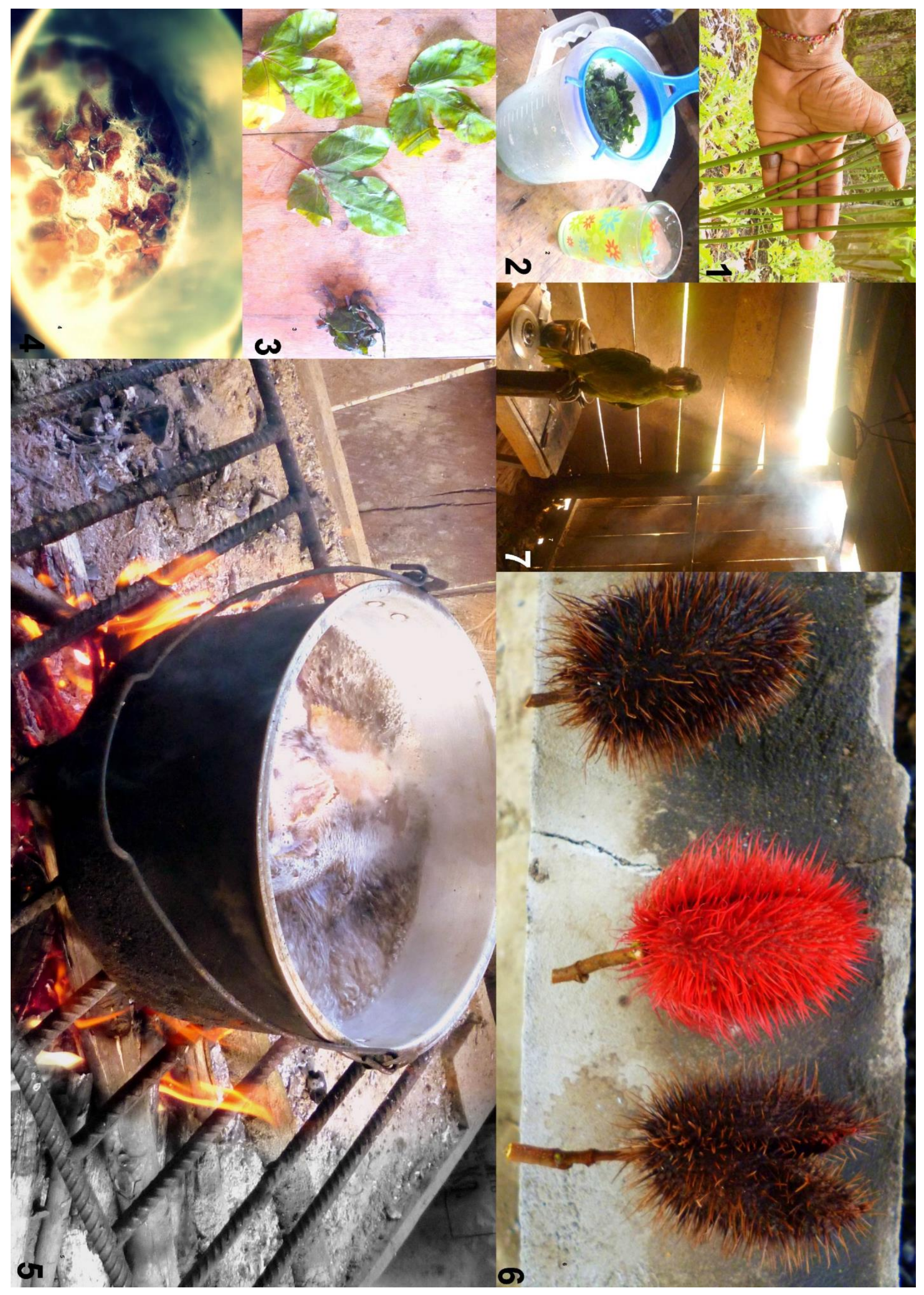


Imagem 9 (pág. anterior): Maneiras de fazer com plantas, I 1 - Piripiris [Eleutherine plicata] do jardim de Isabel, na área de plantío do albergue Mundo de la Yacuruna.

2 - Malva [Malachra ruderalis] preparada em frio (isto é, chapeada) com a finalidade de diminuir o inchaço nas pernas produzido pelo calor, prática cotidiana durante a minha gravidez.

3 - Três folhas de piñón negro [Jatrophagos sypiifolia] usadas durante a noite como cataplasma para as dores articulares. Remédio aplicado por Carl para combater a tendinite.

4 - Isabel ferve a uña de gato [Uncaria tomentosa] no fogo a lenha da cozinha.

5 - Isabel ferve em uma panela os ubos [Spondias mombin] no fogo à lenha da cozinha.

6 - Três frutos de achote [Bixa orellana] do jardim de Isabel.

7 - Pendurada em cima do fogão, uma cabaça de huingo [Crescentia cujete] que age, por magia simpática, como a doença que seca e que ressoa no corpo da pessoa, fazendo com que a doença seque e a abandone. 


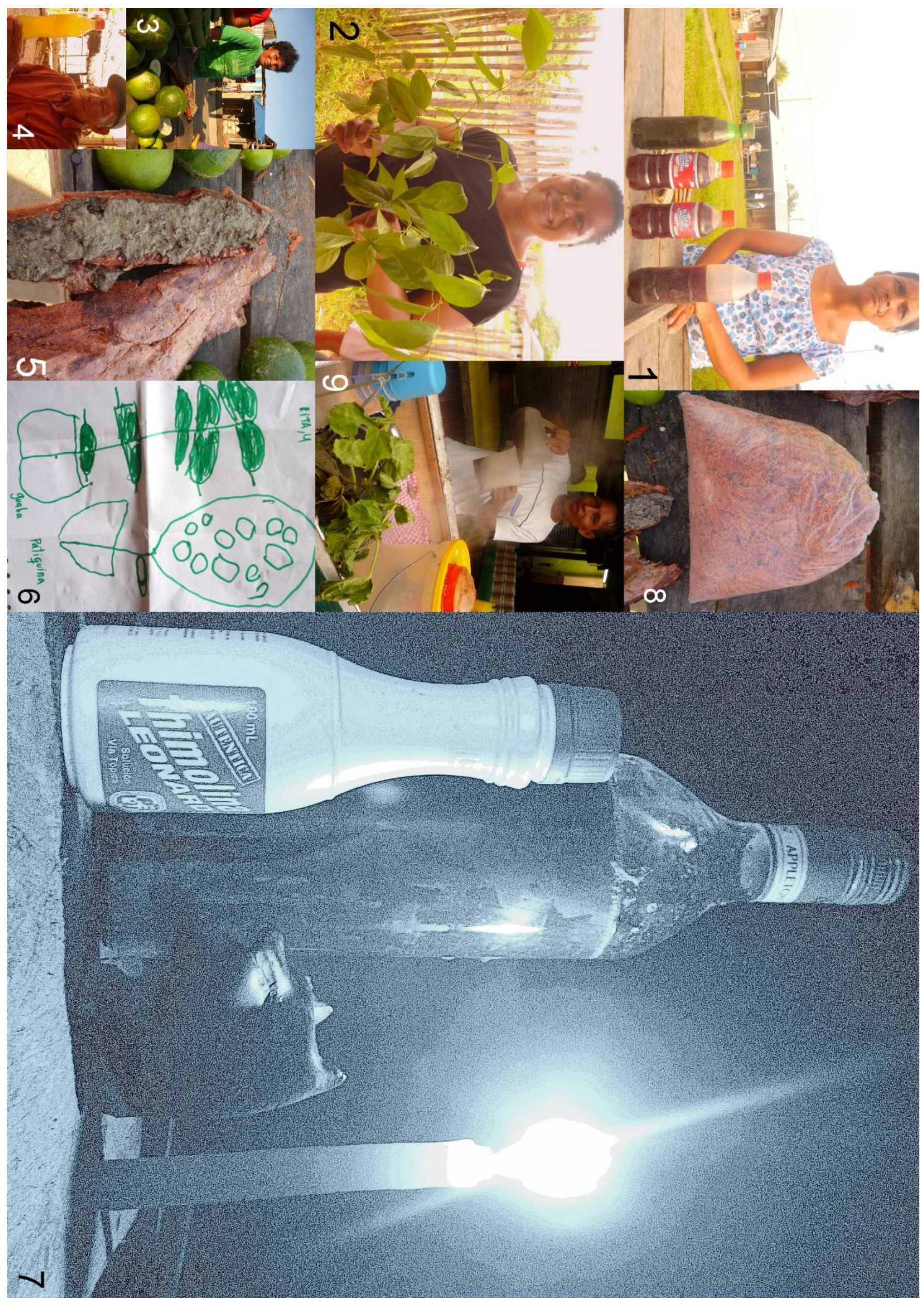


Imagem 10 (pág. anterior): Maneiras de fazer com plantas, II

1 - Vendedora de tintura de ubos [Spondias mombin] no mercado de Tamshiyacu.

2 - Gerónima, a minha vizinha e mãe da yerberita Rita Gretel, também era "um pouco curiosa", e trazia frequentemente em casa novas plantas para nos fazer experimentar sob diversas aplicações.

3 - Vendendo as cascas do ubos [Spondias mombin] no mercado de Tamshiyacu.

4 - Marcos, purguero, mostrando um preparo de várias plantas que combate a diabetes e que ele mesmo preparou.

5 - Primeiro plano das cascas do ubos [Spondias mombin], prontas para serem vendidas no mercado de Tamshiyacu. Os ubos são muito procurados no tratamento de todo tipo de perturbações femininas: dores menstruais, infecções vaginais, tumores nos ovários e descenso (fluidos vaginais).

6 - Desenho da yerberita Rita Gretel, copiando as folhas da guaba [Psidum guajava] e da patiquina [Caladium bicolor].

7 - Garrafa com purga de plantas, thimolina, cachimbo com tabaco e velas. A mesa pessoal de quem está curando um mal.

8 - Cascas de ubos [Spondias mombin] trituradas, à venda no mercado de Tamshiyacu.

9 - Malva [Malachra ruderalis] em primeiro plano, no preparado do emoliente no mercado de Belén. 


\section{- Interações}

Independentemente de serem frios ou quentes, os vegetais demoram mais para trabalhar nos corpos frios, me diz Isabel, curandera. No caso da ayahuasca, este pode ser o motivo pelo qual uma pessoa não tem visões. Para isso, a pessoa interessada deve de tomá-la várias vezes, até o corpo esquentar, já que, como vimos acima, a ayahuasca é uma planta tida como quente. Quando uma pessoa tem o corpo quente, tem maior facilidade de comunicação com a planta.

Os corpos, tanto dos homens como das mulheres, podem ser frios ou quentes. De acordo com alguns depoimentos de curiosxs e pacientes entrevistadxs, as mulheres teriam uma maior tendência a padecer doenças próprias do corpo frio, pois elas estão mais abertas para o frio passar e se instalar, fazendo-as adoecer. Porém, Isabel me disse que as mulheres têm uma maior facilidade de comunicação com as plantas. Isso se deveria ao fato de elas serem mais blandas, brandas, do que os homens. Com isso se define sutilmente uma nova dicotomia, entre brando e duro, entre frágil e forte, com a qual se correspondem os palos [paus] e as hierbas [ervas]. Tal esquema e suas correspondências com uma divisão genérica do mundo são desenvolvidos no capítulo 8.

\section{-Patco}

Há também a qualidade patco, que corre paralela à classificação bipolar frio/quente. Patco é uma propriedade de certas plantas e outros elementos. É definido como uma espécie de amargor seco. Tudo aquilo que é patco é muito valorado por suas propriedades curativas. Por exemplo, o comején é patco. Comején é um tipo particular de térmite amazônica. O formigueiro do comején é queimado e são as suas cinzas as que se utilizam para colocar em feridas no corpo produzidas por bruxaria. De acordo com dona Anita del Carmen: 
También para la tuberculosis, me han contado que se corta la casa del comején entero, con su madre [de raíz]. Se parte en cuatro. No puede ser cualquier comején, tiene que ser un nido de comején que tenga la forma de una cabeza. Se hierve en tres litros de agua. Se deja [evaporar] hasta que quede un litro. Se toma un poquito todos los días. El comején regenera el cuerpo porque ellos mismos regeneran su casa cuando uno la rompe. Si le sacan la madre, no va a poder regenerar ${ }^{149}$.

Nesse procedimento de magia simpática, a forma que possui o comején que vai ser escolhido para a cura é muito importante. Também é vital que o ninho seja extraído de maneira total: ao precisar regenerar, ele regenera no corpo da pessoa, e não no seu lugar natural. O fato de precisar regenerar não é menor: contém uma arraigada percepção de ordem, de sistema, de causa e efeito dos elementos do mundo que, colocados no corpo, reproduzem a sua dinâmica. Continua Anita del Carmen:

El sabor del comején no es amargo. Es patco. Es seco, o mejor dicho, que te llena de sequedad la boca ${ }^{150}$.

Não é amargo, não é doce, não é salgado, não é azedo. É seco. Também a raiz do wasaí é patco, e se utiliza em infusões chispeadas contra as febres da malária. Segundo Antônio, hospedeiro de Padre Cocha,

Uno no puede mezclar la ayahuasca con cualquier cosa. Por ejemplo, se mezcla con las hojas de la chacruna para endulzarla, para que el sabor no sea $\tan$ patco, tan amargo ${ }^{151}$.

149 "Também para a tuberculose, me contaram que se corta a casa do comején inteiro, com a sua mãe [de raíz]. Se parte em quatro [pedaços]. Não pode ser qualquer comején, tem que ser um ninho de comején que tenha a forma de uma cabeça. Se ferve em três litros de água. Se deixa [evaporar] até ficar um litro. Se toma um pouquinho todos os dias. O comején regenera o cuerpo [da pessoa] porque eles mesmos regeneram a sua casa quando agente a quebra. Se tirarem a mãe do comején, então ele não vai poder regenerar".

150 "O sabor do comején não é amargo. É patco. É seco, ou melhor dito, que enche de sequedade a boca".

151 "Agente não pode misturar a ayahuasca com qualquer coisa. Por exemplo, se mistura com as folhas da chacruna [Psychotria viridis] para the dar uma doçura, um sabor que não seja tão patco, tão amargo". 
De maneira diferente da interpretação farmacológica, onde a Banipsteriosis caapi inibe a ação enzimática de certos receptores e permite à Psychotria viridis uma ação psicoativa prolongada, considera-se que a própria ayahuasca é um vegetal patco, pelo que se adiciona a chacruna para lhe dar um sabor mais doce.

\section{- Mapachos e a proteção contra o invisível}

"Los bufeos se roban la ropa de las personas que lavan al borde [del río]. Se la roban y se la ponen abajo del agua"152. Notas de campo. Narração de uma menina de seis anos em uma viagem de barco desde El Chino até Iquitos. Setembro 2012.

Das concepções sobre a natureza fria, quente ou patco das perturbações, os corpos e as plantas, passarei agora para uma descrição das maneiras de fazer com plantas, que não é outra coisa que a abordagem prática das representações terapêuticas e mágicas locais a partir de uma diversidade de estilos de ação executados pelxs curiosxs de Tamshiyacu. Aqui, as trajetórias biográficas fornecerão o material sobre o qual será possível realizar uma análise minuciosa do cenário local, e as experiências etnográficas proporcionam uma lente aprimorada de aproximação às texturas, formas e cheiros das vivências particulares. Comecemos pelo emblemático tabaco. O mapacho é o cigarro de tabaco feito na mão. O tabaco [Nicotina tabacum] é uma das mais importantes plantas maestras do curandeirismo amazônico. Sua fumaça é um dos principais elementos de limpeza mágica do ambiente exterior assim como do corpo humano. Outros usos costumeiros também incluem a decocção das folhas para curar cefaleias, dores de dente e parasitas na pele (Mejía e Rengifo, 2000).

152 "Os bufeos roubam as roupas das pessoas que lavam na beira [do rio]. Eles as roubam e as colocam no corpo deles, embaixo d'água". 
Genoveva, vendedora de comidas na rua, é uma excelente contadora de histórias contemporâneas e próximas. Ela gosta de conversar, e enquanto agente come um prato rápido feito ali mesmo, ela vai contando da própria vida e da vida dxs outrxs. Um dia de agosto de 2013, quando Genoveva decidiu ir ver a sua mãe, Alicia, que mora na ilha de San Pedro, há uns poucos quilômetros de Tamshiyacu, pediu-me para acompanhá-la. Eu aceitei. Fomos bogando [remando] pelo rio com três das crianças dela (Ver Imagem 11, Ilha San Pedro). Contou-me então que é bom ir sempre fumando mapacho, para se proteger de qualquer coisa que venha da água. O rio é o templo móvel dos povoados ribeirinhos do amazonas peruano. Ele tem uma vida oculta que pulula embaixo da água, há seres encantados e cidades maravilhosas. A relação entre esses seres e as pessoas em Tamshiyacu é intensa.

É verdade que xs curandeirxs têm uma relação especial com essas profundezas. Mas também outras pessoas, crianças e adultas. Uma criança de 10 anos morreu afogada nesse mesmo mês de agosto de 2012, enquanto eu realizava meu trabalho de campo. Encontraram, dias depois, somente as suas roupas. Escutei na rua uma mulher dizendo que essa criança pertencia à água, que estava somente voltando ao seu lugar. Genoveva me contava essas estórias, que configuravam à água e ao rio como elementos e espaços próximos do tabu e do perigo. Depois que chegamos, já na ilha de San Pedro, Alicia me disse que ela teve, quando era mais jovem, o mal del bufeo ${ }^{153}$. Isso lhe aconteceu por nadar sozinha no rio. Ela

153 Os bufeos são seres extraordinários que moram na água e que vivem em belas cidades e sofisticadas sociedades. Esses seres têm uma importante curiosidade pelo mundo do humano, procurando às vezes ter relações sexuais com humanxs e tentando levá-los a viver embaixo d'água. As relações entre bufeos e humanxs são secretas e antigas, e xs curandeirxs conhecem delas melhor do que ninguém. Os bufeos se personificam nos golfinhos de rio, animais respeitados e temidos de maneira estendida. Nos portos, os golfinhos abundam, atraídos pelos restos de carne derivados das ações de pesca. As pessoas das cidades locais não os toucam e nem sequer os olhame muito menos os fotografam. Eles estão dentre os poucos animais de rio que não se consideram de consumo humano. 
sentia ardor e coceira nas mãos, como se alguém lhe estivesse perfurando com uma agulha. Assistida pelo curandeiro dom Roque, de Tamshiyacu, aspirou três vezes a fumaça do tabaco, até sentir náuseas. Ao voltar para casa, comeu manitoba ${ }^{154}$ durante vários dias. Esse prato é la contra del bufeo, isto é, combate ao bufeo "por dentro". Então, ela sarou.

154 Manitoba é um prato feito com carnes de monte cozidas no interior de folhas. 


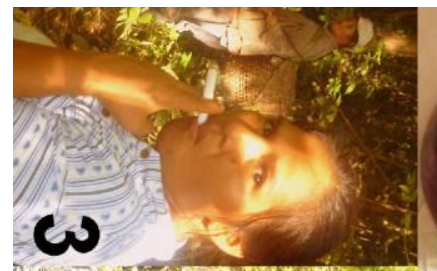

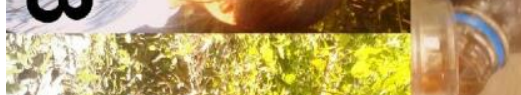

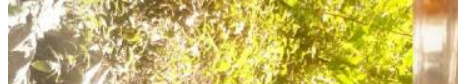

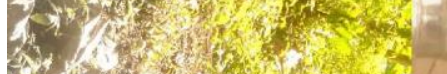

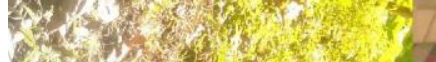
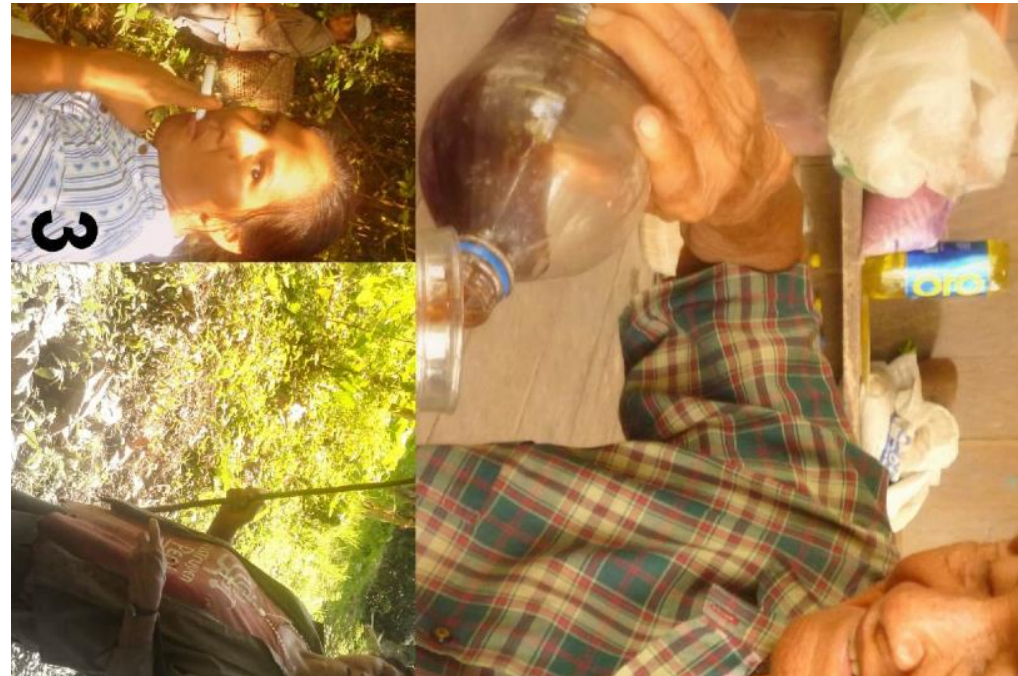

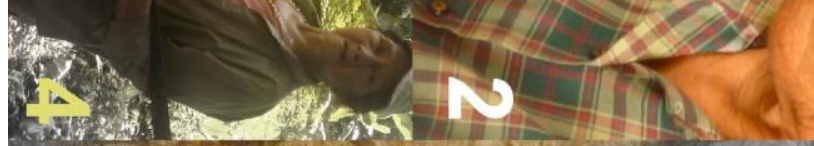

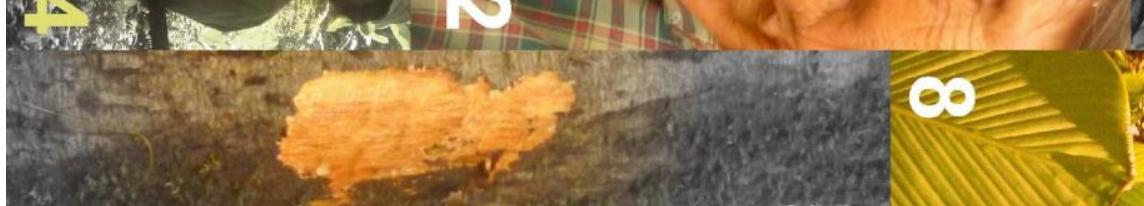
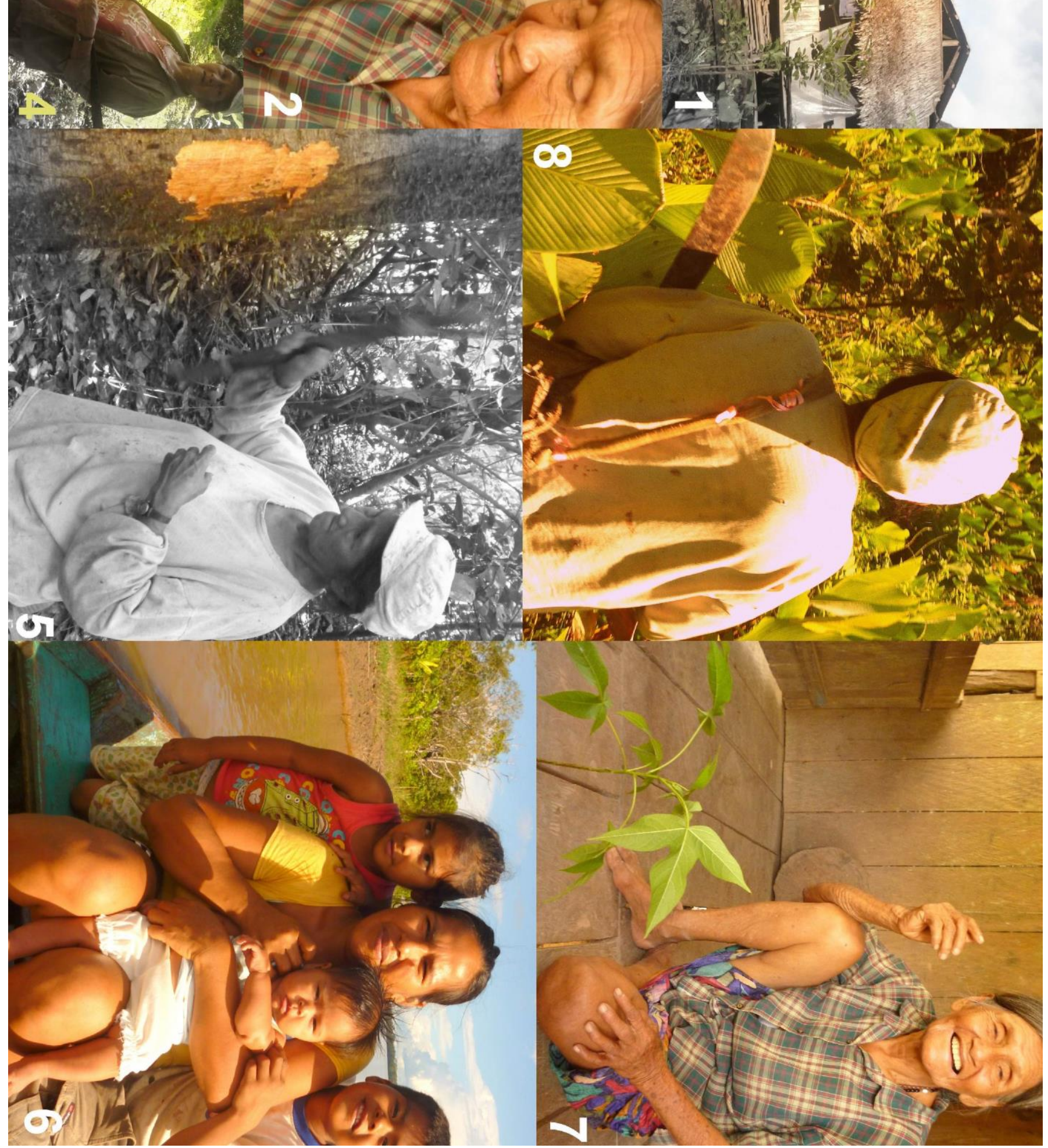


\section{Imagem 11 (pág. anterior): Ilha San Pedro}

1 - Em primeiro plano, flor de toé [Brugmansia suaveolens]. Em segundo plano, cabana de Bernardina e Alicia na Ilha San Pedro.

2 - Bernardina se servindo a sua dose diária de purga (vegetal macerado no álcool).

3 - Genoveva no caminho ao rio, fumando mapacho para proteção contra os maus espíritos e animais perigosos.

4 - Alicia, pronta para pescar.

5 - Com machado, Alicia extrai a casca da árvore de ubos [Spondias mombin].

6 - Genoveva, Britany (no colo), Zulma (à esquerda) e Daniel (à direita). Todas as crianças são filhas de Genoveva.

7 - Bernardina, no chão da cabana, contando histórias engraçadas sobre partos e parturientes.

8 - Alicia e sua ferramenta de uso diário na ilha, o machado. 
O Tocayo, curandero de Tamshiyacu, sopra o tabaco nas cabeças das pessoas. Conversa com o espírito do tabaco e lê a brasa do mapacho. As duas técnicas the ajudam a diagnosticar e tratar doenças que vão do mal de dios ao mal de gente ${ }^{155}$. $\mathrm{O}$ tabaco também é uma parte essencial das suas cerimônias com ayahuasca. Fumando as folhas secas desta planta em um grande cachimbo, ele abre as sessões. Com tabaco, ele limpa o ambiente, limpa seu corpo, assopra o recipiente com a ayahuasca, assopra cada taça que serve às pessoas que vão bebê-la. Fecha as cerimônias assoprando e entoando todos os cantos da maloca. Dona Asteria, sobadora de lisiadxs de Tamshiyacu, tem uns cinquenta anos e há mais de vinte trata das afeições mais diversas. Na sua ocupação, que ela complementa com a de costureira, tem contato diário com plantas como a patiquina [Caladium bicolor], o piñón [Jatropha gossypiifolia] e a suelda consuelda [Phthirusa adunca]. Asteria conta que costuma fumar seu mapacho quando vai recolher uma planta para ser utilizada na cura de alguma das afeições que costuma tratar. Me diz: "le soplas a la planta y le dejas un cigarro. Ahí la planta te agradece, y te ayuda"156.

O tabaco é uma planta à qual se acode como proteção em momentos de contato coma floresta - tal é o caso de Genoveva - e como cura de doenças mágicas vinculadas ao mundo da água - como aconteceu com Alicia. Também é um vegetal essencial no diagnóstico e cura de doenças, assim como na realização das cerimônias de consumo de ayahuasca, como observamos no caso do curandeiro Tocayo. Finalmente, é uma planta que tem relações de amizade com outras plantas. Desta maneira, como nos comenta Asteria, outras plantas como a patiquina, o piñón e a suelda consuelda agradecem o mapacho e a partir desta oferenda se dispõem a ajudar a tratar as doenças humanas.

155 No capítulo 8 me refiro a essas duas categorias aproveitando um maior tempo e espaço.

156 "Você assopra na planta e deixa um cigarro [para ela]. Ali a planta te agradece, e te ajuda". 
- Madres, donos, gênios e duendes das plantas

"Las plantas nunca andan solas".

Isabel, curandera. Entrevista em seu campamento. Março de 2013.

O mundo das plantas, assim como o mundo do humano, está permeado por esquemas de gênero. Se bem que há trânsitos, os palos são direta ou indiretamente relacionados ao mundo do masculino e as hierbas são vinculadas especialmente ao mundo do feminino. Nesse capítulo, apresentarei uma discussão mais específica sobre o caráter animado e familiar das plantas na percepção local. Wolfgang, psicólogo austríaco estabelecido em Tamshiyacu faz catorze anos, comentou em entrevista de abril de 2013:

Cuando uno aplica una planta, honra el poder medicinal de esa planta. Pero es diferente en el vegetalismo. El vegetalismo cree en el genio de esa planta, que es un espíritu (...) ahí hay muchísimos biólogos y médicos que hacen un corte, porque no continúan reflexionando sobre lo que significa eso. Por ejemplo, para el vegetalista, este árbol es consciente [señalando un árbol de guaba que crece en la puerta de su casa]. Ellos [los científicos] no quieren saber de eso (...)El vegetalista ve el árbol y dice: allí hay un espíritu. No es el espíritu individual de este árbol, sino el espíritu familiar de la guaba (...) porque lo que el vegetalista sabe, para este bruto, ignorante, tonto científico occidental... para él es una locura! ${ }^{157}$

No contexto das maneiras de fazer com plantas locais, as plantas não são regidas por princípios ativos, mas por entidades ou famílias de entidades. Delas devém a sua identidade vegetal, material, orgânica. Devido a isso, o segredo da cura de uma doença não reside tanto na correta dosagem dos princípios ativos da planta nos preparos utilizados, quanto no fato de possibilitar as condições de

157 "Quando agente aplica uma planta, honra o poder medicinal dessa planta. Mas é diferente no vegetalismo. O vegetalismo acredita no gênio dessa planta, que é um espírito (...) ali há muitíssimos biólogos e médicos que fazem um corte, porque não continuam refletindo sobre o que significa isso. Por exemplo, para o vegetalista, essa árvore é consciente [apontando para uma árvore de guaba que cresce na porta da sua casa]. Eles [os cientistas] não querem saber disso (...) O vegetalista vê a árvore e diz: ali há um espírito. Não é o espírito individual dessa árvore, mas o espírito familiar da guaba (...) porque o que o vegetalista sabe, para esse bruto, ignorante, tolo científico ocidental... para ele é uma loucura!". 
comunicação com os seres de uma planta particular, através de ações concretas para convocá-los e habilitar um diálogo.

Esse diálogo é indireto: acontece em sonhos ou visões diurnas, geralmente depois de ter entrado em contato com a planta durante a colheita, chapeado, chispeado, ingestão, banho, fricção, fumo ou colocando uma parte da planta embaixo da almofada, na hora de dormir. Tais interações acontecem especialmente entre curandeirxs e plantas, sobretudo em períodos de dieta,e tal experiência é fundamental na iniciação dxs mesmxs. Porém, também há experiências deste tipo entre pessoas que não praticam o curandeirismo e que não estão dietando.

Em seguida, comentarei algumas vivências de comunicação diagnóstica, curativa, pedagógica, disciplinadora ou de violência com as entidades das plantas, isto é, suas madres, donos, gênios e/ou duendes ${ }^{158}$. Escolhi histórias de contato de sete pessoas com os donos de diferentes plantas. Gerlyn, Isabel, Ariel, Clarina, Asteria, Román e Estela tiveram experiências de contato com entidades vegetais e a partir disso estabeleceram um vínculo de afeto ou repulsa pelas plantas em questão.

\section{- Gerlyn, as belas piñón e o exigente tabaco}

Em abril de 2013, fiz uma entrevista formal com Gerlyn, o filho da curandeira Isabel, que tinha então 24 anos. Comentava Gerlyn que quando tinha treze anos a sua mãe lhe pediu para começar a provar as plantas. Foi ali que ele deixou Pucallpa, a cidade onde morava com uma das suas tias, e veio encontrar a mãe em Tamshiyacu. Decidiu começar a sua dieta, isolado na parte alta do caminho de Pinche Seco, a umas horas do povoado de Tamshiyacu, caminhando na direção

158 Todos esses nomes se usam como sinônimos. Escolhi trabalhar com maior frequência com a acepção dona ou dono, pois é a que mais frequentemente aparece em campo. 
oeste. Ficou lá durante três meses. Na sua volta, começou a trabalhar a madeira. Passou cinco anos entre o povoado, onde trabalhava a madeira, e a floresta, onde fazia a dieta em solidão.

Ele conta que na solidão da floresta "las plantas le hacían soñar"159, as plantas começaram a aparecer nos seus sonhos com uma série de mensagens. No início foi difícil. Teve que dietar durante um ano para poder começar a ver e ouvir às plantas. As visões apareceram. Eram tímidas no início: vinham aos olhos partes de plantas, folhas. Depois os próprios donos das plantas começaram a aparecer. Foi estabelecendo uma relação com cada uma das plantas da sua dieta, definindo com elxs afinidades e diferenças. As primeiras entidades com as que ele teve contato foram as relativas à planta do piñón negro [Jatropha gossypiifolia]:

Ahí las plantas todas las noches venían... bien clarito les veía. Veía a una mujer. Siempre, todas las noches en mis visiones, tenía una mujer. "No tengas miedo, no te van a hacer nada" [ella decía]. Casi todos los días era mi sueño ese (...) Yo trabajo más que todo con los piñones. Los piñones me gustan muchísimo. Piñón colorado, blanco, negro. El negro es el más querido. Con eso es el primer paciente que he curado, piñón [el dueño del piñón] es una mujer. Yo pensé que era un hombre. [Pero] ...es la mujer más linda. Son dos. En una planta hay dos, que se acompañan. Vienen bailando, con sus canciones. Son jóvenes, y viejas. Son una cantidad. Pero lo que manda es las chicas. Blancas! Cabello bien larguísimo. Vienen riendo. Son divertidos ellos. Entre varios, riendo, cantando (destaques meus) ${ }^{160}$.

Xs curandeirxs podem ter tido representações visuais diferentes do que é o dono de uma planta. Por exemplo, a sobadora Asteria me contou que os donos

159 "As plantas lhe faziam sonhar".

160 "Ali as plantas todas as noites vinham... eu as via bem clarinho. Vinha uma mulher. Sempre, todas as noites nas minhas visões, tinha uma mulher. 'Não tenhas medo, elas não vão te fazer nada' [ela dizia]. Quase todos os dias meu sonho era esse (...) Eu trabalho sobretudo com os piñones. Eu gosto muitíssimo dos piñones. Piñón colorado, blanco, negro. O negro é o mais querido. Com isso curei meu primeiro paciente, piñón [o dono do piñón] é uma mulher. Eu pensei que era um homem. [Mas] ...é a mulher mais linda. São dois. Em uma planta há dois, que se acompanham. Elas vêm dançando, com as suas canções. São jovens, são velhas. São uma quantidade [de seres]. Porém, as que mandam são as meninas. Brancas! Cabelo bem comprido. Elas vêm rindo. São divertidos eles. Entre vários, rindo e cantando". 
do piñón negro [Jatropha gossypiifolia] são "unos doctores com camisa violeta y pantalón morado. Uno les pide para que trabajen con uno, ellos operan y después uno se cura"161. Se para Gerlyn são belas jovens e para Asteria solícitos doutores, não é essa uma questão que gere debate: não se precisa de um consenso coletivo. E se as diferenças nas opiniões sobre a forma que adquirem os donos das plantas não costuma provocar nenhum tipo de desavença é porque é aceito que mais de uma entidade corresponda ao espírito da planta, e que cada uma delas possa ter várias formas. A dxs donxs das plantas é uma família, onde é possível observar toda a diversidade das famílias de forma humana em termos de gênero, idade, cor de pele, ademais de outra diversidade que está além do humano, misturadas.

Ainda que as plantas possam representar uma multidão de seres, geralmente elas são compreendidas como primordialmente masculinas ou femininas. Nesse sentido, é preciso notar que a diferenciação nativa entre plantas masculinas e femininas não coabita, em nenhuma das suas premissas, com as ideias científicas da biologia moderna sobre sexualidade vegetal. Nas primeiras, ainda que características morfológicas como a forma, a cor e o tamanho contribuam à identificação delas como sendo masculinas ou femininas, o gênero das plantas é uma atribuição relativa a seu vínculo com entidades do mundo espiritual. No caso das segundas, a pertinência de uma espécie vegetal à categoria fêmea ou macho é relativa à ampla variedade de sistemas de reprodução existentes no mundo vegetal ${ }^{162}$.

\footnotetext{
161 "Uns doutores com camisa violeta e calça lilás. Agente pede para que trabalhem com agente, eles operam e depois agente se cura".

162 Dentro dos primeiros registros desta diferenciação científica moderna se inscreve o texto de Rudolf Jakob Camerarius, De sexu plantarum epistola, redigido no ano 1694.
} 
No mundo amazônico, as plantas representam seres que são genderizados. Tenho observado que, se a planta é masculina, o espírito tende a ser, geralmente, visualizado como uma entidade masculina. O contrário acontece se ela é feminina. No caso do piñón, a planta favorita de Gerlyn, a entidade é feminina: é uma multidão que canta, dança e ri, e onde as mulheres mandam. No caso de Asteria, são homens, e trabalham em equipe. Não sempre as visões de donos das plantas são alegres, relaxadas ou benéficas. Ao dueño do tabaco [Nicotina tabacum], não é fácil enfrentá-lo. Gerlyn conta:

...el chontaquiro es un árbol que se parte en la mitad. Sale un viejo, sale de su corazón de la madera. Se acerca... es bien increíble. He tenido visiones de ayahuasca, tabaco, ajo sacha. El dueño que más miedo le tengo es el tabaco. No es que le odio pero... me decía "resista, cómo no vas a poder! Tienes que poder". Porque si tu no tomas tabaco, de nada te sirve... tres veces a la semana. O sea por ejemplo hoy día, el tabaco le machacas y le pones hoy día... en la mañanita eso macerado, le tomas. Y tienes que arrojar todito. De ahí en la noche te hace ver... ${ }^{163}$

O lugar do tabaco, na experiência de Gerlyn, é aquele do disciplinador. O mesmo aconteceu com Ariel, de Tarapoto. Ele fez uma purga com tabaco, e me disse "es la planta más fuerte, la que más te hace trabajar mentalmente, no te deja dormir. Pero te hace ver cosas, muchas cosas"164. As plantas não representam sempre o belo, o bom, o elevado. Da mesma forma que xs curiosxs não somente curam: se não estão preparadxs para trabalhar com diferentes energias, as plantas tampouco somente representam os aspectos mais elevados

163 "O chontaquiro [Andira surinamensis] é uma árvore que se parte pela metade. Daí sai um velho, sai do coração da madeira. Se proxima... é bem incrível. Eu tenho tido visões com ayahuasca [Banipsteriosis capapi], tabaco [Nicotina tabacum], ajo sacha [Mansoa alliacea]. O dono ao que mais medo eu tenho é o do tabaco. Não odeio ele mas... ele me dizia "resista, como é que você não vai poder! Você tem que poder". Porque se você não beber o tabaco,de nada serve... três vezes na semana. Ou seja por exemplo hoje em dia, você machuca o tabaco e você coloca hoje mesmo... de manhã, você bebe esse macerado. E tem que vomitar todinho. Daí, à noite ele te faz ver".

164 "É a planta mais forte, a que mais te faz trabalhar mentalmente, não te deixa dormir. Mas te faz ver coisas, muitas coisas". 
e saudáveis de uma existência espiritual. Também podem ser pessoas muito anciãs, monstros sem cabeça, entidades temíveis, bem como plantas perigosas. Isabel me contou uma história com o dono do toé [Brugmansia suaveolens]. Ela costuma colocar essa planta no preparo da ayahuasca que dá para beber no seu campamento ${ }^{165}$. Entre julho e agosto de 2013, Isabel passou por um período triste: a sua mãe morreu em Pucallpa. Foi visitá-la na sua última tentativa de convalescência e ficou um tempo até depois do funeral. Quando retornou para Tamshiyacu, decidiu não atender pacientes por um tempo. Durante esse tempo de resguardo, para "tener más fuerza en el cuerpo"166, Isabel convidou a seu primo, Moisés, para tomar conta de seus pacientes. Ela decidiu iniciar a sua dieta com diferentes ciclos quinzenais de plantas. As plantas que ela desejava dietar eram o ayahúma [Couropita guianensis], o huayruro [Ormosia coccínea], o tahuarí [Tabebuia serratifolia] e o chiricsanango [Brunfelsia grandiflora]. Mas antes de tudo, ela tinha a intenção de dietar o toé [Brugmansia suaveolens]. Ela experimentou o toé pela primeira vez com o seu atual companheiro, Jorge, no contexto de seu trabalho como curandeirxs/xamãs. Quando ingeriu a infusão das folhas do toé, ela teve em visão a presença do dono da planta, que era um ser enorme, com corpo de porco, de cor marrom e sem cabeça. Todo seu aspecto era assustador. Aquela vez, ela teve medo. É por isso que ela quer criar uma nova oportunidade de encontro com essa entidade: "no hay que dejarse ganar" 167 me comenta Isabel.

A partir de experiências como a de Isabel, podemos intuir que a relação das plantas com o gênero humano não é sempre unívoca. Às vezes, as plantas podem fazer o bem, às vezes fazer o mal e se aproveitar dos seres humanos,

165 Campamentos são chamados localmente os espaços onde xs curandeirxs têm suas plantas e realizam as dietas e cerimônias.

166 "Ter mais força no corpo".

167 "Não temos que nos deixar ganhar". 
outras vezes simplesmente assustar. A mesma planta pode ser de ajuda para algumas pessoas e protagonizar uma horrível experiência para outras pessoas. Tal é o caso de Asteria, por uma parte, e de Clarina, pela outra, com plantas de uma mesma espécie, a patiquina.

\section{- Isabel, Asteria, Clarina e a masculinidade das patiquinas}

A patiquina [Caladium bicolor] é uma planta que é muito usada localmente em emplastros para as quebraduras, mas também tem aplicação afrodisíaca e é aliada na proteção espiritual. Quando aprendi a reconhecê-las, elas apareciam por toda parte. Em agosto de 2013, Isabel plantou alguns brotos de patiquina no acampamento. Elas são uma variedade especial, con pitito [com pênis]. Plantasmacho, elas são ideais para as mulheres fazerem seus amarres de amor. "Yo se la preparo en una botella, después la mujer se lava con esto su vagina para que el hombre que ella quiere se quede con ella"168, me diz Isabel.

No povoado de Tamshiyacu é freqüente ver plantas de patiquina negra nos jardins frontais das casas. A sobadora dona Asteria tem patiquinas pintadas em frente à porta de entrada da sua casa-consultório. É ali que, do lado das plantas, senta-se com a sua família algumas tardes, quando o sol vai cair. Asteria sente um grande apreço por essa planta. Conta-me que os donos das patiquinas "son todos varoncitos, unos hombrecitos enanitos, verdes, manchaditos igual que su hojita de la patiquina"169. Ella los conoce: "yo los he visto cuando he pedido para ver. Abuelito, hazme ver, le he pedido [a la planta]. Y he tomado en las noches y he puesto su hoja

\footnotetext{
168 "Eu a preparo em uma garrafa, depois a mulher lava com isso a sua vagina para que o homem que ela quer fique com ela".

169 "São todos homenzinhos, homenzinhos anãozinhos, verdes, manchadinhos do mesmo jeito que a folinha da patiquina".
} 
debajo de la almohada"170. As patiquinas têm lhe ajudado a sarar um abscesso no peito que ainda tem, mas que já não lhe causa dores. No final do encontro, dona Asteria me dá de presente um broto de patiquina do seu jardim, para a minha proteção. Se alguém me enviar algo malo, a planta irá secar, ela me explicou.

Clarina tem 12 anos e às vezes vem desenhar com outras crianças da vizinhança do caminho de Flores, onde moramos durante os últimos meses. Um dia, ela entra em casa. Lá vê a pequena planta de patiquina em uma vasilha feita com garrafa plástica, perto da porta. Fica olhando-a uns segundos. Sacode a cabeça, e me diz que os donos das plantas existem sim. E me conta. Ela, que também mora no caminho de Flores, tem um jardim cheio destas plantas no fundo da sua casa. Um dia, quando tinha oito anos, foi atravessar as plantas para chegar ao poço d'água e se banhar, como é o costume dela, coisa que faz todas as tardes. Caía a noite. De repente, sentiu que algo tocava no meio de suas pernas. Era "un enanito, bien feo, bien gringo. He gritado y me he ido corriendo a ver a mi mamá. El dueño de las patiquinas era, me ha querido violar"171. "Debe haber sido un diablo"172, comenta José, que tem 14 anos e está perto de nós, ouvindo a conversa. "Mi casa está llena de diablos"173, afirma Clarina. Desde então, ela evita ficar só perto de qualquer planta de patiquina. "Yo les tengo miedo"174, me conta.

\footnotetext{
170 "Eu os tenho visto quando tenho pedido para ver. Vovozinho faça-me ver, tenho pedido [à planta]. E tenho tomado durante as noites e tenho colocado a sua folha embaixo da almofada".

171 “Um anãozinho, bem feio, bem gringo [branco]. Eu gritei e fui correndo para ver a mina mãe. O dono das patiquinas era, me quis me estuprar".

172 "Deve ter sido un diabo".

173 "A minha casa está cheia de diabos".

174 "Eu thes tenho medo".
} 
De acordo com os três relatos, os donos das patiquinas são entidades masculinas. Na perspectiva de Isabel, elas têm virtudes viris que podem ajudar à mulher que deseje ter um companheiro. Na vivência de Asteria, são entidades que podem ajudar, proteger, dar até a própria vida pela vida da pessoa humana. No relato de Clarina, a patiquina tem um dono com intenções obscuras e propenso a invadir o espaço da juventude humana.

\section{- Román e uma malva orientadora}

Muitxs curiosxs, ou aprendizes de curiosxs, como Gerlyn, precisaram fazer uma dieta para começar a ter contato com as entidades das plantas. Porém, a possibilidade de vivenciar essa experiência não é restrita a curandeirxs ou iniciadxs no vegetalismo, mas acessível a todas as pessoas em determinadas condições. Casos de extrema doença, e, sobretudo, de perturbações produzidas pelos próprios hábitos, podem ser momentos nos quais o contato com a entidade de uma planta pode ser revelador. Tal era a situação na qual Román, esposo de Gerónima, se encontrava. A história que segue foi contada por Gerónima no mês de agosto de 2013. Diz assim:

Yo estaba embarazada de José [su primer hijo]. Con Román estábamos hospedándonos en Iquitos, en la casa de una señora. La casa de la señora tenía un hermoso jardín de malvas. Bien abundantes eran! Román en ese tiempo estaba tomando [alcohol] por demás ya. Ese día, que yo te cuento, no fue diferente: Román tomó hasta sentir pero... que moría! Cuando volvió a la casa, estaba huasca. Apenas se le podía entender la palabra. Me dijo que estaba mal, que cogiera unas malvas del jardín, las chapeara y se las diera. Pero yo no le he hecho caso. Estaba cansada de las bebederas. Él se quedó dormido ahí nomás, como pudo. Entonces dice que soñó que una viejita con los cabellos blancos iba hasta su cama y le decía: "Hijo, coge unas malvas del jardín. Las chapeas y te las tomas. Esa será tu medicina". Cuando se despertó, se fue así como pudo hasta el jardín, arrastrándose. Cogió las malvas y se las chapeó. Y se las tomo ahí nomás, con todo su 
afrecho [el residuo sólido de las hojas].Y fue un santo remedio. A partir de entonces, Román dice que la malva es una planta buenaza y curativa ${ }^{175}$.

A malva [Malachra ruderalis] que se utiliza na floresta do Peru é um arbusto de médio porte, com folhas arredondadas e desiguais. Ela é considerada uma planta benéfica. Muito utilizada em momentos de gravidez, parto, pós-parto e também no tratamento de diversas aflições dos bebês e crianças. A malva é uma planta que pertence aos jardins das casas. Amiga do espaço doméstico e das curas em casa, ela é uma planta que tenho visto como sendo primordialmente associada ao território do feminino. No caso de Román, em um momento no qual a sua vida precisava de um retorno ao espaço doméstico, que estava abandonando. Mas, ao contrário do tabaco para Gerlyn, a malva não é disciplinadora, não aplica o castigo, mas sim traz o remédio e reconecta a pessoa ao seu lar.

\section{- Estela e a camalonga que cura}

Estela, professora do colégio secundário local, comenta ter sarado de suas moléstias nos ossos vivenciado uma experiência de contato direto com a entidade da planta da camalonga [Thevetia peruviana]. Na sala da sua casa, em uma das áreas mais centrais de Tamshiyacu, me conta:

Yo he visto al dueño de la camalonga. Tenía un fuerte dolor en los huesos. Con mi compañera de la universidad he tomado. Tomamos la camalonga en su casa. "Recién te vas a marear cuando estés en tu casa", me había dicho

\footnotetext{
175 "Eu estava grávida de José [seu primeiro filho]. Com Román estávamos nos hospedando em Iquitos, na casa de uma dona. A casa da dona tinha um belo jardim de malvas [Malachra ruderalis]. Bem abundantes eram! Román estava bebendo muito [álcool] naquele tempo, por demais. Naquele dia que eu te conto não foi diferente: Román bebeu até sentir... que ia morrer! Quando voltou em casa, estava huasca [bêbado]. Apenas podíamos compreender a sua palavra. Disse-me que estava mal, que pegasse umas malvas do jardim, as chapeara [exprimira com a mão] e lhe desse. Mas eu não obedeci. Estava cansada das bebedeiras. Ele ficou dormindo ali mesmo, como ficou. Então diz que sonhou que uma velinha com os cabelos brancos ia até a sua cama e the dizia: 'Meu filho, colhe umas malvas do jardim. Você vai thes chapear e vai beber. Essa será a tua medicina'. Quando acordou, foi como pôde até o jardim, se arrastando. Colheu as malvas $e$ as chapeó. E as bebeu ali mesmo, com todo seu afrecho [o resíduo das sólido das folhas]. E foi um santo remédio. A partir de então, Román diz que a malva é uma planta muito boa e curativa".
} 
ella. Y así fue. En mi casa me agarró. Tuve la visión, lo vi a su dueño de la planta. Era un hombre bajito, con una barba larga, que me abanicaba con plumas y me decía "no te preocupes que nada te va a pasar". Eso hasta que me quedé profundamente dormida. Después de eso, ya no tuve más dolor ${ }^{176}$.

No caso de Estela e de Román, não é necessária a presença de especialistas para obter a cura das suas doenças ou moléstias. Elxs mesmxs estabeleceram uma relação direta com a entidade da planta, que por meio de sua interação benéfica as sarou.

\section{- Espelhos de diversidade}

A variedade de plantas de aplicação popular no contexto das maneiras de fazer com plantas dxs curiosxs da floresta Amazônica do Peru é imensa, e vai muito além da simples ingestão de vegetais. Por outra parte, há uma diversidade de espécies vegetais com as que se estabelece contato cotidiano, tanto por parte de especialistas quanto por parte de não-especialistas. Aqui me concentrei somente em algumas delas, como o tabaco, a ayahúma, o toé, o piñón, a patiquina, a malva e a camalonga, mas na prática, são mais de uma centena de espécies vegetais. Finalmente, as formas em que se estabelece a comunicação com elas acontece através dos mais diversos preparos e aplicações. Os vegetais não somente são ingeridos, mas são usados em banhos, são aproveitados como emplastos [emplastros], fricciones [fricções], vaporizaciones [vaporizações], amuletos, cigarros. Por sua vez, xs donos das plantas não apenas se vêem através do transe produzido pela ingestão daquelas plantas que são psicoativas: ainda que frequentemente ocorra desta maneira, xs donos das plantas podem aparecer

\footnotetext{
176 "Eu tenho visto o dono da camalonga [Thevetia peruviana]. Eu tinha uma forte dor nos ossos. Com a minha colega da universidade foi que tomei. Tomamos a camalonga na casa dela. 'Você vai ficar enjoada só quando estiver [de volta] na tua casa', tinha me dito ela. E assim foi. Na minha casa foi que pegou. Tive a visão, eu vi o dono da planta. Era um homem baixinho, com uma longa barba, que me abanava com penas e me dizia 'não se preocupe que nada vai the acontecer'. Isso até eu ficar profundamente dormida. Depois disso, ja não tive mais dor".
} 
em sonhos diurnos durante a solidão do período de dieta, assim como imprevistamente dentro das dinâmicas da vida cotidiana. As entidades podem ensinar, orientar, curar, e também podem perturbar ou fazer o mal. Tal como acontece no mundo do humano, as madres, donos, gênios e/ou duendes das plantas são pessoas e famílias de pessoas que podem, ou não, ter sentimentos de correspondência por nós, e que podem desenvolver conosco, como aconteceria na relação entre humanxs, relações amorosas ou violentas, de proximidade ou indiferença, de colaboração ou competição. Não há um diálogo perfeito entre um ser humano e todas as plantas: elxs se agrupam por motivos misteriosos, e nessa dinâmica das diferenças é que se interpreta a própria vida e nosso lugar dentro dela. 


\section{Capítulo 7 \\ Escopo aberto: a diversidade de terapeutas de Tamshiyacu}

- Primavera na praça $•$ Uma nota sobre Tamshiyacu • Especialistas e nãoespecialistas, água do mesmo rio $\bullet$ Vinte e poucxs curiosxs

O presente capítulo trata sobre o contexto de terapias e magias populares do povoado de Tamshiyacu dentro do qual se insere o labor de Isabel. Dentro da classificação geral de $\operatorname{curios} x$, como os agentes que operam as maneiras de fazer com plantas locais, fui definindo dez subclassificações: curanderx, chamán/a, vegetalista, médicx tradicional, purguerx, sobador/a de lisiadxs, sobador/a [de mulheres grávidas], parterx, naturalista e yerberx. Tal processo foi realizado através de sucessivas aproximações práticas às maneiras como se estabelece a relação entre agentes terapêuticos, tipos de prática e plantas específicas. O presente capítulo e o capítulo que vem se inspiram em insights vindos de três análises etnográficas de autorxs que trabalharam com grupos amazônicos: o da antropóloga peruana Clara Cárdenas Timoteo (1989), que pesquisou as concepções de saúde e doença entre xs unaya shipibo, o da antropóloga brasileira Juliana Salles Machado (2012), que atuou com grupos ribeirinhos do delta Amazônico do lado brasileiro e o etnobotânico Marc Lenaerts (2006) que realizou a sua pesquisa com povos indígenas asháninka da floresta Amazônica, do lado peruano. Esses textos me proveram de sugestivas análises de categorias nativas relacionadas com as maneiras de fazer com plantas de grupos amazônicos indígenas e ribeirinhos, que aqui disponho em paralelo com as que eu mesma tive a possibilidade de encontrar em campo. 


\section{- Primavera na praça}

No dia dois de setembro de 2013 foi a escolha da Rainha da Primavera e nos dias seis e sete de setembro do mesmo ano foi o certame de danças típicas do povoado de Tamshiyacu. Essa noite estava quente e o rio não estava o suficientemente perto como para refrescar o ar. A praça pública cheirava a frango e peixe assado e estava cheia de gente. $\mathrm{O}$ cenário estava decorado com um imenso mural e luzes de cores. No cenário, alguns vasos com plantas feitas de papel verde. Na fileira das autoridades, a primeira na frente do cenário, e junto com o sacerdote, o comissário da polícia e os diretores das três escolas secundárias do povoado se encontrava Agustín Rivas, "embaixador cultural" do povoado. Em adição, ele é um dos três jurados que escolherão a moça mais bela dessa primavera. Depois de uma estrondosa apresentação, as moças começaram a desfilar. Primeiro com roupas esportivas, depois com trajes de banho. Depois veio uma dança que cada uma delas apresentou, e finalmente o desfile com roupas de noite. Nas performances, as meninas escolheram apresentar motivos típicos: uma personificou a warmi boa, ser mitológico que mora nas águas do rio. Outra escolheu representar a rosa sisa [Tagetes erecta], planta administrada para combater a malária. Uma terceira escolheu ser o huayruro [Abrus precatorius], um forte psicoativo reconhecido pela beleza das suas sementes, de cor vermelha brilhante. Uma quarta se vestiu de algodón [Gossypium barbadense], planta antihemorrágica que acompanha a parteiras e parturientes no processo da gravidez, parto e cuidados do puerpério. A quinta enfim, se vestiu da fruta da piña [Ananas comosus], de uso comestível e medicinal - é costumeiramente aplicada como diurético. Logo depois se deu início a uma roda de três perguntas rápidas sobre "cultura geral", que as jovens deviam responder. Dentre as perguntas sobre a data da fundação do povoado e aquelas sobre o tempo em que duravam os mandatos dos governantes locais, houve uma relativa às plantas medicinais: 
"nombre três plantas medicinales que conozca y sus usos"177. A jovem aludiu à malva [Malachra ruderalis], planta pequeña de uso frequente entre grávidas pelas suas propriedades diuréticas e emolientes das mucosas, ao algodón [Gossypium barbadense] das parturientes, e à abuta [Abuta pahnii], de aplicação em doenças pulmonares. Uma miríade de plantas dava forma e fundo à festa da beleza de Tamshiyacu.

A segunda festa, da qual tive a possibilidade de participar no final de semana seguinte, era um festival de danças típicas. Os grupos locais de dança apresentaram as suas performances com música gravada, coordenados movimentos e detalhadas fantasias. Dentre os sete que apresentaram suas peças, três deles encenavam o mundo das plantas. Uma performance foi referida ao cutipado [doença mágica causada pela raiva de um espírito animal, vegetal ou outra entidade] com um inseto da floresta, outra referia ao valor atribuído ao amarelo fruto da cocona [Solanum nigrum] na vida das pessoas e uma terceira dança contava a história da praga de um inseto que comia os cultivos e que se solucionava com a aparição de uma curandeira e seu remédio: jogar uma água mágica, previamente macerada com a calcinha de uma mulher grávida, em cima das plantas.

Nas duas festividades, exuberantes em música, cor e simbolismos, eu tive a possibilidade de assistir à importância que é dada as plantas medicinais e ao curandeirismo como parte da linguagem pública local. Tal maneira de fazer e de dizer refere a um nós compartilhado e que vem do espaço do popular. Como tal, essa linguagem transborda na imaterialidade dos gestos e no efêmero dos trajes

\footnotetext{
177 "Nomeie três plantas medicinais que você conheça e seus usos".
} 
das celebrações anuais do povoado, e modela de maneira firme o corpo de saberes e fazeres que correspondem à identidade local.

\section{- Uma nota sobre Tamshiyacu}

O povoado de Tamshiyacu (cujo nome se atribui à composição quéchua dos fonemas tamshi [trepadeira] e yacu [água]) tem quase cinco mil habitantes e dista vinte e nove quilômetros ao sul de Iquitos, no nordeste do Perú (Ver Imagem 12, Mapas).
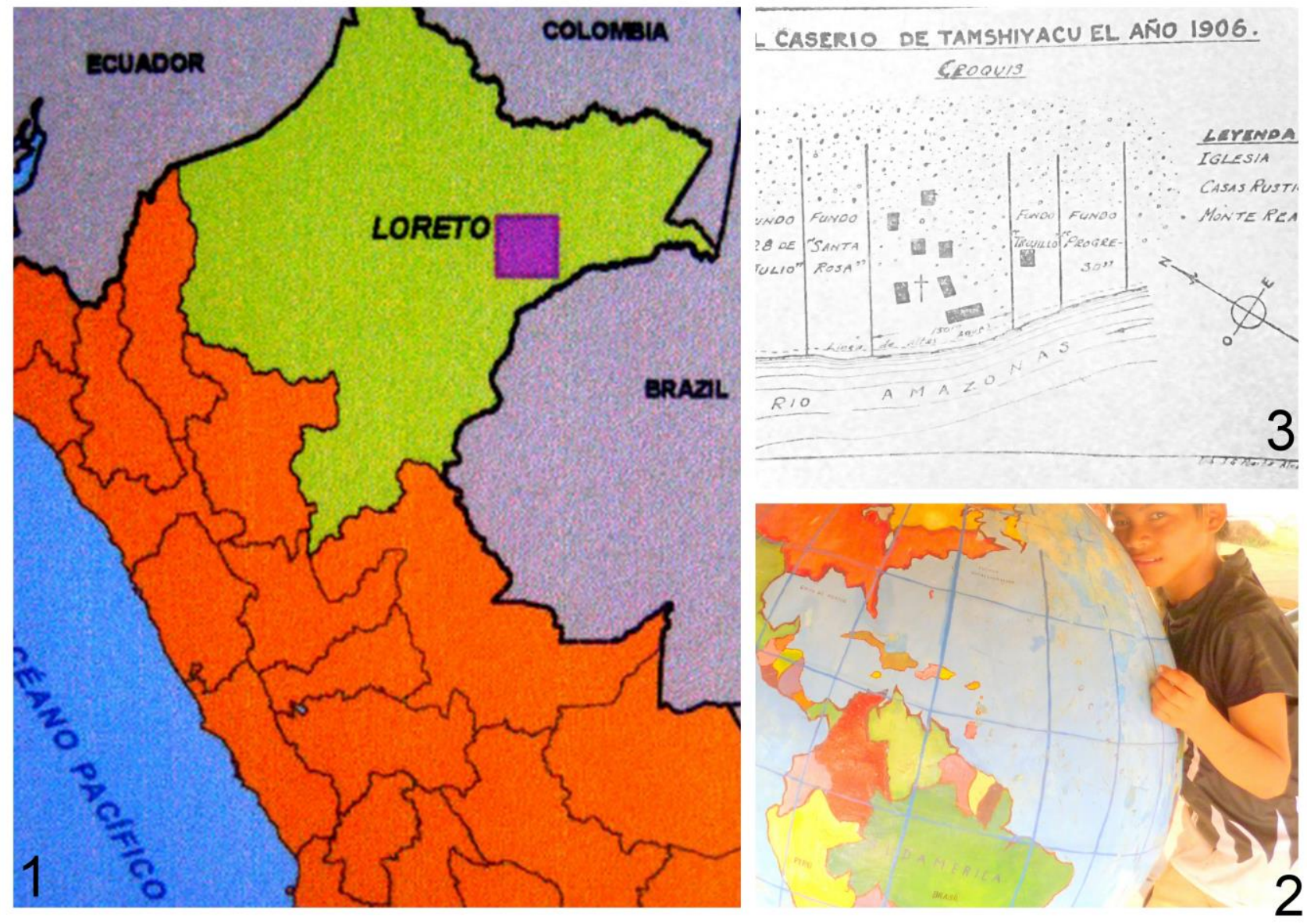


\section{Imagem 12 (pág. anterior): Mapas}

1 -Marcada em lilâs, a localização de Tamshiyacu dentro do Departamento Loreto e deste dentro do Peru.

2 - Uma criança da escola fundada pelo xamã Agustín Rivas, que leva o mesmo nome dele. A internacionalização da ayahuasca trouxe marcos de referência mais globalizados para a população, especialmente no que respeita às novas gerações.

3 - Croqui desenhado por Toríbio Hernández Bautista, fundador do povoado de Tamshiyacu. O desenho foi realizado no ano de 1946.

O povoado foi fundado no ano de 1911 por Toribio Hernández Bautista, arrecadador de rendas fiscais e empresário madeireiro da serra peruana. Entre 1908 e 1910, foram projetados e concretizados trinta blocos de dez mil metros quadrados cada um, assim como setenta e uma ruas de vinte metros de largura por cem de cumprimento. No opúsculo onde narra a epopéia da fundação do povoado, Hernández Bautista (1946) expressa que começou a obra "con bien intencionado entusiasmo y patriotismo" ${ }^{178}$. A mesma tinha como finalidade definir uma fronteira estável frente ao avanço dos países vizinhos, Equador e Colômbia: assim, o povoado se tornaria um ponto chave da peruanidade recuperada. Dando passos firmes nessa domesticação da floresta, Hernández e os colonos migrados

178 "Com bem-intencionado entusiasmo e patriotismo". 
desde as montanhas de Borja, no Alto Marañón ${ }^{179}$, sustinham que "los [hombres y mujeres] blancos" 180 trariam as luzes para o povoado, de maneira que no dia de amanhã "este pueblo llegue a ser grande y culto"181. Como relata o pioneiro Hernández (1946), foram projetados clubes esportivos, uma igreja católica e praças através de mitas [reuniões de trabalho coletivo]. Tamshiyacu se converteu, assim, em uma das poucas cidades projetadas de toda a Amazônia do Peru. Contudo, Tamshiyacu teve um destino diferente daquele sonhado por seus pioneiros. Na atualidade, apresenta uma estrutura cívica que propiciou a sua constituição como foco das atividades econômicas relativas ao turismo xamânico.

As principais atividades produtivas de Tamshiyacu se baseiam na agricultura, especialmente nos cultivos dos proteicos frutos da árvore de umarí [Humiria balsamifera], estendidos por uns seiscentos hectares, assim como de abacaxi [Ananas comosus], estendidos por uns trezentos hectares e finalmente, em menor proporção, mandioca, milho, plátano [Musa sapientum e subespécies relacionadas] e arroz (Torres et al, 1994).

No ano de 2012, capitais internacionais conseguiram concessão estatal para explorar a palma aceitera [Elaeis guineensis], de onde se extrai o óleo de palma, nos arredores do povoado. Compraram dezenas de chacras familiares a preços irrisórios e começaram a derrubar a floresta primária e secundária a um ritmo de 100 hectares por semana, transformando uma exploração extensiva e cuidadosa do ambiente em uma exploração intensiva e antiecológica. Xs trabalhadorxs da palma aceitera, antigxs donos das chacras, se tornaram operários mal pagos sem

179 O Alto Marañón é uma região natural do noroeste do Peru, que compreende as regiões de Huánuco, Ancash, La Libertad, Cajamarca e Amazonas.

180 "Os [homens e mulheres] brancos".

181 "Esse povo chegasse a ser grande e culto". 
a possibilidade de aceder ao sustento vindo do usufruto do próprio território de caça, pesca e colheita.

Por outra parte, dentro da área de serviços, o turismo tem crescido fortemente nos últimos dez anos. Há nos arredores do povoado pelo menos dezoito albergues destinados a hospedar turistas e lhes oferecer plantas medicinais, entre as que se conta especialmente a ayahuasca, a preços diversos. Algumas chacras foram transformadas em albergues turísticos, com uma dinâmica econômica que da autosustentação passou ao acesso a porções importantes de capital nas mãos de pequenxs empreendedorxs. Na medida em que a economia do povoado se tornou mais dependente deste tipo de turismo (os produtos das chacras, a mão de obra de lavandeiras, faxineiras, serenos, guias turísticos e novos xamãs e ajudantes de xamã), as palavras "cerimônia" "xamã" e "ayahuasca" começaram a circular abertamente nas conversas que as pessoas têm no mercado e na avenida principal.

No ano de 2001, foi inaugurada em Tamshiyacu uma escola primária à qual, tempo depois, se adicionou uma área secundária. Essa escola leva o nome de Agustín Rivas Vázquez, e foi fundada por ele. Dom Agustín Rivas é chamado hoje do embaixador cultural do povoado. Ele é um dos xamãs ayahuasqueiros mais conhecidos dentro do povoado e, sobretudo, fora da Amazônia. Ele aprimorou redes na Alemanha e na Bélgica e lá realiza periodicamente cerimônias com ayahuasca faz mais de vinte anos. No dia em que eu e Carl o entrevistamos formalmente, no mês de outubro de 2013, dom Agustín nos comentou que para a sua construção, a escola contou com o apoio de uma fundação alemã. Posteriormente, passou às mãos do estado peruano, que hoje a administra. Essa escola tem orientação artística, pois se sustentou na relação entre arte e ayahuasca que desenvolveu dom Agustín na sua experimentação com plantas 
psicoativas. Ademais, considera a inclusão da prática da ingestão de plantas medicinais. Esse é o caso do chá de coca [Erytroxilum coca], que ajuda a memória $\mathrm{dxs}$ estudantes, ou a purga com o clavohuasca [Tynanthus panurensis] que faz os corpos mais fortes. Dom Agustín conta também que em várias oportunidades ele convidou a algumas/alguns adolescentes a fazerem cerimônias com ayahuasca no albergue dele. O objetivo disso foi o de "enseñarles a manejar su mente $e$ imaginación" ${ }^{182}$, como assevera ele mesmo.

Dom Agustín é, ademais de educador, um empresário de sucesso. Ele conta com quatro albergues: dois em Tamshiyacu, um em Iquitos e um em Pucallpa. No povoado se fala que em Pucallpa, a cidade amazônica onde ele nasceu, ele também é proprietário de uma fábrica de roupas, uma pastelaria e um colégio privado. Um estudioso de Iquitos me disse que dom Agustín é "el primer multimillonario ayahuasquero"183, e uma das pessoas que deu a conhecer a ayahuasca cerimonial aos países do norte: "soy alguien com bastante trayectoria"184, sustenta nosso entrevistado.

Dom Jorge Majipo, companheiro de Isabel, participa ativamente das partidas locais de futebol. As pessoas que se reúnem todos os domingos no campo de futebol da saída do povoado na direção de Flores contam que, dada sua influência mágica, a equipe "difícilmente pierde"185. No rádio, é frequente ouvir a promoção de cerimônias de ayahuasca "cómodas, con visiones aseguradas" 186 .

\footnotetext{
182 "Ensinar-lhes a manejar a sua mente e imaginação".

183 "O primeiro multimilionário ayahuasqueiro".

184 "Sou alguém com bastante trajetória".

185 "Dificilmente perde".

186 "Econômicas, com visões asseguradas".
} 
Quando xs turistas arribam na localidade, costumam ser abordados por jovens meninos que têm o hábito de carregar e descarregar as mercadorias do porto. " $V a$ para lo de Lucho Panduro? (...) va para lo de Jorge Majipo?(...) va para lo de Pedro Guerra?"187.

Ao mesmo tempo, uma parte da população de Tamshiyacu - geralmente a pequena classe urbana do povoado - reivindica a civilidade herdada da sua fundação, com eixo nos valores católicos, a exaltação da peruanidade e o apoio às instituições do Estado. Desta maneira, as correntes antípodas do mundo globalizado não escapam a Tamshiyacu, e sustentam o cultivo de duas forças contraditórias no espaço social desta localidade: por uma parte, a da civilidade iluminista, desejada desde dentro pela sua própria classe média urbana desde a sua criação ainda por Hernández, e pela outra, a de uma espécie de primitivismo, anelado pelxs turistas que buscam nisso uma via privilegiada de retorno à natureza.

Em meio às diferenças de percepção local, uma variada gama de sujeitxs sociais empreendem pequenos negócios mais ou menos exitosos. Embora os empreendimentos turísticos se encontrem no centro da cena social, nem todas as atividades dependem completamente deles. Há um espaço que eu chamaria de não oficial, onde se encontra o restante de terapeutas populares que não pertence completamente ao domínio do turismo xamânico. Esse espaço é escorregadio, e a possibilidade da sua apreensão obriga a etnografias mais aprofundadas e com um maior e melhor contato com as pessoas de Tamshiyacu, estejam elas ou não envolvidas em atividades relativas ao turismo.

187 "Vai para [o albergue] de Lucho Panduro? (...) vai para [o albergue] de Jorge Majipo?(...) vai para [o albergue] de Pedro Guerra?". 


\section{-Especialistas e não-especialistas, água do mesmo rio}

O etno-botânico Marc Lenaerts (2006) pontua como introdução à sua etnografia com povos indígenas asháninka da Amazônia do Peru: "Indigenous Amazonian ethnomedicine usually relies on numerous forms of healing, exercised by both specialists and non-specialists ${ }^{188}$ (p: 1)". O mesmo poderia se estender para as populações mestiças e ribeirinhas da baixa Amazônia peruana. Na medida em que nos aproximamos da vida diária destas pessoas, diversas manifestações terapêuticas e magias, imbuídas em maneiras de fazer com plantas aparecem e se emaranham entre si, acompanhando as rotinas cotidianas de mulheres e homens da região.

Na presente tese, narro alguns relatos e experiências terapêuticas e mágicas de algumas pessoas não especialistas, que não se chamam de curiosxs nem outras categorias semelhantes, mas que já se autocuraram ou curaram outras pessoas, geralmente da família ou vizinhos, que é outra importante forma de agrupação social local. Essas são as que eu defino genericamente como as pessoas que sabem lidar com plantas. Este é o caso de Genoveva, neta de Bernardina - que é, por sua vez, uma das parteiras mais idosas da localidade - que lança mão de uma estreita relação mágica com o tabaco [Nicotiana tabacum] na hora de ir pescar ou mesmo de navegar águas estando solitária. Também o de Román, trabalhador da construção de casas com madeira que modifica seu hábito de beber álcool em excesso em virtude da intervenção mágica da malva [Malachra ruderalis] em seus sonhos, que o leva a acordar, beber o suco de suas folhas e sarar. Finalmente a planta da camalonga [Thevetia peruviana] faz parte da história de luta de Estela, professora de um dos dois colégios secundários de Tamshiyacu, contra dores crônicas no corpo. No capítulo 6, relato com mais vagar as experiências que elxs

188 "A etno-medicina indígena amazônica frequentemente descansa em numerosas formas de cura, exercidas tanto por especialistas quanto por não especialistas". 
protagonizaram e que me foram confiadas em contextos de cotidianidade, como durante uma conversa ao frescor da sala da casa de Estela, no centro do povoado de Tamshiyacu; uma visita ao casal de Román e Gerónima, que eram meus vizinhxs na casa que habitei na rua Atahualpa, na margem leste de Tamshiyacu; uma viagem de bote com Genoveva para visitar a sua avó parteira, Bernardina, na ilha de San Pedro, há uns dez quilômetros do povoado de Tamshiyacu, no rio Amazonas. Essas pessoas tiveram experiências de relação mágica e/ou terapêutica com plantas, mas não precisaram ser especialistas para isso. Nesse tipo de vivência, o saber sobre as plantas é direto, corporal e não necessariamente transmissível, e não está relacionado com certa formação empírica ou teórica para se tornar curiosx.

Em um grupo social com maioria de pessoas que sabem lidar com plantas, sobressai a prática dxs especialistas. Dentro dessa paisagem diversa de pessoas que souberam se curar ou curar a outras pessoas por experiência própria, e sem outra preparação senão dos conteúdos gerais da cultura é que sobressaem aquelxs que se chamam propriamente de curiosxs. Como definir a um/a curiosx? As práticas que são específicas dxs curiosxs são relativas a um fazer e a um fazer fazer (isto é, a própria influência através de ações mágicas) que vai desde o singelo lavado de rosto com pepino silvestre [Cucumis anguria] que $\mathrm{x}$ yerberx aplica no rosto da pessoa febril, até paralisar o inimigo com o olhar e lhe envenenar com ajuda da madre da venenosa planta do barbasco [Lonchocarpus nicou] - técnica que realizam cotidianamente xs chamanxs da região.

Entre magias e terapias há uma diferença muito sutil. Xs curiosxs de Tamshiyacu não são unicamente terapeutas populares, pois também realizam atos mágicos que podem se intrometer, prejudicar ou inclusive matar a outras pessoas. Eu preferi usar o conceito nativo de curiosxs, pois ele indica uma atitude perene relativa a 
esse ofício: conhecer e praticar, colocar a mão em territórios misteriosos, agir sobre o desconhecido. Creio especialmente importante sublinhar isso quando me refiro à atividade dxs curiosxs, levando em conta tanto os procedimentos terapêuticos quanto os procedimentos mágicos. Isso é o que tenho definido como intenções terapêuticas e intenções etótropas (ver cap. 5), e são relativas não só às artes de fazer, mas também as de fazer fazer.

Um pouco terapeutas, um pouco mágicos, lidando com palos e hierbas, males de dios e males de gente (ver capítulo 8), xs curiosxs amazônicxs do lado peruano distribuem as suas práticas em um amplo escopo: desde aquelxs que conversam com os espíritos da planta até aquelxs que oram a deus; desde aquelxs que cobram seus serviços em quantidades de dinheiro fixo até aquelxs que cobram $a$ vontade $\mathrm{dx}$ sujeitx que está sendo tratadx; desde aquelxs que colhem as plantas até aquelxs que pagam para outrxs as colherem; desde aquelxs que trabalham com palos, feitiçaria e doenças que põem a vida em risco imediatamente até aquelxs que trabalham com hierbas, prevenção, cuidados básicos e sutis melhoras na qualidade de vida.

\section{- Vinte e poucxs curiosxs}

No povoado de Tamshiyacu e arredores, as acusações entre curiosxs são frequentes. Em alguns casos, elas se referem ao fato dx colega curiosx ser um farsante, charlatán, não saber nada. Outras vezes, são relativas à incriminação $\mathrm{dx}$ outrx como brujo ou hechicero. Frente à gama de possíveis difamações entre diferentes sujeitxs, tenho observado que a auto-adscrição se conforma em uma importante ferramenta analítica para a descrição desta complexa dinâmica social. Sem desmerecer o quão interessante pode ser um estudo sobre o conflito entre 
$\operatorname{curios}{ }^{189}$, escolhi me deter na auto-definição dxs mesmxs a certas categorias e à experiência prática destxs especialistas dentro de cada uma delas. Dentro do circuito das práticas terapêuticas e mágicas que estão dentro de espaços não oficiais, mulheres e homens de Tamshiyacu desenvolvem técnicas que, em um movimento criativo entre o ancestral herdado e o improvisado in loco, afetam diariamente os corpos e emoções dxs sujeitxs sociais ao seu redor.

A etnografia que realizei durante meu trabalho de campo na Amazônia do Peru, durante todo o ano 2013, permitiu-me elaborar a referência de sessenta e uma pessoas que praticam alguma forma de terapia ou magia popular. Dentre elas, são quarenta e duas as que eu conheci pessoalmente. Ainda quando elxs possuem práticas e orientações bastante heterogêneas, todxs elxs ostentam uma característica comum: elxs se auto-classificam como curiosxs. Dentro desse grupo mais amplo, escolhi realizar a minha amostra com vinte e duas pessoas, mulheres e homens, que são aquelxs com xs quais tive um contato mais direto e constante no tempo. Elas são parte da minha amostra significativa ${ }^{190}$, e se encontram ao redor de Isabel, a curiosa, curandera e chamana na qual destaco a análise etnográfica da presente pesquisa.

É importante assinalar que os nomes nem sempre representam completamente as práticas dxs sujeitxs que com esses nomes se identificam. É desta maneira que as

189 O trabalho de Edward Evans-Pritchard (1937) sobre bruxaria zande foi uma das primeiras monografias antropológicas pioneiras a elaborar esse tipo de estudos que combinam o interesse por questões mágicoreligiosas assim como por tópicos relativos ao conflito social.

190 Uma amostra significativa, ao contrário de uma amostra representativa, não é extensiva mas sim intensiva, não procura tanto a validade externa quanto a validade interna. Ela é definida de acordo com critérios de corte qualitativo, e não representa um valor relativo dentro de uma série numérica, mas sim um grupo com características particulares que a análise etnográfica focaliza e significa (Saltalamacchia, 1992). 
categorias funcionam mais como portas abertas a determinadas práticas, isto é, como marcos que definem maneiras de fazer próprias e originais de cada curiosx, do que como espaços de cargos/funções/identidades estritamente delimitados. Assim, foi possível observar que esses conjuntos se encontram relativamente dissolvidos uns nos outros, de maneira tal que xs curiosxs podem se autoadscrever como pertencendo a mais de uma categoria simultaneamente. Enquanto isso, também se apaga o contraste entre especialistas e não especialistas quando as suas práticas são colocadas em conjunto. De fato, práticas de terapia e magia fazem parte do cotidiano $d x s$ sujeitxs comuns que habitam Tamshiyacu, e muitas destas pessoas, sejam as que se auto-denominem como curiosas ou não, sabem lidar com plantas.

Ainda quando a cotidianidade das práticas de magia e cura por parte de não especialistas permanece como um fato etnográfico riquíssimo e indiscutível, a diferença entre figura (especialistas) e fundo (não especialistas) se tornou mais nítida quando o olhar se colocou na prática específica de sobadorxs, chamanxs e outrxs especialistas, em contraste com o restante das pessoas que sabem lidar com plantas.

Em conversas formais e informais com as vinte e duas pessoas que se autoclassificam como curiosxs, tive a possibilidade de constatar: a) o caráter guardachuva da categoria curiosx, que inclui uma enorme diversidade de maneiras de fazer. O termo abarca uma multiplicidade de identidades práticas correspondentes ao grupo de especialistas em terapias e magias populares da baixa Amazônia peruana, e b) a existência de dez termos que podemos colocar como correspondendo a uma sub-classificação do ofício de curiosx. Elxs são: 1. curanderx; 2. chamán/a; 3. vegetalista; 4. médicx tradicional; 5. purguerx; 6. sobador/a de lisiadxs; 7. sobador/a [de mulheres grávidas]; 8. parterx; 9. naturalista e 10. 
yerberx. Desta maneira, todxs xs yerberxs são curiosxs, mas não todxs xs curiosxs se entendem como yerberxs. Graficamente, o universo que se estende dentro e fora da categoria de curiosx poderia ser definido como segue:

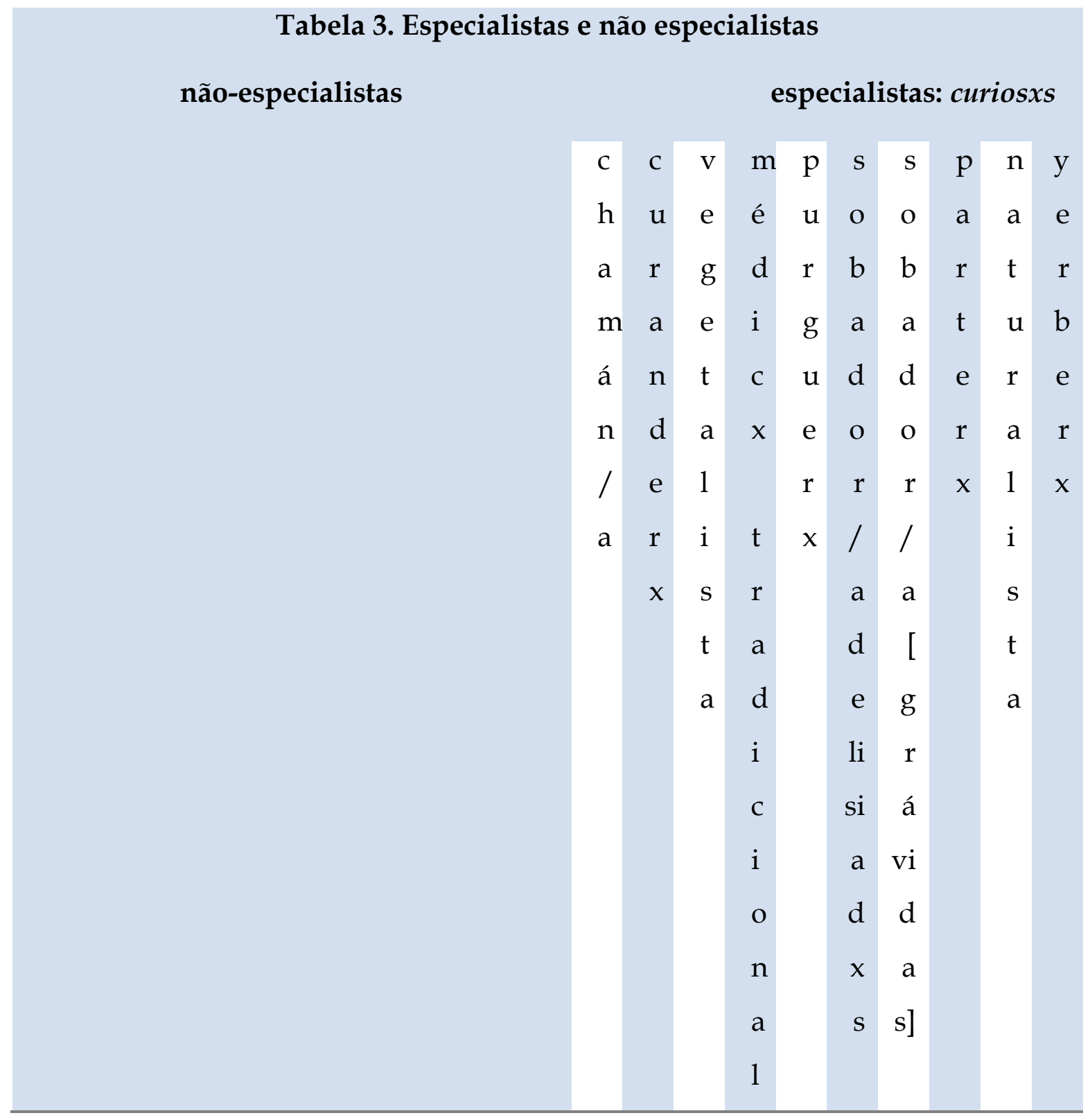


$\mathrm{Na}$ análise, posiciono chamanxs e yerberxs como os dois pontos extremos dentro do que é um continuum de práticas mágicas e terapêuticas próprias dxs curiosxs de Tamshiyacu. Partindo de uma dicotomia similar àquela entre xamãs e herbalistas que propõe Lenaerts (2006), onde xs xamãs manejam umas poucas plantas de uso mágico e xs herbalistas uma grande diversidade de plantas de uso terapêutico, a classificação que eu proponho aqui estende essa dicotomia pelos seus extremos e coloca, dentro deles, uma série de categorias intermediárias.

Apresento aqui o grupo de vinte e duas pessoas que fazem parte de minha amostra significativa. Elas pertencem, por auto-adscrição, à categoria curiosx, e que também fazem parte das seguintes dez categorias complementares: 
Tabela 4. Sub-especialidades dxs curiosxs

\begin{tabular}{|c|c|c|c|c|c|c|c|c|c|c|}
\hline \multirow[t]{2}{*}{ Nome } & \multicolumn{10}{|c|}{ Classificação } \\
\hline & chamán/a & curanderx & vegetalista & $\begin{array}{c}\text { médicx } \\
\text { tradicional }\end{array}$ & $\begin{array}{l}\text { pur } \\
\text { gue } \\
\text { rx }\end{array}$ & $\begin{array}{c}\text { sobador/ } \\
\text { a de } \\
\text { lisiadxs }\end{array}$ & $\begin{array}{c}\text { sobador/a } \\
\text { [mulheres } \\
\text { grávidas] }\end{array}$ & parterx & $\begin{array}{c}\text { naturalist } \\
\text { a }\end{array}$ & $\begin{array}{c}\text { yerber } \\
\mathrm{x}\end{array}$ \\
\hline Agustín & - & $\bullet$ & $\bullet$ & & & & & & & \\
\hline Lucho & $\bullet$ & $\bullet$ & $\bullet$ & & & & & & & \\
\hline Jorge & $\bullet$ & $\bullet$ & $\bullet$ & & & & & & & \\
\hline Luis & $\bullet$ & $\bullet$ & $\bullet$ & & & & & & & \\
\hline Moisés & $\bullet$ & $\bullet$ & $\bullet$ & & & & & & & \\
\hline Tocayo & & $\bullet$ & $\bullet$ & $\bullet$ & & & & & & \\
\hline Leoco & & $\bullet$ & $\bullet$ & $\bullet$ & & & & & & \\
\hline Marcos & & & $\bullet$ & & $\bullet$ & & & & & \\
\hline Gerlyn & $\begin{array}{c}\bullet \\
\text { (aprendiz) }\end{array}$ & $\begin{array}{c}\bullet \\
\text { (aprendiz) }\end{array}$ & & & & & & & & \\
\hline Ernesto & & & & & & & & $\bullet$ & & \\
\hline Julio & & & $\bullet$ & & & & & & $\bullet$ & \\
\hline Isabel & - & $\bullet$ & $\bullet$ & & & & & & & \\
\hline Adela & $\bullet$ & $\bullet$ & $\bullet$ & & & & & & & \\
\hline Pasquita & $\bullet$ & $\bullet$ & $\bullet$ & & & & & $\bullet$ & & \\
\hline Zoila & & & & & & & & $\bullet$ & & \\
\hline María & & & & & & & & $\bullet$ & & \\
\hline Bernardina & & & & & $\bullet$ & & & $\bullet$ & & $\bullet$ \\
\hline Milena & & & & & & & & $\bullet$ & $\bullet$ & \\
\hline Asteria & & & & & & $\bullet$ & & & & $\bullet$ \\
\hline $\begin{array}{l}\text { Anita del } \\
\text { Carmen }\end{array}$ & & & & & & & & & & $\bullet$ \\
\hline Betina & & & & & & $\begin{array}{c}\bullet \\
\text { (aprendiz) }\end{array}$ & $\begin{array}{c}\bullet \\
\text { (aprendiz) }\end{array}$ & & & \\
\hline Corina & & & & & & & & $\begin{array}{c}\bullet \\
\text { (ajudante) }\end{array}$ & & \\
\hline
\end{tabular}


Os dez tipos apareceram como maneiras de auto-classificação, descrevendo dez matizes dentro da realidade do que se entende como curios $x$ na localidade. Ainda quando flexíveis e altamente permeáveis entre si, apresento em seguida uma definição breve de cada uma das categorias dentre as quais se distribui o ofício dxs curiosxs:

a) Chamanxs: são as pessoas que icaram [entoam cânticos mágicos], trabalham com a chacapa [arranjo de folhas vegetais secas cuja vibração chama aos espíritos] e se comunicam com umas poucas outras plantas, sendo a maior parte delas palxs (ver próximo ponto). Curam especialmente os chamados males de gente, entre os quais se contam trabalhos de des-possessão e desenfeitiçamentos. Trabalham corpo a corpo com xs pacientes, e também fazem curas à distância. A de xamã é uma categoria relativamente recente, começou a ser usada por turistas a década de 1980 e foi sendo incorporada de maneira rápida pelxs próprixs sujeitxs categorizadxs ao mesmo tempo em que iam sendo apropriados elementos pertencentes às múltiplas expressões do xamanismo globalizado (paus de chuva, massagens, psicoterapia, mantras, arcos de cordas). Usam as plantas trazidas por outras pessoas da floresta adentro - especialmente, vegetalistas e purguerxs. Xs chamanxs costumam cobrar quantidades fixas por seu trabalho e são xs menos flexíveis na hora de negociar o valor deles.

b) Curanderxs: da mesma forma que na categoria anterior, são as pessoas que icaram, trabalham com a chacapa [arranjo de folhas vegetais secas cuja vibração chama aos espíritos] e se comunicam com umas poucas outras plantas, sendo a maior parte delas palos (ver próximo ponto). Curam especialmente os chamados males de gente, entre os quais se contam trabalhos de exorcismo $\mathrm{e}$ desenfeitiçamentos. Praticam suas técnicas corpo a corpo com xs pacientes, 
fazendo também curas à distância. Alguns/algumas curanderxs não aceitam serem chamadxs de chamanxs. Tais casos são relativos a pessoas que trabalham geralmente nas margens do turismo xamânico e são mais próximxs do que é considerada a tradição local, ao mesmo tempo em que tendem a ser relutantes à incorporação das práticas do xamanismo globalizado. Xs curandeirxs usam as plantas próprias dos fundos de quintal das suas casas ou casas vizinhas, das suas chacras ou aquelas que trazem outras pessoas da floresta adentro especialmente, vegetalistas e purguerxs. Xs curanderxs costumam cobrar quantidades fixas por seu trabalho, se bem que também aceitam somas menores ou pagamento em produtos.

c) Vegetalistas: são assim chamadas as pessoas que conhecem os vegetais. Da mesma maneira em que xs chamanxs e curandeirxs, costumaram fazer dietas e tomada de vegetais na floresta. Nessa categoria, sublinha-se a importância do isolamento temporário do mundo social. No dizer do vegetalista Walter, "lo mejor es practicar sin que nadie te enseñe. Aprender en secreto, sin que nadie te vea"191. A maior ênfase na formação dxs vegetalistas está 1) no tempo de preparação do corpo para o ofício por meio da incorporação de plantas (via ingestão, fumar, friç̧ões, vibrações acústicas ou banhos), 2) na comunicação com as madres das plantas que se gera a partir destas aproximações e 3) no fato de saber preparar os vegetais (na água ou em álcool, no caso daqueles que serão ingeridos). Xs vegetalistas, ao contrário dxs chamanxs e dxs curandeirxs, não têm pacientes com os quais estabelecer curas corpo a corpo nem à distância. Elxs costumam vender seus preparados vegetais para xs curandeirxs e os chamanxs. Há curandeirxs ou chamanxs que podem também ser vegetalistas e vice-versa, mas não é imperativo que os ofícios se exerçam conjuntamente. Os vegetalistas usam as plantas que

191 "O melhor que há é treinar sem que haja ninguém para te ensinar. Aprender em segredo, sem que ninguém te veja". 
costumam procurar após longas caminhadas floresta adentro. Xs vegetalistas não costumam cobrar quantidades fixas por seu trabalho, e cobram de acordo com o tipo de proximidade, empatia e situação da pessoa interessada.

d) Médicxs tradicionais: Essa categoria corresponde amplamente a de curandeirx. Assim, essa categoria corresponde às pessoas que icaram [entoam cânticos mágicos], trabalham com a chacapa [arranjo de folhas vegetais secas cuja vibração chama aos espíritos] e se comunicam com umas poucas outras plantas, tanto palos quanto hierbas. Trabalham corpo a corpo com xs pacientes, fazendo também curas à distância. Xs médicxs tradicionais curam tanto os chamados males de gente quanto os males de dios. Aquela pessoa que se auto-classifica como médicx tradicional enfatiza nas maneiras de fazer terapias e magias que são locais, e sublinha a importância destas maneiras de fazer como sendo parte de uma medicina que está no mesmo nível do que a medicina oficial que se oferece e impõe desde o sistema público de saúde. Usam as plantas que cultivam no jardim de casa, na chacra ou floresta adentro. Xs médicxs tradicionais não costumam cobrar quantidades fixas por seu trabalho, e valorizam o custo de seu serviço de acordo com o tipo de proximidade, empatia e situação da pessoa interessada.

e) Purguerxs: trata-se daquelas pessoas que sabem preparar as purgas. Chama-se de purgas àqueles preparos vegetais (na água, mas especialmente no álcool) que se bebem em caso de doenças ou mal-estares. Em linhas gerais, a prática dx purguerx é equiparável a dx vegetalista. Porém, a ênfase não está tanto no tempo de preparação do corpo para o ofício por meio da incorporação de plantas (via ingestão, fumar, fricções, vibrações acústicas ou banhos) nem na comunicação com as madres das plantas que se gera a partir destas aproximações. A maior ênfase se encontra no fato dxs purguerxs saberem preparar os vegetais (na água 
ou em álcool, no caso daqueles que serão ingeridos). Tais vegetais são, em termos gerais, da categoria dos palos. Poderíamos dizer que xs purguerxs são vegetalistas práticos, especializadxs na tarefa de preparo dos remédios e não tanto nas bases teóricas da cura com plantas e madres das plantas. Usam as plantas que costumam procurar após longas caminhadas floresta adentro. Xs purguerxs não costumam cobrar quantidades fixas por seu trabalho a sujeitxs afetadxs, aceitando o intercâmbio de produtos como forma de pagamento. Quando os produtos ou serviços se destinam a chamanxs que trabalham em atividades relativas ao turismo, é comum se estabelecerem quantias fixas de dinheiro.

f) Sobadorxs de lisiadxs: Também são chamadxs de hueserxs. Atendem a problemas de luxações, dores de articulações, torceduras e fraturas. Tratam os mal-estares com remédios externos (untos de diverso tipo) e internos (plantas preparadas na água ou no álcool). Os untos se preparam com gordura animal (galinha, porco ou arraia) e algumas plantas (piñón negro [Jatropha gossypiifolia], patiquina [Caladium bicolor] e suelda consuelda [Tassadia berteriana], entre outras) ou resinas semi-sintéticas como a cânfora. Com elxs, fazem suas frições, massagens e acomodações de ossos, músculos e vértebras. Usam as plantas que cultivam no jardim de casa ou na chacra. Costumam cobrar dinheiro, serviços ou favores pelos seus serviços, dependendo do tipo de proximidade, empatia e situação da pessoa interessada.

g) Sobadorxs [de mulheres grávidas]: são aquelas pessoas que se dedicam a massagear e acompanhar mulheres em processo de gravidez. Muitas delas são parteiras. Conhecem maneiras de acomodar a criança dentro do ventre se ela está de cócoras ou de lado. Xs sobadorxs de mulheres grávidas sabem também estabelecer formas de comunicação com o feto através do corpo da mulher grávida, a partir das quais deduzem o sexo da criatura e seu temperamento de 
acordo com os movimentos fetais, a temperatura da mão da mulher grávida, a expressão do rosto da mesma, os sonhos delxs ou da própria grávida, assim como a forma da barriga desta última. Sabem preparar untos com gordura animal (galinha, porco ou arraia) e algumas plantas (como a toronja [Citrus grandis]) ou resinas semi-sintéticas como a cânfora. Com elxs, fazem suas massagens em mulheres grávidas e crianças pequenas. No caso das últimas, elas se fazem tratar com xs sobadorxs de grávidas uma afeição chamada de huihuano. O huihuano é a primeira vértebra inferior, que se torce devido a esforços inapropriados da criança. Usam as plantas que cultivam no jardim de casa ou na chacra. Xs sobadorxs [de mulheres grávidas] entendem seu trabalho como um serviço. Não costumam cobrar quantidades fixas por seu trabalho e valorizam o custo de seu serviço de acordo com o tipo de proximidade, empatia e situação da pessoa interessada.

h) Parterxs: São aquelas pessoas especialmente dedicadas a acompanharem a gravidez e os partos. Também aconselham em casos de abortos espontâneos ou provocados, ao mesmo tempo em que ajudam a estabelecer e manter o processo de aleitamento. Conhecem uma diversidade de plantas, especialmente do mundo das hierbas. Não icaram, mas realizam orações, geralmente destinadas ao Deus cristão. Há parteirxs recordadxs pela sua habilidade de comunicação com o feto no ventre da mãe. Dom Ernesto, parteiro, conta que a sua mãe, dona Clara Dominga, fazia o bebê que estava de pé dentro do ventre dar a volta somente falando com elx. Cada um/a delxs desenvolveu técnicas para fazer sellado [técnica de vaporização da área inferior do corpo com folhas de plantas, cuja finalidade é proteger o corpo da mulher e da criança], diagnosticar a posição da criança no ventre, ajudar à expulsão do feto e da placenta, cortar o cordão e acompanhar a amamentação e o pós-parto. Uma técnica comum, chegada a hora de parir, é apalpar o pulso e a coronilla [moleira] da mulher. Usam as plantas que 
cultivam no jardim de casa ou na chacra. Em geral, xs parterxs entendem seu trabalho como um serviço. Não costumam cobrar quantidades fixas por seu trabalho e valorizam o custo de seu serviço de acordo com o tipo de proximidade, empatia e situação econômica da pessoa interessada.

i) Naturalistas: São aquelas pessoas que trabalham com plantas, fazem massagens e preparam remédios. Têm relação com plantas tanto do grupo dos palos quanto do grupo das hierbas. Xs que pertencem ao evangelismo não lidam com plantas psicoativas. Ao mesmo tempo, defendem um acesso às plantas marcado pelos princípios empiristas da medicina oficial. Em tal relação, o/a naturalista não é protagonista, mas simplesmente um/a administrador/a: "el chamán tiene que tomar la planta para ver, la medicina natural es más directa, va directo al cuerpo"192, afirma Milena. Tentam um distanciamento explícito frente ao que elxs chamam de "medicina tradicional", com a sua carga de práticas mágicas e espiritualidades diversas. Como afirma o naturalista Julio, "queremos rescatar los conocimientos naturales transmitidos por nuestros ancestros" ${ }^{193}$. Tal proposta faz parte de uma "medicina científica" que adota as plantas a partir de uma filtragem das chamadas "supersticiones" [crenças populares], ficando as propriedades medicinais da planta per se: como espécie vegetal com uma lista de substâncias redutíveis a princípios ativos. Contudo, a filtragem não é completa, e acontece na prática um diálogo profícuo entre a biomedicina e as formas locais de tratamento de doenças. Usam as plantas que cultivam no jardim de casa, nas chacras ou que foram colhidas floresta adentro. Xs naturalistas não costumam cobrar

\footnotetext{
192 "O xamã tem que tomar a planta para poder ver, a medicina natural é mais direta, entra direito no corpo".

193 "Queremos resgatar os conhecimentos naturais transmitidos pelos nossos ancestrais".
} 
quantidades fixas por seu trabalho e valorizam o custo de seu serviço de acordo com o tipo de proximidade, empatia e situação econômica da pessoa interessada.

j) Yerberxs: São pessoas que trabalham com plantas, sobretudo aquelas que são classificadas dentro do grupo das hierbas. De prática empírica, seu ofício se desenvolve entre o que foi herdado, o que foi aprendido de forma horizontal (vizinhxs, parentes, amigxs) e as próprias provas e erros diante de doenças e malestares. Como afirma a yerbera Anita del Carmen: "yo voy contando, me van dando consejos y voy probando" ${ }^{194}$. Xs yerberxs preparam remédios e os administram. Não costumam cobrar por seus serviços. Cuidam e prevêem doenças comuns relacionadas com os males de Dios. Não icaram, dietam ou usam a chacapa para curar. Praticam a arte da oração (majoritariamente ao Deus cristão). Usam as plantas que cultivam no fundo da casa ou nos jardins de casas vizinhas. Xs yerberxs não cobram dinheiro pelos seus serviços e somente aceitam produtos ou favores em troca.

Uma vez apresentada essa classificação da tabela de curiosxs, marcando diferenças entre cada ofício, traremos uma importante variável para a análise, a qual explica o posicionamento de chamanxs e yerberxs nos extremos do continuum. Tal variável se refere aos diacríticos de gênero, uma importante referência que orienta a natureza das práticas terapêuticas, das plantas utilizadas, das doenças a serem tratadas e outras características distintivas entre xs curiosxs de Tamshiyacu.

Se olharmos para a Tabela 4, apresentada páginas atrás, pelas manchas de pontos, observamos entre xs curiosxs de Tamshiyacu uma divisão de gênero que

194 "Eu vou contando [os problemas], as pessoas vão me aconselhando e eu vou provando". 
é bastante notória: no extremo superior esquerdo se encontram os homens, com prevalência nos ofícios de chamán/a, curanderx, vegetalista, médicx tradicional e purguerx; enquanto no extremo inferior direito se encontram as mulheres, com prevalência nos ofícios de sobador/a [de mulheres grávidas], sobador/a de lisiadxs, parterx, naturalista e yerberx. Purguerx e naturalista são categorias que incidem em mulheres e homens de maneira equivalente.

Durante o trabalho de campo, entrevistei um total de sete homens que se definem como curandeirxs: Agustín, Lucho, Jorge, Luis, Moisés, Leoco e Tocayo (Ver Imagem 13, Alguns Curandeiros). Dentro desse grupo, os cinco primeiros, Agustín, Lucho, Jorge, Moisés e Luis se reconhecem como chamanes, enquanto que os dois últimos, Leoco e Tocayo, não desejam se identificar ou serem identificados como tais, e se apelidam positivamente sob a categoria de médico tradicional. Contudo, todos eles se identificam sob a categoria de vegetalistas. Em adição, Marcos se identifica como purguero, enquanto que Julio se reconhece como vegetalista e naturalista. Ernesto é o único parteiro e Gerlyn, filho de Isabel, se reconhece como aprendiz de curandeiro, vegetalista e chamán ao mesmo tempo em que se localiza ao redor da prática de seu ofício atual, o artesanato em madeira.

Dentre as mulheres, são cinco as que se definem como parteirxs: María, Pasquita, Zoila, Bernardina e Milena. Bernardina é, ademais, purguera enquanto que Milena se define também como naturalista, algo que, como teremos a possibilidade de ver, delimita a sua prática de uma maneira diferencial em relação ao restante de curiosxs locais. Já Asteria se auto-classifica como sobadora de lisiados, Anita del Carmen se define como yerbera, enquanto que Betina e 
Amanda ${ }^{195}$ são aprendizes: Betina está aprendendo os ofícios de sobadora de mulheres grávidas e de sobadora de lisiados; Amanda está aprendendo a ser curandeira. Corina é sobadora de mulheres grávidas e também é ajudante de partos de Ernesto, seu marido partero.

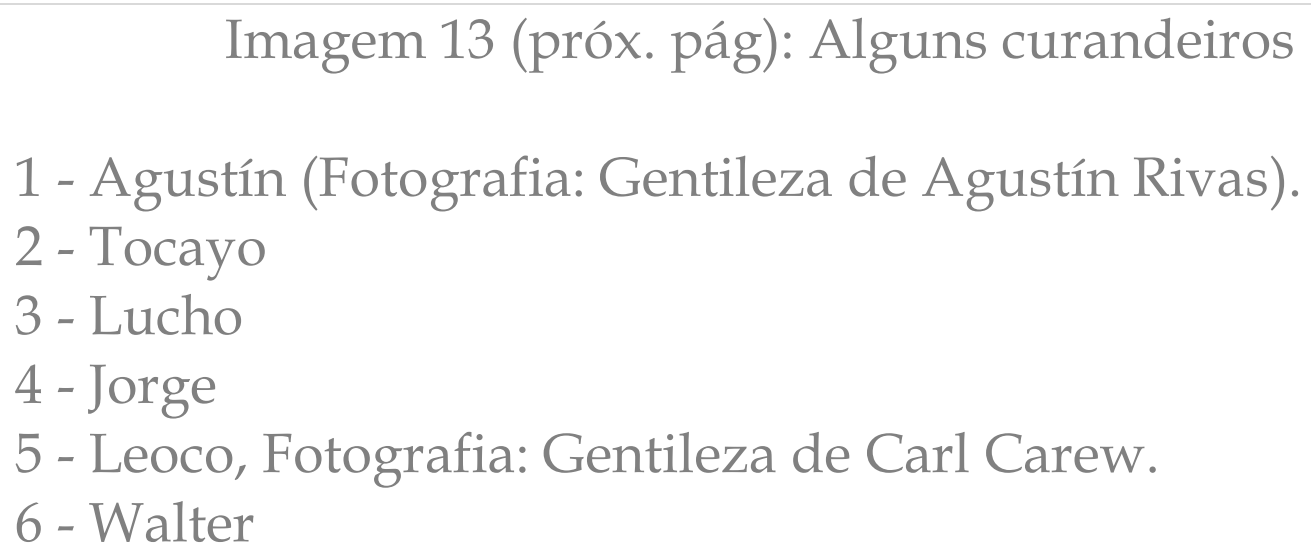




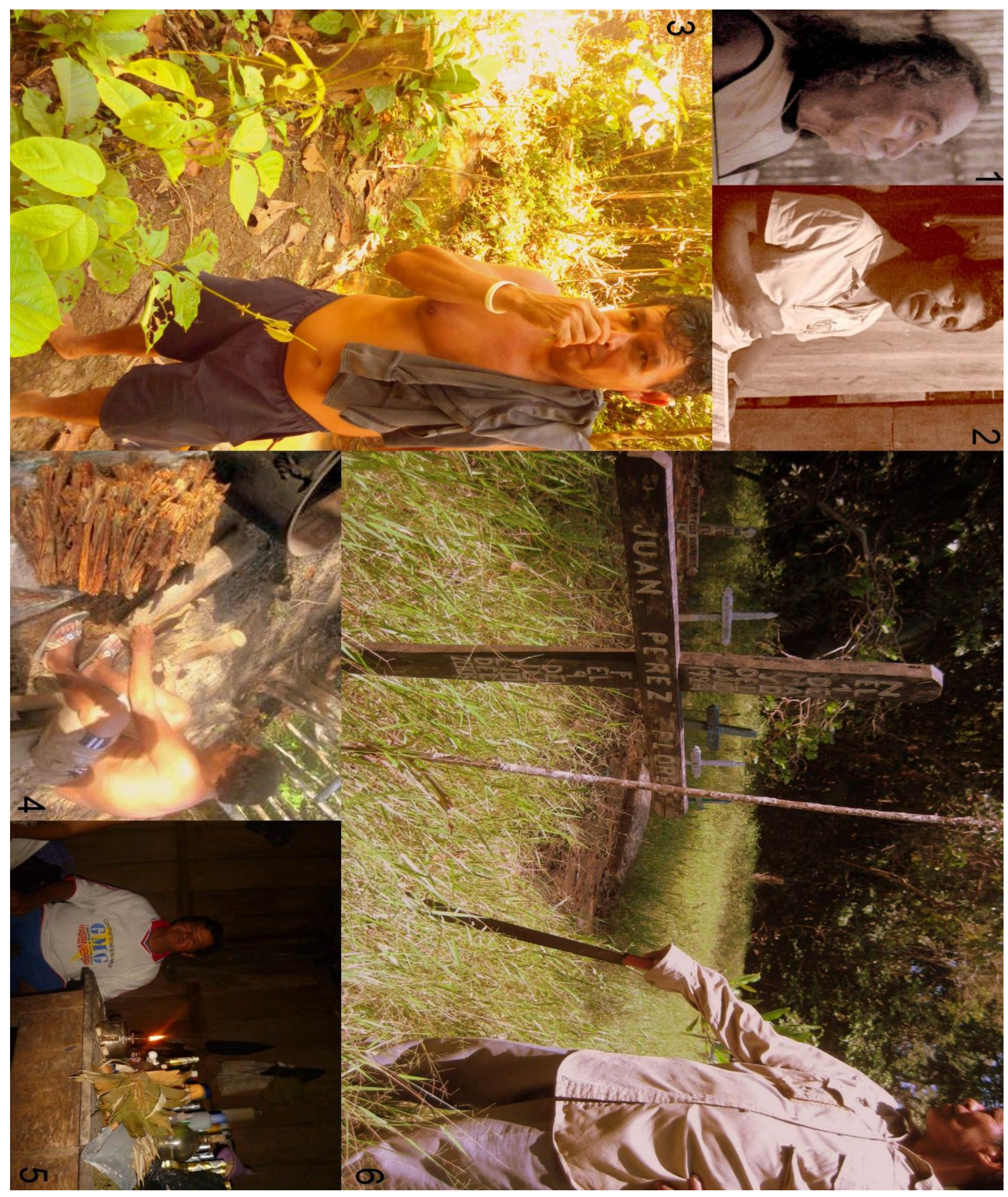


É possível observar interessantes diferenças de gênero dentro dos ofícios. Dentre essas mulheres, há somente três delas - Isabel, Adela e Pasquita - que escolheram se definir a si mesmas como sendo chamanas, vegetalistas e também curandeiras. Observamos essas três categorias como maneiras de fazer com plantas que lidam, especialmente, com os palos. Os ofícios de sobador de lisiadxs e o de parteirx também apresentam diferenças em virtude do gênero. Comenta Betina, que é filha de Otilio, sobador de lisiadxs e de María, que é parteira:

Yo aprendí las cosas de mi padre, pero no tanto las de mi madre. Son cosas distintas. Unas son cosas de mujer y otras son cosas de hombre. Pero hay parteros y hay sobadoras de lisiados. Menos, pero hay. A mí por ejemplo me gusta más el oficio de mi papá, yo quiero aprender para ser sobadora de lisiados ${ }^{196}$.

Desta maneira, as mulheres estariam mais perto do ofício de acompanhar partos e da sobada de mulheres grávidas enquanto para os homens seria mais habitual a tarefa de sobar lisiadxs: acomodar ossos, endereçar músculos, aliviar tensões. Contudo, conheci duas mulheres, Betina e Asteria, uma em processo de aprendizado de sobar mulheres grávidas e também lisiadxs e a outra em pleno exercício do ofício de sobadora de lisiadxs, de maneira contrária ao que a tendência indica. Mulheres e homens curiosxs trabalham com diferentes classes de plantas. Na extraordinária variedade de espécies de conhecido uso humano (terapêutico ou mágico) do mundo das plantas se encontra a interessante classificação nativa de palos e hierbas. A relação dos palos com os riscos e outras tarefas e atributos impressos na masculinidade local, e das hierbas com os serviços e outras tarefas e atributos que definem a feminilidade local, e sua relação com as maneiras que têm xs curiosxs de sarar doenças, fazer trabalhos e se posicionar frente ao mundo serão exploradas nos pontos que seguem.

196 "Eu aprendi as coisas do meu pai, mas nem tanto as da minha mãe. São coisas diferentes. Umas são coisas de mulher e outras são coisas de homens. Mas também há parteiros e sobadoras de lisiados. Tem menos, mas tem. Eu, por exemplo, gosto mais do oficio do meu pai, eu quero aprender para ser sobadora de lisiados". 


\section{Parte III: Formas de organizar a multiplicidade}




\section{Capítulo 8 \\ Palos e hierbas}

- Mal de dios e mal de gente - As plantas e xs curiosxs - Palos e hierbas • Vocações: as práticas de risco, a coragem e o serviço $\bullet \mathrm{O}$ gênero da ayahuasca e dxs ayahuasqueirxs $•$ Casais no meio das plantas

"Para la elaboración de una teoría de la mujer, creo que los hombres son suficientes"197 Luce Irigaray, 1985.

No presente capítulo, sublinharei o caráter relacional da construção de terapias e magias na floresta amazônica peruana que encaram xs curiosxs locais. Com Irigaray, considero que para a construção de qualquer teoria sobre a mulher, falar da relação com os homens é fundamental. Contradizendo a radicalidade de Irigaray, talvez não seja suficiente com isso, mas apoiando seu insight, creio que a percepção da masculinidade é estritamente necessária para compreender a feminilidade, em qualquer contexto que seja. Essências que se constituem como tais a partir da sua permanente relação: é assim que acontece nessa aproximação com curiosas e curiosos da Amazônia do Peru. Mulheres e homens que sabem fazer com plantas lidam com um mesmo esquema de saberes e práticas, a partir do qual modelam as suas ações cotidianas.

No intuito de desenvolver uma reflexão genderizada sobre as relações de mulheres e homens entre elxs e dos dois com seres do domínio do não-humano (plantas, espíritos das plantas e outras entidades) é que me debruçarei sobre os parâmetros nativos desse esquema binário genderizado que encontrei na etnografia que realizei na localidade. Considero, junto com a estudiosa indiana

197 "Para a elaboração de uma teoria da mulher, creio que os homens são suficientes". 
Gayatri Spivak (1995), que uma estratégia crítica com esquemas binários do pensamento não implica na anulação dos mesmos, mas da compreensão da sua utilização com fins estratégicos. E, o que provê uma perspectiva que é muito mais interessante ainda, não é necessário que isso seja feito desde o pódio da escrita acadêmica nem desde a posição academicamente visível de um feminismo militante. Algumas/alguns sujeitxs aqui retratadxs estão ressignificando esses binarismos de maneira permanente e, ainda quando os reconhecem, circulam de maneira criativa entre um e outro extremo da sua aparente insolubilidade.

Desta maneira, traçarei primeiro uma instantânea visual (à maneira de uma fotografia conceitual) das formas fixas deste esquema binário. Em seguida, as categorias que foram primeiramente dispostas como estáticas pela mesma natureza da instantânea proposta observarão a mobilidade, a flexibilidade e a permeabilidade que também as constitui. O reconhecimento da existência desse esquema me levará a explorar a interessante relação entre $\mathrm{x}$ especialista, a perturbação e os tipos de plantas utilizados no marco dos vínculos genericamente condicionados pelo seu pertencimento alternativo ao mundo dos palos, por uma parte e das hierbas, por outra. Da análise dos sentidos vindos do trabalho de campo, pude observar que as diferentes categorias de curiosxs podem ser definidas: a) em virtude da origem, humana ou divina, das perturbações que tratam; b) em relação ao tipo de plantas que são indicados para prática terapêutica ou mágica em questão; e c) em virtude do gênero, feminino ou masculino, dx especialista que trata da perturbação. Desenvolverei aqui uma reflexão sobre esses três pontos, começando pela diferenciação nativa entre as perturbações como males de dios ou males de gente, perturbações recebidas como desígnio divino ou perturbações sofridas pela vontade de outras pessoas em aliança com seres não-humanxs. Continuarei com uma classificação do tipo de plantas que xs curiosxs contemplam nas suas magias e terapias: palos ou hierbas. 
Finalizarei com uma incursão no gênero, feminino ou masculino, dxs próprixs curiosxs. O fato de "terem nascido" e serem socialmente percebidxs como mulheres ou como homens define a própria formação do habitus dxs curiosxs. Desta maneira, condiciona o exercício do ofício ora como um risco ou como um serviço, e tende a limitar a relação $\mathrm{dx}$ curiosx com as plantas: o acesso ao cultivo ou colheita de determinadas espécies e a própria possibilidade da sua autoaplicação pela via dos banhos, do fumo ou da ingestão. Há também uma via genderizada que define a maneira como se estabelece a conexão com o mundo não-humano (via icaros ou orações) e finalmente o tipo de perturbações que cada curiosx está mais treinadx para tratar. Elaborei esse trecho do texto com os depoimentos de uma parteira, Zoila, uma sobadora de lisiados, Asteria e um curandeiro, Tocayo; foram três curiosxs que, com suas sensíveis metáforas e eloquentes expressões, ajudaram-me a compreender melhor como é que se constrói o habitus de alguém que trabalha com hierbas, assim como de alguém que trabalha com palos.

\section{- Mal de dios e mal de gente}

Del Carpio (1989), estudioso do folclore peruano, apresenta uma classificação das perturbações que é própria das populações da floresta amazônica do Peru (pp. 124-125):

Enfermedades de Dios: males naturales de orden providencial [que] no dependen de la voluntad humana (...) [y son] ocasionadas por Dios para que el hombre alcance el perdón divino (...) Enfermedades producidas por daño: ocasionadas por el hombre y que no dependen de la voluntad divina $^{198}$.

198 "Enfermidades de Deus: males naturais de ordem providencial [que] não dependem da vontade humana (...) [e são] ocasionadas por Deus para que o homem alcance o perdão divino (...) Enfermidades produzidas por dano: ocasionadas pelo homem e que não dependem da vontade divina". 
As noções de mal de dios e mal de gente fazem parte de uma etiologia dual que diferencia tratamentos a partir da relação de cada perturbação, distúrbio ou malestar com a vontade humana. Desta maneira, se a perturbação, distúrbio ou malestar se originam pela ação de outra pessoa com a intervenção de práticas de curandeirismo, ela é entendida como um mal de gente. Se, pelo contrário, ela tem uma origem espontânea, considera-se parte de um desígnio divino, pelo que tende a ser caracterizada como um mal de dios. A cura do mal de dios deverá ser uma prática ou série de práticas guiadas pela intenção terapêutica, enquanto a cura para o mal de gente deverá ser uma prática ou série de práticas guiadas pela intenção etótropa.

No capítulo 7, observamos que em Tamshiyacu há uma miríade de curiosxs atuantes, tratando os mais diversos tipos de perturbações e desejos, influenciando e sendo influenciadxs pelo sistema oficial de saúde pública que está representado pelo hospital. É assim que, perante os primeiros sintomas de um mal-estar, há uma diversidade de opções disponíveis. Notei que quando as pessoas visitam um/a curiosx no meio de um processo de perturbação, o primeiro objetivo destx é determinar se o mal-estar foi produzido por forças humanas. Isto é, se a perturbação é um mal de gente. As perturbações produzidas pela intenção etótropa se denominam comumente brujerías, daños, trabajos ${ }^{199}$. Se for assim, $\mathrm{x}$ curiosx avaliará a sua competência nessa área ou bem derivarão a pessoa para outrx curios $x$ que trate esses problemas, como um/a curanderx, vegetalista, médicx tradicional ou chamán.

Caso se diagnostique que a pessoa sofre de uma perturbação produzida por outras pessoas, a vida inteira dessa pessoa se transforma a partir de então. Essa

199 "Bruxarias, danos, trabalhos". 
pessoa ingressará em um mundo de icaros, banhos com plantas, sopladas, dietas e até exorcismos. Essa pessoa dedicará uma grande parte das suas energias, a partir de então, a descobri $r$ duas coisas: a pessoa que lhe fez o mal e as maneiras de sarar dele. Nesses dois processos, a ação dx curanderx, vegetalista, médicx tradicional ou chamán é de fundamental importância.

Há algumas pistas que guiam a aventura desta interação entre $\mathrm{x}$ especialista, $\mathrm{x}$ paciente e o mal que lhe foi infligido. O território das perturbações produzidas pela intenção humana, aquele que faz fazer a outrxs humanxs é compreendido um espaço permeável onde outrxs humanxs, por sua vez, podem influir. Desta maneira, todo mal que tem sido produzido em um nível humano é, por definição, passível de ser combatido por humanxs. No meio da imensidade das energias não humanas com as quais xs humanxs convivem na floresta, o território das perturbações produzidas pela gente denota uma autonomia energética a respeito das forças divinas, das forças de dios [deus]. O território dos males de gente é uma espécie de espaço guarda-chuva onde enraízam fenômenos do mundo humano que não dependem da vontade divina, e onde as forças de doença e cura estão sujeitas, primordialmente, à ação transformadora de homens e mulheres.

Se durante a anamnese $\mathrm{dx}$ paciente ficar descartado que a perturbação foi produzida por outra/s pessoa/s, diagnostica-se então um mal de dios. Essa informação é geralmente recebida como uma boa notícia, pois significa um tratamento menos traumático e com menos risco de vida. Também é um tratamento mais autônomo, menos supervisado pelx curiosx em questão. A possibilidade de tratamento de um e outro tipo de perturbação por parte dxs diferentes curiosxs é relativa a duas coisas: o gênero dxs curiosxs e a experiência $\mathrm{dx}$ curios $x$ em questão. No que tange aos condicionantes de gênero, observei que 
a maior parte das mulheres que são curiosas costuma atender pessoas com males de dios, enquanto que a maior parte dos homens curiosos se dedica a tratar pessoas que têm males de gente. No tocante à experiência, costuma-se dizer que aquelxs que são principiantes geralmente tratam os males de dios e os mais avançados já podem tratar os males de gente. O Tocayo, curandeiro de Tamshiyacu, contou-me que no início da sua formação como curandeiro, ele começou curando enfermedades de dios ${ }^{200}$, para mais tarde continuar "avanzando hacia las enfermedades de los hombres" ${ }^{\prime 201}$. Do cruzamento entre experiência de trabalho, gênero dx curiosx e dificuldade das perturbações a serem tratadas, é possível observar que perturbações mágicas que implicam um maior risco de vida se destinam a serem abordadas pelos especialistas homens com maior experiência no ofício. Em sua tese de doutorado com o grupo indígena amazônico sanumá, a antropóloga Silvia Guimarães (2005) observa que o especialista em terapias e magias do grupo, que ela identifica como xamã, é durante toda a sua existência um ser liminar, que habita vários mundos e que, por isso, não está completamente inserido dentro das redes de sociabilidade do interior do próprio grupo. No caso dxs curiosxs de Tamshiyacu, certamente as práticas arriscadas que envolvem a relação com os palos, desde a colheita na floresta até a ingestão (muitas vezes psicoativa e outras inclusive intoxicante) fazem com que as pessoas que melhor sabem tratar os males de gente sejam aquelas que se arriscam a caminhar nas bordas da sociabilidade humana e se relacionam com o mundo que está além dela, isto é, aquelas que têm a capacidade de tomar distância do restante da gente.

\footnotetext{
200 "Doenças de deus".

201 "Avançando até as doenças dos homens".
} 
- As plantas e xs curiosxs

Xs curiosxs do povoado de Tamshiyacu poderiam também ser definidxs em virtude do tipo, da maneira e da quantidade de plantas com as quais trabalham. Para podermos apresentar uma classificação etnográfica de curiosxs e plantas que tenha em conta perspectivas locais, farei um rodeio analítico e me centrarei (focarei), por um instante, em insights etnográficos de dois outros contextos amazônicos.

Clara Cárdenas Timoteo descreve, na sua etnografia do ano 1989 sobre o sistema de saúde shipibo, a formação dos onanya, onaya ou unaya [curandeirxs shipibo] como um processo de vida que envolve a seleção de relações privilegiadas com determinados materiais vegetais. Dentre as milhares de plantas existentes na floresta e as dezenas de plantas de reconhecido uso humano, umas poucas farão parte da botica de ervas dx unaya. Timoteo afirma: "no es necesario dominar todos los secretos de la herbolaria médica para ser unaya. Eduardo Shanuano, unaya del Pueblo de sinuna, afirma: cuestión de plantas medicinales no me enseñaba mi maestro, para eso mi madre que conocía todas las plantas"202 (1989:275). É interessante a aparente pouca importância concedida ao conhecimento de uma diversidade de plantas na formação dxs unayas shipibo. Explorando essas noções um pouco mais, descobrimos que até para xs especialistas que trabalham com plantas, o universo das plantas é um espaço ao qual se acede com algumas restrições.

No seu trabalho etnográfico com as comunidades indígenas asháninka da Amazônia do Peru (2006), o etno-botânico Marc Lenaerts aponta (p.1):

A shaman does not necessarily need to be a good botanist. His main concern is managing a network of personal relationships involving all kinds

202 "Não é necessário dominar todos os segredos da herbolária médica para ser unaya. Eduardo Shanuano, unaya do povo de sinuna, afirma: em matéria de plantas medicinais não me ensinava meu mestre, para isso a minha mãe era quem conhecia todas as plantas". 
of living beings. This network is supposed to be the mainspring of illness a belief shared by both shamans and ordinary people. However, most ordinary people have detailed herbal knowledge. In fact, this everyday herbalism amounts to an alternative explanatory model. Such a coexistence of two contrasting explanatory systems is frequent in Amazonia ${ }^{203}$ (grifos meus).

Tanto para os unaya shipibo que Timoteo retrata quanto para os xamãs asháninka que Lenaerts analisa, o conhecimento sobre as plantas não é, de forma alguma, quantitativo. Desta maneira, não é o manejo de uma maior quantidade de plantas o que permite definir um maior grau de especialização da pessoa como curandeirx. É sim o acesso a certos tipos de plantas.

Tenho observado que no contexto de Tamshiyacu acontece algo similar. Algumas pessoas ostentam uma "erudição prática" que xs coloca como conhecedorxs da imensa variedade das expressões vegetais da floresta e das suas potenciais aplicações à vida humana. Outras pessoas, como xs xamãs asháninka e os unaya shipibo, conhecem umas poucas plantas. No caso deste último grupo, é a própria experiência de contato com essas plantas específicas e com os espaços geográficos onde elas crescem e prosperam o que define a sua competência como curiosxs. As plantas que $\mathrm{x}$ curiosx conhece melhor são aquelas com as que já fez dieta, já manteve algum tipo de comunicação mágica, já receberam icaros dela ou já houve um processo de auto-cura.

Na localidade, as experiências com as plantas não são determinadas, mas sim certamente condicionadas, a partir de esquemas genderizados entre as polaridades

\footnotetext{
203 "Um xamã não precisa ser, necessariamente, um bom botânico. A sua maior preocupação é a de gerenciar uma rede de relações pessoais que envolvem todas as classes de seres vivos. Essa rede é considerada a força que contém a doença - uma posição compartilhada tanto por xamãs quanto por pessoas comuns. De todas as formas, a maioria das pessoas comuns possui um detalhado conhecimento de ervas. De fato, esse herbalismo cotidiano senta as bases para um modelo de explicação alternativo. Tal coexistência dos dois sistemas de explicação é frequente na Amazônia".
} 
do masculino e do feminino. A metáfora dos palos e das hierbas define bem essa relação disposta de acordo aos gêneros entre xs curiosxs e o abundante mundo das plantas da floresta. Diremos, a princípio, que os palos são dos homens. Xs curanderxs, vegetalistas, médicxs tradicionales ou chamanes têm um conhecimento mais detido em umas poucas plantas com as quais se comunicam de maneira direta, as que guiam a sua experiência. Por sua vez, diremos também que as hierbas são das mulheres. As pessoas que são yerberas, sobadoras, parteras e naturalistas se viram afetadas pela relação com um número determinado de hierbas, levando em conta uma diversidade de plantas aliadas.

Curiosos dos palos, curiosas das hierbas. A maioria dos primeiros, homens; a maior parte das segundas, mulheres. Construindo a trama de dois universos diferentes, regidos por lógicas diversas. De um lado xs curanderxs, vegetalistas, médicxs tradicionales ou chamanes, com um conhecimento profundo de umas poucas plantas; e do outro xs yerberxs, sobadorxs, parterxs e naturalistas, com seu conhecimento pontual de uma diversidade enorme de plantas. Nessa relação entre a perturbação, a planta e $x$ especialista que se encontra condicionada em termos de gênero, encontram-se as experiências, únicas e originais, dxs sujeitxs.

Nesse ponto, parece significativo destacar que o desentranhamento dessa relação específica entre plantas, perturbações e especialistas significou um antes e um depois na estruturação desta tese, assim como a possibilidade de abrir, pela chave do condicionamento de gênero, uma porta para o complexo mundo das magias e terapias locais. Xs curiosxs locais sabem como os processos sociais e corporais que envolvem a si mesmxs e seu entorno podem ser lidos na linguagem dos palos e das hierbas, e diagnosticam e tratam das perturbações, construindo os corpos e recriando o mundo a partir dessa percepção. 


\section{- Palos e hierbas}

A antropóloga brasileira Juliana Salles Machado realizou a sua pesquisa de doutorado entre benzedeiras do delta Amazônico, do lado brasileiro, no ano 2012. $\mathrm{Na}$ tese, ela analisa as diferentes tarefas que correspondem a experientes/pajés por um lado, e benzedeiras/parteiras, pelo outro. Os experientes são sujeitos que realizam curas e atos mágicos por meio do diálogo com os "encantados" - entidades correspondentes a todo tipo de espíritos nãohumanos que se encontram nas plantas, em espaços geográficos ou que correspondem a mortos ou entidades da natureza. Dentro desse grupo, os pajés são reconhecidos como os experientes mais poderosos. Na tese, as referências aos experientes/pajés se encontram todas no masculino. Entretanto, as benzedeiras aparecem sendo sempre mulheres. Essa divisão tão clara em termos de gênero me trouxe de volta para a análise dxs curiosxs de Tamshiyacu. Comecei então a prestar atenção para um entendimento mais amplo que fizesse correspondência entre certas maneiras de fazer com plantas e a atribuição social ao gênero masculino ou feminino.

O antropólogo peruano Freder Arredondo Baquerizo (2006) redigiu a sua dissertação de mestrado estabelecendo relações com uma série de princípios dualistas ao redor dos quais se organizariam as terapias do sistema de saúde tradicional andino. Ele sustenta que as mesmas se organizam em torno do (pp. 67)

.... diagnóstico y tratamiento de enfermedades o síndromes culturales con una connotación dual simbólica de valores relativos, contextuales y circunstanciales basados en: cualidades térmicas de frío-calor (...) género: macho-hembra, jerarquía: arriba-abajo, posiciones: derecha-izquierda, interno-externo, biosocial: cuerpo-alma, ciclo biológico: maduro-tierno, fisiopatológico: bien-mal; las mismas que se adscriben e interactúan según 
(...) el equilibrio psicosomático del hombre en relación a la sociedad, la naturaleza y lo sobrenatural ${ }^{204}$.

Essa série de dualismos representa o que, para ele, é a organização polar das terapias locais. Arredondo Baquerizo (2006) observa que, dentro dessa polaridade, a genderização do mundo vegetal assume um lugar de importância (p. 67):

Los vegetales machos se distinguen por su aspecto físico externo, en primer término la solidez, robustez y podría decirse cierta rudeza (...) Contrariamente las llamadas hierbas hembras se distinguen por la delicadeza y esbeltez externa y por sus propiedades intrínsecas en general suaves, benignas, atenuadas cuando son frígidas y aumentadas cuando son cálidas (...) [por su vez], generalmente las plantas machos se caracterizan por ser de hojas más grandes, alargadas, colores "fuertes" y en algunas con vellosidades y las hembras generalmente son de hojas pequeñas, redondeadas, colores tenues (...) Según las circunstancias una misma planta puede ser "macho" o "hembra", estas adscripciones a uno y otro género son relativas acorde a la percepción cultural de los pobladores andinos ${ }^{205}$.

Muito interessante é a descrição deste mundo dual organizado em torno da genderização do mundo vegetal, da qual fazem parte as formas, as cores e os tamanhos das plantas em questão. Também é expressiva a relação cruzada que o

$204 \quad$ "... diagnóstico e tratamento de doenças e síndromes culturais com uma conotação dual simbólica de valores relativos, contextuais e circunstanciais baseados em: qualidades térmicas do frio-quente (...) gênero: macho-fêmea, hierarquia: acima-embaixo, posiçôes: direita-esquerda, interno-externo, bio-social: corpo-alma, ciclo biológico: maduro-terno, fisiopatológico: bem-mal; as mesmas que se adscrevem e interagem segundo (...) o equilíbrio psicossomático do homem em relação com a sociedade, a natureza e o sobrenatural".

205 "Os vegetais machos se distinguem por seu aspecto físico externo, em primeiro termo a solidez, robustez e poderia se dizer certa rudeza (...). De maneira contrária, as chamadas ervas fêmeas se distinguem pela delicadeza e esbeltez externa e pelas suas propriedades intrínsecas pelo geral suaves, benignas, atenuadas quando são frígidas e aumentadas quando são cálidas (...) [por sua vez], geralmente as plantas machos se caracterizam por serem de folhas maiores, alargadas, cores 'fortes' e em algumas com pelo e as fêmeas são geralmente de folhas pequenas, arredondadas, com cores ténues (...) Segundo as circunstancias, uma mesma planta pode ser 'macho' ou 'fêmea', esses vínculos com um e outro gênero são relativos à percepção cultural dos nativos andinos". 
autor faz entre plantas cálidas e frias e entre plantas machos e plantas fêmeas que, ainda potencialmente produtiva, não foi explorada nessa tese.

Inspiradxs no caso andino, voltamos para o caso de Tamshiyacu. Da mesma maneira que nas altas cumbres do país, também na floresta amazônica é possível observar uma forte genderização do mundo vegetal. Os palos e as hierbas aparecem como sendo uma metáfora recorrente, que organiza os espaços onde crescem as plantas e que condiciona a forma com que x curios $x$ vai se relacionar com elas. De maneira explícita ou implícita, ela retrata diversos aspectos relativos aos domínios simbólicos do masculino e do feminino nos campos da terapêutica e da magia local. Essa metáfora não se instala somente no plano do simbólico: ela também é uma ferramenta que demarca uma série de práticas concretas que condicionam a comunicação/proximidade com as plantas e xs outrxs sujeitxs sociais. Para fins desta análise, elaborei duas tabelas que dão conta desses contrastes, organizando a experiência dxs curiosxs locais.

No seguinte gráfico (Tabela 5) descrevo de maneira esquemática a relação entre gênero, classificação $\mathrm{dx}$ curiosx, tipo de perturbação e tipos de plantas com os quais essas perturbações se tratam. A tabela se organiza como segue:

Tabela 5: Gênero, especialista, perturbação e planta

\begin{tabular}{lll}
\hline Gênero & Feminino & Masculino \\
\hline Especialista & yerberas, sobadoras, & curanderxs, vegetalistas, \\
parteras e naturalistas & $\begin{array}{l}\text { médicxs tradicionales ou } \\
\text { chamanes }\end{array}$ \\
Perturbação & mal de dios & mal de gente \\
Tipo de planta & hierbas & palos \\
\hline
\end{tabular}


Na outra tabela (Tabela 6) desdobro a classificação básica dos palos e das hierbas em torno do contexto etnográfico em questão, ressaltando a condição genérica do especialista manipulador e sua particular relação com os dois grupos de plantas: as maneiras com que elas são aplicadas, a sensação que suscitam no corpo, uma breve lista de algumas espécies privilegiadas, a localização delas no espaço, as partes da planta mais comumente utilizadas, o tamanho físico dos vegetais, as pessoas que costumam ser indicadas para essas plantas, a qualidade delas no sistema de apreciação frio/quente (ver também o capítulo 6) e, finalmente, as situações (perturbações ou atos mágicos) que elas tratam. Distribui as variáveis como segue:

\section{Tabela 6: A divisão do mundo segundo palos e hierbas}

\begin{tabular}{|c|c|c|}
\hline & Palos & Hierbas \\
\hline Condição genérica & Masculina & Feminina \\
\hline Especialista manipulador & $\begin{array}{c}\text { chamanxs, curandeirxs, vegetalistas, } \\
\text { médicxs tradicionais, sobadorxs de lisiadxs, } \\
\text { purguerxs }\end{array}$ & $\begin{array}{l}\text { yerberxs, parteirxs, sobadorxs [de mulheres } \\
\text { grávidas], naturalistas }\end{array}$ \\
\hline Aplicação & $\begin{array}{l}\text { Costumam ser preparadas na água ou } \\
\text { no álcool. Esses líquidos se chamam de } \\
\text { purgas. Elas também podem ser } \\
\text { aplicadas em forma tópica, como parche } \\
\text { usando as partes mais moles da planta. }\end{array}$ & $\begin{array}{l}\text { Usualmente, bebem-se chapeadas na água } \\
\text { fria ou tíbias em infusão. Também se } \\
\text { colocam no corpo em forma de banhos } \\
\text { de assento, cataplasmas, vaporizações } \\
\text { [vapor vaginal], fricções e duchas } \\
\text { corporais. }\end{array}$ \\
\hline
\end{tabular}

Sensação
Geralmente, possuem sabor e cheiro intensos. Preparam-se de maneira concentrada. Muitas delas possuem propriedades farmacológicas relacionadas com o alívio de dores reumáticas, a eliminação de tumores, a prevenção do câncer. São usualmente psicoativas. Segundo a percepção local, agem de maneira direta no corpo, limpando suas impurezas e excessos. Muitas das vezes incomodam: geram
Geralmente, possuem sabor e cheiro suaves. Preparam-se de maneira diluída.

Muitas delas possuem propriedades farmacológicas emolientes, antiinflamatórias, antipiréticas e diuréticas. Muitas delas se usam para tratar lesões ligadas aos órgãos reprodutivos femininos. Outras são indicadas para facilitar o trabalho de parto. 
cansaço, enjôos, sonolência, visões.

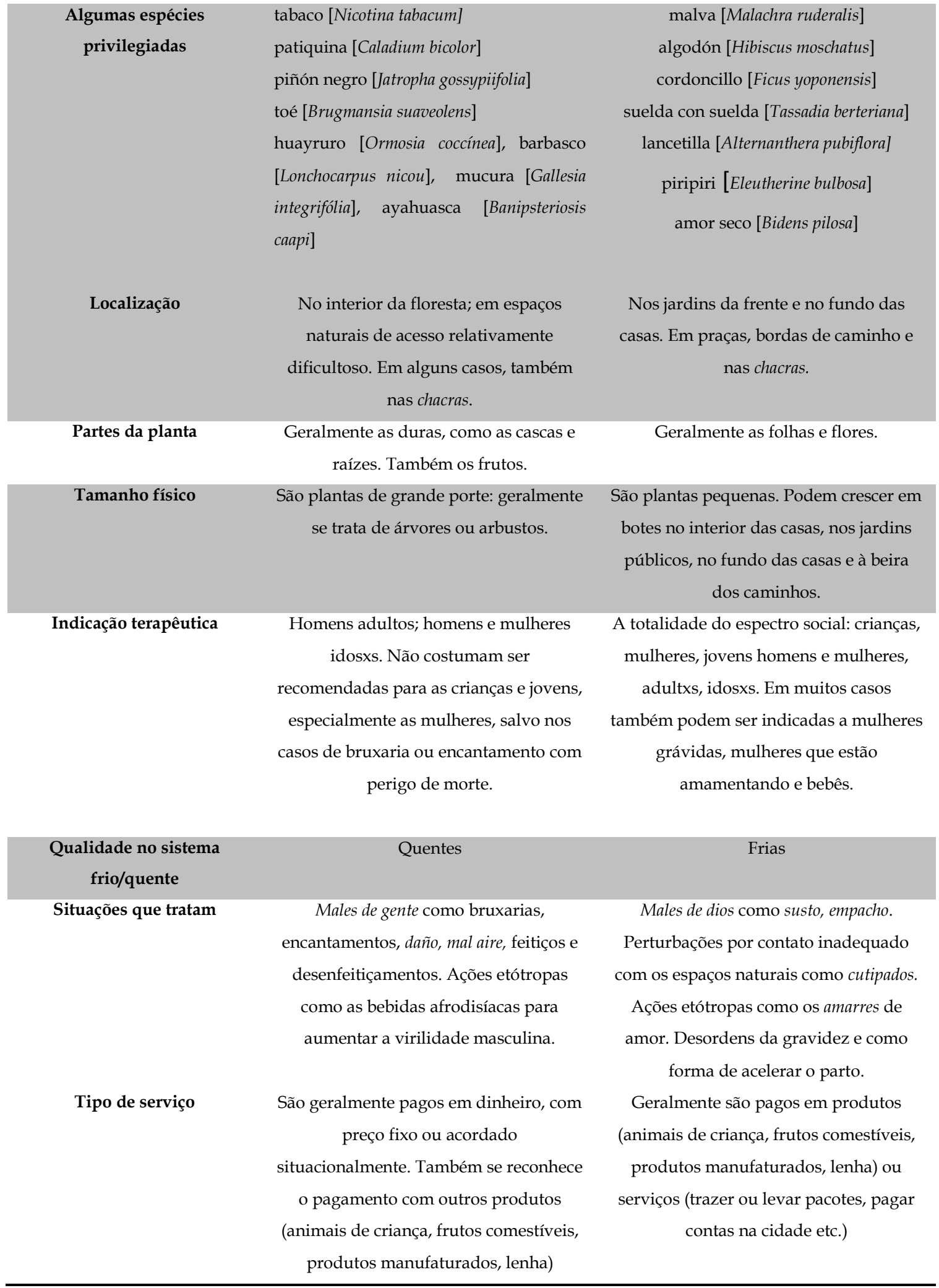


Nessa correspondência entre especialidades, gênero e grupos de plantas, estão vinculadxs com os palos as pessoas que se autodefinem como chamanxs, curandeirxs, vegetalistas, médicxs tradicionais e purguerxs. Por sua vez, encontram-se relacionadas com as hierbas aquelas pessoas que se entendem como yerberxs, parterxs, sobadorxs [de mulheres grávidas] e naturalistas. Também há atitudes e maneiras de fazer que diferenciam os dois grupos. A ação de quem se relaciona com os palos é intensa e específica: procuram-se plantas que provêm do mundo dos palos para apreender os segredos do mundo vegetal, para fortalecer o sangue, para combater bruxarias e perturbações graves. Esses vegetais contam com espíritos que se personificam com facilidade, e circulam nas conversas e histórias das múltiplas formas, geralmente assustadoras, que elxs podem assumir. As ações de relação com as plantas e os espíritos do mundo dos palos são tidas como perigosas: requerem coragem da pessoa que as encara, virtude tida como sendo eminentemente masculina dentro do mundo amazônico.

A ação humana relativa às hierbas é diferente. Tanto no que faz aos espaços onde elas são recolhidas, à atitude com a qual x curios $x$ se aproxima delas e ao espírito que elas personificam. Outros espaços amazônicos sustentam uma relação similar. Salles Machado afirma (2012: 281) em sua abordagem das plantas usadas pelas benzedeiras na ilha de Caviana, no Pará:

As plantas sendo vegetais são filhas das "mães-do-mato" ou da "mães-doslugares" e contêm em si poderes terapêuticos relacionados a sua origem. No entanto, possuem pouca agência, ou uma agência secundária (...), e não assumem uma forma antropomorfa, ou seja, não conseguem por si só utilizar seus poderes.

Em Tamshiyacu também se entende que os espíritos das hierbas são mais leves e menos imponentes do que os espíritos que emanam dos palos. 
Consequentemente, eles requerem outra atitude para ativá-los. Aqui, não é tanto a vocação de risco, mas sim a de serviço, a que marca o modo com que a mão das curiosas colhe, prepara e dá para consumir as ervas. Quando em contato com o corpo, a ação das hierbas é menos intensa, porém, ela é constante. Seu poder parece se situar no inespecífico, no invisível, no que permanece por baixo dos processos aparentes.

\section{- Vocações: as práticas de risco, a coragem e o serviço}

No mês de agosto, durante o segundo mês da minha gravidez, eu fui visitar o curandeiro Tocayo. Fiz algumas entrevistas, vi como ele atende a alguns pacientes e tirei algumas fotos do consultório, instalado na sala da casa dele, e de algumas performances de cura a crianças. Até aí, havíamos tido três encontros em duas semanas e já me sentia confortável na presença dele. Na semana seguinte, fui já não como antropóloga, mas como paciente. O motivo disso é que vinha me sentindo extremamente débil, com pesadelos e medos recorrentes. Tinha medo de perder a gravidez. Como tantas outras pessoas em Tamshiyacu, começava a interpretar meus sintomas como sendo parte de um possível mal de gente. "Acá los miras fuerte y ya te echan un daño"206, ressoam em mim as palavras de Eva, vendedora do mercado.

Um anoitecer desses de agosto, depois de um escaldante sol diurno, encaminheime para a casa do Tocayo. Esperei que entrassem no consultório três pessoas que estavam antes de mim. Quando chegou minha vez, ele me fez sentar. Expliqueilhe brevemente a minha condição, e meus medos de que o estranho estado em que me sentia tivesse a sua origem em algum tipo de mal de gente. "Vamos a

206 "Aqui você os olha com força e já te lançaram um dano". 
ver ${ }^{\prime \prime 207}$, me disse. Pediu-me para ficar em pé. Tirou uma garrafinha d'água que descansa em cima de uma estante, onde também havia a imagem de um santo (San Francisco, acredito) e uma sacola transparente cheia de mapachos. Soprou na água, começou a entoar uma melodia que se iniciou leve e foi ascendendo seu volume. Era um icaro. Enquanto cantava, molhou o dedo na água e me fez cruzes: nas palmas das mãos, nas costas, na frente, nos pés. Depois, passou o tão precioso elixir da agua florida pela minha coroa. Acabou de cantar o icaro. Passou a agua florida pela coroa dele, os ombros, os braços. Tirou a chacapa e fez vibrar as suas folhas no ar. Diferentemente da que usam outrxs curandeirxs, a chacapa do Tocayo não tem muitas ramas. Quando raspa no ar, vibra com um som parecido ao daqueles insetos que na floresta chamam de chicharras [Quesada gigas; em português, cigarras] que cantam quando vai chover. Enquanto mexia a chacapa ritmicamente, começou a entoar um novo icaro. O instrumento de folhas vibrava próximo dos mesmos lugares onde tinha sido colocada a água. Sem tocar o meu corpo, o Tocayo o expus a um segundo elemento de limpeza mágica. Um terceiro elemento veio imediatamente depois, reforçando o caminho traçado pelos outros: era a fumaça do tabaco de um mapacho especialmente aceso para finalizar a limpeza. Enquanto a água, as vibrações vegetais e a fumaça do tabaco eram acionados no meu corpo, soava um icaro que pedia, em espanhol, pela minha proteção. O icaro acabou abruptamente quando a fumaça do tabaco percorreu todos os lugares onde já tinha passado a água e a vibração da chacapa. O Tocayo me pediu para sentar. Enquanto eu me sentei, ele permaneceu de pé, olhando para a brasa que se consumia na ponta do mapacho. Sem mudar de posição, ele continuou fumando por um tempo não maior do que um minuto. Depois disso, ele me disse que não há mal de gente no meu corpo, mas o simples desarreglo [desarranjo] que é próprio da gravidez. Pediu-me para voltar por mais dois dias,

207 "Vamos ver". 
com a finalidade de ajudar, através dos icaros, a componer [compor] o corpo, isto é, devolver-lhe seu estado de integridade física e espiritual.

A chacapa é um elemento fundamental nas consultas que se fazem nos consultórios dxs curandeirxs: diagnostica o estado de um corpo, chama aos espíritos das plantas para perto de sim, protege da possível interferência de espíritos negativos. Mas isso não é usado por todxs os curiosxs. Vejamos os detalhes disso. Nos relatos de outrxs especialistas de Tamshiyacu, é habitual a busca de apoio na presença e vontade do Deus cristão na hora de realizar os próprios trabalhos. "Solamente Dios es el médico de médicos", afirma Zoila, a parteira. Asteria, sobadora de lisiados, é católica praticante e María, parteira, reza à Virgen Maria. A mesma dona María, em entrevista que tenho com ela no mês de outubro de 2013, contou-me a sua posição: "Yo no uso la chacapa. Eso es cosa de chamanes. Yo con el mapacho [cigarro de tabaco puro] curo nomás" 208 . O receio não se limitava a ela somente. Quando perguntei para a curandeira Zoila se ela cantava icaros, ela me respondeu:

- No señorita, eso sí no... eso se corre riesgos... mucho enemigos hay (...)

- Y chacapa usa?

- No. Eso ya es cuando son los chamanes. Yo simplemente soy una partera tradicional $^{209}$.

Zoila se reconhece, simplesmente, como uma parteira tradicional. Não há complicação nisso. Às vezes, não há sequer muitas palavras estabelecidas no discurso público para explicitar a própria prática. Essa janela de silêncio é, aos fins do presente trabalho, provocativa. Trago aqui, à maneira de exercício meta-etnográfico, a conversa que Salles Machado destaca. O diálogo se dá

"Eu não uso a chacapa. Isso é coisa de xamãs. Eu somente curo com o mapacho". 
entre ela e dona Tereza, benzedeira privilegiada na sua etnografia: "Pergunto pela diferença entre o pajé e ela, benzedeira, e ela responde: 'a diferença não é nenhuma, mas eu não sou pajé"'" [minha ênfase] (Salles Machado, 2012: 271).

A dona Tereza se define por uma operação de negação: o que ela não é. Tal operação indica que há mais palavras para falar sobre aquilo que não se é do que sobre aquilo que, efetivamente, se é. A mesma coisa acontece com as mulheres que trabalham no mundo das hierbas em Tamshiyacu. Como a dona Tereza da etnografia citada, na localidade nem Asteria, nem María, nem Zoila se chamam a si mesmas como chamanas ou sequer como curandeiras. De igual modo, não incluem nas suas práticas mágicas ou terapêuticas a chacapa, nem cantam os icaros. Elas afirmam que a sua conexão com as realidades extraordinárias se propicia através da oração a deus.

De forma diferente, observei que, para as pessoas que costumam trabalhar com palos e combater (ou acionar) os males de gente, o horizonte de relações com o mundo do não-humano se constrói de uma maneira diferente. Enquanto parteiras e sobadoras se curvam em oração a um único deus, xs curiosxs que se encontram mais perto do mundo dos palos costumam pedir ajuda a seres com os quais se encontram em uma situação de relativa horizontalidade. Diferente do ato de ajoelhar-se, pedir a colaboração do espírito de uma planta, por mais assustador que ele seja, aparece aqui como um ato de coragem e empoderamento. Os seres extraordinários contidos nas plantas são seres que gostam de fugir, criar conflitos, aparecer pelas costas e assustar aquelxs que estão desprevenidxs. Ademais, eles têm interesses próprios. Não há nesses polimorfos sujeitos uma noção de bem nitidamente definida: por trás da dimensão material das folhas de cada planta com a qual se estabelece um diálogo há uma vida de gênios vegetais que podem fazer o bem assim como propiciar o mal no nível 
humano. Desta maneira, cantar icaros e usar a chacapa não é a mesma coisa que rezar orações a Deus. As duas atitudes exigem certa predisposição, certa relação com o mundo do extraordinário que aqui chamo de vocações de risco, por um lado e de serviço, pelo outro.

Para compreender como é que se entende um/a curios $x$ a si mesmx e qual costuma ser a própria atitude para encarar o trabalho diário, é interessante conhecer alguns relatos de primeira mão referentes à maneira com que elxs apreenderam seu ofício. Essas narrativas dão conta de fontes diversas de aprendizado: umas humanas, outras não humanas. Tomarei as entrevistas que realizei com duas mulheres, Asteria e Zoila, e também com um homem, o Tocayo, xs quais me fizeram referência aos caminhos que atravessaram sua própria formação como curiosxs.

Zoila tem uns sessenta anos e mora na periferia de Tamshiyacu. Tanto ela como outrxs membrxs da sua família vendem no mercado o plátano, pescados e carnes de monte que obtêm da própria chacra [terra familiar de plantio, caça e pesca]. Mas ela também se reconhece como partera tradicional. Em uma entrevista do mês de outubro de 2013, Zoila me comentou que sempre lhe agradou aprender por meio da observação:

Y a mí me gusta mirar pues toda cosa, aprender... porque a veces no se tienen los recursos... no hay trabajo... y a veces es así... el señor es para todos, nos escucha! Difícil es para mi ir al hospital ${ }^{210}$ (grifos meus).

A curiosidade, compreendida como a condição ativa de se interessar pelo que existe no próprio espaço, aparece aqui como uma atitude chave que muitas vezes desencadeia o processo de aprendizado das artes do cuidar, curar e fazer magia

210 "Eu gosto de olhar para toda coisa, aprender... porque às vezes não temos os recursos... não há trabalho... e às vezes é assim... o senhor é para todos, nos escuta! Difícil para mim é ir para o hospital". 
no mundo das hierbas. Zoila, como muitxs outrxs curiosxs, enfatiza a importância do aprender mirando, por meio de uma atitude aberta perante o desconhecido. Nesse caminho, que é acessível para todxs, há uma simplicidade e uma leveza daquelx que observa o que é quase óbvio, e o modifica a partir de pequenas intervenções. Assim, frente ao caótico mistério do mundo, xs curiosxs o ordenam com praticidade e minúcia. Ao mesmo tempo, a curiosidade aparece como sendo, por si mesma, um trabalho que ajuda a fazer frente às carências. Uma ocupação frente à falta de trabalho do mundo do comércio, dos escritórios. E uma ocupação que aparece como sendo ajuda de deus, destinada a ajudar, por sua vez, às outras pessoas.

Asteria Yauarcani tem uns sessenta e cinco anos, é sobadora de lisiados e também costureira. Mora no centro de Tamshiyacu, em uma casa que ostenta uma bela planta de patiquina [Caladium bicolor] na sua frente. Ela aprendeu o ofício de sobadora da mãe dela, que era partera e sobadora de mulheres grávidas assim como também sobava lisiados. Nesse delicioso trecho, gravado em entrevista em agosto de 2013, Asteria expressa a importância dos sentidos colocados na direção do aprendizado do ofício:

Viendo he aprendido de mi mamá. Ella era partera y sobaba el hueso. Ella se fue, a mí me ha quedado. Yo veía todo. Cómo sobaba! Y de ahí yo solita me di valor. Cuando ellos venían, yo les sobaba. Hay los huesos que suben. Se sube el brazo y el hueso queda chiquito. Esos enderezco yo. Así, varios enderezco. Que están doblando el hueso, también les enderezco así. Los que están flotando también. Yo tengo los preparados que hago con el unto del chancho. Eso se lo amaso, se lo amaso, le echo alcanfor, timolina, agua florida... y eso te cura. De ahí aprendí. Ah, tengo bastantes experiencias! Me buscan bastante. Yo soy curiosa, me gusta mirar como es. Todo es bonito, cuando se nace para eso, todo eso nos gusta. A mí me gusta. Soy curiosa, miro cómo es todo o sea eso. No hay que tener miedo. Si hay un 
hueso chancado, no hay que tener miedo. Hay que cobrar valor para hacer alguna cosa. Es lo que hago yo. Salvarle a las personas! ${ }^{211}$

Assim, Asteria conta como ela aprendeu olhando a interação entre outra curiosa (nesse caso, a mãe dela) e xs pacientes dela. Certa mimese entre a sua mãe e ela se repete, a partir de então, em cada ato terapêutico ou mágico. Ademais, na base da coragem e da observação, Asteria foi apreendendo mais. Ela conta como foi precisou aguçar seus sentidos olhando para o corpo das outras pessoas e aprendeu a controlar o medo. Medo da dor dx outrx, receio dos ossos quebrados dentro do corpo, temor de não poder ajudar.

Asteria foi aprendendo a exercitar as diversas tarefas relativas ao ofício: conversar, tocar e perceber o tom e a temperatura corporal, reconhecer os movimentos, texturas e formas do corpo, observar a reação perante a dor para poder fazer um diagnóstico. Então, aprendeu a preparar os remédios com a planta indicada e tratar a área afetada com massagens, com sobadas. Todo esse processo, onde o corpo dela e o dx sujeitx que a procura estão em íntima interação, requer uma atitude sem medo, focalizada, sem dúvidas nem receios, na matéria urgente do corpo dolorido.

Wilson Vázquez, el Tocayo, tem uns quarenta e poucos anos e mora na saída do povoado, na direção do ex-balneário de Flores. Ele pondera que ser curandeirx

211 "Vendo é que eu tenho aprendido da minha mãe. Ela era parteira e sovava o osso. Ela foi embora, eu tenho ficado. Eu via tudo [o que ela fazia]. Como sovava! E a partir dai eu sozinha peguei coragem. Quando eles vinham, eu thes sovava. Há desses ossos que sobem. Sobe o braço e o osso fica pequenininho. Esses são os que eu corrijo. Assim, vários eu corrijo. Esses ossos que estão dobrados, esses também corrijo eu. Aqueles que estão flutuando também. Eu tenho os preparos que faço com o unto do porco. Isso eu amasso, eu coloco alcanfor, timolina, agua florida... isso te cura. Dali foi que eu aprendi. Ah, tenho bastantes experiências! Procuram-me bastante. Eu sou curiosa, gosto de olhar como é que é. Tudo é bonito, quando se nasce para isso, de tudo isso nós gostamos. Eu gosto. Sou curiosa, eu olho como é tudo, ou seja isso. Não há que ter medo. Se há um osso partido, não há que ter medo. Há de se ter coragem para fazer alguma coisa. Isso é o que faço eu. Salvar a vida das pessoas!". 
não é uma ocupação qualquer, mas é um dom. E sustenta que, das coisas que se apreendem, elas não se aprendem de humanxs, mas sim diretamente das entidades da floresta:

Para algunos, el don de hacer el bien. Para otros, el don de hacer el mal. Esos, por más que se esfuercen, no pueden hacer el bien. Por eso, enseñar a otro a ser curandero es irresponsable. Uno no puede saber nunca a quién está enseñando. La persona tiene que irse solita a la montaña y ahí aprender de las plantas (...) Nosotros los curanderos tenemos un camino muy solitario. Cuando yo comencé, éramos varios de la familia en el mismo grupo. Pero ahí ya uno quiso ser más, y los otros hicieron lo que él quería... En este trabajo cada uno tiene que saber lo que va aprendiendo, lo que es para él. Si tuviéramos todos lo mismo, de la misma fuente, sabríamos lo mismo. Pero hemos nacido cada uno en horas diferentes, no somos iguales y recibimos cada uno cosas distintas ${ }^{212}$.

Ainda que nos relatos de Zoila e Asteria seja possível identificar um componente relativo à vocação, à importância de ter nascido curiosa pelas coisas do mundo, ou de ter recebido esse presente de deus, elas enfatizam o aprendizado por meio da observação das pessoas mais velhas. No caso de Zoila, foi uma tia paterna que ela observou, no caso de Asteria, a própria mãe. Porém, o Tocayo não tinha ninguém da família que fosse curandeiro. Várias pessoas da família começaram a querer aprender a serem curandeirxs juntxs, e isso foi, para o Tocayo, um terrível erro. Não há possibilidade de aprender a partir dos ensinamentos de pessoa nenhuma, não há possibilidade de aprender junto a outras pessoas. $\mathrm{O}$ aprendizado é na solidão, nos próprios termos, e na única companhia desses sutis seres extraordinários que são os espíritos das plantas. O mundo é um

212 "Para alguns, o dom de fazer o bem. Para outros, o dom de fazer o mal. Esses, por mais que se esforcem, não podem fazer o bem. Por isso, ensinar a outro a ser curandeiro é irresponsável. Agente não pode saber nunca a quem está ensinando. A pessoa tem que ir sozinha à montanha e lá apreender das plantas (...) Nós os curandeiros temos um caminho muito solitário. Quando eu comecei, vários pessoas da familia estávamos no mesmo grupo. Mas então teve um que quis ser mais, e os outros fizeram o que ele queria... Nesse trabalho cada um tem que saber que o que cada um vai apreendendo, é para si mesmo. Se tivéssemos todos o mesmo, da mesma fonte, sabreriamos o mesmo. Mas temos nascido cada um em horas diferentes, não somos iguaiss e recebemos cada um coisas distintas". 
espaço onde aprender pode ser interminável: não há uma única fonte para aprender. Cada um/a, pelo fato de ser diferente desde o preciso momento da hora do seu nascimento - pois diferente é a hora do próprio nascimento à de qualquer outra pessoa -, deve apreender o mundo por si mesmx.

Vejamos dessa vez um novo relato, o de Zoila, partera de Tamshiyacu. Em uma entrevista que eu e Carl fizemos na casa dela no mês de setembro de 2013, Zoila nos contou que ela começou a ajudar a outras pessoas a partir da necessidade vital de salvar a própria vida. O processo foi assim: Zoila sofreu durante a adolescência de uma doença mortal, que foi produto da bruxaria realizada por outra mulher sobre a mãe dela. Ela narra:

O sea que yo he caído en un mal que no era para mí... si hubiese sido para mí, ahí nomás me hubiese quedado... yo no podía ni orinar, no podía ni caminar, para orinar una gota de sangre me costaba lágrimas... y ese mi rodilla se me ha hecho así, como unas cabezas... se me hinchaban ... ella me había [echado un embrujo]... así he sufrido como un mes. Gracias a Dios que ha habido un señor que me ayudó... a muchas personas que también las salva las medicina de las plantas ${ }^{213}$.

Foi assim que Zoila salvou a vida da mãe colocando, involuntariamente, a sua própria vida em risco. Para isso, ela precisou da ajuda de um curandeiro, um homem que salvou a vida dela com a ajuda das plantas. Zoila reconhece o ofício de curandeira como sendo uma atividade corriqueira na sua linha familiar de origem, que envolvia algumas das suas ancestrais mulheres. E conta:

Mi tía Nisia era curandera. De Yacapana, la comunidad de donde yo vengo. Ella trabajaba con gente del agua. Ella tenía unos encantos, que eran como unas cabecitas de personas. Ella icaraba, soplaba. Mi papá recibía a la gente. Ella estaba echada. Como banco. Ahí ella hacía sus oraciones. Después le

213 "Eu caí em um malefício que não era para mim... se tivesse sido para mim, ali mesmo eu teria morrido... eu não podia nem urinar, não podia nem caminhar, para urinar uma gota de sangue custava lágrimas... e meus joelhos ficaram assim, como duas cabeças... inchadas... ela [uma mulher] lançou o maleficio... assim foi que sofri perto de um mês. Graças a Deus, um homem me ajudou... muitas pessoas também são salvas pela medicina das plantas". 
levantaban. Ella hablaba idioma. Mi papá también quería ser curandero. El ha dietado año tras año, pero nunca ha podido serlo. Es que él no quería recibir lo malo, "no quiero matar a la gente", él decía. Curioso era, convidaba remedios vegetales. El convidaba, pero no curaba. Quizás sería yo también curandera, pero he pedido a Dios que no quería. Tanto que tomaba yo los vegetales. Ah! Yo veía clarito. Oía. Pero no le hacía caso. Solamente oraba, y [la presencia] se retiraba. Queriendo ser curandera, qué tiempo ya que sería curandera! Pero es un peligro ser curandero. Muchos enemigos. Persiguen. Y para eso mejor no, pues. Por eso me he metido en los partos. Ahí si me he metido. Hasta ahorita ${ }^{214}$.

Nisia, tia paterna de Zoila, era reconhecida com a categoria mais alta do curandeirismo shipibo e também mestiço: a posição de banco [bruxo superior]. Já o pai de Zoila escolh era um caminho diferente: o da prudência por sobre o risco. Com isso, define um escopo de ações mágicas e terapêuticas de caráter diferente daquele da irmã dele. Enquanto aprender a fazer grandes curas envolve aprender também a fazer grandes daños [danos], e isso envolve perigo para si próprio e para a família, ele escolhe somente convidar remédios vegetais.

Parecida com a do próprio pai é a escolha de Zoila. Ela possui muitas condições: ela tem a curiosidade, um background de trajetória familiar e capacidade para ver e ouvir realidades extraordinárias. Tudo isso faria dela uma pessoa potencialmente apta a exercer as artes do curandeirismo. Mas, apesar de preparar ela mesma os remédios com plantas e de fazer trabalhos contra manchari

214 "Minha tia Nisia era curandeira. De Yacapana, a comunidade de onde eu venho. Ela trabalhava com gente d'água. Ela tinha uns encantos, que eram como umas cabecinhas de pessoas. Ela icaraba, soplava. Meu pai recebia às pessoas. [Enquanto isso], ela estava deitada. Como banco. Aí ela fazia suas orações. Depois a levantavam. Ela falava uma língua indígena. Meu pai também queria ser curandeiro. Ele dietou ano trás ano, mas nunca conseguiu. É que ele não queria receber o que era do mal, "não quero matar às pessoas", ele dizia. Curioso era, convidava remédios de vegetais. Ele convidava, mas não curaba. Talvez eu poderia ter sido curandeira, mas eu tenho pedido a Deus que não queria.Tanto que tomava eu os vegetais. Ah! Eu conseguia ver tudo claro. Ouvia. Mas eu não fazia caso. Somente orava, e [a presença] se retirava. Querendo ser curandeira, já teria sido eu faz tempo uma curandeira! Mas é um perigo ser curandeiro. Há muitos inimigos. Eles te perseguem. E para isso, melhor não. Por isso é que tenho me metido nos partos. Ali mesmo tenho me metido. Até agorinha". 
[mal do morto], susto [perda temporal da alma] e daño [dano], Zoila não se reconhece como curandeira nem como xamã. Ela se assume como, simplesmente, uma partera tradicional.

Com o explícito intuito de evitar os riscos que envolvem o exercício do curandeirismo, Zoila escolhe a profissão de parteira. Sem precisar sair do plano das relações familiares e dentro de uma lógica que guia esse serviço como um incessante fluir de favores recíprocos, Zoila escolhe o caminho da ajuda e do cuidado. Comenta Zoila: "Cuando me piden un servicio, voy a hacerles un servicio. Como dicen, las cosas son prestadas, señorita... un día para ellos, otro día para mí"215. Da mesma forma em que Asteria, Zoila destaca o caráter benéfico do seu afazer, e deposita nisso um contentamento contido pela lógica do serviço às outras pessoas.

Asteria e Zoila, sobadora de lisiados e partera respectivamente, trabalham com hierbas, rezam orações a deus para pedir ajuda nas curas e guiam o próprio ofício pela lógica do serviço às outras pessoas. Tocayo, curandero, trabalha com palos, convoca aos espíritos das plantas para pedir ajuda e guia o próprio ofício pela lógica do risco frente ao desconhecido para o mundo humano. Assim acontece com a maioria dxs curiosxs entrevistadxs: as mulheres permanecem de um lado, os homens do outro por um invisível fio que divide o mundo das maneiras de fazer com plantas no povoado. Essa divisão do trabalho é também uma divisão do espaço social, baseada em uma partição genderizada das tarefas, ferramentas, modos de apreender e atitudes perante a vida e a morte. Nos próximos dois pontos, veremos territórios onde percebi pontos de conflito, explícitos ou não, dentro da bipolaridade do modelo dos palos e as hierbas.

215 "Quando me pedem um serviço, eu vou a thes fazer um serviço. Como dizem, as coisas são emprestadas, moça... um dia para eles, outro dia para mim". 


\section{- O gênero da ayahuasca e dxs ayahuasqueirxs}

Para alguns grupos étnicos da Amazônia, a relação das mulheres com as plantas é uma relação mítica. No mito de origem do mundo dos shipibos, a origem da mulher é posterior a um dilúvio que acabou com o abundante mundo natural precedente. A mulher representa um envio das divindades para repovoar o mundo não só de seres humanos, mas também de plantas. O mito de origem da agricultura se encontra, assim, intrinsecamente ligado ao mito de origem do feminino (Cárdenas Timoteo, 1989).

Isso se corresponde, de certa forma, com as maneiras de fazer com plantas locais. Como já comentei no capítulo 7, eu pude observar que entre as yerberas, naturalistas, sobadoras e parteras há o manejo e o conhecimento de uma série de plantas diversas, enquanto para xs curiosxs que se aut-definem como xamãs, médicos tradicionais ou curandeirxs não há a necessidade de lidar com tanta diversidade vegetal, e a relação que se estabelece é uma relação de confiança, apoio e até cumplicidade com umas poucas espécies vegetais.

Mais acima apresentei como dentro do vegetalismo peruano há uma classificação, mais ou menos variável, entre as plantas e seus espíritos em termos do gênero. Assim, há plantas com espírito masculino e há plantas com espírito feminino. Geralmente, as plantas femininas correspondem às hierbas, enquanto as plantas masculinas correspondem aos palos.

$\mathrm{Na}$ tradição vegetalista, tem-se entendido costumeiramente à ayahuasca [Banipsteriosis caapi] como uma planta com características e essência femininas ${ }^{216}$.

216 Isso não é assim em todos os contextos ayahuasqueros. Dentro da linha religiosa da Barquinha, corrente ayahuasqueira brasileira, se entende que o yagube (como é o nome dado à planta da ayahuasca, Banipsteriosis caapi) é masculino, enquanto que a rainha (como é o nome dado à chacruna, Pshychotria viridis, planta que conjuntamente com a ayahuasca forma a própria 
Curiosamente, essa planta, sendo feminina, é uma das mais importantes para curandeirxs e xamãs. É possível perceber isso principalmente na cena contemporânea, que centra o tradicional sistema de magias e terapias da floresta em torno, quase que exclusivamente, da ayahuasca.

Em março de 2013, o curandero dom Agustín Rivas, sem dúvidas o mais famoso de Tamshiyacu e um dos mais reconhecidos ayahuasqueiros do Peru no mundo afora, encontrou-me em uma das ruas principais do povoado. Estava indo jantar com a sua esposa, Marlene, e as duas jovens que são a sua mão direita em Tamshiyacu, Eva e Nicole. Eu estava com Nathálie, amiga que veio à Amazônia para aprender o xamanismo. Estávamos fazendo as nossas primeiras incursões nas casas dxs xamãs, e ainda não tínhamos ido vê-lo. Ele nos convidou para acompanhar o grupo que ia tomar um refrigerante. Aceitamos. Eu lhe perguntei se costumava receber mulheres locais nas suas cerimônias. Ele respondeu: "la ayahuasca no es para que tomen tanto las mujeres. Las mujeres que toman mucha ayahuasca se vuelven brutas. ${ }^{217 "}$. Logo depois, ele se referiu à chacruna, ou chacuruna [Psychotria viridis]: "ésta es masculina. Cuando la tomo tengo sueños eróticos, sueños de posesión de vírgenes. Viridis tiene que ver con virilidad"218, disseme, brincando com as palavras e revelando conhecer seu nome científico. Porém, o fato de a ayahuasca ser uma planta feminina não interfere, mas ajuda no trabalho das mulheres que são curandeiras. "La ayahuasca quiere a la mujer, porque

bebida ayahuasca) é concebida como sendo feminina. Para ver mais detalhes sobre a relação da Barquinha com essas duas plantas, é possível consultar a etnografia de Marcelo Mercante (2012) no Acre brasileiro.

217 "A ayahuasca não é para as mulheres tomarem tanto. Quando elas tomam a ayahuasca, se tornam brutas".

218 "Essa daí é masculina. Quando a bebo, tenho sonhos eróticos, sonhos de possessão de virgens. Viridis tem a ver com virilidade". 
es más blanda" ${ }^{219}$. Viviana ${ }^{220}$ é de Tamshiyacu, ali viveu toda a sua vida e tem duas filhas que têm seis e oito anos, respectivamente. Ela trabalha administrando e tomando conta da faxina do "Hospedaje Acosta", uma das quatro hospedagens do povoado. Durante as tardes, ela gosta de tirar uma cadeira para a calçada, do lado de fora da hospedagem e conversar. Ela me contava dxs turistas que chegavam, de como tinham mudado a dinâmica do povoado à mercê do turismo xamânico. Uma tarde, ela me contou que também ela tomou ayahuasca. "Bonito se ve! Te concentras y ves lo que precisas ver" ${ }^{\prime 221}$. Ela conta que a ayahuasca lhe serviu para tomar decisões importantes em sua vida:

Yo tomé la primera vez con don Leonardo. Cuando supo que me había separado, Don Leonardo me ofreció para hacerme un amarre para mi esposo. Y yo le he dicho que prefiero quedarme sola. El me preguntó 'sientes que eres lo suficientemente fuerte?' y yo le dije que sí. La ayahuasca me ha dado fuerzas pues ${ }^{222}$.

Ainda quando para Agustín a ayahuasca pode ser nociva para as mulheres, para Isabel, que é de origem shipiba, mas trabalha em contexto urbano, há uma relação especial entre elas em virtude da natureza feminina tanto da planta quanto da mulher. No entanto, para Viviana, o fato de beber a planta lhe deu a coragem que precisava para tomar a decisão de separar.

Aparece aqui uma ponta do que poderia ser uma luta dos gêneros pela possibilidade de tomar e administrar a ayahuasca: Viviana tomou a ayahuasca e

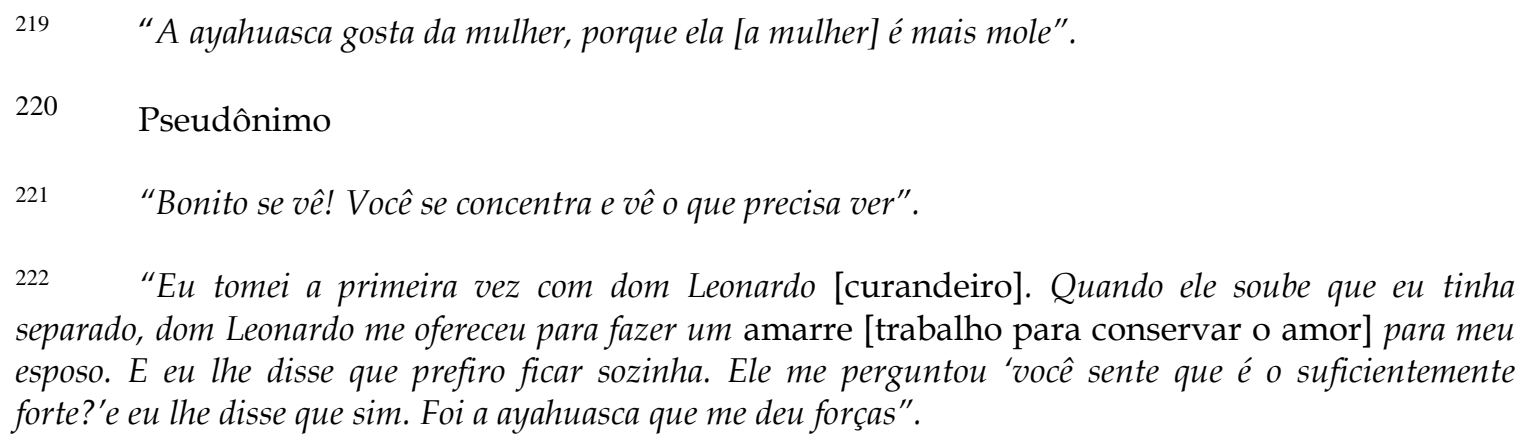
separado, dom Leonardo me ofereceu para fazer um amarre [trabalho para conservar o amor] para meu esposo. E eu the disse que prefiro ficar sozinha. Ele me perguntou 'você sente que é o suficientemente forte?'e eu the disse que sim. Foi a ayahuasca que me deu forças". 
isso a favoreceu, dando-lhe coragem. Isabel fez da ayahuasca uma das principais plantas da lista com a que trabalha como curandeira e xamã. Dom Agustín, porém, ainda quando reconhece que a ayahuasca é feminina, sustenta que são os homens a ter acesso privilegiado a ela. As mulheres se tornam brutas, não precisam dela. São os homens que devem tê-la.

\section{- Casais no meio das plantas}

Em setembro de 2013, eu e Carl fomos visitar a casa que dom Agustín tem no povoado de Tamshiyacu. O objetivo era the fazer uma entrevista formal sobre sua longa trajetória como curandeiro. Dom Agustín morava junto com Marlene, sua companheira, há mais de vinte anos. A mesa era redonda e tinha café, canecas, biscoitos doces e açúcar branco. Dom Agustín nos ofereceu café e cigarros de tabaco fresco. Nós bebemos o café, comemos os biscoitos. Marlene sentou perto da janela, fora do círculo da mesa. Passava muito mais tempo em pé do que sentada, levando e trazendo coisas da mesa à cozinha. Ela trouxe um cinzeiro. Trouxe a garrafa com o café. Abanou a dom Agustín enquanto o sol escaldava lá fora. Na longa entrevista que fizemos - a mesma durou quase três horas - ela se manteve cautelosamente por trás dele. Em pé para abanar, sentada por momentos. A entrevista acabou e Marlene, reservada desde o início ao final, esteve atenta por momentos à conversa, observando nossos gestos e palavras, e conversando com vizinhxs que faziam aparecer esporadicamente as suas cabeças pela janela ou pela porta entreaberta.

Agustín Rivas está casado há mais de vinte anos com Marlene. Contou-me Zulmira que conviveu com eles durante anos, que faz um tempo Marlene começou a acompanhar as cerimônias. Ela costuma preparar o espaço antes da reunião, alcança-lhe os elementos durante a cerimônia, ajuda às pessoas que precisam de assistência para ir ao banheiro, sustenta aos corpos que, invadidos 
pela urgência da purga, precisam vomitar. Zulmira me contou também que Marlene quis ficar independente faz poucos anos e que tentou começar a dirigir cerimônias por si mesma. Porém, seu esposo insistiu para que ela continuasse trabalhando com ele, pois assegurava não poder fazer as próprias cerimônias sozinho, além de lhe dizer que seu trabalho não era organizar cerimônias, mas ajudar os especialistas durante as mesmas. Depois do conflito inicial, o casal o superou. Marlene continua até hoje ajudando a seu esposo Agustín nas cerimônias: "debe ser porque él ya está viejito y precisa apoyo"223, argumenta Zulmira.

No povoado de Tamshiyacu, comentam que há quarenta anos morreu uma mulher chamada de dona Pepa, que preparava plantas, tomava ayahuasca, fazia trabalhos mágicos e curava pessoas de diversos distúrbios. Ela ensinou o curandeirismo ao seu sobrinho Leoco, hoje um reconhecido curandeiro local. Também contam que Juana, esposa de Leoco, era um pouco brujilla ${ }^{224}$ e que por isso a mataram, também com bruxarias. Em entrevista em junho de 2013, perguntei a Leoco pelas duas. Leoco me contou que tanto a sua mentora, Pepa, como a sua primeira esposa, Juana, eram muito queridas para ele, mas elas não eram propriamente curandeiras. Elas faziam coisas simples: "solamente hacían sus perfumitos para atraer el amor, y ya"225.

Também em Tamshiyacu, Luis se reconhece como xamã e curandeiro. Faz uns dez anos que trabalha com plantas. Norma é sua esposa. Juntxs, elxs têm duas filhas adolescentes, Ruperta ${ }^{226}$ e Lisete. Casiana ${ }^{227}$, que é parente dele, disse-me que

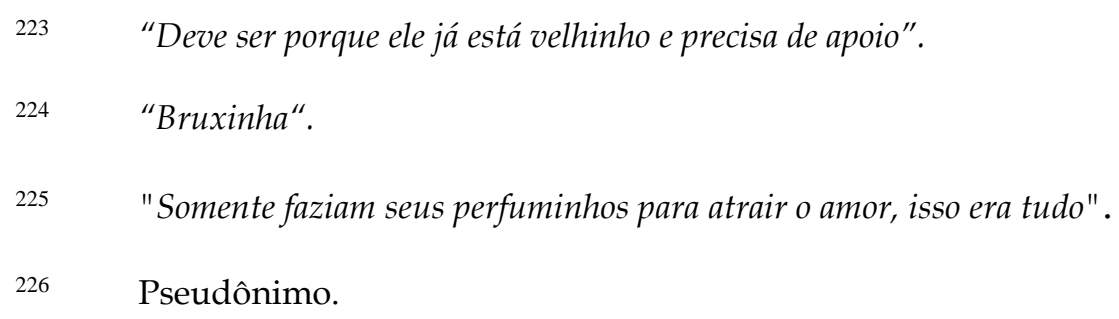


Norma é indígena, do grupo bora, e que fez alguns trabalhos mágicos para mudar algumas condutas de Luis. Luis bebia constantemente álcool e costumava bater nela. Norma interveio através de trabalhos com plantas no comportamento dele, e que a partir de então, Luis cambió mucho ${ }^{228}$. A violência doméstica e o alcoolismo parecem ter ficado para trás: Luis trabalha hoje como curandeiro e xamã, e cultiva plantas medicinais na chacra da família. Uma tarde, perguntei a Luis se Norma também sabe de plantas. Ele o nega de pronto: "ella simplemente me ayuda cocinando para las chicas ${ }^{1229}$.

Carola e Juan ${ }^{230}$, casal de curandeirxs de Picuroyacu, localidade próxima a Iquitos, fazem a maior parte das suas cerimônias juntos. Eu os visitei em seu acampamento em setembro de 2012. Carola me contou parte de sua vida: ela e Luis se casaram muito novos, tiveram dez filhxs e curaram a todxs elxs com medicina natural. Eu perguntei para ela onde foi que aprendeu a curar. Com devoção, ela me respondeu: "él me lo ha enseñado todo" 231 . Nos dois dias que passei no acampamento, eu pude observar uma divisão de tarefas entre o casal: enquanto ele conversava sobre curandeirismo, magias e curas com xs visitantes, ela se encarregava das tarefas domésticas e alimentava e banhava filhxs e netxs. Na cerimônia de ayahuasca da última noite, foi ele que a conduziu, enquanto que a participação dela se restringiu ao canto de alguns icaros em momentos específicos.

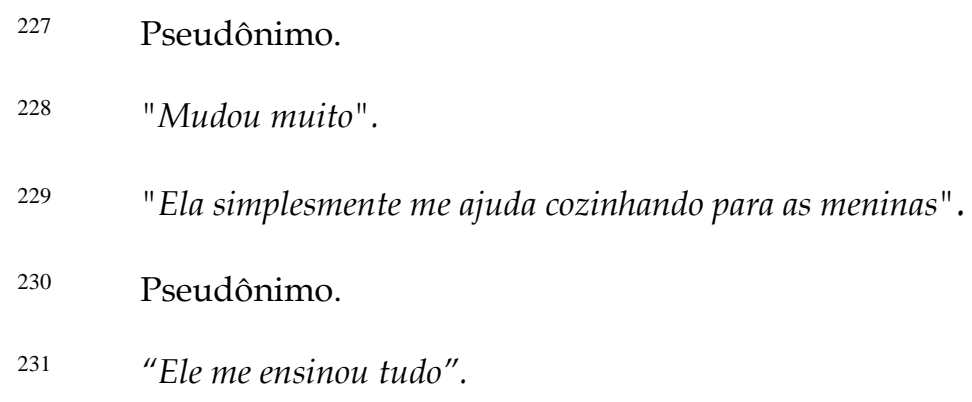


Divergindo da proposta de estudos etnográficos centrados nas mulheres (ScheperHughes, 1992), e da minha própria etnografia com mulheres quilombolas do nordeste brasileiro (Echazú Böschemeier, 2014), tenho apostado aqui em realizar uma etnografia levando em conta a relação entre homens e mulheres. Assim, relatos tanto de mulheres quanto de homens fazem parte dessa análise etnográfica, e isso funcionou como estratégia para não perder a perspectiva sobre o cotidiano relacional em que se constrói o mundo das maneiras de fazer com plantas dxs curiosxs de Tamshiyacu. Nesse sentido, a perspectiva dos casais heterossexuais em todos os casos existentes - de curiosxs que conheci (Ver Imagem 14, Casais) apareceu como um espaço muito interessante para observar essas dinâmicas na dimensão, voraz e sutil, da intimidade do teto compartilhado. Nem todos os casais que trabalham com plantas dependem dessa dinâmica que conjuga e divide tarefas segundo um esquema tão definido e desigual: teremos a possibilidade de ler experiências divergentes deste esquema nos casos de três mulheres, Adela, Pasquita e Isabel, e de dois homens, Julio e Ernesto, mais adiante no capítulo 11.

Porém, há uma tendência majoritária para a qual o presente apartado aponta. A maioria dos casais de mulheres e homens que trabalham no curandeirismo dependem de um esquema de trabalho onde, mesmo que a mulher tenha experiência e conhecimentos sobre plantas, ela será colocada como aquela que ajuda a manter a estrutura familiar básica (limpar, cozinhar, lavar) e, no máximo, auxilia ao homem com coisas básicas nas diversas encomendas de cura ou magia. Nesse sentido, os casais vinculados ao curandeirismo são interessantes janelas para observar as dinâmicas de desapropriação do gênero feminino na prática cotidiana dxs curandeirxs peruanxs. 


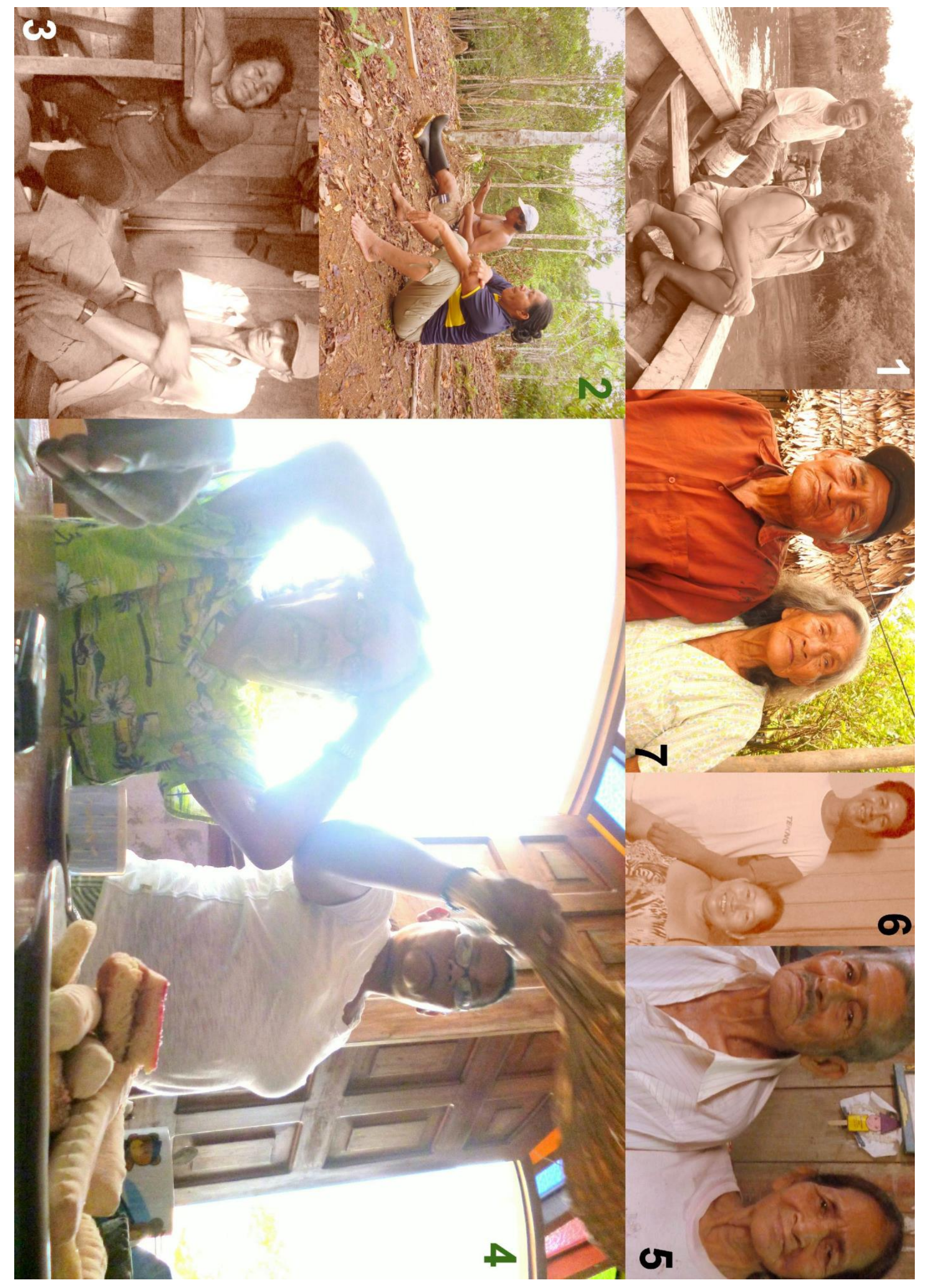




\section{Imagem 14 (pág. anterior): Casais}

1 - Lidia e Walter.

2 - Isabel e Jorge.

3 - Zoila e Abel. Fotografia: Gentileza de Carl Carew.

4 - Marlene e Agustín. Fotografia: Gentileza de Carl Carew.

5 - Corina e Ernesto. Fotografia: Gentileza de Carl Carew.

6 - Milena e Julio.

7 - Olinda e Marcos.

Se bem que identifiquei sete casais, analisei aqui quatro casais que trabalham em atividades relativas ao curandeirismo - Marlene e Agustín, Juana e Leoco, Norma e Luis e finalmente Carola e Juan. Depois de ter observado em campo as dinâmicas desses casais, eu tive a possibilidade de advertir que não é incomum o fato de que sejam os homens aqueles que minimizam a participação das mulheres, mesmo quando sirvam à prática diária do ofício também os conhecimentos e práticas pertencentes às próprias mulheres. Em todos esses casos, elas tenderam a permanecer no segundo plano. Ocupar uma posição de segundo plano em uma relação a dois tende a condicionar todas as atividades da vida pessoal, desde a visibilidade, a mobilidade até o acesso ao patrimônio da família. Essas mulheres se reconhecem publicamente como as esposas dos curandeiros, e estão socialmente condicionadas a lhes ajudar, acompanhar, assistir e servir frente às diversas necessidades do ofício. Somado a isso, as estratégias masculinas pelo controle da preparação e ingestão de ayahuasca também se observam na prática diária do ofício do curandeirismo, e juntas configuram uma parte central do esquema de poder desigual a partir do qual mulheres e homens, que são curiosxs, circulam, organizam-se e constroem a vida em comum. 


\section{Capítulo 9 \\ O corpo dxs curanderxs e os males de gente}

- Realidades mágicas - Anoitece em Tamshiyacu - Icaros: chamando às entidades pelo nome • A mulher, o curandeiro e o marido dela - Corpo de curanderx, corpo de pacientes - Dietar, ver e materializar • Visões e conflitos entre curandeirxs - O norte político e um olhar colonial sobre a "magia negra".

Nesse capítulo, mergulharei em alguns aspectos do dia a dia dxs curandeirxs de Tamshiyacu. Decidi me dedicar a elxs, pois são elxs que, dentre a miríade de curiosxs locais, protagonizam a incursão cotidiana nos arriscados territórios que se encontram fora do mundo humano. Aqui relatarei experiências etnográficas relativas às visitas às casas dxs curandeirxs que realizam as pessoas do povoado durante o anoitecer, assim como alguns detalhes que se referem à função mágica dos icaros para chamar aos espíritos das plantas. Em seguida, contarei como é que Gerónima limpa o corpo dela com icaros e banhos de flores sob a guia do curandeiro Leoco, com a intenção de tomar decisões relativas a seu matrimônio. Depois, desenvolverei aspectos da interpretação local a respeito da maneira como as plantas agem no corpo dxs curandeirxs, e também a maneira como o corpo do/a curanderx se relaciona com o corpo dxs pacientes através das visões que geram o contato direto com as plantas. Continuando na descrição desse particular caminho que envolve as maneiras de fazer com plantas $\mathrm{dxs}$ curandeirxs de Tamshiyacu, descreverei a experiência de Gerlyn, filho da curandeira Isabel, e os dois ofícios que ele escolheu para viver: o curandeirismo e a talha em madeira. Em estreito vínculo, as duas atividades que Gerlyn desempenha são relativas a uma maneira de se aproximar das plantas que sublinham a solidão, a originalidade e a força do olhar individual $\mathrm{dx}$ curandeirx frente ao mundo da floresta, ao mesmo tempo em que possibilita a materialização da experiência através do trabalho sobre a madeira. As esculturas que Gerlyn talha costumam 
ser materializações das visões dos espíritos das plantas com as quais ele teve contato. Uma vez terminadas, ajudam-lhe a lembrar da experiência e conectar com os aprendizados dela derivados.

Posteriormente, reflito sobre o fenômeno de tapar as visões. O rumor corriqueiro de que alguns curandeirxs são capazes de tapar o trabalho dxs outros e thes impedir de influir sobre o mundo pode, nesse sentido, ser lido como uma invasão no segredo dos próprios territórios de saber fazer. Essa invasão parece se acionar em momentos de conflito entre uns/umas e outrxs curandeirxs, e delimita as competências de trabalho entre uns/umas e outrxs curandeirxs. Nesse ponto, detenho-me a analisar o conflito entre curandeirxs como parte inerente de uma dinâmica de éticas relacionais onde não há noções absolutas de bem ou de mal, mas sim ações que são empreendidas no marco de uma densa rede social de favores e que devem ser lidas no seu sentido relacional e histórico.

Finalmente, discuto a maneira como xs turistas que querem aprender $o$ xamanismo na localidade postulam como "magia negra" às importantes técnicas etótropas para mudar o comportamento das pessoas. Tais pessoas condenam moralmente qualquer prática orientada a influenciar o comportamento de outras pessoas a partir de uma interpretação europeia e cristã do bem e do mal. Eu afirmo que tais práticas que xs turistas consideram como de "magia negra" são aquelas formas de influir nas relações sociais que muitas vezes ficaram relegadas às margens do xamanismo globalizado, e cujas moralidades locais permaneceram invisibilizadas pelo preconceito e a carreira das pessoas que estudaram em instituições formais pela adoção da ciência como "novo Deus todo-poderoso". As moralidades locais referentes a daños e trabajos estão conjugadas com dinâmicas históricas de cooperação e conflito entre pessoas e 
grupos a partir da especial relação que xs diferentes curandeirxs têm apreendido a estabelecer com as plantas.

- Realidades mágicas

$X$ curandeirx, como sabe fazer qualquer outrx curiosx, trata dos males que correspondem àquilo que na perspectiva local é chamado de males de Dios. Mas elxs são especializadxs em outro tipo de ação sobre o mundo, diferenciação cujas linhas mais expressivas estabelecemos no capítulo 7. O exercício da magia é uma das características que mais salientam como sendo parte imprescindível das maneiras de fazer próprias do curandeirismo. Entendo magia desde a sua concepção clássica na antropologia, isto é, como a influência indireta da ação que se realiza sobre certos objetos que alcançam, por simpatia ${ }^{232}$, o corpo de um/a pessoa. A magia guia aquilo que no capítulo 2 defini como intenção etótropa, e proporciona uma maneira de reconhecer a realidade como múltipla, dinâmica e cheia de possibilidades que devem ser conhecidas e reconhecidas por pessoas especializadas na arte de transitar nas delicadas relações entre as entidades da floresta e o mundo do humano.

Dentre a miríade de curiosxs locais (sobre a qual me debrucei no capítulo 7), aquelxs que lidam com entidades não humanas de uma maneira constante se chamam a si mesmxs, e são chamadxs por outrxs, de curanderxs. Se bem que também é possível contemplar práticas similares naquelxs que se autodenominam como chamanxs, médicxs tradicionales e vegetalistas: o termo curanderx é o mais comum. São elxs os que cantam os ícaros, tapam as visões e realizam trabajos e outras ações etótropas em cima da vida dxs outrxs. São elxs que

232 A noção de magia simpática provém da análise clássica da magia que James Frazer realiza. Segundo ele, em muitas culturas há o suposto de que uma coisa pode ser influenciada pela outra pelo fato da sua similaridade na forma e/ou função, que ele designa como formas de imitação e correspondência (Frazer, 1993). Efigies, fetiches e bonecxs de vodu são exemplos dessa conexão casual entre objetos que se consideram vivos e capazes de ação. 
aplacam os males de gente, curando às pessoas de perturbações estranhas à medicina oficial. Mas também são elxs que sabem fazer os males de gente, gerando perturbações ou morte a certas pessoas. Em uma complexa dança entre gerar o mal e curar as consequências do mal é que xs curanderxs existem, cooperam e competem. E, como já notamos, eles gozam de uma visível importância, fazendo parte central da vida social local. É então aos e às curanderxs e às dinâmicas da sua relação transformadora entre mundos e pessoas que é dedicado o presente capítulo.

\section{-Anoitece em Tamshiyacu}

Em Tamshiyacu, o anoitecer emerge como a melhor hora de sair às ruas. Depois do trabalho do dia, ao retornar da chacra, depois de ter lavado as roupas na quebrada [cachoeira] e as crianças terem voltado da escola, depois de ter lavado o corpo no fundo da casa e de ter jantado o restante que ficou da comida do meio dia, é o momento de colocar a cadeira na frente da casa e conversar com parentes e vizinhxs. Algumas pessoas vão para a única praça iluminada, a praça central, que costuma estar lotada de postos de comida, e pedem seu juane $e^{233}$ ou seu peixe ou frango na brasa enquanto bebem um suco de frutas, um refrigerante ou uma cerveja. Outras assistem aos serviços das suas respectivas igrejas: há no povoado de Tamshiyacu uma igreja católica e duas igrejas evangélicas. E finalmente, outras vão visitar os/as curanderxs ${ }^{234}$.

$\mathrm{Na}$ área urbana de Tamshiyacu há pelo menos nove curanderxs que atendem a pacientes em suas casas: Isabel, Jorge, Agustín, Lucho, Leoco, Luis Bocanegra,

\footnotetext{
233 Espécie de bola preparada com milho, frango, azeitonas e ovo de galinha envolto em folhas de bijao [Calathea lutea].

234 Sobretudo no que concerne às igrejas católicas, as atividades de missa e visita a curandeirxs não são excludentes umas às outras: as mesmas pessoas que assistem um dia ao serviço eclesiástico podem ir, no dia seguinte, visitar aos/às curanderxs.
} 
Tocayo, Pedro e Vladimiro. A maior parte delxs instalou albergues xamânicos em antigas chacras que herdaram ou compraram, e neles costumam receber aos turistas. Desta maneira, xs curandeirxs trabalham sob um duplo esquema de atenção: recebem a turistas nos albergues enquanto atendem a pacientes locais nas próprias casas que elxs habitam no povoado. Essa forma de organizar o trabalho é bastante respeitada, sendo rara a presença de pessoas da localidade nos albergues, por um lado, ou de turistas nas casas de família dxs curanderxs, pelo outro.

Quando estão nas suas casas de Tamshiyacu, xs curanderxs costumam abrir rotineiramente as portas dos seus consultórios, às vezes construídos do lado das casas, às vezes habilitados nas próprias salas das casas. Com o cair do sol, habilitam-se um a um os consultórios dxs curandeirxs da localidade. $\mathrm{O}$ anoitecer é, sem dúvidas, a hora por excelência dos amarres secretos, das curas contra os ciúmes ou a inveja, dos trabalhos contra os daños e contra outros trabajos realizados por alguém com más intenções para com x consulente. Mulheres e homens entre trinta e cinquenta anos são xs que mais frequentam esses espaços, se bem que também há desde bebês com suas mães até idosxs. No povoado, as pessoas participam dos trânsitos entre consultórios de curanderxs com assombroso frenesi: as consultas aos/às curanderxs consomem uma proporção generosa de tempo, energia e dinheiro das pessoas que fazem parte da comunidade urbana de Tamshiyacu.

Durante o trabalho de campo, descobri que fazer uma etnografia crepuscular nas ruas que estão próximas das casas dxs curanderxs é uma atividade deliciosa. Apesar de ser uma prática tão comum na comunidade, a chegada e o ingresso ao consultorio [consultório] dx curanderx é uma ação que requer prudência e baixa visibilidade. A busca de um/a curanderx parece evidenciar, aos olhos das outras 
pessoas da comunidade, a necessidade de um consolo, uma ajuda mágica, uma mudança, uma solução. É uma exposição que ninguém costuma querer para si próprix nem para seus/suas afetxs. Xs curanderxs mais populares do povoado costumam ter uma agenda carregada de responsabilidades e encomendas, das quais não costumam derivar. Aquelxs curanderxs que trabalham com pessoas da localidade não costumam viajar. Ao contrário da percepção própria do xamanismo globalizado, que coloca as viagens como sendo prática característica do ofício, xs curandeirxs que trabalham com um grupo local de pessoas gozam de fortes raízes de inserção na comunidade local. De fato, o atendimento a turistas, por uma parte, e a pessoas da comunidade local, por outra, traça uma sutil linha divisória entre quem permanecerá como curanderx, atendendo a parentes, vizinhxs e conhecidxs, e quem se tornará xamã e trabalhará para pessoas isoladas cujas redes, história e cultura lhes são pouco familiares ou diretamente desconhecidas. Essxs últimxs começarão a aceitar ofertas de viagem para realizar os próprios trabalhos em geografias distantes.

Um dxs curandeirxs mais populares de Tamshiyacu é dom Leoco. No mês de maio, dom Leoco aceitou uma entrevista no consultório dele. Eu fui com Estela, uma professora da localidade. Ele me recebeu com efusão, comentando de um amigo argentino muito querido que ele tem imediatamente após saber que eu sou argentina. Logo no início, ele enfatizou que trabalha com ayahuasca, e me convidou para compartilhar uma cerimônia no sábado seguinte. Há umas sete pessoas esperando a consulta com Leoco do lado de fora, dom Leoco, preocupado com o rendimento de seu atendimento dessa noite, concede-nos alguns minutos mais. Ele afirma:

Atiendo por noche quince [personas], veinte, a veces diez, a veces cinco... estoy atendiendo ahorita desde las cuatro de la tarde. No estoy cansado... Ya estoy acostumbrado a este trabajo, ya no lo siento! Después de que termino todos los trabajos me voy a hacer los trabajos de amor acá [señala al 
jardín que se abre por un camino desde el consultorio] ... que quedan para el final. Con eso ya regreso a casa a dormir. A las cinco de la mañana la gente ya me está tocando la puerta, llamándome ${ }^{235}$.

Dom Leoco é um curandeiro bastante procurado na localidade. Todas as pessoas que são da localidade o conhecem, e a maioria fala histórias de alívio de perturbações relativas a seu trabalho. Contudo, ele é pouco conhecido pelxs turistas. Ele me diz que não está de acordo com o xamanismo tal e como ele está sendo tomado hoje, e que ele se auto-classificaria como médico tradicional, deixando a denominação de xamã para aquelxs que gostam de enganar às pessoas. Como parece cada vez mais claro, o fato de se reconhecer ou não como xamã é um posicionamento político com amplas consequências: ele define xs pacientes, mas, sobretudo, define às/aos clientes. Define tipos de práticas, estabelece a duração dos tratamentos, acondiciona tipos de pagamento e, finalmente, delineia os riscos da interação.

\section{- Icaros: chamando às entidades pelo nome}

Xs curandeirxs costumam lidar com as plantas de uma maneira que pouco ou nada tem a ver com a farmacologia moderna. Alguns deles até leram ou escutaram a respeito das propriedades dos vegetais reconhecidas pela etnofarmacologia, mas não baseiam nisso o entendimento da capacidade de cura destes vegetais. De fato, de forma geral, não se considera que seja o princípio ativo de determinada espécie de planta o componente que define o processo de saúde da pessoa, mas se entende que é o próprio espírito da planta em relação com a pessoa (assim como com $\mathrm{x}$ curandeirx) que tem essa capacidade de

235 "Atendo pela noite quinze [pessoas], vinte, às vezes dez, às vezes cinco... estou atendendo agora desde as quatro da tarde. Eu não estou cansado... Ja estou acostumado com esse trabalho, eu já não sinto mais cansaço! Depois de terminar todos os trabajos eu vou fazer os trabajos de amor aqui [aponta para o jardim que se abre através de um caminho desde o consultório] ... esses ficam para o final. Com isso já volto em casa para dormir. Às cinco da manhã já tem gente batendo na porta, me chamando ". 
transformar estados patológicos em estados de saúde. Xs curandeirxs têm uma maneira especial de marcar encontro com as plantas e as entidades que elas são. Com o cantar de icaros acompanhados de maracas ou simplesmente com a vibração das folhas secas de uma específica planta no ar, urdidas em um ramalhete chamado de chacapa, xs curanderxs convocam aos espíritos das plantas e lhes pedem ajuda. A comunicação com o espírito da planta costuma ser através do canto e com o acompanhamento da ingestão, fricção ou fumo da planta por parte $\mathrm{dx}$ curandeirx. "Es como llamarlas por sus nombres" ${ }^{1236}$, me conta Leoco, médico tradicional. Ícaro, o icaro é o nome que se dá às litanias sonoras que se cantam no contexto das ações terapêuticas e mágicas dxs curandeirxs. São melodias curtas que $x$ especialista afirma ter aprendido diretamente das plantas. Como conta Gerlyn, que é filho de Isabel e é aprendiz de curandeiro:

Yo conozco casi la mitad de plantas de mi mamá, y la mitad de plantas de Jorge. Y sé sus canciones de Jorge, y de mi mamá también sé. Ellos no me enseñan... mi mamá no me enseña. Las plantas me enseñan. Yo también escucho... yo esperaba que ellos me dicen "te voy a enseñar". Hasta ahora sigo esperando eso de ellos, no hay cuándo me digan... yo tengo que tomar ayahuasca, escuchar y concentrarme. Hay una canción que las plantas me han dado, es una mujer que toda la vida cuando tomo viene su canción acá... pone la canción de Jorge de un lado, y viene la chica acá... bonito su sonido, me gusta eso ${ }^{237}$.

Apesar de encontrar-se tão perto da sua mãe e do companheiro dela, que são curandeirxs e xamãs, Gerlyn não aprendeu os icaros que conhece e canta da boca delxs nem de nenhum outrx ser humanx. Gerlyn conta que durante os períodos

236 "É como lhes chamar pelos seus nomes".

237 "Eu conheço quase a metade das plantas da mina mãe e a metade das plantas de Jorge. Eu sei as canções de Jorge, e as da minha mãe também sei. Eles não me ensinam... a minha mãe não me ensina. As plantas é que me ensinam. Eu também lhes escuto... eu esperava que me dissessem "eu vou te ensinar". Até agora continuo esperando isso deles, não há quando me digam... eu tenho que tomar ayahuasca, escutar e me concentrar. Há uma canção que as plantas me deram, é uma mulher que cada vez que eu tomo vem com a sua canção aqui... ela coloca a canção de Jorge de um lado, e chega a menina aqui... é bonito o som dela, eu gosto disso". 
de isolamento na floresta que ele atravessou duraram três anos no total, ele pôde obter a melodia precisa dos icaros que hoje canta diretamente das plantas. Assim, cada vez que vai curar, Gerlyn é acompanhado pelo espírito de uma planta. Entende-se que icarar é uma arte que envolve o conhecimento das plantas e uma relação com elas que dura a vida inteira. No icaro, encontra-se a intenção de comunicação que xs humanxs iniciam com os espíritos que habitam o mundo das plantas. Dentro do amplo escopo de curiosxs de Tamshiyacu, observei que são xs curandeirxs e xamãs xs únicxs autorizadxs a cantá-los.

Cada um/a delxs conhece pelo menos umas três melodias, as quais costumam durar uns três minutos e serem repetidas por longos períodos de tempo. Cada uma delas tem uma intenção específica, dentre as quais as mais frequentes são: curar um mal de dios, sarar ou prevenir um mal de gente, favorecer uma união amorosa ou limpar o corpo. A convocação às plantas por meio do icaro não é uma súplica, mas sim uma humilde, mas enérgica, solicitação de ajuda.

Gerlyn também conta que escuta e concentração são duas atitudes que x curiosx deve treinar para escutar o icaro que lhe é atribuído, uma espécie de presente da floresta, instrumento de cura de corpos e espíritos e de ação sobre o mundo. Na prática etnográfica, observei que os icaros também podem ser transmitidos entre curiosxs e ainda copiados uns dos outros. Há icaros secretos, impossíveis de repetir, pois xs curiosxs os cantam quase murmurando. Também há icaros afamados, que podemos escutar das bocas de várixs curiosxs durante as cerimônias com ayahuasca ou trabajos [trabalhos] de limpeza. Por sua vez, o turismo xamânico popularizou icaros como Ábrete corazón. Esse ícaro particular foi criado por Rosa Giove, médica peruana que trabalha com terapia ayahuasqueira e foi umas dos co-fundadoras do Centro Takiwasi de reabilitação de dependências com medicina tradicional, especialmente ayahuasca. Milhares 
de pessoas escutam na atualidade esse icaro pelo youtube, interpretado por diversxs autorxs, convertendo-o em símbolo de uma ética de aprendizado de valores de vida que coloca em questão a racionalidade moderna:

\author{
Ábrete corazón \\ ábrete pensamiento \\ ábrete sentimento \\ deja a un lado la razón \\ y deja brillar el sol \\ escondido en tu interior 238
}

Ábrete corazón, cantado como um mantra incansável durante as cerimônias de ayahuasca próprias do circuito se tornou uma espécie de propriedade coletiva que distingue o curandeirismo amazônico contemporâneo. Os icaros podem ser cantados em língua espanhola ou em língua indígena, ainda em contextos mestiços ribeirinhos, onde as línguas indígenas têm sido tão desarticuladas e quase que desapareceram, permanecendo somente modismos isolados.

Os icaros possuem uma qualidade quase material: eles se acoplam ao corpo $\mathrm{dx}$ paciente e o protegem ainda depois do momento da convocação através da voz $\mathrm{dx}$ curios $x$. Natividad, minha vizinha, contou-me que seu filho Samuel, de seis anos, estava com febre. Levou-lhe para ver de novo o curandero Leoco, que semanas atrás tinha lhe tratado o mal aire. Leoco examinou a criança e concluiu que o icaro dele tinha caído. Natividad lhe contou que a criança caiu no chão duas vezes, e Leoco confirmou então seu diagnóstico: quando a criança cai no chão, existe o risco do icaro dele ter caído junto. Foi preciso icarar a criança de novo, que voltou para casa com o icaro composto. Tal episódio desenha uma

238 "Abre-te coração/ abre-te pensamento/ abre-te sentimento/deixa a um lado a razão/ e deixa brilhar o sol/ escondido em teu interior". 
percepção quase física do icaro que é compartilhada tanto pelo curiosx quanto pelo jovem paciente e a mãe dele: o icaro de proteção contra o mal aire possui uma materialidade que faz com que, depois de ser cantado ao corpo da criança, o icaro fique colado a ela, como um amuleto invisível.

\section{- A mulher, o curandeiro e o marido dela}

Há dezessete anos, Gerónima, a nossa vizinha da casa da rua das Flores, tomou a ayahuasca pela primeira vez com Dom Leoco. Ela tinha quinze anos então, e decidiu ingerir a beberagem para ver como podia superar um conflito que ela tinha com a ex-mulher do marido, Román. Ela teve a visão de um jaguar negro, que era ela mesma. Assustou-se. Foi então que Leoco cantou um icaro para que a mareación, o efeito da ayahuasca no corpo, amainasse. Há anos Leoco acompanha Gerónima na sua vida sentimental. Em várias das crises que experimentou com o marido, Gerónima procurou Leoco para lhe ajudar a decidir pela continuidade ou pela ruptura do seu matrimónio.

Um dia, Gerónima chegou em casa e me contou que se sentia cansada e entediada, que o marido está sempre de viagem e nem podem conversar sobre os sentimentos que a perturbam. Ela sente "una preocupación en la mente y un peso en el corazón ${ }^{239 "}$. No dia seguinte, encontrei-a na rua. Ela me disse que Leoco the pediu que comprasse um perfume industrial e que o trouxesse, pois ele ia icararlo [lhe cantar um icaro]. E que ia lhe fazer, de forma paralela, alguns banhos de limpeza com plantas para renovar o ânimo. Uma semana depois, tive a possibilidade de entrevistar Leoco, que me confidenciou estar preparando um tratamento com plantas para Gerónima. Segundo ele, ela precisa, primeiro de tudo, arreglar el cuerpo [consertar o corpo]. Uma semana depois, Leoco me falou

"Uma preocupação na mente e um peso no coração". 
abertamente sobre Gerónima. Contou-me que lhe estava fazendo um tratamento com mucura hembra [Gallesia integrifolia], gallinazo pango [Cassipourea peruviana] e ajo sacha [Mansoa alliacea]. Todas essas plantas estão no jardim dele, pelo que só precisa colhê-las pouco tempo antes de dispor os banhos. Leoco comenta:

Esta señora estoy limpiando su cuerpo, estaba yendo medio mal en su relación con su marido. Ya no quería, quería dejarle a sus hijos. Y yo qué te está pasando, le digo. Ella me dice que ya no quiere estar con un viejo. Pues aguántale al viejo! Que ya tiene sus hijos... Y no sé cómo ha venido que quiere hacer sus baños. Y me dice que ahora está muy tranquila, contenta con su marido. Y así debe ser el hogar, pues. Así trabajo (...) hacer uniones entre las personas ${ }^{240}$.

Leoco diz que Gerónima vai ficar bem boa, sem mais vontade de se separar. Dias depois, Gerónima me conta que efetivamente está repensando a decisão de se separar, e que os banhos estão lhe fazendo sentir renovada. O seu corpo está arreglado, ela está limpia e o médico tradicional e as plantas que ele convocou através dos icaros e os banhos intercederam em favor da continuidade do casal.

\section{- Corpo de curanderx, corpo de pacientes}

Ao contrário do icaro, que se apega provisoriamente ao corpo, permanecendo nele como uma aderência transitória, as plantas com as quais se teve contato navegam dentro do corpo durante a vida toda. A partir do momento em que elxs se relacionam com o corpo através de banhos, fricciones, aspiração por vapores ou por fumaça, vibrações acústicas ou simples contato corporal, ficam dentro da memória da matéria corporal. Isso me conta Julio, que é artesão da madeira e naturalista. Ele afirma não se reconhecer como curandeiro devido ao seu

240 "Estou limpando o corpo dessa senhora, que ia meio que mal na relação com o marido. Ela não queria mais ficar com ele, estava querendo abandonar os filos. E eu lhe disse o que é que está te acontecendo. Ela me diz que já não quer ficar mais com um homem velho. Mais, você deve de aguentar o velho! Você já tem filos com ele... Eu não sei como, ela veio fazer os seus banhos. E me diz que agora está muito contente, tranquila com o marido. E assim é que deve de ser o lar, pois... Assim eu trabalho (...) fazendo uniões entre as pessoas." 
pertencimento ao evangelismo, religião que condena as práticas historicamente associadas ao curandeirismo como a bruxaria, os trabalhos de possessão ou despossessão e os daños [danos] realizados sobre outras pessoas. Porém, ele experimentou com palos durante anos, e considera que foi trabalhado por dentro devido à ação modeladora dos mesmos. Julio me conta que cada vegetal que se bebe fica para sempre no corpo, deixando dentro dele a marca inapagável da sua influência. Se os vegetais que se tomam são vários, é dentro do próprio corpo que acontecem diálogos e disputas. Julio exemplificou essas dinâmicas ao me explicar porque ele não toma a ayahuasca, e sim outras plantas, das quais ele aprendeu o que sabe:

Hay plantas que yo vengo tomando desde hace tiempo, cuando era un niño, en Tarapoto. Esas plantas forman una cortina que no deja que el ayahuasca, ni ninguna otra planta, entre. Esas plantas son celosas. Yo tomaba bastante ayahuasca en una época, para ver si me vencía. Pero era como una pared que el ayahuasca no podía atravesar. Las plantas que tomas, te quedan para siempre allíi ${ }^{241}$.

Julio assume que as plantas que fazem parte da história do aprendizado do corpo dxs curandeirxs permanecem "navegando dentro del cuerpo" durante a vida toda (Ver Imagem 15, As plantas e o Corpo). É assim que as plantas escolhidas e os espíritos que as animam estabelecem uma relação de longa data com o corpo $d x$ curandeirx. Desse diálogo decorrem muitas das visões, intuições e assunções com as quais $\mathrm{x}$ curandeirx vai guiar o seu trabalho diário com xs seus/suas pacientes. Jean Langdon, uma pesquisadora norte-americana radicada no Brasil, começou a observar, a partir de materiais obtidos na sua etnografia com povos indígenas siona do sul da Colômbia, que não é tão comum as pessoas tomarem a ayahuasca, sendo $x$ curandeirx que é consultado quem procede a bebê-la

241 "Há plantas que eu venho tomando desde faz tempo, quando era uma criança, em Tarapoto. Essas plantas formam uma cortina que não deixa que a ayahuasca, nem nenhuma outra planta, entre. Essas plantas são ciumentas. Eu tomava bastante ayahuasca em certa época, para ver se ela me vencia. Mas era como um muro que a ayahuasca não podia atravessar. As plantas que você tomar, ficam para sempre ali". 
(Langdon, 2013). A antropóloga peruana Clara Cárdenas Timoteo no seu estudo sobre a medicina shipiba observa uma situação similar: "por lo general, el unaya no invita a los otros a beber la poción [del ayahuasca]" (1989: 200). A informação dessas duas etnografias contradiz a ideia, tão frequente nos circuitos do turismo xamânico, de que é necessária a ingestão da beberagem da ayahuasca para conseguir o efeito da ação terapêutica desta planta sobre a saúde. 


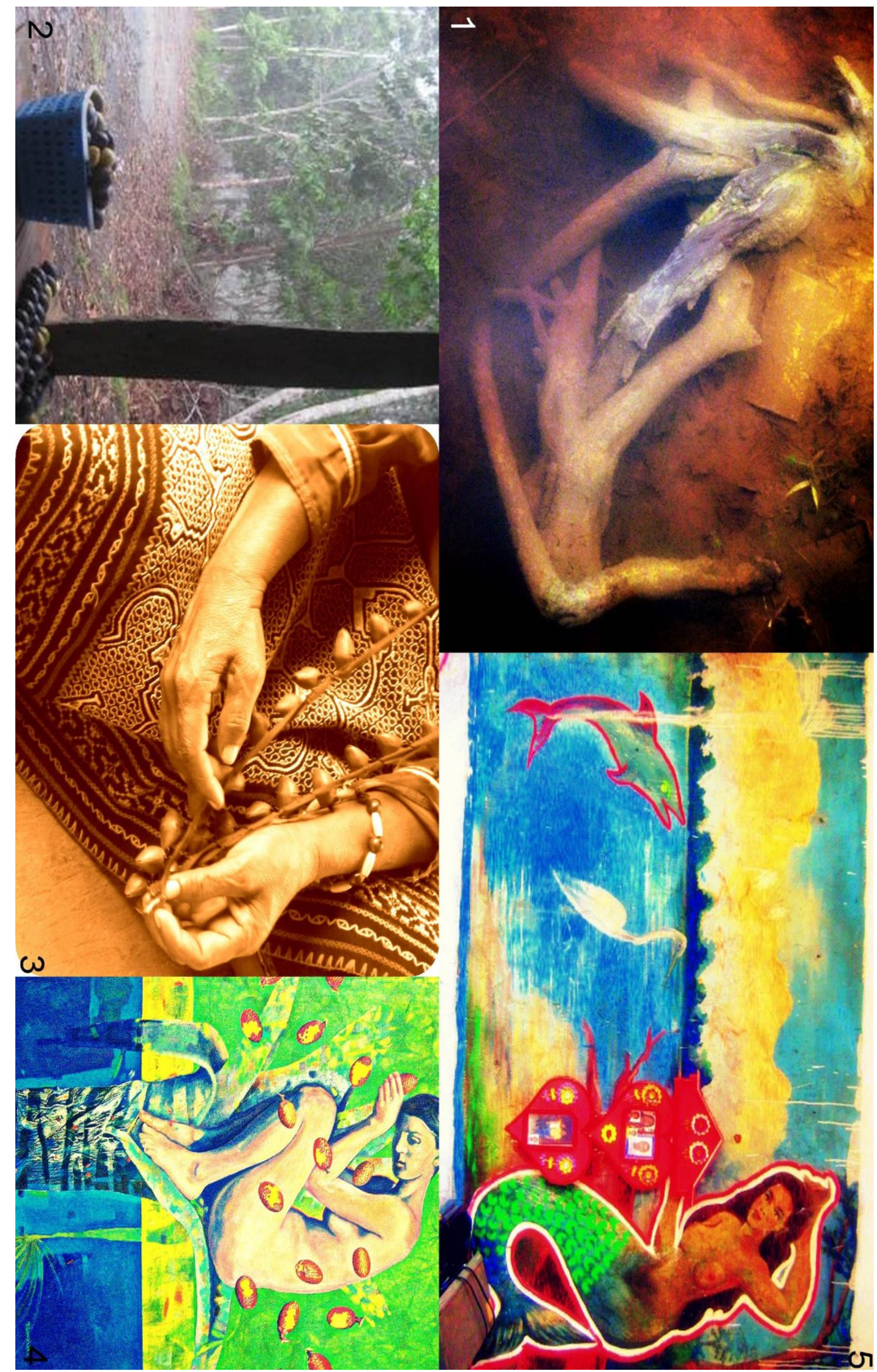


Imagem 15 (pág. anterior): As plantas e o corpo

1 - O espaço da floresta é um espaço genderizado, que provê sinais a partir das relações sensuais que há entre suas entidades, e destas com o mundo do humano. Na fotografia, madeiras em processo de decomposição no leito de um braço do rio Amazonas, no caminho para o acampamento de Isabel.

2 - A floresta é, como o próprio corpo, um espaço vivo e cheio de sinais a serem interpretados. $\mathrm{Na}$ foto, dia de chuva durante a colheita do humarí [Humiria balsamifera].

3 - Isabel, acariciando seu colar de sementes de camu camu [Myrciaria cauliflora] enquanto eu lhe entrevisto.

4 - "Mujer de los aguajes", colagem apresentada no Museo de Iquitos em Agosto de 2013. Autor/a não referenciadx.

5 - Na floresta, os animais também estão encantados. $\mathrm{Na}$ fotografia, pintura mural decorativa plasmada no comedor de uma casa em Tamshiyacu. Aqui aparecem as sereias, deidades femininas da água junto com outros animais que moram perto dos rios.

- Ainda que o uso de plantas seja tão extenso, também se acode a partes de animais e aos espíritos dos mesmos. $\mathrm{Na}$ foto, Juan, esposo de Zulma, mostrando a pata de um mamífero cujo osso ralado é usado de maneira externa para o combate às varizes que costumam aparecer na gravidez. 
Isabel me comentou em várias oportunidades que, antes de realizar um diagnóstico e inclusive de aceitar fazer um trabalho para uma pessoa, ela decide tomar a ayahuasca e "preguntar a la planta" [perguntar à planta] sobre a natureza da situação. A partir desta vivência, ela se sentirá em condições de aceitar ou não o pedido. Da mesma maneira, em casos onde a vida da pessoa está em risco, xs afetadxs pedem aos e às curanderxs para identificar o problema. Frente a isso, xs curanderxs costumam não dar a planta à pessoa afetada, mas tomá-la por si mesmxs. As plantas que são ingeridas pelx curanderx nesse tipo de consulta dependem de uma história de relação que é específica entre cada planta e cada curanderx: as plantas com as quais se dietó [se fez dieta], com as quais se teve as visões mais claras e promissoras, os vegetais dos quais se aprendeu mais ou aqueles que mais ajudaram na resolução de um caso complicado: ayahuasca [Banipsteriosis caapi], toé [Brugmansia suaveolens], mucura [Gallesia integrifolia], huayruro [Abrus precatorius] e ajo sacha [Mansoa alliacea] não possuem propriedades que podem ser colocadas em uma tabela de correspondências. Elas são sujeitxs e, da mesma maneira que se espera dxs sujeitxs humanxs, elas travam relações de reciprocidade, cooperação, indiferença ou até inimizade com xs curanderxs que as convocam.

\section{- Dietar, ver e materializar}

A noção de limpeza del cuerpo [limpeza do corpo] é uma parte muito importante da terapêutica local. Todo corpo, pelo simples fato de existir, acumula suciedad [sujeira]. "Comer chancho y picante, tener rabia de alguna persona, querer acostarse con uno o con otro"1242, explicava-me o curandero Winston, de Tarapoto, são ações que inevitavelmente sujam o corpo. "Los cuerpos son como las casas, hay que limpiarlos de

242 "Comer porco e picante, ter raiva de alguma pessoa, querer se deitar com um ou com o outro". 
vez en cuando" 243 , continuava. Não há efeito positivo possível do remédio vegetal se não há um corpo limpo com o qual o remédio vai interagir. As sopladas [o assoprar] com a fumaça do tabaco de curandeirxs a pacientes, os banhos com plantas e as purgas são maneiras de limpar, interna e externamente, o corpo. É importante salientar que a distinção entre uma internalidade e externalidade do corpo não é enfatizada na concepção local, e muito menos no contexto do curandeirismo, onde substâncias, ânimos e objetos entram e saem do corpo de forma permanente, e onde se considera que todo corpo visível está estreitamente ligado a outros corpos e forças invisíveis.

As purgas, que produzem violentos vômitos e diarreia, têm como finalidade a limpeza por eliminação. Purga-se com diferentes tipos de planta. Uma das preferidas, pela sua rapidez e intensidade, é a purga com o tabaco [Nicotina tabacum]. As assopradas são sempre com tabaco e os banhos com plantas são realizados com uma variedade de plantas, dentre as quais o ajo sacha [Mansoa alliacea] é uma das mais frequentemente escolhidas.

Outro ponto importante da terapêutica local são as dietas. Elas consistem em períodos mais ou menos prolongados de afastamento da vida social no espaço da floresta, na maior solidão possível, tomando vegetais e respeitando uma série de tabus alimentares, sexuais e do comportamento. As dietas podem ser lidas como uma purga no nível macro. Na procura do isolamento na floresta, purga-se o corpo da sua relação com outras pessoas e da sua relação habitual com o mundo. Despoja-se o ser social construído para se tornar um silencioso receptor de outros códigos de comunicação. É nas dietas que se obtém o aprendizado sobre como tratar a própria perturbação, é das dietas que se pode voltar sabendo quem fez

243 "Os corpos são como as casas, devem de ser limpos de vez em quando". 
um daño ou roubou um objeto ou animal, é aderindo a uma dieta que se consegue aprimorar os métodos de caça de animais na montaña [espaços da floresta adentro]. É também no isolamento das dietas, necessariamente, que as maneiras de fazer com plantas se aprendem e aprimoram.

Gerlyn, filho da curandeira Isabel, tem vinte e poucos anos. Chegou em Tamshiyacu com doze anos. Ele, que morava no interior de Pucallpa com uma irmã da mãe, foi chamado por Isabel para morarem juntxs na nova cidade. Isabel queria reunir xs filhos e filhas dispersxs para conviverem de novo. Gerlyn tinha sido criado em uma chacra no interior de Pucallpa e ao chegar em Tamshiyacu sentiu estranheza frente à vida urbana. As pessoas do povoado the pareceram fúteis, cheias de preconceitos. A mãe dele, contemplando as dificuldades que ele tinha para se adaptar no novo local, ofereceu-lhe dietar na chacra de umas pessoas conhecidas, permanecer por lá fazendo dieta por um tempo. Conta-me, na entrevista que fizemos em abril de 2013:

Me convencí a tomar ayahuasca y entré [en dieta]... entré, ese día he tomado ayahuasca, ese día mismo he dietado, ese día no he salido como tres meses... paraba en el monte, a diario, [tomando las plantas] hasta que las plantas me conocieran... me puse bien flaco! Dietando, comiendo sin sal... Yo [hacía todo] solo, mi mamá me dejaba solito. Ahí las plantas todas las noches venían... bien clarito les veía. ${ }^{244}$

Depois da dieta na floresta, Gerlyn voltou para o povoado com uma sensação de estar renovado. Poucos dias depois de ter chegado, observou a atividade de um vizinho. Era um homem que carregava madeiras e as trabalhava dentro de um galpão próximo da casa dele. Era dom Medardo.

244 "Convenci-me de tomar ayahuasca e entrei [em dieta]... entrei, nesse dia tomei ayahuasca, nesse mesmo dia dieté [fiz dieta], desde esse dia não tenho saído [há] três meses... ficava o tempo todo no monte, todo dia [tomando las plantas] até que as plantas me conhecessem... fiquei bem magro! Dietando, comendo sem sal... Eu [fazia tudo] sozinho, a minha mãe me deixava só. Aí as plantas vinham toda noite... bem claro eu lhes via". 
Mi vecino que talla... me fui a verlo, no me conocía y casi me gustaba pero no tanto me interesaba que trabajaba... miraba... veía... el señor Medardo un día me ha dicho "te gusta?". Sí, le digo, pero no sé cómo hacerlo. "Inténtalo", me dijo. Pero ahora no, le digo. Mañana. "Yo te voy a dar un pedazo de madera para que hagas". "Ya", le digo. Amaneció, vine al taller, el primer trabajo era una hojita de ayahuasca con su víbora. Me pasé toda la semana eso... empecé el día lunes, terminé el sábado (...) Una pipa terminaba en una semana de trabajo diario. Una semana, sólo una. Mi primer trabajo, he vendido a cinco soles. Ese era mi primer trabajo, he vendido a cinco soles ${ }^{245}$.

Com a ajuda de Medardo, um purguero de uns cinquenta anos e que foi um dos tantos alunos do curandeiro e artesão da madeira dom Agustín Rivas, Gerlyn começou a aprender o ofício. Os primeiros objetos eram cachimbos para uso em contexto de curandeirismo, com imagens de entidades talhadas no seu contorno. Depois de ter realizado a sua primeira venda, Gerlyn se sentiu estimulado. Foi então que decidiu voltar à floresta, dando continuidade a um movimento circular de dieta na floresta e produção de esculturinhas no povoado:

Descansé 15 días y otra vez a la dieta. Ahí salí de 8 meses, casi, un año (...) y de 8 meses salí, y vine otra vez con la misma idea de querer tallar (...) Vine al taller, he comprado mi madera de 10 soles. Y poco a poco... no tanto me daba interés... poco a poco. He dietado un año (...) Me acostumbraba poco a poco nomás. Me hacían comer sal... no mucho, poquito nomás. Poco a poco... dos meses y ahí si entré 6 meses otra vez a la dieta... de los 6 meses que he entrado a la dieta, ahí volví al taller... en un mes, aprendí a hacer sólo una pipa en un día. Y yo veía las visiones, la parte de cara, sólo eso... mis pipas eran todos diferentes... cara la mitad, tigre la mitad... y me decía

245 "Meu vizinho que talha... eu fui the ver, ele não me conhecia e quase gostava [do que ele fazia] porém não me interessava tanto... eu ficava só olhando... o senhor Medardo me disse um dia 'você gosta?'. Sim, lhe digo, mas não sei como fazê-lo. 'Tenta aí', me disse. Mas agora não, lhe digo. Amanhã. 'Eu vou te dar um pedaço de madeira para você fazer'. 'Está bom', lhe disse eu. Amanheceu, vim para a oficina, o primeiro trabalho era uma folhinha de ayahuasca com a sua serpente. Passei a semana inteira nisso... comecei na segunda feira, terminei no sábado (...) Eu terminava de fazer um cachimbo em uma semana de trabalho diário. Uma semana, só uma. Meu primeiro trabalho, vendi por cinco soles [uns 2,5 dólares]. Esse foi o meu primeiro trabalho, vendido por cinco soles". 
el señor Medardo, pue... "Qué haces?" Sólo lo que me viene a la cabeza estoy haciendo... "bonito!"... (...) sólo tigres me gustaba hacer. Parte tigre, parte humana. Ya estaba meses acá, tenía a mis amigos, el Pedro, que es un tallador también... y de ahí entré, tres meses a la dieta... ya estaba un año y medio con la dieta. En total he hecho cuatro años de dieta... y hasta más... hace poco he dietado tres meses... me fui con el grupo. Redondeando 5 años, desde que he venido (...) mi mama me preguntaba, "No te aburres?" no era cosa de obligatorio, era cosa mía, que yo quería hacer... sin que me daba cuenta, estaba haciendo. Era muy chibolo cuando he dietado, tenía 13 años (...) de ahí, de los 17, una vez que me han conocido, la gente venía "tu hijo sabe!" yo no quería que le contase... De ahí la gente me hallaba en la calle: "Mi hijo está enfermo!". No sé nada decía yo... "Tu mamá me dice que sabes"... no me animaba. Y hasta ahora, hay veces que me animo y hay veces que no. El trabajo con la madera, con eso estoy más... las plantas me han ayudado mucho para trabajar la madera ${ }^{246}$.

Nessa entrevista, Gerlyn me proporcionou uma interessante percepção dos caminhos na constituição $d x$ curandeirx. A relação do ofício de curandeiro com o ofício de artesão da madeira, e dos dois com a masculinidade, é amplamente reconhecida. Agustín, Medardo e Julio precederam a Gerlyn nessa combinação de ofícios. E, de fato, um deles o ajudou proporcionando os elementos e o espaço

\footnotetext{
246 "Descansei por 15 dias outra vez [voltei para fazer] a dieta. Saí dali 8 meses depois, quase com um ano (...) saí com 8 meses e vim outra vez com a mesma ideia de querer talhar... (...) Vim para a oficina, e comprei a minha madeira por 10 soles. E aos poucos... eu não tinha tanto interesse nisso... foi aos poucos. Fui dietando por um ano (...) Me acostumava aos poucos mesmo. Me faziam comer sal... não muito, só um pouquinho. Aos poucos.... daí sim, entrei 6 meses outra vez à dieta... dos 6 meses que entrei na dieta, votei para a oficina... em um mês, aprendi a fazer um cachimbo em somente um dia. E eu via as visões, a parte do rosto, só isso... meus cachimbos eram todos diferentes... uma metade rosto, a outra metade tigre... e me dizia o senhor Medardo, 'o quê você faz?'... 'Somente o que vem na mina cabeça estou fazendo' ... 'bonito!'... (...) só tigres eu gostava de fazer. Uma parte tigre, outra parte humana. Ja fazia meses que eu estava por aqui, tinha já meus amigos, o Pedro, que é talhador também... e dali entrei três meses à dieta... já estava há um ano e meio com a dieta. No total, tenho quatro anos de dieta.... e até mais. Faz pouco tempo, dieté por três meses... eu fui com um grupo [de turistas]. Arredondando, 5 anos, desde que cheguei (...) a minha mãe me perguntava, 'Você não fica entediado?' não era uma coisa obrigatória, era coisa minha, que eu queria fazer... que eu estava fazendo. Eu era muito novo quando estava dietando, tinha 13 anos (...) daí, desde os 17, uma vez que me conheceram, as pessoas vinham 'teu filho sabe!' eu não queria que [a minha mãe] thes contasse... Daí as pessoas me encontravam na rua: 'Meu filho está doente!'. Eu não sei nada dizia eu... 'A tua mãe me disse que você sabe'... eu não tinha a coragem. E até agora, tem vezes que tenho coragem e tem vezes que não. O trabalho com a madeira, com isso estou mais... as plantas têm me ajudado muito a trabalhar a madeira".
} 
físico do atelier. O ofício da madeira pode ser exercido com os insumos que as visões tidas durante a dieta provêem. Isso pode resultar em uma saída econômica também. Simultaneamente, o ofício de aprender o curandeirismo leva mais tempo e requer uma maior segurança: mantém-se em segredo até que o nome da própria pessoa seja reconhecido a partir do sucesso nas curas. Então, as pessoas falam dx jovem curandeirx, e começam a aparecer pela sua casa. As dietas na floresta são espaços de inspiração: as plantas ensinam as músicas que poderão tomar forma nas vozes humanas através dos icaros, mostram as visões que poderão ser materializadas no trabalho com madeira e mostram a maneira como uma pessoa doente pode se curar. A relação entre xs humanxs e as plantas é, nesse sentido, uma relação pedagógica onde xs humanxs se instruem, formam-se e constroem novas formas de relação a partir do aprendido (Albuquerque, 2009).

\section{- Visões e conflitos entre curandeirxs}

As experiências que se vivenciam durante as dietas na floresta são, primordialmente, de isolamento e individualidade do humano frente à multiplicidade do mundo não-humano. Tais experiências constituem a original maneira de fazer de cada curandeirx, de forma individual. Se pudéssemos fazer um mapa cognitivo do que foi aprendido por cada curandeirx, poderíamos definir círculos de territórios de saberes que nunca se sobrepõem: eles constituem o secreto do trabalho de cada curandeirx, e vão se tornando mais densos na medida em que $x$ curandeirx fica mais velhx.

Nesse sentido, xs curandeirxs, da mesma forma que xs parteirxs, não podem ser vistos como sujeitxs que ostentam um saber tradicional, cujos conteúdos se transmitem de geração para geração (Fleischer, 2007). Desde esse ponto de vista, o curandeirismo é um saber experiencial, onde se aprende através de vivências de contato direto com as plantas e o mundo não-humano. Aqui, se houver um 
curandeirx mais velho próxim $x \mathrm{dx}$ curandeirx em formação, a função deste é a de possibilitar as condições de criação desse espaço de solidão, onde o contato entre $x$ iniciadx e as plantas possa acontecer. Na hora em que xs curandeirxs aprendem seu ofício, começam a ter uma série de cuidados que tendem a respeitar essa prerrogativa de fazê-lo de uma maneira solitária e original. Enfatiza-se a importância do aprender das plantas, não das pessoas. Na solidão das dietas na floresta, cada um/a encontra seu próprio modo de acionar a relação entre o mundo do conhecido e o mundo do desconhecido, e, com o tempo, desenvolve uma lógica de trabalho particular. Conta-me o curandeiro Tocayo:

Cuando uno enseña no tiene que revelar sus secretos, que son su llave. Porque cualquiera viene y lo puede derrumbar. Uno tiene que ayudar al otro a que descubra su propia llave, eso es todo ${ }^{247}$.

Tentar descobrir a lógica que guia aos e às curandeirxs nos seus trabalhos é considerada uma perigosa invasão no segredo dos próprios territórios de saber fazer. Isso faz parte da delimitação das competências de trabalho entre uns/umas e outrxs curandeirxs, e se respeita conscientemente. Porém, a animosidade entre curandeirxs não é pouca. É sabido que uns/umas podem interromper o trabalho de outrxs, causar perturbações ou até propiciar a morte delxs ou de membros da própria família. Para se proteger destes ataques, xs curandeirxs desenham rotinas de proteção do próprio corpo com icaros, com sopladas de tabaco, com banhos de plantas e também realizam dietas e purgas que os reconectam com os espíritos aliados do mundo vegetal e animal. Durante as visões que teve na sua dieta, Gerlyn aprendeu a proteger seu corpo contra as ações de outrxs curandeirxs:

A mí me han hecho muchísimo daño... me han querido matar. Clarito en visión se veía, que un rayo pasaba ZAC! Me querían matar, venían con unas

\footnotetext{
247 "Quando agente ensina não tem que desvendar seus segredos, que são a sua chave. Porque qualquer um pode vir e te derribar. Agente tem que ensinar o outro a descobrir a sua própria chave, isso é tudo".
} 
flechas... en dieta es pucha, bien complicado. Me han hecho enfermar, y me he ido a su padre de Jorge, que vive por Tahuayo... casi no tenía la fuerza... me querían hacer botar la dieta. Me he curado, regresé otra vez a la dieta. Eran los espíritus de otros chamanes que tienen espíritus malos... de dos años sí, nadie se acercaba, estaba más fuerte... no voy a decir que soy muy fuerte pero sí, ya me defiendo de todo... Y la fuerza se gana (...) más dietas, tienes más fuerza. Si tú dietas poco, nada! De dos años ya tenía la fuerza. Y ahorita mi cuerpo, pucha está bien protegido. Yo cuando veo mi cuerpo en visión, veo puro raíces, y bien brillante. Más, unas flores blancas me tapan. Za! Todo. Y cómo brilla... ellos me protegen de toda la maldad que viene. Ellos le rebotan. Yo estoy defendido ${ }^{248}$.

Às vezes é necessária a ajuda de um/a curandeirx mais experiente que faça frente aos ataques de outrxs curandeirxs. No caso, Gerlyn procurou dom José, que é o pai de seu padrasto, Jorge. Porém, quem deve se fortalecer é x próprix aprendiz de curandeirx. Os sintomas da proteção aparecem nas visões: um corpo cheio de raízes e flores, que cheira bem, um corpo iluminado pela luz é um corpo que está sendo protegido. O corpo material que dieta as plantas fortalece o corpo espiritual, que depois do tempo necessário começa a aparecer belo, cheiroso e iluminado nas visões. Por outra parte, se uma pessoa está em contato com várixs curandeirxs, há o risco dos trabalhos ficarem inúteis, pois xs curandeirxs costumam tapar as visões xs uns/umas dxs outrxs.

O jogo de forças entre curandeirxs é considerado muito perigoso e a exposição da própria vida nele é constante. De fato, contam que a esposa de Dom José,

\footnotetext{
248 "Fizeram-me muitíssimo dano... quiseram me matar. Eu via bem claro na visão, um raio passava e ZAC! Queriam me matar, eles vinham com umas flechas... em dieta é bem complicado. Me fizeram adoecer, e tenho ido para a casa do pai do Jorge, que vive por Tahuayo... eu quase que não tinha força... queriam me fazer sair da dieta. Então sarei e retornei outra vez à dieta. Eram os espíritos de outros xamãs que têm espíritos que são do mal... dois anos depois, ninguém se aproximava, eu estava mais forte... eu não vou dizer que sou muito forte mas sim, eu já me defendo de tudo... E a força se ganha... na dieta se ganha... mais dietas, você tem mais força. Se você dietar pouco, então nada! Dois anos depois, eu já tinha a força. E agorinha meu corpo está bem protegido. Eu, quando vejo meu corpo em visão, vejo todas as raízes e bem brilhante. E umas flores brancas que me tapam. Za! Tudo. E como brilha!... Eles me protegem de toda maldade que possa vir. Eles a rebotam. Eu estou defendido".
} 
curandeiro do rio Tahuayo e pai do curandeiro Jorge, morreu por bruxaria e que Juana, a esposa de Leoco, também morreu por um trabalho que enviaram para Leoco. Todxs eles têm alguma história na qual conta que adoeceram de daños até quase morrer, e se salvaram em virtude da ajuda de certas plantas específicas, das quais se tornaram aliadxs a partir de então. A animosidade entre curandeirxs não envolve somente disparidades humanas, mas também batalhas no mundo invisível. Isabel me contou que houve trabalhos que ela não conseguiu fazer porque um espírito lhe disse que ia matá-la se sarasse a pessoa. Julio, por sua vez, conta como ele esteve a ponto de se queimar vivo por conta do ataque de uma curandeira com um fogo invisível que veio do tabaco [Nicotina tabacum].

A história, contada por Julio na casa dele em junho de 2013, é como segue: no ano de 1989, Julio começou a tomar a ayahuasca com um grupo de pessoas. Eram todos homens, e estavam se preparando para serem xamãs. Quem teve a iniciativa de abrir esse grupo foi dom Agustín, pioneiro em práticas que desafiam as maneiras de fazer do curandeirismo, essencialmente solitárias. Adela, curandeira de Iquitos, foi convidada uma vez para participar do grupo. Ela soube que Julio era um homem que não se mareaba com a ayahuasca: não sentia nenhum efeito. Segundo Julio, isso parecia incomodar à curandeira. Ela icarou o corpo dele duas vezes e lhe deu três vezes a dose da beberagem que deu aos outros: Julio, porém, não se mexeu. Adela, furiosa, preparou dez cigarros mapacho em um cachimbo enorme e se colocou a dez metros de distância. Quando ele a viu, ela estava arrojando nele a fumaça do tabaco, que tinha se convertido em uma enorme bola de fogo destinada a lhe queimar. Mais rápido que o lacerante elemento, ele se esquivou. Desde então, Julio conta que Adela não volta no povoado de Tamshiyacu, pois tem medo dele. 
Assim, as relações entre curandeirxs distam de ser harmoniosas e o espaço que entre elxs se guarda costuma ser amplo: enquanto xs curandeirxs mais pacíficxs trabalham de maneira pouco ostentosa, xs mais animosxs costumam procurar conflitos com outros curandeirxs. Em qualquer conflito que envolva tensões entre curandeirxs, podemos ver uma paisagem de éticas relacionais onde não há noções absolutas de bem ou de mal, mas sim lutas de força que às vezes envolvem histórias de conflito entre famílias ou grupos. Mas, quando pessoas que não fazem parte desse entendimento observam os trabajos de magia, daño e mal feitos por curandeirxs?

\section{- O norte político e um olhar colonial sobre a "magia negra"} Nathálie, jovem de Sri Lanka que viajou à Amazônia para aprender o xamanismo peruano, tem aversão aos "trabajos", aqueles procedimentos rituais que se realizam com a finalidade de afetar o comportamento dxs demais: "amarres", "daños", "venganzas" e beberagens para atrair possibilidades laborais, para ficar perto do amor, para esquecer, para separar outros casais. Nathálie afirmava que esses procedimentos não são outra coisa do que "magia negra" e essa prática eram moralmente condenáveis devido à influência mágica que $\mathrm{x}$ interessadx exerceria sobre a livre vontade das outras pessoas. Essa concepção é comum aos e às turistas estrangeiros, homens e mulheres, que viajam na Amazônia para aprender o xamanismo. Tito, um jovem venezuelano que morou em uma cabana próxima de Tamshiyacu durante uns quatro anos, comentou um dia na saída da única lanhouse do povoado, em tom certamente grave: "acá los chamanes trabajan todos con la oscuridad. Yo quiero trabajar sólo en la luz"249.

249 "Aqui os xamãs trabalham todos na escuridão. Eu quero é trabalhar somente na luz." 
Em outras etnografias relativas às/aos especialistas em terapias e magias em contexto popular é possível observar que o pagamento é um aspecto importante do trabalho, e às vezes é até a garantia de que o trabalho terapêutico ou mágico chegará a bom porto. Há um caso de etnografia com parteiras da cidade de Melgaço, Pará, em que a antropóloga Soraya Fleischer (2007) narra uma polêmica pelo cobrar no partejar. De maneira geral, as especialistas costumam cobrar, ainda que em produtos ou favores, o próprio trabalho.

No contexto dos comentários dxs turistas sobre curiosxs e curandeirxs amazônicxs, não é infrequente impor um tom quase moral a respeito de como deveria ser o trabalhx $\mathrm{dx}$ especialista. A higienização do campo de estudos do xamanismo talvez tenha contribuído a essa negação da importância do dinheiro para o ofício dxs especialistas populares. Segundo essa perspectiva, até o fato de cobrar dinheiro pelo trabalho de curandeirismo pode ser considerado como uma prática que se afasta da luz. Por exemplo, uma prática que produz o dano, como uma perturbação ou a morte pode ser avaliada tanto por curandeirxs quanto por pessoas próximas a elxs como uma ação do bem, pois restabelece a justiça por um crime antes cometido. É compreendido que não há uma vontade divina única e definitiva. Há instâncias nas quais fazer o bem a uma pessoa pode significar fazer o dano a outra, como no caso dos amarres de amor. Para a maioria dxs curandeirxs com os quais eu conversei, fazer amarres o trabajos são práticas perfeitamente legítimas, e que se avaliam não de maneira absoluta, mas sim relacionalmente: isto é, de acordo com uma história de vínculos, redes, reciprocidades e mútuas obrigações. Tais laços são próprios de histórias sociais de larga data. Antigas afinidades, antigas inimizades que não são visíveis ao olho de quem recém está chegando e carece de referências, de pontos de contato, de bases onde se apoiar. 
Observo o discurso dxs turistas, que se repete uma e outra vez, nos mais variados cenários etnográficos: nas ruas, nos albergues, nos bares, nas casas dxs curandeirxs, na única lan-house local. "I want to learn the shamanism, but not this black magic that they practice here. I just wanna heal and help others" ${ }^{250}$ nos comenta a jovem canadense Pamela, sentada conosco em uma roda improvisada em um local da rua perto da praça de Tamshiyacu, onde casualmente nos encontramos e compartilhamos uma bebida e uns cachorros quentes certa vez. Vejo na apreciação de Pamela, de Nathálie e de Tito conceitos que são muito parecidos com aqueles da caridade cristã: fazer o bem, ajudar aos que o necessitam, ser melhores pessoas, ficar livre do mal. Essas noções se desdobram, silenciosas, na avaliação do que é considerado "magia negra" e de tudo aquilo que aparece como moralmente condenável dentro das práticas dxs curandeirxs da floresta.

Várixs autorxs escreveram sobre o risco desta classe de projeção. A antropóloga russa Valentina Kharitonova (2004), no seu artigo sobre magia branca e negra, comenta que sociologicamente, os xamãs obscuros (que fazem danos) tendem a serem mais pobres e estarem posicionados nos estratos sociais mais baixos do que os chamados xamãs brancos (eventualmente dedicadxs somente a fazer o bem). Também a antropóloga francesa Roberta Hamayon (2004), no seu artigo sobre a relação entre colonialismo e xamanismo, observa que junto com a expansão do termo xamã a todas as terapias e práticas mágicas do globo, houve uma idealização do xamã como um ser espiritual, de práticas ascéticas e tendentes a fazer o bem. Nesse sentido, é possível observar que xs turistas que viajam para apreender o xamanismo na Amazônia do Peru beberam das fontes desta linha de pensamento que Hamayon (2004) chama de neo-xamanismo, que

\footnotetext{
$250 \quad$ "Eu quero aprender o xamanismo, mas não essa magia negra que eles praticam aqui. Eu somente quero curar e ajudar aos outros."
} 
tende a igualar todas as práticas xamânicas do globo, desenraizá-las do seu contexto e projetá-las sob o lustre rotundo de um romantismo globalizado.

Durante a minha experiência com diversxs turistas, curiosxs e pessoas da localidade de Tamshiyacu e arredores, tenho observado que a convivência com xs curandeirxs tende a desiludir muitxs turistas. Depois de terem aceitado a guia delxs e convivido com elxs nos seus albergues (como eu mesma o fiz), xs turistas começam a observar uma série de ações que não esperam e também não aprovam: xs curandeirxs também fazem trabalhos para fazer adoecer outras pessoas, ou separá-las, ou matá-las, ou fazê-las ir embora da localidade.

Projetadas na tela gigante do norte político, as imagens do grande xamã, generoso e espiritual e da mulher xamã, criatura próxima da natureza, sábia, livre e generosa se desmoronam para dar lugar à realidade diária de pessoas com lutas e realidades que lhes são desconhecidas. Creio oportuno reconhecer que até para mim mesma, como estrangeira e interessada em questões referentes à espiritualidade, às vezes foi difícil lidar com maneiras tão diferentes de compreender o que é considerado como sendo do bem, o que é compreendido como sendo do mal; o que é tido como desejável e indesejável; o que é concebido como negociável ou inegociável. Meu interesse foi trabalhar nessa própria projeção de maneira consciente e fazer um esforço para me manter à certa distância do discurso de meus pares turistas, que reconheci depois como altamente idealista e moralizante. $\mathrm{O}$ interesse nas micro-cenas da vida cotidiana e a prática de reconhecer os conceitos locais para compreender as lógicas de cada contexto me permitiram uma aproximação diferente para os códigos que são tão particulares aos trabalhos e vidas dxs curiosxs de Tamshiyacu. O trabalho de campo com Isabel e outrxs curiosxs de Tamshiyacu propiciou o caminhar não só por belas passagens na floresta, mas também por territórios invisíveis de 
encarniçadas inimizades. Foi ocasião para descobrir áreas de maior risco e aprender a respeitá-las. Foi lidar com formas de diplomacia muito sutis que, em um exercício constante de proximidades e distâncias, foi me posicionando como parte dessa rede histórica de energias sociais em constante movimento. 


\section{Capítulo 10 O corpo dxs yerberxs e os males de dios}

- Rita Gretel e Anita del Carmen, yerberita e yerbera $\bullet$ Segredinhos e outras rezas $\bullet$ O corpo feminino e o mundo $\bullet \mathrm{O}$ corpo da mulher quando é mãe $\bullet$ Sobada de uma partera $\bullet$ Mulher, corpo e saúde mental • Corpo da criança: o mal aire e os cutipados

No capítulo anterior, referi-me a detalhes do ofício dxs curanderxs e outrxs especialistas que trabalham com palos, reunidxs sob o próprio termo de curanderxs. No presente capítulo, tratarei dxs outrxs especialistas que trabalham com hierbas, reunidxs, por sua vez, sob o conceito de yerberxs. Pertencem a essa categoria as pessoas que se chamam a si mesmas de yerberxs, parterxs, sobadorxs [de mulheres grávidas] e naturalistas.

A grande maioria dxs yerberxs é de mulheres: yerberas. Porém, conheci um homem, Julio, que também se chama yerbero, pelo que em virtude dele, preservo os dois gêneros com o $x$ no termo. Contudo, o ofício de yerberx está indiscutivelmente ligado ao âmbito do feminino. A relação dxs yerberxs com os homens existe e é muito frequente: são os homens, junto com o restante da família, pacientes diários na prevenção, tratamento e cura dos mais diversos pormenores da saúde básica. Porém, o sistema das hierbas se desenvolve em torno da natureza do corpo e das doenças, desejos e possibilidades de dois tipos sociais: nas redes mais próximas dxs yerberxs são as mesmas mulheres e as crianças, sua descendência a cargo. São elxs xs pacientes em torno dxs quais as pessoas que trabalham com hierbas apuram seus conhecimentos e aperfeiçoam seus recursos práticos, são elxs xs que delineiam o território corporal e espiritual sobre o que as yerberas delineiam o seu saber.

Xs yerberxs rezam, curam os males de dios e combatem as perturbações do corpo feminino e infantil, dois tipos de corpo com inúmeras conexões que os vinculam 
a seu ambiente exterior. Para xs yerberxs, o corpo da mulher é compreendido como um espaço receptivo. Em determinados momentos de seu ciclo de vida, como menstruação, gravidez, parto e puerpério, ele permanece aberto. Nessas situações, tanto ele quanto o ambiente que o rodeia podem se modificar. É assim que se torna preciso conhecer maneiras de lidar com essas aberturas, de ligar a pessoa a si mesma, e dessas sutis estratégias de tratamento de perturbações conhecem fartamente xs yerberxs, que as tratam com rezas e com as ervas que colhem na sua chacra ou no seu quintal.

No presente capítulo, conto algumas histórias referentes às experiências com mulheres yerberas, parteras e sobadoras e uma curandera, e às maneiras como se diagnosticam doenças e se prescrevem tratamentos no caso das mulheres e as crianças (Ver Imagem 16, Yerberas). Narro o caráter de certas técnicas e receitas para tratar problemas considerados femininos, ao mesmo tempo em que defino algumas maneiras que elas têm de perceber o corpo feminino e infantil a partir do contato diário com as problemáticas de outras mulheres e crianças. Conto aqui as minhas experiências e conversas com Gerónima, Rita Gretel, Betina, Rosa, Isabel, María, Anita del Carmen e Pasquita a partir da minha identidade como mulher que se encontrava, então, grávida. Esse particularíssimo estado me permitiu acessar não só como observadora, mas também como paciente, às maneiras de fazer com plantas relativas a momentos de gravidez e ao tratamento dos corpos das sujeitas mulheres da localidade.

Assim, soube que há métodos específicos e plantas escolhidas para acompanhar o parto, para curar o sobreparto e o descenso, o pulsario e as dores de barriga provocadas pelos nervios. Pude observar algumas maneiras de ver o corpo a partir de uma dimensão espiritual: a partir da vivência das cerimônias com ayahuasca das que participei com Isabel, curandeira e xamã, soube que ela pode 
perceber o corpo e seu estado geral a partir de termos como florido ou opaco, cheiroso ou repugnante. Conheci como é que as ações espontâneas de uma criança podem ser interpretadas como sinais da possessão do dom de ser yerbera, coisa que provavelmente condicione a sua inclinação futura e a aproxime do ofício. Finalmente, deterei-me a explorar algumas concepções locais referentes ao corpo das crianças, especialmente no que se refere a duas síndromes: o mal aire e os cutipados. Eles são tratados como entidades materiais que devem ser vistos na base de uma série de cuidados muito sensíveis. Finalmente, como vimos no capítulo 8 , aprendi que todas as perturbações, dentro do território considerado como sendo próprio dos males de dios, tenderão a ser acompanhadas por um tratamento com mulheres que estão perto dos saberes das hierbas, e que se identificam como parteras, sobadoras, naturalistas e yerberas. Todavia, se a doença ou mal estar se identifica como mal de gente, as pessoas afetadas são orientadas a procurarem curandeirxs e xamãs que trabalhem com palos para a diagnose da doença ou desequilíbrio, a identificação $\mathrm{dx} / \mathrm{s}$ agressor/xs e a cura da mesma.

A observação diária das práticas dxs yerberxs de Tamshiyacu me levou a imaginar as e aos yerberxs como xs mais eficientes jardineirxs do povoado, aqueles que colocaram na consciência dos moradores e em lugares estratégicos (jardins, fundos, praças) as plantas que são valiosas para a preservação da vida humana; assim como sabem cuidar da própria preservação delas. Xs yerberxs criam as plantas como se cria qualquer outro ser vivo e, chegada a hora da necessidade, sabem lhes pedir permissão para serem usadas no tratamento de diversos problemas. 


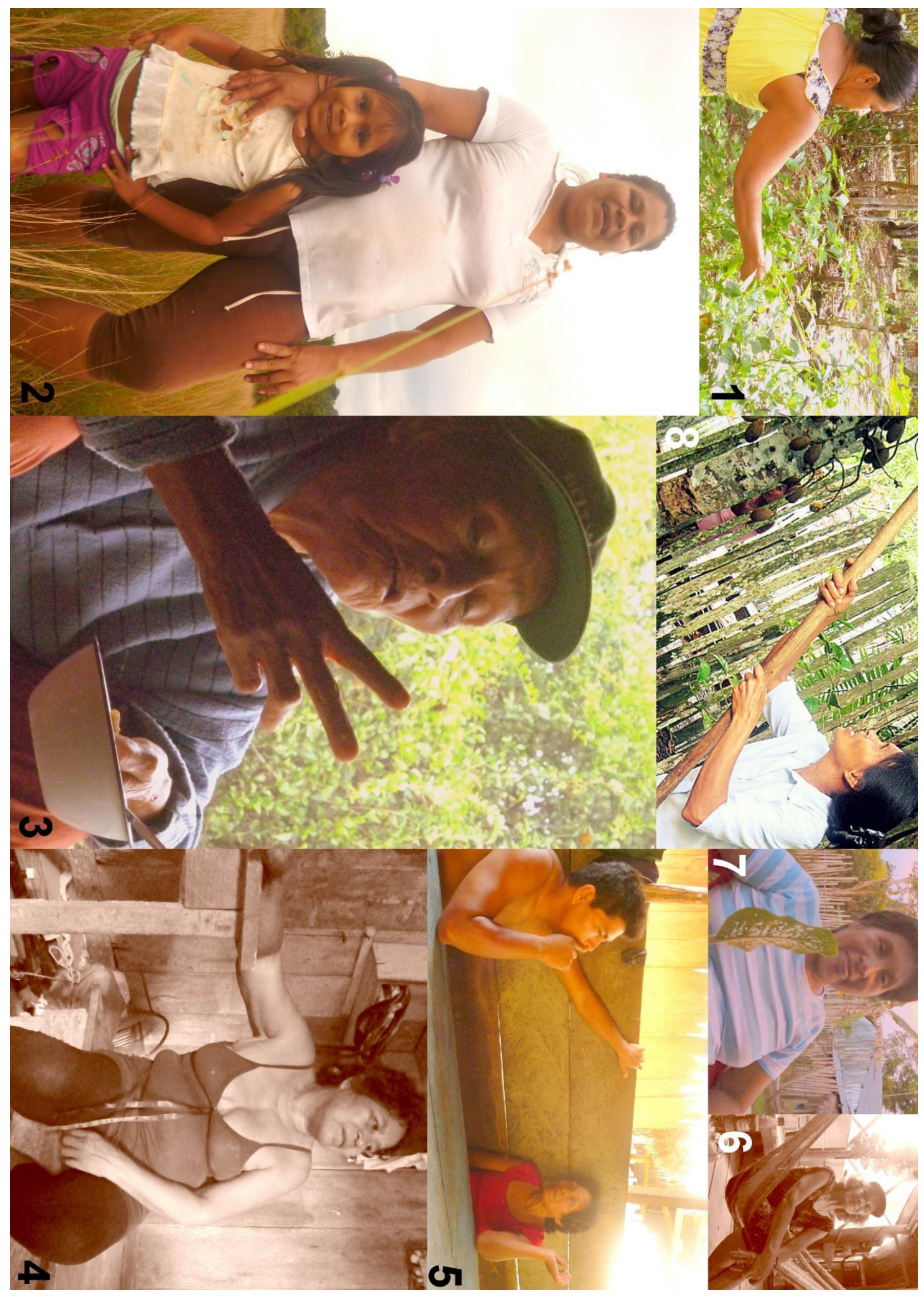




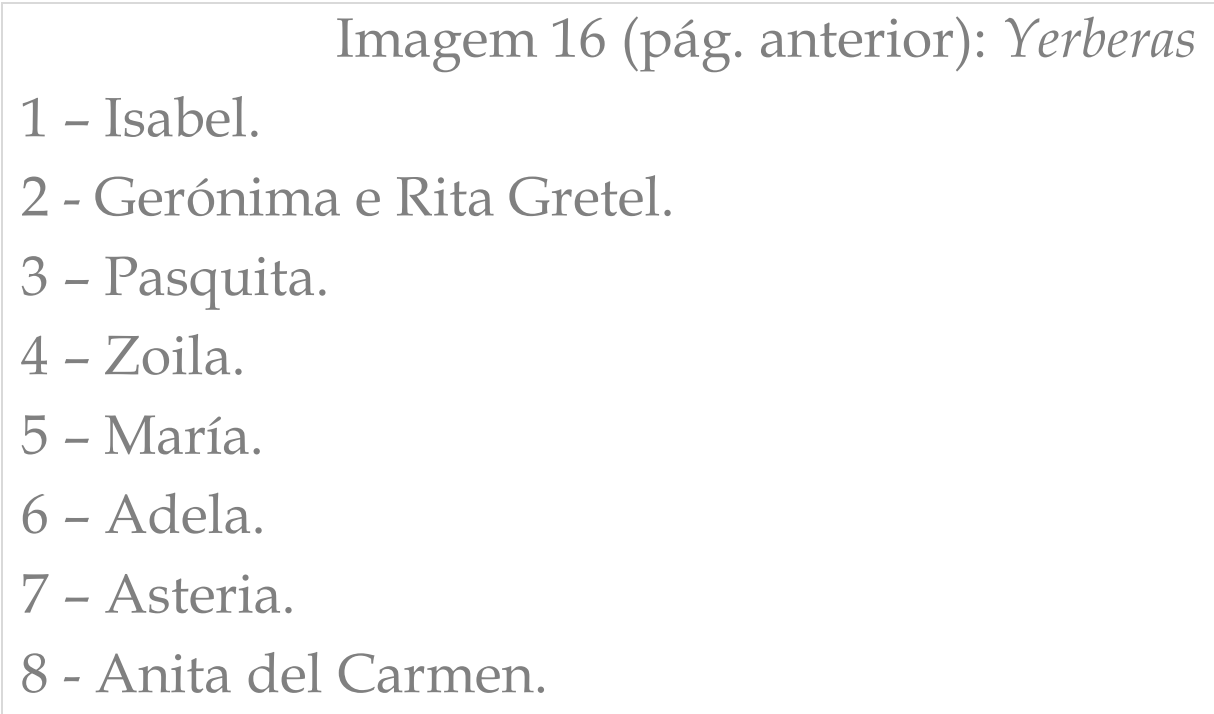

- Rita Gretel e Anita del Carmen, yerberita e yerbera Rita Gretel tem cinco anos. É uma criança esperta: gosta de dançar, brinca com os dois gatos que tem em casa, gosta de copiar as formas de folha e flores com lápis e papel. Gerónima, a mãe de Rita Gretel, disse-me que Rita nasceu um pouco diferente das outras crianças. Uma vez, ela adivinhou qual político iria ganhar nas últimas eleições. "El de la palita mamá, eseva a ganar"251, dizia se referindo a Jefferson Pizango, ex-alcalde do povoado, e a pá vermelha que simbolizava seu partido. Gerónima comenta: "Ella siempre está así, con preguntas que no sé de dónde saca. Es curiosa, la Ritita. De chiquita me trae plantas, me dice que se las haga en tecito. No es como la Gaby [irmã mais velha da Rita], que no le gusta nada de eso. Yerberita digo yo, yerberita parece que va a ser"1252. Yerberita quando criança, testando e experimentando livremente. Yerbera quando adulta, colocando seu saber a serviço da sua rede de afetos.

\footnotetext{
251 "Aquele da pazinha mamãe, esse vai ganhar".

252 "Ela sempre está assim, com perguntas que não sei de onde é que ela tira. É curiosa, a Ritita. De pequenininha que ela traz plantas, me diz para preparar um chazinho com elas. Não é como a Gaby, que não gosta de nada disso. Yerberita falo eu, yerberita parece que vai ser".
} 
Anita del Carmen mora do lado da casa do curandeiro e xamã Lucho Panduro e duzentos metros da casa de Isabel e Jorge, também curandeirxs e xamãs. Na janela exterior, ela colocou um prato com frutos de zapote [Pouteria sapota]. Um dia, ia passando pela calçada e vi alguns frutos em cima do prato. Lembrando aquele delicioso sabor do zapote, decidi comprar alguns. Bati as mãos. Segundos depois, saiu de dentro uma senhora de uns quarenta e poucos anos, magra, com camisa de cores claras e saia comprida. Eu lhe comentei que queria quatro zapotes, o que dá o valor de uma moeda de um sol peruano (0,50 U\$ aprox.) e ela me disse que tudo bem, que já voltava. Um minuto depois apareceu com uma faca, enorme como são as facas que mulheres e homens costumam usar na Amazônia. Cortou-me um pedaço do zapote, e me deu para experimentar. Do marrom da casca aparece uma cor laranja vibrante. Comi um pouco. Pareço estar desfrutando muito da sensação, Anita ri, eu elogio as frutas, as árvores, a floresta. Convidou-me então para ver a árvore de zapotes de onde ela tirara esse fruto, no quintal da casa. Eu aceito, feliz. Entramos pela casa, longa e obscura, até o fundo. Sala, cozinha, quartos cujas portas são cortinas. O chão é de barro e está úmido. As crianças nos seguem, correndo. $O$ fundo é um jardim imenso, molhado pela chuva da manhã. Anita me mostra os outros frutos do zapote, pendurados como balões de uma árvore imensa. E, em uma conversa que se estende por mais de uma hora, ela me dá a conhecer uma série de plantas grandes e pequenas de seu jardim. Wasaí [Euterpe oleracea], toronja [Citrus grandis], bijau [Calathea lutea], sachamango [Eschweilera gigantea], pan de árbol [Siparuna thecaphora], cacao [Sterculia pruriens], malva [Malachra ruderalis], cilantro [Coriandrum sativum]: reconheço em Anita uma cuidadora das árvores que estão antes da chegada dela nesse quintal, ao mesmo tempo em que uma cultivadora de trepadeiras, rasteiras e arbustos: uma mulher sabedora com inúmeras 
experiências na aplicação dos conhecimentos sobre as plantas que crescem nesse quintal.

Em uma segunda oportunidade, era quase de noite e Anita estava assistindo à TV junto ao marido dela. Convidou-me para sentar com elxs. Conversei largamente com ela então. Ela me contou do remédio para os cálculos nos rins com chancapiedra [Phyllanthus nirurie] e papa [Solanum tuberosum] ralada e serenada, assim como do remédio contra o angochupo [espécie não identificada de verme amazônico] com ajuda da pomada da beladona [Atropa belladonna]. E também me contou de remédios que não são elaborados com vegetais, mas com as casas dos insetos. A casa do comején [espécie de térmite amazônica], que também se usa contra as bruxarias e a tuberculose. Deve se encontrar a madre [que é assim como se chama ao formigueiro] do comején, e se deve extrair inteiro e levar para a casa. Inteiro assim, o formigueiro do comején parece com uma cabeça enorme. O formigueiro, "madre" do comején, a casa das formigas, se deve partir agora em quatro partes e colocar para ferver em três litros de água. Deixase que ferva até ficar só um litro de água, retirando em seguida a preparação do fogo. Coa-se e bebe-se meia taça durante vários dias. Eu perguntei à Anita del Carmen se ela se considera curandera. Ela me disse que está longe disso. Em primeiro lugar, mesmo que ela tivesse todo o conhecimento e a experiência do mundo, a sua religião, o evangelismo, não lhe permitiria se tornar uma curandeira. Em segundo lugar, ela assevera que o que ela faz é bem mais simples: "Cosa de curiosa. De yerbera nomás. Yo voy contando, la gente me va dando consejos y yo voy probando" ${ }^{1253}$.

253 "Coisa de curiosa. De yerbera mesmo. Eu vou contando, as pessoas vão me dando conselhos e eu vou provando". 
Um terceiro dia, eu fui à casa dela e ficamos conversando na porta. Eu the propus, então, fazer uma entrevista. Anita mudou o gesto, e fechando o sorriso, me disse que não queria. A partir daquele dia, não encontrei mais Anita em casa. Quando eu batia as palmas, saíam alguma das crianças ou o esposo dela. Eles me diziam que Anita não estava em casa. E assim durante três vezes. Tempo depois, encontrei Anita no mercado. A sua frieza contrastou com a simpatia das outras vezes, e eu confirmei que alguma coisa tinha acontecido. Senti-me triste de perder a possibilidade de conhecer aquela pessoa e de ter acesso aos saberes que ela com tanta paixão praticava.

Conversando sobre essa situação com Roger Rengifo Ruiz, professor de antropologia da $\mathrm{UNAP}^{254}$, de Iquitos, ele me comentou que, em virtude da religião de Anita, a situação lhe parecia compreensível. Trabalhando há alguns anos com curandeirxs ayahuasqueirxs, Roger me contou que teve a possibilidade de ver um deles se transformar em virtude da sua adesão à religião evangélica: "Ya no llamaba a los espíritus de las plantas, sino a Dios. Hacía pocos trabajos, todos en secreto. No quería que le acusaran de brujo". ${ }^{255}$ Nesse contexto, eu compreendi que talvez o meu erro pudesse ter sido o fato de pedir para Anita del Carmen fazermos uma entrevista formal. Os saberes que ela me contava com tanto deleite requeriam muita discrição de minha parte como ouvinte: ainda que ela gostasse de partilhar esse conhecimento, e talvez tivesse se sentido cômoda fazendo-o com uma estrangeira: isto é, alguém que não tem parentes na localidade e que está, nesse sentido, desapegada de qualquer rede social próxima. Porém, para qualquer pessoa que é evangélica, ficar muito perto das plantas medicinais e

\footnotetext{
$254 \quad$ Universidad Nacional de la Amazonia Peruana.

255 "Já não chamava aos espíritos das plantas, mas a Deus. Fazia poucos trabalhos, todos eles em segredo. Não queria ser acusado de ser um bruxo".
} 
mágicas é se expor à condenação social do grupo: nessa doutrina, qualquer forma de magia é considerada um exercício da bruxaria, e consequentemente, do Mal. E se ela queria transitar nos dois mundos, aquele dos saberes das plantas e aquele da religião que escolheu, precisava colocar o primeiro dentro do espaço da intimidade e do segredo, preservando-o do segundo.

Rita yerberita, Anita yerbera. Uma criança, a outra adulta. O caminho de uma vida de aprender cuidando, de testar curando. Muito mais discretxs do que xs curandeirxs, xs yerberxs lançam mão do próximo, do pequeno e do invisível. Também são, proporcionalmente, muito mais xs yerberxs do que xs curandeirxs. Elxs sabem dar uso às plantas dos seus jardins e às plantas dos jardins $d x s$ vizinhxs. Elxs cresceram aprendendo da experiência e das conversas na porta de casa. Poderia lhes caber a denominação de "empíricas" se isso não envolvesse a pretensão de um acesso à realidade desprovido de magia. Dessa categoria, xs yerberxs escapariam. Pois ainda que se trate de remédios caseiros feitos com plantas do quintal, para xs yerberxs não há uma apropriação simplória da planta como medicina destinada a curar perturbações corporais óbvias à vista. Elxs observam o sutil, e rezam. Rezando cuidam dxs outrxs, se aproximam das realidades da dor e da perturbação, dizem a sua oração ao mesmo tempo em que se encontram com os corpos, em que delineiam maneiras de previr infortúnios, de paliar incômodos, de curar as dores. Elxs não precisam rezar o tempo todo, mas necessitam saber rezar quando a situação assim o requeira. Isso faz parte dos segredos do ofício, que quando se aprende, traz consigo, como uma fonte de fortaleza, a prática de murmurar, de maneira sentida, uma oração. 


\section{- Segredinhos e outras rezas}

Apesar de não se considerar ainda uma partera, Betina ${ }^{256}$, a filha da parteira dona María, afirma: "Yo sé dar las hierbas para apurar el parto y otros secretitos, y sé por el pulso y la coronilla la hora de parir de la mujer" ${ }^{257}$. Como são aqueles segredinhos? O espaço do misterioso impede aqui uma descrição clara e sistemática de técnicas, práticas e maneiras de acesso a essas outras realidades. Mas, sem dúvidas, cada parterx, yerberx e sobador/a de lisiadxs de Tamshiyacu possui técnicas para lidar com o invisível e as aplica diariamente. Cada um/a delxs transita, de alguma forma ou outra, entre os sonhos, as visões, os palpites, a leitura de sinais no clima, no corpo e nos sons dos animais, assim como por tantas outras formas de reconhecimento oracular da realidade. No final da longa conversa do dia em que conheci a partera María, depois um amável encontro na sala da casa dela, ela me contou: "Anoche soñé com um ramito de florcitas y una cajita, um paquetito. No sabía lo que tenía adentro. Y me parece que ha sido que ibas a venir tú". Ela me conta que sonhar com flores é augúrio da visita de uma pessoa à casa. Bernardina, a idosa partera da ilha de San Pedro - que fica no rio Amazonas, a poucos quilômetros do povoado de Tamshiyacu, na direção norte - , disse-me que quando vão chegar visitas em casa, a ave pucacunga [da família das Phasianidae], que elxs domesticaram, corre e dá voltas pela casa.

\section{- O corpo feminino e o mundo}

O corpo feminino é considerado diverso em tom, ritmo e flexibilidade em relação ao corpo masculino. O corpo feminino é tido como um espaço receptivo, aberto às diversas influências energéticas, e passível de se renovar por si mesmo a partir da purga mensal da menstruação. O corpo da mulher, nos diferentes momentos

\footnotetext{
256 Pseudônimo.

257 "Eu sei dar as ervas para aprontar o parto e outros segredinhos, e sei pelo pulso e a coronilla [coroa] qual é a hora de parir da mulher".
} 
da sua vida, está conectado por fios invisíveis às realidades, ordinárias e extraordinárias do mundo que está ao seu redor. Durante a menstruação, os fluidos que excreta a mulher podem influenciar magicamente qualquer trabalho de magia que tenha sido feito por perto dela. A placenta de uma mulher pode ser usada para fortalecer o corpo do bebê que acaba de nascer. O leite da mulher primigesta pode curar doenças, como a perda da alma em bebês. $\mathrm{O}$ cabelo de uma mulher pode servir para amarrar um trabalho de magia, conseguindo uma união que não se dissolverá mais.

Diversas práticas terapêuticas e mágicas dão conta dessa compreensão de uma conexão corpórea, mas invisível, entre o corpo de uma mulher e os elementos que existem no mundo que a circunda. Um dia cheguei à cozinha de Rosa, irmã de Genoveva, a neta da partera Bernardina. E vi uma espécie de bola arredondada pendurada perto do fogo, nesse espaço que se chama de candela. Rosa me conta que tinha problemas no estômago. E que uma curiosa lhe receitou pendurar tal fruto na candela. Tal fruto é o huingo [Crescentia cujete], usado como espelho do mal no corpo de uma pessoa, seja ele uma bola ou tumor interno. Devido ao calor do fogão, o fruto seca. Então, deve secar também o tumor interno do corpo da pessoa afetada. Rosa me conta que ultimamente tem se sentido muito melhor, e me mostra como o fruto está duro e cheio de surcos, quase como o couro de um animal. É a conexão simpática entre a bola interior e a bola exterior a que permite que, ao secar a bola exterior, seque também a bola interior.

O corpo e a percepção (visual, da temperatura, dos sons, da densidade) do corpo são ferramentas fundamentais na hora do trabalho que se faz em interação entre xs curiosxs e seus/suas pacientes. O corpo faz sexo, adoece, envelhece, fica sucio [sujo], se expõe a influências negativas e positivas. O corpo feminino é 
considerado um material mais aberto às influências do que o corpo masculino. Nesse sentido, para as mulheres resulta mais direta a influência dos vegetais. Elas podem absorvê-los melhor e ter uma comunicação mais rápida com os espíritos. Ao mesmo tempo, as mulheres podem adquirir com maior facilidade as influências negativas do ambiente.

\section{- O corpo da mulher quando é mãe}

Nesse ponto, agruparei as experiências relativas à preparação para o parto e nas doenças do sobreparto e descenso e os tratamentos mais frequentes. As concepções a respeito do corpo da mulher estão culturalmente marcadas por noções de abertura, tibieza, frieza e fraqueza. Quando a mulher engravida, essas características se tornam mais deliberadas. $\mathrm{O}$ ventre da mulher passa a ser, a um mesmo tempo, lugar de preparação da vida e também lugar de riscos, vulnerabilidades e potenciais doenças. Há uma estreita relação entre o corpo da mulher grávida e o ambiente que o circunda. Ele está, literalmente, aberto. Desta maneira, ele está exposto a todo tipo de influências, tanto positivas quanto negativas. Uma é a influência da água. Gerónima me diz que é bom fazer xixi na água que corre. É garantia de um bom parto, de um parto que vai correr bien [correr bem]. A partera María me conta que para ajudar a placenta a sair depois do parto, a mulher deve assoprar e assobiar na boca de uma garrafa. Aqui, não se considera que a garrafa representa, mas é o próprio canal de parto da mulher ${ }^{258}$.

Genoveva me conta que deve estar sofrendo de sobreparto, uma doença que pode acontecer com mulheres até vários anos depois de terem dado a luz. Genoveva

258 Por sua vez, esses exercícios são similares aos que propõe a eutonia (do grego "eu": bom, justo, harmonioso; e "tônus": tono, tensão) uma disciplina corporal contemporânea para mulheres em preparação para o parto que foi proposta pela terapeuta alemã Gerda Alexander em 1959. Um dos exercícios consiste em abrir a boca em forma de $\mathrm{O}$ e entoar som correspondente para abrir o canal que conecta a cavidade bucal ("boca de cima") à cavidade vaginal ("boca de baixo"). Ver Alexander (1979). 
dizia que deve estar sendo isso mesmo, pois bebeu uma água de côco e a vomitou. Se sofrer de sobreparto, a mulher experimentará enjôos, diarreia, retenção da placenta e/ou hemorragia pós-parto. Gerónima me conta que com as pastilhas que deram à sua filha mais nova no hospital, que eram contra a diarreia, ela acabou melhorando. Interessante notar, aqui, que sobreparto, síndrome cultural, pode ser paliado com remedios de botica. O sobreparto também pode ser prevenido. Primeiro, com vaporizações. Depois, com lavagens. Para as vaporizações, colhem-se algumas folhas do plátano verde. Colocam-se em uma panela com água quente, na cozinha da casa. O vapor que sai da panela é aproveitado pela mulher que, com um pano ao redor da cintura, deposita a panela no chão e coloca-se por cima da panela. Enquanto recebe o vapor na vagina, ela bebe um fresco de malva [Malachra ruderalis], bebida feita com as folhas comprimidas da planta em água fria.

As lavagens pós-parto para prevenir o sobreparto são, assim mesmo, muito frequentes. Gerónima me contou que depois de ter nascido sua terceira filha, que morreu dentro do ventre, ela ficou fazendo lavagens com ubos [Spondias mombin] e chuchuasha [Maytenus macrocarpa]. Isso lhe cerró [fechou] os órgãos por dentro, impedindo o sobreparto e fazendo com que seu ventre ficasse "como nuevecito" [como se estiver novo] para gestar outra vez. Foi então que, três meses depois desse parto, Gerónima engravidou de Rita Gretel. "Dios te envía rápido otro para que no te quedes sin nada después de lo que te ha quitado"259, me comentou. Outra das afeções comuns da mulher também é relativa ao espaço de seu ventre. Chama-se de descenso, e representa o fluido vaginal patológico. Um dos remédios mais comuns é o cordoncillo [Piper aduncum], que é administrado segundo diversas

\footnotetext{
259 "Deus te envia rápido outro [bebê] para você não ficar sem nada depois daquele que ele tirou de você".
} 
receitas. A que segue me foi descrita por Genoveva, a neta da parteira Bernardina: colhem-se sessenta folhas de cordoncillo, colocam-se para descansar na água fria, sem mexer e nos próximos dias se tomam como agua de tempo. Coloca-se a bebida em uma garrafa e bebe-se cada vez que der sede. O descenso é considerado muitas vezes um simples mal de dios, mas, quando é muito abundante ou fétido, pode ser sintoma de um mal de gente.

\section{- Sobada de uma partera}

Era o início de outubro de 2013. Eu estava entrando no quarto mês da minha gravidez e os enjoos típicos do primeiro trimestre estavam passando, mas continuavam me importunando. Um belo dia, de manhã, decidi ir fazer sobar a minha barriga grávida com a dona María (Ver Imagem 17, Parteras). Essa iria ser a segunda vez que eu ia visitá-la, depois da primeira incursão no segundo mês da gravidez. Carl decidiu me acompanhar. Ele levava uma sacola com verduras que compramos da feira e o guarda-chuva que nos protegia do intenso calor da manhã. Eu tinha acordado especialmente enjoada. O calor estava batendo forte no meu corpo. A casa de María ficava a não mais de cem metros do mercado, pelo que chegamos prontamente. Já no jardim da frente, batemos as palmas. Apareceu a filha da dona María, Betina. Conduziu-nos até a cozinha da casa. María estava lá, preparando peixe para assar mais tarde. Enquanto me contava que estavam frescos - María dizia que haviam sido pescados durante a madrugada anterior pelo seu marido-, ela lavava as suas mãos, secava-as rapidamente e estendia, em gesto breve, a sua mão direita para nos cumprimentar. María estava usando óculos escuros. Eu perguntei como estava da vista (ela está ficando cega do olho direito) e me disse que iria fazer uma cirurgia dentro de poucos dias. Depois disso, María perguntou por mim. Mas, antes de esperar a resposta, convidou-nos a ingressar no quarto cuja porta dava à cozinha. O quarto estava fresco, úmido, escuro. Betina jogou um lençol claro em 
cima do colchão, onde fui convidada a me deitar. Betina e Carl estavam de pé, olhando a cena. María trouxe uma cadeira e sentou. Então levantou a minha camisa até as costas e me sobó com uma pasta oleosa que tirou de uma garrafa plástica reciclada. Era o unto, uma preparação branquicenta feita na base de gordura de galinha e de gotas do fruto da toronja [Citrus grandis]. Então ela nos disse que toda partera o sobadora deve de ter um unto sempre pronto, pois ele é ferramenta básica do trabalho. Enquanto estava deitada, María ia me contando. Ela parecia ter os olhos fechados por trás dos óculos, e tocava o meu ventre com uma mistura delicada de cuidado e firmeza. María me contou então que atendeu há mais de cem partos durante a vida dela. E que as mulheres devem se cuidar. Cuidar dos nossos ventres, da nossa alimentação. E não deixar que a gravidez nos aborreça ou nos deixe deitadas na cama. "Es importante cuidar de los pensamientos ${ }^{1260}$, me disse María, tocando a sua própria cabeça, sovando os cabelos com uma mão oleosa e lançando uma risada.

260 "É importante cuidar dos pensamentos". 


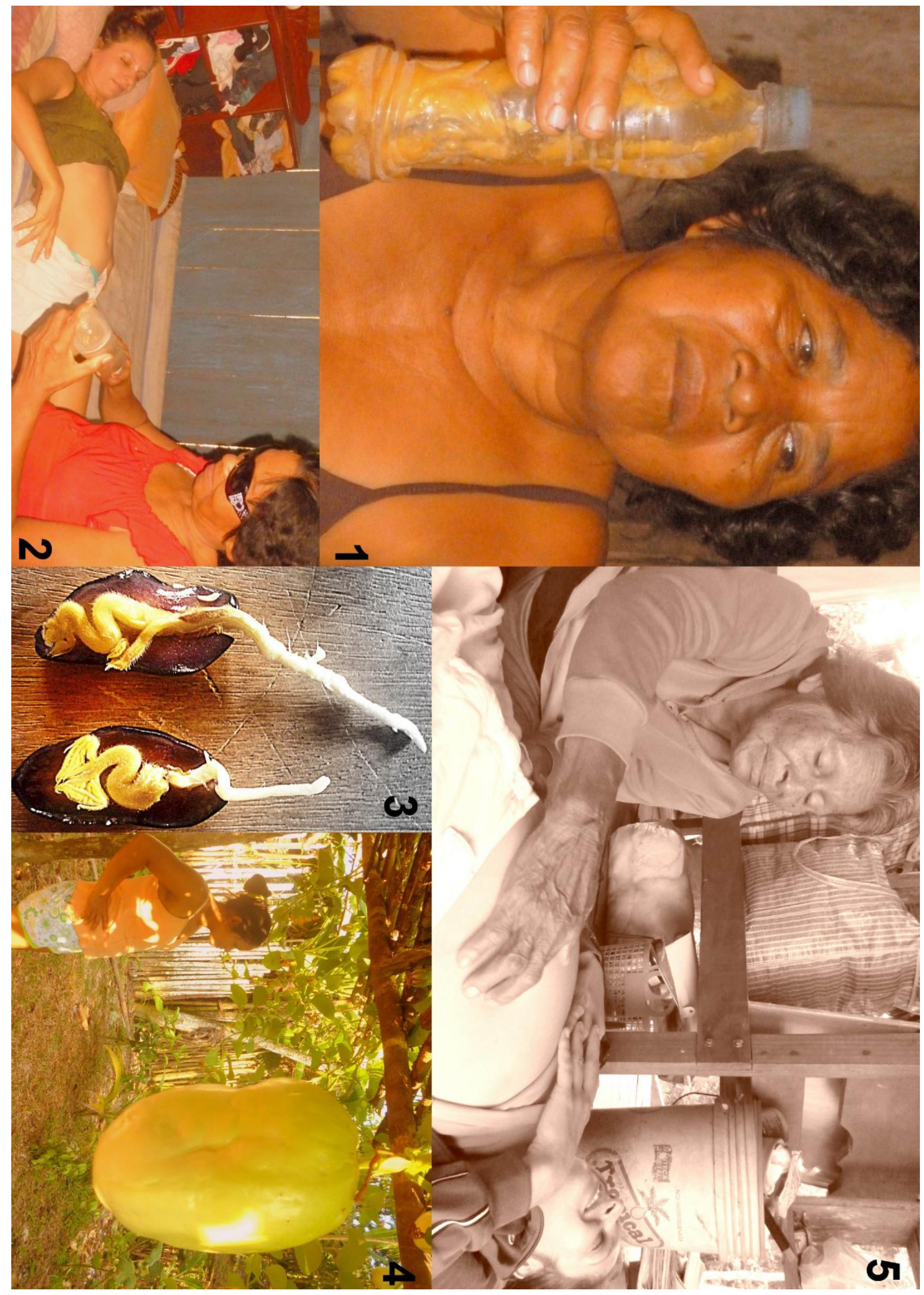




\begin{abstract}
Imagem 17 (pág. anterior): Parteras
1 - Zoila, mostrando o unto feito com gordura animal com o qual ela faz as sobadas. Fotografia: Gentileza de Carl Carew. 2 - María, sobando a minha barriga. Tamshiyacu, Outubro de 2013. Fotografia: Gentileza de Carl Carew.
\end{abstract}

3 - Duas sementes da árvore da guaba [Psidum guajava], semelhantes a embriões humanos.

4 - Betina, mostrando o jardim do fundo da casa e, em primeiro plano, as trepadeiras do tumbo [Passiflora tripartita].

5 - Pasquita, também sobando a minha barriga. El Chino, Outubro de 2013. Fotografia: Gentileza de Carl Carew.

\footnotetext{
-Mulher, corpo e saúde mental

Isabel, curandeira e xamã, costuma mirar o que acontece ao redor e dentro dos corpos das pessoas durante as cerimônias com ayahuasca, quando tanto ela quanto xs pacientes presentes ingerem a beberagem. Às vezes, ela vê corpos cheirosos, cheios de flores, frutos e cores. Alguns até fazem soar chocalhos e outros sons rítmicos junto à visão. Tais elementos são considerados de bom augúrio para a vida, assim como de uma relação de afinidade com o mundo vegetal. Em outras oportunidades, porém, Isabel mira corpos apagados, sem formas definidas, opacos. Em alguns casos, vê espíritos por perto, formas assustadoras que não se afastam da pessoa enquanto ela está lá, deitada. Elementos como esse são considerados de mal augúrio ou até o sinal de um trabalho de mal de gente feito sobre o corpo da pessoa em questão. Essa pessoa provavelmente vai requerer da ajuda tanto $\mathrm{dx}$ curios $x$ quanto das plantas, e de um tratamento que pode durar vários meses.
} 
A possessão no corpo de uma mulher pode ser atribuída a conflitos com outras mulheres quando ambas desejam permanecer com um mesmo homem. Contame Sofia ${ }^{261}$ a história da sua mãe, Casiana ${ }^{262}$ :

Ella era alcohólica, bebía aguardiente, no se encargaba de la casa ni de los chicos. Mi papá, cuando veía que ella no hacía nada, le pegaba. Y yo, que era la uinsha, sufría de ver como el la sacudía, como una muñequita. A veces ella dejaba de beber. Entonces decía que no era ella misma que quería beber, que era como si algo le obligase. Una vez, llevaron a mi mamá con un curioso. Allá les dijeron que era un mal que la ex mujer de mi papá le había hecho. Y que era muy, muy difícil de curar. Cuando ella estaba bien, era una artista. Bailaba todos los años para la fiesta de Tamshiyacu, participaba de los concursos. Murió de cirrosis y antes de morir, pidió perdón para todos los hijos ${ }^{263}$.

As atitudes estão coladas nos corpos destas mulheres, e determinam, além dos males de dios que elas tenham que atravessar durante a própria existência, a experiência delas perante a vida. Por exemplo, durante esse momento tão crucial que é o parto. Betina, filha da parteira María, que a ajuda nos partos e que ademais gosta de jogar vôlei, disse-me que a mulher parturiente e a parteira que está acompanhando o parto devem se sentir parte de uma mesma equipe. A parteira deve ser valente e dar valor e confiança à mulher. A mulher deve ser corajosa e também aprender a confiar na parteira. Se a confiança ou a coragem

\footnotetext{
$261 \quad$ Pseudônimo.

262 Idem.

263 "Ela era alcoólatra, bebia aguardente, não se encarregava da casa nem das crianças. O meu pai, quando via que ela não fazia nada, batia nela. E eu, que era a uinsha [a filha mais nova], sofria de ver como ele a sacodia que nem uma bonequinha. Às vezes, ela deixava de beber. Então dizia que não era ela mesma que queria tomar, que era como se algo a obrigasse. Uma vez, levaram a minha mãe com um curioso. Lá the disseram que era com certeza um mal que a ex-mulher do marido tinha lhe feito. E que era muito, muito difícil de sarar. Quando ela estava bem, era uma artista. Dançava todos os anos para a festa de Tamshiyacu, participava dos concursos. Morreu de cirrose e antes de morrer, pediu perdão para todos os filhos."
} 
falharem no momento do parto, são as duas que morrem! A mulher morre no corpo por não ter podido dar conta do processo, a parteira morre para as outras pessoas porque faleceu uma parturiente em suas mãos.

A saúde mental é uma questão bastante recorrente quando se trata de distúrbios relativos às mulheres e aos corpos femininos. Assim como um mal de gente como aquele que teve Casiana pode enlouquecer a uma mulher, uma doença vinda de deus, que aloja estados anímicos negativos pode chegar a matar à pessoa. Pasquita, curandeira idosa da comunidade de El Chino, conta que ela já era casada com Fidel, mas não conseguia conceber uma criança. Então Fidel the convidou a tomar ayahuasca. Na sessão, a ayahuasca lhe contou tudo o que ela precisava saber: diagnosticou-lhe pulsario e lhe deu as instruções a seguir se ela quisesse sarar. Era uma doença muito debilitante: a barriga dela batia, pulsava, que nem um coração. Ela soube então que o pulsario é um mal de dios relativo às necessidades que a pessoa atravessa durante a vida, e que a melhor cura para isso é um elemento humano que se entende como a própria abundância: um copo com leite materno da mulher que foi mãe pela primeira vez. Convida-se o leite durante três luas verdes. Isto é, durante três ciclos lunares. A cada lua verde, o leite se toma durante três dias. Nos que são, no total, quase três meses de tratamento, a moléstia passou, a possibilidade se abriu. Aí ela sangrou bastante, como a ayahuasca tinha previsto. Tomou então a feminina planta chuchuasha [Maytenus macrocarpa] que ela tinha já pronta e preparada no álcool, na forma de uma tintura. Esse seria o remédio para curar o seu ventre, cuja natureza indicava como sofrendo do estado frio. Então, ela sangrou. Sangrou bastante, como limpando o corpo. Logo depois, Pasquita ficou grávida de Lidia. 


\section{- O corpo da criança: o mal aire e os cutipados}

Floresta e jardins, palos e hierbas, curanderos e yerberas, homens e mulheres. Até os fetos das crianças humanas experimentam a divisão de gênero desde dentro do ventre. Segundo a concepção local, os meninos tomam forma durante os três primeiros meses, enquanto as meninas não têm forma senão até os últimos dias que permanecem dentro do ventre. Ademais, os meninos tendem a se mover muito, já as meninas costumam serem mais tranquilas. Porém, tanto meninos quanto meninas são propensxs a padecer de doenças, tanto males de dios quanto de serem afetados por bruxarias. No folhetim do Instituto de Medicina Tradicional do ano 1993, há uma lista de síndromes culturais que são, ainda que não exclusivos, são mais comuns nas crianças: mal de aire, susto o manchari, mal de gente, cutipado, mal del agua, mal del monte e mal de ojo. Para as pessoas da localidade, são doenças que não se curam no hospital. E, se a pessoa for levada ao hospital para curar qualquer uma destas doenças, corre o risco de piorar ou até morrer. É por isso que o trabalho dxs curiosxs é, nesse ponto, insubstituível, enquanto que a oportuna intervenção destxs pode definir a vida ou a morte de uma criança.

A descrição do mal aire que se faz no boletim é como segue (Folhetim IMET, 1993): "Es um espíritu maligno que sustrae el alma del niño. Sus síntomas son vómitos, fiebre y postración. Se cura con ícaros y sopladas con humo de tabaco ${ }^{264 " . ~ A ~}$ partera María me explicou sobre o mal aire com maior detalhe: ele se produz quando a criança ou $x$ adultx estão débeis e os maus espíritos aproveitam a ocasião para vir lhes perturbar. Contudo, a doença é mais frequente nas crianças, que são os seres humanxs com menor proteção. Se o pai ou a mãe da criança voltar tarde em casa com ela nos braços, os espíritos podem sair ao

\footnotetext{
264 "É um espírito maligno que subtrai a alma da criança. Seus sintomas são vômitos, febre e prostração. Se cura com ícaros e sopladas com a fumaça do tabaco".
} 
encontro dela e produzir a doença. A experiência do mal aire é muito frequente, especialmente em bebês. Manifesta-se com uma repentina incomodidade: observa-se uma inquietação no corpo delas. A incomodidade se expressa na impossibilidade que elas têm para dormir ou ainda se alimentar. Depois, aparecem os vômitos e a diarreia. O corpo se desajusta. Não comem, não dormem. A agitação é grande, a perturbação seca os olhos.

Para curar o mal aire é preciso ir a um/a curiosx, pode ser alguém que trabalhe com hierbas ou também pode ser alguém que trabalhe com palos. $\mathrm{X}$ especialista vai usar a fumaça do tabaco ou queimar outro elemento para obter uma fumaça que, junto com ícaros ou orações, espante do corpo o espírito invasor. A receita de María aproveita a fumaça do corno de uma vaca. O cacho [corno da vaca] deve ser raspado e colocado em um prato de alumínio com carvão. Esse prato vai ficar no chão da cozinha, perto do fogo. Usa-se a fumaça que surge do cacho e o carvão: coloca-se o bebê deitado em cima dela, para receber os eflúvios mágicos da fumaça no corpo. Se for mal aire, espera-se que o bebê melhore nas próximas horas.

Outro dos mal-estares que são mais comuns nas crianças é o cutipado. No folhetim do IMET (1993) consta: "El niño adopta la actitud de imitar animales (mono, perro, gato, víbora, pelejo, achuni) u objetos (pelota)"265. Essa síndrome é expressiva de distúrbios nas relações com o mundo. Há um complexo universo de relações entre plantas, animais, espíritos não-humanxs e humanxs através do corpo que é a doença do cutipado. Em Tamshiyacu, todo mundo teve um cutipado alguma vez. São moléstias raramente mortais, mais muito desconfortáveis. Na loja que ela

\footnotetext{
265 "A criança adota a atitude de imitar animais (macaco, cachorro, gato, serpente, pelejo [uma espécie de primata], achuni [uma espécie de ave]) ou objetos (pelota)".
} 
atende no mercado, Eva, uma jovem de trinta anos, me contou que seu filho Jesus $^{266}$, quando tinha um ano de idade, foi cutipado pelo lagarto negro. A causa disso parece ter sido o fato de alguém da família ter lhe dado um pedacinho dessa carne para ele chupar quando ainda não tinha dentes. Eva me conta que essa pessoa não lhe consultou. "Tenía la barriga hinchada y no podia salir nada por debajo"267, ela me comenta, aludindo à impossibilidade da criança para defecar. Levaram-lhe para o hospital da cidade de Iquitos, deram-lhe medicamentos de farmácia e Jesus não sarava: "nada lhe hacían los jarabes ni las pastillas!"268. Eva me faz sentir o desespero daquele momento: primeira criança, síndrome desconhecida, a falta de alternativas do lado da biomedicina. Ela começou a suspeitar de um mal de gente, alguma bruxaria enviada por alguém que queria lhe fazer o mal. Quando a criança é pequena, há um risco grande de ela pegar o mal que foi enviado para a mãe, explicou-me Eva.

Aflita, Eva decidiu voltar a Tamshiyacu e ir ver um curandeiro de nome Chamuco. Ele lhe disse que não era daño [bruxaria], mas simplesmente cutipado. Durante três dias, Chamuco assoprou o corpo da criança, deu-lhe uma planta icarada para beber, colocou-lhe no peito cera de vela em forma de cruz. "Si no fuera por eso, mi hijo se hubiera muerto"269, suspira Eva. Por sua vez, María, a partera, contou-me que há diferentes tipos de cutipado:

Cutipado del majaz: Cuando la madre ha comido majaz estando embarazada. El majaz no deja dormir al niño. Se cura humeando la cerda y el hueso del majaz en el cuerpo del niño.

\footnotetext{
266 Pseudônimo.

267 "Tinha a barriga inchada e não podia sair nada por debaixo".

268 "Nada lhe faziam os jarabes nem as pastilhas!".

269 "Se não fosse por isso, meu filho teria morrido".
} 
Cutipado del pelejo: Cuando la madre come pelejo estando embarazada o le tiene miedo al animal. El bebé no aprende a caminar, tiene los ojos con lagañas, anda agachadito. Con la cerda y el hueso se le humea.

Cutipado del perro: Si se le pega al animal, éste lo cutipa al niño.

Cutipado del gato: El niño anda con ojos lagrimosos.

Cutipado de la pelota: Cuando el padre es pelotero y juega al fútbol en los primeros días después de haber nacido el niño. Se le hincha la barriga al bebé. Para curarlo, se le pone la pelota en una bandejita con agua. Suavemente, se lepasala pelota por la barriga ${ }^{270}$.

Pelo que María, Eva e outrxs pessoas do povoado me contaram, o cutipado pode ser definido como um desequilíbrio causado por uma transgressão. Essa transgressão desata uma espécie de fúria da natureza ou do entorno (especialmente animal, mas também vegetal, anímico ou de outros objetos). Esses tabus tendem a serem transgredidos de forma coletiva: muitas vezes são xs adultxs que xs transgridem e xs bebês e crianças, que se consideram mais fracxs, sofrem as consequências disso e adoecem. Assim, o cachorro que foi golpeado na casa pode cutipar um bebê, da mesma maneira que o homem que está com outras mulheres e deixa a mãe em casa sozinha com a criança pode cutipar à criança com seu comportamento de abandono. O cutipado fala não somente sobre o que deveria ser feito corretamente, mas também sobre a natureza delicada das relações entre as pessoas e o mundo não-humano. Também se fala da natureza fundida do corpo da mãe e da criança, como nos casos de cutipado por susto ou

\footnotetext{
270 "Cutipado do majaz [mamífero amazônico]: Quando a mãe da criança, ainda grávida, come a carne de monte de majaz. O animal não deixa a criança dormir. A cura consiste em jogar a fumaça do pelo e do osso queimados do majaz em cima do corpo da criança. Cutipado do pelejo [primata amazônico]: Quando a mãe come o animal ou tem medo dele. É possível detectar essa sindrome quando o bebê tem dificuldades para aprender a caminhar, produz grandes quantidades de remela nos olhos ou caminha encurvado. A cura deste mal é possível com a exposição do corpo da criança ao pelo e o osso do animal, queimados. Cutipado do cachorro: se bater no cachorro da casa, ele pode cutipar à criança. Cutipado do gato: É possivel detectar porque a criança tem olhos que lacrimejam. Cutipado da bola: Pode aparecer quando o pai da criança gosta muito de jogar futebol, e vai jogar nos primeiros dias depois de ter nascido a criança. Então, a barriga do bebê fica inchada. A cura desta síndrome consiste em colocar a bola em uma bandeja com água e depois passar, suavemente, a bola pela barriga da criança".
} 
ingestão da mãe e, no caso do cutipado da pelota, reconhece-se a influência espiritual das ações do pai sobre o corpo da criança. O cutipado é a síndrome que, por excelência, põe em evidência a densa rede de relações dxs humanxs entre si e entre humanxs e não humanxs.

Como pudemos observar ao longo do capítulo, a conexão que cada um/a dxs yerberxs faz entre os conhecimentos das plantas e os distúrbios do corpo é particularíssima. Ela está marcada pela própria experiência de vida em relação às hierbas, assim como pelas experiências das pessoas que elxs trataram. A socialização dxs yerberxs ao longo da vida envolve a proximidade com uma grande diversidade de espécies vegetais (e, em alguns casos, também animais) especialmente plantadas nos jardins das casas e do povoado, assim como a especialização no tratamento e alívio dos males de dios, isto é, das doenças produzidas pela fatalidade da vida.

Devido ao espaço no qual trabalham, considero que xs yerberxs são xs agentes invisíveis que mantêm o sistema básico de saúde local, agindo como filtragem para quaisquer doenças que possam ser tratadas nos centros de saúde e nos hospitais da localidade. Criando as plantas nos jardins do povoado de Tamshiyacu, xs yerberxs sabem controlar e deter processos de doença e cuidar dos corpos das pessoas que estão próximas da rede social de referência, especialmente das mulheres e das crianças. Os corpos delxs são compreendidos como territórios que se conectam aos remédios das hierbas de maneira particularmente efetiva: em consequência disso, eles são o espaço privilegiado em torno do qual xs yerberxs aprimoram diária e silenciosamente seus conhecimentos e suas criativas maneiras de fazer com plantas. 


\section{Capítulo 11 \\ Trajetórias excepcionais}

\footnotetext{
- Desvios e exceções • Dois homens, Julio e Ernesto • Três mulheres, Adela, Pasquita e Isabel $\bullet$ Artes de fazer
}

\section{- Desvios e exceções}

"Qué harían las mujeres sin los hombres y los hombres sin las mujeres. Y todos sin el agua!" Curandeiro Tocayo. Entrevista em Tamshiyacu, setembro de 2013.

Desde o início mesmo da constituição da antropologia e a sociologia como disciplinas, elas têm se ocupado da reprodução das normas sociais até o ponto em que regras, leis, ditames e rituais dominaram o cenário da imaginação da escrita social. Desde o século XIX em diante, tal tendência dominou esses campos de saber: enquanto xs mentorxs da sociologia assumiam a apreciação, o cumprimento e a transgressão das normas dentro da sociedade conhecida urbana e tida como ocidental - constituía-se o "funcionalismo" em antropologia. Aqui, a imaginação antropológica se alimentava, por meio de viagens a regiões distantes do globo, de informações etnográficas concernentes a sanções, tabus, penalidades e outras formas de regulação do comportamento social em relação ao uso do corpo, a alimentação, a guerra, as relações familiares e o habitar dos territórios de maneira organizada. Com o florescimento da escola de Chicago, nos Estados Unidos dos anos 1920`s/1930`s, os estudos sobre desvio social na cidade combinaram perspectivas sociológicas e antropológicas para interpretar os comportamentos dos grupos de jovens de bairros peri-urbanos e a sua relação com práticas fora da norma que a sociedade majoritária colocava no obscuro espaço da criminalidade. Assim, a vida nas ruas, a deserção escolar, o uso recreativo de drogas ilegais e a violência dos corpos foram lidas primeiro como 
transgressões a normas de convivência social e depois sob a noção sociológica de estigma (Goffman, 1963). O conceito de estigma foi definido como uma desaprovação social severa que redunda em maneiras negativas de marcar corpos e pessoas pelo fato de serem percebidos como contrários às normas culturais estabelecidas.

Contudo, a própria apreciação que a sócio-antropologia da escola de Chicago construiu a respeito dos comportamentos que fogem das normas convencionais não só o objeto enxergado, mas também o próprio olhar. A noção de desvios, como maneira privilegiada de ler as exceções às regras sociais, dotou a esse tipo de estudos de um bias normalizador que balizou, ao mesmo tempo em que ponderou, os limites entre uma normalidade-positiva e uma abnormalidadenegativa.

No ano 1974, o filósofo francês Michel Foucault propôs durante um curso no Colégio de França uma genealogia histórica do conceito de normalidade, desconstruindo a sua força normativa intrínseca e situando-o como uma noção construída e variável, distribuída em tempos históricos e espaços geográficos diversos (Foucault, 1999). Seguindo a linha de raciocínio de Foucault, o sociólogo britânico Nicholas Rose refere em uma publicação recente (2009) à relação, historicamente construída, entre normalidade e noções de média estatística, magnitudes típicas e a sua relação moral com ideias não explicitadas de saúde e moralidade. Rose traz para a discussão uma distinção que o filósofo da medicina Georges Canguilhem fez entre normas sociais e normas vitais. As primeiras se refeririam a dimensões como a legalidade, a docilidade, a produtividade, a pontualidade, a civilidade; enquanto as segundas estariam relacionadas à luta da vida mesma contra a morte. É certo que a distinção entre normas orgânicas do corpo e normas artificiais da sociedade foi colocada em questão por uma série de 
críticas ao binarismo natureza/cultura, feitas desde os estudos do feminismo e da pós-modernidade (Haraway, 1995). Porém, o que aqui interessa é a relação, teoricamente estabelecida, entre uma normatividade social e uma oculta moralidade que dá, de maneira automática, às normas o status de construtos ideais positivos em si mesmos; enquanto atribui aos desvios o status negativo intrínseco de serem meros expoentes das degenerações, anomalias e irregularidades do social.

A sociologia e a antropologia lutaram contra a herança funcionalista de relevar somente as normas sociais e a idealidade das regras, deixando de lado as práticas particulares, as exceções à regra, as estratégias, as reapropriações e a criatividade das escolhas singulares. Nesse capítulo, a minha proposta é trazer um olhar particularista e localizado da maneira como certxs sujeitxs sociais se posicionam frente às regras explícitas de um conjunto de maneiras de fazer com plantas que é próprio de um grupo social específico, xs curiosxs da Amazônia do Peru. Sujeitxs que, como diz De Certeau, "circulam, vão e vêm, saem da linha e derivam num relevo imposto, ondulações espumantes de um mar que se insinua entre os rochedos e os dédalos de uma ordem estabelecida" (1998: 97). Xs sujeitxs que aqui retrato foram capazes, ao longo de seus itinerários biográficos, de percorrer trajetórias distantes do que para elxs foi socialmente construído como uma regra ou conjunto de regras, e resolveram de maneiras criativas a sua própria relação com as normas sociais em termos de seu gênero, o tipo de plantas com as quais trabalham e as especialidades que cultivam dentro do ofício, mais amplo, de curiosx.

A classificação binária do mundo das hierbas e do mundo dos palos se manifesta especialmente no plano das ideias sobre o dever-ser da cultura local, condicionando a cotidianidade dxs sujeitxs sociais a prerrogativas, divisões, tabus e direcionamentos orientados para a ação. Porém, nem todas as mulheres 
estão destinadas a trabalhar com hierbas, nem todos os homens são designados a organizar suas terapias e magias ao redor dos palos. O presente capítulo narra algumas trajetórias de vida de curiosxs que estão marcadas pela excepcionalidade às regras. E, desde a minha perspectiva, essa excepcionalidade deve ser tratada como algo mais do que um desvio. Ela é a apropriação criativa de um conjunto de regras que, como mutável que é, vai se transformando e inclui a prática cotidiana dxs sujeitxs nessa transformação.

No seu trabalho sobre concepções sobre bruxaria entre mulheres dentro de comunidades pescadoras da ilha de Santa Catarina, Sônia Maluf (1992) relata que "os modelos apresentados pelos moradores apontam para uma rígida divisão sexual das atividades" (pp. 99). Porém, "uma análise mais apurada faz desaparecer a distância entre os gêneros nas práticas efetivas de homens e mulheres" (pp. 100). Podemos traçar um paralelismo com o caso estudado em Tashiyacu. Desta maneira, o fato de que no nível das representações os palos se correspondam com o mundo do masculino, enquanto que as hierbas sejam relativas ao mundo do feminino não se traduz de forma automática nas trajetórias biográficas das pessoas da localidade. Como a mesma autora aponta em um texto posterior (Maluf, 1999), "é o sujeito portador de uma experiência impar e singular que pode reunir experiências (...) tão dispares e thes dar um sentido" (pp. 71). As narrativas sobre trajetórias biográficas são um método privilegiado para enfrentar as excepcionalidades, pois elas permitem desenhar as muito particulares "maneiras, caminhos, veículos da experiência e do sentido" (pp.71) dxs sujeitxs.

Escolhi falar aqui de alguns aspectos chave das trajetórias biográficas de Isabel, Pasquita, Adela, Julio e Ernesto, cinco mulheres e homens que, de maneiras diversas, transitam entre o campo dos palos e o das hierbas ressignificando criativamente as diferenças e possibilidades que cada conjunto de saberes e 
fazeres lhes propõe. Sem perder a perspectiva a respeito do lugar que lhes é socialmente condicionado, elxs desconstroem as expectativas sociais tecidas ao redor delxs. Como salientou uma vez o curandeiro Tocayo: "Qué harían las mujeres sin los hombres y los hombres sin las mujeres. Y todos sin el agua!". Sem esquecer a dimensão do organismo vivo, essxs homens transgridem os limites entre as maneiras de fazer com palos do restante dos homens curiosos, enquanto que essas mulheres transgridem, por sua vez, os limites entre as maneiras de fazer com hierbas do restante das mulheres curiosas.

Não é a intenção negar aqui a possível perspectiva de uma mútua dependência funcional no que diz respeito aos papéis sociais designados para lidar com plantas, curas e magias. Porém, uma ênfase muito enérgica na diferença entre palos e hierbas e entre as pessoas que trabalham com um ou outro grupo de plantas corre o risco de criar uma versão automatizada e binarista da vida social, onde toda costura prática que desafia essa divisão é uma ameaça à própria armação teórica da análise.

Frente à sensação de ausência que uma perspectiva funcionalista deixa frente a todo comportamento que foge da norma, eu prefiro ver um território desnudo, marcado por trajetórias aparentemente aleatórias. Lá onde a vida oferece novas possibilidades de escolha e ação tanto para mulheres quanto para homens, aquele é o espaço que têm aprendido a transitar estrategicamente xs curiosxs cujas trajetórias aqui eu destaco. Itinerários de excepcionalidade que matizam a distância entre o dizer e o fazer, e realocam as dicotomias em novos marcos, multiplicando-as. As práticas destas cinco pessoas foram, devido à força do hábito e sua inércia repetida ao longo do tempo, dando forma a trajetórias, trilhas e itinerários de vida particulares. Vidas originais, costuradas na mão tal qual fossem um vestido especialmente desenhado para a forma de um corpo 
único. Histórias de sortes e azares que hoje são olhadas desde um presente que lhes dá um sentido em termos biográficos e existenciais.

As movimentações alternativas destas vidas matizam o bi-cromatismo espectro de práticas limitado a duas cores do fazer -, dos palos e das hierbas. Nem verde nem vermelho, nem cima nem baixo, nem palos nem hierbas. Desde a perspectiva de quem transita entre os dois mundos, enlaçando elementos da dimensão dos palos e da dimensão das hierbas, esses mundos não se excluem, mas se somam: desta maneira, não deixam de adicionar feixes de possibilidades onde as limitações são tratadas estrategicamente, burladas ou até dissolvidas.

São as trajetórias de exceção as que colocam em perspectiva os jogos automáticos de cada cultura e dão pistas para enxergar, além da aparente quietude de um

presente estável, possíveis modificações nas dinâmicas de constituição e incorporação das regras sociais no futuro. Daqui em diante, aporto os insumos etnográficos para essa reflexão, abraçando as histórias de Julio, Ernesto, Pasquita, Adela e Isabel, que, pela sua condição de gênero, desafiam a trajetória típica dxs curiosxs da localidade e se relacionam desta maneira, por vias pouco convencionais e pouco convencionadas, com os universos humanos e de seres não-humanos, como dueños das plantas, entidades da água e espíritos da floresta.

\section{- Dois homens, Julio e Ernesto}

Julio Rengifo tem quase cinquenta anos. Ele nasceu em Tarapoto, na alta Amazônia, e migrou junto com os pais e irmãos para Tamshiyacu quando tinha menos de vinte anos. Pouco depois de chegar a Tamshiyacu, começou a namorar com Milena, que é a mãe de seus três filhos, todos eles homens, dois dos quais são hoje adolescentes. A família mora ao lado dos pais de Julio que, por uma 
interessante coincidência da vida com a qual eles costumam brincar, chamam também Julio e Milena.

Julio constrói casas de madeira, malocas [casas cerimoniais], talha a madeira e vende os remédios que Milena prepara. Milena é professora na escola primária de San Felipe, um vilarejo que fica a uns doze quilómetros de Tamshiyacu. Também coloca as madeiras que Julio prepara e as sementes que Julio perfura em coloridos colares, típico adorno de venda rápida a turistas. Pelo fato de que Milena trabalha longe de casa, Julio permanece muitas horas cuidando do espaço doméstico e das crianças desde que elas são bem novas. Vejo a Milena e a Julio como um casal com um importante capital cultural dentro da localidade, de fato xs vejo como fazendo parte da intelligentsia do povoado. Julio opina que a política partidária é um espaço que pertence a todxs, e do qual as pessoas, especialmente xs jovens, deveriam se apropriar. Ele faz parte do grupo do candidato Clever Ruiz, que naquele tempo, sob o lema "Juventud con capacidad"271" estava se preparando para se apresentar nos comícios do ano de 2014.

Julio e Milena se converteram ao evangelismo, religião à qual pertencem os pais e a maioria dxs irmãos/irmãs de Milena, há mais de dez anos. Julio se considera uma pessoa religiosa, mas com reservas. Nem Julio nem Milena assistem aos serviços da igreja, mas guiam suas ações pelos seus preceitos. "La religión es una cosa muy personal"272, afirma Julio. Carlos, o filho mais velho do casal, costuma assistir a missas de diversas igrejas: "en esos lugares me siento bien, nada más"273

\footnotetext{
$271 \quad$ "Juventude com capacidade".

272 "A religião é uma coisa muito pessoal".

273 "Nesses lugares eu me sinto bem, nada mais".
} 
A profissão na qual Julio se reconhece é a de escultor em madeira. Ele foi um dos alunos mais queridos de Agustín Rivas Vázquez, xamã e escultor local. Julio conta que foi ele quem lhe trouxe o interesse pelo trabalho com carpintaria: com ele deu seus primeiros passos, e o honrou fazendo duas esculturas naturalistas, em tamanho real, do busto de Agustín. Julio reconhece nele a pessoa que the despertou o interesse nas formas escondidas dentro das árvores. A respeito daqueles tempos em que ele aprendia o xamanismo, porém, não permanece com o mesmo entusiasmo. Antes de vir para Tamshiyacu, conta Julio, ele já tinha tomado plantas e passado por purgas. Essas plantas foram suas primeiras maestras [maestrinas] nos ofícios de curar e de fazer magias. A ayahuasca e o tempo de aprendizado com Agustín e os outros jovens alunos dele vieram depois.

Julio não toma ayahuasca faz dez anos, o que coincide com a sua conversão ao evangelismo. A relação entre esses dois fatos não parece ser casual: há restrições, dentro da doutrina, para a ingestão de qualquer substância psicoativa, mesmo que ela seja de uso tradicional local, como é o caso da ayahuasca. Ao mesmo tempo, o evangelismo insta às pessoas a abandonarem toda superstição e descansarem na paz do evangelho. Julio e Milena encontraram um equilíbrio entre seus interesses pelas plantas e sua adesão à religião: eles desenvolveram um vínculo com as plantas que se dá a partir do que elxs designam como naturalismo, uma aproximação cujo objetivo é compreender os poderes curativos de cada planta sem lhes atribuir propriedades mágicas. Assim, a aproximação deles aparece como o resultado de um processo que tende a higienizar as concepções locais que, sob uma nova compreensão como superstições, convertem-se para os saberes considerados científicos e empíricos. Assim, o naturalismo abraça a tradição das maneiras de fazer com plantas de um modo seletivo, gerando uma particularíssima síntese entre saberes locais históricos e 
saberes biomédicos apropriados pela via da auto-aprendizagem. Com um privilegiado acesso à cultura do texto escrito, Julio e Milena consultam livros sobre ervas e compilações referentes a plantas medicinais, e a partir dessa perspectiva, lêem sobre os processos de melhora e cura que seus/suas pacientes atravessam.

Julio e Milena guardam reservas em relação às novas práticas de xamanismo que vêm se manifestando localmente de maneira crescente. Julio se diferencia de maneira explícita até do seu estimado mentor Agustín: "Don Agustín tiene una opinión para todo, él no da vueltas com nada. Pero él tiene su manera de hacer las cosas y nosotros tenemos la nuestra"274. O casal costurou a sua identidade de maneira próxima às plantas, porém se afastando do circuito do xamanismo ayahuasqueiro, tão repercutido na região na atualidade. Um dia do mês de abril de 2013, Milena estava sentada do lado de fora da casa. Cheguei, cumprimentei-a com um beijo e ela me trouxe uma cadeira. Conversamos uns cinco minutos e Julio assomou a cabeça de dentro da casa, pela janela. Permanecemos conversando assim por quase uma hora. Foi então que me falaram abertamente da sua posição a respeito do turismo xamânico. Milena me disse: "todo el mundo viene conociendo el ayahuasca, pero están las otras plantas!"275. E Julio adicionou, não sem ironia: "Yo voy a ser un chamán de esas otras plantas"276.

Para além da postura explicitamente crítica a respeito do turismo ayahuasqueiro que Julio e Milena cultivam, há uma série de outras escolhas diferenciais que o

\footnotetext{
274 "Dom Agustín tem uma opinião para tudo, ele não dá voltas com nada. Mas ele tem a sua maneira de fazer as coisas e nós temos a nossa".

275 "Todo mundo vem conhecendo a ayahuasca, mas há também as outras plantas!".

$276 \quad$ "Eu vou me converter em um xamã dessas outras plantas".
} 
casal decidiu fazer ao longo da vida em comum. Um dia do mês de maio de 2013, a família me convidou para comer em casa. Era a hora do almoço e estavam fazendo uma sopa de galinha. Cheguei na área da cozinha, no fundo da casa, e Julio estava tirando as penas do animal com água quente. Depois, o cortou e colocou em uma panela que já fervia sobre o fogão a lenha. Em seguida, lavou batatas e as cortou. Eu estava sentada no outro extremo da longa mesa de madeira, com Milena ao meu lado. Conversávamos de assuntos leves, o calor, o encontro que finalmente aconteceu. Naquele momento, Milena interveio: "Julio no se anima a matar las gallinas que criamos. Él se va afuera a leer el diario. Eso sí, no tiene problema en cocinarlas. Y mucho menos en comerlas!"277. Ainda que Milena e Julio coordenem as rotinas e dividam o trabalho como qualquer casal, fazem-no sob condições bem particulares. Milena mata o animal, Julio o cozinha. Milena também costumava deixar claro outros aspectos da distribuição do trabalho doméstico: "Cuando duermo mal, al otro día no me dan ganas de hacer nada. Mis tres hijos y Julio ya saben. Ellos cocinan, lavan y ordenan la casa. En casa, todos hacen de todo"278. Não só Julio acompanhava na realização das tarefas da casa, mas também os outros três filhos homens do casal.

Por outra parte, em todos os encontros que tivemos - pelo menos uns dez encontros - , a visibilidade de Milena no espaço doméstico era notável. Não era infrequente que ela falasse sobre si mesma: "Las plantas me quieren. Deben creer que yo misma soy una planta! [risos]. Las personas creen que soy más vieja, porque sé de

\footnotetext{
277 "Julio não tem coragem de matar as galinhas que nós criamos. Ele vá para fora e fica lendo o jornal. Isso sim, não tem problema em cozinhá-las. E muito menos em comê-las!"

278 "Quando eu durmo mal, no dia seguinte não sinto vontade de fazer nada. Meus três filos e Julio já sabem. Eles cozinham, lavam e colocam em ordem a casa. Em casa, todo mundo faz de tudo".
} 
plantas. Cuando sea vieja voy a ser una mujer sabida!"279. Julio, ao contrário de Milena, tende a falar pouco sobre si mesmo. Ele prefere discutir questões referentes à corrupção política no povoado, ou contar histórias que se referem a curas de pessoas que estavam já sem esperanças com plantas Amazônicas. Dos diversos encontros que tivemos, a única vez que Julio tomou tempo para falar em si mesmo foi quando contou a experiência de conflito e enfeitiçamento que sofreu em uma cerimônia com ayahuasca dirigida por uma mulher curandeira, há uns vinte anos atrás. Daquela narração, eu posso resgatar dois importantes elementos: por uma parte, a afirmação enfática de que seu corpo não pertence à ayahuasca, mas a outras plantas com as quais ele anteriormente dietou, e que a ayahuasca não faz nenhum efeito, nem positivo nem negativo, nele. Por outra parte, posso observar que Julio identifica seu corpo e espírito como sendo excepcionalmente fortes e preparados para lidar com os influxos negativos de outras pessoas em contexto de bruxaria. Porém, ele não trabalha nem curando bruxarias nem fazendo males de gente. Delineando claramente um dentro e um fora do que é próprio, ele se limita a se proteger a si mesmo e à própria família dos eflúvios negativos que a má intenção de outras pessoas possa ter sobre suas vidas. Além da função básica de proteção que elxs assumem para seu próprio lar, o escopo de patologias a que elxs se dedicam a curar é o definido pelos males de dios, diferente do Capítulo 7, onde estavam bem divididas as patologias conforme o sexo $\mathrm{dx}$ terapeuta responsável pela cura.

O casal cultiva várias plantas no fundo da casa, assim como também na chacra da família na localidade próxima de San Felipe. As plantas com as que trabalham Julio e Milena são, em geral, classificáveis dentro do grupo das hierbas. Milena

279 "As plantas gostam de mim. Elas devem acreditar que eu mesma sou uma planta! [risos]. As pessoas acham que eu sou mais velha, porque sei de plantas. Quando for velha, vou ser uma mulher sabida!" 
vende gel de malva [Malachra ruderalis], chapeada na água fria ou chispeada na água quente. Também fazem lavagens do couro cabeludo com pepino [Cucumis sativus] em casos de febre, da mesma maneira que contam com xarope de huito [Genipa americana] para aliviar as doenças respiratórias de adultxs e crianças. Milena soba as pernas varicosas das mulheres com unto de galinha e também com gel de sábila [Aloe vera]; assim como os dois preparam remédios para as mulheres com câncer de ventre de mama tomarem. Primeiro, indicam limpar o corpo com chá de unha de gato [Uncaria tormentosa]. Depois, indicam beber durante três meses, três vezes por dia, uma poção feita de uma mistura da resina de três plantas: renaquilla [Ficus cuatrecasana], pan de árbol [Siparuna thecaphora] e sapohuasca [Cissus obliqua]. Essas três plantas são palos, e o casal me conta que vem lançando mão deles para a cura de doenças autoimunes e de difícil cura para a medicina das farmácias, como acontece com o câncer e o AIDS.

O casal Julio e Milena, que às vezes trabalha de maneira conjunta e às vezes de maneira separada, costuma cobrar preços relativamente baixos pelo preparo e aplicação dos remédios, e aceita intercâmbios com produtos ou serviços. Tratam a membros da própria família (xs próprixs pais e filhxs) e trabalham com pessoas locais, amigxs, vizinhxs e conhecidxs. Também cultivam uma especial afeição por conhecer pessoas de fora da região e do país e intercambiar conhecimentos, experiências e opiniões sobre o mundo. Elxs têm um casal amigo, Florence que é uma arqueóloga francesa e Javier, que é um pintor de Lima. Florence e Javier também moram em Tamshiyacu, e Javier é padrinho de Marcos Javier, o mais novo filho de Milena e Julio. Julio e Milena também têm amizade com José, um comerciante espanhol que manufatura e exporta cremes com óleos vegetais locais e com Céline, uma fabricante francesa que elabora azeites essenciais a partir das folhas da árvore do palo de rosa [Aniba rosaeodora]. 
Observei que é costume do casal convidar turistas para aprender a fazer as medicinas na casa delxs, cobrando pelo aprendizado taxas quase que inexistentes. Em meu caso, o casal me cobrou dois quilos de açúcar para que eu aprendesse a fazer um xarope medicinal de huito [Genipa americana], com a possibilidade de levar comigo uma garrafinha com xarope que eu poderia tomar quando sofresse de algum resfriado ou gripe. Assim foi. Depois de uma longa tarde de preparo dos frutos do huito e movimentação da beberagem na panela fervente em meio a conversas informais, eu tive a possibilidade de levar para casa minha poção de xarope para consumo pessoal.

José Ernesto Capuena Cauasa, diferentemente de Julio, não conhece tão de perto as ideias e dinâmicas da elite local. Ele tem uns cinquenta e cinco anos e mora na periferia de Tamshiyacu, na área baixa perto da praia do rio Amazonas. A sua casa tem o chão de terra, os muros de tábuas de madeira aberta. Ele é casado com Corina Sangama, uma mulher magra e enérgica com quem teve quinze filhxs, dxs quais seis estão hoje com vida. Eles se conheceram em Alianza, um povoado ribeirinho do interior de Loreto, e ali moraram por nove anos.

Corina e Ernesto obtêm a maior parte de seu sustento a partir do próprio trabalho na chacra que possuem, localizada na beira do rio Amazonas, uns poucos quilômetros distante da casa que habitam. Peixes, plátanos, frutos silvestres e mandioca são a base diária da alimentação da família. Hoje em dia, Ernesto é o único parteiro homem do povoado. Corina o acompanha nos partos, ela se define como sua ayudante [ajudante]. Em uma entrevista que fizemos eu e Carl na casa deles, Ernesto conta que dietó [fez dieta] durante mais de um ano, tomando palos tais como a ayahuasca e outras plantas fortes. "La ayahuasca no me ha gustado tanto, porque enseña venganzas y maldad. Más me han enseñado el tabaco, la 
chuchuasha, el tahuari, el sanango"280. Assim, os palos lhe ensinaram a tratar corpos e espíritos, presentes ou ausentes. Além disso, Ernesto aprendeu o ofício de parteiro da própria mãe, que era também parteira. Assim, ele conta que desde os 12 anos acompanha e auxilia nos partos. E desde que casou com Corina, há mais de trinta, juntxs preparam as plantas, sovam as barrigas e acompanham partos e puerpérios. Mais de trezentos, segundo as contas que Ernesto faz. Corina se encarrega de preparar as plantas para alguns problemas da gravidez como a pressão arterial alta e o frio interior, assim como para encaminhar os partos. Para isso, ela lança mão do caimito [Manilkara bidentata], a guayaba [Myrciaria fallax], o algodón [Gossypium barbadense], a malva [Malachra ruderalis] e a toronja [Citrus grandis]. Também sabe curar algumas perturbações típicas das crianças, como o mal-estar do huihuano, que se cura massageando a área afetada. Mas quem está especializado nas artes de sovar é Ernesto, que ademais de parteiro se reconhece como sobador de mulheres grávidas e sobador de lisiados. É Corina quem prepara a unção com a qual ele vai realizar seu trabalho. Usualmente, ele contém gordura de porco, toronja [Citrus grandis], aguardente e às vezes cânfora.

O casal é católico. Ele contempla que é importante rezar a deus durante o trabalho, mas somente quando há perigo. Em todo momento, importante é manter a calma e aprender a observar o que está acontecendo no corpo dxs pacientes. O filho mais velho de Ernesto e Corina está aprendendo a sobar lisiados, mas nenhum delxs está aprendendo as artes de partear ${ }^{281}$. O ofício é duro, afirma Ernesto. Sobretudo quando, como elxs, não se cobra nada, ou somente se cobra la voluntad, isto é, aquilo que a vontade $\mathrm{dx}$ outrx indique.

280 "Eu não gostei tanto da ayahuasca, porque ela ensina vinganças e maldade. Mais foi que me ensinaram o tabaco [Nicotiana tabacum], a chuchuasha [Maytenus macrocarpa], o tahuari [Cariniana decandra], o sanango [Duroia hirsuta]".

281 Acompanhar partos, partejar. 
Gostaria de fazer uma breve síntese das duas narrativas biográficas masculinas aqui escolhidas, e colocar aspectos chave da vida dos sujeitos biografados em relação ao esquema imaginário já descrito de palos e hierbas. Tanto Julio quanto Ernesto aprenderam muito do que eles sabem hoje das próprias plantas, mas também aprenderam a partir da influência de outras pessoas. No caso de Julio, ele deu forma aos dois ofícios mais importantes da sua vida, construtor/escultor e curioso das plantas com o xamã dom Agustín. No caso de Ernesto, ele aprendeu o ofício de parteiro da mãe dele. Os dois continuaram a aprender a partir da prática do ofício, acompanhados das suas respectivas esposas, Milena e Corina. Com elas, eles têm incursionado no acompanhamento de processos e na cura de perturbações que são tipicamente femininas. Para isso, eles têm aprendido a curar tanto a partir da dieta na floresta com palos quanto a partir da aplicação habitual de hierbas. A posição dos dois curiosos é crítica do uso indiscriminado da ayahuasca por parte dxs novxs xamãs. De fato, eles ressaltam o valor de outras plantas no seu aprendizado das artes do ofício. Por sua vez, a maneira como se auto-denominam os posiciona de maneira crítica em relação aos chamanxs e curanderxs locais. Julio é naturalista, Ernesto é partero, e nenhum dos dois trabalha exclusivamente com turistas. Ernesto atende pessoas de Tamshiyacu e das comunidades rurais vizinhas. Ele cobra uma taxa pelos seus serviços que é proposta pelxs próprixs pacientes, e costuma ser entre um dólar e cinco dólares. Já Julio, que pertence a um setor mais letrado da sociedade local, interage cotidianamente com visitantes do mundo inteiro. Muitas vezes ensina a preparar e administrar as plantas. Porém, pela informação ou pela consulta com tratamento costuma cobrar entre dez e vinte soles peruanos (isto é, entre cinco e dez dólares). Decididamente, Julio e Ernesto se afastam da corrente que congrega tantos homens de meia idade que sabem fazer com plantas na Amazônia peruana atual, no marco das demandas atuais do turismo xamânico. 


\section{- Três mulheres, Adela, Pasquita e Isabel}

Se há uma tendência que prescreve que os curiosos homens devem trabalhar com palos e verter seu ofício na direção das artes do xamanismo, com as mulheres a prescrição é a contrária. A condição das mulheres indica que se deve trabalhar com hierbas, curar à família e se manter nas margens da circulação do dinheiro e do alcance de pessoas que não pertencem à rede familiar.

Pasquita, Adela e Isabel nasceram mulheres e, transitando pelas avenidas da prática dxs curiosxs, não se formaram como sua condição indicava: elas não escolheram serem sobadoras, nem parteras, nem yerberas: elas se tornaram curandeiras e xamãs. É desta maneira que, no último ponto deste capítulo, desenvolvo uma reflexão sobre as atitudes e condições que poderiam ter sido favoráveis ao trânsito por esse caminho pouco comum para as mulheres no caso das vidas destas três especialistas de exceção (Ver Imagem 18, Isabel, Pasquita e Adela). 


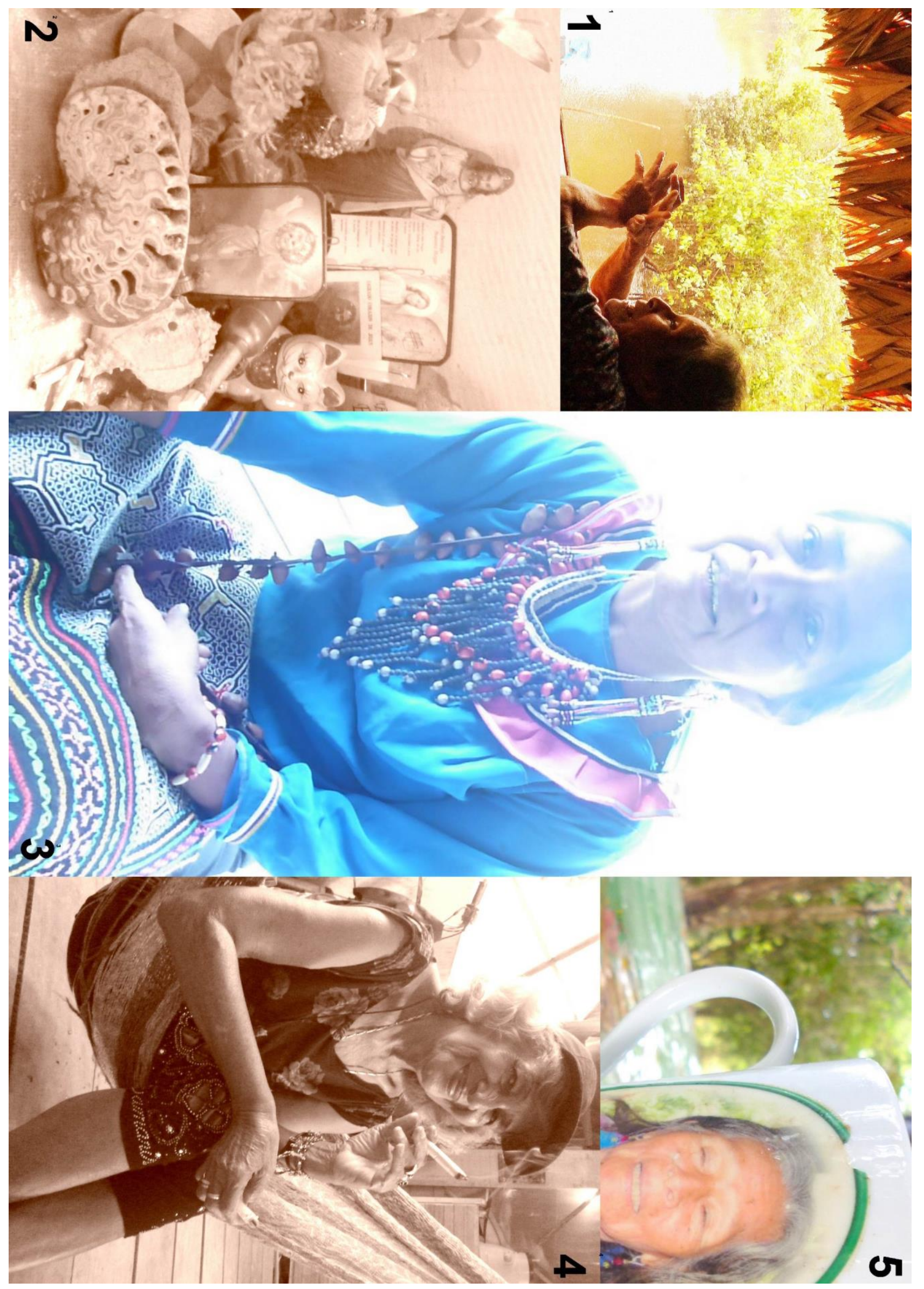




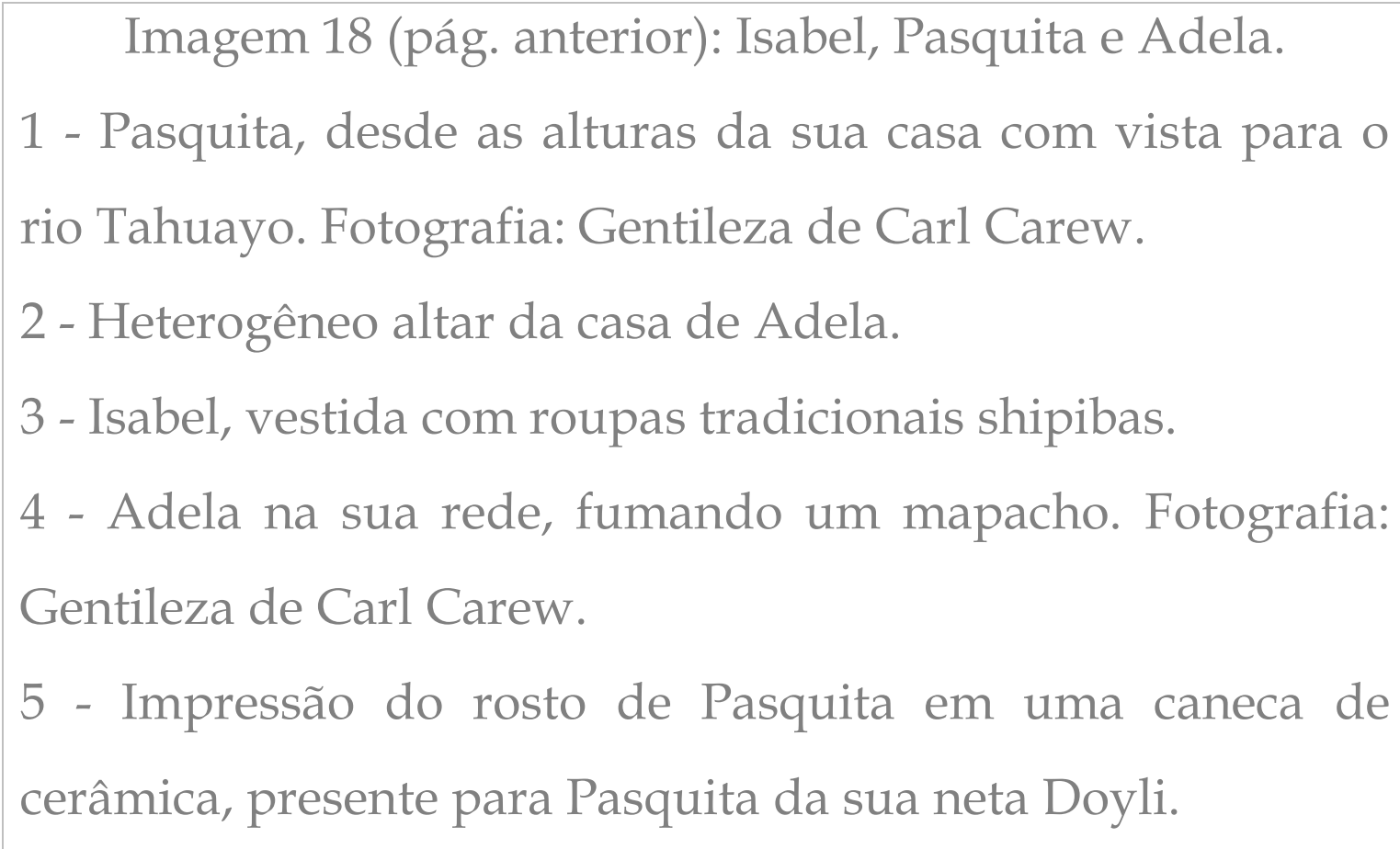

Apresento aqui alguns traços significativos da narrativa biográfica de três mulheres que se auto-reconhecem como curandeiras e xamãs: Adela, Pasquita e Isabel. A primeira e a segunda delas são viúvas enquanto que a terceira se casou, separou-se e agora mora e trabalha com um homem curandeiro. À mercê das casualidades do destino ou a um especial caráter que molda a vida, o fato de estarem relativamente "sozinhas" coloca essas três mulheres em espaços intersticiais que aparecem menos cristalizados pela força das leis sociais.

A dona Pasquita tem noventa e poucos anos. Ela mora na comunidade El Chino $^{282}$, localizada sobre o rio Tahuayo, a oito horas de Tamshiyacu por barco. Na casa moram dona Pascuala (apelidada de Pasquita), sua filha Lidia e o esposo

282 A comunidade está em processo de titulação coletiva das suas terras. Vivem nela 213 pessoas agrupadas em 44 famílias. Está localizada do lado da Área de Conservación Regional Comunal Tamishiacu-Taguayo, instituída como tal no ano de 1991. 
dela, Walter. Pasquita conta que, quando jovem, casou-se com Fidel, do rio Putumayo. Ele foi seu primeiro marido. Ele era curandeiro e fazia muitos trabalhos. Juntos viajavam e criavam as crianças. Tiveram duas. Dez anos depois, Fidel faleceu, vítima de mal de gente. Pasquita se casou, tempo depois, com Juan Pérez, que também era curandeiro. Ele morreu em 2005, envolto em uma loucura progressiva que o levou a morrer afogado. Pasquita atribui essa condição a um mal de gente lançado a Juan.

Pasquita conta que ela aprendeu o curandeirismo com seu primeiro esposo. Diz que já seu segundo esposo, entretanto, aprendeu com ela. Também dietava plantas em meio à vida cotidiana. "Lo mejor es aprender sin que nadie te enseñe. Aprender en secreto, sin que nadie te vea" ${ }^{283}$, me contou. Ela se reconhece como partera e curandera. Do mega-empreendimento hoteleiro que se encontra próximo da comunidade e dentro da área de conservação regional, Amazon Lodge, ela é chamada para realizar cerimônias para turistas. Ali, xs guias turísticxs locais apresentam-na como xamã. Walter, seu genro, a ajuda a manter as plantas da chacra, a procurar árvores e trepadeiras na floresta, a cortar troncos e cascas, a trazer a água do rio para cima da casa, a preparar os remédios e também a consumar as cerimônias.

Por sua vez, Pasquita trabalha tanto com palos quanto com hierbas. Ela, Lidia - a filha dela - e seu genro, Walter, cultivam um belo jardim com diversas hierbas que costumava utilizar quando hacía servicios ${ }^{284}$, isto é, quando a juventude lhe permitia acompanhar os partos de vizinhas da comunidade. Ainda quando já as forças não são suficientes para hacer servicios, Pasquita continua lançando mão

\footnotetext{
283 "O melhor é aprender sem ninguém te ensinar. Aprender em secredo, sem que ninguém esteja te vendo".

284 "Fazia serviç̧os."
} 
dessas plantas para tratar suas próprias perturbações, pois, como ela mesma declara, nunca vai para o hospital.

Pasquita também é ayahuasqueira. Em outubro de 2013, contou-me como foi que salvou a própria vida com a ayahuasca, pois a planta a ajudou a descobrir um pulsario que a estava consumindo. Durante uma sessão que lhe ofereceu Fidel, o primeiro marido dela, a ayahuasca conversó ${ }^{285}$ com ela durante a noite toda, diagnosticou o seu problema e lhe indicou quais os remédios vegetais que devia tomar para sarar. Ela fez tal qual lhe foi indicado. E, sem demorar muito, sarou. A partir de então, dona Pasquita começou a contar com o conselho da ayahuasca para que a orientasse em casos de doenças de outras pessoas. Ela não reza a Deus, mas pede, durante as cerimônias, ajuda e claridade para o espírito finado de Fidel, que ela afirma ser até hoje a sua guia.

Dona Pasquita atendeu aos partos da sua única filha, assim como de várias outras mulheres da localidade. Hoje se sente fraca para se dedicar ao ritmo e à energia que são necessárias para acompanhar um parto. Mesmo já tendo se dedicado a curar males de gente, hoje ela se dedica somente a tratar as perturbações consideradas mais simples (como susto, mal de aire ou cutipado) assim como a oferecer cerimônias com ayahuasca para turistas. Pasquita hoje deriva seus trabalhos a outro especialista: Dom Gilmar, que mora do outro lado do rio, exatamente em frente à sua casa. A pessoa afetada por uma bruxaria e que precisar de um trabalho mais duro, pode cruzar o rio e procurar o curandeiro e ayahuasqueiro Gilmar, quem trata com palos dos males de gente.

285 Conversou. 
O segundo caso que aparece como especialmente interessante para desenhar trajetórias de excepcionalidade no mundo feminino das mulheres curiosas é o da dona Adela. Ela tem, hoje, 82 anos. Filha de mãe portuguesa e pai colombiano, ela se criou na periferia de Iquitos, onde ainda mora. Adela ostenta um discurso eloquente, articulado, cheio de tonalidades, risos, silêncios escolhidos. Durante uma entrevista que fizemos, Carl e eu, na casa-consultório dela em setembro de 2013, Adela se sentou na rede, enquanto bebia aos sorvos uma purga de aguardente e plantas. E, entre brincadeiras, narrou-nos alguns pontos chave da própria vida. Contou-nos que o fato de ter estado prestes a morrer por conta de um mal de gente originou o interesse dela no ofício:

Hay gente que paga y hay gente que se encarga de hacer el mal. Eso me duele mucho porque yo también he sido prisionera! (...) Yo salvé a mi madre de esa muerte que era para ella. Yo me la comí. Pero si hubiera sido para mi mamá, ella no se hubiese levantado, allí nomás se habría quedado. Ese ha sido el motivo para que yo me concentre en proteger a mi familia ${ }^{286}$.

Foi assim que começou a dietar na floresta, mergulhando primeiro nos segredos de diferentes tipos de ayahuasca e depois no saber vindo dos palos:

... hice dieta en el monte. Diez años tomando todas las variedades del ayahuasca. Cuando se sale, con los encantos, con los icaros, vienen los palos, los árboles medicinales. Por eso digo yo! Yo no soy naturalista, yo no soy yerbera... Yo soy dietera de palos, raíces, árboles... a lo grande! No porque me jacte. Es porque me gusta, siempre me gustó. Tomar lo más fuerte $^{287}$.

286 "Tem gente que paga e tem gente que se encarrega de fazer o mal. Isso dói muito porque eu também fui prisioneira! (...) Eu salvei à minha mãe da morte que era para ela. Eu a engoli. Mas se tivesse caído na minha mãe, ela não teria se levantado, ali mesmo teria ficado. Esse foi o motivo para que eu me concentrasse em proteger a minha família".

287 "... fiz dieta na floresta. Dez anos tomando todas as variedades da ayahuasca. Quando se sai, com os encantos, com os icaros, então é que vêm os palos, as árvores medicinais. Por isso eu digo! Eu não sou naturalista, não sou yerbera... Eu sou dietera de palos, raízes, árvores... o que é mesmo grande! Não é jactância. É porque eu gosto, eu sempre gostei. Tomar o que é mais forte". 
Depois de um longo caminho de relação com as plantas em meio à construção da sua vida familiar, ela se reconhece hoje como curandera e chamana. Adela se casou com um dentista português. Juntxs tiveram seis filhxs, três mulheres e três homens. Ela criava e trabalhava. Adela conta que o marido dela a apoiava:

Tener hijos no me interrumpió en ningún momento. Estaba embarazada, con el ayahuasca curando. Allá, en aquel terreno, atendía trescientas personas cuando todavía los chicos eran chiquitos ${ }^{288}$.

Da mesma forma em que outrxs curanderxs de palos, Adela aprendeu o ofício dela sozinha: isto é, diretamente da conversação íntima com as plantas. Isso nem sempre envolveu o isolamento: Adela aprendia das plantas enquanto levava adiante uma atarefada vida de mulher e mãe de família. Um dos momentos mais difíceis de que ela se lembra, onde aprender como curar envolvia uma especial urgência, foi quando o marido dela sofreu um grave acidente:

Lo atropellaron y no reaccionaba. Así durante varios días. Después de hacer una investigación de varias plantas medicinales, si aceptaban curar a mi esposo... todas me negaban! Hasta que vino cierta planta que sí me aceptó: el toé. Yo tomé toé! Pero una cantidad... dosificada. Que me mareó por ocho días! A los nueve días desperté. Al lado de mi esposo, que no podía ver nada. A los dos días de comenzar a tratarlo, quiero agua!, dijo. Yo le pedía a los chicos que le dieran el agua, yo estaba recontra mareada. A los tres días, mi esposo abre los ojos y me dice que ya renació ${ }^{289}$.

Dessa vez, o marido dela se recuperara. Anos depois, ele teve outro acidente produzido por uma queda, e faleceu. Deste modo, Adela ficou viúva quando as

\footnotetext{
288 "Ter filhos não me interrompeu em nenhum momento. Eu estava grávida e continuava curando com a ayahuasca. Lá, naquele terreno, eu atendia trezentas pessoas quando ainda as crianças eram novas".

289 "Atropelaram-no e não reagia. Assim foi durante vários dias. Depois de fazer uma pesquisa entre várias plantas medicinais, se elas aceitavam curar meu esposo... todas me negavam! Até que veio certa planta que me aceitou: o toé [Brugmansia suaveolens]. Eu tomei toé! Mas uma quantidade... dosificada. A mareação durou oito dias! No nono dia, eu acordei. Do lado de meu esposo, que não podia ver nada. [Com] dois dias de começar o tratamento, quero água!, ele me disse. Eu pedia para as crianças the darem a água, pois eu estava muito mareada. No terceiro dia, meu esposo abriu os olhos e me diz que já renasceu".
} 
crianças eram ainda novas. Assim, ela conta que o trabalho redobrou enquanto custou muito a superar a ferida emocional causada pela perda do marido:

Ser padre y madre para nuestros hijos. Cuando mi esposo se fue con Dios, me quedé un año inválida, paralizada. Postrada. Y tuve que morir en paz o levantarme. He resucitado ${ }^{290}$.

A ressurreição que Adela descreve foi o início de uma nova etapa na vida dela. Hoje Adela cura, como costumava fazer, às pessoas da própria família, assim como a outras pessoas locais. Em adição, ela começou a trabalhar com turistas também. Costuma não misturar os grupos: ela assegura que turistas e pessoas da localidade têm problemas diferentes. E, frente ao tabu impresso no cânone dxs curiosxs locais, ela continua defendendo a sua prática de proteger e tratar às pessoas do círculo próximo:

Yo he aprendido a tomar lo más fuerte para poder proteger a mi familia en especial y luego a los demás (...) Y hay muchos médicos y curanderos que dicen que no pueden curar ellos mismos a la familia. Pero no! Yo curé en diversas ocasiones a mi esposo, a mis hijos, a todos! ${ }^{291}$

Hoje, Adela já não trabalha sozinha. Um filho dela que tem uns quarenta anos lhe ajuda e está aprendendo o ofício. Ele não canta icaros ainda, mas toca o violão nas cerimônias, organiza as pessoas e provê as plantas para preparar os remédios. Adela continua a ser quem encabeça as cerimônias e coloca o próprio corpo para combater as maldades. Ela diz que, para ela, xs filhxs que ela teve são ainda crianças, e que vai cuidar deles não só até a morte, mas depois dela.

\footnotetext{
290 "Ser pai e mãe para nossos filhos. Quando meu esposo se foi com Deus, eu fiquei um ano inválida, paralisada. Prostrada. E tive que morrer em paz ou me levantar. Ressuscitei".

$291 \quad$ "Eu aprendi a tomar o que há de mais forte para poder proteger à minha família em especial e depois aos demais (...)Tem muitos médicos e curandeiros que dizem não poder curar eles mesmos [nem] à família. Mas não! Eu curei em diversas ocasiões a meu esposo, a meus filhos, a todos!"
} 
Outra mulher de exceção é Isabel, com quem iniciei a minha etnografia sobre xs curiosxs de Tamshiyacu. Pelos fatos centrais da vida dela já terem sido narrados (nos capítulos 4 e 5 da presente tese), eu quero me focar agora em alguns dados que podem fornecer certos elos de comparabilidade entre a vida de Isabel e as trajetórias biográficas das outras duas mulheres aqui narradas, Pasquita e Adela. Isabel é uma mulher indígena, da tribo shipiba. Ela tem cinquenta e quatro anos e mora há seis anos em Tamshiyacu. Com menos de vinte anos, ela se casou à força com um jovem shipibo de religião evangélica. Tiveram juntxs seis filhxs. Depois ela se separou e teve outros companheiros. Produto de uma dessas uniões é Jordi, último filho dela, que tem 12 anos. Hoje Isabel está casada novamente: ela mora e trabalha com Jorge, que também é curandeiro. Juntxs atendem pessoas da localidade assim como turistas. Isabel não reza a deus, mas faz suas preces pedindo proteção aos espíritos das plantas e aos espíritos dos seus mortos, especialmente a Antonio, pai dela, falecido há mais de vinte anos. E se ela aprendeu do pai a usar uma chacapa de yerba luisa [Coix lacryma] nos seus trabalhos, hoje em dia ela simplesmente icara e limpa os corpos com a fumaça do tabaco. Isabel narra que ela aprendeu seu ofício diretamente das plantas, dietando na floresta, e que foi para isso supervisionada pelo pai. Houve múltiplas intermitências nesse processo de aprendizado, paradas no caminho do ofício para gestar, parir, amamentar e criar filhxs assim como cuidar de parentes. Tecendo os dois mundos em relação, a vida dela como mulher-mãe e o ofício de onanya, curandeira e xamã, ela aprendeu a curar e proteger às pessoas da família e também a outras pessoas da localidade, assim como a turistas. Hoje em dia, ela trabalha exclusivamente com palos, não incluindo as hierbas dentro do conjunto da sua farmacopéia. Assim, tem como aliados aos espíritos do toé [Brugmansia suaveolens], a ayahúma [Couropita guianensis], o tabaco [Nicotina tabacum] e o huayruro [Abrus precatorius]. No contato com seu atual companheiro, aprendeu da ayahuasca, e hoje se considera ayahuasqueira, convidando a ayahuasca em 
cerimônias. Ela e Jorge costumam organizar as cerimônias, xs dois a cantar icaros e a soplar as pessoas participantes. Quando Jorge não está no albergue, quem lhe ajuda é Gerlyn, seu filho, que se iniciou no curandeirismo por estímulo dela. A filha mais nova, Jenny, começou a dietar em 2014, pois quer ser curandeira tal qual sua mãe.

Apesar de Jorge, seu companheiro, asseverar que não é possível curar as pessoas da própria família, ela cura seus filhxs em casa, com magias e terapias vindas das plantas e afirma não tê-lxs levado nunca ao hospital. Também participou do tratamento das doenças de outras pessoas de sua própria família, como o câncer no ventre da mãe, assim como doenças menores dxs suas/seus netxs. Isabel sabe rudimentos de leitura e matemática, e pede a ajuda da sua filha Jenny, que terminou o estudo secundário, para resolver assuntos práticos como receber o dinheiro de seu trabalho. Contudo, isso não the impede de viver do que faz: o artesanato que trabalha como mulher shipiba, os serviços de cura de males de gente que faz como curandeira, os rituais com ayahuasca que faz como xamã. Com isso, Isabel encontra a maneira de manter a uma família de três filhxs, dois/duas delxs na adolescência, e um neto, assim como ajuda à sua família materna em Pucallpa, a sua cidade de origem.

\section{- Artes de fazer}

Chegadxs nesse ponto da argumentação, convido-nos a recapitular. Até agora, eu vim desenvolvendo uma série de diferenças em torno da dualidade das plantas utilizadas, palos e hierbas. Encontrei este mundo dividido em categorias práticas bastante definidas: por uma parte a utilização de um número limitado de plantas dentro da categoria palos, a assunção de uma vocação inclinada pelos riscos na hora de curar ou de realizar trabalhos mágicos, o recurso aos icaros e a utilização do instrumento cerimonial da chacapa. Também se destaca o aprendizado direto 
das plantas, sem sublinhar a participação de nenhum/a mestre educador/a humanx. No mesmo grupo, observei a incorporação de uma regra de impossibilidade de curar a membrxs da própria família, e uma tendência crescente de cobrar por produtos e serviços derivados do trabalho em dinheiro. A maioria das pessoas que encontrei dentro desta categoria são homens, que se fazem chamar de chamanes, curandeirxs, médicxs tradicionais, vegetalistas, purguerxs e sobadores de lisiados. Por outra parte, encontrei um número mais amplo de plantas dentro da categoria hierbas, assim como a incorporação de uma vocação de serviços às outras pessoas e o recurso da fé e das orações a deus na consecução dos trabalhos mágicos e de cura. As pessoas que se encontram dentro desse grupo costumam atribuir a alguém da própria linhagem familiar o fato de ter aprendido o ofício, e estão orientadas para curar membrxs da própria família, assim como vizinhxs e amigxs, e raras vezes cobram em dinheiro, tendo a consulta um preço flexível e podendo ser paga em troca de favores ou produtos. A maioria das pessoas que encontrei dentro desta categoria são mulheres, e se chamam a si mesmas de parterxs, sobadorx, yerberxs e naturalistas.

No meio desse mundo ordenado segundo a bipolaridade dessas categorias práticas, as trajetórias particulares dxs curiosxs locais ostentam detalhes que as transgridem. A cada clara divisão do mundo e das tarefas, correspondem-se destinos excepcionais, trajetórias de pessoas que destoam, em maior ou menor medida, que estão fora desse molde normativo que modula a relação entre xs especialistas da magia e saúde popular e as plantas. É importante remarcar aqui que há uma interessante série de estudos que se ocupam dos fenômenos de transgenderização no contexto dxs especialistas em terapias e magias no mundo inteiro. Assim, há muitos casos nos quais espíritos de gênero oposto àquele $\mathrm{dx}$ especialista penetram no corpo delx e lhe fazem agir de determinadas maneiras. A antropóloga norte-americana Barbara Tedlock (2004) apresenta uma 
interessante compilação de situações como essa, enquanto que a antropóloga chilena Mariella Bacigalupo (2007) coloca uma variada gama de reflexões sobre a vivência transgênero a partir do caso das machi, curandeiras da etnia mapuche do sul de Chile e Argentina292.

Encontrei em Isabel, Pasquita e Adela maneiras muito particulares e originais de serem mulheres e, ao mesmo tempo, fazerem suas as artes do curandeirismo e do xamanismo ayahuasqueiro através do aprendizado com os palos. As curanderas e xamãs Adela, Pasquita e Isabel burlam cotidianamente esse padrão, fazendo uma história e uma trajetória por si próprias. Elas aprenderam a transitar por fora do território das hierbas do jardim, dos serviços à família, das orações a deus e do limitado espaço do doméstico. Isso não significa que elas tenham renunciado completamente ao mundo das yerberas, palos e hierbas. No caso de Adela, ela sabe rezar a deus e também cantar icaros e fazer vibrar a chacapa; no caso de Pasquita, ela é ayahuasqueira e curou males de gente assim como assistiu a partos e curou as moléstias relativas a eles durante muitos anos. Já Isabel soube curar às pessoas da própria família, sendo para elas referência no fazer, cuidando da saúde e da proteção da pessoa. No caso destas três mulheres, elas se casaram e exerceram a sua maternidade em meio a esse complicado ofício, que requer uma disposição para o combate corpo a corpo frente a forças invisíveis, a ingestão rotineira de plantas psicoativas e a regulação das comidas, a sexualidade e os movimentos do próprio corpo através dos períodos do isolamento físico e/ou espiritual das

292 As trajetórias de curiosxs apresentadas aqui (Isabel, Pasquita e Adela, por uma parte, e de Julio e Ernesto, pela outra) poderiam ser compreendidas enquanto que relativas à fenômenos de transgenderização, devido a que a ambiguidade e liminalidade de gênero são fundamentais nos trânsitos destxs sujeitxs. Contudo, a qualidade propriamente transgênero desses processos não é, analisada aqui em toda a sua extensão. Os movimentos dxs sujeitxs entre um e outro território definido social e espiritualmente pelos gêneros são percebidos aqui como sendo parte de dinâmicas sutis de trânsito entre os mundos masculino e feminino, não sendo explorados outros interessantes aspectos que poderiam decorrer destes trânsitos, como aqueles relativos a práticas de possessão e sexualidade transgênero por parte dxs curiosxs em questão. 
dietas. Elas aprenderam a curar suas famílias ao mesmo tempo em que curavam às pessoas de fora da própria rede: dentro dessa última categoria é que se faz possível a inclusão dxs turistas. Finalmente, elas aprenderam a fixar preços pelo seu trabalho e produtos e a manejar o dinheiro e os cálculos e valores.

Retomando a presente reflexão sobre desvio e excepcionalidade, seria uma violência com os sentidos desprendidos da própria etnografia considerar que as histórias de Pasquita, Julio, Isabel, Adela e Ernesto são produto de trajetórias desviantes. Elas não são consideradas patológicas nem anormais para elxs mesmxs nem para as pessoas da própria rede social. Porém, elas podem sim ser consideradas excepcionais, pois lidam de maneira inovadora com os limites propostos pela sociedade local em relação ao gênero, perturbações a serem tratadas e os grupos de plantas com as quais elxs sabem fazer. A excepcionalidade também não adquire a premissa ontológica de certa genialidade inata. As que estão aqui retratadas são pessoas comuns que escolheram, em alguns pontos da própria vida, transitar as bordas dos condicionamentos sociais impostos ao gênero e ao ofício. O que esse capítulo sublinha é a inventividade de cinco trajetórias de vida concretas que entrelaçam, de maneiras muito particulares, as águas convencionalmente divididas entre xs curiosxs dos palos e xs das hierbas.

Nas maneiras de fazer com plantas que cada uma das pessoas cuja trajetória narro nesse capítulo encara, é possível observar uma soma quase caleidoscópica de matizes correspondentes ao mundo dos palos e das hierbas. Artesãos e artesãs do fazer, a original síntese que resulta ser a narrativa de vida de cada uma dessas pessoas é, certamente, consequência desses movimentos, traçados graciosamente sobre o espaço da vida disponível. O gesto destas vidas tem sido para mim, ao longo do trabalho de campo e das estações que o seguiram, um presente duradouro de inspiração e criatividade do viver. 


\section{Capítulo 12 \\ Transações: saberes escritos, sistema de saúde e dinheiro}

- Grafocentrismo e os saberes que vêm dos livros - Uma díade constante: remedios vegetales, remedios de botica $\bullet$ O espaço hospitalar $\bullet$ O território do intercambiável

A presente tese relata as maneiras de fazer com plantas dxs curiosxs de Tamshiyacu como um universo que está centrado nas noções de mal de dios e mal de gente, a partir de divisões genéricas da realidade entre o masculino mundo dos palos e a feminina dimensão das hierbas, salientando a importância das trajetórias individuais. Porém, essa descrição seria incompleta se ela não contasse com outros aspectos da realidade que influenciam as terapêuticas e mágicas dxs curiosxs locais. À mercê da globalização da floresta, as maneiras de fazer com plantas dxs curiosxs de Tamshiyacu não são impermeáveis às tendências econômicas e sociais do capitalismo e do Estado contemporâneo. O presente capítulo, último da tese, está dedicado a três forças que se encontram de maneira permanente na dinâmica desses universos tão sutis, permeando suas práticas costumeiras e fazendo-as estar em permanente tensão. No presente capítulo, proponho que a realidade dxs curiosxs de Tamshiyacu esteja em transformação sob a reiterada influência de três fatores: a) a cultura grafocêntrica, b) o sistema de saúde oficial, orientado à biomedicina e c) o mercado capitalista, que transforma as maneiras de fazer com plantas que praticam xs curiosxs em bens e serviços que são passíveis de serem cobrados em dinheiro. Vou tratar destes três fatores porque julgo que o grafocentrismo, a biomedicalização e a monetarização são poderosas influências no afazer diário dxs curiosxs, e que afetam as suas práticas, assim como transformam seu discurso e as concepções sobre corpo, o eu e o mundo que xs curiosxs possuem. 


\section{- Grafocentrismo e os saberes que vêm dos livros}

No folhetim do ano de 1985 da Ametra (Asociación de Medicina Tradicional) de Iquitos, o curandero peruano Guillermo Arévalo, impulsionador de iniciativas de integração da medicina tradicional à medicina oficial, declarou: "antiguamente no había libros, solo se aprendía de purgas y palos puros. Ahora son tres cosas: palos, purga, libros $^{11293}$. Esse trecho me pareceu especialmente significativo porque incorpora ao dinâmico universo das maneiras de fazer com plantas dxs curiosxs de Tamshiyacu um elemento ao qual até agora não me referi: o do saber escrito, aquele que requer a perícia do saber ler.

Frente à serra e costa peruanas, é a região amazônica que possui as mais altas taxas de analfabetismo do país. Segundo o censo do ano 1994, cerca de metade da sua população adulta não tem acesso à leitura e à escrita. Por sua vez, são as mulheres as que se encontram mais afetadas por essa situação, uma vez que $76 \%$ das chefas de família (em relação a $21 \%$ dos chefes homens de família) são analfabetas (Rodríguez Achung, 2003). Com uma enorme diversidade étnica e linguística, a Amazônia peruana ostenta 52 línguas indígenas na atualidade, distribuídas em 1335 comunidades indígenas e dezenas de povoados e cidades mestiços localizados especialmente nas ribeiras dos rios (op. cit, 2003). Esse rico panorama dá conta de uma enorme diversidade de práticas, pontos de vista e ontologias do viver que coabitam no extenso território amazônico. Porém, a proximidade cultural às línguas indígenas é muitas vezes vivenciada, especialmente pelas elites mestiçxs locais, como um traço do fracasso da integração da floresta à modernidade. A leitura e escrita da língua espanhola que é a língua oficial do Estado do Peru, assim como da maior parte dos estados latino-americanos -, sendo tão pouco acessível à maioria das pessoas, assume as

\footnotetext{
293 "Antigamente não tinha livros, somente se aprendia de purgas e palos puros. Agora são três coisas: palos, purga e livros".
} 
características de bem de troca nas cidades: ela permite vender, comprar, promover produtos e serviços e, finalmente, tirar ideias inovadoras ou apreender novos conteúdos a partir da leitura de revistas e livros.

No universo dxs curiosxs, a pirâmide de acesso ao enorme capital social que representa não só falar a língua oficial, mas também lê-la e escrevê-la, reproduz a desigualdade de gênero antes referenciada: dentre mulheres e homens, são esses últimos os que têm maior acesso à fala, leitura e escrita do espanhol. Essa vantagem abre rapidamente outras portas: xs curandeirxs que aprendem inglês se transformam, à mercê de uma leitura especular da própria realidade em relação ao olhar classificatório do norte político, em xamãs. Esse espaço é dominado por homens jovens de meia idade. São eles que irão se tornar, consequentemente, os mais famosos curanderos.

Replicando as proporções estatísticas de acesso à fala e escrita do espanhol (e, em menor proporção, do inglês) uma porção minoritária de pessoas que se dedicam ao curandeirismo se volta para o turismo, promovendo pacotes de purgas, cerimônias com ayahuasca e dietas de limpeza ou aprendizado do xamanismo na floresta. Para tal fim, habilitam, perante o Ministério do Turismo, o que muitas vezes representa o território das suas antigas chacras como albergues xamânicos. São também elxs, finalmente, xs que souberam aprender estratégicos detalhes do seu afazer a partir do material escrito por outrxs. Aprender dos livros se torna, então, estratégico em um mundo onde a palavra escrita representa acesso aos tipos mais diversos de capital.

Assim, xs curanderxs que sabem ler e escrever costumam ler as experiências que jornalistas e antropólogxs descrevem em jornais, livros e páginas da internet e comentam casos paradigmáticos de xamãs famosxs e formas de cura, que 
replicam ou rejeitam conscientemente na sua prática diária. Com o passar do tempo e o exercício do ofício, o seu labor como xamãs da floresta peruana começa a se desenvolver, cada vez com maior força, em torno de um ansiado reconhecimento fora do país. Para isso, xs xamãs trabalham no próprio estilo, cânticos e filosofia, difundindo sua investidura em páginas de internet, jornais e revistas locais.

Tocayo, curandeiro de Tamshiyacu, contou-me na primeira visita a seu consultório, em agosto de 2013, que não quer dar entrevistas muito alongadas a estrangeirxs: ele prefere escrever, por si próprio, um livro. Contudo, nos meses seguintes, as conversas com ele se estenderam longamente: ele gosta de conversar, de dar forma às palavras, de expressar ideias de uma maneira filosófica, de contar as histórias que modelaram o pensamento que ele tem na atualidade. Do outro lado, estão mulheres como Isabel, que dependem de outras pessoas para ler, para escrever, para contar o dinheiro. Muitas mulheres como ela aproveitam a escolarização de seus filhxs e os colocam na posição de ajudantes privilegiadxs. Xs filhxs de Isabel se reconhecem como shipibo e falam essa língua indígena de forma cotidiana e fluida (de fato, elxs se comunicam com Isabel em shipibo). Em adição, estão todxs alfabetizadxs em espanhol. Nestor, o mais velho filho de Isabel, casou-se recentemente com Fanny, uma jovem francesa. Elxs ajudaram Isabel a fazer um blog do albergue ${ }^{294}$. Jenny e Gerlyn, por sua vez, acompanham Isabel nas contas do dia a dia. Com todas essas limitações, Isabel não tem deixado de viajar por sua conta dentro do Peru, de fazer as compras nem de receber o dinheiro pelos seus trabalhos, ainda que com o risco de serem

294 O endereço virtual deste blog é: www.mundodelayacuruna.blogspot.com. Acesso em 02/01/2014. 
expostas às intenções, que não são sempre benéficas, dxs seus parceiros comerciais.

Alguns meses depois de voltar de meu trabalho de campo, Jenny, a filha mais nova de Isabel, contatou-me pela rede virtual do facebook. Eu fiquei muito feliz de ter um contato tão próximo com a realidade da família. Com a câmera de fotos do celular, Jenny me enviava fotos recentes dela e de sua mãe, no seu cotidiano de comprar, curar e cuidar das crianças mais novas da casa. Ela coloca na sua linha de tempo fotos de plantas medicinais e com sua família, ou com turistas de pele queimada pelo sol amazônico. Costuma ser Jenny quem envia os e-mails para xs visitantes que deixaram o albergue com a promessa do retorno. $\mathrm{O}$ acesso à cultura do ler, escrever e fazer contas é, sem dúvidas, uma preciosa possibilidade que se encontra primordialmente aberta aos homens, mas que, contudo, as mulheres, sobretudo as mais jovens, estão começando a aproveitar.

Os saberes que vêm dos livros são também, na atualidade, saberes que circulam pela mídia eletrônica: ter acesso a eles significa saber manejar a língua espanhola e/ou a língua inglesa, e também saber como acionar as novas tecnologias da comunicação à distância: blogs, e-mails, chats, redes sociais. Quem aprende essas habilidades poderá se comunicar instantaneamente com pessoas do restante do mundo, iniciando ou fortalecendo qualquer tipo de ofício ou empreendimento comercial. Assim como o grafocentrismo e os saberes que vêm dos livros são influências permanentes na vida dxs curiosxs de Tamshiyacu, da mesma maneira ocorre com os remédios de botica, cuja importância se filtra no fazer diário dxs curiosxs, que os incorporam a seus tratamentos de acordo com esquemas de compreensão próprios. 
- Uma díade constante: remedios vegetales, remedios de botica

Os estudos clássicos do folclore peruano identificam usualmente dois sistemas de saúde imersos no âmbito das práticas populares: o tradicional e o moderno (Del Carpio, 1989). Uma dicotomia similar se ativa nos conceitos locais. Acontece assim no âmbito das instituições. A Ametra (Asociación de Medicina Tradicional) foi fundada no ano de 1985, em Iquitos. Dentre seus principais objetivos, encontrava-se "lograr la aceptación de la medicina tradicional por parte de las instituciones locales de salud. Obtener un uso extendido de remedios herbolarios adecuados. Integrar el uso de remedios vegetales con el de remedios comerciales químicos farmacéuticos (...). Fomentar la utilización correcta de remedios de ambos grupos"295 (Cárdenas Timoteo, 1989: p. 281). Desde os anos oitenta, tem havido várias iniciativas de integração entre as chamadas medicina tradicional e medicina moderna. Em Tarapoto, região da alta Amazônia peruana, a casa de retiros Takiwasi tem se constituído em centro paradigmático de uma proposta que integra as duas medicinas no tratamento de dependências ${ }^{296}$.

Contudo, na prática cotidiana das pessoas comuns destas pequenas cidades amazônicas, o trânsito entre os universos da medicina chamada tradicional e da moderna, que aqui prefiro chamar de biomedicina, é muito menos estruturado. As pessoas circulam pelo mundo da biomedicina com elementos próprios do mundo que elas melhor conhecem, e esse é o mundo das maneiras de fazer $\mathrm{dxs}$ curiosxs da região. Por exemplo, as práticas tradicionais de magia e cura não estão relegadas somente a meios rurais. No ano de 1993, o Instituto da

295 "Conseguir a aceitação da medicina tradicional por parte das instituições locais de saúde. obter um uso estendido de remédios herbolários adequados. Integrar a utilização de remédios vegetais junto com remédios comerciais químicos farmacêuticos (...). fomentar a utilização correta de remédios dos dois grupos".

296 Para maiores referências, pode ser consultada a página do centro: www.takiwasi.org. Acesso em: 22/01/2014. 
Previdência Social de Iquitos realizou uma enquete com a população adulta na cidade de Iquitos, referente aos níveis de uso e aceitação da medicina tradicional: $86,5 \%$ das pessoas entrevistadas fazia uso de plantas medicinais ${ }^{297}$. Isto é: até nas cidades, há uma forte valorização dos remédios de origem vegetal e a sua importância, no âmbito doméstico, traduz-se em prevalência frente aos métodos e remédios da biomedicina.

Em lugar de tentar uma classificação espacial dos sistemas oficiais e não oficiais, priorizo os conceitos elaborados pelxs próprixs sujeitxs na sua vida cotidiana. Assim, a diferenciação entre um sistema de saúde biomédico e oficial e uma série de práticas locais atribuídas à tradição é visível através de duas denominações utilizadas costumeiramente: remedios vegetales ${ }^{298}$ e remedios de farmacia ou remedios de botica ${ }^{299}$. Os primeiros são aqueles elaborados com diferentes partes de plantas (colhidas ou compradas) e segundo padrões de reprodução criativa das prescrições tradicionais: cigarros, infusões, tinturas, frescos [produzidas a partir da trituração manual das partes vegetais frescas em água fria]. As raízes, folhas, flores e frutos destes vegetais costumam ser administrados em determinados momentos do mês lunar (luna verde, luna llena ${ }^{300}$ ) e em quantidades que variam grandemente segundo quem as prepare.

Os segundos, remedios de farmacia ou remedios de botica, são aqueles medicamentos de caráter industrial, os quais são na sua maioria sintéticos, que foram

\footnotetext{
$297 \quad$ Folheto: "Plantas medicinales de la amazonia peruana utilizadas por los curanderos, chamanes y herbolarios con fines antiinfecciosos". 1998. Iquitos: IPSS.

298 "Remédios vegetais".

299 "Remédios de farmácia" ou "remédios de botica".

300 "Lua verde, lua cheia".
} 
produzidos em laboratórios e distribuídos em grandes quantidades de acordo com os padrões da circulação capitalista de bens e serviços. Eles podem ser obtidos nas farmácias locais ou conseguidos nos hospitais ou nos postos de saúde pela via da prescrição de um/a médicx profissional ${ }^{301}$. Eles têm diferentes vias de aplicação, interna ou externa: injeções, pastilhas, xaropes, e costumam ser administrados de acordo com doses e horários fixos.

O sistema de saúde público peruano alcançou à Amazônia a partir das suas mais recentes políticas de abrangência nacional. A primeira delas foi, em 1980, a criação do Instituto Peruano de Seguridad Social, que previu a cobertura de vastos setores da população, e a segunda delas foi a criação, em 1997, do Seguro Integral de Salud sobre a base do Seguro Escolar Gratuito e o Seguro Materno Infantil, que alcançou às faixas das mulheres-mães, da primeira infância e da infância, três dos setores considerados mais vulneráveis e com maiores taxas de mortalidade (Alcalde-Rabanal et al, 2011). Os medicamentos industrializados foram introduzidos na população por parte dos executores do sistema de saúde público, produzindo de maneira rápida um considerável impacto nas práticas e concepções sobre corpo, saúde, perturbação, maneiras de fazer. Tanto é assim que, na comunidade, há na fala dxs sujeitxs uma permanente referência às virtudes e defeitos vis à vis dos dois tipos de remédios, os de botica e os vegetales.

Os remedios de botica muitas vezes são escrutinados pela comunidade local. Conta-me Milena, partera e naturalista, durante a entrevista que tivemos no mês de maio de 2013: "Ahora hasta en los cuartos de los bebés hay remedios de botica.

\footnotetext{
301 O número de medicamentos providos pelas farmácias diminuiu de $83 \%$ para $70 \%$ entre 1995 e 2005. Isso se deve à crescente participação do sistema público de saúde na provisão de medicamentos industriais (Alcalde Rabanal et al, 2011).
} 
Ibuprofeno, paracetamol... por cualquier cosita ya les están dando para tomar" ${ }^{\prime 302}$. Essa narrativa faz parte de um posicionamento crítico que não é incomum, não só dentro dxs curiosxs, mas também dxs outrxs pessoas que fazem parte da comunidade. "Los remedios de botica son calmantes, son rápidos pero no curan"303, é comum ouvir nas conversas sobre as doenças, mal-estares e indisposições mais diversas.

Ainda que com todas as críticas que eles possam receber por parte da população local, os remedios de farmacia são, apesar disso, amplamente utilizados. Walter, aprendiz de curandero, disse-me em uma entrevista informal que eu lhe fizera em outubro de 2013:

...los químicos de la farmacia vienen con fecha de vencimiento. Pero esta química no, esta te va a durar todo el tiempo. (...) A veces cosas de la botica no hacen nada, hacen peor. A veces, por el contrario, lo que se precisa es de un remedio fuerte, porque ahí hay microbio! Y con oración solamente no se cura $^{304}$.

Não existe a divisão ilusória de um grupo de pessoas que use somente remédios de botica e outro grupo que use somente remédios vegetais: as pessoas navegam entre um ou outro tipo de medicina. Como pode ser interpretado a partir do comentário de Walter, é dependendo da situação que vai se lançar mão dos elementos de um ou outro sistema. Por uma parte, há distúrbios - como as bruxarias ou síndromes como o mal aire - que quando se tratam com remédios de botica ou no hospital só fazem piorar o estado geral da pessoa. Por outra

\footnotetext{
302 "Agora até nos quartos dos bebês têm remédios de botica. Mejoral, paracetamol... por qualquer coisinha já lhes estão dando para beber".

303 "Os remédios de botica são calmantes, eles são rápidos, mas não curam".

304 "Os químicos da farmácia vêm com data de vencimento. Mas essa química daqui não, essa vai te durar o tempo todo (...) às vezes, coisas da botica não fazem nada, fazem pior. Às vezes, pelo contrário, o que se precisa é de um remédio forte, porque ali tem micróbio! E somente com oração não se cura".
} 
parte, há doenças que têm micróbio e que por esse motivo precisam, para serem saradas, de remédios que vêm da farmácia.

Para a maior parte das pessoas da população local, a utilização dos remédios de botica é essencialmente intuitiva. Essa intuição não provém de nenhum estado de natureza: ela foi construída a partir dos parâmetros de valores estabelecidos pelo riquíssimo sistema de medicinas amazônico, comumente chamado de medicina tradicional. Muitas vezes, os remédios de botica requerem de um saber letrado para serem interpretados: os prospectos de pílulas e pastilhas, as caixas, as etiquetas dos frascos. Frente à realidade de analfabetismo que exploramos mais acima, muitas pessoas utilizam ferramentas diversas. No caso de muitas mulheres de Tamshiyacu, elas aprendem a reconhecer as pastilhas pelas suas cores e tamanhos. Por exemplo, a sobadora Asteria costuma prescrever uma pastilha branca que chama mejoral - a marca comercial para um composto realizado a partir das drogas paracetamol e fenilefrina:

Si la fiebre no te quiere dejar, le machacas la lancetilla con la tangua, eso le machacas, le echas limón, una pastillita bien molidita, y adentro! puro jugo! sin echarle agua. Es bien bueno! - y cuál es esa pastilla? porque hay muchas! [perguntei eu]- Sí, son muchas pastillas! Por decir, yo utilizo el mejoral para la infección. Un blanquito, así [hace con la mano un gesto indicando el tamaño]. Eso le mueles, eso le pones ahí. Bueno es... mezclas los remedios. Pero hay que tener fe para curarse ${ }^{305}$.

Na relação entre os dois tipos de medicina, os hibridismos são compreendidos como estados de resolução perfeitamente possíveis. Às vezes, eles potencializam os aspectos positivos dos dois sistemas em prol das melhores estratégias de

305 "Se a febre não quer te deixar, você machuca a lancetilla [Alternanthera brasiliana] com a tangua [Cybistax antisyphilitica], isso você machuca, você coloca limão, uma pastilha bem moidinha, e adentro! puro suco! Sem colocar água. É muito bom! - e qual é essa pastilha? porque tem muitas! - São muitas pastilhas! Por assim dizer, eu utilizo o mejoral para a infecção. Um branquinho, assim [faz com os dois dedos um gesto indicando o tamanho]. Isso você machuca, isso você coloca ali. Você mistura os remédios. Mas temos de ter fé para sarar". 
alívio e cura. Remedios vegetales e remedios de botica são dois princípios que não necessariamente se opõem, mas podem operar juntos para se fortalecerem mutuamente em prol do sucesso de determinado tratamento.

No terceiro mês da minha gravidez, em setembro de 2013, acabei indo ao hospital, com vômitos e enjoo. Afetada pela desidratação e a purga pela qual meu corpo estava passando, eu estava com medo de perder meu neném. A médica local, doutora Jessica, indicou-me que podia permanecer lá durante uma noite. Resolvi ficar. Lá encontrei a prima da minha vizinha Gerónima. Ela me indicou "unas pastillitas rojitas, bien chiquititas, que vienen de a doce y se venden en la farmacia. Son una buena purga. A veces una embarazada se pone así porque tiene que

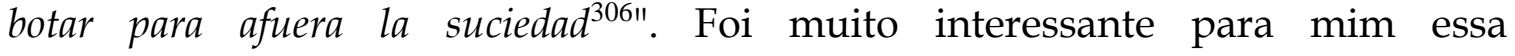
possibilidade de estar sendo diagnosticada a partir da visão da medicina local dentro do hospital, espaço de poder da biomedicina.

\section{- O espaço hospitalar}

Nesse ponto, tratarei de algumas transações e negociações entre xs curiosxs e esse espaço altamente simbólico, com tão alto poder de intervenção sobre as vidas e as mortes das pessoas locais como é o hospital público Regional de Tamshiyacu, dependente da DIRESA, Dirección de Salud de Loreto. O hospital está a quatro quadras da praça central. Ele conta com serviços de saúde básica, um laboratório, uma sala de emergências e dez leitos para internação. O hospital mais próximo com uma complexidade tipo III é o Hospital Regional de Iquitos, a quarenta quilômetros de distância e uma hora em bote rápido. O mesmo possui dois quartos com dez leitos para internação, e está classificado dentro da categoria I-3, hospital de baixa complexidade.

\footnotetext{
306 "Uma pastilhas vermelhinhas, bem pequenininhas, que se vendem em pacotes de doze e que se vendem na farmácia. Elas são uma boa purga. Às vezes, uma mulher grávida fica assim porque precisa botar para fora a sujeira".
} 
No início de abril de 2013, eu fiz uma entrevista a Olinda, técnica em enfermagem que foi contratada há cinco anos para fazer parte do pessoal hospitalar. Na entrevista, que aconteceu em um incômodo banco de corredor na frente da sala de urgências, Olinda me comentava: "A veces la gente ignora lo que es la enfermedad. No toma conciencia. A veces se dan cuenta cuando ya están graves, y aparecen graves [en el hospital] pues. A veces en casa solitos ellos se automedican"1307. Desde a perspectiva dxs agentes de saúde, a ignorância aparece como o fator principal que caracteriza as problemáticas de saúde da população. Como fator que determina as condições de saúde da população, também aparece a falta de acesso ao sistema de saúde. Jessica, a médica de plantão no local que havia me atendido, aceitou depois ser entrevistada. Ela afirmou em abril de 2013: "Uno de los motivos por los que la gente que se enferma y no asiste es la difícil geografia de Loreto $^{1308}$.

Assim, por uma operação de silenciamento e invisibilização, o vasto universo dos remédios e das técnicas terapêuticas locais é considerado como um espaço vazio, regido pela falta: falta de consciência no caso da fala da técnica em enfermagem Olinda; falta de recursos para chegar ao hospital na hora indicada, como no caso da fala da médica Jessica. Dentro dessa concepção, a automedicação seria indicativa de uma falta: a necessidade de cobrir a carência que as instituições estatais de saúde não conseguem preencher levaria as pessoas locais a se auto-medicarem. Porém, desde o ponto de vista das pessoas locais, o entendimento é completamente diferente. Para elxs, criadxs dentro da prática de

\footnotetext{
307 "Às vezes as pessoas ignoram o que é a doença. Elas não tomam consciência. Às vezes se dão conta quando já estão graves, e aparecem graves [no hospital]. Às vezes, em casa, eles se automedicam".

$308 \quad$ "Um dos motivos pelos quais as pessoas que adoecem não chegam ao hospital é a difícil geografia de Loreto".
} 
diversas terapêuticas e magias relacionadas com o mundo vegetal, o hospital é uma opção dentre várias possíveis.

Posso apresentar três opções de tratamento em virtude de três espaços: a casa, o consultório dxs curiosxs, o hospital. Para cada espaço haveria, de maneira tácita, a possibilidade de tratar certas doenças ou mal-estares. Como afirma o curandero Jorge, em entrevista realizada em abril de 2013: “Algunas personas dicen cómo un médico tradicional puede ir al hospital! Pero los médicos también nos enfermamos. Y en el hospital se curan cosas diferentes de las que cura un médico tradicional" ${ }^{\prime 309}$.

Quais seriam as diferenças entre esses espaços e o que determinaria que uma pessoa tratasse da sua doença ou mal-estar em casa, ou fosse aos consultórios dxs curiosxs ou ao hospital? Durante meu trabalho de campo etnográfico em Tamshiyacu, muitas pessoas me disseram que é muito importante saber definir se a doença é um mal de dios ou um mal de gente. Os primeiros podem ser tratados tanto em casa, por curiosxs ou pelo pessoal do hospital - às vezes até de maneira colaborativa: curiosxs como Tocayo, Isabel, María e Anita del Carmen me relataram terem sido chamadxs do hospital para soplar com tabaco alguém que estava muito nervoso, para lhe acalmar. Os segundos só podem ser tratadxs por um tipo específico de curiosxs, os curandeirxs ou xamãs. Se você levar para o hospital uma pessoa que tem uma doença que é causada por um tipo de daño [doença gerada pela vontade humana de fazer o mal], isso pode ser mortal. A cura do daño é secreta, envolve intimidade e isolamento, e, finalmente, não pode demorar. Os daños costumam serem perturbações de avanço muito rápido, que intervêm de maneira estrepitosa na cotidianidade $\mathrm{dx}$ afetadx, colocando suas vidas em risco em questão de horas.

309 "Algumas pessoas dizem como é que um médico tradicional pode ir para o hospital! Mas nós, os médicos, também adoecemos. E no hospital se curam coisas diferentes das que cura um médico tradicional". 
Frente a esse cenário, o que faz com que uma pessoa escolha ir para o hospital? Quais os possíveis benefícios que pode trazer para as pessoas locais o fato de serem atendidas no hospital? Em geral, o hospital é tido como um espaço que permite a resolução de problemas práticos: obter leite e vitaminas para as crianças, fazer análises periódicas, obter o número de seguro social do Seguro Nacional de Salud que permite a habilitação para o acesso a certos programas sociais. O hospital é também considerado um espaço que pode atuar como paliativo frente às doenças, que pode ajudar a atravessar uma dor urgente ou de um mal-estar especialmente molesto. Finalmente, outra das suas funções mais importantes é como dispensário de recursos materiais com peso simbólico. Assim, os mesmos elementos que desde certo ponto de vista poderiam se considerar de ordem puramente prática, como pastilhas, leite de vaca em pó ou vitaminas, também se podem avaliar desde o ponto de vista simbólico. Tais elementos são sinônimos de uma maior inclusão na vida moderna, nas dinâmicas do estado peruano e nas práticas relacionadas com uma urbanidade desejada anseio que, como vimos, faz parte da própria história de constituição do povoado de Tamshiyacu.

Em muitos outros casos, o hospital é considerado um espaço violento de produção de experiências de desapropriação do corpo. Foco de eterna desilusão, as histórias populares atestam relatos sobre doenças que não podem ser saradas no hospital e que precisam da expertise de um/a curios $x$ para serem, finalmente, saradas. Xs próprixs curiosxs, via de regra, evitam ingressar no hospital. Comentam que ali se sentem estranhos, ignorados, despossuídos das suas potencialidades e habilidades. Jorge, o curandeiro, conta-me uma vez: "cuando 
uno entra al hospital, se siente todavía más enfermo. ${ }^{310 " . ~ I s a b e l, ~ c u r a n d e i r a, ~ d i s s e-m e ~}$ que jamais levou axs filhxs dela para serem tratados no hospital. Somente levou uma vez a seu neto Diego, que tinha vômitos e diarreia. E então teve problemas. Acabou brigando com a médica porque ela não deixava que Isabel pudesse vê-lo. "Terminé peleándome con la médica, lo sacamos de ahí y lo cure yo misma con vegetales $^{\prime \prime 311}$, conta Isabel, em setembro de 2013, com o que aparece como um sutil sorriso de satisfação. "Yo ya no voy más, ni por mi ni por nadie. Si quieren que los cure, que me busquen en mi casa" ${ }^{312}$, ela conclui.

De fato, xs curiosxs ostentam uma lista interminável de experiências negativas relacionadas com o hospital. Não há dúvidas de que falar nisso é também uma maneira indireta de promover a própria prática. Milena, partera e naturalista, conta:

Por ejemplo, hay algunas que vienen con dolencias vaginales, las mujeres. Desahuciadas del hospital, acudiendo a la medicina natural. Y acá se les da el tratamiento. Acá les tratamos con la resina del pan del árbol, con la resina de la renaquilla, con la resina del sapohuasca... esas tres mezclas se convierten en uno solo, una sola resina para tomar por el cáncer del vientre. Hay algunas que vienen con cáncer de seno. Vienen a recibir un tratamiento, y acá empezamos con la limpieza del cuerpo ${ }^{313}$.

\footnotetext{
310 "Quando agente entra no hospital, se sente ainda mais doente".

311 "Acabei brigando com a médica, tiramos ele dali e curei-o eu mesma com vegetais".

312 "Eu vou mais não, nem por mim nem por ninguém. Se querem que os cure, que me procurem na minha casa".

313 "Por exemplo, há algumas que vêm com doenças vaginais, as mulheres. Desahuciadas do hospital, acudindo à medicina natural. E aqui é que lhes damos o tratamento. Aqui as tratamos com a resina do pan del árbol [Siparuna thecaphora], com a resina da renaquillla [Clusia rosea], com a resina do sapohuasca [Omphalea diandra]... essas três misturas se convertem em uma só, uma resina só para tomar para o câncer no ventre. Há algumas que vêm com câncer no seio. Elas vêm receber um tratamento e aqui começamos com a limpeza do corpo".
} 
Ao mesmo tempo em que Milena ressalta as limitações reais da medicina oficial, ela pondera os benefícios do tratamento dentro do campo que ela chama de medicina natural. Ela salienta como, em um movimento quase que de expulsão, as pessoas saem do circuito da biomedicina oficial para se tratarem - e curarem fora dela. A relação dxs curiosxs com o hospital é especialmente delicada quando se trata dos partos, o acompanhamento/intervenção no nascer. O partero Ernesto conta algumas das dificuldades de negociar com o hospital quando se trata de atender às mulheres parturientes que foram atendidas por ele durante todo o processo da gravidez:

El hospital de acá no nos consiente. Nunca fuimos a auxiliar partos al centro de salud de Tamshiyacu. En el centro de salud los enfermeros obligan a las mujeres a hacer fuerza. Y no es así. Muchos exigen a las mujeres antes de su hora. Primero se tocan el pulso y la coronilla. Y cuando los latidos son bien seguidos, se le pide a la mujer 'haga tu fuercita'. Se cuenta uno, dos, tres. Ahí la fuercita va despacito. Ya el número cuatro, ese tiene que hacer fuerte. Y ahí ya está afuera el bebé ${ }^{314}$.

Nesse relato, Ernesto pontua as práticas inadequadas por parte do pessoal do hospital nos casos de parto, salientando, ao mesmo tempo, a maneira correta de acompanhar os partos de acordo com a sua perspectiva. Outro relato de conflito entre parteirxs e o pessoal do hospital me foi dito por María. Em agosto de 2013, a partera María me contou como foi que salvou a vida do neto a partir de uma intervenção sua no espaço do hospital:

Los médicos decían que era mejor esperar y ya se estaba pasando la hora. Cuando nació, parecía muertito. Pero estaba calentito! Los enfermeros ya lo estaban poniendo en una bolsa. Lo sacamos, yo chupé su boquita, pellizqué las palmas de sus manos, lo puse panza abajo, le hice cosquillas en sus

314 "O hospital daqui não nos consente. Nós nunca vamos auxiliar partos no centro de saúde de Tamshiyacu. Lá os enfermeiros obrigam as mulheres a fazerem força. E não é assim. Muitos exigem das mulheres antes da sua hora. Primeiro se tocam o pulso e a coroa. E quando os latidos são bem frequentes, pedimos à mulher para 'fazer a sua forcinha'. Contamos um, dos, três. Ali a forcinha vai devagar. Já no número quatro, esse tem que ser forte. E então já está fora o bebê". 
piecitos, volví a chuparle la boquita y ahí pataleó... revivió! Y el padre ya estaba llorando de alegría! ${ }^{315}$

O hospital aparece, nas experiências de várias das pessoas que entrevistei, como um lugar onde a vida não é suficientemente cuidada, os corpos não são respeitados e não se encontra uma cura efetiva. Por sua vez, a colaboração entre xs curiosxs e o hospital é difícil. O Tocayo destaca alguns aspectos da sua própria experiência pessoal:

Hay veces que me mandan a llamar para ir a colaborar en el hospital. Por ejemplo, el señor que vino ahora. El bebé de ellos está de los bronquios. Ayer fui a verlo al hospital. Estaba con la carita hinchada por las drogas. No, ni la máscara le habían puesto... acá solo le ponen la máscara si es el hijo del senador. El sistema funciona así... como en todas partes! Es inhumano... por eso no me gusta este hospital. Atienden sin voluntad y a veces hacen más mal que bien ${ }^{316}$.

Desta maneira, para as pessoas da localidade, o hospital é um espaço restrito a determinados usos específicos e, ainda quando a influência dele tenha sido maior nos últimos anos é ainda território de disputas, desilusões e conflitos.

\section{- O território do intercambiável}

O último dos fatores de mudança que aqui analisaremos é a influência do mercado capitalista nas práticas $\mathrm{dxs}$ curiosxs, que transforma as suas maneiras de fazer com plantas em bens e serviços. Tais bens e serviços em troca podem se tornar passíveis de serem cobrados em dinheiro, sobretudo no caso do trabalho

\footnotetext{
315 "Os médicos diziam que era melhor esperar e que se estava passando a hora. Quando nasceu, parecia mortinho. Mas estava quentinho! Os enfermeiros já o estavam colocando em uma sacola. Nós o tiramos, eu chupei na sua boquinha, belisquei as palmas das suas mãos, o coloquei com a barriga para abaixo, the fiz cócegas nos seus pezinhos, voltei a lhe chupar a sua boquinha y ali o bebê chutou... ele reviveu! E o pai do neném já estava chorando da alegria".
}

316 "Tem vezes que mandam chamar para ir colaborar no hospital. Por exemplo, esse senhor que veio agora. O bebê deles tem problemas dos brônquios. Ontem eu fui the ver no hospital. Ele estava com a carinha inchada pelas drogas. Não, nem a máscara tinham the colocado... aqui somente colocam a máscara se é filho do senador. O sistema funciona assim... como em todas as partes! É inumano... por isso é que não gosto deste hospital. Eles atendem sem vontade e às vezes fazem mais mal do que bem". 
de determinadxs curiosxs. Para compreender as modalidades destes intercâmbios, sugiro retornar à chave analítica dos palos e das hierbas, como grupos de plantas, mas também como conjuntos de saberes-fazeres que condicionam condutas e posições objetivas no mundo social dxs curiosxs de Tamshiyacu.

Jorge, que trabalha com palos e se reconhece como xamã, contou-me que, no caso de adoecer, não poderia ser curado por seu pai José, que é curandeiro, nem por nenhum outro membro da sua família. O motivo disso é que pessoas que são de la misma sangre ${ }^{317}$ não podem tratar das suas doenças, mal-estares o pedidos entre si. Por outra parte, pessoas que trabalham com hierbas como as parteras, sobadoras, naturalistas e yerberas como María, Milena, Asteria ou Anita del Carmen, na hora de me contarem as vantagens de serem curiosas, relatavam como fator primordial a possibilidade de tratar às pessoas achegadas, sejam elas da própria família, amigxs ou vizinhxs.

Essas mesmas pessoas que trabalham com palos possuem outro tipo de relação com o dinheiro. Soraya Fleischer (2007) observa para o caso das parteiras de Melgaço, em Belém do Pará, que o fato de estarem mais próximas das cidades transforma o ofício das parteiras: oferece-se trabalho, não somente ajuda. Oferecem-se serviços, não dádivas desinteressadas. Junto com Fleischer (2007) e Zelizer (2005), durante o trabalho de campo em Tamshiyacu eu não pude observar territórios de intimidade completamente livrados de contraprestações econômicas. Nesse sentido, não foi possível definir mundos hostis, como os chamou a antropóloga argentina Viviana Zelizer (2005), mundos dicotômicos

317 "Do mesmo sangue". 
entre si, de relações afetivas não contaminadas de interesses econômicos ou, no outro extremo, relações financeiras não tingidas de afetividade.

Porém, o turismo traz consigo uma força transformadora da dinâmica das relações sociais que é inegável, e que as coloca em territórios onde a mercantilização abraça novos aspectos da vida social. No caso específico do turismo xamânico, essa condição não é infrequente. O curandeiro Tocayo diz a respeito de seus colegas xamãs que trabalham com turismo: "acá les cobran en euros a los europeos y en dólares a los norteamericanos" ${ }^{318}$. A relação com os bens monetários é direta, clara e explícita. É possível enxergar isso a partir do fato de que são elxs xs mais visíveis, xs mais acessíveis ao turismo. Muitas das vezes, elxs podem colocar preços fixos para seus produtos (uma tintura vegetal de uso interno, um banho de flores, uma cerimônia com ayahuasca, uma purga). Às vezes, esse preço é em dólares ou em euros. Essas pessoas também são xs que ganham mais, também são xs que consomem mais dos bens do mercado. Xs que têm veículo, xs que mais compram no mercado, xs que viajam mais. Para aquelxs que trabalham com palos, é comum compreender o próprio trabalho como um ocupação que coloca a vida em risco e exigirem quantias de dinheiro em troca pelos trabalhos realizados. Essas pessoas têm uma liberdade de circulação muito maior dentro das condições do mundo capitalista globalizado, e costumam ser homens em uma proporção não menor do que 20/1 em relação às mulheres ${ }^{319}$.

Por sua vez, as pessoas que trabalham com hierbas costumam curar pessoas próximas, conhecidas, achegadas pela via das suas extensas redes sociais. Como

\footnotetext{
318 "Aqui cobram em euros aos europeus e em dólares aos norte-americanos".

319 No capítulo 11 foram narradas algumas situações que podem ser compreendidas como exceções a essa regra.
} 
destaca Salles Machado (2013: 195) “as trocas fazem parte do código de conduta do que seja uma 'boa vizinhança'". As pessoas que trabalham com hierbas consideram o seu trabalho como um "serviço" que não requer, necessariamente, forma de pagamento alguma. Quando há pagamento, costuma ser colocado à vontade da pessoa que requer o produto ou serviço. Como me conta Asteria em entrevista de agosto de 2013: "No tiene precio fijo mi consulta. Yo les cobro, por decir, cinco soles. Después si son personas que vienen de las comunidades, ya me dan dos, tres soles" ${ }^{320}$. Ou bem como relata María:

La gente acá es pobre. Yo cobro por parteada. Pero si no me pueden pagar no importa. Ellos no me pagan, pero el Señor me paga ${ }^{321}$.

Ainda quando costuma haver um pagamento, a desproporção entre o pagamento a uma pessoa que trabalha com hierbas em relação ao pagamento a outra pessoa que trabalha com palos é enorme. Uma sobada, uma soplada ou outro serviço de uma pessoa que trabalha com hierbas pode ser o retorno de um favor, o um produto extraído da chacra: galinhas, plátanos, ovos. Quando o pagamento é monetário, a consulta e o serviço costumam custar entre um e três dólares. Enquanto isso, uma purga ou uma cerimônia com ayahuasca em um resort de turismo xamânico podem custar entre vinte e cinquenta dólares, ascendendo, nos casos dxs xamãs mais renomadxs, até cem dólares.

Vejo uma interessante relação entre os grupos de opostos aqui apresentados. As pessoas que trabalham com palos estão limitadas pela impossibilidade de tratar às pessoas da própria família, coisa que as obriga a trabalharem com pessoas que se encontram fora de seu grupo de pertencimento. Ao mesmo tempo, elas ostentam a possibilidade de cobrar com dinheiro pelos seus serviços. Por outra

\footnotetext{
320 "Não tem um preço fixo a minha consulta. Eu lhes cobro, por dizer, cinco soles. Depois, se são pessoas que vêm das comunidades, elas me dão dois, três soles".

321 "As pessoas aqui são pobres. Eu cobro sim por cada parto que eu faço. Mas se eles não podem me pagar, não importa. Eles não me pagam, mas o Senhor me paga".
} 
parte, as pessoas que trabalham com hierbas cobram somente às vezes com dinheiro e, quando o fazem, é em quantidades mínimas. Por outra parte, contam com o estímulo cultural para curar às pessoas da própria família, a vizinhxs, a amigxs. Essas pessoas contam com uma rede social próxima mais densa e acolhedora, e seu ofício está orientado a elas.

Tal diferenciação nas condições de pagamento pode indicar uma particular maneira em que o dinheiro e outros bens do capitalismo circulam dentro da comunidade: as pessoas que trabalham com palos costumam ser homens, oferecerem seus serviços para fora das redes familiares, de amizade e de vizinhança e captam a maior parte dos recursos financeiros para si próprios. Isso os torna os terapeutas mais visíveis. Também pode estar contribuindo para um prolongamento das desigualdades de acesso dos homens e das mulheres a todo tipo de espaços e possibilidades da vida social. Enquanto os homens continuam tendo acesso às áreas de maior liberdade dentro do que é culturalmente definido (seja o interior da floresta, seja o espaço público, seja o letramento ou os espaços oficiais e hospitalares), assim como aos bens do capitalismo, as mulheres costumam permanecer dentro dos circuitos da família ou da vizinhança e permanecem fora do acesso aos serviços monetários.

O grafocentrismo, a biomedicalização e a monetarização são poderosas influências no afazer diário dxs curiosxs, e cada uma destas dimensões xs afeta de maneira diferente. Os três modificam, de maneira mais ou menos sutil, às maneiras de fazer com plantas, colocando-as em relação com outras forças. Assim, desde que existem os livros sobre "plantas medicinais" e "plantas sagradas", xs curiosxs que têm acesso à leitura transformam seu discurso. Desde que há "remedios de botica", xs curiosxs os comparam constantemente com os remédios que vêm das plantas e, às vezes, misturam-nos com a finalidade de melhorar os 
resultados dos tratamentos. Finalmente, o fato de que os serviços mágicos e/ou terapêuticos sejam pagos em dinheiro faz com que as perturbações penetrem no território do mercantilizável, e que a saúde física, mental ou espiritual seja, nesses contextos, crescentemente considerada um bem possuído pelx sujeitx que a detém. 


\section{Conclusão \\ "Essencialismos estratégicos" e os gêneros da floresta}

A presente tese segue o itinerário de várias estações. Inicio o texto com a crítica do que chamei o mito do "homem-xamã-que-cura-com ayahuasca", onde exponho o caráter desta construção caricaturesca e política, apresentando imediatamente quatro saídas pontuais que tornam possíveis outras maneiras de descrever esse particular cenário peruano. Em primeiro lugar, a crítica à invisibilização das mulheres dá lugar a uma proposta de etnografia das relações de gênero entre plantas que apresento na tese. Em segundo lugar, o comentário sobre os limites do conceito de xamanismo traz consigo a opção pelo termo local curiosx, partindo da valorização heurística do estudo de caso realizado na localidade de Tamshiyacu. Em terceiro lugar, a revisão daqueles dois processos, que chamo a higienização das práticas e a focalização na cura, tem a sua contraparte na proposta dos conceitos de práticas terapêuticas e práticas etótropas, que estão integrados no trabalho diário dxs curiosxs. Finalmente, a crítica à centralidade da ayahuasca encontra a sua contrapartida no apelo etnográfico pela visibilização de um mundo de maneiras de fazer com plantas que são muito diversas.

Apresentei aqui as práticas de uma diversidade de mulheres e homens que exercem maneiras de fazer com plantas que se afastam claramente do cânone do xamanismo definido pelos estudos sobre a área. No decorrer da análise etnográfica, fui construindo uma estrutura que abrange a todos os casos de curiosxs de Tamshiyacu. Essa estrutura é móvel e, enquanto se cristaliza em aspectos narrativos paradigmáticos, inclui, ao mesmo tempo, as excepcionalidades, que a desfazem desde diferentes pontos de vista. Porém, o esquema não perde a sua identidade por ser flexível. Nas sociabilidades 
amazônicas que aqui estudo, a divisão genderizada tanto do mundo humano quanto do mundo das plantas é uma constante, e delineia fortemente a maneira de se relacionar dos dois grupos. Ainda que não tenham sido enfatizados nessa tese, nessa relação intervêm outras formas de materialização, mais ou menos sutil, da energia vivente, como animais, mortos e entidades da água ou do mato. Dentro de coordenadas que facilitam o esquema genderizado de palos e hierbas podem ser lidos aspectos muito diversos da prática dxs curiosxs como: a maneira como se aprende o ofício, o grupo de plantas escolhidas para estabelecer a comunicação (aprender a curar, curar, fazer trabalhos de amarre ou daño, evitar daños), a natureza das doenças tratáveis. Se as doenças são males de dios, poderão ser tratadas tanto por yerberxs quanto por curandeirxs; porém, se elas são atribuídas a males de gente, poderão ser tratadas somente por curandeirxs.

As experiências de vida que matizam aspectos do mundo dos palos e das hierbas, e os combinam de maneira única, são as que aqui eu coloco como vidas excepcionais. Julio e Ernesto são homens que, por condicionamento social, deveriam situar a sua prática dentro das orientações do mundo dos palos, porém, por motivos diversos, escolhem muitos dos recursos e possibilidades que oferecem o acesso ao mundo das hierbas, considerado feminino. Por sua vez, Adela, Pasquita e finalmente Isabel são mulheres que escolheram se situar em espaços estratégicos do mundo dos palos, considerado masculino. No seu final, a tese adquire certo caráter circular: a presença de Isabel abre e fecha o ciclo da leitura. Como sustenta Sônia Maluf (1999), "é o sujeito portador de uma experiência impar e singular que pode reunir experiências (...) tão díspares e lhes dar um sentido" (pp. 71). Desta maneira, as narrativas sobre trajetórias biográficas podem desenhar "maneiras, caminhos, veículos da experiência e do sentido - mesmo que se trate de um sentido precário" (pp.71). A operação que alterna os detalhes com as paisagens provê uma dupla possibilidade: a narrativa dos detalhes biográficos de 
Isabel interessa enquanto a constitui como veículo para a compreensão do mapa mais amplo de curiosxs locais, enquanto as explicações mais macro sobre a constituição das maneiras de fazer com plantas de cada curiosx especialista são a referência que permite compreender os itinerários biográficos de cada curios $x$ em questão.

De uma teimosa vocação pela enunciação das margens é que emerge a proposta heurística aqui apresentada. A presente etnografia estende suas raízes nas margens da regra do masculino invisível, nas bordas da universalização das práticas xamânicas, nas beiras da concepção higienizada da medicina local, que coloca uma ênfase ilusória nos aspectos "terapêuticos" do ofício destxs especialistas. Finalmente, também se estende nas beiradas da concepção exclusivista e excludente da ayahuasca como planta que se encontra no centro das práticas de magia e cura dxs curiosxs da Amazônia peruana.

Contudo, todo trânsito pelas bordas envolve o risco de uma, ou várias, quedas na direção do centro, que seria também possível de ser pensado como o espaço produtor de sentidos maioritários. No processo de construção desta etnografia e de escrita desta tese descobri que as margens do turismo xamânico são escorregadias: quando menos esperamos, estamos navegando na sua corrente de pensamento, centrada ao redor da masculina apropriação de uma ayahahuasca ritualizada. Uma âncora que favoreceu uma presença continuada nas margens do pouco explicitado, uma antropologia da escuta e uma etnografia apaixonada pelos detalhes, que ainda quando procurava práticas comuns, não compreendia o que era diferente como desvio, mas sim como manifestação de excepcionalidade. 
Condensando teoria e prática a partir de um campo prolífico e multiforme, observo que as práticas dxs curiosxs de Tamshiyacu podem ser lidas como ações que envolvem tanto resistências quanto táticas: resistência ativa às linhas de uma ordem colonial que silenciou as formas de fazer magias e curas com plantas. Por outra parte, há uma resistência genderizada que envolve as mulheres, que resistem à inexpressividade das figuras femininas no campo das terapias e magias da Amazônia do Peru. Quanto às táticas, elas são relativas a formas de inserção nas relações de trabalho de tipo capitalista, onde a mercantilização do ofício se sobrepõe à compreensão da reciprocidade nos termos de uma lógica mais ampla, que envolve humanxs e não-humanxs. No que diz respeito às mulheres especificamente, observei algumas táticas femininas de apropriação de espaços: do amor que se quer, dxs filhxs que se quer conceber, dos novos nichos que abre o mercado xamânico contemporâneo, que colocam às mulheres em lugares ativos e de escolha, ainda quando essas escolhas continuem sendo socialmente condicionadas por esquemas de gênero desiguais.

Porém, devo dizer que observei que são impossíveis de se aplicarem às práticas dxs curiosxs de Tamshiyacu os princípios de um eco-feminismo à la Ocidental (Donaldson, 1999). A cultura das pessoas etnografadas, ainda quando indígena, ainda quando mestiça, ainda quando em permanente e cru contato com a floresta, não é nem ginocrática nem matriarcal. As mulheres dançam em meio a movimentos de aceitação e apropriação das estruturas desiguais nas quais foram alocadas, como em um berço apertado, desde o momento da seu nascimento.

Ao analisar as práticas sociais da Amazônia do Peru é possível pensar não somente nas diferenças, mas também nas desigualdades entre mulheres e homens. As mulheres possuem menos acesso à escolarização, uma menor comercialização da sua prática terapêutica e mágica (isto é, cobram pouco ou 
nada pelas terapias e magias que sabem fazer), contam com menores possibilidades de mudar de cidade, estão socialmente mais restritas para aprenderem coisas novas fora do âmbito doméstico, etc. Nesse contexto, o ofício de curiosa parece permitir um acréscimo das redes de mobilidade doméstica, onde os movimentos de aprendizado na direção do mundo das plantas permite, em contrapartida, o exercício de um suave poder de magias e curas no mundo humano. Por sua vez, o ofício daquelas poucas mulheres que trabalham com palos consente uma liberdade de movimentos que é ainda maior e o exercício de um poder ainda mais aberto, coisa que posiciona a essas mulheres excepcionais em uma situação mais arriscada frente aos espíritos, porém com os prêmios de uma maior inserção social em redes de diverso alcance (locais, regionais, nacionais e internacionais). Ao acessarem ao xamanismo à la Ocidental e, com isso, aos territórios de maior comercialização do turismo xamânico na região, essas mulheres podem produzir seus próprios ingressos e acessar a melhoras em sua própria qualidade de vida assim como a de suas/seus filhxs. Elas transgridem a regra vegetalista segundo a qual xs curandeirxs não podem curar à própria família, e fazem suas magias e terapias tanto dentro do íntimo mundo dos laços familiares, de vizinhança e amizade, quanto no espaço impessoal onde cada remédio, limpeza, ritual e tratamento se elaboram a partir de um preço pactuado.

Encontrei em um conceito vindo das produções feministas pós-coloniais uma particular riqueza, que permite compreender de maneira reflexiva os cenários nos quais a minha tese focalizou. Esse conceito é o de "essencialismos estratégicos", proposto pela estudiosa indiana Gayatri Spivak. A proposta política e acadêmica de um "essencialismo estratégico" aceita que as categorias essencialistas da identidade humana ("mulher", mas também "negro", "homem", "branco", "homossexual", "heterossexual") devem ser relativizadas, historicizadas 
e criticadas, mas enfatiza que a utilização de tais categorias pode ser estratégica na hora de dar sentido, metafórico, mas sobretudo prático, ao mundo social e político. No caso dos esquemas binários de gênero, frente a um mundo organizado em dois polos, talvez seja conveniente registrar essas divisões binárias ideais e fragmentá-las a partir do estudo prático dos trânsitos entre as mesmas, trânsitos que são interessantes enquanto geradores de identidades excepcionais. Desta maneira, não se trata de procurar a origem de uma feminilidade per se, nem sequer de compreender a especificidade dos espaços femininos como uma reação especular aos espaços masculinos. O feminino é muito mais daquilo que não é, a floresta inteira goza de famílias de seres masculinos e femininos que impõem estranhas regras sobre o mundo humano: o feminino assim como o masculino são colocados em uma perspectiva que está além do domínio daquilo que é exclusivamente humano. A ideia de essencialismo estratégico aqui proposta se propõe a nomear tanto os espaços do feminino quanto os espaços do masculino sem congelá-los, tentando observar seus limites nas práticas de relação entre o mundo humano e o mundo nãohumano que é próprio da floresta circundante.

Assim, a presente pesquisa se guia pelas diferenças de gênero em estreita relação com esse espaço de seres não-humanos que os saberes da modernidade chamaram de Natureza e que aqui designo simplesmente como floresta. Mas delineia esse interesse não já à maneira do eco-feminismo, onde as mulheres estariam mais próximas da Natureza e das virtudes a ela atribuídas (generosidade, espontaneidade, desinteresse, beleza, bondade). Na presente proposta, xs sujeitxs humanxs contam com uma relação diferencial com a floresta, na qual os homens estariam mais próximos de certos espaços do mundo vegetal, como é a floresta aberta, enquanto as mulheres seriam frequentes visitadoras de um espaço de plantas domesticadas, cultivadas nos jardins. 
É interessante sublinhar aqui que o esquema dos palos e das hierbas designa diferenças não só entre homens e mulheres, mas também entre atributos femininos e masculinos da floresta circundante. Um esforço epistemológico que se faz no presente trabalho é o de desativar a perspectiva centrada no que é humano, onde a floresta existiria simplesmente como uma projeção deste mundo, e mudar o foco para a multiplicidade de perspectivas possíveis de um mundo onde também o que é não-humano designa o gênero da própria humanidade. Nesse sentido, resignifico aqui o conceito de "essencialismos estratégicos" para sublinhar a construção dinâmica das relações de poder no mundo humano e não-humano da floresta, que trilha os esquemas de ação a partir da percepção genderizada do mundo através dos esquemas binários dos palos e das hierbas, que não os prefiguram como modelos determinados por uma anatomia, mas pela posição na qual x curios $x$ se coloca estrategicamente na hora de encarar tanto as suas magias e terapias quanto as práticas mais banais da sua vida cotidiana. Assim, em um jogo de diferenças que são, até certo ponto, modificáveis em virtude da posição que se ocupa a partir da própria trajetória, as feminilidades e masculinidades na floresta se referem ao mundo humano e ao mundo não-humano, e não determinam outra coisa que as milhares de possibilidades criativas nas quais cada caminhante deve traçar seu particular itinerário. Desde a proposta de uma epistemologia parcial e localizada, aciono os saberes locais aqui expostos para que os estudos sobre xamanismo que se realizam na região da Amazônia peruana detenham a pretensa vocação de universalidade que as impulsiona, e comecem a apreciar com maior atenção aos matizes locais e regionais, historicamente constituídos: talvez no vazio de sentidos totais, nesse vazio de universais estejam as sementes para a compreensão de uma verdadeira universalidade, aquela que conecta todos os particulares no mesmo nível de validez e existência. 


\section{Referências bibliográficas}

AGAMBEN, Giorgio. 2005. Lo abierto. El hombre y el animal. Valencia: Pretextos.

AHLERT, Martina. 2013. Cidade relicário. Uma etnografia sobre Terecô, precisão e encantaria em Codó (Maranhão). Tese de Doutorado em Antropologia, Universidade de Brasília.

ALBUQUERQUE, Maria Bethânia. 2009. “Uma heresia epistemológica: as plantas como sujeitos do saber". In: CES, 328. Disponível em: http://www.ces.uc.pt/publicacoes/oficina/index.php?id=2613. Acesso em: 03/01/2014.

ALCALDE-RABANAL, Jacqueline. 2011. "Sistema de Salud de Perú". In: Revista Salud Pública Mexicana. N. 53, supl. 2. pp. 243-54.

ARREDONDO BAQUERIZO, Freder Lorgio. 2006. Dualidad simbólica de plantas y animales en la práctica médica del curandero-paciente en Huancayo. Dissertação de Mestrado. Pontificia Universidad Católica de Lima.

ATKINSON, Jane Monnig. 1992. "Shamanisms Today". In: Annual Review of Anthropology. N. 21. pp. 307-30.

BACIGALUPO, Mariella. 2007. Shamans of the Foye Tree. Gender, power and healing among the Chilean Mapuche. Texas: University of Texas Press.

BENDAYÁN, Christian, Gino CECCARELLI e Luis González POLAR (curadores). 2006. La soga de los muertos: el conocer desconocido del ayahuasca. Lima: UNMSM.

BERKIN, Sarah Corona e Olaf KALTMEIER (orgs.). 2012. En diálogo. Metodologías Horizontales en Ciencias Sociales y Culturales. Barcelona: GEDISA.

BIGLIA, Bárbara. 2005. Narrativas de mujeres sobre las relaciones de género en los movimientos sociales. Tese de doutorado, Universidade de Barcelona.

BIGLIA, Bárbara e Jordi BONET MARTÍ. 2009. "La construcción de narrativas como método de investigación psicosocial. Prácticas de escritura compartida". In: Revista Forum, Qualitative Social Research. N. 1, vol. 10, art. 8, Janeiro. Disponível em: http://www.qualitative-research.net/. Acesso em: 03/01/2014. 
BRABEC DE MORI, Bernd. 2014. "From the native's point of view. How Shipibo Conibo experience and interpret ayahuasca experience with 'gringos'". In: LABATE, Beatriz e Clancy CAVNAR: Ayahuasca shamanism in the Amazon and beyond. New York: Oxford. pp. 206-30.

BUTLER, Judith. 2003. Problemas de gênero: feminismo e subversão da identidade. Rio de Janeiro: Civilização Brasileira.

CABIESES, Fernando. 1993. Apuntes de medicina tradicional. La racionalización de lo irracional. Lima: A y B editores.

CALAVIA SÁEZ, Oscar. 2014. "Teorías, Actores y Redes de la Ayahuasca". In: Ilha - Revista de Antropologia, vol. 16, nro. 1, jan./jul. pp. 7-40.

CAMERARIUS, Rudolf Jakob. 1694. De sexu plantarum epistola. Disponível em: http://search.library.utoronto.ca. Acesso em: 22/02/2015.

CAMPOS, José. 2011. The Shaman EAyahuasca. Compilado por Geraldine Overton. California: Divine Art.

CÁRDENAS TIMOTEO, Clara. 1989. Los unaya y su mundo. Iquitos: CAAAP.

CAVNAR, Clancy. 2011. "The effects of participation in ayahuasca rituals on gay's and lesbian's self-perception". Tese de Doutorado, John F. Kennedy Graduate School of Professional Psychology, California.

CERNADAS, César e WRIGHT, Pablo. 2004. "Latin American Christianity and Shamanism". In: NAMBA WALTER, Mariko e Eva Jane NEUMANN FRIDMAN (eds.): Shamanism. An Encyclopedia of world beliefs, practices and culture. Oxford: ABC Clio. pp. 409-14.

CHAKRABARTY, Dipesh. 2007. Provincializing Europe: Postcolonial thought and Historical Difference. Princeton: Princeton University Press.

CHIDESTER, David. 2004."Colonialism and Shamanism". In: NAMBA WALTER, Mariko e Eva Jane NEUMANN FRIDMAN (eds.). Shamanism - An Encyclopedia of world beliefs, practices and culture. Oxford: ABC Clio. pp. 4149.

CSORDAS, Thomas. 1985. "Medical and sacred realities: between comparative religion and transcultural psychiatry". In: Culture, Medicine and Psychiatry, n. 9. pp. 103-16. 
CSORDAS, Thomas e Arthur KLEIMAN. 1996. "The Therapeutic Process". In: SARGENT, Carolyn e Thomas JOHNSON, (eds.). Medical Anthropology: Contemporary Theory and Method. Westport: Praeger.

DE CERTEAU, Michel. 1998. A invenção do cotidiano - As artes de fazer. Vozes: Rio de Janeiro.

DEGREGORI, Carlos e Pablo SANDOVAL. 2007. "La antropología en el Perú. Del estudio del otro a la construcción de un nosotros diverso". In: Revista Colombiana de Antropología. Vol. 43, enero-diciembre. pp. 299-334.

DESHAYES, Patrick, 2003. "L'Ayawaska n'est pas un hallucinogène". In: Psychotropes. N. 8, vol. 1. pp. 65-78.

DIAS DUARTE, Fernando e Ondina FACHEL LEAL. 1998. Doença, sofrimento, perturbação. Perspectivas etnográficas. Rio de Janeiro: Fiocruz.

DOBKIN DE RIOS, Marlene. 1972. Visionary vine: hallucinogenic healing in the Peruvian Amazon. Prospect Heights: Waveland Press.

. 1994. "Drug Tourism in the Amazon". In: Newsletter - Society for the Anthropology of Consciousness. N. 5, vol. 1. pp. 16-19.

DONALDSON, Laura. 1999. "On medicine woman and white shame-ans: new age native Americanism and commodity fetichism as pop culture feminism". In: Journal of Women in Culture and Society. N. 3, vol 24, pp. 67796.

DIAS DUARTE, Luiz Fernando. 1986. Da vida nervosa nas classes trabalhadoras urbanas. Rio de Janeiro: Zahar/CNPQ.

ECHAZÚ BÖSCHEMEIER, Ana Gretel. 2012. "Ayahuasca, corpo e auto transcendência, perspectivas xamânicas de cura e dissolução do eu". In: Núcleo de Estudos sobre Psicoativos. Disponível em: www.neip.info. Acesso em: 03/01/2014.

ECHAZÚ BÖSCHEMEIER, Ana Gretel. 2013a. "Entre 'moléculas espirituais' e 'plantas maestras': DMT, Ayahuasca e desafios da epistemologia". No prelo.

ECHAZÚ BÖSCHEMEIER, Ana Gretel. 2013b. "Remédio caseiro, oráculo, droga, erva dos bruxos: aquém da legitimação da ayahuasca pela via terapêuticoespiritual". In: Revista Pós. Dossiê Saúde Popular. Vol. 1, n. 12, pp. 39-65. Disponível em: seer.bce.unb.br/índex.php/revistapos/issue/current. Acesso em: 18/09/2014. 
ECHAZÚ BÖSCHEMEIER, Ana Gretel. 2014. Elos de leite, elos de sangue. Notas etnográficas na comunidade quilombola de Boa Vista dos Negros, 2008-2010. Natal: EDUFRN.

ESPINOZA, Yalila. 2013. The erotic intelligence of plants: a heuristic inquiry of women's sexual/spiritual experiences with sacred Amazonian plant teacher. Tese de Doutorado em Filosofia. California Institute of Integral Studies.

EVANS-PRITCHARD, Edward. 1937. Witchcraft, Oracles and Magic among the Azande. London: Oxford University Press.

FLEISCHER, Soraya. 2007. Parteiras, buchudas e aperreios. Uma etnografia do atendimento obstétrico não oficial na cidade de Melgaço, Pará. Tese de Doutorado. PPGAS, UFRGS. 315 p.

FLEISCHER, Soraya. 2013. "Saúde popular, esforços etnográficos para definir o conceito". In: Revista Pós. Dossiê Saúde Popular. Volume 1, n. 12, pp. 7-17. Disponível em: seer.bce.unb.br/índex.php/revistapos/issue/current. Acesso em: 18/09/2014.

FOUCAULT, Michel. 1999. Les anormaux. Cours au Collège de France 1974-1975. Paris: Gallimard.

FOUTIOU, Evgenia. 2014. "On the uneasiness of tourism. Considerations on shamanic tourism in Western Amazonia". In: LABATE, Beatriz e Clancy CAVNAR, Ayahuasca Shamanism in the Amazon and beyond. London: Oxford University Press. pp. 159-81.

FRAZER, James. 1993. The Golden Bough. London: Wordsworth.

GEERTZ, Clifford. 1966. "Religion as a Cultural System". In: BANTON, Michael (ed.). Anthropological Approaches to the Study of Religion. London: Tavistock. pp. 1-46.

GIBOVICH DEL CARPIO, Lorgio. 1989. Medicina folklórica en el antiguo Perú y su proyección en el mundo moderno. Lima: Conytec.

GIRARDET, Raoul. 1987. Mitos e Mitologias Políticas. São Paulo: Cia. das Letras.

GIOVE, Rosa. 2001. "Warmi Kuraini: La Mujer-Medicina, la Espiritualidad y el espíritu de las Plantas." In: MABIT, Jacques (ed.). Memória do Segundo Foro Inter-americano sobre Espiritualidade Indígena. Tarapoto: CISEI. pp. 33-44.

GLASER, Barney e Anselm STRAUSS. 1967. The Discovery of Grounded Theory. New York: Aldine Publishing Company. 
GLASS-COFFIN, Bonnie. 2003."La perspectiva de género en el curanderismo en el norte del Perú: Metáforas, modelos y manifestaciones de la diferencia". In: MILLONES, Luis, Hiroyasu TOMOEDA e Tatsuhiko FUJII (eds.). Serie Etnhological Reports. Tradición popular: Arte y religión de los pueblos del norte del Perú. N. 43, Lima: SER.

GOFFMAN, Erving. 1963. Stigma. Notes on the management of spoiled identity. New Jersey: Prentice-Hall.

GOW, Peter. River people. "Shamanism and history in Western Amazonia". In: THOMAS, Nicholas e Caroline HUMPREY (org.). Shamanism, history and the State. Michigan: University of Michigan Press. pp. 90-112.

GROSFOGUEL, Ramón. 2009. “Para descolonizar os estudos de economia e os estudos poscoloniais: transmodernidade, pensamento de fronteira e colonialidade global". In: SOUSA SANTOS, Boaventura e Paula MENESES (orgs.). Epistemologias do Sul. Coimbra: Almedina.

GUIMARÃES, Silvia Maria Ferreira. 2005. Cosmologia sanumá: o xamã e a constituição do ser. Tese de Doutorado. Programa de Pós-Graduação em Antropologia. Brasília, Universidade de Brasília.

HAMAYON, Roberta. 2004. "History of the study of shamanism". In: NAMBA WALTER, Mariko e Eva Jane NEUMANN FRIDMAN (eds.): Shamanism. An Encyclopedia of world beliefs, practices and culture. Oxford: ABC Clio. pp. $142-46$.

HARAWAY, Donna. 1995. Simians, Cyborgs, Women. The reinvention of nature. New York: Routledge.

HARNER, Michael. 1973. Hallucinogens and Shamanism. London: Oxford University Press.

HAWTHORNE, Sîan. 2007. "Study of religion". In: MALTI-DOUGLAS, Fedwa (ed.), Encyclopedia of Sex and Gender. Vol.4. Detroit: Thomson Gale. pp. 1253-6.

HEELAS, Paul. 1993. "The New Age in Cultural Context: the Premodern, the Modern and the Postmodern." In: Religion. N. 23. pp. 103-16.

HERBERT, Andrea. 2010."Female Ayahuasca Healers Among the ShipiboKonibo (Ucayali- Peru) in the Context of Spiritual Tourism". In: Núcleo de Estudos Interdisciplinares sobre Psicoativos. Disponível em: www.neip.info. Acesso em18/09/2014. 
HERNÁNDEZ BAUTISTA, Toribio. 1946. Historia de la fundación del pueblo de Tamshiyacu, Dpto. Maynas, Prov. Loreto. 1906-1924. Editora sem nome, cidade não consignada.

HOLMAN, Christine. 2010. Spirituality for Sale. An Analysis of Ayahuasca Tourism. Tese de Doutorado, Arizona State University.

IRIGARAY, Luce. 1985. This Sex Wich is Not One. Ithaca: Cornell University Press.

KHARITONOVA, Valentina. 2004. "Black shamans, white shamans". In: NAMBA WALTER, Mariko e Eva Jane NEUMANN FRIDMAN (Eds.): Shamanism. An Encyclopedia of world beliefs, practices and culture. Oxford: ABC Clio. pp. 536-38.

LABATE, Beatriz Caiuby. 2011. Ayahuasca Mamancuna merci beaucoup: internacionalização e diversificação do vegetalismo ayahuasqueiro peruano. Tese de Doutorado em Antropologia, Universidade Estadual de Campinas.

LABATE, Beatriz e Clancy CAVNAR. 2014. Ayahuasca Shamanism in the Amazon and beyond. London: Oxford University Press.

LABATE, Beatriz, Edward MC RAE e Sandra GOULART. 2012. "Brazilian Ayahuasca Religions in Perspective". In: Núcleo de Estudos Interdisciplinares sobre Psicoativos. Disponível em: www.neip.info. Acesso em: 03/01/2014.

LANGDON, Jean. 1996. "Introdução: xamanismo - velhas e novas perspectivas". In: LANGDON, Jean (ed.): Xamanismo no Brasil: novas perspectivas. Florianópolis: Editora da UFSC. pp. 9-28.

. 2010. "Xamãs e xamanismo: reflexões autobiográficas e intertextuais sobre a antropologia". In: Ilha - Revista de Antropologia. N. 2, vol.1, pp. 16192.

2013. "La eficacia simbólica de los rituales: del ritual a la performance". In: LABATE, Beatriz e José Carlos BOUSO (eds.). Ayahuasca y Salud. Madrid: La Liebre de Marzo.

LA SERNA SALCEDO, Juan Carlos. 2010. "Viviendo con el diablo en casa. La enfermedad, hechicería infantil y violencia entre los asháninka desde la perspectiva misionera adventista". In: Bulletin de l'Institut Français d'Études Andines, vol. 40, n. 1, pp. 81-121. 
LEAL RODRIGUES, Mariana. 2007. Mulheres da Rede Fitovida: Ervas medicinais, envelhecimento e associativismo. Dissertação de Mestrado em Ciências Sociais. Rio de Janeiro. Universidade Estadual de Rio de Janeiro.

LÉVI-BRUHL, Lucien. [1927] 1947. El Alma Primitiva. Barcelona: Ediciones Península.

LÉVI STRAUSS, Claude. 1966. The savage mind. Chicago: Chicago University Press.

LEVINS MORALES, Aurora. 2001. "Certified Organic Intellectual". In: The Latina Feminist Group, Telling to Live. Latina Feminist Testimonios. Durham/London: Duke University Press. pp. 27-32.

LLOYD, G.E.R. 1964. "The hot and the cold, the dry and the wet in Greek philosophy". Journal of Hellenic Studies, vol. 84, pp. 92-106.

LUNA, Eduardo. 1986. "The Concept of Plants as Teachers among four Mestizo Shamans of Iquitos, Northeastern Perú". In: Journal of Ethnopharmacology, n. 11, pp.135-56.

MALINOWSKI, Bronislaw. 1948. Magic, Science and Religion, and Other Essays. Boston: Beacon.

MALUF, Sônia Weidner. 1992. "Bruxas e bruxarias na Lagoa da Conceição. Um estudo sobre representações do poder feminino na ilha de Santa Catarina". In: Revista Crítica de Ciências Sociais. N. 34, fev. pp. 99-112.

MALUF, Sônia Weidner. 1999. "Antropologia, narrativas e busca de sentido". In: Revista Horizontes Antropológicos. Porto Alegre, ano 5, n. 12, dez. pp. 69-82.

MANTERE, Ville. 2013. Westerners in search of the legendary potion. Ayahuasca travel in the borderland between tourism and pilgrimage. Dissertação de Mestrado em Religião Comparativa. Faculty of Theology, Åbo Akademi University.

MARTINEZ GONZALEZ, Roberto. 2009. "Chamanismo y la corporalización del chamán: argumentos para la deconstrucción de una falsa categoría antropológica". In: Cuicuilco, n. 46, mai-ago. pp. 197-220.

MC KENNA, Dennis e Neil TOWERS. 1984."Biochemistry and pharmacology of tryptamines and beta-carbolines". In: Jornal of Psychoactive Drugs, vol. 16. pp. 347-58. 
MC KENNA, Dennis, CALLAWAY, James e Charles GROB. 1998. "The Scientific Investigation of Ayahuasca. A Review of Past and Current Research". In: The Heffter Review of Psychedelic Research, vol. 1. pp. 65-77.

MC KENNA, Dennis. 1999. "Ayahuasca: An Ethnopharmacologic History". In: Ralph METZNER (ed.). Ayahuasca: Hallucinogens, Consciousness, and the Spirit of Nature. New York: Thunder's Mouth Press.

MEJÍA, Kember e Elsa RENGIFO. 2000. Plantas Medicinales de Uso Popular en la Amazonía Peruana. Lima: Agencia Española de Cooperación Internacional.

MERCANTE, Marcelo. 2012. Imagens de cura: ayahuasca, imaginação, saúde e doença na Barquinha. Rio de Janeiro: Fiocruz.

MIGNOLO, Walter. 2006. “Os esplendores e as misérias da 'ciência': colonialidade, geopolítica do conhecimento e pluri versalidade epistémica". In: SOUSA SANTOS, Boaventura (org.). Conhecimento prudente para uma vida decente. Um discurso sobre as Ciências revisitado. São Paulo: Cortez Editora. pp. 631-671.

MOHANTY, Chandra. 2008. "Bajo los ojos de Occidente: Academia feminista y discurso colonial". In: SUÁREZ NÁVAZ, Liliana e Aída HERNÁNDEZ (eds.): Descolonizando el feminismo. Teorías y prácticas desde los márgenes. Madrid: Cátedra. pp. 117-164.

MOURE, Walter. 2005. Saudades da cura. Estudo exploratório de terapêuticas de tradição indígena na Amazônia peruana. Tese de Doutorado em Psicologia. Universidade de São Paulo.

NAMBA WALTER, Mariko. 2004. "Introduction". In: NAMBA WALTER, Mariko e Eva Jane NEUMANN FRIDMAN (eds.). Shamanism. An Encyclopedia of world beliefs, practices and culture. Oxford: ABC Clio. pp. I-XXVI.

NARBY, Jeremy. 1998. The cosmic serpent: DNA and the origins of knowledge. New York: Tarcher/Putnam.

NOVIÓN, Martín. 2012. "O conceito de farmácia doméstica e suas implicações no estudo do sistema de cuidados em saúde". In: FLEISCHER, Soraya e Carlos Emanuel SAUTCHUK (orgs.). Anatomias populares, a antropologia médica de Martín Ibáñez-Novión. Brasília: Editora UNB. pp. 166-88.

PACHECO, Gustavo de Britto Freire. 2004. Brinquedo de cura: um estudo sobre a pajelança maranhense. Tese de Doutorado em Antropologia. Universidade Federal de Rio de Janeiro. 
PELUSO, Daniela. 2014. "Ayahuasca's attractions and distractions: examining sexual seduction in shaman participant interactions". LABATE, Beatriz e Clancy CAVNAR. Ayahuasca shamanism in the Amazon and beyond. New York: Oxford. pp. 231-255.

PINA CABRAL, João e Antônia PEDROSO DE LIMA. 2005. “Como fazer uma história de família: um exercício de contextualização social". In: Revista Etnográfica, vol. IX, n. 2. pp. 355-88.

PRESSLEY, Lauren. 2005. Whose Knowledge is it Anyway? Feminist Epistemology and Science. North Carolina: University of North Carolina.

QUIJANO, Aníbal. 2000. “Colonialidad del poder, eurocentrismo y América Latina". Em: LANDER, Edgardo (comp.). La colonialidad del saber: eurocentrismo y ciencias sociales. Perspectivas Latinoamericanas. Buenos Aires: CLACSO.

RASMUSSEN, Knud. 2004. "'Magic', power and ritual in shamanism". In: NAMBA WALTER, Mariko e Eva Jane NEUMANN FRIDMAN (eds.): Shamanism. An Encyclopedia of world beliefs, practices and culture. Oxford: ABC Clio. pp. 161-69.

RENGIFO RUIZ, Roger. 2012. "Ayahuasca, medicina ancestral". Comunicação apresentada na Mesa de Antropologia Amazônica do V CNIAP. 2 a 5 de Outubro. Puno, Peru.

RENGIFO SALGADO, Elsa. 2007. Las ramas floridas del Bosque. Experiencias en el manejo de plantas medicinales amazónicas. Iquitos: IIAP.

RIVIERA, Diana. 2010. "A review of doing visual ethnography images media and representation in research". In: The Qualitative Report, vol 15, n. 4, pp. 98891.

RODRÍGUEZ ACHUNG, Marta. 2003. Pobreza, degradación ambiental y violencia: la herencia del siglo XX para las mujeres amazónicas. Lima: CISEPA/PUC.

ROSE, Nicholas. 2009. "Normality and pathology in a biomedical age". In: Sociological Review, n. 57, pp. 66-83.

RUMRILL, Roger. 1972. Amazonia hoy: crónicas de emergencia. Iquitos: CETA.

RUSELL WALLACE, Alfred. 1889. A narrative of travels on the Amazon and Rio Negro, with an account of the native tribes and observations on the climate, geology and natural history of the Amazon Valley. Londres: Ward Lock and Co. 
RUSH, Brian et al. 2014. "Statement Critiquing the Ethnobotanical Stewardship Council (ESC)". Disponível em: www.neip.info. Acesso em: 03/02/2015.

SCHEPER-HUGUES, Nancy. 1992. Death without weeping. The violence of everyday life in Brazil. Berkeley: University of California Press.

SPIVAK, Gayatri. 1995. The Spivak Reader: Selected Works of Gayatri Chakravorty Spivak. In: LANDRY, Donna e Gerald MC LEAN (eds.). London: Routledge.

SIDKY, Homayun. 2010. "Ethnographic Perspectives on Differentiating Shamans from other Ritual Intercessors". In: Asian Ethnology, vol. 69, n. 2, pp. 21340.

STEIL, Carlos. "Turismo e peregrinação". 2000. Trabalho apresentado no Fórum 21 de Turismo da XXII Reunião Brasileira de Antropologia de Pesquisa 21: Disponível em: abant.org.br/conteudo/ANAIS/CD_Virtual_22_RBA/pdf/F21\%20Carlos \%20Alberto\%20Steil.pdf. Acesso em 03/01/2014.

SALLES MACHADO, Juliana. 2012. Lugares de gente: mulheres, plantas e redes de troca no delta Amazônico. Tese de Doutorado em Antropologia. Universidade Federal do Rio de Janeiro.

SALTALAMACCHIA, Homero. 1992. Historia de Vida: reflexiones a partir de una experiencia de investigación. Puerto Rico: CIJUP.

SANTOS, Boaventura de Sousa. 2009. "Más allá del pensamiento abismal: de las líneas globales a una ecología de saberes". In: OLIVÉ, León (org.): Pluralismo epistemológico. La Paz: Muela del Diablo Editores. pp. 31-84.

SANTOS GRANERO, Fernando e Frederica BARCLAY. 2002. La frontera domesticada - Historia económica y social de Loreto, 1850-2000. Lima: PUC.

SCHULTES, Richard Evans. 1967. "The place of ethnobotany in the ethnopharmacologic search for psychoactive drugs". In: EFRON, Daniel (org.). Ethnopharmacologic Search for Psychoactive Drugs. U.S. Public Health Service Publication. N. 1645. Washington: U.S. Government Printing Office.

SPRUCE, Richard. 1908. Notes of a botanist on the Amazon \& Andes. Londres: MACMILLAN and Co.

SPIVAK, Gayatri. 2010. Crítica de la Razón Poscolonial. Hacia una crítica del presente evanescente. Madrid: Akal. 
STRATHERN, Marilyn. 2004. Partial connections. Oxford: Altamira Press.

TAMBIAH, Stanley. 1990. Magic, Science, Religion, and the Scope of Rationality. Cambridge: Cambridge University Press.

TAURO DEL PINO, Alberto. 1960. Enciclopedia Ilustrada del Perú. Lima: Amauta.

TAUSSIG, Michael. 1993. Xamanismo, colonialismo e o homem selvagem. São Paulo: Paz e Terra.

TEDLOCK, Barbara. 2004. "Gender in shamanism". In: NAMBA WALTER, Mariko e Eva Jane NEUMANN FRIDMAN (eds.): Shamanism. An Encyclopedia of world beliefs, practices and culture. Oxford: ABC Clio. pp. 131135.

TEDLOCK, Barbara. 2008. A Mulher no Corpo de Xamã. O feminino na religião e na medicina. Rio de Janeiro: Rocco.

TOMPKINS, Peter e Christopher BIRD. 1974. La vida secreta de las plantas. México: Editorial Diana.

TORRES, Roger et al. 1994. Estudio detallado de suelos de la zona "Fernando Lores", Tamshiyacu, Región Loreto. Iquitos: IIAP.

TOURNON, Jacques, CÁUPER PINEDO, Samuel e URQUÍA ODICIO, Rafael. 1998. "Los piripiri, plantas paradójicas de la Amazonia". In: Revista Anthropológica. N. 16. pp. 215-40.

TOURNON, Jacques. 2006. “Las plantas, los rao y sus espíritus: etnobotánica del Ucayali". Pucallpa: Gobierno Regional del Ucayali.

VALENCIA, Marco Antonio. 2010. "Salud y extirpación de idolatrías". In: NARANJO, Plutarco (org.). Etnomedicina y botánica: avances en la investigación. Quito: Editorial Abya Yala. pp. 29-60.

VIVEIROS DE CASTRO, Eduardo. 2004. "Exchanging perspectives. The transformation of objects into subjects in Amerindian ontologies". In: Common Knowledge, n. 10, pp. 463-84.

VOUJIOULAKOU, Sofia. 2012. "An interview with Elisabeth Hsu on Plants, Health and Healing: on the interface of Ethnobotany and Medical Anthropology". In: Ethnobiology Letters, vol. 3, pp. 91-95.

WHYTE, Susan Reynolds. 1989. "Anthropological Approaches to African Misfortune. From Religion to Medicine". In: JACOBSON-WIDDING, Anita 
e David WESTERLUND (eds.). Culture, Experience and Pluralism. Essays on African Ideas of Illness and Healing. Suécia: Uppsala University.

WILHELMI, Barbara. 2004. "Christianity and shamanism". In: NAMBA WALTER, Mariko e Eva Jane NEUMANN FRIDMAN (eds.): Shamanism. An Encyclopedia of world beliefs, practices and culture. Oxford: ABC Clio. pp. $35-41$.

WINKELMAN, Michael. 2000. Shamanism: The Neural Ecology of Consciousness and Healing. Westport: Bergin \& Garvey.

WHITMAN, Walt. 2005. Folhas de relva. São Paulo: Iluminuras.

YOUNG, David e Jean-Guy GOULET. 1994. "Introduction". In: YOUNG, David e Jean-Guy GOULET (eds). Being Changed by Cross-Cultural Encounters: The Anthropology of Extraordinary Experience. Toronto: University of Toronto. pp. 7-13.

ZELIZER, Viviana. 2005. "Curcuits between capitalism". In: NEE, Victor e Richard SWEDBERG (orgs). The economic sociology of capitalism. Princeton: Princeton University Press. pp. 289-322.

\section{Outros formatos}

FOLHETIM "Plantas medicinales del jardín botánico". 1993. Iquitos: IMET-ES Salud.

FOLHETIM "Plantas medicinales de la amazonia peruana utilizadas por los curanderos, chamanes y herbolarios con fines antiinfecciosos". 1998. Iquitos: IPSS.

\section{Web Sites}

Albergue Mundo de la Yacuruna. Disponível em:

www.mundodelayacuruna.blogspot.org. Acesso em 18/09/2014.

Centro Takiwasi. Disponível em: www.takiwasi.org. Acesso em 18/09/2014.

Conferência Mundial Ayahuasca. Ibiza, Espanha. 2014. Disponível em: www.aya2014.org. Acesso em 18/09/2014. 
GMT (Grupo Multidisciplinar de Trabalho Ayahuasca). 2006. Relatório final. Brasília: Conad. Disponível em: http://obid.senad.gov.br/OBID/Diversos/salvarlocal.jsp?id=18276. Acesso em 18/09/2014.

Resolución Directorial Nacional Número 836/INC. Disponível em: http://www.bialabate.net/wpcontent/uploads/2008/08/declarion_ayah uasca_patrimonio_cultural_peru.pdf. Acesso em 18/09/2014.

Spirit Plant Medicine Conference. Toronto, Canadá. 2012. Disponível em: www.spiritplantmedicine.com. Acesso em 18/09/2014.

Therapy. Dicionário Etimológico Online. Disponível em: http:/ / www.etymonline.com/index.php?allowed_in_frame $=0 \& s e a r c h=t h$ erapy\&searchmode=none. Acesso em 18/09/2014 